\title{
OCDE - Avaliações de Desempenho Ambiental
}

\section{BRASIL}

2015
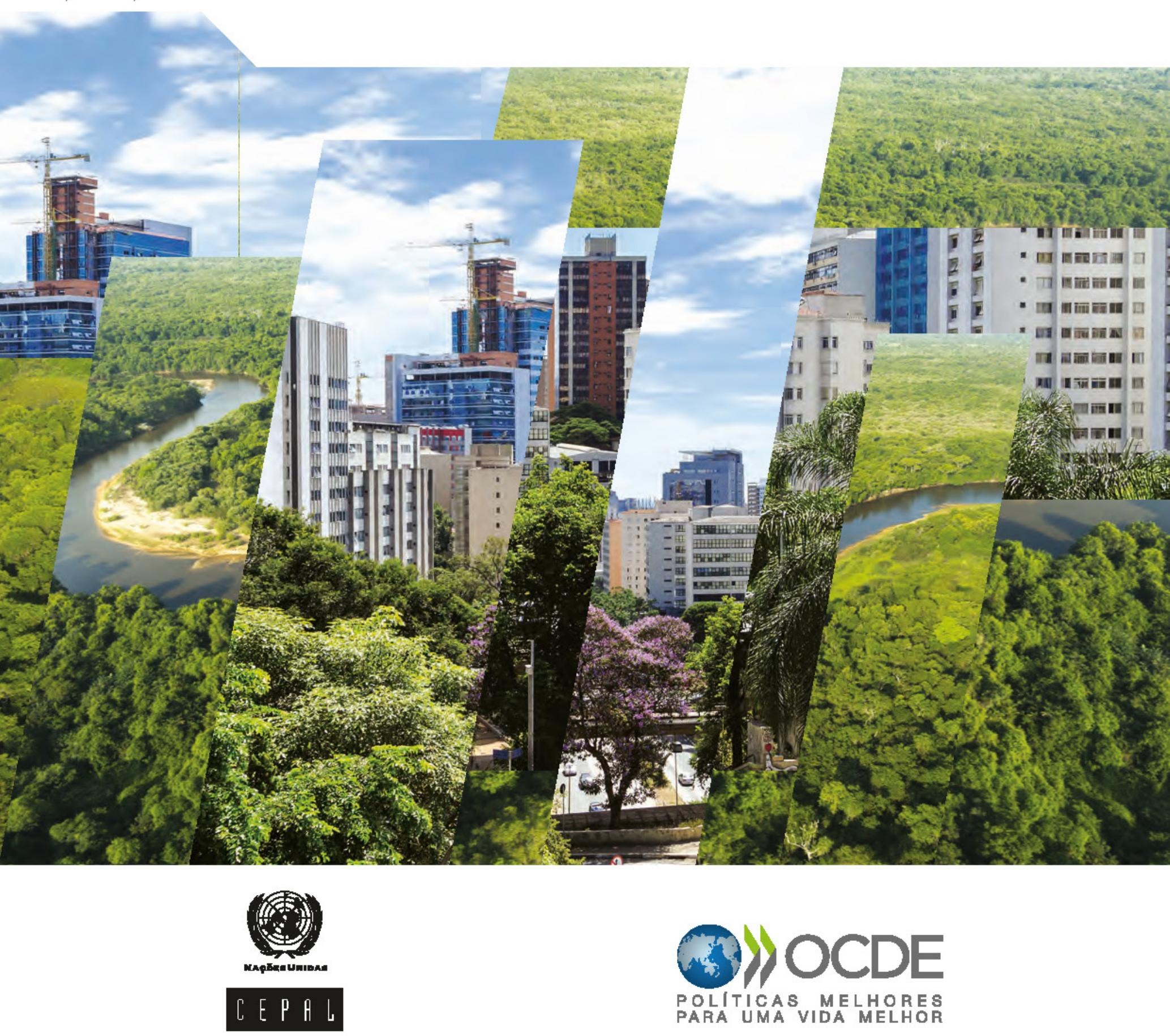



\section{OCDE - Avaliações de Desempenho Ambiental: Brasil 2015}


Este documento é publicado sob a responsabilidade do Secretário-Geral da OCDE. As opiniões expressas e os argumentos utilizados nesta publicação não refletem necessariamente a opinião oficial da OCDE, nem dos governos de seus países-membros, tampouco da Comissão Econômica para a América Latina e o Caribe (CEPAL).

Esta tradução é publicada mediante acordo entre a CEPAL e a OCDE. Não é uma tradução oficial da OCDE. A CEPAL é a única responsável pela qualidade da tradução para o português, incluída sua coerência com o texto original. Em caso de alguma discrepância entre o original e a tradução, prevalecerá a edição original em inglês.

LC/BRS/L.30

ISBN 978-92-1-121920-3 (impresso e eletrônico)

ISBN 978-92-1-057544-7 (pdf)

Este documento e qualquer mapa incluído são apresentados sem prejuízo da condição ou soberania de qualquer território, da delimitação das fronteiras e dos limites internacionais, nem do nome de qualquer território, cidade ou área.

As autoridades israelenses forneceram sob sua responsabilidade os dados estatísticos relativos a Israel. O uso desses dados pela OCDE não prejudica o estatuto das Colinas de Golã, Jerusalém Oriental e os assentamentos israelenses na Ribeira Ocidental, segundo as leis internacionais.

Créditos fotográficos: @ iStockphoto/filipefrazao, @ iStockphoto/Alatom.

Publicado originalmente em inglês pela OCDE sob o título:

OECD Environmental Performance Reviews: Brazil 2015

() 2015 OCDE

@ 2016 Nações Unidas para esta edição em português 


\section{Sumário}

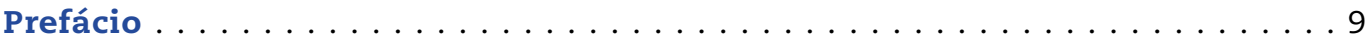

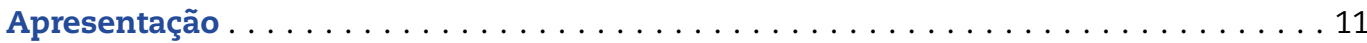

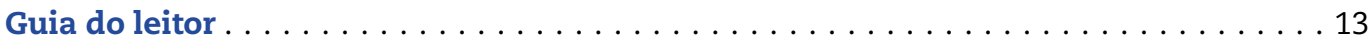

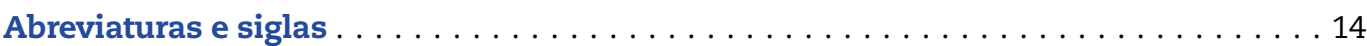

Estatísticas Básicas do Brasil . . . . . . . . . . . . . . . . . . . . . . . . . . . 16

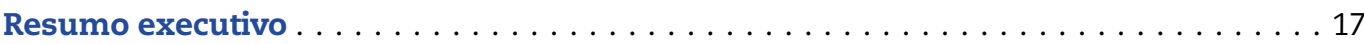

Avaliação e recomendações . . . . . . . . . . . . . . . . . . . . . . 21

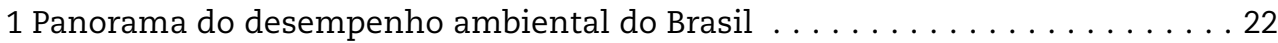

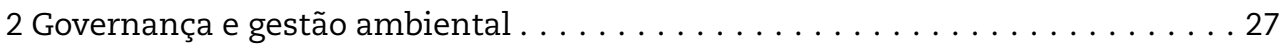

3 Esverdeamento da economia no contexto do desenvolvimento sustentável . . 30

4 Conservação e uso sustentável da biodiversidade . . . . . . . . . . . . 37

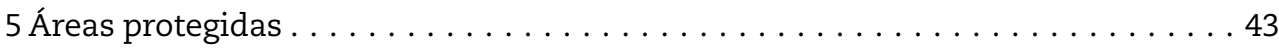

Notas . . . . . . . . . . . . . . . . . . . . . . . . . . . . . . 51

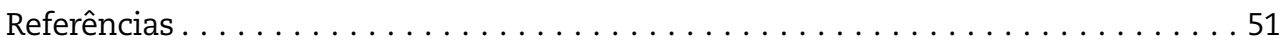

Parte I

Progresso Rumo ao Desenvolvimento Sustentável

Capítulo 1. Principais Tendências Ambientais . . . . . . . . . . . . . . . . . 57

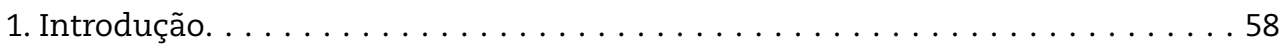

2. Principais desdobramentos econômicos e sociais $\ldots \ldots \ldots \ldots \ldots \ldots \ldots$

3 Transição para uma economia de eficiência energética e de baixo carbono . . . . 63

4 Transição para uma economia de aproveitamento eficiente de recursos . . . . . 69

5 Gestão da base de ativos naturais . . . . . . . . . . . . . . . . 72

Recomendações sobre a política de mudança do clima e a gestão do ar, da água e de resíduos . . . . . . . . . . . . . . . . . . . . . . . . . . . 79

Notas . . . . . . . . . . . . . . . . . . . . . . . . . . . . . . 79

Referências.....................................88

Anexo 1.A. Dados sobre energia e transportes . . . . . . . . . . . . . . 85

Anexo 1.B. Dados sobre mudança do clima e poluição atmosférica . . . . . . . . . 89

Anexo 1.C. Dados sobre gestão de resíduos e recursos . . . . . . . . . . . . 95

Anexo 1.D. Dados sobre a biodiversidade e recursos hídricos . . . . . . . . . . . . 99

Capítulo 2. Governança e gestão ambiental . . . . . . . . . . . . . . . . . . . . . . 103

1. Marco institucional de governança ambiental em diversas instâncias . . . . . 104

2. Orçamentos de instituições ambientais e fundos ambientais . . . . . . . . 110

3. Principais políticas e regulamentos relacionados ao meio ambiente . . . . . . 113

4. Avaliação de impacto e licenciamento ambiental . . . . . . . . . . . . . . 121 


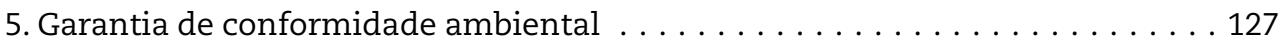

6. Promoção da democracia ambiental . . . . . . . . . . . . . . . 133

Recomendações sobre gestão e governança ambiental . . . . . . . . . . . . . . 138

Notas . . . . . . . . . . . . . . . . . . . . . . . . . . . . . . . . . . . . . . . . . . 139

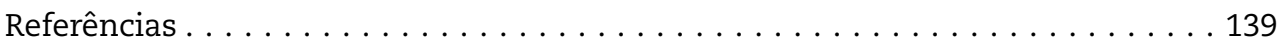

Capítulo 3. Esverdeamento da economia no contexto do

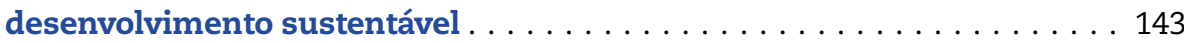

1. Introdução . . . . . . . . . . . . . . . . . . . . . . . . . . 144

2. Marco político para o desenvolvimento sustentável e a economia verde . . . . 145

3. Esverdeamento do sistema de tributos e encargos . . . . . . . . . . . 147

4. Reforma de subsídios e incentivos prejudiciais ao meio ambiente . . . . . . 156

5. Investimentos em infraestrutura ambiental e de baixo carbono . . . . . . . . 161

6. Promoção da ecoinovação, produtos e serviços ambientais . . . . . . . . 173

7. Meio Ambiente e cooperação para o desenvolvimento . . . . . . . . . . . . 180

Recomendações sobre o esverdeamento da economia no contexto do desenvolvimento sustentável . . . . . . . . . . . . . . . . . . . . . . . . . . . . . . . . 184

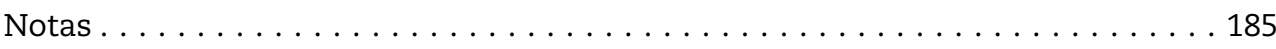

Referências.................................... 188

Anexo 3.A. Avanços na Consecução dos Objetivos de Desenvolvimento do Milênio . . . . . . . . . . . . . . . . . . . . . . . . . 193

Anexo 3.B. Dados Sobre o Desempenho do Crescimento Verde . . . . . . . . . . . . 195

Parte II

Progresso rumo a objetivos ambientais selecionados

Capítulo 4. Conservação e uso sustentável da biodiversidade . . . . . . . . . . . . . . . 201

1. Situação e tendências da biodiversidade brasileira . . . . . . . . . . . . 202

2. Principais atores na política de biodiversidade . . . . . . . . . . . . 209

3. Marco estratégico de políticas para conservação e uso sustentável

da biodiversidade . . . . . . . . . . . . . . . . . . . . . . . . . 210

4. Estratégia integrada de combate ao desmatamento . . . . . . . . . . . . 211

5. Instrumentos da política de conservação e uso sustentável

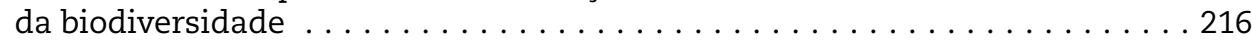

6. Financiamento da conservação e uso sustentável da biodiversidade . . . . . . . 227

7. Transversalização do tema da biodiversidade nas políticas setoriais . . . . . 230

8. Acervo de conhecimento e valoração da biodiversidade na formulação

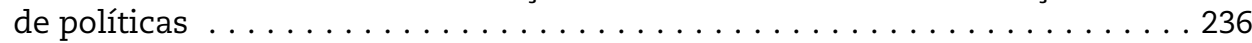

Recomendações sobre conservação e uso sustentável da biodiversidade . . . . . . . . . 238

Notas . . . . . . . . . . . . . . . . . . . . . . . . . . . . . . . . 240

Referências..................................... 241

Anexo 4.A. Metas Nacionais de Biodiversidade 2011-2020 . . . . . . . . . . . . 245

Capítulo 5. Áreas protegidas . . . . . . . . . . . . . . . . . . . . . . . . . . . . . . 247

1. Categorias, extensão e benefícios das áreas protegidas $\ldots \ldots \ldots \ldots \ldots 248$

2. Marco institucional das unidades de conservação . . . . . . . . . . . . 256

3. Criação de unidades de conservação . . . . . . . . . . . . . . . . 257

4. Gestão das unidades de conservação . . . . . . . . . . . . . . . . . 260 
5. Uso sustentável das unidades de conservação . . . . . . . . . . . . . . . . 270

Recomendações sobre áreas protegidas . . . . . . . . . . . . . . . . . . 275

Notas final do arquivo . . . . . . . . . . . . . . . . . . . . 276

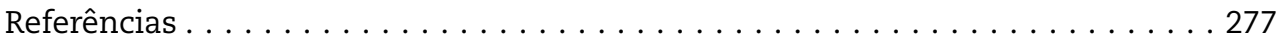

Boxes

2.1. Quadro institucional para a governança da água . . . . . . . . . . . . . . . 106

2.2. Programa Município VerdeAzul de São Paulo . . . . . . . . . . . . . . . . . . . 108

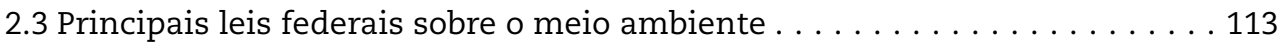

2.4. Pacto Nacional pela Gestão das Águas . . . . . . . . . . . . . . . . . . . . 120

2.5 Seleção de regulamentos de licenciamento ambiental . . . . . . . . . . . . 124

2.6. Os Princípios do Equador . . . . . . . . . . . . . . . . . . . . . . . 129

2.7. Indicadores de desenvolvimento sustentável do Brasil . . . . . . . . . . . 135

2.8. Litígio sobre a construção da usina de Belo Monte . . . . . . . . . . . . . . 136

3.1. Bolsa Família, carro-chefe dos programas de proteção social do Brasil . . . . . 146

3.2. Destinação de receitas do petróleo e gás para fins ambientais . . . . . . . . . 148

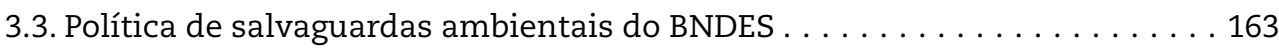

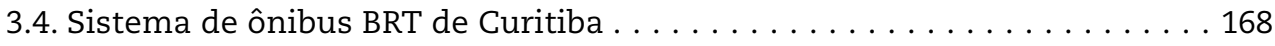

3.5. Exigências de conteúdo local nos mercados de energias renováveis . . . . . . . 171

3.6. Eficiência energética potencial do Brasil . . . . . . . . . . . . . . . . . 173

3.7. Políticas gerais de inovação . . . . . . . . . . . . . . . . . . . . . . 174

3.8. Sustentabilidade como modelo de negócio: Natura . . . . . . . . . . . . . . 180

4.1. Os seis biomas terrestres do Brasil . . . . . . . . . . . . . . . . . . . 203

4.2. Plano de ação para a biodiversidade do Estado de São Paulo . . . . . . . . . . 211

4.3. Programa Terra Legal . . . . . . . . . . . . . . . . . . . . . 212

4.4. Sistemas de monitoramento do desmatamento no Brasil . . . . . . . . . . . 213

4.5. Instituto Nacional de Pesquisas da Amazônia . . . . . . . . . . . . . . . . . . . 214

4.6. Plano de Ação para a Prevenção e Controle do Desmatamento e

das Queimadas no Cerrado . . . . . . . . . . . . . . . . . . . . . . . . . . 214

4.7. Novo Código Florestal: Alguns elementos críticos . . . . . . . . . . . . 219

4.8. Bolsa Floresta e Bolsa Verde . . . . . . . . . . . . . . . . . . . . . . . 223

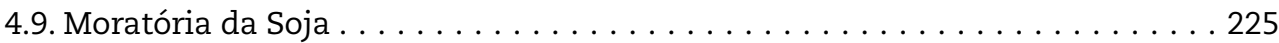

4.10. Programa Agricultura de Baixa Emissão de Carbono . . . . . . . . . . . . . . 230

4.11. Iniciativa Valoração do Capital Natural do Brasil . . . . . . . . . . . . . . . . . . 237

5.1. Programa de Áreas Protegidas da Amazônia . . . . . . . . . . . . . . . . . . . . 251

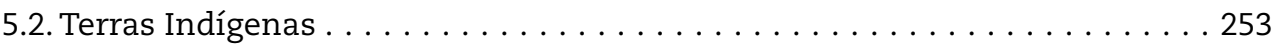

5.3. Valor econômico das áreas protegidas brasileiras . . . . . . . . . . . 255

5.4. Unidades de Conservação Urbanas no Brasil . . . . . . . . . . . . . . . . . 257

5.5. Sem plano de manejo, sem turismo: o caso do Parque Nacional

de Anavilhanas . . . . . . . . . . . . . . . . . . . . . . . . . 261

5.6. Gestão de unidades de conservação em escala da paisagem:

o Mosaico Baixo Rio Negro . . . . . . . . . . . . . . . . . . . . . . . . . . . . 262

5.7. Rota Lund: primeira parceria público-privada do Brasil para a gestão de unidades de conservação . . . . . . . . . . . . . . . . . . . . . . 265

5.8. Fundo Brasileiro para a Biodiversidade . . . . . . . . . . . . . . . 267

5.9. O potencial turístico inexplorado do Parque Nacional

da Chapada dos Veadeiros . . . . . . . . . . . . . . . . . . . . . . . . 272

5.10. O valor da visitação a áreas protegidas: O caso da Parks Canada . . . . . . . 272 
Tabelas

2.1 O SISNAMA em diferentes níveis de governo . . . . . . . . . . . . . . . . . . . 104

2.2 Fundos ambientais federais . . . . . . . . . . . . . . . . . . . . 112

2.3 Planos setoriais de mitigação e adaptação à mudança do clima até 2020 . . . . . . . . . . . . . . . . . . . . . . . . . . . . . . 115

2.4. Normas nacionais de qualidade do ar versus diretrizes da OMS . . . . . . . 117

2.5 Perspectiva estadual sobre licenciamento ambiental: Desafios e propostas . . 123

2.6 Resoluções e circulares do Banco Central do Brasil relacionadas ao meio ambiente . . . . . . . . . . . . . . . . . . . . . . . . . . . . 129

3.1. Alíquotas do imposto sobre consumo de combustível, 2001-15 . . . . . . . . 151

3.2. Exemplos de estímulo ao consumo de combustíveis fósseis e de despesas fiscais relacionadas . . . . . . . . . . . . . . . . . 158

3.3. Investimentos no âmbito do PAC $2 \ldots \ldots$. . . . . . . . . . . . . . . . . . 162

3.A.1. Objetivos de Desenvolvimento do Milênio metas e indicadores selecionados . . . . . . . . . . . . . . . . . . . . . . . . . 194

4.1. Estimativa quantitativa de espécies em biomas terrestres brasileiros . . . . . . 208

4.2. Principais instrumentos da política de conservação e uso sustentável da biodiversidade no Brasil . . . . . . . . . . . . . . . . . . . 216

4.3. Exemplos da legislação estadual sobre PSA . . . . . . . . . . . . . . . . 222

4.4. Desembolsos orçamentários federais para determinados programas relacionados à biodiversidade. . . . . . . . . . . . . . . 228

5.1. Categorias de unidades de conservação do SNUC . . . . . . . . . . . . . . . . . . 249

5.2. Áreas protegidas e terras indígenas, por bioma, 2015 . . . . . . . . . . . . . . 253

Figuras

1. Indicadores de desempenho ambiental selecionados . . . . . . . . . . . . . . 24

2. Investimentos do Banco Nacional de Desenvolvimento Econômico e Social

(BNDES) para o meio ambiente aumentaram significativamente . . . . . . . 33

3. Expansão das áreas protegidas ajudou a reduzir o desmatamento na Amazônia . . 38

1.1. A renda per capita no Brasil alcançou níveis mais altos que na maioria dos países BRIICS . . . . . . . . . . . . . . . . . . . 59

1.2. O desemprego diminuiu, enquanto que a renda do trabalho aumentou . . . . 60

1.3. A renda per capita varia bastante entre os estados brasileiros . . . . . . . . . 61

1.4. A satisfação com a vida no Brasil é alta, mas permanecem algumas limitações . . . . . . . . . . . . . . . . . . . . . 62

1.5. Fontes renováveis respondem por parcela cada vez maior da energia produzida . . . . . . . . . . . . . . . . . . . 63

1.6. O consumo de energia para os transportes e a indústria vem aumentando rapidamente . . . . . . . . . . . . . . . . 65

1.7. As emissões GEE provenientes do desmatamento diminuíram, mas estão aumentando em outros setores . . . . . . . . . . . . . . 66

1.8. A intensidade do carbono do Brasil continua baixa em

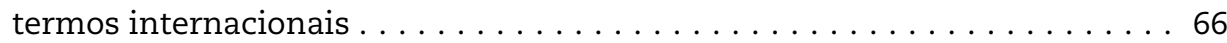

1.9. Emissões atmosféricas provenientes do transporte vêm diminuindo, mas as emissões globais vêm aumentando . . . . . . . . . . . . . 67

1.10. Consumo interno de materiais aumentou mais rápido que o PIB . . . . . . . 69

1.11. A gestão de resíduos melhorou, mas os desafios persistem nas áreas rurais . . . . . . . . . . . . . . . . 70

1.12. O uso de produtos químicos na agricultura é elevado e vem aumentando . . 72 
1.13. A cobertura vegetal diminuiu em alguns biomas brasileiros . . . . . . . . 73

1.14. Grande parte do território brasileiro está sob proteção ambiental . . . . . . . . 74

1.15. O uso da água, especialmente na agricultura, aumentou consideravelmente . . 76

1.16. A qualidade da água é ruim em muitas áreas urbanas . . . . . . . . . . . 76

1.17. O acesso às redes de coleta e tratamento de esgoto precisa ser ampliado . . 78

2.1. Muitos municípios criaram uma instituição ambiental . . . . . . . . . . . . 109

2.2. Alocações do orçamento da União para instituições

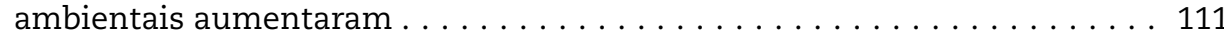

2.3. O desmatamento é a principal preocupação ambiental dos brasileiros, exceto entre moradores de áreas urbanas . . . . . . . . . . . . . 138

3.1. Receita de tributos relacionados ao meio ambiente tem diminuído . . . . . 149

3.2. As alíquotas tributárias efetivas sobre emissões de $\mathrm{CO}_{2}$ pelo consumo de energia são baixas . . . . . . . . . . . . . . . . 151

3.3. Tributação sobre emissões de $\mathrm{CO}_{2}$ provenientes de combustíveis para transporte é menor que na maioria dos outros países . . . . . . . . . 152

3.4. A receita de tributos sobre veículos cresceu com o aumento da frota . . . . 153

3.5. As tarifas de água e saneamento são suficientes para cobrir

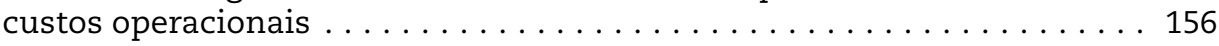

3.6. Apoio a agricultores aumentou, mas continua moderado, pelos padrões internacionais . . . . . . . . . . . . . . . . . . 160

3.7. Desembolsos do BNDES relacionados ao ambiente aumentaram significativamente . . . . . . . . . . . . . . . . . 164

3.8. O Brasil está entre os principais investidores mundiais em energias renováveis . . . . . . . . . . . . . . . . . . . 169

3.9. Aumentou o número de patentes em tecnologias relacionadas ao meio ambiente e ao clima . . . . . . . . . . . . . . . . 176

3.10. Meio ambiente é uma das principais áreas para a assistência oficial ao desenvolvimento do Brasil . . . . . . . . . . . . . . . . . . . 181

4.1. O estado de conservação da biodiversidade varia muito entre regiões e estados . . . . . . . . . . . . . . . . . . . . . 204

4.2. O Brasil tem a segunda maior área de florestas do mundo e a maior taxa de desmatamento . . . . . . . . . . . . . . . . . . . . . . 204

4.3. As taxas anuais de desmatamento diminuíram na maioria dos biomas brasileiros . . . . . . . . . . . . . . . . . . 205

4.4. Os direitos de propriedade ainda estão indefinidos para grande parte das terras da Amazônia . . . . . . . . . . . . . . . . . 205

4.5. A produção de peixes tem aumentado consideravelmente, desde 2000 . . 207

4.6. Os planos de conservação cobrem cerca de metade das espécies da fauna ameaçada . . . . . . . . . . . . . . . . . . 208

4.7. As medidas políticas têm efetivamente ajudado a conter o desmatamento . . . . . . . . . . . . . . . . . . . 215

4.8. Expansão da área sob zoneamento ecológico-econômico . . . . . . . . . . . 218 4.9. A participação no programa Bolsa Verde vem crescendo constantemente . . 224 4.10. O Fundo Amazônia vem apoiando um número crescente de projetos . . . . 229 4.11. A área dedicada à agricultura orgânica é pequena e vem diminuindo . . . . 231

5.1. Categorias de proteção integral abrangem cerca de um terço das áreas protegidas . . . . . . . . . . . . . . . . . . . . . 250

5.2. Área terrestre sob proteção ambiental mais do que duplicou . . . . . . . . . . . 250

5.3. A maioria das unidades de conservação estão na Amazônia . . . . . . 252 
5.4. Expansão das unidades de conservação reduziu consideravelmente o desmatamento na Amazônia . . . . . . . . . . . . . 255

5.5. A área protegida sob responsabilidade de cada servidor é muito maior no Brasil que em outros países . . . . . . . . . . . . . . . . 263

5.6. Investimento em unidades de conservação é menor do que em outros países . . . . . . . . . . . . . . . . . . . . . . . . . . . . . . 264

5.7. A efetividade da gestão em muitas unidades de conservação é baixa . . . . . 269

5.8. O número de visitantes a parques nacionais vem aumentando . . . . . . . 271 


\section{Prefácio}

Brasil alcançou progresso significativo, alinhando seus esforços de crescimento econômico e redução da pobreza com os avanços na sustentabilidade ambiental. Os recursos naturais são fundamentais ao desenvolvimento do país: o Brasil é o quarto maior produtor agrícola do mundo e importante ator global na produção de minérios e de petróleo, e as fontes hídricas geram a maior parte da sua energia elétrica. No entanto, o crescimento econômico, a urbanização, a expansão agrícola e o desenvolvimento da infraestrutura também acarretaram aumento do consumo de energia e pressões ambientais. Atualmente, o Brasil necessita retomar o crescimento e, ao mesmo tempo, dar continuidade à erradicação da pobreza, reduzir as desigualdades e a exclusão social e assegurar o uso sustentável de seu patrimônio ambiental.

Esta é a primeira Avaliação de Desempenho Ambiental do Brasil efetuada pela OCDE. Traz a avaliação dos avanços alcançados pelo país na busca por seus objetivos ambientais, focalizando o período desde o ano 2000. A Avaliação oferece 53 recomendações para auxiliar o Brasil no "esverdeamento" da sua economia e no aprimoramento da sua governança e gestão ambiental, com forte ênfase sobre o fomento da política de biodiversidade e de manejo de áreas protegidas.

Brasil, um país megadiverso, abriga a maior floresta tropical do mundo. Notável progresso foi alcançado com a redução do desmatamento na Amazônia, fruto de esforços do governo e da expansão de milhares de quilômetros quadrados de áreas sob proteção. De fato, sua estratégia abrangente de controle de desmatamento pode servir de modelo para outros países. O Novo Código Florestal e a sua implementação de instrumentos de fiscalização inovadores devem auxiliar na redução ainda maior do desmatamento ilegal, reconciliando objetivos de desenvolvimento agrícola com os de conservação da biodiversidade. Mesmo assim, o Brasil precisa manter-se vigilante e assegurar a plena implementação de todos os programas ambientais já instituídos. É uma questão de assegurar recursos financeiros e humanos suficientes, melhorar a coordenação entre diferentes instâncias de governo e assegurar a efetividade da implementação de políticas em nível subnacional.

A presente Avaliação é fruto de um diálogo construtivo sobre políticas entre o Brasil e os países participantes do Grupo de Trabalho sobre Desempenho Ambiental da OCDE. Nos prontificamos a apoiar o Brasil na implementação das recomendações delineadas neste estudo. Tenho confiança de que este esforço colaborativo será proveitoso ao aprimoramento do nosso entendimento sobre como melhor abordar os desafios ambientais que compartilhamos.

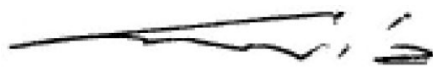

Angel Gurría

Secretário-Geral da OCDE 



\section{Apresentação}

O programa de Avaliação de Desempenho Ambiental da OCDE tem como principal objetivo auxiliar países-membros e parceiros selecionados, no sentido de melhorar seu desempenho coletivo e individual em gestão ambiental, por meio de:

- assistência aos governos na avaliação de avanços alcançados na consecução de objetivos ambientais;

- promoção contínua do diálogo político e aprendizagem entre pares; e

- estímulo à maior responsabilização entre instâncias governamentais e perante a opinião pública.

O presente relatório apresenta uma primeira análise da OCDE acerca do desempenho ambiental do Brasil. Avalia os avanços alcançados pelo país na consecução de objetivos internos e compromissos internacionais, podendo esses refletir compromissos de cunho geral, objetivos qualitativos ou metas quantitativas. Faz uma distinção entre intenções, ações e resultados. A avaliação de desempenho ambiental contempla ainda o contexto dos antecedentes ambientais históricos do Brasil, as atuais condições ambientais, as potencialidades de seus recursos naturais, a conjuntura econômica e as tendências demográficas.

A OCDE agradece ao governo do Brasil pela cooperação e fornecimento de informações e pela organização das visitas da missão de avaliação a Brasília, ao Parque Nacional de Anavilhanas e ao Parque Nacional da Chapada dos Veadeiros (de 17 a 27 de agosto de 2014), bem como da missão política a Brasília, Rio de Janeiro e São Paulo (de 23 a 27 de março de 2015) e, ainda, por facilitar os contatos com interlocutores de instituições governamentais e de outros setores.

Agradece também aos representantes dos três países examinadores: Catherine Dumouchel (Canadá), Øyvind Lone (Noruega) e Pedro Liberato (Portugal). A avaliação contou também com a colaboração de Carlos Mussi e de Kristina Taboulchanas, da Comissão Econômica para a América Latina e o Caribe (CEPAL), e com a participação de Aaron Bruner e Susan Edda Seehusen, do Fundo Estratégico de Conservação (CSF).

Os autores do presente relatório foram Ivana Capozza, Britta Labuhn, Eugene Mazur e Sara Moarif, da Diretoria de Meio Ambiente da OCDE. A supervisão e a orientação foram feitas por Brendan Gillespie e Nathalie Girouard. Carla Bertuzzi prestou suporte estatístico. Rebecca Brite editou a apresentação do relatório. Annette Hardcastle e Clara Tomasini assessoraram na produção e na publicação do relatório e Jennifer Calder prestou apoio administrativo.

O Grupo de Trabalho sobre Desempenho Ambiental da OCDE discutiu a Avaliação de Desempenho Ambiental do Brasil em sua reunião de 17 de junho de 2015, em Paris, e aprovou a Avaliação e as Recomendações. 



\section{Guia do leitor}

\section{Notas gerais}

\section{Sinais}

Os sinais abaixo são utilizados nas figuras e nas tabelas:

.. $\quad$ : indisponível

- $\quad$ : nulo ou insignificante

, : casa decimal

\section{Agregados de país}

OCDE Europa: Esta zona inclui todos os países-membros europeus da OCDE, ou seja, Áustria, Bélgica, República Tcheca, Dinamarca, Estônia, Finlândia, França, Alemanha, Grécia, Hungria, Islândia, Irlanda, Itália, Luxemburgo, Países Baixos, Noruega, Polônia, Portugal, República Eslovaca, Eslovênia, Espanha, Suécia, Suíça, Turquia e Reino Unido.

OCDE: $\quad$ Esta zona inclui todos os países-membros da OCDE, ou seja, os países da OCDE Europa, mais Austrália, Canadá, Chile, Israel, Japão, Coreia, México, Nova Zelândia e Estados Unidos.

BRIICS: $\quad$ Brasil, Rússia, Índia, Indonésia, (República Popular da) China e África do Sul.

\section{Moeda}

Unidade monetária: Real (R\$).

Em 2014, US\$ $1.00=R \$ 2,35$.

Em 2012, US\$ $1.00=R \$ 1,95$.

Em 2010, US\$ $1.00=R \$ 1,76$.

\section{Recorte temporal}

O presente relatório baseia-se em informações e dados disponíveis até maio de 2015. 
Abreviaturas e siglas

AAE

ABEMA

AIA

ANA

ANAMMA

AOD

APP

ARPA

BNDES

BSA/EGS

CAR

CDB

CDM/MDL

CEPAL

CETESB

CIDE-Combustíveis

CNRH

$\mathrm{CO}_{2}$

CONABIO

CONAMA

CRA

CTN

CTTE

DMC

EAP

FAO

GEE

GEF

IBAMA

IBGE

ICMBio

ICMS

INPE

IPEA

IPI

IPVA

ITR

LCR

LULUCF

MCid

MCTI

MMA

No
Avaliação Ambiental Estratégica

Associação Brasileira de Entidades Estaduais de Meio Ambiente

Avaliação de Impacto Ambiental

Agência Nacional de Águas

Associação Nacional de Órgãos Municipais de Meio Ambiente

Assistência Oficial ao Desenvolvimento

Área de Preservação Permanente

Programa Áreas Protegidas da Amazônia

Banco Nacional de Desenvolvimento Econômico e Social

Bens e Serviços Ambientais

Cadastro Ambiental Rural

Convenção sobre Diversidade Biológica

Mecanismo de Desenvolvimento Limpo

Comissão Econômica para a América Latina e o Caribe

Companhia Ambiental do Estado de São Paulo

Contribuição de Intervenção no Domínio

Econômico-Combustíveis

Conselho Nacional de Recursos Hídricos

Dióxido de carbono

Comissão Nacional de Biodiversidade

Conselho Nacional do Meio Ambiente

Cota de Reserva Ambiental

Comissão Tripartite Nacional

Comissão Técnica Tripartite Estadual

Material de Consumo Doméstico

OCDE Estimativa de Apoio ao Produtor

Organização das Nações Unidas para Agricultura e Alimentação

Gás de Efeito Estufa

Fundo Global para o Meio Ambiente

Instituto Brasileiro do Meio Ambiente e dos Recursos

Naturais Renováveis

Instituto Brasileiro de Geografia e Estatística

Instituto Chico Mendes de Conservação da Biodiversidade

Imposto sobre Circulação de Mercadorias e Serviços

Instituto Nacional de Pesquisa Espacial

Instituto de Pesquisa Econômica Aplicada

Imposto sobre Produtos Industrializados

Imposto sobre a Propriedade de Veículos Automotores

Imposto sobre a Propriedade Territorial Rural

Exigência de Conteúdo Local

Uso da Terra, Mudança do Uso da Terra e Florestas

Ministério das Cidades

Ministério da Ciência, Tecnologia e Inovação

Ministério do Meio Ambiente

Óxidos de nitrogênio 


OMS
ONG
PAC
P\&D
PDE
PPCDAm
PET
PIB
PM/MP
PNIA
PNMA
PNMC
PNRS
PNUMA
PSA
REDD
RL
RSC
RSU
SFB
SGA
SINIMA
SISNAMA
SNCR
SNIS
SNUC-Áreas protegidas
SO
tCO
TCU
TPES
ZEE

Organização Mundial da Saúde

Organização não governamental

Programa de Aceleração do Crescimento

Pesquisa e Desenvolvimento

Plano Decenal de Expansão de Energia

Plano de Prevenção e Controle do Desmatamento

Amazônia Legal

Politereftalato de etileno

Produto Interno Bruto

Material particulado

Painel Nacional de Indicadores Ambientais

Política Nacional de Meio Ambiente

Plano Nacional sobre Mudança do Clima

Política Nacional de Resíduos Sólidos

Programa das Nações Unidas para o Meio Ambiente

Pagamento por Serviços Ambientais

Redução de Emissões por Desmatamento e

Degradação Florestal

Reserva Legal

Responsabilidade Social Corporativa

Resíduos Sólidos Urbanos

Serviço Florestal Brasileiro

Sistema de Gestão Ambiental

Sistema Nacional de Informação sobre Meio Ambiente

Sistema Nacional do Meio Ambiente

Sistema Nacional de Crédito Rural

Sistema Nacional de Informações sobre Saneamento

Sistema Nacional de Unidades de

Conservação-Áreas protegidas

Óxidos de enxofre

Toneladas de dióxido de carbono equivalente

Tribunal de Contas da União

Fornecimento de energia primária total

Zoneamento Ecológico-Econômico 
ESTATÍSTICAS BÁSICAS DO BRASIL (2013 ou últimos anos disponíveis) Os números entre parênteses são médias da OCDE*

\begin{tabular}{|c|c|c|c|c|c|}
\hline \multicolumn{6}{|c|}{ POPULAÇÃO E SOCIEDADE } \\
\hline População (milhões) & 198,0 & & $\begin{array}{l}\text { Crescimento demográfico (\% crescimento anual médio nos últimos } \\
5 \text { anos) }\end{array}$ & 0,9 & $(0,6)$ \\
\hline Parcela da populaçao por região (Brasil-2010) & & & Densidade demográfica por km² & 23,3 & $(34,8)$ \\
\hline Predominantemente urbana $(\%)$ & 26,0 & $(48,0)$ & Desigualdade de renda (coeficiente de Gini, 2012) & 52,7 & $(31,4)$ \\
\hline Intermediário (\%) & 24,0 & $(26,2)$ & $\begin{array}{l}\text { Taxa de pobreza } \\
\text { (\% da população com menos de U\$ } 2 \text { por dia, PPP) }\end{array}$ & 6,8 & \\
\hline Predominantemente rural (\%) & 50,0 & $(25,1)$ & Expectativa de vida & 73,7 & $(80,2)$ \\
\hline \multicolumn{6}{|c|}{ ECONOMIA E CONTAS EXTERNAS } \\
\hline Produto interno bruto - PIB total (PIB, R \$ bilhão) & 4845 & & Importações de bens e serviços (\% do PIB) & 15,3 & $(28,8)$ \\
\hline Total do PIB (PIB, USD bilhão) & 2247 & & Principais exportações (\% das exportações totais de bens) & & \\
\hline PIB, média de crescimento real dos úlitmos 5 anos & 2,8 & $(0,8)$ & Vegetais, animais e produtos alimentícios & 35,1 & \\
\hline PIB per capita (1000 USD PPP)) & 15,2 & $(37,9)$ & Combustívies, minerais & 22,2 & \\
\hline Parcela de valor agregado (\% Brasil-2012 e OCDE-2011) & & & Maquinaria, transporte & 18,3 & \\
\hline Setor primário & 5,7 & $(1,4)$ & Principais importações (\% das importações totais de bens) & & \\
\hline Indústria incluindo construção & 25,0 & $(23,8)$ & Máquinas, transporte & 33,8 & \\
\hline Serviços & 69,3 & $(74,7)$ & Combustíveis, minérios & 20,0 & \\
\hline Exportações de bens e serviços (\% do PIB) & 13,1 & $(28,6)$ & Produtos quimícos & 15,9 & \\
\hline \multicolumn{6}{|c|}{ GOVERNO GERAL } \\
\hline \multicolumn{6}{|c|}{ Por cento do PIB } \\
\hline Despesa & 38,6 & $(41,9)$ & Saldo das contas públicas & $-3,1$ & $(-4,2)$ \\
\hline Receita & 35,6 & $(37,7)$ & Tributos ambientais (\% do PIB) & 0,7 & $(1,6)$ \\
\hline Dívida da financeira bruta & 62,2 & $(109,3)$ & (\% total das receitas fiscais) & 1,9 & $(5,1)$ \\
\hline \multicolumn{6}{|c|}{ MERCADO DE TRABALHO, COMPETÊNCIAS E INOVAÇÃO } \\
\hline $\begin{array}{l}\text { Taxa de desemprego } \\
\text { (\% força de trabalho civil) }\end{array}$ & 5,4 & $(7,9)$ & $\begin{array}{l}\text { Patentes solicitadas em desenvolvimento de tecnologias ambientais } \\
\left(\% \text { de todas as tecnologias, média 2009-2011) }{ }^{\mathrm{a}}\right.\end{array}$ & 9,2 & $(11,3)$ \\
\hline Escolaridade superior - pop. 25-64 anos (\% 2012) & 13,0 & $(32,2)$ & Despesa interna bruta com P\&D, \% do PIB & 1,2 & $(2,4)$ \\
\hline \multicolumn{6}{|c|}{ MEIO AMBIENTE } \\
\hline $\begin{array}{l}\text { Intensidade energética (Brasil 2012): } \\
\text { OIE per capita (t/cap.) }\end{array}$ & 1,4 & $(4,2)$ & Estresse hídrico (captações como \% do recurso disponível) & 1,0 & $(9,5)$ \\
\hline OIE por PIB (t/ 1000 USD, 2005 PPP) & 0,11 & $(0,13)$ & Captação de água per capita (m³/hab./ ano, 2012) & 420 & $(830)$ \\
\hline Energias renováveis (\% da OIE, Brasil 2012) & 40,7 & $(8,8)$ & Resíduos municipais per capita (Brasil, 2012) (kg/hab.) & 290 & $(520)$ \\
\hline $\begin{array}{l}\left.\text { Intensidade de Carbono (energia relative ao } \mathrm{CO}_{2}, 2012\right) \text { : } \\
\quad \text { per capita (t/cap.) }\end{array}$ & 2,2 & $(9,7)$ & Produtividade material (2011), (USD, 2005 PPP/kg) & 0,4 & $(1,8)$ \\
\hline por PIB (t 1000 USD, 2005 PPP) & 0,2 & $(0,3)$ & Áreas protegidas terrestres e aquáticas (\% da área total) $)^{\mathrm{b}}$ & 17,2 & \\
\hline $\begin{array}{l}\text { Intensidade de GEE (2012): }{ }^{\circ} \\
\quad \text { per capita (t } 1000 \text { USD } 2005 \text { PPP) }\end{array}$ & 5,3 & $(12,5)$ & Área terreste $(1.000$ km², 2012) & 8358 & \\
\hline por PIB (t 1000 USD, 2005 PPP) & 0,40 & $(0,40)$ & \% de aráveis e cuiltiváveis & 10 & $(12)$ \\
\hline Exposição à poluição do ar $\left(\mathrm{PM}_{2,5}\right)\left(2012, \mu / \mathrm{gm}^{3}\right)$ & 5,7 & & $\%$ de prados e pastagens & 23 & $(23)$ \\
\hline \multirow[t]{2}{*}{ Estoque de veículo rodoviário (veículo/100 hab. 2012) } & 35 & $(57)$ & $\%$ de florestas & 62 & (30) \\
\hline & & & $\%$ de outras terras (construídas e outras) & 5 & (34) \\
\hline
\end{tabular}

* Sempre que o agregado da OCDE não é fornecido na base de dados de origem, a média simples da OCDE, dos últimos dados disponíveis, é calculada onde existam pelo menos dados para 29 países-membros.

a Invenções de alto valor que buscaram proteção de patentes em pelo menos duas jurisdições.

b Áreas oficialmente protegidas de acordo com o Sistema Nacional de Unidades de Conservação (SNUC).

c Excluindo as emissões/remoções de uso da terra, mudança no uso da terra e das florestas.

Fonte: cálculos baseados em dados extraídos de bancos de dados das seguintes organizações: OCDE, IEA, FMI, ONU, Banco Mundial. 


\section{Resumo executivo}

\section{A continuidade do desenvolvimento do Brasil depende do aproveitamento sustentável de recursos ambientais}

O Brasil é o quinto maior país do mundo e o que tem a maior biodiversidade. A selva Amazônica, maior floresta tropical do mundo, $12 \%$ da água doce do planeta, bem como as imensas reservas de hidrocarbonatos e minérios encontram-se no Brasil. Uma matriz energética fundamentada, principalmente, em fontes hidráulicas e biocombustíveis auxilia na manutenção de uma economia de baixo carbono. O crescimento econômico acelerado e as políticas sociais eficazes retiraram milhões de pessoas da pobreza durante os anos 2000. No entanto, desde 2012, o ritmo de crescimento tem diminuído e as desigualdades de renda permanecem elevadas.

Aumentou a proporção de pessoas com acesso à energia elétrica, à água potável e aos serviços de saneamento e de gestão de resíduos, contudo, grandes disparidades regionais persistem. A rápida urbanização, a expansão da agricultura e o desenvolvimento de infraestruturas aumentaram as pressões sobre o meio ambiente. Graves crises de desabastecimento de água afligiram a região Sudeste em anos recentes; o tratamento inadequado de águas servidas tem provocado contaminação do solo e das águas, especialmente em áreas densamente povoadas. A poluição atmosférica é uma grande preocupação nos grandes centros. A geração de resíduos tem aumentado, acompanhando a elevação de padrões de vida e os lixões são a principal forma de disposição de dejetos. O volume total das emissões de gases de efeito estufa (GEEs) caiu em mais de $40 \%$ desde o ano $2000 \mathrm{com}$ a diminuição da taxa de desmatamento, porém as emissões provenientes do consumo de energia pelas indústrias e pelo transporte aumentaram. O Brasil necessita continuar a assegurar o aproveitamento sustentável de seus recursos ambientais, a reduzir a pobreza e as desigualdades e, ao mesmo tempo, lidar com a redução do crescimento e o aumento do desemprego. Com a queda nos preços dos produtos primários e a menor demanda pelas exportações, o aprimoramento de políticas internas se torna ainda mais importante.

\section{O progresso alcançado com a redução do desmatamento na Amazônia é impressionante}

Em 2004, o Brasil lançou, como política de estado, um plano de ação para o controle do desmatamento, por meio de um conjunto de medidas que incluem: aplicação de sistemas avançados de monitoramento, fiscalização reforçada, restrições ao crédito, ampliação de áreas protegidas e promoção do aproveitamento sustentável de recursos 
naturais. A enérgica implementação desse plano com apoio internacional, com destaque para o inovador Fundo Amazônia, resultou em uma diminuição de $75 \%$ na taxa anual de desmatamento na Região Amazônica. Contudo esse progresso foi desigual nos estados da região: cerca de $4.800 \mathrm{~km}^{2}$ de matas da Amazônia continuam a ser perdidos a cada ano, e as pressões sobre os cerrados continuam acirradas. O Brasil precisa promover maiores opções de sustento econômico em áreas de floresta, tornando-as mais atraentes que o desmatamento ilegal, ao mesmo tempo em que continua fortalecendo suas ações de monitoramento e fiscalização. A implementação do Novo Código Florestal e do Cadastro Ambiental Rural (CAR) será de fundamental importância para conciliar os objetivos de conservação da biodiversidade e do desenvolvimento da agricultura, desta forma contribuindo para o controle do desmatamento na Amazônia e em outros biomas.

\section{Cerca de 2.000 áreas protegidas proporcionam grandes oportunidades socioeconômicas}

O número e a extensão das áreas sob proteção oficial mais que dobrou desde o ano 2000, quando o Brasil criou seu Sistema Nacional de Unidades de Conservação-Áreas protegidas (SNUC-Áreas protegidas). Em grande parte, o programa de Áreas Protegidas da Região Amazônica contribuiu para esse resultado positivo. Atualmente, as áreas protegidas pelo SNUC englobam mais de $17 \%$ da área terrestre e de águas interiores do País, mas menos de $2 \%$ das áreas marinhas. Ademais, há áreas protegidas dentro de terras indígenas e em reservas particulares estabelecidas em conformidade com o Código Florestal. A gestão de áreas protegidas melhorou, contudo ainda não há recursos humanos e financeiros adequados para assegurar que as áreas sob proteção alcancem seus objetivos ambientais e para liberar todo o seu potencial em termos de desenvolvimento socioeconômico. O turismo e a silvicultura sustentável poderiam ser ampliados, com maior participação do setor privado, o que auxiliaria a diminuir a dependência sobre recursos públicos e financiamentos internacionais.

\section{O Brasil tem metas ambiciosas de biodiversidade, mas a coerência das políticas necessita ser melhorada}

As 20 metas nacionais de biodiversidade do Brasil para 2020 estão em consonância com seus compromissos internacionais. Em 2015, o Congresso aprovou uma legislação abrangente para facilitar o aproveitamento comercial e científico de recursos genéticos e de conhecimentos tradicionais que, ao mesmo tempo, garante tratamento equitativo às comunidades indígenas e tradicionais. Cada vez mais, o Brasil vem se valendo de programas de pagamento por serviços ambientais (PSA) e de apoio à renda de comunidades rurais. Contudo o regulamento dos programas estaduais de PSA são muito heterogêneos; muitos carecem de monitoramento sistemático e sua efetividade ambiental é incerta. Uma legislação federal sobre PSA poderia aprimorar a consistência e a efetividade de tais programas. São necessários maiores esforços para incorporar temas de biodiversidade a políticas setoriais, incluindo as dos setores de agricultura e energia.

\section{A legislação ambiental é rigorosa, mas as lacunas de implementação persistem}

O Brasil desenvolveu um marco legislativo avançado e abrangente para o meio ambiente. Os recursos financeiros e as capacidades institucionais dos órgãos ambientais em nível 
federal cresceram notavelmente e a colaboração entre agências melhorou. Houve avanços no esclarecimento dos limites das atribuições ambientais das diferentes instâncias de governo e na racionalização do licenciamento ambiental. Contudo há relatos de que os procedimentos de licenciamento continuam excessivamente complexos, provocando atrasos no andamento de importantes projetos de infraestrutura. As capacidades institucionais variam bastante entre regiões e são muitas vezes limitadas, o que prejudica a implementação efetiva e o cumprimento de conformidade com políticas ambientais.

\section{O Brasil deve se fazer valer de tributos verdes e suprimir isenções fiscais prejudiciais}

Em 2013, os tributos relacionados ao meio ambiente respondiam por 0,7\% do PIB, proporção abaixo da média observada na maioria dos países da OCDE. A maior parte dessas receitas provêm de tributos sobre a propriedade de veículos automotores, mas as alíquotas não são relacionadas ao desempenho ambiental dos veículos. Em uma medida positiva, no início de 2015, o governo aumentou a alíquota da contribuição federal sobre a gasolina e o diesel, mantida a zero desde meados de 2012. Contudo, as alíquotas permanecem baixas em termos internacionais e não têm qualquer relação com o teor de carbono dos combustíveis. Em geral, os combustíveis utilizados em outros setores, que não o transporte rodoviário (ex. agricultura e indústria) não são tributados. Cobranças pela extração da água e pela poluição, implementadas em alguns estados, são os únicos encargos sobre recursos naturais e poluição. De forma geral, o Brasil poderia se beneficiar com a ampliação do uso de tributos e tributos verdes e com a extinção de isenções prejudiciais, no contexto de uma reforma tributária mais ampla, o que ajudaria a estimular o uso mais eficiente da energia e dos recursos naturais.

\section{O Brasil necessita aprimorar suas infraestruturas e remover barreiras à ecoinovação}

O Brasil vem ampliando o investimento público em infraestruturas relevantes para o meio ambiente. Em 2014, 15\% dos financiamentos do Banco Nacional de Desenvolvimento Econômico e Social (BNDES), o maior provedor de créditos de longo prazo, foram direcionados a projetos relacionados ao meio ambiente. Várias formas de apoio contribuíram para que, em 2014, o Brasil se tornasse o sétimo maior investidor mundial em energias renováveis. Contudo a cobertura e a qualidade da infraestrutura necessitam ser ampliadas e aprimoradas, especialmente no que diz respeito ao tratamento de águas servidas, aterros sanitários e sistemas de transporte público. A precificação inadequada de serviços de abastecimento de água e de saneamento, a burocracia e as debilidades nos processos de planejamento atrasam a entrega de infraestruturas e desestimulam a participação do setor privado. O Brasil detém mais especialização em tecnologias verdes que os outros países BRIICS, contudo fracos elos entre os setores da ciência e indústria, as lacunas de capacidade e as complexidades do sistema de fomento prejudicam a ecoinovação e a difusão de tecnologias, bens e serviços ambientais. Diversas formas de proteção comercial, incluindo regras de conteúdo local, limitam a concorrência e aumentam os custos de tecnologia. O Brasil poderia se beneficiar de uma integração mais sistemática de objetivos ambientais nos programas de investimento público e nos programas econômicos de forma geral. 



\section{Avaliações e recomendações}

As Avaliações e Recomendações apresentam as principais conclusões da Avaliação de Desempenho Ambiental do Brasil e identificam 53 recomendações para ajudar o Brasil a avançar na consecução de seus objetivos de política ambiental e compromissos internacionais. O Grupo de Trabalho (GT) da OCDE sobre Desempenho Ambiental analisou e aprovou a avaliação e as recomendações na reunião de 17 de junho de 2015. 


\section{Panorama do desempenho ambiental do Brasil}

O Brasil é o quinto maior país do mundo em extensão territorial, possuindo uma imensa diversidade em termos de clima, vegetação, uso da terra, população, padrões sociais e atividade econômica. É dotado de grandes extensões de terras férteis, de abundantes recursos hídricos e florestais, bem como de minérios e reservas de petróleo e gás natural. Seus recursos naturais sempre foram o pilar principal do desenvolvimento econômico, com forte atribuição social. Os brasileiros orgulham-se da riqueza natural de seu país, e sua consciência ambiental vem aumentando. Assim como em outros países de economia emergente, o crescimento econômico, a urbanização e a elevação dos níveis de renda significaram também um aumento de pressões sobre o meio ambiente, provocado por demandas crescentes por terra, água, materiais, energia e transportes, bem como pelo aumento da poluição e da geração de resíduos. A gestão sustentável e equitativa de bens naturais, bem como a dissociação do crescimento econômico das pressões ambientais, será de fundamental importância para que o Brasil possa alcançar um desenvolvimento econômico inclusivo e duradouro.

\section{Mudança climática}

O Brasil possui uma matriz de energia limpa, de baixo carbono baseada, principalmente, no aproveitamento de fontes renováveis. As energias renováveis, em especial a energia hidrelétrica e os biocombustíveis, representam mais de $40 \%$ do total da energia primária disponibilizada em 2012, uma das mais altas porcentagens no mundo (figura 1). Em consequência, as emissões de gases de efeito estufa (GEEs) decorrentes da geração e do uso de energia são relativamente baixas, comparadas com as de muitos países da OCDE. O forte crescimento econômico nos anos 2000 e a ascensão da classe média provocaram um rápido aumento no uso da energia, principalmente na indústria e nos transportes. No entanto, a intensidade energética da economia (fornecimento de energia por unidade do produto interno bruto - PIB) manteve-se relativamente estável, em níveis abaixo da média da OCDE.

O marco político para mitigação da mudança climática é um exemplo positivo de incorporação de temas relativos ao meio ambiente às políticas setoriais. A Política Nacional sobre Mudança do Clima, lançada em 2010, estabeleceu uma meta abrangente para toda a economia, no sentido de limitar as emissões de GEEs projetadas, entre $36,1 \%$ e 38,9\%, até o ano de 2020. O Brasil lançou programas de mudança climática para os setores de energia, siderurgia, agricultura, entre outros, assim como de controle do desmatamento. Também está desenvolvendo o sistema SMMARE para acompanhar a implementação e os resultados da redução de GEEs alcançados por esses programas. Dezenove estados já adotaram leis e metas para o enfrentamento de mudanças climáticas, contudo ainda é frágil a coordenação entre as instâncias nacionais e subnacionais no que se refere à política de clima. 
O Brasil tem alcançado grandes avanços na redução de sua pegada de carbono. As emissões de GEEs diminuíram mais de 40\% desde o ano 2000; já em 2012, ficaram abaixo da meta de 2020 (figura 1). A súbita diminuição nos índices de desmatamento e de emissões de GEEs associadas mais do que compensou o rápido crescimento das emissões advindas dos setores de energia e agricultura, atualmente responsáveis pela maior parte das emissões. A crescente demanda por mobilidade levou a uma duplicação da frota de veículos, elevando a demanda por energia e a emissão de GEEs decorrente do setor de transportes e agravando pressões ambientais em vários centros urbanos (figura 1).

O Brasil vem formulando um plano de adaptação às mudanças climáticas. Há consenso de que a mudança climática pode ter impactos negativos significativos sobre alguns setores da economia, notadamente a agricultura e a infraestrutura, exacerbando pressões existentes, a exemplo da escassez de água. 
Figura 1. Indicadores de desempenho ambiental selecionados

Abastecimento de energia total por fonte, 2012

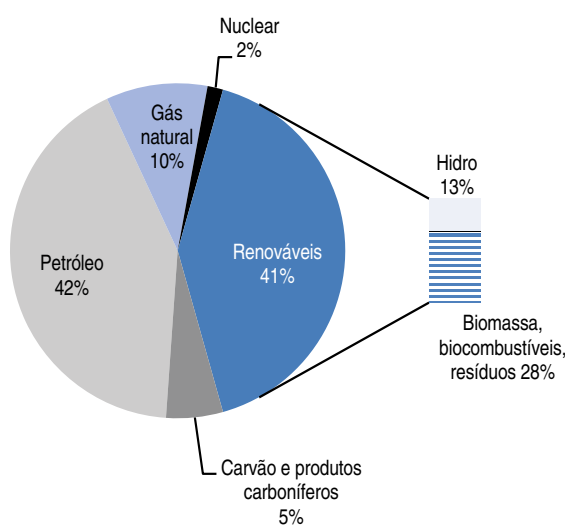

Emissões atmosféricas causadas por transporte terrestre, 2002-12

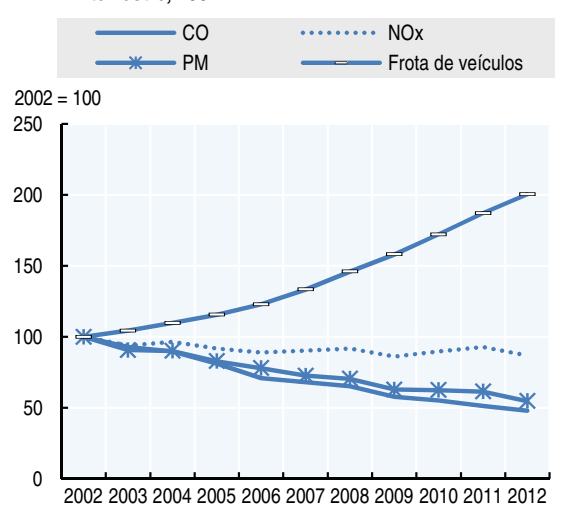

Captação bruta de água doce e perdas de água, 2000-12

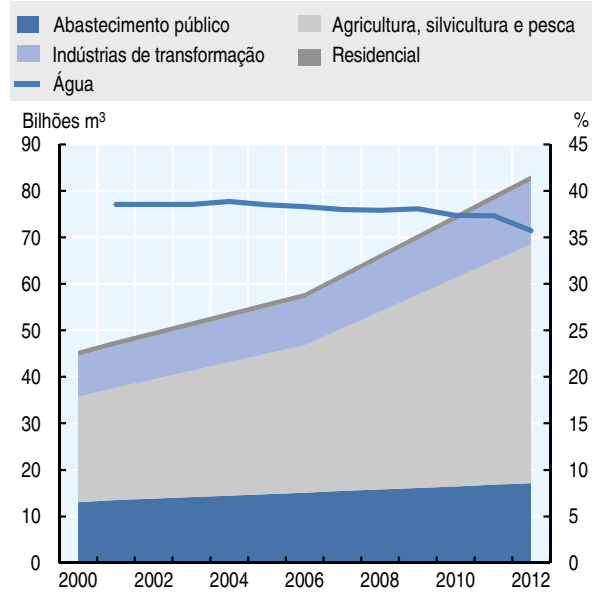

Emissões de GEEs por setor, 2000-12

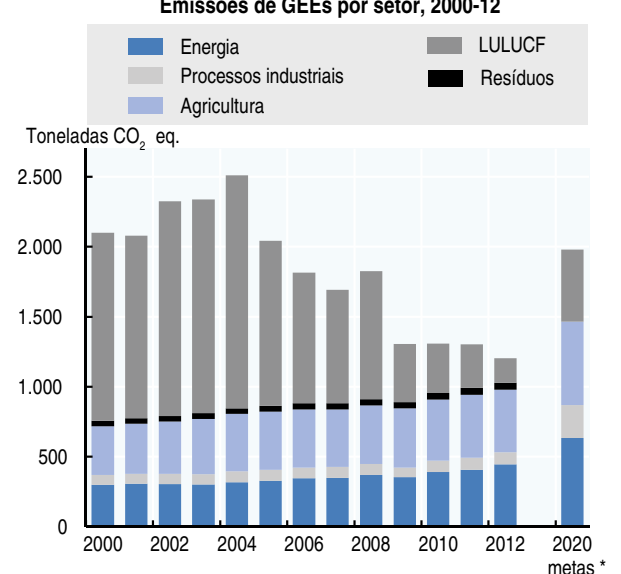

"Metas nacionais no cenário de "nada muda" (Decreto 7.390/2010).

Dados sobre processos nacionais incluem emissões relacionadas a resíduos.

Manejo municipal de resíduos sólidos, ${ }^{\mathrm{a}} 2000$ e 2008

- Reciclagem, incineração e outros Compostagem

Lixão Aterro controlado

- Aterro sanitário

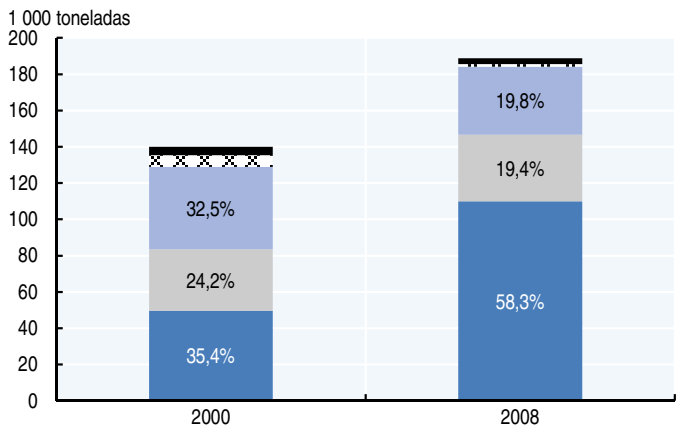

Índice de qualidade da água, ${ }^{\mathrm{b}} 2011$

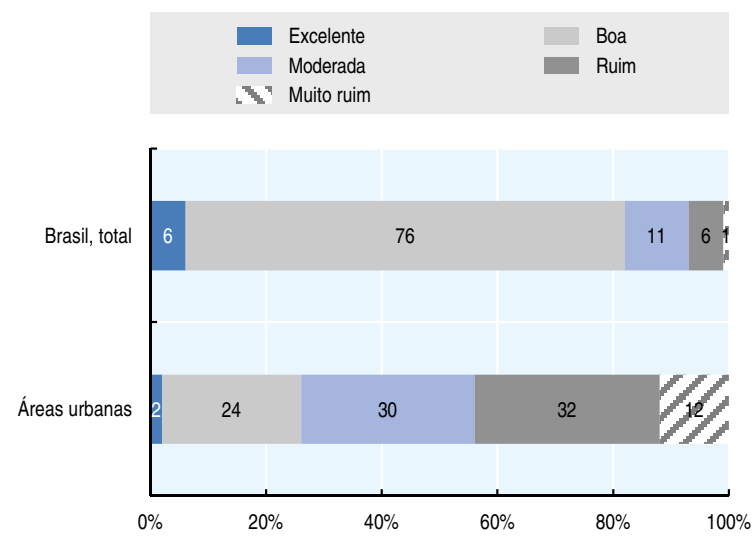

$0 \%$

$100 \%$

a Inclui resíduos provenientes de domicílios, escritórios, instituições, comércios e resíduos de serviços municipais selecionados. Aterro controlado: operado de acordo com procedimentos técnicos de controle, mas sem necessitar de medidas de mitigação ambientais. Aterro sanitário: operado de acordo com procedimentos técnicos de controle e medidas de mitigação ambiental.

b Índice de qualidade da água (IQA) calculado como média ponderada de nove parâmetros. 0 índice varia de 0 a 100. Classes de água: "excelente" ( $\leq 79)$; "boa" (51-79); "moderada" (36-51); "ruim"(19-36); "muito ruim" ( $\leq 19)$. As duas últimas categorias referem-se à água imprópria para o consumo humano.

Fonte: ANA (2013), Conjuntura dos Recursos Hídricos no Brasil; IEA (2014), IEA World Energy Statistics and Balances (banco de dados); MCTI (2014), Estimativas anuais de emissões de gases de efeito estufa no Brasil; MMA (2014), Inventário Nacional de Emissões Atmosféricas por Veículos Automotores Rodoviários, 2013; MMA (2012), Plano Nacional de Resíduos Sólidos; UNSD (n.d.), UNSD Indicadores Ambientais. 


\section{Qualidade do ar}

A poluição atmosférica vem diminuindo em todas as grandes cidades, contudo, tem havido aumento nas concentrações de pequenas partículas em horários de pico, com frequência excedendo as normas nacionais de qualidade do ar (IBGE, 2013). A poluição atmosférica provoca elevados prejuízos econômicos, sociais e à saúde nas grandes áreas metropolitanas. O Brasil está revisando seus padrões nacionais de qualidade do ar, em conformidade com as diretrizes da Organização Mundial da Saúde (OMS). Os estados são responsáveis pela regulação e pelo monitoramento da qualidade do ar, contudo, em 2012, apenas 12 deles tinham algum tipo de sistema de monitoramento instalado e poucos forneceram dados acessíveis e consistentes. Menos de $2 \%$ dos municípios monitoram a qualidade do ar.

\section{Gestão de resíduos}

A geração de resíduos em áreas urbanas dos municípios aumentou, acompanhando o aumento do padrão de vida e a urbanização. A parcela da população com acesso a serviços de coleta de resíduos aumentou; porém, nas áreas rurais, apenas metade da população teve acesso a esses serviços. A exemplo de muitas ecomomias emergentes, a deposição final em aterros é o principal método de eliminação de resíduos (figura 1). A Política Nacional de Resíduos Sólidos (PNRS) de 2010 estabeleceu princípios básicos e diretrizes para a gestão responsável de resíduos, compatíveis com as normas da OCDE. Entretanto a implementação da PNRS vem sendo prejudicada pela falta de dados consistentes e carências de capacidades em nível municipal (Seção 2). $\mathrm{O}$ apoio do governo federal para a construção de aterros sanitários ajudou a reduzir a quantidade de lixo depositado em aterros não controlados (lixões), embora o país tenha ficado aquém da meta nacional de fechar todos esses aterros, até 2014.

A PNRS introduziu também um "sistema de logística reversa", abordagem semelhante à dos sistemas de responsabilidade estendida do produtor, operantes na maioria dos países da OCDE. Esse sistema exige que todos os fabricantes, distribuidores e varejistas de pesticidas, baterias, pneus, óleos lubrificantes, lâmpadas fluorescentes, aparelhos eletrônicos e seus componentes recolham esses produtos, ao final de sua vida útil. Os principais gargalos para a implementação de tais programas de responsabilidade estendida do produtor são a insuficiência de infraestrutura de reciclagem e limitações de capacidade de coleta seletiva por parte dos municípios. O governo federal incentivou a formação de cooperativas de catadores de lixo, que são os principais atores no negócio de reciclagem, dessa forma, ligando objetivos ambientais e sociais. No entanto a compostagem e a reciclagem continuam muito limitadas.

\section{Conservação da biodiversidade e uso sustentável*}

O Brasil é o país de maior biodiversidade do mundo. A área sob proteção ambiental foi substancialmente ampliada nos anos 2000 , fator preponderante para o combate ao desmatamento. A taxa de desmatamento caiu substancialmente na Amazônia, a partir de seu último pico em 2004, embora as pressões permaneçam elevadas em algumas outras regiões, notadamente em áreas de Cerrado (Seção 4). Em 2014, as áreas de proteção ambiental representavam cerca de $17 \%$ do território nacional. Ademais, as áreas sob proteção nas terras indígenas e em propriedades privadas cumprem com a legislação

\footnotetext{
* Para maiores detalhes, veja seções 4 e 5.
} 
do Código Florestal. O código exige que os proprietários mantenham uma parcela de suas terras para reflorestamento, conservação e restauração do solo, incluindo corpos d'água e áreas sensíveis (Seção 4). Como um todo, essas áreas cobrem mais de $40 \%$ do território nacional, ou mais que duas vezes a superfície dentro das áreas protegidas oficiais, o que faz do sistema de áreas protegidas do Brasil um dos maiores do mundo. No entanto, a parcela da área total e o grau de proteção variam entre as regiões e os ecossistemas. Estão em curso gestões no sentido de ampliar as áreas marinhas sob proteção, dos atuais 1,5\% das águas territoriais e da zona econômica exclusiva, para $5 \%$ até 2020 (Seção 5).

\section{Recursos hídricos}

O Brasil é dotado de $12 \%$ dos recursos de água doce do mundo, cerca de $70 \%$ dos quais localizados na Bacia Amazônica. Foram introduzidos instrumentos modernos de gestão integrada de recursos hídricos. Planos de recursos hídricos, elaborados com ampla participação dos interessados, nos níveis nacional, estadual e de bacia hidrográfica, estabelecem prioridades, programas e projetos. No entanto esses planos abrangem apenas metade do território e, onde existem, sua implementação é falha e as orientações quanto à locação de recursos hídricos deixam a desejar (OCDE, 2015a).

As licenças para uso da água (captação e outros usos) são emitidas pela agência nacional ou pelas agências estaduais, dependendo do domínio do corpo d'água. Os sistemas federal e estaduais de outorga do direito de uso da água poderiam ser melhor integrados, com vistas a facilitar a gestão em bacias hidrográficas de domínio compartilhado. As captações de água, especialmente para uso na agricultura, aumentaram significativamente, desde 2000 (figura 1). A escassez de água tornou-se uma limitação ao desenvolvimento econômico e social em áreas mais populosas e economicamente desenvolvidas da região Sudeste, em consequência de fatores climáticos e aproveitamento inadequado (ANA, 2013). Infraestruturas obsoletas e subdimensionadas constituem uma das principais causas de perda na rede de distribuição de água (Seção 3).

Em uma abordagem plenamente consistente com as boas práticas de países da OCDE, o Brasil introduziu um sistema de classificação de qualidade de corpos d'água superficiais, que se baseia nas suas principais categorias de uso e estabelece padrões de qualidade, de acordo com a categoria de uso. A qualidade da água é baixa em muitas áreas urbanas de maior densidade demográfica, geralmente em consequência de infraestrutura inadequada para coleta e tratamento de águas servidas (figura 1). Embora, atualmente, o acesso à água potável em áreas urbanas seja praticamente universal, apenas 56\% da população urbana teve acesso aos sistemas de coleta de esgoto em 2011, com amplas variações regionais. Em algumas áreas, há impactos negativos sobre o meio ambiente e a saúde da população, decorrentes de falhas no saneamento, bem como sobre elevados níveis de contaminação por fertilizantes e pesticidas (MMA, 2010, 2015). 


\section{Recomendações sobre a política de mudança do clima e a gestão do ar, da água e de resíduos}

Política de mudança do clima

- Implementar rapidamente programas setoriais para mitigar as emissões de GEEs e acelerar o desenvolvimento do SMMARE, a fim de monitorar os resultados; assegurar que medidas efetivas sejam replicadas e ampliadas.

- Avançar no desenvolvimento e na implementação do plano de adaptação às mudanças do clima, com o envolvimento de todos os setores, instâncias governamentais e partes interessadas; assegurar que a estratégia reflita adequadamente os impactos econômicos, sociais e ambientais, inclusive a biodiversidade, a qualidade e a disponibilidade da água.

\section{Gestão da poluição atmosférica, hídrica e de resíduos}

- Desenvolver um eficaz sistema nacional de monitoramento da qualidade do ar, com metodologias consistentes e coleta de dados nos estados.

- Estabelecer critérios consistentes e compatíveis para a alocação de água e assegurar que os limites do desperdício estejam definidos conforme os padrões de qualidade da água, com base na categoria de uso.

- Fortalecer a gestão de resíduos sólidos por meio:

* do melhor cumprimento das normas referentes à eliminação de resíduos sólidos perigosos sem o tratamento prévio, em aterros municipais; e

* do estabelecimento do Sistema Nacional de Informação sobre a Gestão dos Resíduos Sólidos, conforme exige a lei, usando-o para facilitar a implementação dos programas de "Iogística reversa" para fiscalizar fluxos de resíduos de produtos-chave.

\section{Governança e gestão ambiental}

\section{Marco de governança ambiental de várias instâncias}

Desde a década de 1980, o Brasil vem desenvolvendo uma política ambiental e um marco institucional abrangentes, cujo principal comitê consultivo e deliberativo de alto nível é o Conselho Nacional do Meio Ambiente (CONAMA), órgão criado em 1981, com representação de todas as instâncias de governo e dos principais setores interessados. A capacidade institucional e o quadro funcional do Ministério do Meio Ambiente (MMA) cresceram significativamente nos últimos dez anos. Paulatinamente, o MMA vem saindo de seu longo isolamento para se engajar, cada vez mais, em diálogo construtivo com outros ministérios setoriais, visando à formulação de políticas públicas, assim impulsionando os recentes avanços na integração de temas ambientais com as pautas sociais e econômicas. No entanto, a exemplo do que ocorre em muitos outros países, ainda prevalece uma cultura institucional dominada por múltiplos ministérios dissociados. Assegurar o fortalecimento da liderança ou a coordenação poderia auxiliar no aprimoramento da coerência das políticas e permitir uma abordagem única de todos os setores do governo em prol do desenvolvimento sustentável.

Todos os estados e praticamente todos os municípios com população acima de 100.000 habitantes já criaram e instituíram órgãos ambientais, embora o nível de desenvolvimento varie consideravelmente. Por exemplo, cerca de um quarto dos conselhos municipais de meio ambiente estavam inoperantes em 2013 (IBGE, 2014). Muitas agências estaduais enfrentam dificuldades significativas para atrair e reter quadros técnicos funcionais qualificados. O Instituto Brasileiro do Meio Ambiente e dos Recursos Naturais Renováveis (IBAMA) tende a desempenhar papel complementar junto aos órgãos estaduais, especialmente em regiões como o Norte e o Nordeste, onde a capacidade institucional é mais limitada. 
Os governos federal e os estaduais vêm investindo em capacitação, mas ainda existe uma necessidade de melhorar as informações sobre a implementação de políticas ambientais nos níveis estadual e municipal. As associações dos órgãos de meio ambiente dos estados (Associação Brasileira de Entidades Estaduais de Meio Ambiente - ABEMA) e dos municípios (Associação Nacional de Órgãos Municipais de Meio Ambiente - ANAMMA) realizam atividades para promover a cooperação e a troca de informações entre suas instituições membro. O Pacto Nacional de Gestão das Águas é um bom exemplo de estratégia de cooperação, envolvendo autoridades de todos os níveis administrativos, que poderia ajudar a melhorar o diálogo e a capacidade em diferentes instâncias de governo e servir como modelo para outras áreas da política ambiental.

A combinação de alta heterogeneidade econômica e social do País com seu sistema descentralizado de governança federativa gera desafios significativos de governança em vários níveis. Avanços foram alcançados com a edição da Lei Complementar $n^{\circ} 140 / 2011$ e do Decreto $n^{\circ} 8.437 / 2015$, que esclareceram os limites da jurisdição federal, estadual e municipal sobre questões ambientais. Entretanto os desafios relacionados à implementação e à cooperação permanecem. Há grande número de organismos de coordenação, mas frequentemente esses carecem de ferramentas de tomada de decisão, capacidade e recursos para enfrentar interesses institucionais corporativos. Uma abordagem que levasse em conta a fragilidade e a baixa capacidade da maioria dos órgãos subnacionais poderia auxiliar no estabelecimento de uma conjuntura menos desigual para a formulação e fiscalização de normas ambientais.

Direcionar sua fraqueza e a baixa capacidade da maioria das autoridades subnacionais ajudaria a estabelecer um escopo de nível nacional para colocar e fazer cumprir os requisitos ambientais.

\section{Financiamento de instituições ambientais}

Na classificação orçamentária do Tesouro por função governamental, as dotações para a gestão ambiental aumentaram em $48 \%$ no período de 2010-2014, para cerca de 0,4\% do Orçamento Geral da União (SENADO FEDERAL, 2015). Em 2014, o Ministério do Planejamento, Orçamento e Gestão (MPOG) em parceria com o Instituto de Pesquisa Econômica Aplicada (IPEA) lançou um projeto para rastrear gastos relativos ao meio ambiente em todos os setores do governo. A importância do projeto reside no fato de o orçamento do MMA ser relativamente pequeno, pois outros ministérios e órgãos contribuem com grande parte da despesa pública em matéria ambiental. O projeto ajudará ainda a melhorar a compreensão da eficácia e eficiência da alocação dos gastos públicos, devendo seu rigor e continuidade serem garantidos para que, ao longo do tempo, possa ser ampliado para contemplar também gastos estaduais e municipais.

Os dois maiores fundos federais relacionados ao meio ambiente (Fundo Nacional sobre Mudança do Clima e Fundo Amazônia) possuem sólidos sistemas de monitoramento e se comprovaram capazes de angariar recursos para projetos ambientais, inclusive por meio de financiamento internacional. A maioria dos estados e dos grandes municípios operam fundos ambientais, em parte, abastecidos por receitas provenientes de multas ambientais; em contraste com a maioria dos países da OCDE, onde as receitas provenientes de multas são direcionadas ao Tesouro, uma vez que o incentivo à geração de receitas pode conflitar com ações para coibir o descumprimento de normas. O Brasil utiliza, também, parte das receitas de petróleo e gás para financiar iniciativas ambientais e de mitigação de mudança climática. A destinação de recursos para finalidades ambientais 
pode ser necessária para garantir disponibilidade e regularidade de fundos, mas pode também reduzir a flexibilidade e eficiência da alocação de receitas.

\section{Legislação ambiental}

A Constituição Brasileira reconhece o direito das pessoas a um ambiente ecologicamente equilibrado. Desde a aprovação da Lei Nacional de Política Ambiental de 1981, o Brasil desenvolveu um marco regulatório legislativo ambiental abrangente e avançado, em nível nacional e na maioria dos estados. Há, no entanto, falhas de implementação a serem corrigidas. O rigor das exigências ambientais varia substancialmente entre as jurisdições, refletindo prioridades locais e restrições de capacidade, o que suscita preocupações quanto à possibilidade de dumping ambiental, no qual indústrias altamente poluentes poderiam estabelecer unidades nos estados que carecem de capacidade para aplicar e fazer cumprir normas ambientais.

\section{Licenciamento ambiental, conformidade e fiscalização}

O Brasil não possui um sistema integrado de administração de terras operante nos três níveis de governo. A indefinição de direitos de propriedade, tanto para particulares, quanto para o poder público tem, historicamente, exacerbado os problemas de uso não planejado e não autorizado de terras, entre eles o desmatamento. A criação recente do sistema de Cadastro Ambiental Rural (CAR) foi um passo importante para a resolução de aspectos ambientais de regularização de propriedades rurais (Seção 4). Não existe qualquer exigência na legislação federal para a avaliação ambiental estratégica de planos territoriais ou de outros programas de desenvolvimento, ainda que alguns estados os tenham tornado obrigatórios e o zoneamento ecológico-econômico (ZEE) abranja mais de $70 \%$ do seu território. Nas áreas urbanas, os planos diretores municipais se tornaram obrigatórios, desde 2005. Esses planos abrangem, mas não integram componentes isolados relativos a saneamento, transporte, habitação etc. e são, ainda, raramente implementados.

O licenciamento ambiental (que incorpora o Estudo de Impacto Ambiental - EIA) é instrumento regulatório fundamental em todos os níveis de governo. Na prática, contudo tornou-se um processo burocrático administrativo, sem consideração adequada de fatores, como localização, possíveis alternativas tecnológicas, impacto ambiental e potenciais medidas de mitigação (ABEMA, 2013). Mesmo tendo melhorado a capacidade técnica e institucional para licenciamento ambiental em nível federal, a fragilidade institucional de órgãos ambientais subnacionais, a estruturação e o planejamento inadequados de projetos, bem como eventuais interferências de interesses políticos e econômicos locais ainda prejudicam a eficácia, a tempestividade e a transparência do processo. O processo de licenciamento tem se tornado foco de discussões sobre opções de desenvolvimento e suas consequências - ambientais, sociais e outras. A Lei Complementar n ${ }^{\circ} 140 / 2011$ e o subsequente decreto presidencial tornaram mais objetivo o compartilhamento de responsabilidades pelo licenciamento nas três instâncias de governo, condicionado à escala do projeto, à sua localização e à extensão do seu potencial impacto ambiental. Contudo faz-se necessário uma regulação mais clara de medidas e mecanismos de compensação de impactos ambientais.

Assim como em outras áreas, vários fatores contribuem para enfraquecer a aplicação da lei em muitos estados e municípios: por falta de recursos humanos, as fiscalizações se limitam a responder às ocorrências; multas administrativas são, muitas vezes, ineficazes devido aos baixos níveis de recolhimento; e a responsabilização por dano ambiental 
é esporadicamente aplicada. Ao mesmo tempo, a atuação de procuradores federais e estaduais na fiscalização ambiental por responsabilidade civil e penal vem aumentando, o que ajuda a garantir a conformidade. As iniciativas de responsabilidade socioambiental do setor financeiro são fatores importantes na promoção da conformidade e de boas práticas. A partir de 2008, o Banco Central vem emitindo resoluções que incorporam temas socioambientais em atividades financeiras, inclusive a restrição de crédito por não cumprimento (Seção 4). Contudo, muitas vezes, as empresas não dispõem de informação e incentivos suficientes para adotar voluntariamente práticas sustentáveis.

\section{Democracia ambiental}

A participação pública é uma característica preponderante da governança ambiental no Brasil, incluindo a participação de organizações não governamentais (ONGs) nas instâncias de tomada de decisão que reúnem as várias partes interessadas - por exemplo, os conselhos governamentais e os comitês de gestão de áreas protegidas (Seção 5) - as consultas públicas obrigatórias que fazem parte do processo de licenciamento ambiental, bem como o acesso garantido do cidadão a informações ambientais e à justiça cidadã. No entanto, os mecanismos que incorporam as opiniões da sociedade civil na tomada de decisão ambiental deveriam ser fortalecidas.

A legislação federal proporciona ao cidadão garantias importantes de acesso a informações ambientais. O Sistema Nacional de Informação sobre o Meio Ambiente (SINIMA) é responsável pelo desenvolvimento de uma política consistente direcionada à produção, à coleta, à sistematização e à disseminação de informações ambientais. O Instituto Brasileiro de Geografia e Estatística (IBGE) publica, a cada dois anos, relatórios de indicadores de desenvolvimento sustentável e o MMA vem trabalhando no sentido de desenvolver um conjunto de importantes indicadores ambientais (o Painel Nacional de Indicadores Ambientais - PNIA) para a consolidação dos dados ambientais disponíveis. Apesar desses esforços, as informações ambientais permanecem fragmentadas, o que prejudica a análise política e a capacidade da sociedade civil de influenciar o desenvolvimento e a implementação da política ambiental.

\section{Esverdeamento da economia no contexto do desenvolvimento sustentável}

\section{Marco do desenvolvimento sustentável}

O Brasil subiu no ranking das maiores economias mundiais, alcançando progresso considerável rumo ao crescimento sustentável e inclusivo. Desfrutou de um crescimento econômico robusto na maior parte dos anos 2000, o que ajudou a diminuir a diferença de renda com países da OCDE. No entanto, desde 2012, o crescimento desacelerou (OCDE, 2015b). O Bolsa Família, reconhecido internacionalmente como boa prática, ajudou a reduzir pela metade o número de pessoas vivendo na extrema pobreza. A cobertura do serviço de saúde e os resultados educacionais também melhoraram, mas a desigualdade de renda e as disparidades sociais e regionais continuam grandes. O Brasil precisa retomar seu crescimento econômico e dar continuidade ao processo de superação de desafios sociais e, ao mesmo tempo, melhorar a conservação e o uso sustentável de seus ativos ambientais. 


\section{Recomendações sobre gestão e governança ambiental}

\section{Governança ambiental}

- Racionalizar a multiplicidade de órgãos de coordenação vertical e horizontalizados, no intuito de eliminar sobreposições e lacunas de responsabilidades e, por último, melhorar a coerência e a eficácia política; considerar a criação de um sistema nacional para controle de qualidade e responsabilização.

- Fomentar, nas associações estaduais (ABEMA) e municipais (ANAMMA), a criação de órgãos ambientais para compor uma rede de reguladores em todas as instâncias administrativas e aumentar sua capacidade por meio da troca de experiências e boas práticas; considerar a implementação de um programa de fortalecimento de capacidades em nível subnacional.

- Considerar a replicação de mecanismos de governança nos diversos níveis para outras áreas da política ambiental, a exemplo do Pacto Nacional de Gestão de Água, com a finalidade de promover a integração e o diálogo entre diferentes instâncias governamentais e reduzir disparidades regionais no desempenho ambiental.

- Racionalizar os fundos voltados aos projetos e à política ambiental; monitorar sistematicamente o uso dos fundos ambientais, para garantir conformidade com as prioridades políticas, em termos de transparência e de custo-benefício.

- Desenvolver um sistema uniforme para coleta e gestão de dados ambientais, inclusive sobre a implementação da legislação ambiental (indicadores de insumos, produtos e resultados) e sobre aspectos econômicos de políticas ambientais (contas de despesas e receitas; bens, serviços e empregos relacionados ao meio ambiente).

\section{Licença ambiental, execução e conformidade}

- Introduzir e aplicar um requisito legal de avaliação estratégica ambiental de planos territoriais municipais e programas de desenvolvimento setorial, que devem ser utilizados para a integração de aspectos econômicos, sociais e ambientais do uso da terra.

- Racionalizar o processo de avaliação de impactos ambientais e os requisitos de licencenciamento ambiental entre as diversas instâncias administrativas; esclarecer os limites entre ações compensatórias com objetivos socioambientais e aquelas com objetivos sociais; desenvolver orientações procedimentais para cada estágio do processo de licenciamento e construir a capacidade dos órgãos de licenciamento.

- Fortalecer a capacidade de fiscais ambientais em todas as instâncias governamentais; enfatizar o controle proativo (planejado) de conformidade; melhorar a colaboração com promotores federais e estaduais; ampliar as oportunidades para a "fiscalização cidadã" por meio do engajamento das comunidades locais no controle da conformidade.

Desde o início dos anos 2000, o Brasil lançou várias iniciativas para enfrentar, de forma integrada, as vertentes econômicas, sociais e ambientais do crescimento e do desenvolvimento sustentável. Essas iniciativas incluíram a Agenda 21 de 2002, já há tempos considerada a estratégia nacional de desenvolvimento sustentável, apesar de carecer de mecanismos de implementação. Alguns programas de transferência de renda foram direcionados simultaneamente a objetivos sociais e ambientais, uma vez que uma significativa parcela da população, especialmente nas áreas rurais, depende do uso sustentável de recursos naturais (Seção 4). Alguns programas para o desenvolvimento da agricultura, da indústria, da energia e da infraestrutura já começam a incluir uma dimensão ambiental. Essas iniciativas positivas poderiam ser consolidadas em um marco estratégico coerente para fomentar a economia verde e o desenvolvimento sustentável.

\section{Esverdeamento do sistema tributário e de encargos}

No contexto de uma reforma tributária mais ampla, há espaço para ampliar e aprimorar a aplicação de tributos relativos ao meio ambiente e suprimir eventuais isenções fiscais e subsídios ambientalmente perversos, de modo a promover o aproveitamento mais eficiente e sustentável dos recursos. Em 2013, as receitas provenientes de impostos ambientais no Brasil representaram aproximadamente $2 \%$ da receita fiscal total e 0,7\% do PIB; abaixo dos níveis observados na maioria dos países da OCDE. 
Mesmo após a desregulação dos preços dos combustíveis no início dos anos 2000, entre 2006 e 2012, o governo manteve os preços abaixo dos praticados no mercado mundial. Além disso, a alíquota do imposto federal sobre combustíveis - Contribuição de Intervenção no Domínio Econômico-Combustíveis (CIDE-Combustíveis) - caiu gradativamente. Esses subsídios implícitos mantiveram os preços da gasolina artificialmente baixos - sinalizando um desincentivo ao uso moderado de automóveis particulares - e prejudicaram a indústria do etanol. Com o aumento dos preços da gasolina e do diesel em 2012, a alíquota da Cide foi definida em zero, como medida de compensação.

Providencialmente, no começo de 2015, o governo reintroduziu alíquotas positivas da CIDE-Combustíveis, contudo a contribuição não tinha relação com o teor energético ou de carbono do combustível. Como na maioria dos países, o diesel é tributado a uma alíquota mais baixa que a gasolina, apesar do seu maior teor de carbono e emissões de poluentes atmosféricos locais. O consumo de combustíveis, nos setores de agricultura e indústria, permanece, em grande parte, não tributado. A alíquota efetiva sobre emissões de $\mathrm{CO}_{2}$ na economia como um todo é, portanto, uma das mais baixas entre os países da OCDE e do grupo BRIICS de economias emergentes (Brasil, Rússia, Índia, Indonésia, China e África do Sul) (OCDE, 2015c). O Ministério da Fazenda (MF) fez uma avaliação abrangente das opções de precificação do carbono, incluindo um imposto sobre o carbono e um regime de comércio e limites de emissões (cap-and-trade) com vistas a apresentar recomendações políticas em 2017. Trata-se de uma iniciativa positiva que poderia se aproveitar de esforços anteriores para a introdução de sistemas subnacionais de comercialização de títulos de emissão de GEEs.

As receitas provenientes de tributos sobre veículos automotores têm crescido com o aumento da propriedade de automóveis, porém as alíquotas não levam em consideração as características ambientais dos veículos. Alíquotas reduzidas sobre a comercialização de automóveis do tipo flex serviram de estímulo para a venda dessa categoria de veículos que, atualmente, representa a maioria de todos os automóveis de passeio. Apenas alguns estados implementaram a cobrança pela captação de água e pela descarga de poluentes, mas os valores unitários são baixos e têm efeito limitado sobre as decisões acerca da alocação e do uso da água (OCDE, 2015a). Não existem outros encargos sobre o uso de recursos naturais e a poluição.

\section{Investimento e financiamento ambiental}

O investimento público em infraestrutura aumentou com o Programa de Aceleração do Crescimento (PAC) de 2007 e com sua reedição de 2011, o que ajudará a sustentar o crescimento e melhorar a prestação de serviço. O programa de 2011 incluiu também forte dimensão ambiental com o aumento de recursos para saneamento, transporte e energia. Alguns programas de investimento contemplaram critérios de sustentabilidade e potenciais impactos climáticos, embora não de forma sistemática.

O Banco Nacional de Desenvolvimento Econômico e Social (BNDES), maior provedor de financiamento de longo prazo, intensificou suas atividades de empréstimos relativos ao meio ambiente, que responderam por 15\% do seu total de empréstimos em 2014 (figura 2). O BNDES introduziu ainda critérios ambientais em seus principais projetos de concessão de empréstimo para alguns setores com alto potencial de impacto 
ambiental (por exemplo, soja, açúcar e etanol, processamento de carne, energia fóssil). Entretanto deficiências no planejamento de projetos, estruturação, implementação e monitoramento atrasaram a conclusão de obras de infraestrutura, desestimulando a participação do setor privado e prejudicando a execução orçamentária federal. Projetos de infraestrutura de grande relevância para o meio ambiente em setores - tais como, saneamento e mobilidade urbana, para os quais a responsabilidade reside na instância municipal, bem como grandes projetos em áreas sensíveis, como a Amazônia - foram os mais prejudicados por esses fatores.

Figura 2. Desembolsos do BNDES para o meio ambiente aumentaram significativamente

Desembolso por setor, 2002-14

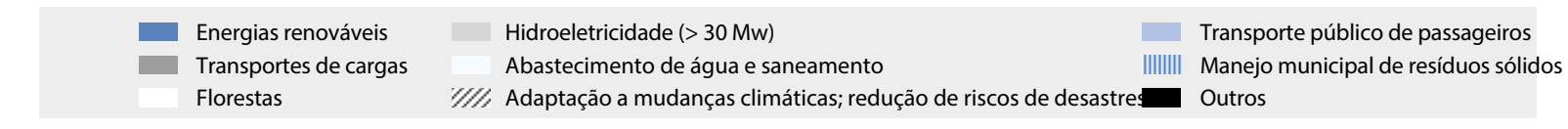

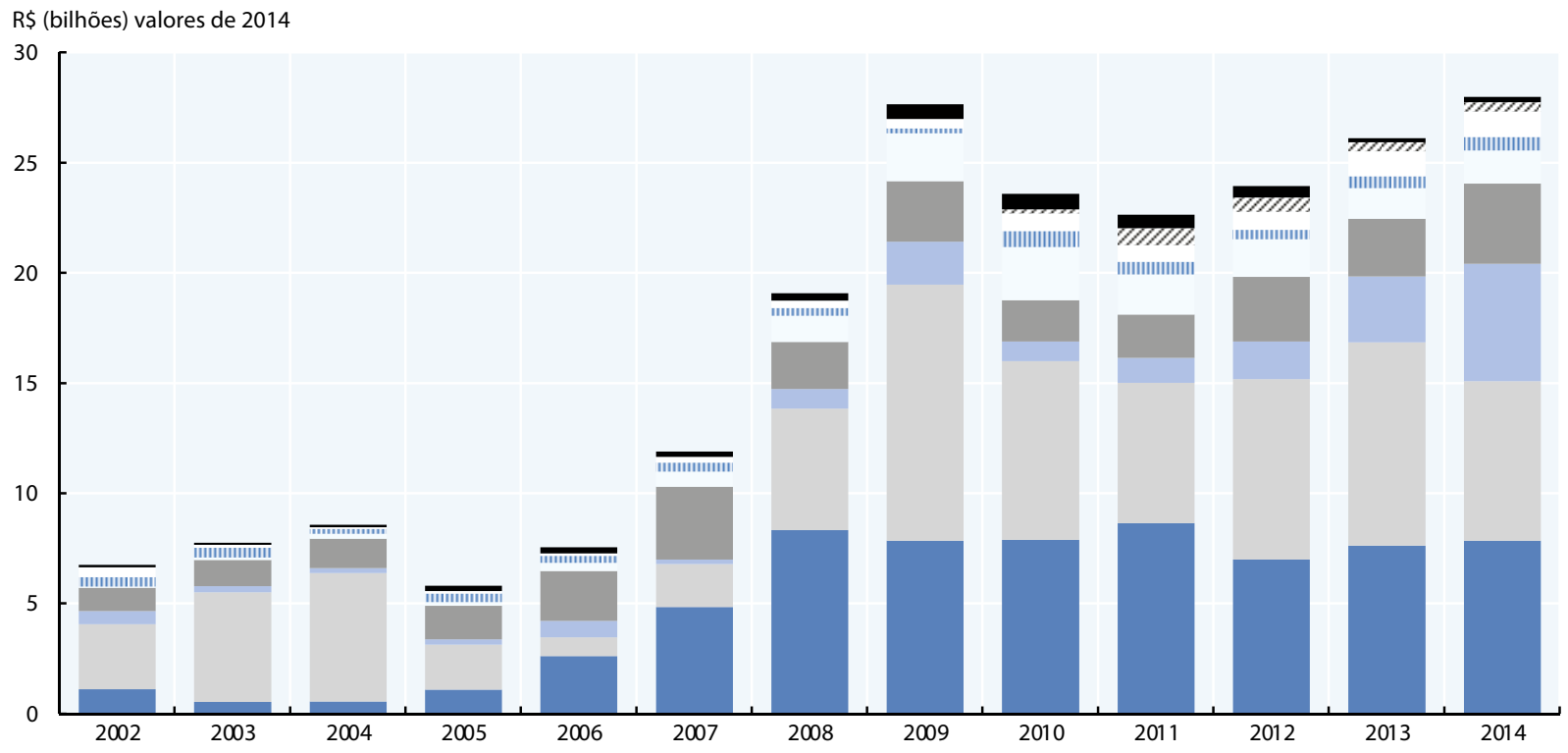

Nota: valores de desembolsos anteriores a 2007 podem ser subestimados, devido à alteração da classificação de despesas. Dados de 2014 para energias renováveis incluem investimentos do Programa de Eficiência Energética PROESCO.

Fonte: com base em BNDES (2014), Relatório Anual 2013; BNDES (2013), Relatório Anual 2012.

Atualmente, mais pessoas têm acesso à energia elétrica, ao abastecimento de água potável, ao saneamento e serviços de manejo de águas servidas. Contudo, a cobertura e e a qualidade das infraestruturas precisam ser ampliadas e melhoradas, especialmente no que diz respeito ao tratamento de águas servidas, aterros sanitários e reciclagem (Seção 1). A precificação inadequada está entre os maiores gargalos para a ampliação de infraestruturas de serviços de abastecimento de água e de águas servidas. A maioria dos municípios não cobra pelos serviços de coleta de resíduos sólidos ou os financiam por meio de tributos sobre a propriedade, o que não proporciona qualquer incentivo para a redução do volume do lixo gerado ou pela triagem seletiva para fins de reciclagem. Em média, as tarifas pelo abastecimento de água cobrem os custos operacionais e de manutenção, mas são insuficientes para arcar com novos investimentos de infraestrutura, havendo grandes 
variações de tarifa e de eficiência operacional entre municípios e prestadores de serviços de abastecimento (MCid, 2014). A exemplo de outros países da América Latina, grande parcela da água distribuída não gera receitas. As receitas são menores nos municípios mais carentes, consequência, em parte, de tarifas reduzidas para domicílios de baixa renda; o que pode desestimular o investimento na ampliação da rede de abastecimento, justamente onde este se faz mais necessário. Uma alternativa seria a utilização de programas de transferência de renda para compensar domicílios de baixa renda.

\section{Investimento em energia limpa e transporte sustentável}

Em 2014, o Brasil era o sétimo maior investidor do mundo em fontes de energias renováveis (BNEF, 2015). O Plano Decenal de Expansão de Energia 2022 prevê a manutenção da ênfase sobre fontes de energias renováveis (Seção 1). Os investimentos têm se concentrado em grandes usinas hidrelétricas, que receberam a maior parcela dos financiamentos ambientais do BNDES no período de 2008-2014 (figura 2). Várias formas de apoio, inclusive leilões para aquisição de tecnologias específicas de energias renováveis, ajudaram a aumentar o fornecimento de energia a partir de outras fontes que não a de grandes hidrelétricas, especialmente a eólica. Regras de conteúdo local, condição para o financiamento do BNDES, levaram à criação de uma indústria eólica no Brasil, embora essa forma de proteção industrial possa prejudicar a competitividade do setor, no longo prazo.

Desde 1970, o Brasil vem estimulando o desenvolvimento da produção, em larga escala, do etanol de cana-de-açúcar para uso em veículos automotores, inclusive por meio de quotas de mistura obrigatória e de tributação favorável. Em consequência, os biocombustíveis responderam por $17 \%$ dos combustíveis utilizados no transporte rodoviário em 2012, de longe, a mais elevada participação do mundo. No início da década de 2010, o governo e o BNDES retomaram os investimentos de apoio à indústria do álcool e à produção da cana-de-açúçar, em resposta à queda de produtividade no setor, em parte provocada pelo preço artificialmente baixo da gasolina.

Em 2011, o Brasil lançou o Plano Nacional de Eficiência Energética e definiu uma meta de economia de energia para todo o país, até 2030. A empresa estatal de energia elétrica, Eletrobrás, implementou os programas de gestão da demanda de energia na indústria e nos municípios. Novos regulamentos e programas de rotulagem melhoraram a eficiência energética de aparelhos e equipamentos. Entretanto a abordagem à eficiência energética e à gestão da demanda tem sido fragmentada. O Brasil pode se beneficiar com a aplicação sistemática de critérios de eficiência energética integrados às políticas setoriais, incluindo habitação, planejamento urbano e transporte.

No Brasil, a maior parte do transporte de passageiros e de cargas é realizado pelas rodovias. As insuficiências de infraestrutura do transporte público e o aumento dos custos para o usuário, assim como a tributação relativamente baixa sobre a propriedade e uso de veículos contribuíram para o agravamento das condições de trânsito nos grandes centos urbanos. O PAC 2011 incluiu a expansão de redes ferroviárias de longa distância e urbanas, o que é bastante positivo. Poderia ser dada maior ênfase ao sistema de ônibus de trânsito rápido, que já vem sendo operado com sucesso em algumas cidades, como Curitiba, e também introduzido no Rio de Janeiro e em Brasília, em 2014. Esse sistema pode ajudar a reduzir o congestionamento nas cidades e ao longo da malha viária, com a consequente redução de acidentes rodoviários e de emissões de GEEs e de poluentes atmosféricos. 


\section{Ecoinovação e bens e serviços ambientais}

A ecoinovação está entre as prioridades da estratégia de inovação do Brasil. O País tem importantes empresas inovadoras e elevada especialização em certas áreas de alta tecnologia, tais como energias renováveis e agrotecnologia. Estima-se que os investimentos em pesquisa e desenvolvimento (P\&D) ecológicos respondam por cerca de $3 \%$ dos gastos totais de P\&D (FRISCHTAK, 2011). O desempenho em ecoinovação tem aumentado e o Brasil vem aprimorando sua especialização em tecnologia ambiental, comparável com outras economias BRIICS. O número de patentes em tecnologia ambiental e climática cresceu, representando cerca de $9 \%$ de todas as patentes registradas no Brasil no período de 2009-2011 (a média dos BRIICS foi de 7,8\%). O Brasil gerou o terceiro maior volume mundial de créditos de redução de emissões certificadas no âmbito do Mecanismo de Desenvolvimento Limpo (MDL), o que tem sido uma das forças motrizes por trás da transferência de tecnologia além de, também, estimular a inovação no plano interno.

O Brasil poderia se beneficiar de uma melhor coerência nas políticas industrial, de inovação e de mercado de trabalho, bem como de uma maior cooperação entre governo, instituições de pesquisa e setor empresarial. A ecoinovação enfrenta barreiras similares àquelas enfrentadas pela inovação em geral, incluindo a fragilidade de relações entre setores da ciência e da indústria, lacunas de competências, entraves regulatórios, alto custo de registro de patentes e complexidade do regime de incentivos econômicos e fiscais. Junto com o apoio oficial à $\mathrm{P} \& \mathrm{D}$, surgiram recentemente algumas medidas políticas impulsionadas pela demanda, tais como normas de sustentabilidade em compras do setor público, programas de rotulagem e políticas que estabelecem metas de desempenho ambiental setoriais. Entretanto os programas de rotulagem ambiental são onerosos e os produtos sustentáveis representam parte insignificante das compras governamentais (MMA, 2015). A expectativa é que a Lei da Biodiversidade de 2015 facilite a inovação e a atividade industrial com base no uso justo dos ativos genéticos e do conhecimento tradicional (Seção 4).

Aparentemente, o setor de bens e serviços ambientais vem crescendo mais rapidamente que a economia do País como um todo (ABDI, 2012) e as estimativas indicam que o setor poderá servir de estímulo para o crescimento do País (1\% a 7\% do PIB). Contudo, várias formas de proteção das empresas nacionais (por exemplo, requisitos de conteúdo local e elevados tributos sobre importações) reduzem a concorrência, aumentam os custos tecnológicos e desestimulam a inovação e a difusão de maior eficiência, de tecnologias mais limpas e de bens e serviços. As empresas líderes do Brasil investem apenas $1 \%$ do seu faturamento em tecnologias sustentáveis, e as pequenas e médias empresas tendem a investir menos ainda (AHK, 2009). Mesmo assim, a adoção, cada vez mais comum, de práticas de responsabilidade social corporativa e de sistemas de gestão ambiental revela que houve melhora da consciência empresarial relativa às questões ambientais.

\section{Cooperação para o desenvolvimento}

O Brasil aumentou seus gastos em relação à cooperação para o desenvolvimento e é um dos parceiros mais ativos na cooperação triangular. Ao mesmo tempo em que o foco dessa cooperação tem sido, tradicionalmente, a saúde, a agricultura e a educação, houve expansão no número de projetos ambientais, sendo boas as perspectivas de crescimento nesse campo, no futuro próximo. O Brasil está se articulando com outros países, com 
vistas a compartilhar seus conhecimentos sobre monitoramento de florestas e de uso da terra; e o governo planeja ampliar a cooperação sul-sul em matéria de recuperação de florestas (Seção 4).

\section{Recomendações sobre o esverdeamento da economia no contexto do desenvolvimento sustentável Esverdeamento do sistema de impostos e encargos}

- Reformar o sistema de tributos e encargos no que tange ao meio ambiente, possivelmente no contexto de uma reforma fiscal mais ampla, incluindo:

* manutenção de alíquotas positivas para a contribuição CIDE sobre combustíveis, ajustando-as de modo a refletir o teor do carbono do combustível e as emissões de poluentes atmosféricos locais; aplicação da CIDE para combustíveis usados na aviação e máquinas estacionárias (por exemplo, nas indústrias);

* introdução de tributos sobre poluição (ex.: emissões atmosféricas), resíduos (materiais de embalagem), aproveitamento de recursos (minerais) e alinhamento de alíquotas de tributos sobre veículos com o desempenho ambiental; e

* garantia de que a cobrança pela captação de água ou pela descarga de poluentes reflita a escassez e as pressões sobre o meio ambiente e seja aplicada, de forma consistente, em todas as bacias hidrográficas do país (em conformidade com a legislação).

- Prosseguir com a avaliação de opções de preço de carbono; considerar o ensaio de precificação de GEEs em um regime de comércio e limites de emissões (cap-and-trade) em nível estadual, visando a adquirir a experiência necessária para a implementação de um sistema nacional interligado aos mercados internacionais de carbono.

\section{Investimentos em infraestrutura e serviços relativos ao meio ambiente}

- Integrar, de forma sistemática, objetivos ambientais às políticas setoriais e aos programas de investimento público, cuja implementação deve contemplar critérios de sustentabilidade ambiental e indicadores para o monitoramento de seu progresso.

- Simplificar os procedimentos administrativos e fomentar a capacitação para melhorar a execução de programas de investimento em infraestrutura relacionados ao meio ambiente, especialmente no nível local. Estimular a forte colaboração intermunicipal, visando a alcançar economias de escala na prestação de serviços de saneamento e de tratamento de resíduos.

- Estender a aplicação de encargos pelo uso da água, pelos serviços de saneamento e coleta de resíduos e reforçar a sua cobrança, com vistas a estimular o uso eficiente de recursos, ampliar a recuperação de custos, melhorar a viabilidade financeira do investimento e alavancar recursos do setor privado; usar transferências sociais para garantir que famílias de baixa renda tenham acesso adequado a esses serviços.

- Reforçar medidas para melhorar a eficiência energética por meio da introdução de normas para prédios e aparelhos, integrando-as aos programas de habitação social e aplicando normas obrigatórias de economia de combustível e rotulagem para promover uma mudança em prol de veículos mais eficientes.

- Continuar a ampliar investimentos em ferrovias e sistemas de transporte público urbano; considerar a ampliação do uso de instrumentos tais como pedágios, taxas de congestionamento, cobrança de estacionamento e restrições sobre a circulação de automóveis, com 0 objetivo de moderar 0 uso de veículos particulares.

\section{Ecoinovação e bens e serviços ambientais}

- Estimular a produção e a difusão de tecnologias, bens e serviços ambientais, com as seguintes ações:

* ampliar a consciência sobre melhores práticas e tecnologias disponíveis, particularmente em pequenas e médias empresas;

* facilitar o acesso a financiamentos para investimento em tecnologias em prol do meio ambiente, energias renováveis e eficiência energética;

* monitorar os efeitos de regras de conteúdo local sobre a competitividade de longo prazo da emergente indústria de tecnologia ambiental (ex.: eólica e solar);

* atualizar regularmente o catálogo de produtos sustentáveis para compras públicas de produtos verdes e treinar gerentes de compras; e

* racionalizar ainda mais as iniciativas de rotulagem ambiental. 


\section{Conservação e uso sustentável da biodiversidade*}

\section{Biodiversidade do Brasil: estado, tendências e pressões}

O Brasil é um país megadiverso que abriga um décimo de todas as espécies conhecidas do planeta e possui mais espécies endêmicas que qualquer outro país. Possui seis ecossistemas terrestres ou biomas (Amazônia, Cerrado, Caatinga, Mata Atlântica, Pantanal e Pampa) e vários outros ecossistemas costeiros e marinhos. ${ }^{1}$ A Amazônia, maior floresta tropical do mundo, ocupa quase metade do território brasileiro. Como na maioria das economias emergentes, o desenvolvimento da infraestrutura, a agricultura, o crescimento demográfico e a urbanização constituem as principais pressões sobre a biodiversidade (MMA, 2015). A situação da conservação da biodiversidade varia bastante entre regiões e estados, sendo geralmente mais pobre nas regiões Sul e Sudeste e ao longo do litoral, onde vive a maior parte da população.

O Brasil alcançou avanços notáveis na redução do desmatamento. Em 2014, após um pico em anos anteriores, a taxa de desmatamento anual na área conhecida como Amazônia Legal ${ }^{2}$ foi $75 \%$ abaixo da média dos 10 anos anteriores (figura 3). Portanto, é provável que o Brasil supere sua meta de redução do desmatamento na região em 80\%, até o ano 2020. No entanto o progresso tem sido desigual entre os estados da região; e o ritmo atual ainda significa uma perda de cobertura florestal equivalente ao tamanho da Eslovênia (ou do estado de Sergipe) a cada quatro anos. Nos anos recentes, as taxas de desmatamento caíram também na maioria dos outros biomas, mas as pressões permanecem altas no Cerrado. No geral, a área total de floresta diminuiu em cerca $5 \%$, desde o ano 2000. Historicamente, as indefinições na situação fundiária tem exacerbado as pressões do desmatamento provocadas pela extração irregular de madeira e pela expansão da agricultura e de pastagens.

As ações para proteger espécies ameaçadas aumentaram, e a situação da conservação de mais de 100 espécies melhorou desde a última avaliação (MMA, 2015). Em 2012, quase metade das espécies ameaçadas da fauna estava sob proteção de um plano de ação para a conservação, e as áreas protegidas federais atualmente abrangem cerca de $60 \%$ das espécies de flora e fauna ameaçadas. No entanto as listas de espécies ameaçadas de 2014 indicam que mais de $45 \%$ das espécies de flora, como também cerca de 10\% das espécies de fauna estão ameaçadas, especialmente nos biomas da Mata Atlântica e do Cerrado. Vários dos estoques pesqueiros costeiros e fluviais estão esgotados ou sobreexplotados (MMA, 2015).

*Veja a Seção 5 para detalhes sobre áreas protegidas. 
Figura 3. A expansão das áreas protegidas ajudou a reduzir

o desmatamento na Amazônia

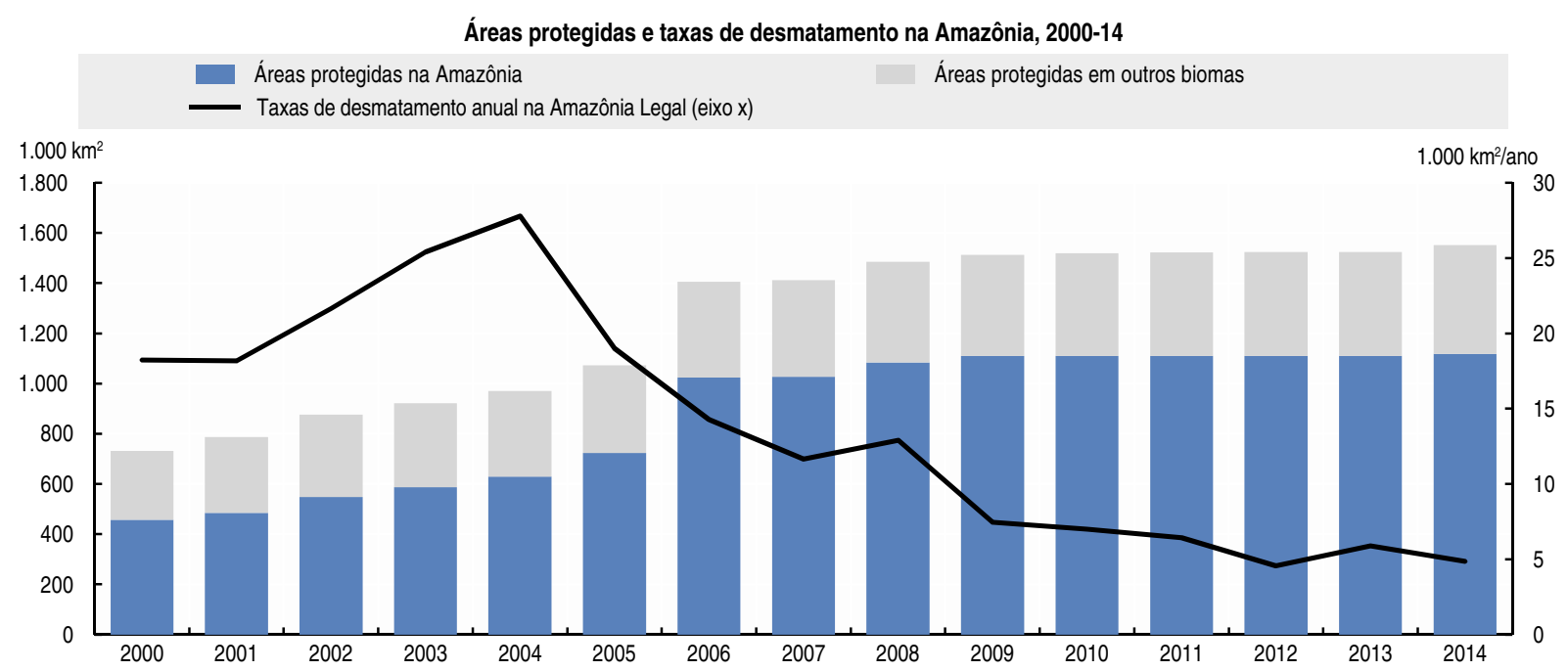

Nota: a Amazônia Legal engloba a Floresta Amazônica (cerca de 4,1 milhões de km²) e a vegetação de transição (1 milhão de km²).

Fonte: INPE (2015), "Projeto Prodes: Monitoramento da floresta Amazônia Brasileira por satélite"; MMA (2015), Cadastro Nacional de Unidades de Conservação.

\section{Melhoria da base de conhecimento para a política de biodiversidade}

O Brasil alcançou notáveis avanços no que tange à melhoria da base de conhecimento sobre espécies e ecossistemas e ao monitoramento da situação e das tendências da biodiversidade. No entanto a abundância de informações concernentes à biodiversidade continuam fragmentadas e nem sempre consistentes. Em 2010, o Ministério da Ciência e Tecnologia (MCT) lançou o Sistema de Informação sobre a Biodiversidade Brasileira ( $\mathrm{SiBBr}$ ) no intuito de sistematizar essas informações e torná-las mais acessíveis à pesquisa e à formulação de políticas.

O Brasil está entre os líderes mundiais no monitoramento de florestas por imagem via satélite, fator crucial para a redução do desmatamento na Amazônia. Um sistema de monitoramento praticamente em tempo real alerta as autoridades sobre o desmatamento e a degradação da floresta na região. O monitoramento via satélite do desmatamento foi também implementado para outros biomas, mas, além de ser menos desenvolvido, os dados não são completamente compatívies entre os sistemas. Os sistemas de detecção de incêndios florestais abrangem todo o País.

Em 2013, o MMA lançou a Iniciativa de Valoração Brasileira do Capital Natural do Brasil como parte do compromisso assumido pelo País para o desenvolvimento do processo nacional de Economias dos Ecossistemas e da Biodiversidade (TEEB Brasil). Essa iniciativa poderia preencher uma lacuna, ao proporcionar a valoração econômica da biodiversidade e ao construir um consenso sobre os benefícios da manutenção de ecossistemas funcionais, o que, em contrapartida, contribuiria para aumentar o apoio político e social necessário para integrar, de forma eficaz, a biodiversidade à agenda do desenvolvimento.

\section{Marco político para conservação e uso sustentável da biodiversidade}

Desde meados dos anos 2000, o Brasil vem fortalecendo seu marco institucional, político e legislativo para conservação e uso sustentável da biodiversidade. Houve uma 
mudança gradual, de uma abordagem de "cerca e protege" e de fiscalização rígida, para uma abordagem de desenvolvimento sustentável com a identificação de regiões prioritárias de biodiversidade e reconhecimento do papel das comunidades rurais, tradicionais e indígenas na manutenção da prestação de serviços ambientais.

Em 2013, a Comissão Nacional da Biodiversidade adotou vinte ambiciosos objetivos nacionais de biodiversidade para 2020, alinhados às Metas de Aichi, no âmbito da Convenção sobre Diversidade Biológica (CDB). Criou também, um painel multissetorial PainelBio - para definir indicadores e monitorar o progresso. Uma avaliação intermediária indica que o Brasil está no caminho certo para atingir a maioria de suas metas, ainda que esforços adicionais sejam necessários (MMA, 2015). Vários estados desenvolveram estratégias e planos de ação de biodiversidade, contudo garantir coerência e sinergia entre políticas federais para a biodiversidade continua sendo um desafio.

No geral, houve uma proliferação de planos e programas relativos à biodiversidade desde o ano 2000, muitas vezes, com sobreposição de objetivos. Contudo ainda não está claro até que ponto esses planos e programas foram implementados ou produziram os resultados esperados. Com poucas exceções, a implementação de políticas e de planos para a biodiversidade carece de monitoramento sistemático e sua eficácia, custos e benefícios raramente são avaliados.

\section{Uma estratégia integrada de combate ao desmatamento}

É compreensível que a política de biodiversidade brasileira tenha se concentrado fortemente no combate ao desmatamento. Em 2004, em resposta às crescentes taxas de desmatamento na Amazônia, o governo lançou o Plano de Prevenção e Controle do Desmatamento na Amazônia Legal (PPCDAm). Efetivamente, o plano incorporou a luta contra o desmatamento a outras agendas setoriais, graças ao respaldo da coordenação da Casa Civil da Presidência da República e à atribuição de responsabilidades de implementação para 13 ministérios. Atualmente, em sua terceira fase, o PPCDAm baseia-se em um conjunto coerente de ações, como: criação de áreas protegidas (Seção 5), regularização fundiária (incluindo o programa Terra Legal), sistemas avançados de monitoramento, fiscalização rigorosa e promoção do uso sustentável de recursos naturais. Instrumentos complementares, como embargos e restrições ao crédito para desmatadores ilegais, reforçaram a eficácia na execução.

O PPCDAm é amplamente reconhecido como uma estratégia eficaz, que pode servir como modelo para outros países. O plano foi de grande valia na redução do desmatamento na Amazônia (figura 3), embora outros fatores possam também ter contribuído, entre eles, a queda dos preços dos produtos agrícolas e o engajamento voluntário do setor privado. Com base no sucesso do PPCDAm, o governo lançou um programa semelhante para controlar o desmatamento no bioma Cerrado. Para que haja maior redução do desmatamento, além do monitoramento e da fiscalização rigorosa, será necessário fazer, cada vez mais, com que a agricultura sustentável e a gestão florestal sejam mais atrativas que a extração ilegal da madeira e a grilagem de terras, e que haja garantias de que práticas sustentáveis possam prover fontes de renda viáveis às comunidades tradicionais (CEPAL et al., 2011).

Em reconhecimento a essa necessidade, desde 2006, o governo vem emitindo concessões para a extração sustentável de produtos florestais madeireiros e não 
madeireiros. As concessões ainda abrangem menos de 1\% da área florestal potencialmente explorável, principalmente devido à burocracia, aos altos custos de transação, à falta de infraestrutura e aos conflitos fundiários. Muitas comunidades rurais carecem de conhecimento ou de meios para adotar práticas florestais sustentáveis ou concorrer nos processos de concessão.

O financiamento advindo da cooperação bilateral e internacional ajudou a financiar o PPCDAm e outros programas de biodiversidade e adicionou capacidade de implementação aos órgãos do governo. Grande parte do financiamento internacional vem sendo aplicada por meio de fundos extraorçamentários, incluindo o inovador Fundo Amazônia. Criado em 2008 e gerido pelo BNDES, em parceira com o MMA, o fundo investe na prevenção de desmatamento e aproveitamento sustentável da floresta, contribuindo, dessa forma, para a redução das emissões dos GEEs. A Noruega é o maior doador, seguido pela Alemanha. Entre 2009 e 2015, o fundo acumulou mais de US\$ 970 milhões e apoiou mais de 70 projetos. Por meio do Fundo Amazônia, o Brasil recebeu cerca da metade do total dos recursos aprovados pelo financiamento internacional para a Redução das Emissões por Desmatamento e Degradação Florestal - REDD e REDD+ (NORMAN et al., 2014). Em junho de 2014, o Brasil foi o primeiro país a submeter o seu nível de referência de emissões florestais para fins de pagamentos por resultados no âmbito do REDD+ conforme estabelecido pelo Marco de Varsóvia 2013. A estratégia nacional da REDD+ vem sendo discutida desde 2010.

O setor empresarial contribuiu para o combate ao desmatamento na Amazônia por meio da Moratória da Soja e de Termos de Ajustamento de Conduta por parte dos Frigoríficos. A moratória envolve um grupo de grandes empresas que concordaram voluntariamente em deixar de usar soja cultivada em áreas da Floresta Amazônica ilegalmente desmatadas desde 2008. A moratória provou-se eficaz, pela tendência de os produtores se adaptarem à procura do mercado. Existe ainda espaço para maior engajamento do setor empresarial na conservação e recuperação de florestas e, de forma mais ampla, na conservação e no uso sustentável da biodiversidade.

\section{O Novo Código Florestal e o Cadastro Ambiental Rural}

Em 2012, o Brasil aprovou o Novo Código Florestal para substituir e atualizar o código de 1965. O antigo código foi o instrumento jurídico fundamental de proteção da vegetação nativa em propriedades privadas e regulação do uso da terra, por meio da exigência de que proprietários mantivessem parte de suas terras para fins de conservação e recuperação da floresta e do solo (as chamadas Reserva Legal - RL e Áreas de Preservação Permanente - APPs). Entretanto esse código foi de difícil aplicação e não evitou que vastas áreas fossem ilegalmente desmatadas. Em resposta, apesar de criticado por ser complacente com interesses comerciais, o novo código introduziu novos instrumentos de fiscalização potencialmente mais eficazes, que poderão proporcionar melhor nível de proteção. O Novo Código Florestal visa a reconciliar os objetivos de preservação da biodiversidade e das florestas com o objetivo de assegurar um bom ambiente de negócios para a agricultura, um dos principais setores da economia do Brasil.

Mais especificamente, o novo código introduziu o Cadastro Ambiental Rural (CAR) com vistas a melhorar o monitoramento e a conformidade com exigências de conservação de florestas em áreas rurais: os proprietários devem registrar suas terras e áreas de reserva no cadastro, até maio de 2016 , sendo que o registro no CAR será um requisito para acesso a créditos rurais, a partir de outubro de 2017. Glebas rurais que não estiverem 
em conformidade com os requisitos das áreas reservadas estarão sujeitas a programas estaduais de regularização ambiental. O sistema faz uso de imagens de satélite de alta resolução para localizar e registrar cada gleba rural.

A implementação do CAR prossegue: até abril de 2015, 53\% das áreas demarcadas haviam sido registradas. O governo federal investiu na criação do sistema de informação e na construção de capacidades em nível estadual, uma vez que os estados são responsáveis pela implementação do cadastro. Espera-se que, com a aplicação rigorosa do novo código, haja, mais adiante, significativa redução nas taxas de desmatamento. Embora o cadastro não tenha sido projetado para fins de regularização de direitos de propriedade da terra, os órgãos responsáveis pelo desenvolvimento rural e pelos assentamentos podem utilizar as informações georreferenciadas sobre localização de glebas rurais (conforme declarado pelos proprietários ou detentores) para esclarecer a situação fundiária.

O Novo Código Florestal prevê a complementação do registro cadastral com um sistema inovador de cotas florestais negociáveis, denominado Cotas de Reserva Ambiental (CRAs). Na prática, os proprietários de terra que não cumpriram com suas obrigações de reserva (anteriores a 2008) poderão restaurar a cobertura vegetal nativa ou adquirir uma quantidade equivalente de cotas. Cotas são expedidas para áreas mantidas com vegetação nativa que excedam os requisitos de reserva. A compensação só será possível dentro do mesmo bioma e, possivelmente, do mesmo estado. O sistema cria demanda por terras florestais e, em consequência, estimula a conservação de florestas. Segundo estimativas, o déficit de conformidade com obrigações de conservação florestal passado é grande (SOARES FILHO et al., 2014). Considerando que a restauração florestal é onerosa, especialmente para pequenos proprietários rurais, o sistema de cotas poderá constituir-se uma maneira econômica de garantir conformidade. O MMA vem buscando formas de lidar com o risco de que apenas áreas de baixa oportunidade de custo sejam competitivas no mercado, o que levaria a um aumento da conservação em áreas que não necessariamente tenham o maior valor de biodiversidade.

O Plano Nacional de Recuperação da Vegetação Nativa (PLANAVEG) desenvolvido pelo MMA e atualmente sob consulta pública, visa a promover, nos próximos vinte anos, a restauração florestal em larga escala em $125 \mathrm{mil} \mathrm{km²}$. O MMA estima que o plano gerará mais de 190 mil empregos diretos em áreas rurais. Para alcançar essas metas, é provável que sejam necessários vultosos recursos financeiros e mecanismos inovadores de financiamento, tais como títulos verdes para investimento em restauração. O CAR permitirá a identificação de áreas de alto valor de biodiversidade e a priorização de ações de restauração florestal.

\section{Pagamentos por serviços ambientais e programas de transferência condicionada de renda}

Ao mesmo tempo em que a abordagem regulatória tradicional prevalece, o uso de instrumentos econômicos foi ampliado. A maioria desses instrumentos visa a premiar ações que beneficiam a biodiversidade, a exemplo de boas práticas agrícolas e aproveitamento sustentável de recursos florestais. O uso de encargos e cobranças, tais como a cobrança pelo uso da água e os ingressos pela entrada em áreas protegidas, é muito limitado (veja Seções 3 e 5).

O Brasil implementou vários programas federais e estaduais de pagamentos por serviços ambientais (PSA) e de geração de renda para comunidades rurais. O Programa 
Produtor de Água (PPA), lançado em 2011 pela Agência Nacional de Águas (ANA) e replicado por alguns estados e municípios, oferece compensação financeira por investimentos na proteção do solo e da água em bacias hidrográficas que servem de fontes de abastecimento para áreas de grande população.

Programas, como o Bolsa Floresta e o Bolsa Verde, visam a suplementar a renda de famílias vivendo em condições de extrema pobreza em comunidades rurais e áreas de florestas e compensá-las pela realização de atividades de conservação ambiental. No estado do Amazonas, o Bolsa Floresta ajudou a controlar o desmatamento, embora seja implementado principalmente em áreas que sofrem pouca pressão de desmatamento (BÖRNER et al., 2013).

O Bolsa Verde é um programa federal direcionado à adoção de boas práticas ambientais e ao treinamento técnico, em apoio ao cumprimento dos compromissos de conservação por parte de seus beneficiários. O programa é considerado uma maneira eficiente de conter o desmatamento e de baixo custo por hectare de desmatamento evitado; entretanto sua implementação é complexa e as atividades de capacitação complementar deixam a desejar (CGU, 2014). Desenvolver mecanismos de monitoramento e garantir maior integração com o CAR ajudaria a melhorar a eficácia e a reduzir os custos de gestão do Bolsa Verde e dos programas de PSA existentes. Desde 2007, vem tramitando no Congresso Nacional um abrangente projeto de lei sobre PSA, cuja aprovação poderia fornecer as bases para expansão e melhoria de tais programas.

\section{Acesso aos recursos genéticos e repartição de benefícios}

O Brasil abriga centenas de comunidades tradicionais, indígenas, quilombolas ${ }^{3} \mathrm{e}$ outras, cujos membros detêm amplo conhecimento sobre o aproveitamento da flora e da fauna. Destaca-se, portanto, a importância de assegurar o acesso aos ativos genéticos e à repartição equitativa de benefícios deles derivados. O Brasil assinou o Protocolo de Nagoia sobre Acesso e Repartição de Benefícios (ARB) ${ }^{4}$ em 2011 e sua ratificação está em tramitação. Após mais de uma década de regime transitório e anos de debate, em maio de 2015, o Brasil aprovou o Marco da Biodiversidade. A nova lei visa a superar gargalos associados à regulação ARB anterior, que continha sérios entraves ao acesso a recursos genéticos para fins comerciais e científicos. Ela reduz a carga administrativa, melhora a participação de grupos indígenas e de comunidades tradicionais na tomada de decisão e cria um fundo para repartição de benefícios. Também estimula o fomento da inovação, criando oportunidades comerciais e potencializando recursos adicionais, por exemplo, para conservação e uso sustentável da biodiversidade em áreas protegidas e terras indígenas. A lei poderá ainda servir de estímulo para a adoção de normas ARB semelhantes em países da África e da Ásia.

\section{Inserção do tema da biodiversidade em políticas para agricultura, pesca e energia}

O Brasil é grande produtor e exportador agrícola. Desde meados dos anos 2000, o governo vem ampliando o foco sobre o estímulo à adoção de práticas agrícolas sustentáveis. O acesso a crédito rural está condicionado ao cumprimento da legislação ambiental. Alguns programas são direcionados a pequenos produtores rurais, à agricultura orgânica e às práticas de produção sustentável; um exemplo é o Programa Agricultura de Baixo Carbono. A agricultura orgânica responde, entretanto, por uma parcela muito pequena da produção agrícola e por menos de $1 \%$ da área sob cultivo. 
De forma geral, o nível de apoio aos agricultores rurais é baixo, se comparado aos países da OCDE e a outros países BRIICS, e está vinculado, principalmente, à produção com base em práticas convencionais (OCDE, 2013) o que pode acarretar impactos negativos sobre o solo e a água. Por focalizar o estímulo à produção e à utilização de insumos, bem como à intensificação e à expansão agrícola, os programas de fomento apresentam o risco de aumentar pressões sobre os recursos naturais e de incentivar o desmatamento. O imposto sobre a propriedade rural, embora não muito significativo, ainda incentiva mais a produção agrícola que a conservação, por ser mais baixo para terras agrícolas. Além disso, os fertilizantes e os agrotóxicos gozam de algumas isenções fiscais, o que contribui para sua crescente utilização, com efeitos nocivos à saúde e ao meio ambiente. $O$ uso de agrotóxicos não autorizados também é alto e, ao contrário da maioria dos países da $O C D E$, as normas não exigem reavaliação ou renovação periódica da licença de pesticidas (MMA, 2015).

O modelo brasileiro de gestão da pesca integra os objetivos de sustentabilidade ambiental com os de inclusão social. Existem várias medidas que visam a limitar o impacto ambiental da pesca, mas não há qualquer exigência ambiental formal para o exercício da atividade pesqueira. $O$ volume de captura de peixes aumentou, e as pressões sobre os estoques pesqueiros são exacerbadas por conflitos entre pesca artesanal e industrial. A maior parte da pesca é realizada por frotas obsoletas e, com frequência, dirigida a estoques pesqueiros já fortemente explorados. Um maior aumento da produção aquícola poderia contribuir para o abastecimento de frutos do mar e pescados com menor custo para a população, reduzindo, assim, pressões sobre os recursos pesqueiros naturais; todavia potenciais impactos negativos sobre ecossistemas aquáticos devem ser levados em conta.

A matriz hídrica continuará a ser importante fonte de energia, mas sua expansão é limitada a questões de localização: a maioria dos potenciais aproveitamentos encontrase na Amazônia, suscitando, portanto, dificuldades com o licenciamento ambiental e a aceitação por parte da opinião pública. Esforços estão em curso para o desenvolvimento de novas abordagens e técnicas, incluindo projetos a fio d'água onde as condições são adequadas, já que a implantação de barragens para grandes usinas hidrelétricas pode causar impactos adversos sobre ecossistemas fluviais e comunidades locais. Tais empreendimentos podem também incentivar a abertura de estradas, a migração e a urbanização, aumentando, mais ainda, pressões sobre a vegetação nativa (BARBER et al., 2014). Como qualquer projeto de infraestrutura, as usinas hidrelétricas estão sujeitas ao licenciamento ambiental e à avaliação de impacto (Seção 2). O Brasil se beneficiaria com a adoção de um processo de licenciamento mais estratégico e integrado em nível de bacia hidrográfica, bem como com a quantificação mais clara do impacto da hidroeletricidade e de medidas compensatórias associadas sobre a biodiversidade.

\section{5. Áreas protegidas}

\section{Expansão do sistema de áreas protegidas}

As áreas protegidas são a pedra angular da política de biodiversidade no Brasil. Entre 2003 e 2008, o Brasil respondeu por mais de 70\% da nova área terrestre global sob proteção ambiental. O Sistema Nacional de Unidades de Conservação (SNUC) criado em 2000, lançou as bases para a notável expansão de áreas protegidas (denominadas unidades de 
conservação) oficiais e consolidou-se em uma estrutura consistente, o conjunto preexistente altamente diverso e fragmentado de áreas protegidas federais, estaduais, municipais e reservas particulares. Introduziu 12 categorias de gestão de áreas protegidas, divididas em dois grupos: áreas de proteção integral, com o objetivo primário de conservação da biodiversidade; e áreas de uso sustentável, onde é permitido o assentamento humano e o aproveitamento de recursos naturais, em conformidade com os planos de gestão sustentável. Em 2006, o MMA criou o Cadastro Nacional de Unidades de Conservação (CNUC) um banco de dados que reúne ampla variedade de dados de biodiversidade e gestão sobre cada área protegida oficial, embora as informações sejam, muitas vezes, incompletas.

Entre o ano de 2000 e início de 2015, o número e a extensão de áreas terrestres protegidas pelo SNUC mais que dobraram. Em março de 2015, 1.940 unidades de conservação abrangiam 17,2\% da área terrestre e de águas interiores do Brasil. Cerca de dois terços da área sob proteção estão sob categorias de uso sustentável, o que reflete o objetivo de vincular a conservação da biodiversidade ao desenvolvimento de atividades econômicas sustentáveis nas áreas rurais. Além disso, as áreas indígenas, a maioria na Região Amazônica, cobrem cerca de $13 \%$ do território nacional. O Brasil já ultrapassou, portanto, a meta de Aichi de proteger pelo menos 17\% de sua área terrestre e de águas interiores, até 2020.

\section{Recomendações sobre conservação e uso sustentável da biodiversidade}

\section{Base de conhecimento e avaliação}

- Expandir o Sistema de Informação sobre a Biodiversidade Brasileira para compilar, consolidar e sistematizar informações de biodiversidade novas e já existentes e torná-las mais acessíveis à pesquisa e à formulação e avaliação da política; garantir que 0 sistema seja regular e tempestivamente atualizado.

- Dar continuidade ao desenvolvimento de sistemas de monitoramento por satélite capazes de detectar o desmatamento florestal e a degradação, dando cobertura a todos os biomas, especialmente o Cerrado, a Caatinga e o Pampa, onde está prevista a maior parte da devastação da vegetação; garantir que os sistemas gerem séries de dados compatíveis e atualizados.

- Dar prosseguimento à Iniciativa de Valoração do Capital Natural do Brasil; realizar, na primeira oportunidade, uma avaliação nacional de ecossistemas para melhorar o conhecimento dos valores da biodiversidade e serviços ambientais, bem como dos riscos associados com suas perdas; garantir que os valores dos serviços ambientais sejam incluídos nas contas nacionais, na formulação e na avaliação de políticas.

\section{Marco político}

- Manter o enfoque político sobre o combate ao desmatamento e a regularização fundiária, e estendê-lo a todos os biomas terrestres e ecossistemas marinhos, costeiros e interioranos.

- Racionalizar a multiplicidade de programas e planos de biodiversidade, com vistas a eliminar a sobreposição e a duplicação de esforços e aumentar o custo-benefício; avaliar sistematicamente a implementação de políticas e medidas, em termos de resultados, custos e benefícios, com a consequente correção de rumos de políticas e programas.

\section{Conservação, restauração e manejo sustentável de florestas}

- Fortalecer a implementação do CAR por meio de incentivos econômicos, para estimular o cadastramento, promover a conformidade e apoiar o manejo sustentável e a restauração de áreas de reserva; expandir o sistema de informação do CAR para melhorar o monitoramento das conformidades, o planejamento da paisagem e 0 estabelecimento de prioridades políticas.

- Apoiar o desenvolvimento de programas estaduais de regularização ambiental e ampliar a capacidade de implementação de estados e municípios.

- Considerar o ajuste do sistema de Cotas de Reserva Ambiental (CRAs) para permitir trocas dentro das mesmas áreas prioritárias, em termos de valor da biodiversidade; monitorar sistematicamente o funcionamento do sistema e permitir os ajustes necessários para alcançar seus objetivos de preservação e restauração de florestas.

- Incrementar o apoio às práticas florestais e agrícolas sustentáveis, inclusive em áreas protegidas, por meio de capacitação e assistência técnica às comunidades tradicionais e rurais e pequenas propriedades agrícolas, e facilitar seu acesso aos mercados de crédito e produtos. 


\section{Recomendações sobre conservação e uso sustentável da biodiversidade (Continuação)}

\section{Conservação, restauração e manejo sustentável de florestas}

- Agilizar o uso de concessões para a gestão sustentável de florestas, inclusive em áreas protegidas, pela simplificação de procedimentos e pelo aumento da capacidade de servidores do governo em elaborar e negociar contratos de concessão; monitorar sistematicamente as áreas sob concessão para assegurar conformidade com as especificações do contrato e a entrega dos resultados ambientais e sociais esperados.

- Acelerar o desenvolvimento do Plano Nacional de Recuperação da Vegetação Nativa proposto, estimar seus custos e identificar áreas prioritárias (com alto valor de biodiversidade) para restauração; identificar fontes de financiamento e avaliar a viabilidade de estender a isenção fiscal concedida a títulos de infraestrutura a investimentos em restauração.

- Prover o setor privado de maior estímulo para implementar cadeias de valor sustentáveis e rastreáveis que minimizariam seu impacto sobre a biodiversidade e os ecossistemas, incluindo o desmatamento.

- Adotar, na primeira oportunidade, uma estratégia nacional de REDD+, indicando objetivos, ações, arranjos institucionais, mecanismos de monitoramento e alocação de recursos necessários.

\section{Pagamento por Serviços Ambientais (PSA)}

- Dar continuidade ao debate sobre o projeto de lei federal atual e adotar uma lei de PSA abrangente que sirva de marco para a implementação de PSA e aprimoramento da consistência entre regulamentos e programas dos estados.

- Instituir, em todo o país, um sistema de monitoramento de programas de PSA, possivelmente no âmbito da lei federal de PSA, com vistas a verificar sua eficácia na manutenção dos serviços ambientais que estão sendo pagos.

- Ampliar e incrementar a gestão do Bolsa Verde e reforçar seu vínculo com o CAR; assegurar o treinamento adequado aos beneficiários, com vistas a ajudá-los a cumprir com seus compromissos de conservação.

\section{Integração da biodiversidade nas políticas setoriais}

- Reorientar 0 apoio à agricultura para estimular a melhoria ambiental e 0 uso eficiente dos insumos agrícolas.

- Reformar a tributação territorial, incentivar a conservação da terra e remover, gradualmente, as isenções fiscais sobre fertilizantes e agrotóxicos; utilizar as receitas fiscais resultantes para aprimorar os conhecimentos dos produtores sobre boas práticas agrícolas, ex.: métodos alternativos de controle de pragas; reavaliar as normas sobre pesticidas, sujeitando as licenças à renovação periódica e intensificando medidas para coibir 0 uso de pesticidas não autorizados.

- Introduzir medidas para melhorar a sustentabilidade da pesca em águas marinhas e interiores, incluindo cotas de captura, planos de manejo para espécies sobre-explotadas e ampliação das áreas marinhas protegidas, especialmente nas zonas marinhas e costeiras onde os recursos pesqueiros estão no seu limite.

- Introduzir o planejamento estratégico, incluindo procedimentos de avaliação ambiental para o desenvolvimento de hidrelétricas, de modo a identificar onde o potencial energético poderia ser utilizado com menor impacto ambiental, levando em consideração efeitos cumulativos e, por último, reduzir os custos da mitigação de impactos ambientais e sociais.

- Esclarecer as regras das compensações ambientais e financeiras no âmbito do processo de licenciamento; melhorar a quantificação do impacto de projetos de infraestrutura sobre biodiversidade e ecossistemas e a definição de medidas compensatórias associadas.

A maior parte das novas áreas protegidas estão no bioma Amazônia, o que reflete os esforços do governo em combater o desmatamento nesse bioma. O Programa Áreas Protegidas da Amazônia (ARPA) lançado em 2002, está no cerne desse progresso. O ARPA, um dos maiores programas de conservação de florestas tropicais do mundo, criou mais de 500 mil km² de unidades de conservação federais e estaduais, inclusive no chamado "arco de desmatamento" e em áreas prestes a receber infraestrutura rodoviária. Prestou, ainda, apoio eficaz ao funcionamento de áreas de conservação por meio de investimentos em infraestrutura básica e capacitação. O programa complementou o PPCDAm na redução do desmatamento na região (figura 3) e contribuiu significativamente para o alcance das metas de combate às mudanças climáticas do Brasil (seções 1 e 4). 
A cobertura de áreas protegidas também aumentou nos outros biomas, mas varia bastante, de quase 27\% na Amazônia, para menos de 3\% nos Pampas. Para que o Brasil possa cumprir suas metas ambiciosas de proteger pelo menos 30\% da Amazônia e 17\% de outros biomas terrestres até 2020, serão necessários maiores esforços em áreas fora do bioma Amazônia. A implementação e a aplicação do novo Código Florestal contribuirão para o alcance dessas metas, por meio da expansão de áreas sob proteção em terras privadas (Seção 4). Apenas 1,5\% das áreas costeiras e marinhas está sob proteção ambiental; o governo está intensificando esforços para trazer essa participação para $5 \%$ até 2020 , ainda distante da meta de Aichi, de $10 \%$.

\section{Marco institucional}

O MMA supervisiona e coordena o SNUC. Órgãos executores de cada instância de governo são responsáveis pela implementação. Como ocorre em diversos países de estrutura federativa, uma agência nacional, a saber, o Instituto Chico Mendes de Conservação da Biodiversidade (ICMBio) é responsável pela supervissão de todos os aspectos das unidades de conservação federais. O ICMBio, criado em 2007, que ajudou a melhorar a transparência e eficácia do SNUC, opera coordenações regionais que agilizam a cooperação com governos estaduais e gestores de áreas protegidas. No entanto o grande número de áreas protegidas, nos diferentes níveis de governo, apresenta desafios para eficácia da cooperação e comunicação. Frequentemente, as agências de cooperação internacional e ONGs desempenham papéis complementares em apoio ao planejamento e à operação das unidades de conservação; o envolvimento do setor empresarial ainda é limitado.

\section{Criação de áreas protegidas}

Como em todos os países, a maioria das terras, que são ou podem ser incluídas nas áreas protegidas, é habitada e destinada a atividades econômicas. Ademais, algumas áreas podem ser potencialmente importantes para implantação de infraestruturas e desenvolvimento urbano. A lei do SNUC reconhece a necessidade de levar em consideração a importância de interesses ambientais, sociais e econômicos concorrentes, quando da criação de unidades de conservação. A lei requer consultas públicas com as comunidades locais, partes interessadas e instituições setoriais relevantes, a serem realizadas antes da criação de unidades de conservação, em todos os níveis de governo. Assim como em outros países, esse processo pode levar alguns anos. Para expandir ainda mais a área sob proteção ambiental, o Brasil poderia promover a criação de áreas protegidas privadas, formalmente reconhecidas pelo SNUC, especialmente em zonas limítrofes com unidades de conservação já existentes. A implementação do Código Florestal poderá servir de incentivo eficaz para que proprietários de terra criem unidades de conservação para proteção e gestão de áreas de reserva (Seção 4).

Algumas categorias do SNUC, incluindo os parques nacionais, são exclusivamente de domínio público. Para criação de áreas protegidas nessas categorias, é necessário que sejam desapropriadas quaisquer terras privadas localizadas dentro de seus limites e que seus proprietários sejam indenizados. Devido, em parte, à abordagem aplicada anterior ao ano 2000 , cerca de $70 \%$ das unidades de conservação federais ou $7 \%$ de sua superfície (VERÍSSIMO et al., 2011) incluem áreas reivindicadas por proprietários particulares. A desapropriação e a indenização de proprietários privados ocupantes de unidades de conservação públicas podem demandar vultosos recursos financeiros. Muitas vezes, a resolução de problemas relacionados à consolidação territorial e à regularização fundiária vão além da atribuição e capacidade dos órgãos ambientais (TCU, 2013). 
Para agilizar a consolidação de áreas públicas protegidas, o Código Florestal de 2012 introduziu um mecanismo inovador de compensação que prevê que proprietários inadimplentes com suas obrigações de reserva legal possam efetuar compensações, por meio do pagamento de indenizações por propriedades privadas localizadas em áreas protegidas oficiais com cessão de direitos ao poder público, dessa forma, reduzindo o ônus da consolidação territorial sobre o Tesouro. Para que esse mecanismo de compensação funcione, o CAR deverá estar plenamente implementado. O Brasil poderia considerar a celebração de acordos contratuais transitórios com proprietários de terras localizadas dentro de áreas protegidas para garantir que o uso da terra não conflite com os objetivos de conservação, até a resolução final das controvérsias de regularização fundiária.

\section{Gestão eficaz de áreas protegidas}

Após a notável expansão das unidades de conservação ao longo da década de 2000, o atual desafio do Brasil é a gestão eficaz dessas áreas. A eficiência da gestão melhorou, especialmente em áreas apoiadas pelo programa ARPA, o que se deve, em parte, à abordagem baseada em resultados, aos consideráveis recursos financeiros disponíveis ao programa e à exigência de que os governos federal e estadual contribuam com servidores qualificados para o manejo das áreas sob proteção. No entanto, muitas áreas protegidas ainda não cumprem plenamente com seus objetivos (TCU, 2013; WWF; ICMBio, 2012).

Muitas áreas protegidas vêm operando sem um plano de gestão, há mais de dez anos, apesar de esses planos serem exigidos por lei. Pelo fato de o plano de gestão ser condição para o uso público sustentável (ex.: turismo, educação ambiental e exploração madeireira sustentável) e o aproveitamento de recursos naturais pelas comunidades locais (ex.: extrativismo, pesca, agricultura), a ausência desse plano reduz oportunidades de desenvolvimento socioeconômico de longo prazo, podendo dificultar o controle efetivo sobre o aproveitamento de recursos da área. A maioria das áreas protegidas federais possui um comitê gestor, com representação de servidores do governo, da sociedade civil e do setor privado. Muitos comitês ainda não definiram regras de funcionamento para assegurar a participação efetiva das partes interessadas, resolver e prevenir controvérsias.

Várias áreas protegidas oficiais e terras indígenas podem ser integradas ao chamado mosaico, cujo objetivo é facilitar a coordenação entre gestores e alcançar economias de escala, por exemplo, no monitoramento, na fiscalização e na promoção da produção sustentável e da comercialização de recursos naturais. O MMA aprovou 14 mosaicos, mas não há evidências de que ajudaram a melhorar a eficácia da gestão.

Para demonstrar como as áreas protegidas podem contribuir para a conservação ambiental e o desenvolvimento sustentável, é fundamental conquistar apoio político e da opinião pública e mobilizar os recursos necessários. Por exemplo, as áreas protegidas do Brasil contribuem significativamente para a conservação e a disponibilização de recursos hídricos e têm alto potencial econômico (MEDEIROS; YOUNG, 2011). Desde 2002, o ICMBio vem monitorando recifes de corais nas áreas protegidas marinhas e, em 2012, lançou programas de monitoramento in loco nas áreas protegidas terrestres federais. A maioria das áreas, entretanto, labutam para monitorar a situação e tendências da biodiversidade e os resultados do desenvolvimento socioeconômico. Maiores estímulos a parcerias com a sociedade civil e com organizações de pesquisas e empresariais poderiam auxiliar no monitoramento em áreas não apoiadas por programas do ICMBio. 


\section{Recursos humanos}

Em geral, a escassez de recursos humanos está entre as principais causas do fraco desempenho de gestão. O gerenciamento do vasto território coberto pelo SNUC requer um efetivo numeroso e bem treinado. Há evidências de que o efetivo atual é insuficiente: estimativas indicam que, no final dos anos 2000, o número de servidores por $\mathrm{km}^{2}$ de área protegida era menor do que em outros países latino-americanos (MEDEIROS; YOUNG, 2011). As estimativas do governo sugerem que as operações em áreas protegidas federais e estaduais demandam, no mínimo, 19 mil trabalhadores adicionais, sendo três quartos deles para atividades de campo.

Tem sido comprovado difícil atrair efetivo para servir durante longos períodos em algumas áreas, especialmente nas regiões remotas da Amazônia, onde as condições de trabalho e de vida são precárias. As exigentes normas trabalhistas do setor público constituem um obstáculo adicional. De modo geral, os gestores e os servidores são altamente motivados e comprometidos; porém, apesar de vários programas de treinamento terem ajudado a melhorar a capacidade nos últimos anos, muitos deles carecem da capacitação necessária para exercer atividades cotidianas de gestão. A realização do pleno potencial ambiental, social e econômico das áreas protegidas requer habilidades e competências adicionais, inclusive sobre gestão financeira e de projetos. Muitas vezes, a falta dessas habilidades e a burocracia resultam na não execução dos recursos financeiros disponíveis. A experiência de outros programas setoriais (ex.: da saúde) poderá ajudar na identificação de estratégias que atraiam servidores qualificados para atuar na gestão de áreas protegidas remotas.

\section{Recursos financeiros}

O orçamento do ICMBio, principal fonte de financiamento do SNUC, cresceu 57\% entre 2008 e 2014. Proporcionalmente, no entanto, o aumento de recursos não acompanhou a expansão das áreas sob proteção ambiental, resultando em déficit financeiro considerável - situação comum na maioria dos países latino-americanos (BOVARNICK et al., 2010). O funcionamento do SNUC é altamente dependente dos orçamentos federal e estaduais, o que torna o financiamento vulnerável a fatores externos e a negociações políticas. A maior parte dos recursos se destina a despesas com pessoal e outros custos operacionais, enquanto que o investimento em equipamento e infraestrutura é relativamente limitado. Outras fontes de financiamento incluem: compensações ambientais; cooperação para o desenvolvimento internacional; doações privadas; e receitas provenientes do turismo e do reflorestamento sustentável, embora esses últimos ainda sejam modestos.

O Brasil foi pioneiro no uso de transferências fiscais como incentivo à conservação da biodiversidade em áreas protegidas. Cerca de metade dos estados redistribui uma parcela da receita do Imposto sobre Circulação de Mercadorias e Serviços (ICMS) com base em critérios ambientais no âmbito de um mecanismo conhecido como ICMS Ecológico,* cujo principal parâmetro é a extensão e o tipo de áreas protegidas e terras indígenas. Na prática, o ICMS Ecológico vem sendo utilizado para compensar os municípios pelo

* O ICMS Ecológico é um mecanismo tributário que possibilita aos municípios acesso a parcelas maiores que aquelas a que já têm direito, dos recursos financeiros arrecadados pelos estados por meio do Imposto sobre Circulação de Mercadorias e Serviços, o ICMS, em razão do atendimento de determinados critérios ambientais estabelecidos em leis estaduais. Disponível em: <http://www.oeco.org.br/dicionario-ambiental/28048-o-que-e-o-icms-ecologico/>. Acesso em: 30 set. 2015. 
custo de oportunidade de manter parte de seu território sob proteção ambiental. Embora a receita não seja necessariamente destinada ao financiamento de despesas nas áreas protegidas, o mecanismo ajudou a ampliar o número e a extensão das áreas protegidas no Brasil; todavia o impacto sobre a conservação da biodiversidade não está claro (MAY et al., 2012). Apenas um estado condiciona as transferências de receita aos indicadores de qualidade, à situação da área protegida e ao volume de recursos municipais destinados a ações de conservação. Esse mecanismo tem potencial para estimular a boa gestão de áreas protegidas, porém implica custos adicionais, inclusive para fiscalização periódica das áreas.

O Brasil atraiu significativos financiamentos internacionais para suas áreas protegidas, especialmente por meio do programa Áreas Protegidas da Amazônia. A Alemanha é o maior doador do programa. Embora a cooperação internacional contribua com parte limitada do orçamento do SNUC, esta ajudou a alavancar financiamentos internos e a melhorar a eficácia da aplicação de recursos. Todavia é provável que o volume de financiamentos provenientes da cooperação internacional diminua, paulatinamente, nos próximos anos. O MMA e o ICMBio preveem alteração das bases do Programa ARPA - de doações, para financiamento governamental - no decorrer dos próximos 25 anos, sendo que, para essa finalidade, foi criado um fundo transitório, modelo esse que poderia ser estendido para o SNUC como um todo. O Brasil se beneficiaria da elaboração de uma estratégia financeira mais abrangente, para o SNUC e para a política de biodiversidade de forma geral. Tal estratégia poderia contemplar fontes alternativas de financiamento, incluindo programas de PSA, concessões para serviços de turismo e gestão sustentável de florestas (Seção 4).

\section{Promovendo a visitação pública}

Ainda há espaço para melhor integração entre as unidades de conservação e a estratégia turística nacional mais ampla. A visitação pública para fins de turismo, lazer e educação ambiental é uma das formas mais relevantes de gerar benefícios sociais e econômicos, de ampliar a sustentabilidade financeira e o apoio social em favor de áreas protegidas. Contudo, mesmo a visitação pública estando em expansão, ainda é incipiente. Desde 2006, o número de visitas vem aumentando gradativamente a cada ano, estando a maioria delas concentrada nos poucos parques nacionais onde programas governamentais, como o Turismo nos Parques e o investimento privado, favorecem a implantação de infraestruturas e a prestação de serviços turísticos. Estima-se que cerca de dois terços das unidades de conservação receberam visitantes em 2012, geralmente em números limitados, embora nem todas registrem e informem o número de visitantes. No entanto menos de $20 \%$ das unidades geraram receitas advindas de ingressos e outros encargos relativos à visitação pública (SEMEIA, 2012).

Foram poucas as unidades de conservação que selaram parcerias com empresas privadas e organizações sem fins lucrativos para gerir serviços de visitação, principalmente devido aos entraves regulatórios e burocráticos, à ausência de planos gestores adequados, à limitação de recursos e à falta de capacidade por parte da administração dos parques. Parcerias público-privadas (PPPs), incluindo concessões, podem estimular o fortalecimento de capacidades de gerenciamento e incrementar investimentos. Em 2011, o MMA e o MPOG firmaram convênio para o lançamento de PPPs e contratos de concessão em dez parques nacionais com alto potencial turístico. Tais convênios poderiam ser estendidos à gestão integral das unidades de conservação, incluindo as atividades de conservação ambiental, dessa forma, permitindo que o poder público mudasse o foco da gestão direta para a supervisão de áreas protegidas, o que requer menor intensidade de recursos. 


\section{Reservas extrativistas e de desenvolvimento sustentável}

As reservas extrativistas e de desenvolvimento sustentável são habitadas por pequenas comunidades tradicionais que dependem dos recursos naturais (ex.: peixes, madeira, castanhas, óleos, borracha) para sua subsistência. Para que essas áreas possam ser geridas de forma eficaz, é importante que sejam oferecidas a essas comunidades oportunidades reais de aproveitamento sustentável dos recursos naturais. Embora, de forma geral, as comunidades tradicionais tendam a possuir bons conhecimentos sobre 0 aproveitamento de recursos naturais, muitas vezes, carecem de capacidades suficientes para desempenhar a agricultura sustentável, o reflorestamento e a pesca ou para acessar os mercados. Programas, como o Bolsa Floresta e o Bolsa Verde (Seção 4) e a política do preço mínimo para produtos da sociobiodiversidade (programa conjunto do MMA, MDS e MDA), visam a abordar essas questões. Considerando que habitantes de reservas extrativistas e de desenvolvimento sustentável têm maior facilidade para acessar os benefícios oferecidos por esses programas, algumas comunidades vêm solicitando que as áreas onde vivem e trabalham também possam fazer parte dessas reservas.

Além de fontes viáveis de subsistência, grande parte da população das reservas extrativistas necessita de melhor acesso a serviços sociais, como educação, saúde e saneamento. Em geral, essas questões extrapolam as atribuições do MMA e de outros órgãos ambientais e requerem uma coordenação intersetorial mais forte.

\section{Recomendações sobre áreas protegidas}

\section{Expansão e consolidação do Sistema Nacional de Unidades de Conservação}

- Fortalecer a cooperação interinstitucional, com vistas a equacionar questões fundiárias dentro de unidades de conservação existentes, ou novas unidades propostas, e melhorar a prestação de serviços sociais às comunidades vivendo nas reservas de uso sustentável.

- Expandir mais ainda a área sob proteção ambiental para o pleno cumprimento das metas nacionais para 2020 e de compromissos internacionais (inclusive por meio de unidades de conservação oficiais, terras indígenas e áreas de reserva, conforme determina 0 Código Florestal); priorizar áreas com alto valor de biodiversidade, onde pressões provocadas pela implantação de infraestruturas, urbanização e agricultura são mais altas; expandir a cobertura de áreas protegidas em zonas marinhas e costeiras para alcançar a meta Aichi.

- Desenvolver uma estratégia para consolidação territorial de áreas protegidas; estimular o uso de mecanismos financeiros e de compensação previstos na legislação de áreas protegidas e no Código Florestal, a partir do momento em que o CAR esteja em pleno vigor; verificar a viabilidade de acordos contratuais transitórios com proprietários de áreas dentro de unidades de conservação, para assegurar a compatibilidade de uso da terra, até que a situação fundiária seja esclarecida.

\section{Gestão de áreas protegidas}

- Desenvolver uma estratégia financeira abrangente para o SNUC, com vistas a reduzir a dependência sobre o orçamento público e financiamentos internacionais; investigar fontes alternativas de financiamento, incluindo pagamentos por serviços ambientais, ingressos e benefícios gerados a partir de recursos genéticos.

- Intensificar esforços para desenvolver planos de manejo para áreas protegidas e avaliar sua implementação; garantir que os planos estabeleçam prioridades, metas e indicadores de progresso claros.

- Desenvolver programas de capacitação e fortalecimento de competências direcionados a gestores e funcionários de unidades de conservação, com vistas a aumentar a eficácia da gestão; promover as redes de gestores de áreas protegidas, a troca de experiências e as melhores práticas. 


\section{Recomendações sobre áreas protegidas (Continuação)}

- Dar continuidade periódica à avaliação da eficiência e da eficácia da gestão de áreas protegidas; dar maior estímulo aos gestores de áreas protegidas para que forneçam informações precisas e oportunas ao CNUC; sistematicamente avaliar essas informações, com vistas a produzir recomendações em nível de sistema.

- Desenvolver métodos padronizados de monitoramento da biodiversidade, com vistas a gerar toda a informação necessária para a avaliação da eficácia ambiental de áreas protegidas; expandir ainda mais programas federais de monitoramento.

\section{Intensificar a visitação pública}

- Integrar unidades de conservação às estratégias nacionais e estaduais de turismo e identificar áreas de alto potencial turístico; desenvolver produtos turísticos vinculados às áreas protegidas.

- Ampliar o uso de concessões e de outras parcerias público-privadas para a visitação púbica e o turismo em áreas protegidas; simplificar os procedimentos e melhorar a capacidade de servidores públicos e gestores de áreas protegidas para a elaboração e negociação de contratos; implementar programas-piloto, para testar e desenvolver novos modelos de gestão.

- Considerar a inclusão de visitação regular de grupos de crianças em idade escolar a áreas protegidas.

\section{Notas}

1 Um bioma é uma grande comunidade natural de flora e fauna que ocupa uma região geográfica.

2 A super-região da Amazônia Legal cobre uma área maior do que o bioma Amazônia, abrangendo tanto a Floresta Amazônica (cerca de 4,1 milhões de km²) quanto a vegetação de transição (1 milhão de $\mathrm{km}^{2}$ ); o bioma Amazônia cobre apenas a área de floresta. A Amazônia Legal abrange os estados do Amazonas, do Pará, do Acre, de Roraima, de Rondônia, do Amapá e de Tocantins e parte do Mato Grosso e do Maranhão.

3 Quilombolas são habitantes de Quilombos, comunidades formadas por descendentes de escravos fugitivos na época da colonização.

4 Protocolo de Nagoia sobre Acesso a Recursos Genéticos e Repartição Justa e Equitativa dos Benefícios Derivados de sua Utilização de 2010 é um protocolo da Convenção sobre Diversidade Biológica.

\section{Referências}

ABDI. Relatório de Acompanhamento Setorial: competitividade do setor de bens e serviços ambientais. Brasília, 2012. Disponível em: <www3.eco.unicamp.br/neit/images/stories/arquivos/Relatorios_NEIT/Bens-eServcos-Ambientais-Setembro-de-2012.pdf>.

ABEMA. Novas propostas para o licenciamento ambiental no Brasil. Brasília, 2013.

AHK. Green Technologies in Brazil. An Overview of the Sustainability Market. São Paulo: Câmara de Comércio e Indústria Brasil-Alemanha/Roland Berger Strategy Consultants, 2009. Disponível em: <www. renewablesb2b.com/data/ahk_brazil/publications/files/GreenTechStudy_AHK_RB.pdf>.

ANA. Agência Nacional de Águas. Conjuntura dos Recursos Hídricos no Brasil. Brasília, 2013. Disponível em: <http://conjuntura.ana.gov.br/docs/conj2013_rel.pdf>.

BARBER et al. Roads, deforestation, and the mitigating effect of protected areas in the Amazon. Biological Conservation, v. 177, p. 203-209, 2014.

BNEF. Global Trends in Renewable Energy Investment 2015. Frankfurt am Main: Bloomberg New Energy Finance/ Frankfurt School/UNEP Centre, 2015. Disponível em: <http://apps.unep.org/publications/pmtdocuments/Global_trends_in_renewable_energy_investment_2015-201515028nefvisual8-mediumres.pdf.pdf>. 
BORNER, J. et al. Promoting Forest Stewardship in the Bolsa Floresta Programme: local livelihood strategies and preliminary impacts. Rio de Janeiro: Center for International Forestry Research/ Manaus: Fundação Amazonas Sustentável/ Bonn: Zentrum für Entwicklungsforschung, 2013. Disponível em: <http:// fas-amazonas.org/versao/2012/wordpress/wp-content/uploads/2014/02/BF_report_ENG_web.pdf>.

BOVARNICK, A. et al. Financial Sustainability of Protected Areas in Latin America and the Caribbean: Investment Policy Guidance. [S.l.]: United Nations Development Programme and The Nature Conservancy, 2010. Disponível em: <www.undp.org/content/dam/aplaws/publication/en/publications/environment-energy/ www-ee-library/biodiversity/financial-sustainability-of-protected-areas-in-latin-america-and-thecaribbean/financial_sus_pa_lac.pdf>.

BRASIL. Ministério das Cidades. Sistema Nacional de Informações sobre Saneamento: diagnóstico dos serviços de água e esgotos - 2013. Brasília, 2014. Disponível em: <www.snis.gov.br>. Acesso em: fev. 2015.

. Ministério do Meio Ambiente. Fifth National Report to the Convention on Biological Diversity. Brasília, 2015. Disponível em: <www.cbd.int/doc/world/br/br-nr-05-en.pdf>.

. Ministério do Meio Ambiente. Fourth National Report to the Convention on Biological Diversity. Brasília, 2010.

. Tribunal de Contas da União. Relatório de Auditoria Operacional: governança das unidades de conservação do bioma Amazônia. Brasília, 2013. Disponível em: <http://portal2.tcu.gov.br/portal/pls/ portal/docs/2642553.PDF>.

CEPAL; GIZ; IPEA. Avaliação do Plano de Ação para a Prevenção e Controle do Desmatamento na Amazônia Legal - PPCDAm 2007-2010. Brasília, 2011. Disponível em: <www.cepal.org/dmaah/publicaciones/sinsigla/ xml/7/45887/IPEA_GIZ_Cepal_2011_Avaliacao_PPCDAm_2007-2011_web.pdf>.

CGU. Relatório de Acompanhamento n 07/2014 Programa Bolsa Verde. Brasília, 2014.

FRISCHTAK. Vantagens Comparativas, Inovação e Economia Verde. [S.1.]: 2011. Documento apresentado no Fórum Nacional BNDES, 21 set. 2011. Disponível em: <www.bndes.gov.br/SiteBNDES/export/sites/ default/bndes_pt/Galerias/Arquivos/empresa/download/inovacao_paper_05.pdf>.

IBGE. Indicadores de Desenvolvimento Sustentável (base de dados). Rio de Janeiro, 2013. Acesso em: mar. 2015. Perfil dos Municípios Brasileiros 2013. Rio de Janeiro, 2014.

MAY, P. et al. The 'Ecological' Value Added Tax (ICMS-Ecológico) in Brazil and its effectiveness in State biodiversity conservation: a comparative analysis. 2012. In: $12^{\mathrm{a}}$ CONFERÊNCIA BIENAL DA SOCIEDADE INTERNACIONAL DE ECONOMIA ECOLÓGICA, Rio de Janeiro, 2012.

MEDEIROS, R.; YOUNG, C. Contribuição das Unidades de Conservação Brasileiras para a Economia Nacional: Relatório final. Brasília: UNEP-WCMC, 2011.

NORMAN, M. et al. Climate Finance Thematic Briefing: REDD+ Finance. London: Overseas Development Institute/Washington, DC: Heinrich Böll Stiftung North America, 2014. (Climate Finance Fundamentals, 5). Disponível em: <www.odi.org/sites/odi.org.uk/files/odi-assets/publications-opinion-files/9330.pdf>.

OECD. Agricultural Policy Monitoring and Evaluation. Paris: OECD Publishing, 2013. Disponível em: <http:// dx.doi.org/10.1787/agr_pol-2013-en>.

. OECD Economic Surveys: Brazil. Paris: OECD Publishing, 2015. Disponível em: <http://dx.doi. org/10.1787/19990820>.

. Taxing Energy Use 2015: OECD and selected partner economies. Paris: OECD Publishing, 2015. Disponível em: <http://dx.doi.org/10.1787/9789264232334-en>.

. Water Resources Governance in Brazil. Paris: OECD Publishing, 2015. (Studies on Water). Disponível em: <http://dx.doi.org/10.1787/9789264238121-en>.

SEMEIA. Análise 2012 - Uso Público e Parcerias para Conservação e Desenvolvimento. São Paulo: Instituto Semeia, 2012. 
SENADO FEDERAL. Portal Orçamento (base de dados). Disponível em: <www12.senado.gov.br/orcamento/ loa>. Acesso em: abr. 2015.

SOARES FILHO, B. et al. Cracking Brazil's Forest Code. Science, v. 344, n. 6182, p. 363-364. Disponível em: < http://dx.doi.org/ 10.1126/science.1246663>.

VERÍSSIMO, A. et al. (Ed.). Protected Areas in the Brazilian Amazon: challenges and opportunities. Belém: Imazon/São Paulo: Instituto Socioambiental, 2011. Disponível em: <www.socioambiental.org/banco_ imagens/pdfs/10381.pdf>.

WWF; ICMBio. Avaliação comparada das aplicações do método Rappam nas unidades de conservação federais, nos ciclos 2005-06 e 2010. Brasília, 2012. Disponível em: <www.icmbio.gov.br/portal/images/stories/ comunicacao/downloads/relatrio\%20rappam\%202005\%20x\%202010\%20-\%20verso\%20integral.pdf>. 

PARTE I

\section{Progresso rumo ao desenvolvimento sustentável}



PARTE 1

Capítulo 1

\section{Principais tendências ambientais}

O presente capítulo apresenta um retrato das principais tendências ambientais no Brasil, salientando algumas das principais conquistas alcançadas e dos desafios a serem superados rumo ao desenvolvimento sustentável e a uma economia mais verde. Analisa o progresso em relação às metas da política nacional e aos compromissos internacionais, focando o período a partir do ano 2000. A partir de um panorama dos principais desdobramentos socioeconômicos, apresenta os avanços brasileiros rumo a i) eficiência energética e uma economia de baixo carbono; ii) eficiência no consumo de materiais, gestão de resíduos e uso de produtos químicos na agricultura; e iii) ao manejo sustentável de recursos naturais, incluindo florestas, biodiversidade e recursos hídricos. 


\section{Introdução}

Para contextualizar o desempenho ambiental do Brasil, é preciso considerar a vastidão do seu território e da sua riqueza natural, bem como o desenvolvimento econômico e social alcançado desde o início dos anos 2000. Quinto maior país do mundo em termos de área terrestre e de população, o Brasil possui enorme diversidade biológica, excepcional riqueza de terras férteis e de florestas, água, minérios e recursos energéticos fósseis. Seu crescimento econômico foi forte durante a década até 2012, e o País alcançou notável progresso no que tange ao desenvolvimento e à inclusão social. Contudo, a expansão da atividade econômica, o crescimento demográfico e a elevação dos padrões de vida vêm impulsionando demanda por energia, alimentos, minérios e outros recursos e ampliando as pressões ambientais tanto no meio rural quanto nas áreas urbanas.

O presente capítulo apresenta um retrato das principais conquistas ambientais do Brasil, bem como dos desafios remanescentes rumo ao desenvolvimento sustentável e a uma economia mais verde. Com base em indicadores de fontes nacional e internacionais, analisa esse progresso em relação aos objetivos da política nacional e aos compromissos e metas internacionais, focando o período a partir do ano 2000. $\mathrm{Na}$ medida do possível, compara as condições do meio ambiente e as principais tendências ambientais com as de países-membro da OCDE e outras economias emergentes do grupo dos BRIICS (Brasil, Rússia, Índia, Indonésia, China e África do Sul). O capítulo proporciona uma linha de base para o restante do relatório, que examina a efetividade das políticas ambientais do Brasil na abordagem dos principais desafios e no uso de objetivos ambientais para a geração de oportunidades econômicas e sociais.

\section{Principais desdobramentos econômicos e sociais}

\subsection{Desempenho econômico}

O Brasil é a sétima maior economia do mundo e a maior da América do Sul. Teve forte crescimento econômico durante a maior parte dos anos 2000, com crescimento médio do PIB bem acima da média da OCDE, mas abaixo do desempenho econômico alcançado por outras economias BRIICS (Figura 1.1; ver também Estatísticas Básicas). A renda per capita aumentou em torno de $30 \%$ entre os anos 2000 e 2013, permitindo a ascensão de cerca de 40 milhões de brasileiros para a classe média. A parcela da população que vivia na pobreza (menos de US\$ 2 por dia) caiu de 19\% em 2002 para menos de $7 \%$ em 2012. No entanto, a renda per capita permaneceu próxima a $40 \%$ da renda média nos países da OCDE em 2013 (Figura 1.1) e a pobreza no Brasil é maior que em alguns outros países da América Latina. O forte crescimento econômico foi, em grande parte, impulsionado pela demanda interna e pela favorável conjuntura econômica externa (OCDE, 2013a; OCDE, 2015a; BIRD, 2015). 
Apesar de a economia brasileira ter resistido bem à crise financeira global de 2009, seu crescimento começou a desacelerar em 2012, chegando a praticamente zero em 2014. A previsão é de que o crescimento seja modesto nos próximos anos, devido ao aperto nas políticas monetária e fiscal, ao enfraquecimento da demanda externa e às barreiras persistentes ao crescimento, tais como gargalos de infraestrutura, baixo investimento, alta tributação e encargos administrativos (o chamado "Custo Brasil"), à proteção comercial e à baixa competitividade interna, bem como ao mercado de trabalho apertado e às carências de capacidade (OCDE, 2013a; OCDE, 2015b; BIRD, 2011). A crise hídrica na região Sudeste (Seção 5.2) e a consequente falta de energia elétrica também apresentam entraves à recuperação da economia.

\section{Figura 1.1. A renda per capita no Brasil alcançou níveis mais altos que na maioria dos países BRIICS}
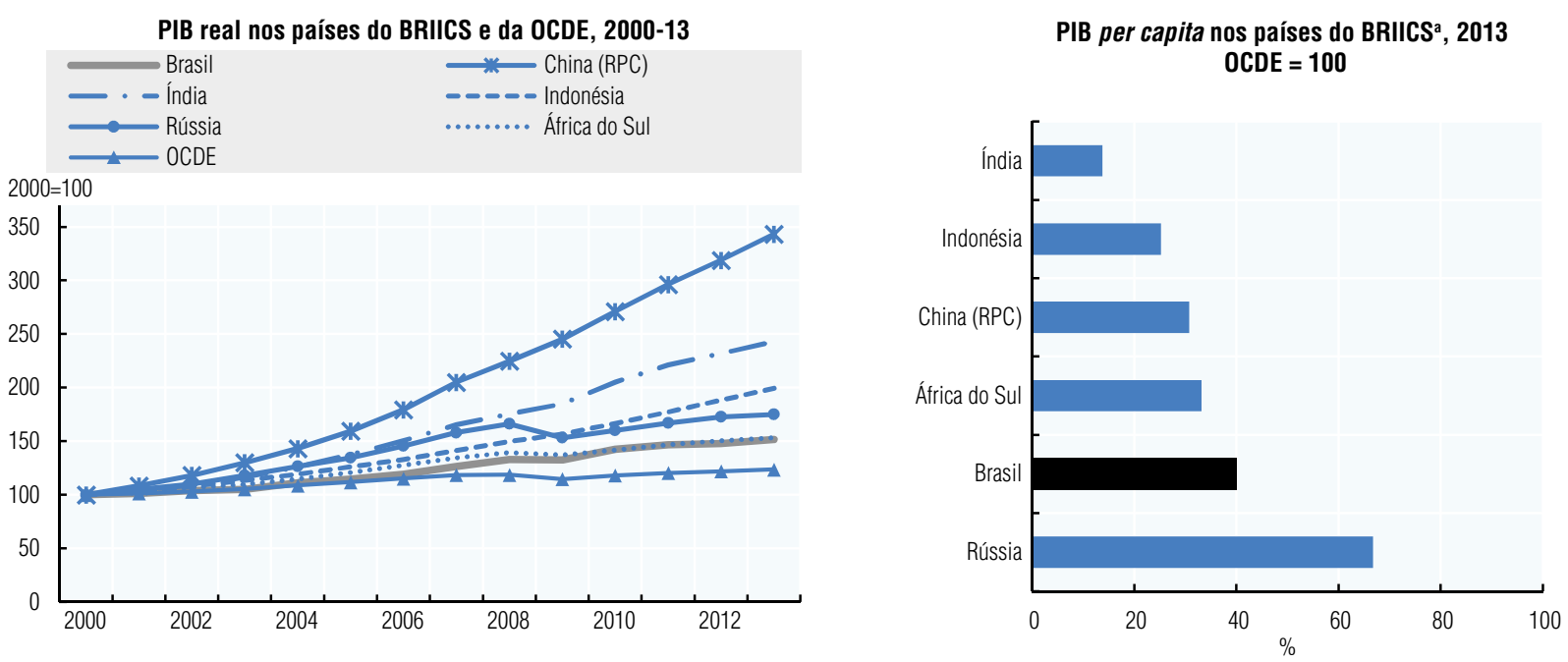

a) PIB per capita em paridade de poder de compra atual. Dados incluem estimativas.

Fonte: OECD (2015), "OECD Economic Outlook No. 96", OECD Economic Outlook: Statistics and Projections (banco de dados); OECD (2015), OECD National Accounts (banco de dados).

O Brasil realizou reformas econômicas significativas nos anos de 1990 e, desde então, vem desfrutando de condições de estabilidade macroeconômica. Contudo, sua merecida reputação por sólidas políticas macroeconômicas e fiscais vem enfraquecendo na medida em que tanto o déficit fiscal quanto a dívida pública aumentaram em $2013 \mathrm{e}$ 2014, enquanto que a inflação permaneceu elevada (OCDE, 2015b; FMI, 2014). Em 2013, as receitas tributárias e as despesas do governo permaneceram em níveis pouco abaixo das respectivas médias da OCDE (ver Estatísticas Básicas). Os tributos ambientais compõem uma parcela menor do total das receitas tributárias, ao passo que as receitas de hidrocarbonetos e da mineração respondiam por 2,4\% do PIB em 2013 (OCDE, 2015c) (Capítulo 3).

O desempenho do mercado de trabalho no Brasil tem sido forte. Segundo estatísticas nacionais, a taxa de desemprego caiu de 10,5\% em 2004 para um patamar histórico de 5,2\% em 2013 (Figura 1.2). No mercado de trabalho, a informalidade diminuiu consideravelmente. Ao mesmo tempo, em termos reais, os salários aumentaram quase 60\% entre 2004 e 2013 (Figura 1.2). O crescimento real dos salários acelerou após 2010, refletindo condições apertadas do mercado de trabalho e falta de capacidades (OCDE, 2013a). No entanto, desde o início de 2015, o desemprego vem aumentando (OCDE, 2015b). 


\subsection{Estrutura da economia e do comércio}

O Brasil tem uma economia diversificada e com ampla base industrial caracterizada, no entanto, por baixos níveis de produtividade e de competividade. (OCDE, 2015b). Nas últimas décadas, o setor de serviços vem ganhando importância na estrutura econômica, enquanto que a participação do setor primário e da indústria, em termos de valor agregado, vem diminuindo. Mesmo assim, o setor primário responde por uma parcela maior do PIB que em outros países da OCDE (ver Estatísticas Básicas) permanecendo como o esteio da economia. O Brasil ocupa o quinto lugar no ranking dos maiores produtores e exportadores de produtos agrícolas (Seção 4.3); é um dos principais atores mundiais no mercado de minerais (incluindo minério de ferro, cobre, bauxita, ouro e manganês) e estará entre os principais produtores de petróleo quando do desenvolvimento, nas próximas duas décadas, das grandes reservas de petróleo e gás descobertas em 2006 (IBRAM, 2012; IEA, 2013). A agricultura e a mineração registraram um maior crescimento de produção, emprego e exportação do que os setores mais intensivos em conhecimento, durante os anos 2000 (IPEA, 2012).

Figura 1.2. O desemprego diminuiu, enquanto que a renda do trabalho aumentou Taxa de desemprego e salário anual médio, 2004-13

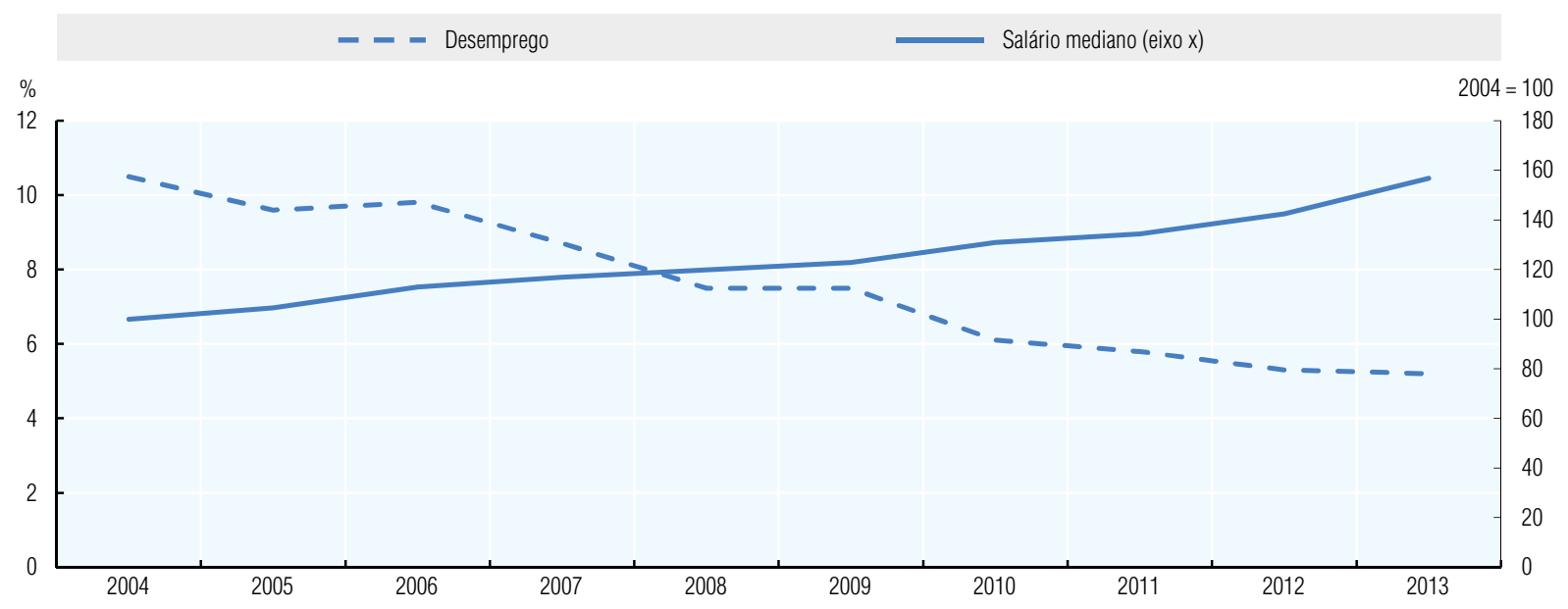

Obs.: Dados com base em pesquisas nacionais que abrangem pessoas com 10 anos ou mais. Fonte: IBGE (2014), Pesquisa Mensal de Emprego.

Os produtos primários predominam na pauta das exportações, respondendo por cerca de dois terços do total das exportações em 2013 (OMC, 2014); ver também Estatísticas Básicas). Enquanto os volumes do comércio exterior quadruplicaram durante a última década, somadas, as exportações e importações respondem por apenas $25 \%$ do PIB, proporção significativamente mais baixa que em outros países de porte similar. O Brasil é também menos integrado às cadeias de valor agregado internacionais e tem elevados níveis de proteção tarifária (OMC, 2014).

\subsection{Desigualdades e disparidades regionais}

Em termos geográficos, a atividade econômica no Brasil é altamente concentrada, com a maior parte das indústrias localizadas na região Sudeste e, em menor escala, no Sul; já a agropecuária e outras atividades dependentes de recursos naturais prevalecem nas regiões Norte, Nordeste e Centro-Oeste. ${ }^{1}$ As regiões Sul e Sudeste têm níveis de renda significativamente mais elevados (Figura 1.3) e melhor desempenho socioeconômico, conforme os principais indicadores. As desigualdades entre as regiões vêm diminuindo 
desde 2000, principalmente em consequência de taxas de crescimento acima da média em áreas especializadas da agropecuária e da mineração; contudo, a posição das áreas mais atrasadas (maior parte delas na região Nordeste) melhorou apenas marginalmente (OCDE, 2013b).

O Brasil é a única economia dos BRIICS a registrar uma diminuição na desigualdade de renda. Medido pelo coeficiente Gini, a desigualdade baixou de 58,6 para 52,7 entre 2002 e 2012; contudo, permanece entre as mais elevadas do mundo (BIRD, 2015; ver também Estatísticas Básicas). A queda da pobreza e da desigualdade é atribuída a alterações nos rendimentos do trabalho, bem como à redistribuição direta de renda, inclusive por meio do abrangente programa de transferências condicionadas, o Bolsa Família (Box 3.1) (OCDE, 2013a; BIRD, 2011).

\section{Figura 1.3. A renda per capita varia bastante entre os estados brasileiros}

PIB per capita por estado e região, 2000 e 2011

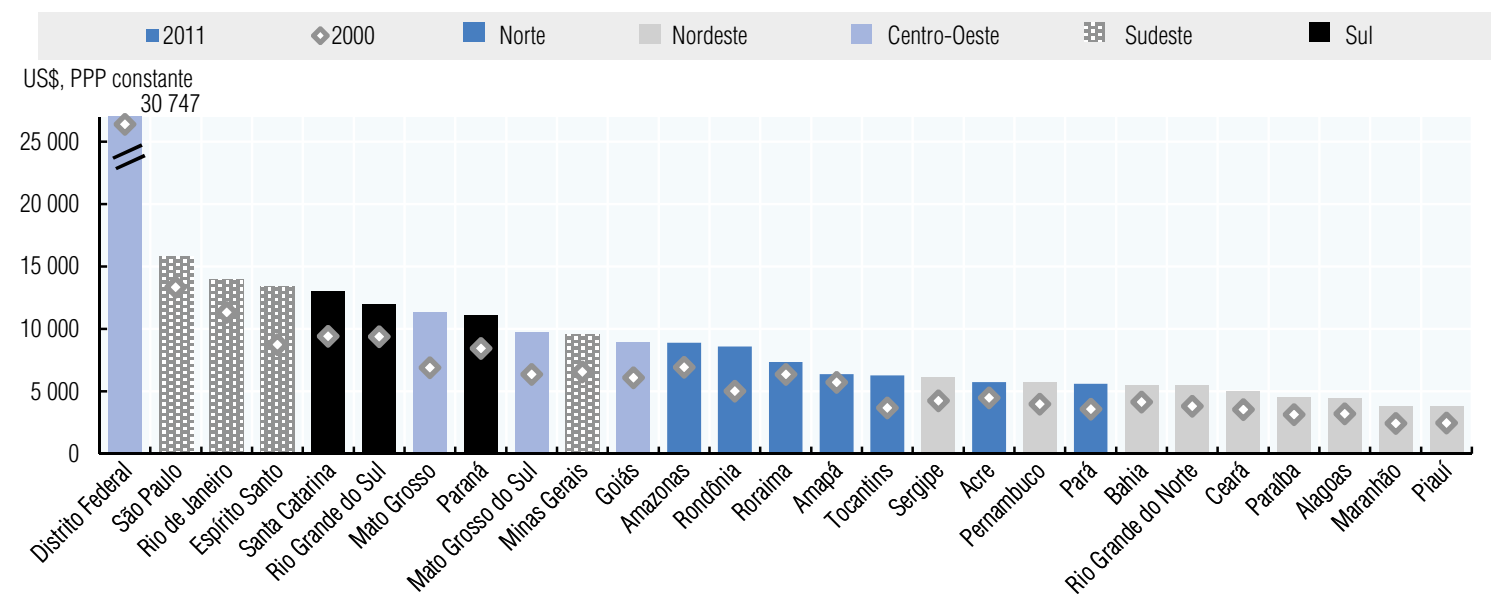

Fonte: OCDE (2015), "Large regions, TL2: Regional accounts", OECD Regional Statistics (banco de dados).

\subsection{População, urbanização e qualidade de vida}

A população vem crescendo rapidamente (ver Estatísticas Básicas) com projeção para alcançar um pico de cerca de 230 milhões de habitantes até 2040 (IBGE, 2014). As dimensões do país resultam numa densidade demográfica média relativamente baixa, porém com ocupação altamente concentrada ao longo do litoral. Mesmo assim, a proporção da população que vive em áreas predominantemente rurais é relativamente elevada pelos padrões da OCDE (ver Estatísticas Básicas). Quase cinco milhões de brasileiros vivem em comunidades tradicionais ou indígenas que praticam atividades extrativistas de produtos florestais não-madeireiros, agricultura de pequena escala, caça ou pesca (FUNDAJ, 2014).

Apesar de os processos de urbanização terem sido mais lentos que na OCDE ou nas outras economias BRIICS, a maioria das cidades vem sofrendo pressões ambientais crescentes, tais como congestionamento do trânsito; poluição do ar; volumes de resíduos que excedem a capacidade de tratamento e disposição final adequada; e contaminação das fontes de abastecimento de água, devido a insuficiências de infraestrutura para saneamento e tratamento de águas servidas. A habitação apresenta um enorme desafio: cerca de onze milhões de brasileiros moram em assentamentos urbanos informais caracterizados pela carência de serviços públicos e pela alta criminalidade, isto é, favelas 
(IBGE, 2011). Não obstante recentes melhorias, como avanços na redução da violência à mão armada, a segurança pública ainda constitui um grande problema. ${ }^{2}$

Importantes serviços públicos, como educação e saúde, passaram por melhorias em termos de acesso e qualidade. $O$ acesso à educação fundamental já é praticamente universal, e as taxas de matrícula para o nível médio e superior vêm aumentando. Os indicadores de aproveitamento educacional, conforme medido pelo Programa Internacional de Avaliação de Alunos - PISA, também melhoraram, especialmente entre os jovens e pessoas de famílias de baixa renda (OCDE, 2013a; OCDE, 2013c). No entanto, em 2012, apenas $13 \%$ da população economicamente ativa havia concluído cursos de educação superior; e, pelos padrões da OCDE, o capital humano continua defasado, o que vem limitando as perspectivas de crescimento. Os serviços de saúde tornaram-se mais acessíveis às pessoas de domicílios carentes e sua qualidade vem melhorando, com o consequente aumento da expectativa de vida que, mesmo assim, permanece abaixo da média da OCDE (ver Estatísticas Básicas). As disparidades regionais relacionadas a serviços de educação e de saúde permanecem grandes.

De forma geral, o Brasil vem alcançando avanços na melhoria da qualidade de vida. Os brasileiros aparentam estar um pouco mais satisfeitos com sua qualidade de vida do que o habitante médio de países da OCDE, conforme o Índice para uma Vida Melhor da OCDE (OCDE, 2013c). Além de um nível de renda disponível relativamente baixo, a educação, a segurança e a habitação se apresentam como as principais limitações à qualidade de vida de grande parte da população (Figura 1.4). Os brasileiros se orgulham da riqueza natural do seu país, e é crescente sua consciência e preocupação acerca das pressões ambientais (MMA, 2012a). O desmatamento, a poluição da água e do ar, e a geração e tratamento de resíduos são considerados os problemas ambientais de maior urgência (Figura 2.3).

\section{Figura 1.4. A satisfação com a vida no Brasil é alta, mas permanecem algumas limitações \\ Índice de Vida Melhor da OCDE, 2013}

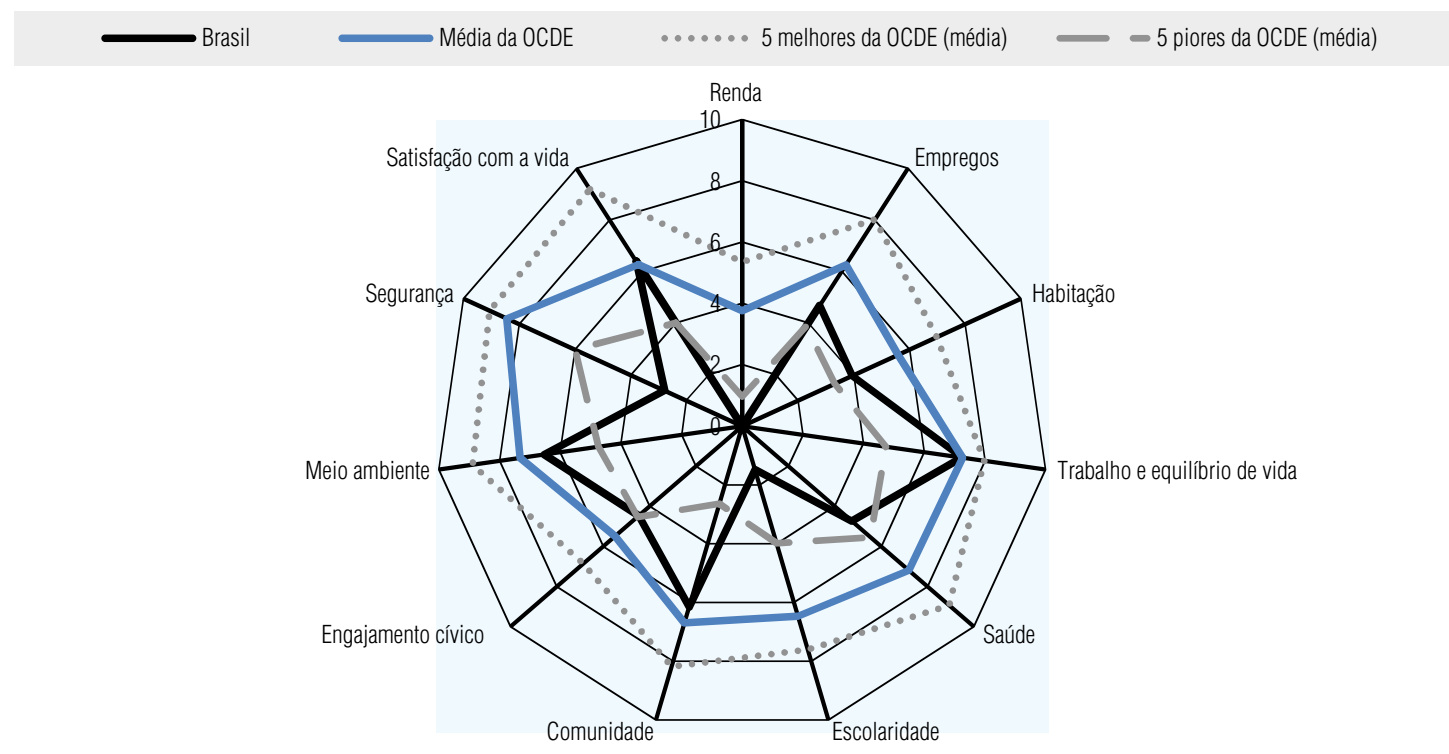

Obs.: Cada dimensão é medida por um dos três indicadores do conjunto de dados do Índice de Vida Melhor da OCDE. A média dos indicadores é tomada com ponderação igual e normalizada para expressar todos os valores da gama de 0 (pior) a 10 (melhor).

Fonte: OCDE (2013), "Better Life Index: Better Life Index 2013", OECD Social and Welfare Statistics (banco de dados). 


\section{Transição para uma economia de eficiência energética e de baixo carbono}

\subsection{Consumo de energia no Brasil}

\section{Matriz energética}

A matriz energética do Brasil é de baixo carbono. O aproveitamento da energia de fontes renováveis vem aumentando constantemente, alcançando $41 \%$ da oferta total de energia primária (OTEP) em 2012 (Figura 1.5), uma das participações mais elevadas do mundo e mais de quatro vezes a média da OCDE (ver Anexo 1.A e Estatísticas Básicas). As fontes renováveis respondem por 83\% da energia elétrica gerada, muito acima da média da OCDE, que é de 21\% (IEA, 2014a). Entre os países da OCDE, apenas a Islândia e a Noruega geram mais energia de fontes renováveis que o Brasil (Anexo 1.A). A matriz hídrica para a geração de energia elétrica e os biocombustíveis utilizados nas indústrias e no transporte constituem as principais fontes renováveis. Desde os anos 1970, o Brasil vem desenvolvendo a produção, em escala industrial, de etanol com base na cana-de-açúcar e estimulando o uso de veículos automotivos movidos a álcool combustível (Capítulo 3). Como resultado, em 2012, os biocombustíveis responderam por $17 \%$ dos combustíveis consumidos no transporte rodoviário no Brasil, o que representou a maior participação do mundo, muito acima da média da OCDE, que é de 4\% (IEA, 2014a; ver também Anexo 1.A). Outras fontes renováveis têm participação menor, porém crescente, na matriz energética. A proporção da energia produzida por turbinas eólicas cresceu mais de 400\% entre 2009 e 2012; há também grande difusão de instalações para a captação de energia solar, principalmente para aplicações descentralizadas (IEA, 2013).

Figura 1.5. Fontes renováveis respondem por parcela cada vez maior da energia produzida

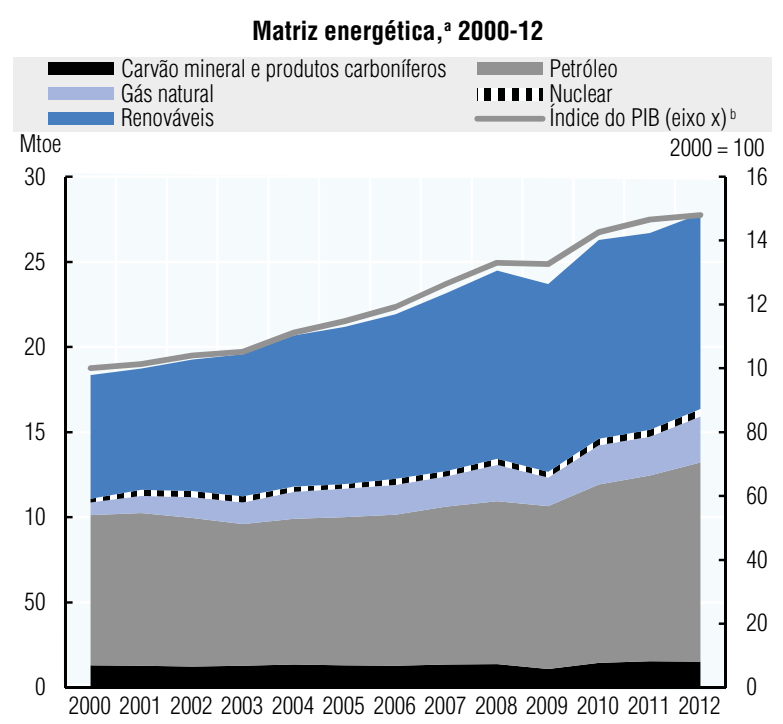

Matriz energética, ${ }^{a} 2012$

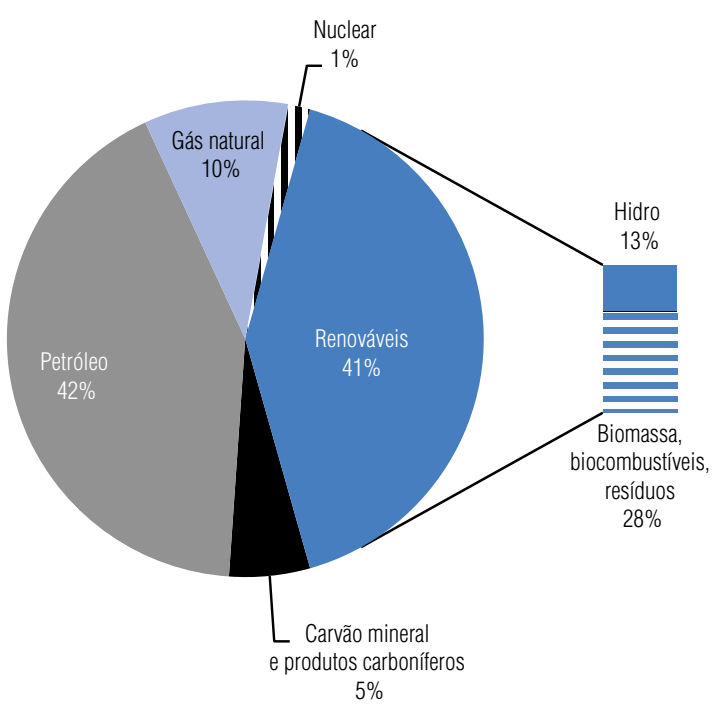

a) Total da energia primária. Desagregação exclui a comercialização de energia elétrica.

b) PIB a preços de 2005 e de paridade de poder de compra. Dados incluem estimativas.

Fonte: IEA (2014), IEA World Energy Statistics and Balances (banco de dados); OECD (2014), "OECD Economic Outlook No. 95", OECD Economic Outlook: Statistics and

Projections (banco de dados). 
O uso de derivados de petróleo, principalmente para o transporte rodoviário, vem aumentando, chegando a mais de 40\% do OTEP em 2012. O Brasil importa parcela significativa do petróleo consumido, mas a exploração das reservas do pré-sal, descobertas em 2006, poderá triplicar a produção nacional de petróleo (IEA, 2013)..$^{4}$ Outros combustíveis fósseis e a energia nuclear têm participações menores (Figura 1.5).

\section{Consumo e intensidade energética}

O forte crescimento econômico e a ascensão da classe média conduziram a um aumento no consumo de energia: tanto no consumo total final quanto na OTEP, que aumentou em cerca de 50\% entre 2000 e 2012 (IEA, 2014a). Mais da metade do aumento na demanda ocorreu nos setores de indústria e transportes, justamente os de maior consumo energético em termos absolutos (Figura 1.6). O aumento da demanda por energia pelo setor de transportes provém quase que exclusivamente do transporte rodoviário, refletindo o rápido aumento da frota de veículos (ANFAVEA, 2015).

O aumento do consumo de energia acompanhou o ritmo do crescimento do PIB, pois a intensidade energética da economia (OTEP por unidade do PIB) permaneceu relativamente estável. A intensidade energética do Brasil é menor que a média da OCDE e significativamente abaixo da dos outros BRIICS devido, principalmente, à quantidade relativamente pequena de energia utilizada para aquecimento e resfriamento e à grande participação da energia hidroelétrica na matriz energética. ${ }^{5}$ A procura por energia per capita aumentou em cerca de $31 \%$ entre os anos de 2000 e 2012, mas permaneceu aproximadamente um terço abaixo da média da OCDE devido, em parte, à persistência da diferença de renda (ver Anexo 1.A e Estatísticas Básicas).

\subsection{Emissões de gases de efeito estufa (GEE)}

\section{Perfil das emissões de GEE}

Em 2010, o Brasil foi o sexto maior emissor de gases de efeito estufa (atrás da China, Estados Unidos, Índia, Rússia e Indonésia) contribuindo em 3,2\% das emissões globais de GEE (IEA, 2014b). Duas características distinguem o perfil brasileiro de emissão daqueles da maioria das economias da OCDE e BRIICS. A primeira sendo que a grande participação de fontes renováveis resulta em níveis de emissões relativamente baixos no setor de energia que, na maioria dos países da OCDE, responde pelo grosso das emissões de GEE. A segunda sendo o chamado LULUCF, ${ }^{6}$ (i.e., Uso da Terra, Mudança no Uso da Terra e Florestas) principalmente o desmatamento, que tem sido uma das principais causas das emissões de GEE no Brasil. De acordo com estimativas nacionais, 60\% das emissões líquidas resultaram do LULUCF na primeira metade dos anos 2000 (MCTI, 2014a). O Instituto de Economia Agrícola (IEA) estimou que, em 2010, o LULUCF (excluindo as remoções) ainda representava 35\% das emissões, assim deixando o Brasil em segundo lugar, atrás apenas da Indonésia (IEA, 2014b; Figura 1.7).?

As emissões totais de GEE do Brasil caíram 43\% entre 2000 e 2012, em virtude de uma queda constante do desmatamento e das emissões associadas desde meados da década de 2000 (Figura 1.7; Seção 5.1). No entanto, projeções indicam que as emissões tendem a aumentar (Figura 1.7). As emissões de GEE provenientes de outros setores que não os do LULUCF aumentaram de forma constante em cerca de $35 \%$ do total, entre 2000 e 2012. A tendência foi especialmente acentuada no que diz respeito a emissões provenientes do setor de energia (+49\%) principalmente em consequência do aumento no consumo de combustíveis fósseis nas indústrias e no transporte rodoviário. 
As emissões provenientes da agricultura também cresceram substancialmente (+28\%). Em 2012, a energia e a agricultura já haviam desbancado o uso da terra no ranking das fontes primárias de emissões, sendo responsáveis por 37\% das emissões totais; seguidas pelo LULUCF (15\%); processos industriais (7\%); e gestão de resíduos (4\%) (MCTI, 2014a).

\section{Figura 1.6. O consumo de energia para os transportes e a indústria vem aumentando rapidamente}

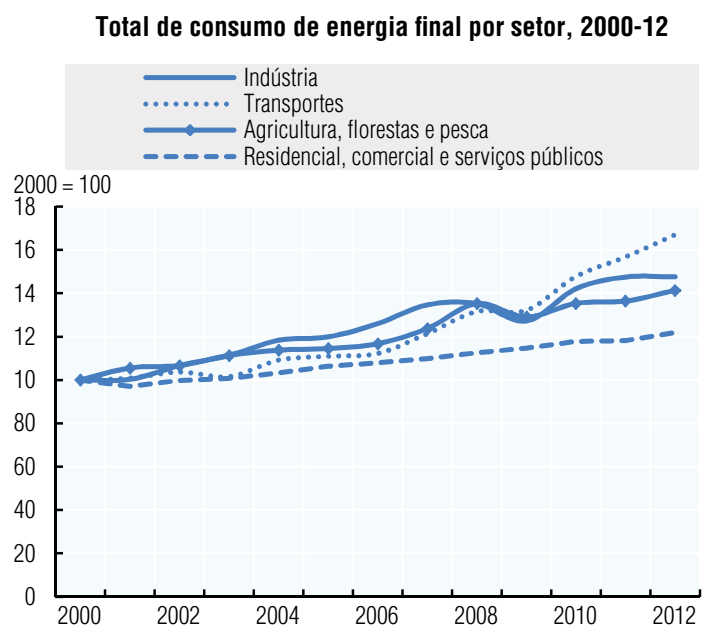

Total de consumo de energia final por setor, 2012

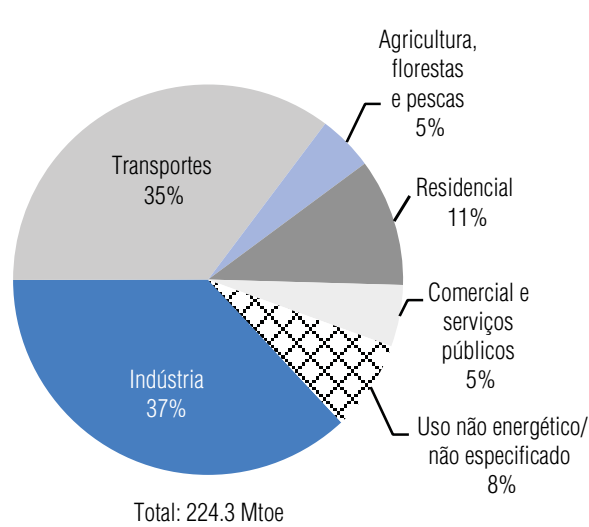

Fonte: IEA (2014), IEA World Energy Statistics and Balances (banco de dados).

Em 2010, o Brasil se comprometeu a limitar as emissões entre $36,1 \%$ e $38,9 \%$, em relação ao cenário "em que nada tivesse sido feito" (Business as usual ou BAU em inglês) até 2020, ${ }^{8}$ o que define um teto de cerca de 2 bilhões de toneladas de $\mathrm{CO}_{2}$ equivalentes ( $\mathrm{tCO}_{2} \mathrm{eq}$ ) representando um aumento em relação a 2012, quando o teto era de cerca de 1,2 bilhão de $\mathrm{tCO}_{2}$ eq (Figura 1.7). Como quase metade das emissões futuras projetadas contempla esforços para conter as emissões provenientes do LULUCF, os avanços alcançados na redução do desmatamento significam que o Brasil está bem posicionado para atingir a meta. No entanto, as últimas estimativas sugerem que tanto o LULUCF quanto as emissões totais cresceram cerca de 8\% entre 2012 e 2013 (SEEG, 2014) ${ }^{9}$ o que pode dificultar o alcance da meta.

\section{Intensidades das emissões}

Apesar de uma queda desde meados dos anos 2000, a intensidade das emissões de GEE do Brasil (emissões de GEE, excluindo LULUCF, por unidade do PIB) permaneceu próxima à média da OCDE em 2012 (ver Estatísticas Básicas). A intensidade de carbono do Brasil (emissões de carbono provenientes da queima de combustível por unidade do PIB) tanto per capita quanto por unidade do PIB é baixa em termos internacionais graças, em parte, à matriz energética de baixo carbono e ao fato de o consumo de energia per capita ainda estar significativamente abaixo dos níveis da OCDE (Figura 1.8 e Anexo 1.B). As emissões de $\mathrm{CO}_{2}$ provenientes da queima de combustíveis fósseis aumentaram num ritmo mais lento que o crescimento do PIB, resultando em um descompasso entre o crescimento econômico e a queda da intensidade de carbono da economia (2\%) no período entre 2000 e 2012. No entanto, as emissões de carbono relacionadas à energia per capita cresceram $26 \%$ no período (Figura 1.8) acompanhando o aumento do consumo de energia per capita. 


\section{Figura 1.7. As emissões GEE provenientes do desmatamento diminuíram, mas estão aumentando em outros setores}
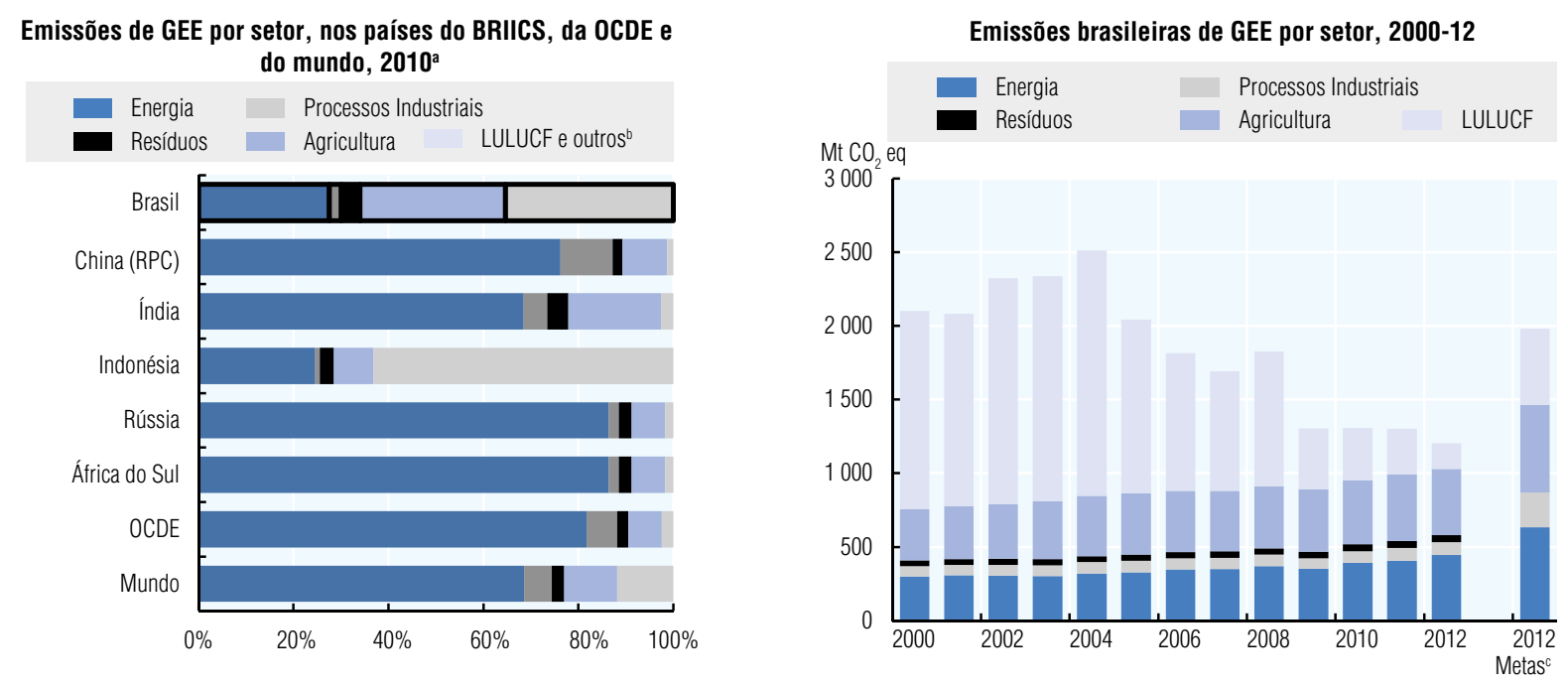

a) Estimativas da IEA

b) Exclui remoções da LULUCF e inclui emissões de: incêndios florestais de turfa e outras vegetações; degradação de solos de turfa drenadas e de biomassa superficial remanescente de atividades madeireiras e do desmatamento (IPCC cat. 5); uso de solventes (IPCC cat. 3); aplicação de calcário na agricultura (IPCC cat. 4); combustão de combustíveis fósseis (IPCC cat. 7); alguns processos industriais como a produção de metanol (IPCC cat. 2); uso de $\mathrm{N}_{2} 0$, descarga de esgoto humano e incineração de resíduos (não energético), e descarga indireta de $\mathrm{N}_{2} 0$ proveniente de deposição atmosférica de $\mathrm{NO}_{\mathrm{x}}$ e NH3 proveniente de fontes não agrícolas (IPCC cat. 3, 6 and 7). c) Conforme Decreto n. 7.390/2010, que define as emissões de GEE previstas no cenário "se nada for feito" (BAU) e metas setoriais de redução de emissões que variam de $36.1 \%$ a $38.9 \%$ do BAU. A categoria " processos industriais " inclui as emissões provenientes da gestão de resíduos.

Fonte: IEA (2014), "Emissions of $\mathrm{CO}_{2}, \mathrm{CH}_{4}, \mathrm{~N}_{2}, \mathrm{O}, \mathrm{HFCS}$, PFCS and SF", IEA CO, Emissions from Fuel Combustion Statistics (banco de dados); MCTI (2014; 2013), Estimativas anuais de emissões de gases de efeito estufa no Brasil; MCTI (2010), Segundo Relatório Nacional do Brasil ao UNFCCC.

\section{Figura 1.8. A intensidade do carbono do Brasil continua baixa em termos internacionais}

Intensidade de carbono do Brasil,a 2000-12

$\mathrm{CO}_{2}$ per capita $\quad-\quad--\mathrm{CO}_{2}$ por $\mathrm{PIB}^{\mathrm{b}}$

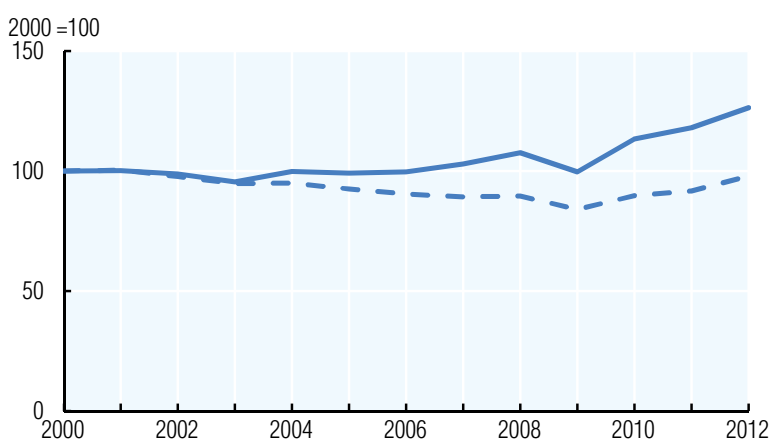

Intensidade de carbono da OCDE e dos BRIICS, ${ }^{2} 2012$

$$
\mathrm{CO}_{2} \text { por PIB } \quad \diamond \mathrm{CO}_{2} \text { per capita (eixo x) }
$$

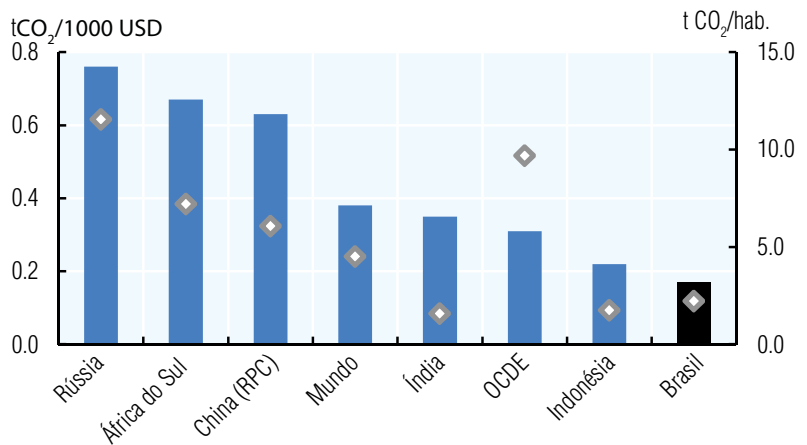

a) emissões de $\mathrm{CO}_{2}$ apenas do consumo de energia; abordagem setorial; exclui bunkers marítimos e de aviação internacional. b) PIB a preços de 2005 e paridade de poder de compra. Dados incluem estimativas.

Fonte: IEA (2014), IEA CO, Emissions from Fuel Combustion Statistics (banco de dados); OCDE (2014), "OECD Economic Outlook No. 95", OECD EConomic Outlook:

Statistics and Projections (banco de dados); OECD (2014), "Population projections", OECD Historical population data and projections statistics (banco de dados).

\subsection{Outras emissões atmosféricas e qualidade do ar}

\section{Emissões atmosféricas}

Dados sobre emissões atmosféricas são limitados; o MMA publicou dois inventários sobre emissões atmosféricas no setor de transportes (2011 e 2013), mas as emissões 
atmosféricas provenientes de fontes pontuais não são sistematicamente capturadas ou agregadas em nível nacional. Como na maioria dos países, os setores de transporte, indústria e geração de energia são as principais fontes da poluição atmosférica.

Dados disponíveis sugerem que as emissões totais de monóxido de carbono (CO) permaneceram relativamente estáveis entre 2000 e 2010, com diminuição nos setores de energia e LULUCF e aumento na agricultura (+77\%). As emissões totais de óxido de nitrogênio $\left(\mathrm{NO}_{\mathrm{x}}\right)$ aumentaram em 15\% no período entre 2000 e 2010, principalmente devido à queima de combustíveis fósseis para a geração de energia, mas também ao aumento das emissões LULUCF (MCTI, 2014b). As emissões de compostos orgânicos voláteis (COVs) aumentaram 37\% no período entre 2000 e 2010, principalmente em consequência da produção e utilização de solventes e processos industriais (Figura 1.9). Não existem inventários nacionais transetoriais sobre outros poluentes atmosféricos, tais como óxidos de enxofre $\left(\mathrm{SO}_{\mathrm{x}}\right)$ e amônia $\left(\mathrm{NH}_{3}\right)$.

\section{Figura 1.9. Emissões atmosféricas provenientes do transporte vêm diminuindo, mas as emissões globais vêm aumentando}
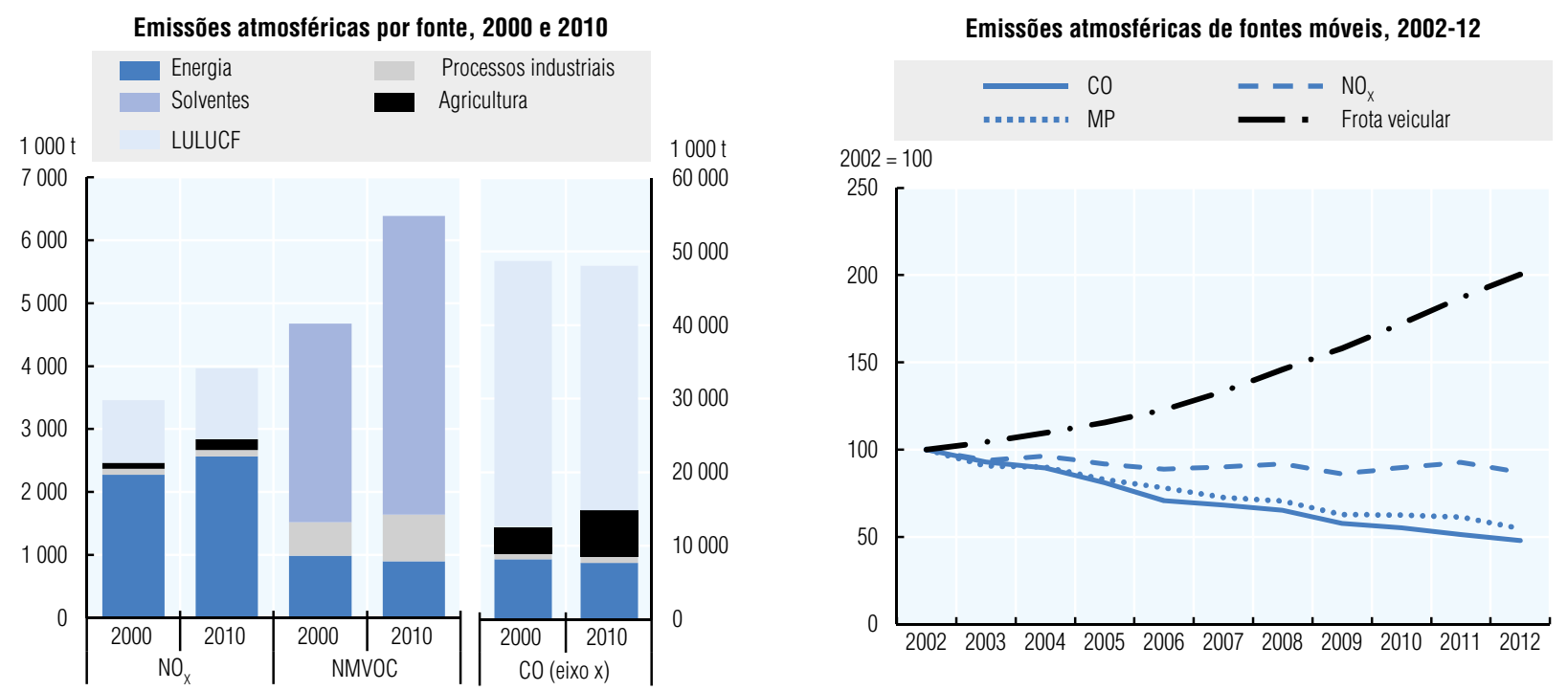

Fonte: ANFAVEA (2014), Anuário da Indústria Automobilística Brasileira; MMA (2014), Inventário Nacional de Emissões Atmostéricas por Veículos Automotores Rodoviários, 2013; Primeiro Relatório de Atualização Bienal do Brasil para o UNFCCC (2014).

O número de veículos em circulação mais que dobrou entre 2000 e 2014, chegando a 35 veículos por 100 habitantes, proporção bem abaixo da média da OCDE e dos índices de propriedade de veículos da maioria dos países da OCDE (ver Anexo 1.A e Estatísticas Básicas). No entanto, as emissões de $\mathrm{CO}, \mathrm{NO}_{\mathrm{x}}$ e de material particulado (MP) de fontes móveis diminuíram significativamente, graças a normas de emissões veiculares mais rigorosas, a aprimoramentos na tecnologia de veículos rodoviários e à ampla difusão do etanol para uso em automóveis (Figura 1.9; ver também Capítulo 3). As emissões de $\mathrm{NO}_{\mathrm{x}}$ e de material particulado relacionadas ao transporte provêm, em grande medida, de ônibus e veículos pesados movidos a diesel. No período entre 2002 e 2012, as emissões de material particulado provenientes de fontes móveis caíram $45 \%$. As emissões de $\mathrm{NO}_{\mathrm{x}}$ provenientes do transporte diminuíram $13 \%$, graças ao melhor desempenho da frota de carros de passeio, enquanto que as emissões de $\mathrm{NO}_{\mathrm{x}}$ provenientes de caminhões pesados aumentaram em cerca de 25\% (MMA, 2014a). 


\section{Qualidade do ar}

A poluição do ar nas áreas urbanas é considerada um sério desafio ambiental (IBGE, 2012a). No entanto, dados quantitativos sobre a poluição atmosférica são escassos, pelo fato de o Brasil não possuir um eficaz sistema de monitoramento da qualidade do ar. A lei determina que os estados monitorem e produzam relatórios anuais de qualidade do ar, mas apenas 12 dos 27 estados (incluindo o Distrito Federal) contavam com algum tipo de sistema de monitoramento instalado em 2012, e poucos estados divulgam e disponibilizam dados consistentes (IEMA, 2012). Menos de $2 \%$ dos municípios monitoram a qualidade do ar (ISS, 2014).

Os problemas de qualidade do ar de maior gravidade são causados pelas emissões de $\mathrm{MP}_{10}$ produzidas pelas indústrias e pelo transporte. Em nível nacional, a exposição média à poluição atmosférica do tipo $\mathrm{MP}_{2.5}$ é relativamente baixa, em comparação com a maioria dos países da OCDE (Anexo 1.B). No entanto, essa média oculta grandes diferenças entre as áreas urbanas e rurais. Os poluentes $\mathrm{MP}_{10}, \mathrm{MP}_{2.5}$ e ozônio $\left(\mathrm{O}_{3}\right)$ são os que mais frequentemente excedem as normas nacionais e/ou internacionais, ao passo que parece haver um melhor controle sobre os poluentes $\mathrm{CO}, \mathrm{SO}_{2}$ e $\mathrm{NO}_{2}$. Essa diferença pode estar parcialmente ligada à composição das névoas poluidoras encontradas nas áreas urbanas brasileiras, que têm relação com a queima do etanol combustível no transporte rodoviário ${ }^{10}$ (IEMA, 2014; MCTI, 2010); entretanto, é possível que tal diferença possa ser explicada pela menor disponibilidade de dados pontuais a respeito dos poluentes $\mathrm{CO}, \mathrm{SO}_{2}$ e $\mathrm{NO}_{2}$.

As concentrações de $\mathrm{MP}_{10}$ foram reduzidas na maioria das cidades com mais de 100 mil habitantes nas duas últimas décadas, graças, principalmente, ao controle mais rígido das emissões veiculares; aos avanços na tecnologia de motores; e à melhoria da qualidade do combustível (BIRD, 2015; IBGE, 2012a; ver também Capítulo 2). Essa redução resultou na diminuição no nível de exposição média anual de residentes de áreas urbanas ao MP atmosférico, de 46 para $36 \mu g / \mathrm{m}^{3}$ no período entre 2000 e 2011 (BIRD, 2015). ${ }^{11}$ Entretanto, as concentrações médias anuais permanecem acima desse nível em várias áreas metropolitanas; ademais, em várias cidades, as concentrações máximas ainda excedem as normas nacionais de qualidade do ar. Entre as cidades monitoradas, o Rio de Janeiro, cidade com grandes problemas de congestionamento de trânsito, registrou os níveis mais elevados de exposição ao $\mathrm{MP}_{10}$ em 2010: tanto em relação à maior concentração média anual $\left(67 \mu \mathrm{g} / \mathrm{m}_{3}\right)$ quanto à maior concentração máxima (574 $\mu \mathrm{g} /$ m3). Em São Paulo, apesar de as concentrações de $\mathrm{MP}_{10}$ terem diminuído ao longo da década de 2000, a cidade ainda enfrenta altas concentrações de $\mathrm{O}_{3}$ : concentrações essas que excederam a média da norma de qualidade nacional (por período de oito horas) 257 vezes em 2010, ou seja, durante mais de 70\% do ano (IBGE, 2013).

A má qualidade do ar apresenta severos riscos à saúde da população brasileira, até mesmo em áreas onde os níveis de poluição permanecem abaixo das normas de emissão nacional (OLMO et al., 2011). Estimativas sugerem que apenas nos estados de São Paulo e Rio de Janeiro, 135 mil pessoas morreram de doenças causadas pela poluição do ar, entre 2006 e 2011 (ISS, 2014).

\section{Substâncias destruidoras da camada de ozônio}

Nas duas últimas décadas, o Brasil reduziu a utilização de substâncias que destroem a camada de ozônio em mais de $80 \%$, superando as metas estabelecidas no Protocolo de Montreal (IBGE, 2013). Os clorofluorcarbonos (CFCs) principal causa de destruição da camada de ozônio e o brometo de metila foram eliminados em 2010, conforme determinação do Protocolo de Montreal. O uso dos hidroclorofluorcarbonos, substituto 
comum para os CFCs, com menor potencial de destruição da camada de ozônio, mas com alto potencial de aquecimento global, aumentou na década de 2000.

\section{Transição para uma economia de aproveitamento eficiente de recursos}

\subsection{Consumo de materiais}

O consumo interno de materiais (CIM) $)^{12}$ aumentou em mais de $70 \%$ entre os anos de 2000 e 2011, crescimento mais acelerado que em qualquer país da OCDE ou dos outros BRIICS, com exceção da China. Como o CIM aumentou mais rápido que o PIB, a produtividade de materiais (PIB por CIM) deteriorou em 14\%, enquanto que, na maioria dos países da OCDE e em todos os países BRIICS, essa proporção melhorou (Figura 1.10; Anexo 1.C). Em 2011, a produtividade de materiais do Brasil era de cerca de um quarto da média da OCDE e abaixo da média dos BRIICS. O consumo de materiais per capita também vem crescendo e é alto: em 2010, o CIM per capita foi 50\% acima da média da OCDE e bem acima dos outros países BRIICS.

\section{Figura 1.10. Consumo interno de materiais aumentou mais rápido que o PIB}

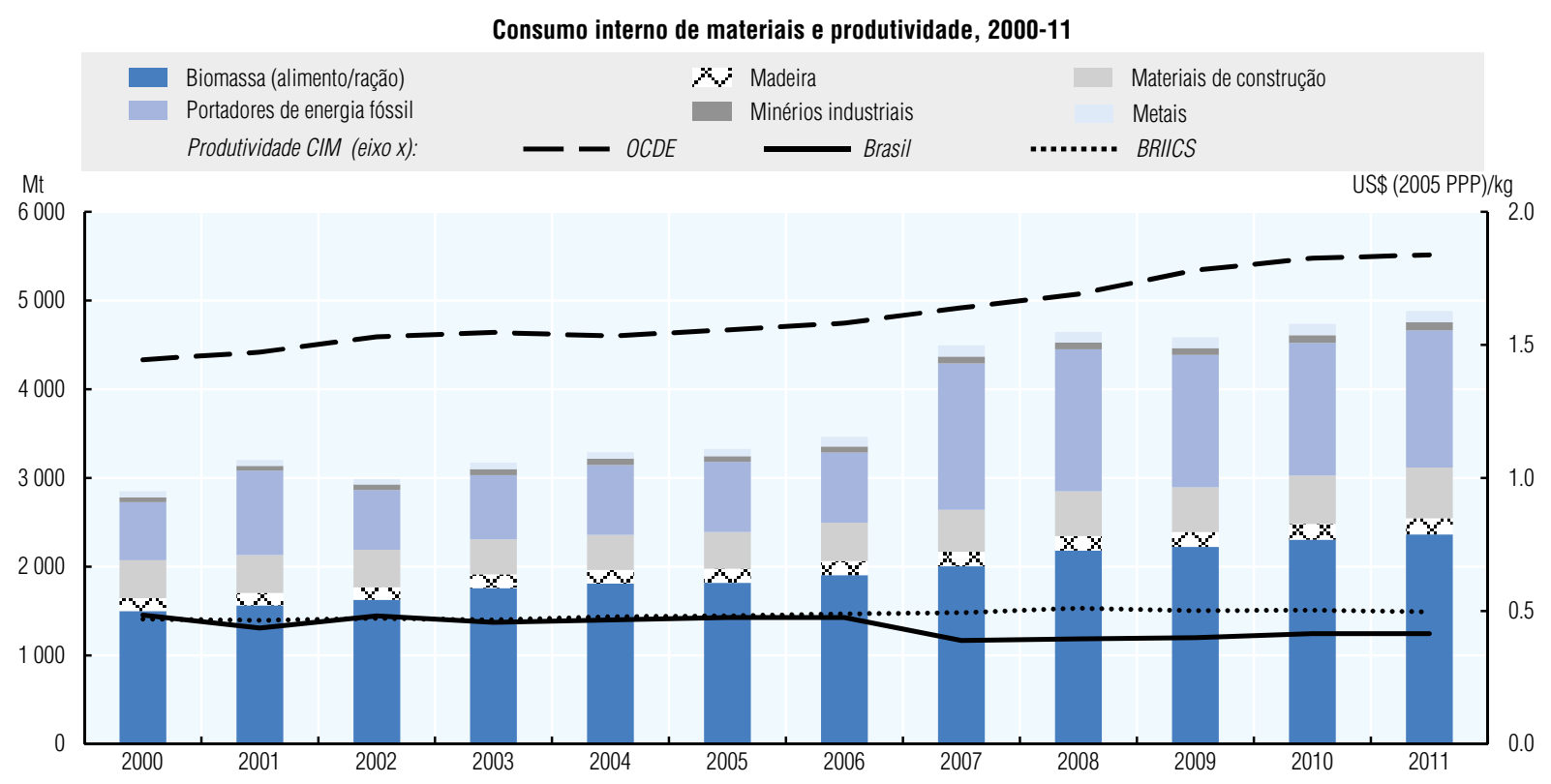

Obs.: Consumo interno de materiais (CIM) designa a soma das matérias primas extraídas e consumidas internamente por uma economia e sua balança comercial física. Produtividade material se refere ao montante do PIB gerado por unidade de material utilizado e corresponde ao coeficiente do CIM/PIB. Um aumento da produtividade material equivale a uma diminuição da intensidade material (i.e., CIM/PIB).

Fonte: OCDE (2015), "Material resources", OECD Environment Statistics (banco de dados).

Devido à pujança dos setores agrícola e florestal, a biomassa e a extração de madeira representam mais da metade do total do CIM do Brasil, proporção maior que em qualquer país da OCDE (Anexo 1.C). O CIM relativo à biomassa aumentou em 58\% entre 2000 e 2011, período de grande expansão da produção de etanol de cana de açúcar. O CIM relativo a combustíveis fósseis e metais aumentou ainda mais rápido, em consequência do salto na extração petrolífera nacional em 2006/2007 e do aumento das exportações de metais (Figura 1.10). As exportações brasileiras de materiais são maiores que as importações, e o superávit comercial vem crescendo, refletindo o papel crescente das commodities (notadamente minerais e biomassa) na pauta de exportações (Ver Estatísticas Básicas). 


\subsection{Gestão de resíduos}

Devido à escassez de dados sobre produção, coleta, tratamento e disposição final de resíduos sólidos, qualquer interpretação exige cautela. ${ }^{13}$ De acordo com a Associação Brasileira de Empresas de Limpeza Pública e Resíduos Especiais (ABRELPE) a quantidade de resíduos sólidos municipais (RSM) produzida anualmente aumentou em cerca de 10\% no período entre 2009 e 2012, refletindo uma elevação nos padrões de vida e nos níveis de consumo. Nos últimos anos, o aumento do volume de RSM foi mais rápido que o crescimento populacional, porém mais lento que o consumo privado (ABRELPE, 2012; BIRD, 2015). A produção de resíduos per capita permanece significativamente abaixo dos níveis da OCDE (ver Anexo 1.F e Estatísticas Básicas).

O Brasil alcançou avanços significativos na expansão do acesso aos serviços de coleta de resíduos domiciliares, apesar de grandes disparidades geográficas. Nas áreas urbanas, o acesso aumentou de $96 \%$ em 2004, para mais de $98 \%$ em 2012; já nas áreas rurais, aumentou de $20 \%$ para $53 \%$, embora os dados não sejam plenamente comparáveis ao longo do tempo (Figura 1.11). A cobertura de serviços tende a ser menor nos pequenos municípios, assim como nas regiões Norte e Nordeste, onde somente $85 \%$ e $88 \%$, respectivamente, da população teve acesso a serviços de coleta de resíduos. Estima-se que, anualmente, mais de 6 milhões de toneladas de resíduos sólidos urbanos (quase $10 \%$ do total) sejam queimados, enterrados ou despejados (ABRELPE, 2012).

\section{Figura 1.11. A gestão de resíduos melhorou, mas os desafios persistem nas áreas rurais}

Acesso a serviços de gestão de resíduos, ${ }^{a} 2012$

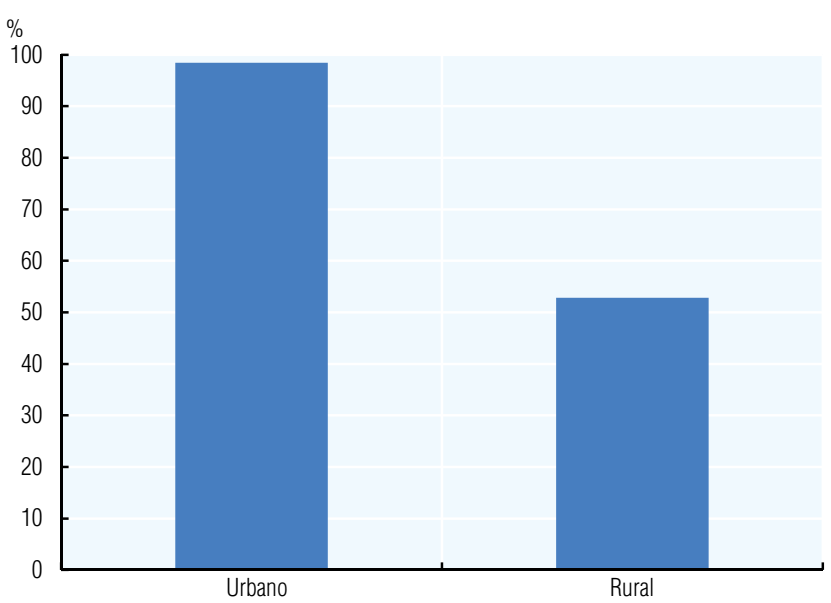

Disposição municipal de resíduos por tipo, ${ }^{\mathrm{b}} 2000$ e 2008

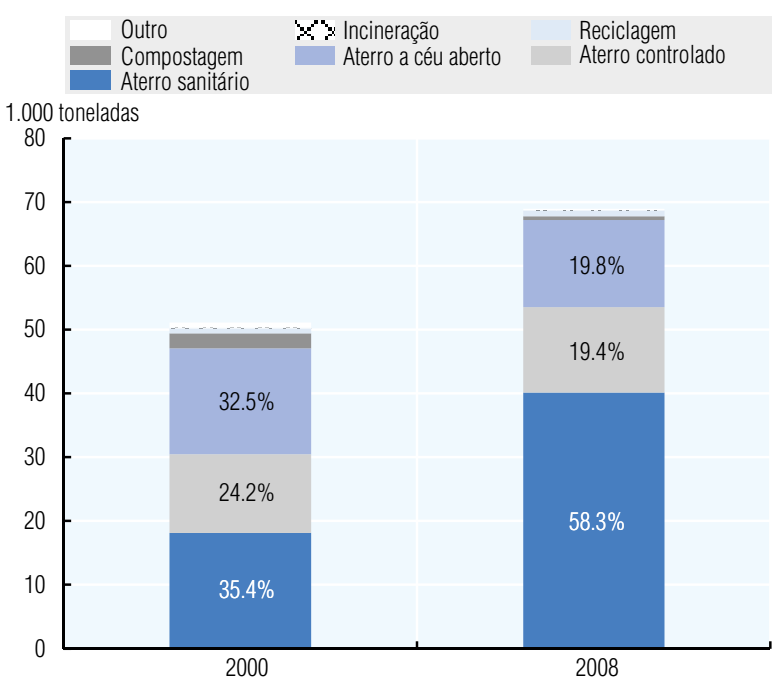

a) Estimativas baseadas em pesquisas por amostragem abrangendo cerca de 50\% dos municípios.

b) Inclui resíduos provenientes de domicílios, escritórios, instituições, comércio e alguns serviços municipais (i.e., limpeza urbana). Aterro controlado: local operado em conformidade com procedimentos de controle técnico, mas sem exigência de medidas de mitigação ambiental. Aterro sanitário: Iocal operando em plena conformidade com procedimentos de controle técnico e medidas para reduzir impactos ambientais (i.e., contaminação de águas subterrâneas).

Fonte: MMA (2012), Plano Nacional de Resíduos Sólidos; UNSD (n.d.), UNSD Environmental Indicators.

O tratamento e a disposição final adequada de resíduos sólidos municipais ainda apresentam grandes desafios. A exemplo de outras economias em desenvolvimento ou emergentes, a principal modalidade de disposição final é em aterros, que, em 2008, responderam por quase $98 \%$ do tratamento no Brasil. A disposição de resíduos em aterros não sanitários (isto é, locais sem medidas para minimizar danos ambientais, como a contaminação de águas subterrâneas) diminuiu no período entre 2000 e 2008, 
especialmente a disposição em lixões a céu aberto (Figura 1.11). Apesar dessa tendência de melhoria, o Brasil ficou aquém da sua meta nacional de eliminação de aterros não controlados até agosto de 2014. Municípios de menor porte e aqueles com grandes zonas rurais têm maior dificuldade em cumprir com a legislação nacional, devido a carências de capacidades institucionais e de economias de escala (Capítulos 2 e 3). Além disso, a gestão de resíduos orgânicos no Brasil é malconduzida, apesar da elevada parcela desses resíduos no total do RSM (51\%). Em 2008, menos de $2 \%$ dos resíduos orgânicos coletados foram direcionados a instalações de compostagem, que são quase inexistentes (MMA, 2012).

A reciclagem é muito limitada. Estima-se que apenas $27 \%$ dos resíduos recicláveis coletados são efetivamente recuperados. A exemplo de outros países em desenvolvimento ou emergentes, a triagem é feita por "catadores", pessoas que ganham a vida coletando e vendendo esses materiais recicláveis para empresas privadas de reciclagem (Capítulo 3). Os catadores são responsáveis por quase $20 \%$ dos resíduos separados para reciclagem, bem como pelas altas taxas de reciclagem de latas de alumínio (98\%) e de embalagens PET (57\%). Apenas cerca de 15\% dos municípios, a maioria localizada nas regiões Sudeste e Sul, oferecem serviços de coleta seletiva (CEMPRE, 2013).

\subsection{Agricultura e aporte de nutrientes}

O Brasil é o quarto maior produtor agrícola do mundo, respondendo por $6 \%$ da produção mundial, atrás apenas da China (23\%), Estados Unidos (10\%) e Índia (10\%). A agricultura é responsável por 15\% dos empregos; $75 \%$ da força de trabalho rural (cerca de 12 milhões de brasileiros) é empregada na agricultura familiar, de pequena escala e produtividade relativamente baixa (IBGE, 2009). A produção agrícola aumentou 70\% entre 2000 e 2012 (MMA, 2015a) tanto por conta de ganhos de produtividade, quanto (especialmente no início dos anos 2000) pela expansão de áreas voltadas à agricultura e à pecuária. A densidade da pecuária aumentou juntamente com o aumento do rebanho, ficando em cerca do dobro da média da OCDE em 2013, mas permanecendo abaixo da de várias regiões com produção pecuária mais intensiva (por exemplo, a Coreia e alguns países europeus; ver Anexo 1.C).

O uso de fertilizantes e pesticidas se intensificou no Brasil. Estatísticas nacionais revelam um forte aumento no consumo de fertilizantes no período entre 2000 e 2010, tanto em termos absolutos (+137\%) (IBAMA, 2013) quanto por unidade de área sob cultivo (Figura 1.12). O Brasil é um dos maiores consumidores mundiais de fertilizantes (atrás apenas da China, Índia e Estados Unidos) (FAO, 2014). A utilização de fertilizantes é notadamente elevada em certas culturas, como a soja (ACCIOLI; MONTEIRO, 2011). É ainda mais alta nas regiões Sul e Sudeste, onde predomina a agricultura de grande escala, e vem sendo associada ao aumento de pressões sobre a qualidade da água e do solo.

O aumento no consumo de pesticidas foi ainda mais forte, de cerca de $200 \%$ desde o ano 2000 (Figura 1.12). Em 2010, o valor das vendas de pesticidas alcançou US\$ 7,2 bilhões, $10 \%$ mais do que no mercado americano (PELAEZ et al., 2013). Quase um terço dos pesticidas consumidos são considerados perigosos ou altamente prejudiciais ao meio ambiente, e várias substâncias amplamente utilizadas foram identificadas como prejudiciais aos polinizadores, especialmente as abelhas (IBAMA, 2013; MMA, 2015a). O uso generalizado de pesticidas está associado à prática agrícola de cultivo mínimo e plantio direto. Práticas alternativas de controle de pragas, como a rotação de culturas e o controle biológico, são incomuns; talvez, em parte, porque uma quantidade relativamente grande de agricultores (78\%) cursou apenas o ensino fundamental (IBGE, 2012a). Essa baixa escolaridade pode explicar também o porquê de $20 \%$ dos consumidores de pesticidas, quando da aplicação dos mesmos, não usarem equipamentos de proteção. 
Figura 1.12. O uso de produtos químicos na agricultura é elevado e vem aumentando
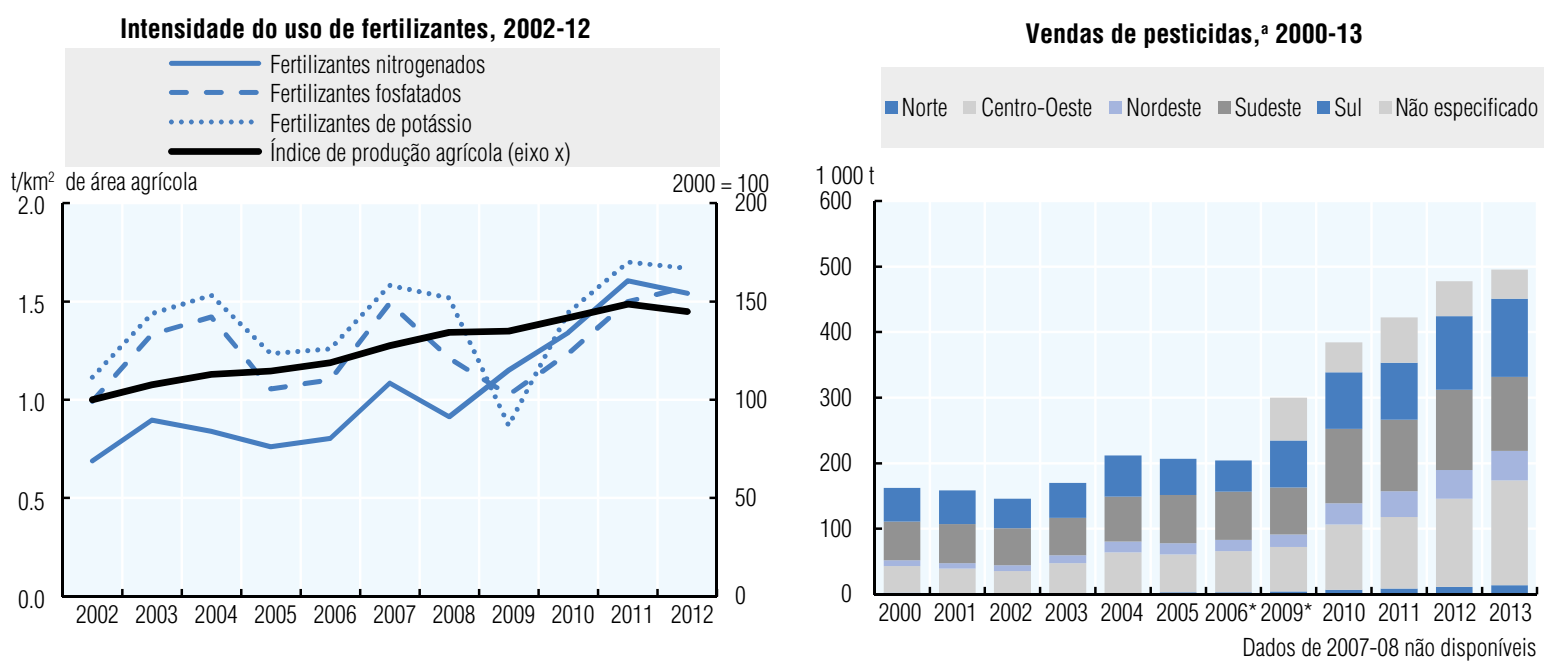

a) Pesticidas e produtos similares, segundo 0 Decreto n. 4.074 de 4 de janeiro de 2002.

Fonte: FAO (2014), FAOSTAT (banco de dados); IBAMA (2013), Agrotóxicos e Afins - Histórico das Vendas - 2000 a 2012.

O elevado uso de produtos químicos agrícolas, e principalmente o de produtos não autorizados, tornou-se um problema de saúde pública. Esses produtos são a segunda causa de intoxicação, perdendo apenas para os medicamentos (MMA, 2010). Um estudo revelou que $36 \%$ de amostras de alimentos em 2011, e 29\% em 2012, continham pesticidas não autorizados e/ou teores de pesticida acima do permitido (ANVISA, 2013).

A agricultura orgânica responde por uma parcela muito pequena da produção agrícola. O último censo agrícola nacional revelou que, em 2006, menos de $2 \%$ das propriedades rurais produziam de forma orgânica e que destas, $82 \%$ eram da agricultura familiar e que, se tivessem acesso, teriam usado insumos químicos (IBGE, 2012b). Em 2014, cerca de 7.200 estabelecimentos registrados produziam produtos orgânicos certificados (MMA, 2015a) ou cerca de 0,1\% da produção total, e menos de 1\% da área dedicada à agricultura (Figura 4.11).

\section{Gestão da base de ativos naturais}

\subsection{Biodiversidade}

O Brasil é o país de maior biodiversidade do mundo. Abriga cerca de 10 a 12\% de todas as espécies conhecidas e mais espécies endêmicas que qualquer outro país (CDB, s. d). Quinto maior país do mundo, engloba $47 \%$ da superfície do continente sul-americano e se estende por 7.500 quilômetros ao longo da costa atlântica. Em virtude da sua vasta dimensão, possui uma grande diversidade de características físicas, de clima, vegetação e padrões de uso da terra. Por conseguinte, são tipificados seis grandes ecossistemas terrestres, ou biomas: ${ }^{14}$ Amazônia, Cerrado, Caatinga, Mata Atlântica, Pantanal e Pampa (Box 4.1). Os biomas Mata Atlântica e Cerrado são dois dos 35 hotspots de biodiversidade do mundo (Capítulo 4). O Brasil possui ainda vastas áreas costeiras e marinhas; abriga ricos ecossistemas de recifes de corais e tem a maior área contígua de manguezais.

Apesar de esforços passados e atuais para proteger as riquezas naturais do Brasil (Capítulo 4) as ameaças à biodiversidade persistem. Os avanços da fronteira agropecuária, a extração de recursos naturais, a implantação de infraestruturas e o desenvolvimento 
são as principais causas de perda de habitat (Figura 1.13). Historicamente, a falta de clareza em relação à situação fundiária tem exacerbado as pressões do desmatamento, mas o Novo Código Florestal e seus mecanismos de implementação (especialmente o Cadastro Ambiental Rural; ver Capítulo 4) prometem reduzir a extração ilegal de madeira para fins de titulação de terras. Outras ameaças à biodiversidade incluem: espécies invasoras e doenças exóticas, superexploração, poluição, incêndios e mudanças climáticas (MMA, 2015a).

\section{Florestas e desmatamento}

Dos imensos recursos florestais do Brasil, $98,5 \%$ são nativos, incluindo a maior floresta tropical do mundo (SFB ,2015). Em 2012, 62\% do território nacional era coberto por florestas, o dobro da média da OCDE (ver Estatísticas Básicas). Menos de 1\% do total da área de floresta é utilizado para produção madeireira (SFB, 2013). ${ }^{15}$ O Brasil é grande produtor e consumidor de madeira tropical: em 2007, o setor florestal representou 3,5\% do PIB; 7,3\% das exportações; e empregou cerca de 7 milhões de pessoas (SFB, 2015).

Cerca de 70\% do território nacional mantêm sua cobertura vegetação original, em distintos graus de conservação (MMA, 2010). A proporção varia muito entre os biomas; com a Amazônia e o Pantanal mantendo mais de $80 \%$ da sua vegetação original; e o bioma Mata Atlântica, onde vivem três quartos dos brasileiros, cerca de 20\% (Figura 1.13).

Figura 1.13. A cobertura vegetal diminuiu em alguns biomas brasileiros

\section{Causas de perda de habitat, final dos anos 2000}

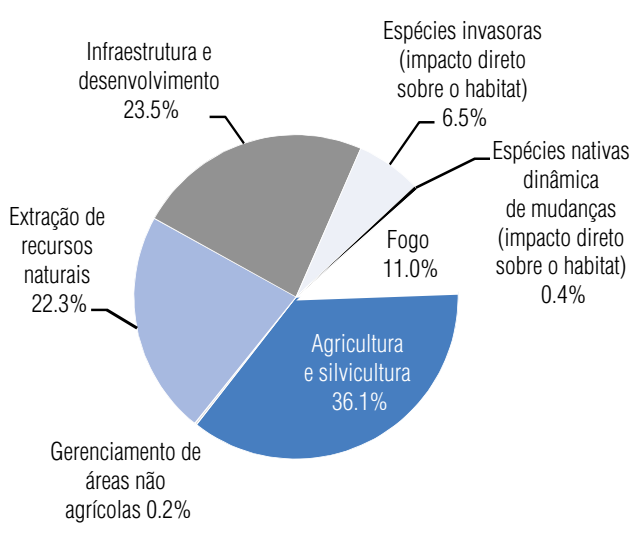

Vegetação nativa por bioma, 2009

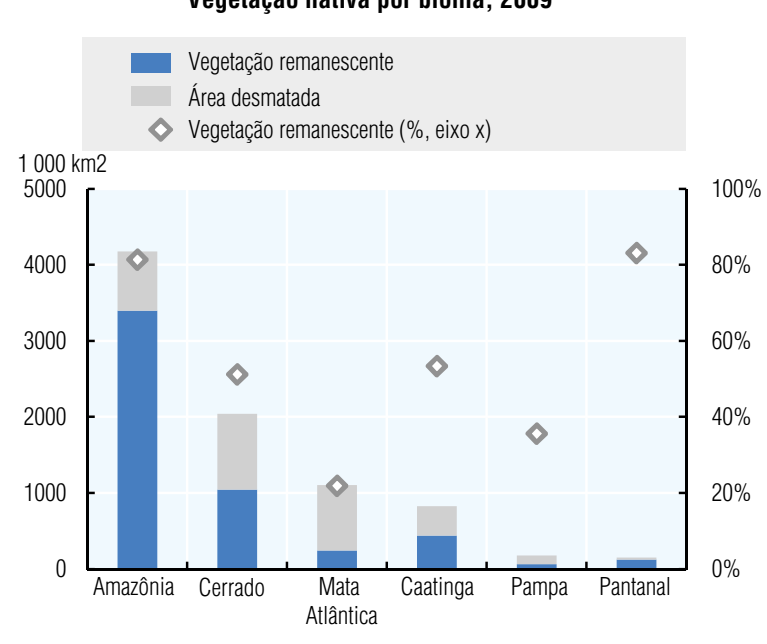

Fonte: Martinelli G. e M.A. Moraes (2013), Livro vermelho da flora do Brasil; MMA (2015), Quinto Relatório Nacional à Convenção sobre a Diversidade Biológica.

A Amazônia Legal ${ }^{16}$ era considerada um hotspot de desmatamento nos anos 1990 e no início dos anos 2000. Picos de desmatamento foram registrados em 1994 e 2004, mas atualmente é reconhecido o sucesso das ações de controle do desmatamento na região. Uma parcela significativa do desmatamento devia-se à extração ilegal da madeira, sendo a terra desmatada utilizada para a pastagem (MMA, 2015a). Em 2006, o governo propôs reduzir o desmatamento na Amazônia Legal em 80\% até 2020 (em comparação com a média dos dez anos anteriores ${ }^{17}$ e desde então ampliou consideravelmente as ações de combate ao desmatamento (ex., criação de áreas protegidas, regularização fundiária e maior monitoramento, controle e fiscalização; ver Capítulos 4 e 5). O resultado foi a redução do desmatamento, de $28.000 \mathrm{~km}^{2}$ ao ano em 2004, para cerca de $4.800 \mathrm{~km} 2$ ao ano em 2014, período em que a taxa de desmatamento caiu em 75\% (Figura 4.3) 
(INPE, 2015). As taxas de desmatamento em outros biomas também caíram nos últimos anos. Entretanto, as pressões permanecem altas no bioma Cerrado, que perdeu 0,4\% da sua área total de floresta no período entre 2008 e 2009 (IBAMA, 2015). No geral, a área total de florestas diminuiu cerca de $5 \%$, desde o ano 2000.

\section{Áreas protegidas}

Um fator propulsor da queda no desmatamento foi a rápida expansão das áreas sob proteção (Capítulo 5). O número oficial de unidades de conservação terrestres aumentou, de 919 em 2000, para 1.940 no início de 2015; ou seja, de 9\% para 17,2\% do território nacional (MMA, 2015b). ${ }^{18}$ O Brasil alcançou a meta de Aichi (proteção de pelo menos 17\% das áreas terrestres e das águas interiores até 2020, no âmbito da Convenção sobre Diversidade Biológica das Nações Unidas) em 2010, bem antes do prazo. A abrangência de áreas protegidas varia entre os biomas, de quase 27\% na Amazônia; para 2,7\% nos Pampas; enquanto que apenas 1,5\% das áreas marinhas são protegidas (Figura 1.14). Em 2013, o Brasil propôs como meta nacional proteger, até 2020, 30\% da Amazônia, 17\% de outros biomas terrestres e $10 \%$ de áreas costeiras e marinhas. ${ }^{19}$

\section{Figura 1.14. Grande parte do território brasileiro está sob proteção ambiental}

Participação das áreas protegidas, por bioma e metas de Aichi, 2015

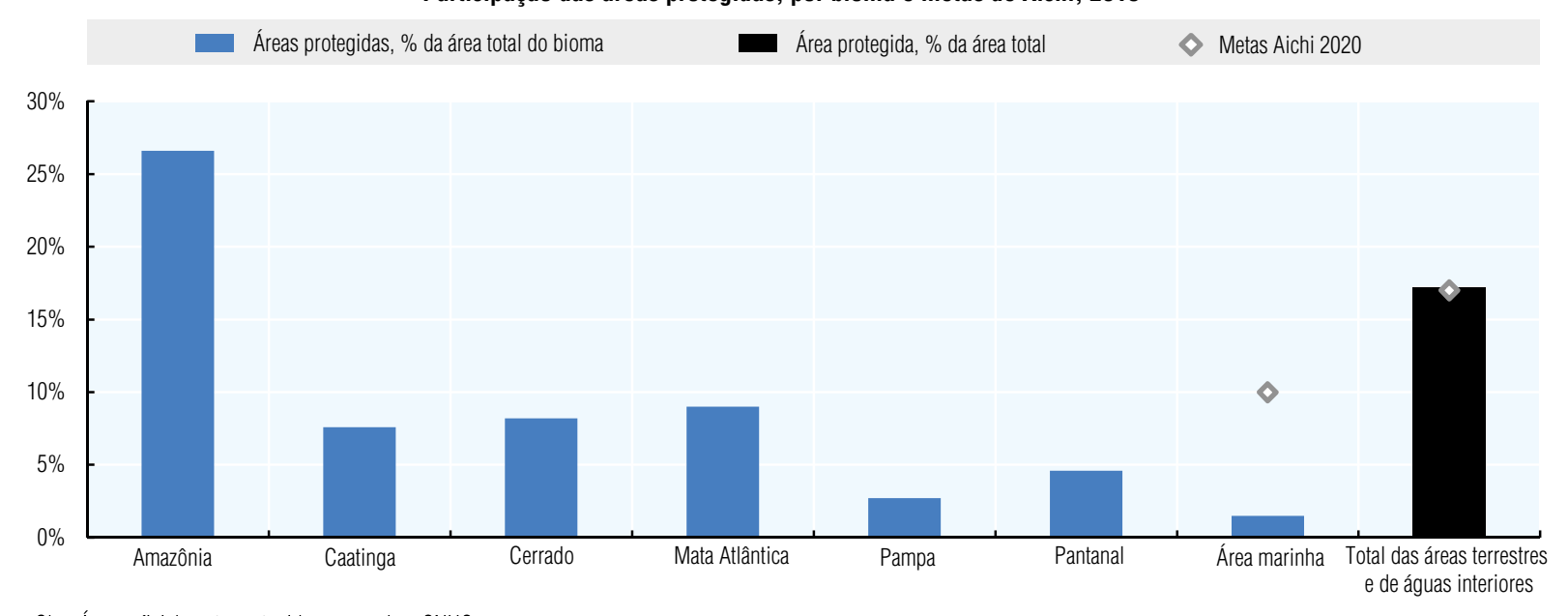

Obs.: Áreas oficialmente protegidas, segundo o SNUC.

Fonte: MMA (2015), Cadastro Nacional de Unidades de Conservação.

Além das unidades de conservação oficiais, cerca de 600 terras indígenas, a maioria localizada na Amazônia, proporcionam proteção para 13\% do território nacional (aproximadamente 1,1 milhão de $\mathrm{km}^{2}$ ). Proprietários privados de terras são obrigados, por lei, a manter a cobertura original, na forma de Áreas de Preservação Permanente (APP) e de Reserva Legal (RL) (Capítulo 4). As APPs abrangem 12\% e as RLs 30\% do território nacional, área equivalente a mais de duas vezes à das unidades de conservação. Embora muitas vezes desrespeitadas no passado (SPAROVEK et al., 2010), o Novo Código Florestal e seus mecanismos de implementação (Capítulo 4) prometem aumentar a conservação efetiva nas APPs e RLs.

\section{Espécies terrestres e marinhas}

A lista oficial de espécies ameaçadas de extinção, atualizada em 2014, engloba mais de 1.000 espécies da fauna e mais de 2.000 espécies da flora brasileira (Capítulo 4). A Mata Atlântica é o bioma com maior número de espécies ameaçadas; seguido 
pelo Cerrado e a Amazônia. Esses são os biomas com maior quantidade de espécies conhecidas (IBGE, 2013). Mais de 400 espécies de peixes marinhos e de água doce estão incluídas na lista oficial de espécies ameaçadas de 2014. A pesca e a piscicultura estão entre as principais pressões, seguidas pela poluição industrial e pelos resíduos urbanos, agrícolas e domésticos, em parte, devido à alta concentração demográfica e, em algumas áreas, às indústrias ao longo do litoral (MMA, 2015a). As ações voltadas à proteção das espécies ameaçadas da fauna vêm aumentando: em 2012, cerca de 50\% de todas as espécies ameaçadas eram protegidas no âmbito do Plano de Ação Nacional, em comparação com os 4\% em 2008 (MMA, 2014b).

A captura de pescados marinhos e de água doce aumentou em quase $15 \%$, no período entre 2000 e 2013. A captura de pescados aumentou quase $20 \%$ nas áreas interiores e cerca de $13 \%$ nas áreas marinhas. Vários estoques pesqueiros costeiros e interiores estão esgotados ou superexplorados em consequência da sobrepesca, geralmente praticada pela pesca em escala industrial (FAO, 2013). Em muitos casos, a queda nos estoques pesqueiros está associada à concorrência entre pescadores artesanais e industriais e a conflitos entre as comunidades pesqueiras (MMA, 2015a).

\subsection{Recursos hídricos}

O Brasil é dotado de $12 \%$ da água doce do mundo; e de algumas de suas maiores bacias hidrográficas, incluindo Amazônia, Paraná e São Francisco (ANA, 2013). A distribuição é desigual, com a Amazônia retendo cerca de 70\% da água doce. A disponibilidade hídrica per capita anual varia entre $1.460 \mathrm{~m}^{3}$ na região semiárida do Nordeste, e 634.887 $\mathrm{m}^{3}$ na Amazônia (PGA, 2013).

Em vista da grande disponibilidade de recursos de água doce do Brasil, a captação representava menos de $1 \%$ da água doce disponível em 2010, bem abaixo da média da maioria dos países da OCDE (ANA, 2013; ver também Anexo 1.D). No entanto, a captação de água aumentou mais de $80 \%$ no período entre 2000 e 2012, refletindo o crescimento econômico e populacional. A agricultura é, de longe, o maior consumidor, representando mais de $60 \%$ da captação em 2012 e mais de 70\% do aumento entre 2000 e 2012. Por outro lado, o uso da água pelas indústrias e para o consumo humano aumentou apenas moderadamente (Figura 1.15). As perdas na distribuição de água, relativas ao total captado, diminuíram ligeiramente desde 2000, mas ainda representaram mais de um terço da água doce captada em 2012 e mais de 50\% em vários estados das regiões Norte e Nordeste, principalmente devido a sistemas de abastecimento obsoletos e a debilidades da infraestrutura de saneamento. O consumo per capita de água foi calculado em 167 litros por dia em 2013: com variação de 126 litros na região Nordeste a 193 litros no Sudeste, refletindo diferenças nas condições climáticas e nos padrões de consumo (MCid, 2014). No geral, a captação anual de água doce per capita do Brasil está abaixo da média da OCDE (ver Anexo 1.D e Estatísticas Básicas) embora com grandes variações regionais.

O equilíbrio entre o abastecimento e o consumo de água é estável na maioria das bacias; porém o balanço hídrico é considerado preocupante, crítico ou muito crítico para quase $25 \%$ das bacias, devido à escassez de água (ex., Nordeste) e ao uso extensivo em áreas densamente povoadas (ex., Sudeste) (ANA, 2013). Em 2013 e 2014, altas temperaturas e baixo índice de chuvas agravado por anos de aproveitamento ineficiente resultaram em grave desabastecimento de água no Sudeste, especialmente no Estado de São Paulo, causando graves impactos sobre o abastecimento de água e a geração de 
energia. Cerca de 4 milhões de pessoas, assim como as indústrias e a agricultura, foram afetadas pelo racionamento de água e por apagões (The Guardian, 2015).

\section{Figura 1.15. O uso da água, especialmente na agricultura, aumentou consideravelmente}

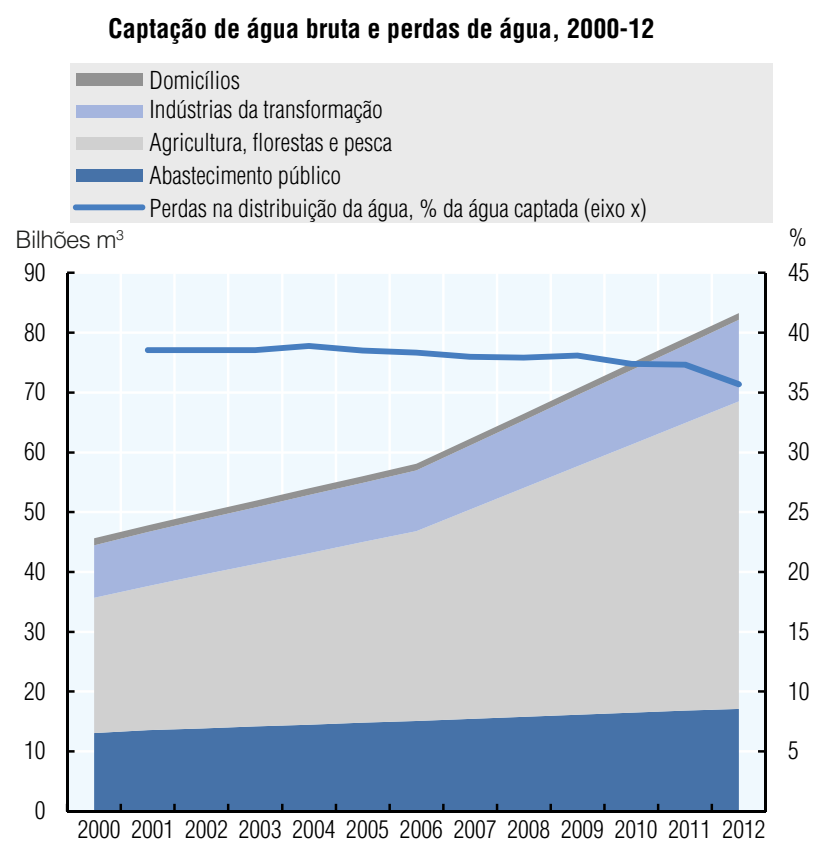

Captação de água bruta por grandes setores, 2012

Fonte: OCDE (2015), "Freshwater abstractions", OECD Environment Statistics (banco de dados).

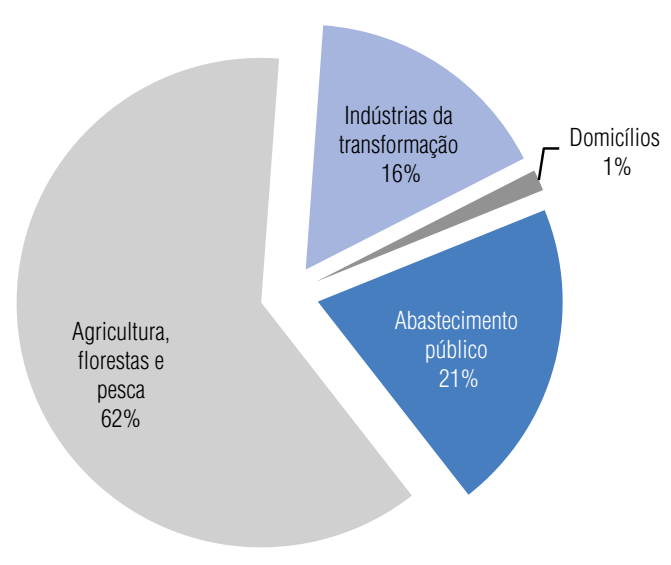

A qualidade da água é boa ou ótima em cerca de $80 \%$ dos corpos d'água; mas crítica em diversas áreas urbanas densamente povoadas. Em 2011, o índice nacional de qualidade das águas mostrou que $44 \%$ dos registros das estações de monitoramento urbanos reportaram qualidade ruim ou péssima (Figura 1. 16). Isto significa que a qualidade da

Figura 1.16 A qualidade da água é ruim em muitas áreas urbanas Índice da qualidade da água, 2011

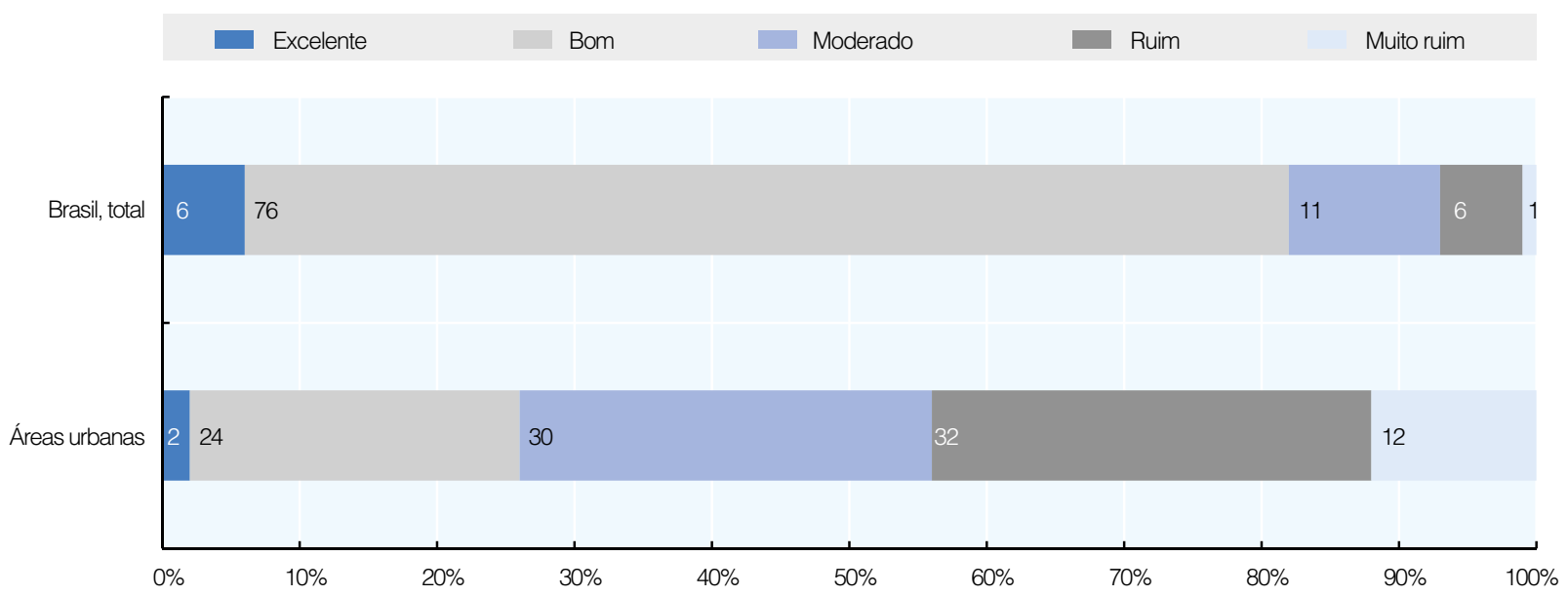

Obs.: Índice de qualidade da água (IQA) calculado como média ponderada de nove parâmetros. 0 índice varia de 0 a 100. Classes d’água: "excelente" ( $\leq 79)$; "bom” (51-79); "moderado" (36-51); "ruim"(19-36); "muito ruim " $(\leq 19)$. As últimas duas categorias (valores $\leq 36$ ) se referem à água imprópria para 0 consumo.

Fonte: ANA (2013), Conjuntura dos Recursos Hídricos no Brasil. 
água após o tratamento convencional é inadequada para o abastecimento público, e requer tratamento avançado. O principal problema que afeta a qualidade da água de superfície é a descarga de águas servidas, tanto de efluentes tratados quanto de águas servidas domiciliares. Em geral, a deterioração da qualidade da água está relacionada ao aumento do volume de águas servidas, refletindo o crescimento populacional e a urbanização, bem como ao descompasso dos investimentos em coleta de águas servidas e sistemas de tratamento (ANA, 2013; MMA, 2015a; ver também o Capítulo 3). Em 2012, apenas 39\% das águas servidas receberam qualquer tratamento (MCid, 2014) e apenas uma pequena fração recebeu tratamento para remover fósforo, hormônios e antibióticos, contaminantes que afetam tanto o ecossistema quanto a saúde humana. Outras grandes pressões sobre a qualidade da água são provocadas pela mineração, efluentes industriais, fluxos difusos da drenagem de solos urbano e agrícola e descarga de resíduos sólidos.

\section{Acesso ao abastecimento de água potável e ao saneamento}

O Brasil alcançou avanços significativos no provimento de serviços de abastecimento de água ao cidadão. A parcela da população com acesso à água tratada aumentou de 88\% em 1990, para quase $98 \%$ em 2012. O abastecimento de água nas áreas urbanas é quase universal, mas $15 \%$ da população rural ainda carece de acesso ao abastecimento com água tratada (Anexo 3.A). A proporção de domicílios conectados às redes adutoras alcançou 94\% nas áreas urbanas em 2013. Contudo, as disparidades regionais permanecem; a maioria dos habitantes de áreas urbanas sem conexão com a rede de abastecimento reside na região Nordeste e Norte, sendo que na região Norte, menos de $60 \%$ está conectada (MCid, 2014). No país como um todo, apenas $24 \%$ das redes urbanas de abastecimento são consideradas satisfatórias; 33\% precisam de reformas para alcançar normas de quantidade e/ou qualidade; e $43 \%$ precisam de expansão para que possam atender aos aumentos de demanda previstos (ANA, 2011).

O progresso no saneamento tem sido mais lento. Estimativas nacionais indicam que a porcentagem da população urbana com acesso à rede de coleta de esgoto aumentou de $48 \%$ para $56 \%$ entre 2006 e 2011. As taxas de cobertura são mais elevadas na região Sudeste (79\% da população urbana) e mais baixas nas regiões Norte (12\%) e Nordeste (28\%) (MCid, 2014). A porcentagem da população urbana nacional atendida por serviços de tratamento de esgoto (por meio de rede ou tratamento local) é ainda menor: passou de 30\% em 2006, para 35\% em 2011 (Figura 1.17). Existe uma grande disparidade entre as áreas urbana e rural. Apenas $5 \%$ dos domicílios rurais tiveram acesso a redes de coleta de esgoto em 2009, em contraste com os cerca de $60 \%$ das áreas urbanas; enquanto que cerca de $20 \%$ não teve acesso a qualquer meio de coleta de esgoto (Figura 1. 17).

As doenças relacionadas ao saneamento inadequado diminuíram em mais de $50 \%$ entre 1993 e 2010, para 325 casos por 100 mil habitantes (IBGE, 2013) o que reflete os avanços alcançados na expansão dos serviços de saneamento. Como é de se esperar, a disparidade regional é grande, com 691 casos no Norte e 121 no Sudeste, refletindo a situação real dos serviços de saneamento nas regiões. 
Figura 1.17. $\mathrm{O}$ acesso às redes de coleta e tratamento de esgoto precisa ser ampliado

População urbana com acesso a serviços de saneamento, por região, a 2006, 2009 e 2011

\begin{tabular}{|l|l|l|}
2006 & 2009 & 2011
\end{tabular}

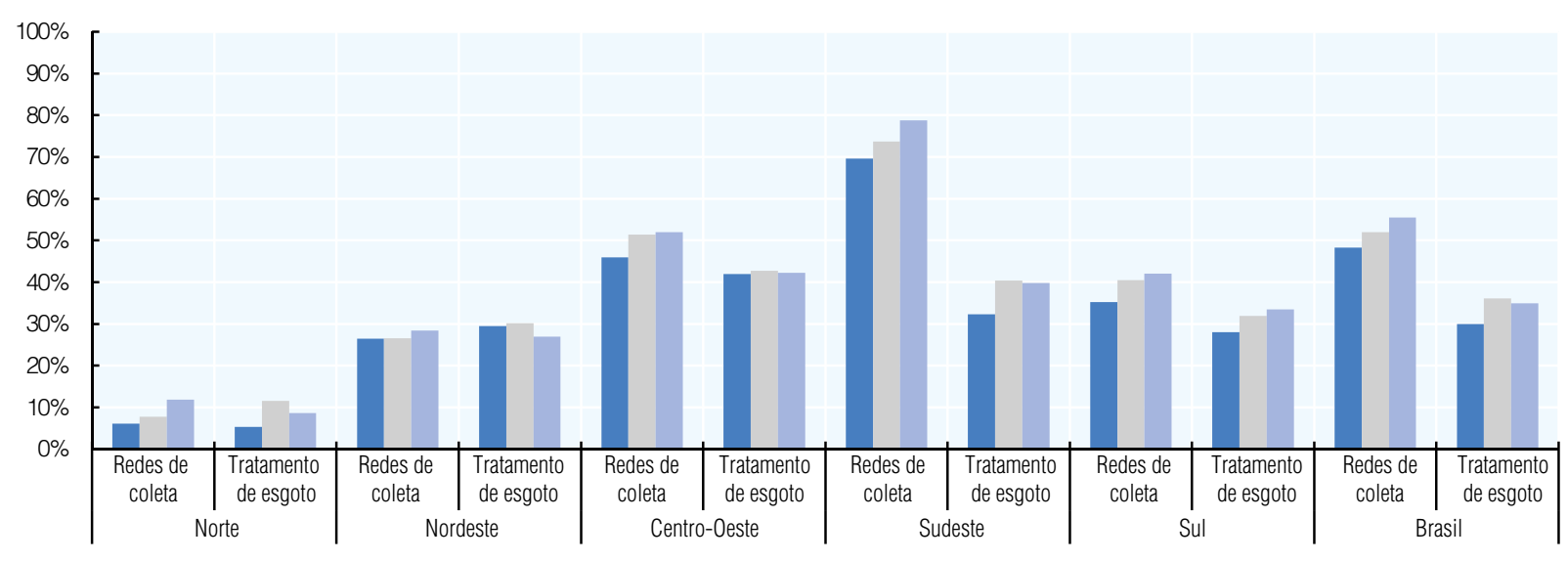

Acesso a saneamento, por tipo de serviço e área, 2009

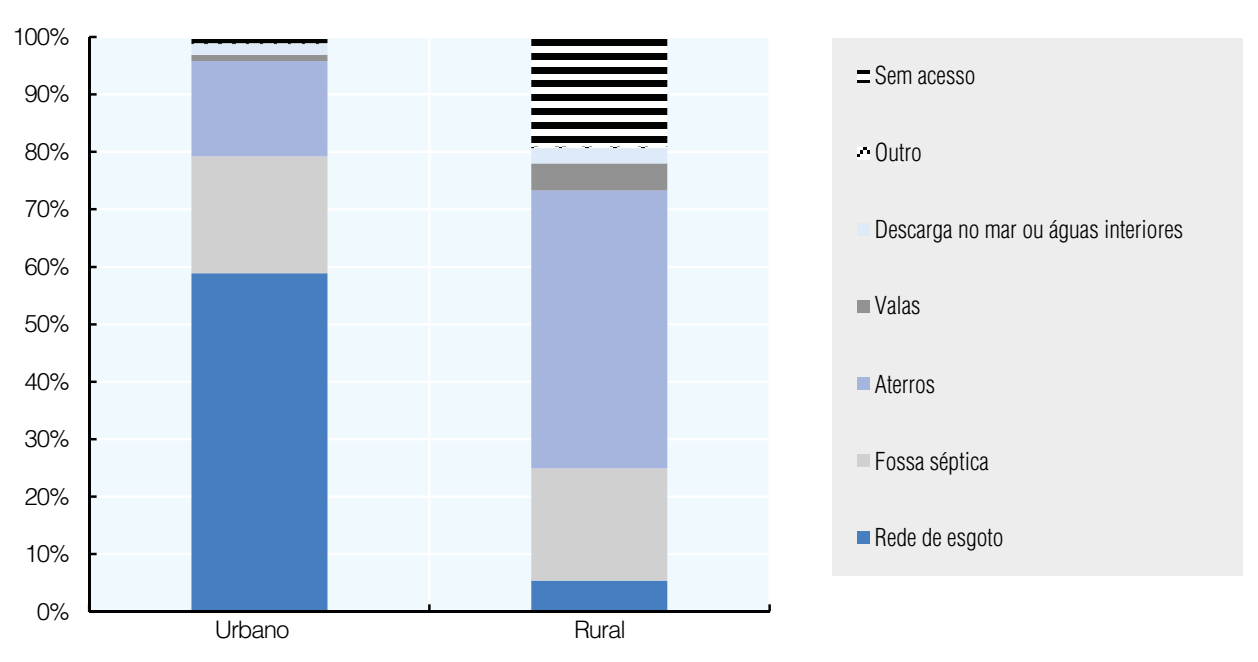

a) Dados se referem à parcela da população urbana residente em municípios atendidos por serviços de abastecimento d'água (93\% do total da população urbana brasileira em 2011, segundo o SNIS).

Fonte: MMA (2014), PNIA 2012: Painel Nacional de Indicadores Ambientais; IBGE (2009), Pesquisa Nacional por Amostra de Domicílios 2009. 


\section{Recomendações sobre a política de mudança do clima e a gestão do ar, da água e de resíduos \\ Política de mudança do clima}

- Implementar rapidamente programas setoriais para mitigar as emissões de GEEs e acelerar o desenvolvimento do SMMARE, a fim de monitorar os resultados; assegurar que medidas efetivas sejam replicadas e ampliadas.

- Avançar no desenvolvimento e na implementação do plano de adaptação às mudanças do clima, com o envolvimento de todos os setores, instâncias governamentais e partes interessadas; assegurar que a estratégia reflita adequadamente os impactos econômicos, sociais e ambientais, inclusive a biodiversidade, a qualidade e a disponibilidade da água.

\section{Gestão da poluição atmosférica, hídrica e de resíduos}

- Desenvolver um eficaz sistema nacional de monitoramento da qualidade do ar, com metodologias consistentes e coleta de dados nos estados.

- Estabelecer critérios consistentes e compatíveis para a alocação de água e assegurar que os limites do desperdício estejam definidos conforme os padrões de qualidade da água, com base na categoria de uso.

- Fortalecer a gestão de resíduos sólidos por meio:

* do melhor cumprimento das normas referentes à eliminação de resíduos sólidos perigosos sem o tratamento prévio, em aterros municipais; e

* do estabelecimento do Sistema Nacional de Informação sobre a Gestão dos Resíduos Sólidos, conforme exige a lei, usando-o para facilitar a implementação dos programas de "Iogística reversa" para fiscalizar fluxos de resíduos de produtos-chave.

\section{Notas:}

1. O Brasil é dividido em cinco regiões geográficas: Sudeste, Sul, Centro-Oeste, Norte e Nordeste. Essas regiões não desfrutam de poderes administrativos ou orçamentários.

2. A taxa de homicídios é uma das mais elevadas do mundo: 21 assassinatos por 100.000 habitantes/ ano, em comparação com a média da OCDE, de 2,2 (OCDE, 2013c).

3. O Índice de Vida Melhor é uma ferramenta web interativa, criada para envolver as pessoas no debate sobre o bem-estar e, por meio desse processo, aprender o que mais lhes importa. A ferramenta possibilita a comparação do bem-estar entre países, de acordo com a importância que cada participante atribui a uma série de tópicos (comunidade, educação, meio ambiente, engajamento cívico, saúde, habitação, renda, emprego, satisfação pessoal, segurança e relação trabalho-vida). O Índice de Vida Melhor faz parte da Iniciativa de Vida Melhor da OCDE, que visa desenvolver estatísticas que melhor representem aspectos da qualidade de vida. Ver <www.oecdbetterlifeindex.org>.

4. Em 2012, as reservas de petróleo comprovadas ficaram em torno de 15,3 bilhões de barris e as reservas de gás natural, em torno de 450 bilhões de $\mathrm{m}^{3}$, com cerca de $90 \%$ de ambos os recursos localizados na plataforma continental (ANP, 2013).

5. As perdas de conversão durante a geração hidroelétrica são mínimas, o que torna essa forma de geração mais eficiente que a queima de combustíveis fósseis.

6. Conforme definido pela Convenção-Quadro das Nações Unidas sobre Mudança Climática (UNFCCC) a categoria Uso da Terra, Mudança no Uso da Terra e Florestas (LULUCF) abrange as emissões e remoções de GEEs resultantes dessas atividades induzidas diretamente pelo homem. As emissões LULUCF, conforme relatadas no âmbito da UNFCCC, são emissões líquidas, ou seja, a soma das emissões positivas para a atmosfera menos as remoções da atmosfera por meio de sumidouros de carbono. As emissões para a atmosfera podem ocorrer por meio de incêndios florestais, conversão de floresta em terras de cultivo e decomposição de biomassa na superfície do solo, remanescente após o desmatamento e a extração madeireira. As remoções advindas da atmosfera ocorrem, por exemplo, através da ampliação da cobertura florestal por meio de florestamento e reflorestamento.

7. Dados nacionais sobre as emissões de GEE, fornecidos pelo Ministério da Ciência, Tecnologia e Inovação (MCTI), não são diretamente comparáveis com os dados da Agência Internacional de Energia (AIE) em virtude das diferentes contagens e dos métodos estimativos: os dados da IEA incluem as emissões positivas provenientes do LULUCF, mas excluem o sequestro de carbono. Os dados do MCTI apresentam emissões LULUCF líquidas (ver nota 6). No Brasil, as emissões de GEE provenientes de LULUCF são mais elevadas que as remoções, resultando em emissões líquidas positivas de GEE no setor LULUCF. 
8. O compromisso do Brasil de reduzir as emissões de GEE foi definido na Lei $n^{\circ} 12.187 / 2009$, que estabelece a Política Nacional de Mudança do Clima. As emissões BAU projetadas e as respectivas metas de emissão por setor estão definidas no Decreto $n^{\circ} 7.390 / 2010$.

9. Os dados oficiais das emissões de GEE estão disponíveis até 2012. O Sistema de Estimativa de Emissão de Gases de Efeito Estufa, uma coalizão de institutos e organizações não governamentais, fornece dados não oficiais até 2013 (www.seeg.eco.br). Suas estimativas sugerem que o total das emissões brasileiras de GEE alcançou 1,57 tCO eq em 2013 - os níveis mais elevados de emissão desde 2008. As emissões cresceram em todos os setores, mas mais fortemente as provenientes do LULUCF e da queima de combustíveis fósseis.

10. A queima do etanol combustível produz menos $\mathrm{CO}$ do que a gasolina, com teores reduzidos de $\mathrm{NO}_{x}$ e possivelmente de concentrações de $\mathrm{MP}_{10}$, mas resulta numa maior emissão de aldeídos e em teor mais elevado de ozônio próximo ao solo.

11. As concentrações de material particulado referem-se a partículas finas em suspensão, de diâmetro inferior a 10 mícrons $\left(\mathrm{MP}_{10}\right)$ que podem penetrar profundamente no sistema respiratório, causando significativos danos à saúde. O estado da tecnologia e dos controles de poluição de um país é um determinante relevante das concentrações de MP. As estimativas citadas são níveis ponderados de $\mathrm{MP}_{10}$ da população urbana em zonas residenciais de cidades com mais de 100.000 habitantes. As estimativas representam a exposição média anual a esses particulados, em ambiente aberto, de um residente urbano.

12. CIM é a soma da extração das matérias primas utilizadas por uma economia e da sua balança comercial física (importações menos exportações de matérias-primas e produtos manufaturados).

13. Existem lacunas de informação significativas sobre a gestão de resíduos sólidos municipais no Brasil. Várias fontes de dados estão disponíveis sobre RSM, mas as metodologias e amostras variam bastante, resultando em estimativas diferentes e, por vezes, contraditórias. As duas fontes de dados oficiais mais importantes são as Pesquisas Nacionais de Saneamento Básico de 2000 e de 2008, realizadas pelo IBGE e pelo Sistema Nacional de Informações sobre Saneamento (SNIS), atualizado anualmente e gerido pelo Ministério das Cidades. Os dados disponíveis são dificilmente comparáveis, no entanto, devido à diferença metodológica e a deficiências nas bases estatísticas (ex., o SNIS se baseia em dados fornecidos pelos próprios municípios, mas o número de municípios participantes é baixo e alguns dos dados são inconsistentes).

14. Bioma é uma grande comunidade natural de flora e fauna ocupando uma região geográfica.

15. Inclui florestas nacionais, estaduais e plantações florestais.

16. A Amazônia Legal corresponde a uma área maior do que o bioma Amazônia, abrangendo tanto a Floresta Amazônica (cerca de 4,1 milhões de $\mathrm{km}^{2}$ ) quanto a vegetação de transição (1 milhão de $\mathrm{km}^{2}$ ); o bioma Amazônia abrange apenas a área de floresta. A Amazônia Legal abrange quase nove estados: Amazonas, Pará, Acre, Roraima, Rondônia, Amapá, Tocantins e parte do Mato Grosso e do Maranhão.

17. O compromisso de reduzir o desmatamento foi posteriormente incorporado à Política Nacional sobre Mudança do Clima.

18. Esses números se referem às áreas protegidas oficialmente designadas no âmbito do Sistema Nacional de Unidades de Conservação. Não incluem terras indígenas, área protegida em propriedade privada (isto é, conforme exige o Código Florestal) e outras áreas que se qualificariam como áreas protegidas no âmbito das convenções internacionais.

19. A meta de 2013 amplia a definição de áreas protegidas e também passa a incluir terras indígenas e áreas referentes ao Código Florestal, inclusive APPs e RLs.

\section{Referências}

Abrelpe (2012), Panorama dos Resíduos Sólidos no Brasil, Associação brasileira de Empresas de Limpeza Pública e Resíduos Especiais, www.abrelpe.org.br/Panorama/panorama2012.pdf.

Accioli, C. e S. Monteiro (2011), “Brazil: World’s Breadbasket”, The Brazilian Economy, Vol. 3, No. 11, FGV IBRE, Rio de Janeiro.

ANA (2011), Atlas Brasil do Abastecimento Urbano de Agua: Panorama Nacional, Brasília, http://atlas.ana.gov.br/ Atlas/downloads/atlas/Resumo\%20Executivo/Atlas\%20Brasil\%20-\%20Volume\%201\%20-\%20Panorama\%20 Nacional.pdf.

ANA (2013), Conjuntura dos Recursos Hídricos no Brasil, Brasília, http://conjuntura.ana.gou.br/docs/conj2013_rel.pdf.

ANFAVEA (2015), "Produção, vendas e exportações de veículos” (banco de dados), www.anfavea.com.br/ tabelas.html 
ANP (2013), Anuário Estatístico Brasileiro de Petróleo, Gás Natural e Biocombustíveis, Rio de Janeiro, www.anp. gov.br/?dw=73191.

ANVISA (2013), Programa de Análise de Resíduos de Agrotóxicos em Alimentos (PARA). Relatório de Atividades de 2011 e 2012, Brasília, http://portal.anvisa.gou.br/wps/wcm/connect/58a5580041a4f6669e579ede61db78cc/ Relat\%C3\%B3rio+PARA+2011-12+-+30_10_13_1.pdf?MOD=AJPERES.

Banco Mundial (2011), Country Partnership Strategy 2012-15, World Bank, Washington, DC, http://documents. worldbank.org/curated/en/2011/09/15273914/brazil-country-partnership-strategy-cps-period-fy2012-2015.

Banco Mundial (2015), World Development Indicators (banco de dados), World Bank, Washington, DC, http:// data.worldbank.org/data-catalog/world-development-indicators.

CDB (n.d.), "Brazil - Country Profile”, www.cbd.int/countries/profile/default.shtml? country=br - facts.

Cempre (2013), Compromisso Empresarial para Reciclagem - Review 2013, São Paulo.

FAO (2014), FAOSTAT (banco de dados), http://faostat.fao.org, Roma.

FAO (2013), "Fishery and Aquaculture Country Profiles: Brazil”, Roma, www.fao.org/fishery/facp/BRA/en.

FMI (2014), World Economic Outlook Banco de dados, October 2014 (banco de dados), International Monetary Fund, Washington, DC, www.imf.org/external/data.htm.

FUNDAJ (2014), "Povos e Comunidades Tradicionais" Fundação Joaquim Nabuco, Recife, http://basilio.fundaj. gov.br/pesquisaescolar.

THE GUARDIAN (2015), "Brazil water shortage: São Paulo devastated by its worst drought on record”, The Guardian newspaper, London, www.theguardian.com/world/2015/jan/23/brazil-worst-drought-history.

GWP (2013), Brazil. National Consultation on Water in the post-2015 Development Agenda, Global Water Partnership, www.gwp.org/Global/About GWP/Publications/Reports/Country Consultation Reports/Brazil Final National Consultation Report.pdf.

IBAMA (2013), Agrotóxicos e Afins - Histórico das Vendas - 2000 a 2012, Brasília, www.ibama.gou.br/phocadownload/ Qualidade_Ambiental/boletim de comercializacao_2000_2012.pdf.

IBAMA (2015), "Projeto de Monitoramento do Desmatamento dos Biomas Brasileiros por Satélite - PMDBBS", Brasília, http://siscom.ibama.gou.br/monitorabiomas/index.htm.

IBGE (2009), Censo Agropecuário 2006. Agricultura Familiar. Primeiros Resultados, Rio de Janeiro, 2009.

IBGE (2012b), Censo Agropecuário 2006. Brasil, Grandes Regiões e Unidades da Federação. Segunda Apuração, Rio de Janeiro, http://biblioteca.ibge.gou.br/visualizacao/periodicos/51/agro_2006.pdf.

IBGE (2011), Censo Demográfico 2010, Rio de Janeiro, http://censo2010.ibge.gov.br/.

IBGE (2012a), Indicadores de Desenvolvimento Sustentável, Rio de Janeiro, ftp://geoftp.ibge.gou.br/documentos/ recursos_naturais/indicadores_desenvolvimento_sustentavel/2012/ids2012.pdf.

IBGE (2013), Indicadores de Desenvolvimento Sustentável (banco de dados), Rio de Janeiro.

IBGE (2014), “Projeção da população do Brasil por sexo e idade: 2000-2060”, Rio de Janeiro, www.ibge.gov. br/home/estatistica/populacao/projecao_da_populacao/2013/default.shtm.

IBRAM (2012), An Optimistic Outlook for Mining in Brazil. Mining Companies in Brazil. Information and Analyses on the Brazilian Mineral Economy, 7th Edition, www.ibram.org.br/sites/1400/1457/00000364.pdf.

IEA (2014b), IEA CO2 Emissions from Fuel Combustion Statistics (banco de dados), http://dx.doi.org/10.1787/ co2-data-en.

IEA (2014a), IEA World Energy Statistics and Balances (banco de dados), http://dx.doi.org/10.1787/enestats-data-en.

IEA (2013), World Energy Outlook 2013, IEA/OECD Publishing, Paris, http://dx.doi.org/10.1787/weo-2013-en. 
IEMA (2012), Padrões de Qualidade do Ar. Experiência Comparada Brasil, EUA e União Europeia, Energy and Environment Institute, www.energiaeambiente.org.br.

IEMA (2014), $1^{\circ}$ Diagnóstico da Rede de Monitoramento da Qualidade do Ar no Brasil, www.energiaeambiente.org.br.

INPE (2015), "Projeto PRODES: Monitoramento da floresta Amazônia Brasileira por satélite” www.obt.inpe. br/prodes/index.php.

IPEA (2012), "Produtividade no Brasil nos anos 2000-2009: análise das Contas Nacionais", www.ipea.gou.br/ portal/images/stories/PDFs/comunicado/120203_comunicadoipea133.pdf.

ISS (2014), Monitoramento da Qualidade do Ar no Brasil, www.saudeesustentabilidade.org.br/site/wp-content/ uploads/2014/07/Monitoramento-da-Qualidade-do-Ar-no-Brasil-2014.pdf.

Martinelli G. and M.A. Moraes (2013), Livro Vermelho da Flora do Brasil, Rio de Janeiro.

MCid (2014), "Sistema Nacional de Informações sobre Saneamento: Diagnóstico dos Serviços de Água e Esgotos - 2013”, Brasília, www.snis.gou.br.

MCTI (2014a), Estimativas Anuais de Emissões de Gases de Efeito Estufa no Brasil. Segunda Edição, Brasília, www. mct.gou.br/upd_blob/0235/235580.pdf.

MCTI (2014b), First Biennal Update Report (BUR) under the United Nations Framework Convention on Climate Change (UNFCCC), Brasília, http://unfccc.int/resource/docs/note/brbur1.pdf.

MCTI (2010), Second National Communication of Brazil to the United Nations Framework Convention on Climate Change, Brasília.

MMA (2015b), “Cadastro Nacional de Unidades de Conservação”, Brasília, www.mma.gou.br/areas-protegidas/ cadastro-nacional-de-ucs.

MMA, (2014a), Inventário Nacional de Emissões Atmosféricas por Veículos Automotores Rodoviários, 2013, Brasília.

MMA (2012b), Plano Nacional de Resíduos Sólidos (minuta agosto de 2012), Brasília, www.sinir.gou.br/ documents/10180/12308/PNRS_Revisao_Decreto_280812.pdf/e183f0e7-5255-4544-b9fd-15fc779a3657.

MMA (2014b), PNIA 2012: Painel Nacional de Indicadores Ambientais. Referencial Teórico, Composição e Síntese dos Indicadores, Brasília.

MMA (2010), Quarto Relatório Nacional para a Convenção sobre Diversidade Biológica, Brasília.

MMA (2012a), O que o Brasileiro Pensa do Meio Ambiente e do Consumo Sustentável: Pesquisa Nacional de Opinião: Principais Resultados, Brasília.

MMA (2015a), Quinto Relatório Nacional para a Convenção sobre Diversidade Biológica, Brasília, www.cbd. int/doc/world/br/br-nr-05-en.pdf.

OCDE (2013c), "Better Life Index: Better Life Index 2013”, OECD Social and Welfare Statistics (banco de dados), OECD, Paris, http://dx.doi.org/10.1787/data-00703-en.

OCDE (2015a), OECD Economic Outlook No. 96 (banco de dados), OECD, Paris, http://dx.doi.org/10.1787/datao0717-en.

OCDE (2015b), OECD Economic Surveys: Brazil, OECD Publishing, Paris.

OCDE (2013a), OECD Economic Surveys: Brazil, OECD Publishing, Paris, http://dx.doi.org/10.1787/eco_surveysbra2013-en.

OCDE (2013b), OCED Territorial Reviews: Brazil, OECD Publishing, Paris, http://dx.doi.org/10.1787/9789264123229-en.

OCDE (2015c), Revenue Statistics in Latin America and the Caribbean 2015, OECD Publishing, Paris, http://dx.doi. org/10.1787/rev_lat-2015-en-fr. 
Olmo, N.R.S. et al. (2011), "A review of low-level air pollution and adverse effects on human health: implications for epidemiological studies and public policy”, Clinics, Vol. 66, No. 4, pp. 681-690.

Pelaez V. et al. (2013), "Regulation of pesticides: A comparative analysis", Science and Public Policy, Vol. 40, pp. 644-656.

SEEG (2014), "Estimativas anuais das emissões de gases de efeito estufa" (banco de dados), Sistema de Estimativas Anuais das Emissões de Gases de Efeito Estufa (SEEG), www.seeg.eco.br/emissoes-totais.

SFB (2014), “Os Biomas e Suas Florestas”, Brasília, www.florestal.gou.br/snif/recursos-florestais/os-biomas-esuas-florestas.

SFB (2013), Brazilian Forests at a Glance 2013, Brasília.

SFB (2015), “Sistema Nacional de Informações Florestais”, Brasília www.florestal.gov.br/snif.

Sparovek G. et al. (2010), "Brazilian Agriculture and Environmental Legislation: Status and Future Challenges", Environmental Science \& Technology, Vol. 44, No. 16.

WTO (2014), Trade Profiles 2014, World Trade Organization, Genebra, www.wto.org/english/res_e/booksp_el trade_profiles14_e.pdf. 

ANEXO 1.A

Dados sobre energia e transportes 
Figura 1.A1. Estrutura e intensidade energética

Oferta de energia por unidade do PIB, 2013

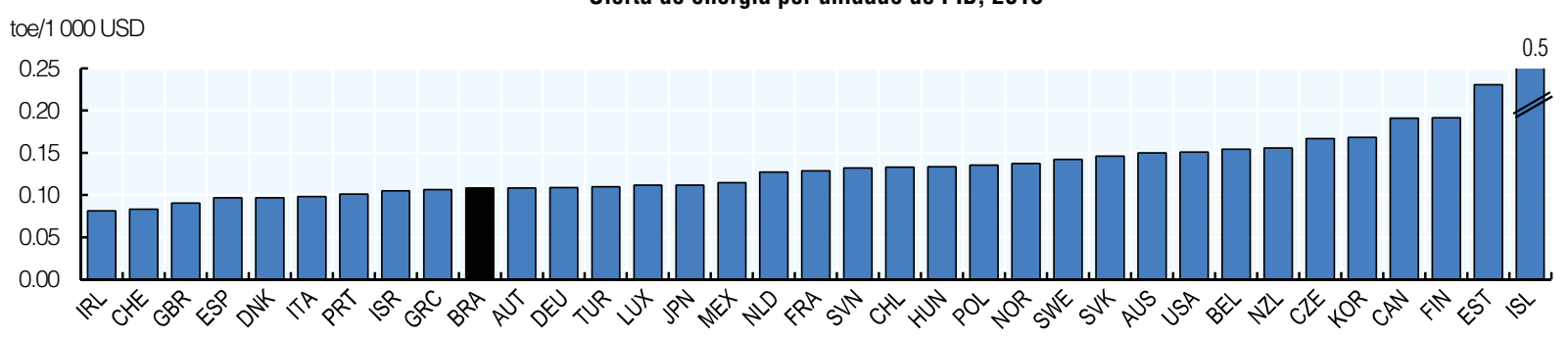

Oferta de energia per capita, 2013

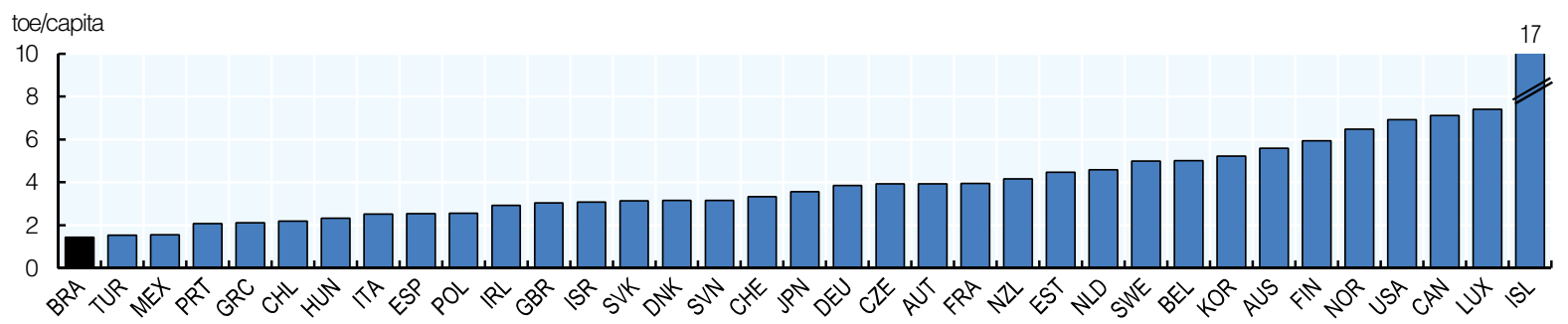

Oferta de energia por fonte, 2013
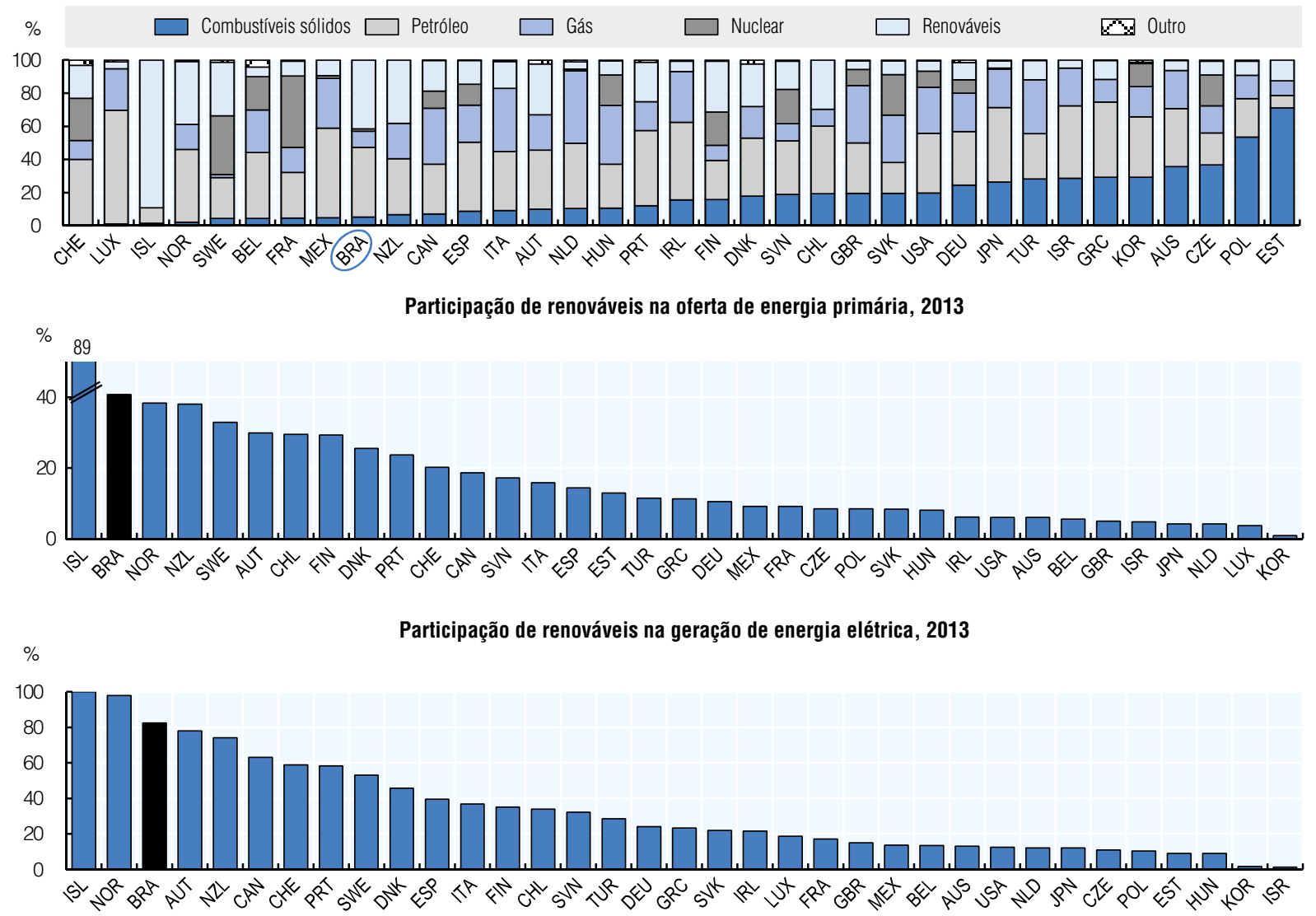

Dados para o Brasil referem-se a 2012. Dados podem incluir números provisórios e estimativas.

Total oferta de energia primária; 0 desmembramento exclui o comércio de energia elétrica. PIB a preços de 2005 e paridades de poder de compra.

Fonte: IEA (2014), IEA World Energy Statistics e Balances (banco de dados); OECD (2014), "OECD Economic Outlook No. 95", OECD Economic Outlook: Statistics and Projections (banco de dados). 
Figura 1.A2. Transportes rodoviários

Propriedade de, 2014

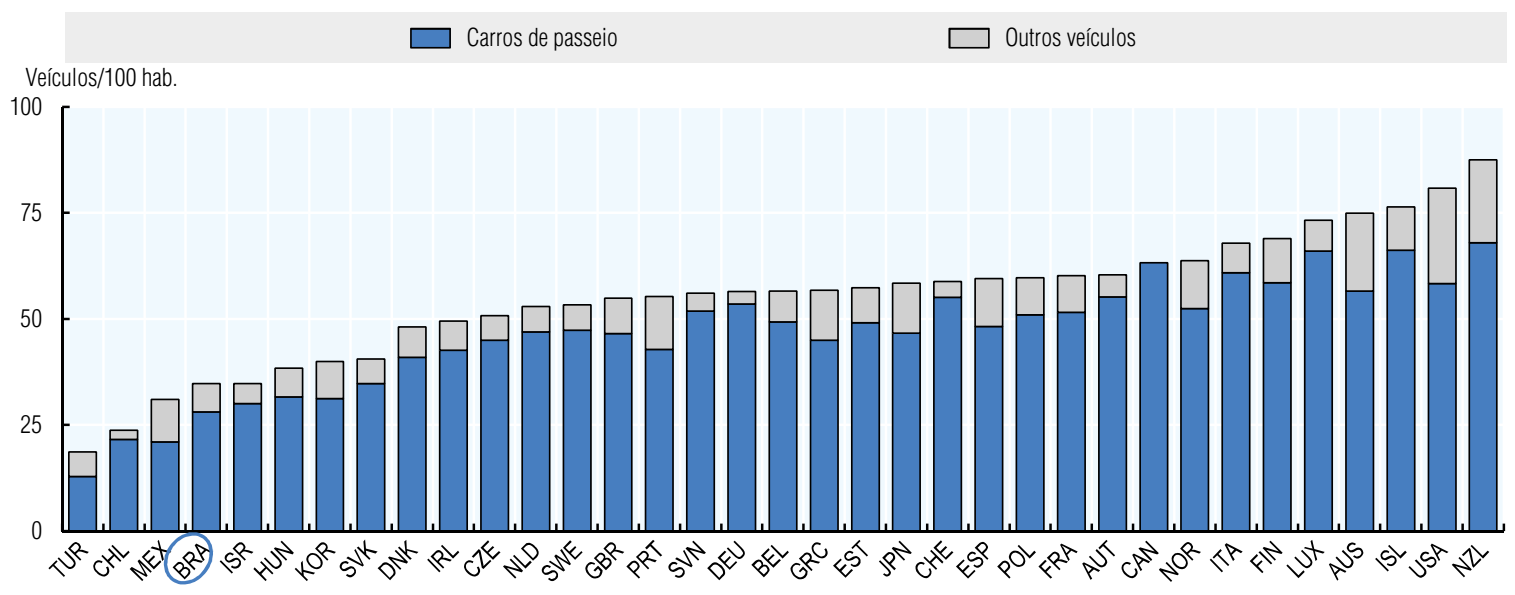

Estoque de veículos automotores, \% alteração 2000-14

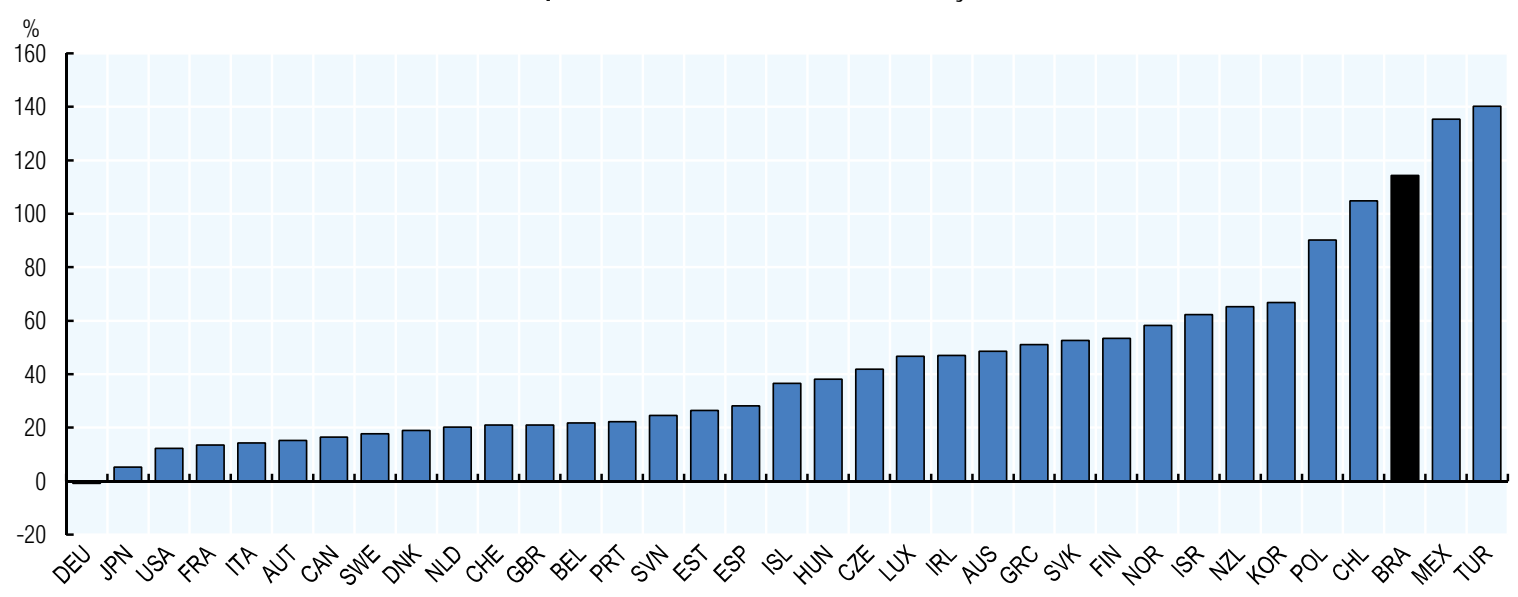

Total de consumo de energia final por transportes rodoviários, 2012

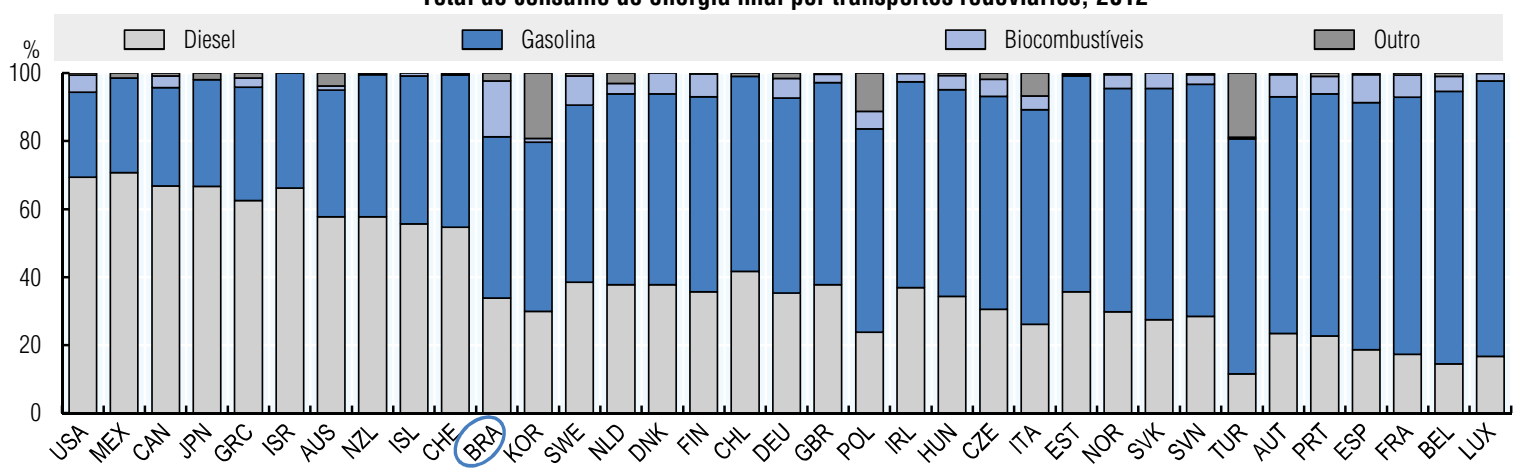

Obs.: Os dados referem-se ao ano indicado ou ao último ano em que estavam disponíveis. Podem incluir números provisórios e estimativas. Veículos: Veículos automotores com quatro ou mais rodas; Canadá: os dados referem-se ao de total veículos.

Fonte: IEA (2014), IEA World Energy Statistics and Balances (banco de dados); OECD (2015), OECD Environment Statistics (banco de dados). 

ANEXO 1.B

Dados sobre mudança do clima e poluição atmosférica 


\section{Figura 1.B1. Emissão e intensidade de GEE}

Alteração no total das emissões de GEE, 2000-12

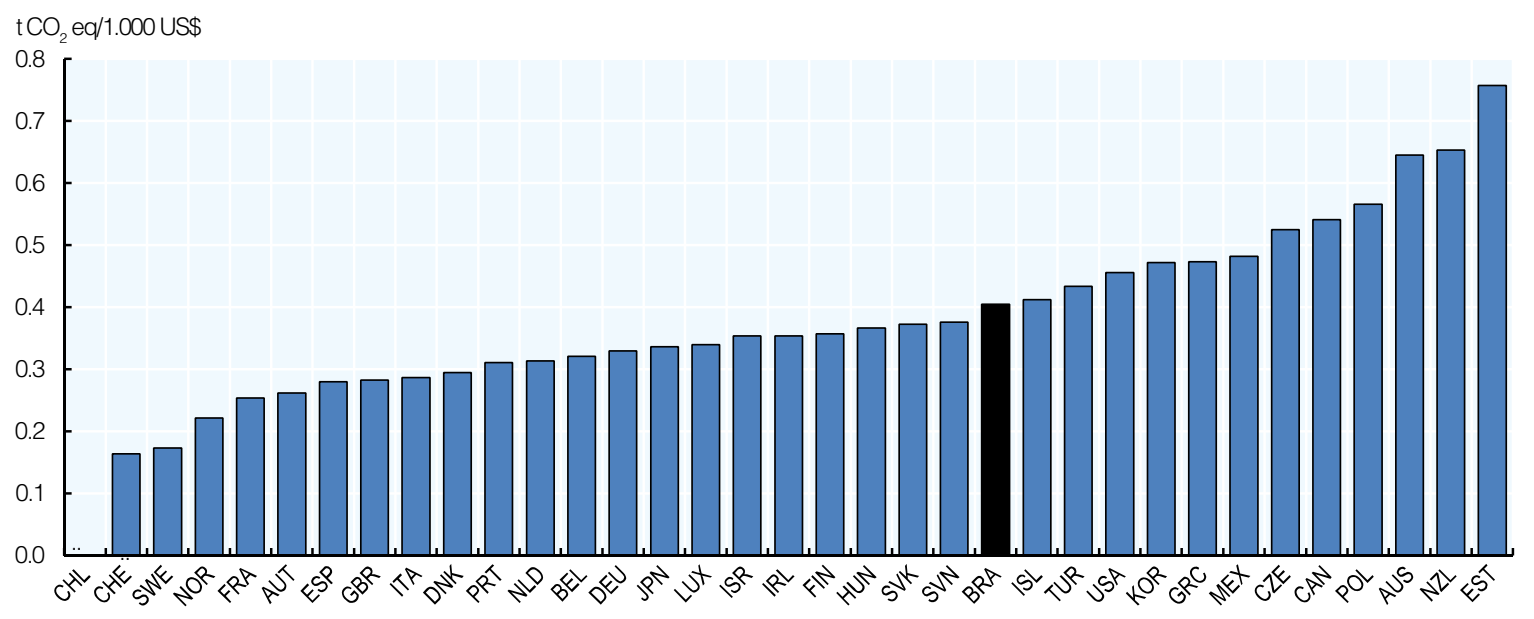

Emissões de GEE per capita, 2012
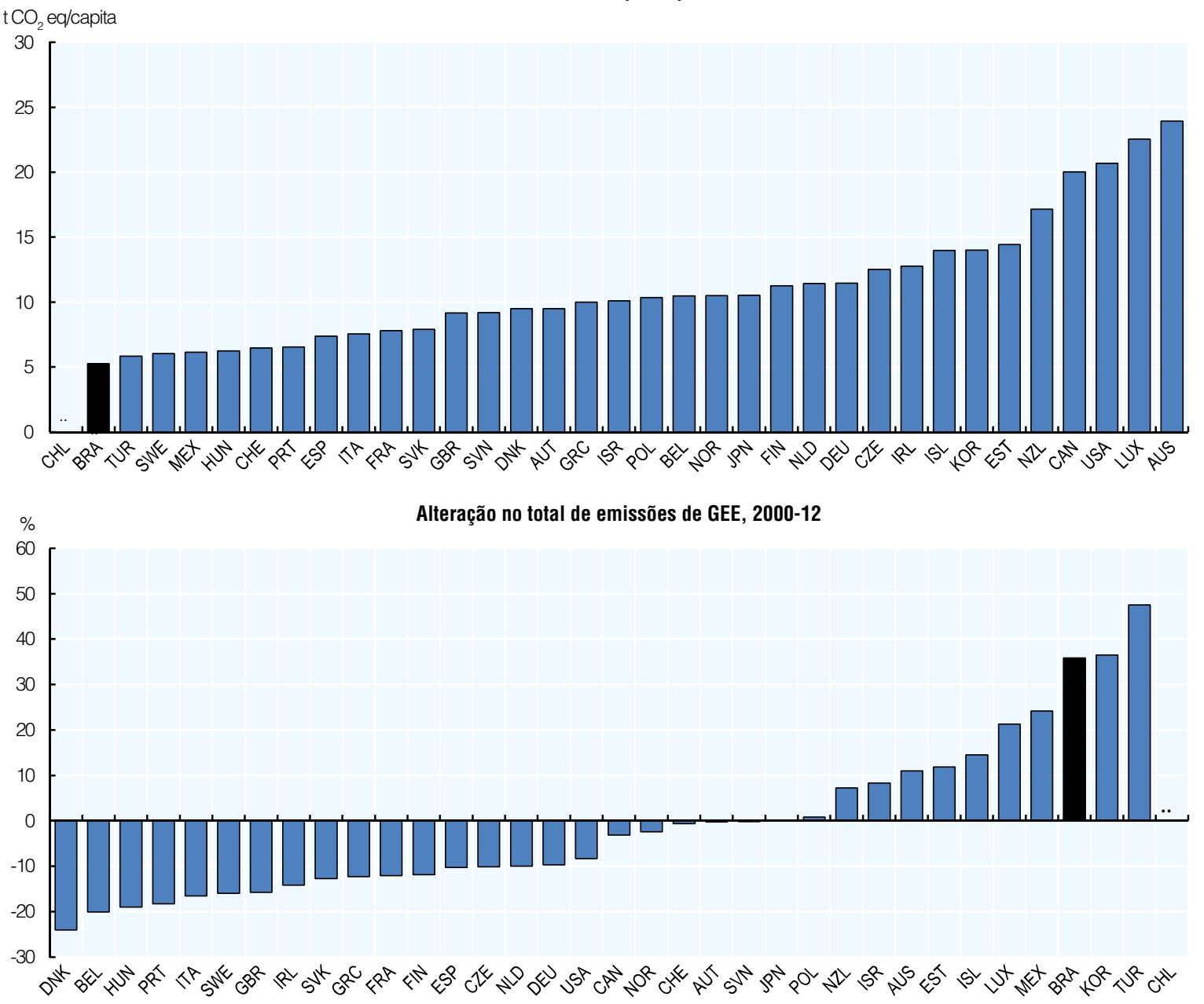

Obs.: Os dados referem-se ao ano indicado ou ao último ano em que estavam disponíveis. Podem incluir números provisórios e estimativas. Emissões de GEE excluindo emissões/remoções de uso da terra, alterações de uso da terra e florestas. Israel: 2000 dados excluem F-gases.

PIB a preços de 2005 e paridades de poder de compra.

Fonte: OCDE (2015), "Greenhouse gas emissions by source", OECD Environment Statistics (banco de dados); OECD (2014), "OECD Economic Outlook No. 95", OECD Economic Outlook: Statistics and Projections (banco de dados). 
Figura 1.B2. Emissões e intensidade de $\mathrm{CO}_{2}$

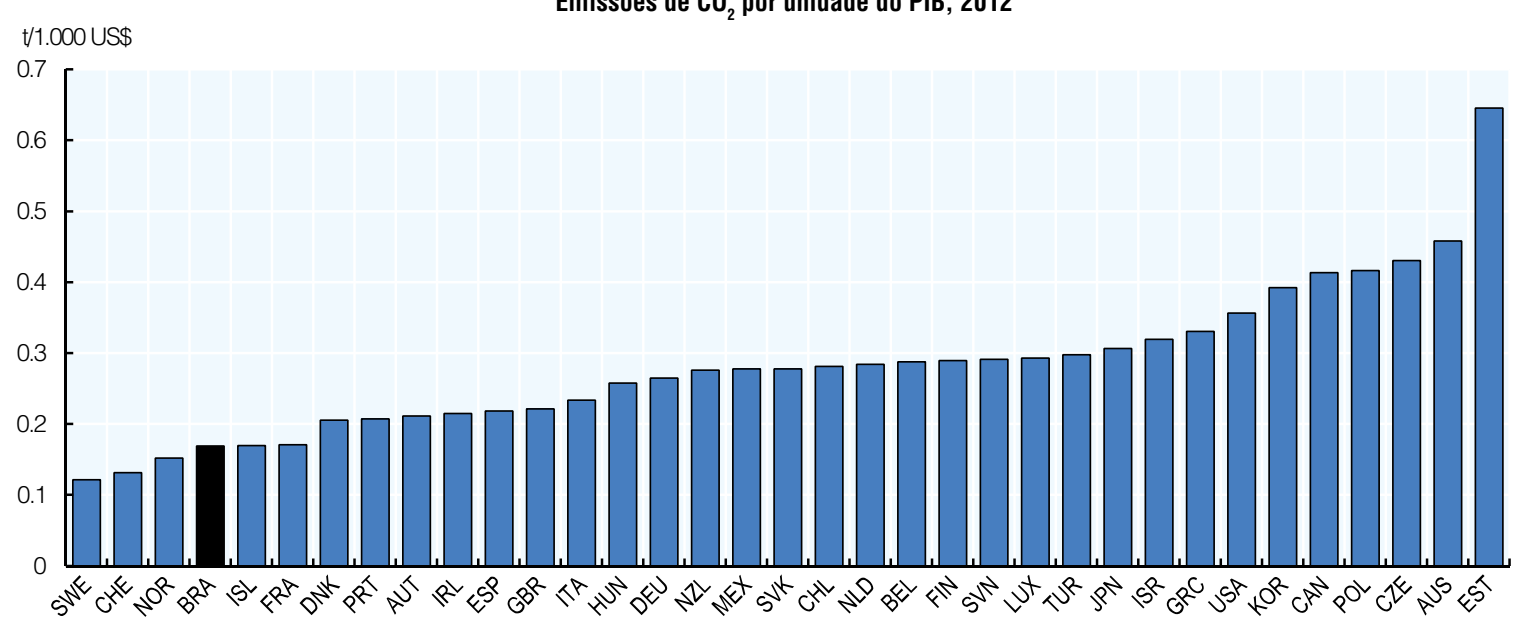

Emissões de $\mathrm{CO}_{2}$ per capita, 2012
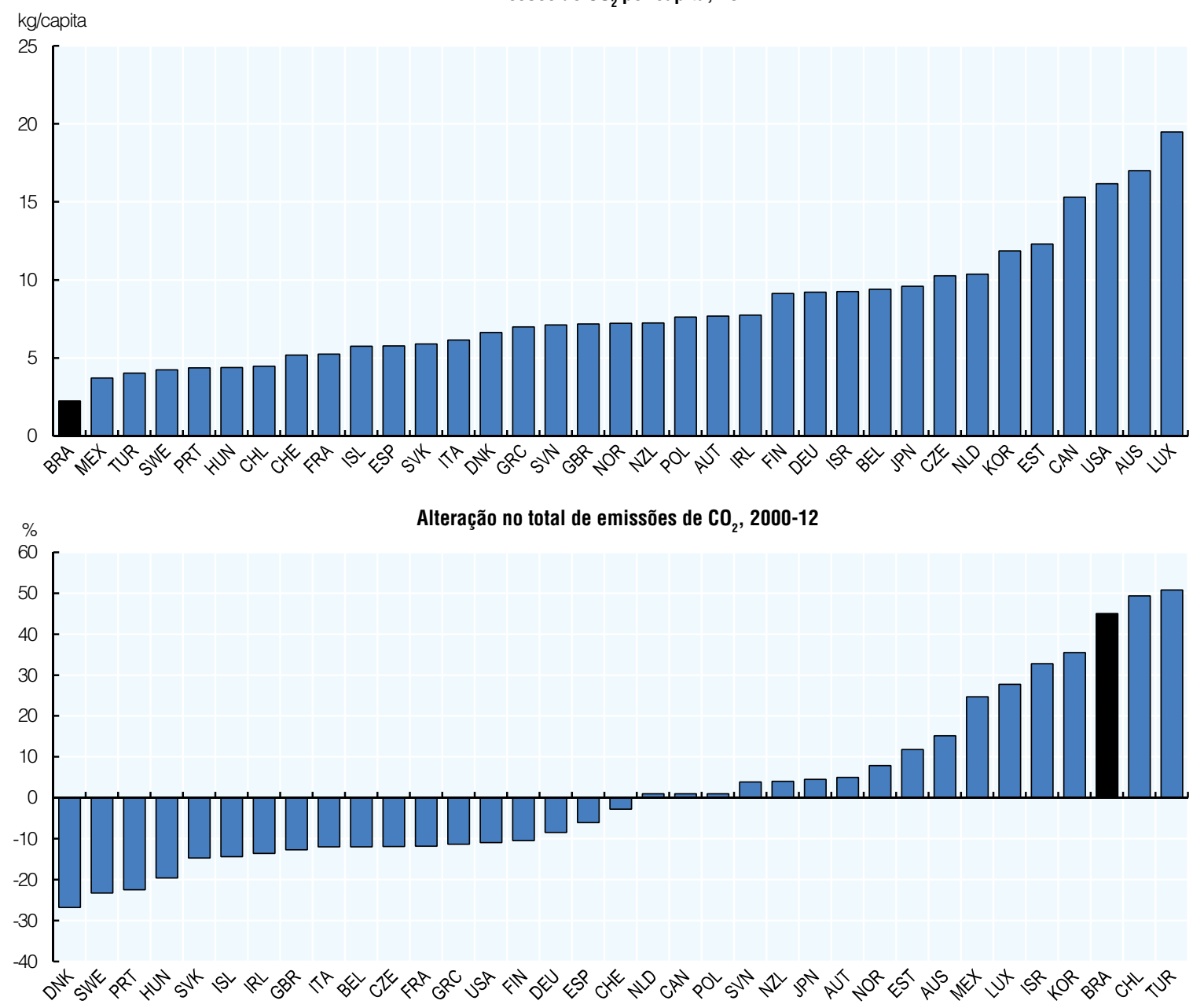

Obs.: Os dados referem-se ao ano indicado ou ao último ano em que estavam disponíveis. Podem incluir números provisórios e estimativas.

Emissões de $\mathrm{CO}_{2}$ apenas do uso de energia; excluindo bunkers internacionais marítimos e de aviação; abordagem setorial. PIB a preços de 2005 e paridades de poder de compra. Fonte: IEA (2014), IEA Emissions of CO from Fuel Combustion Statistics (banco de dados); OECD (2014), "OECD Economic Outlook No. 95", OECD Economic Outlook: Statistics and Projections (banco de dados). 
Figura 1.B3. Emissão e intensidade de $\mathrm{SO}_{\mathrm{x}}$

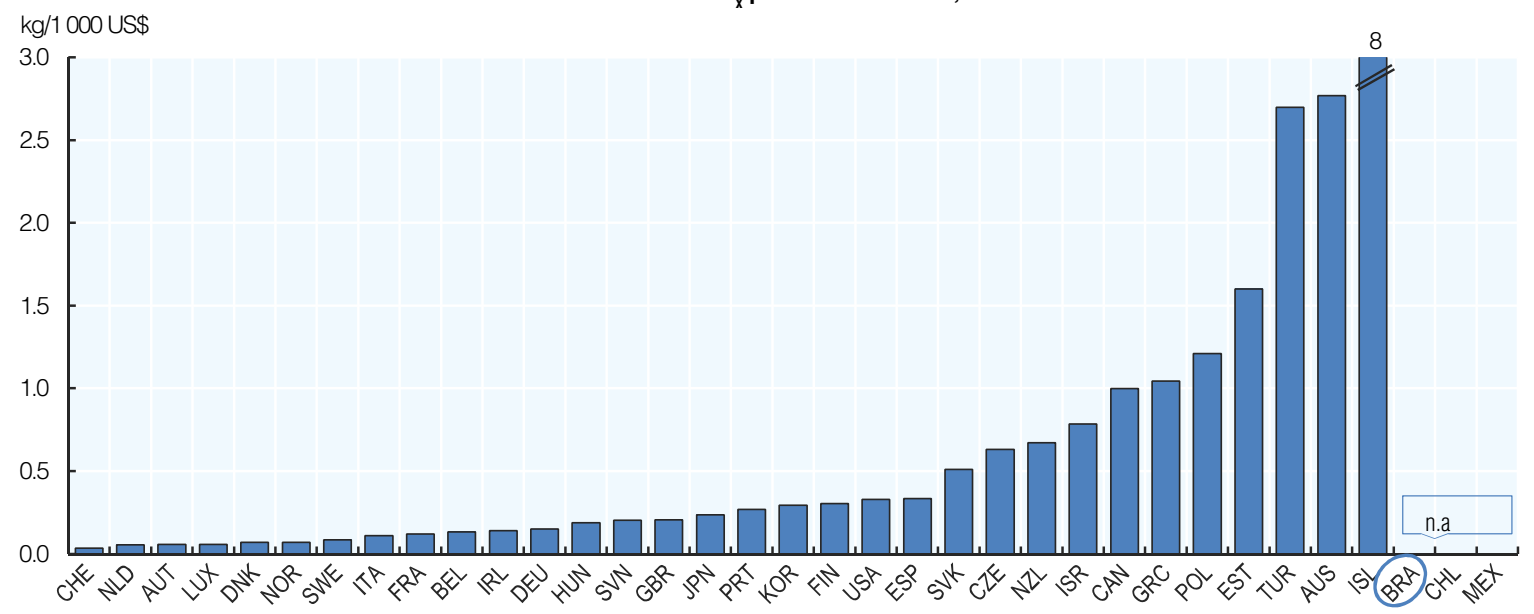

Emissões de $\mathrm{SO}_{\mathrm{x}}$ por unidade do PIB, 2012

Emissões de S0 ${ }_{x}$ per capita, 2012
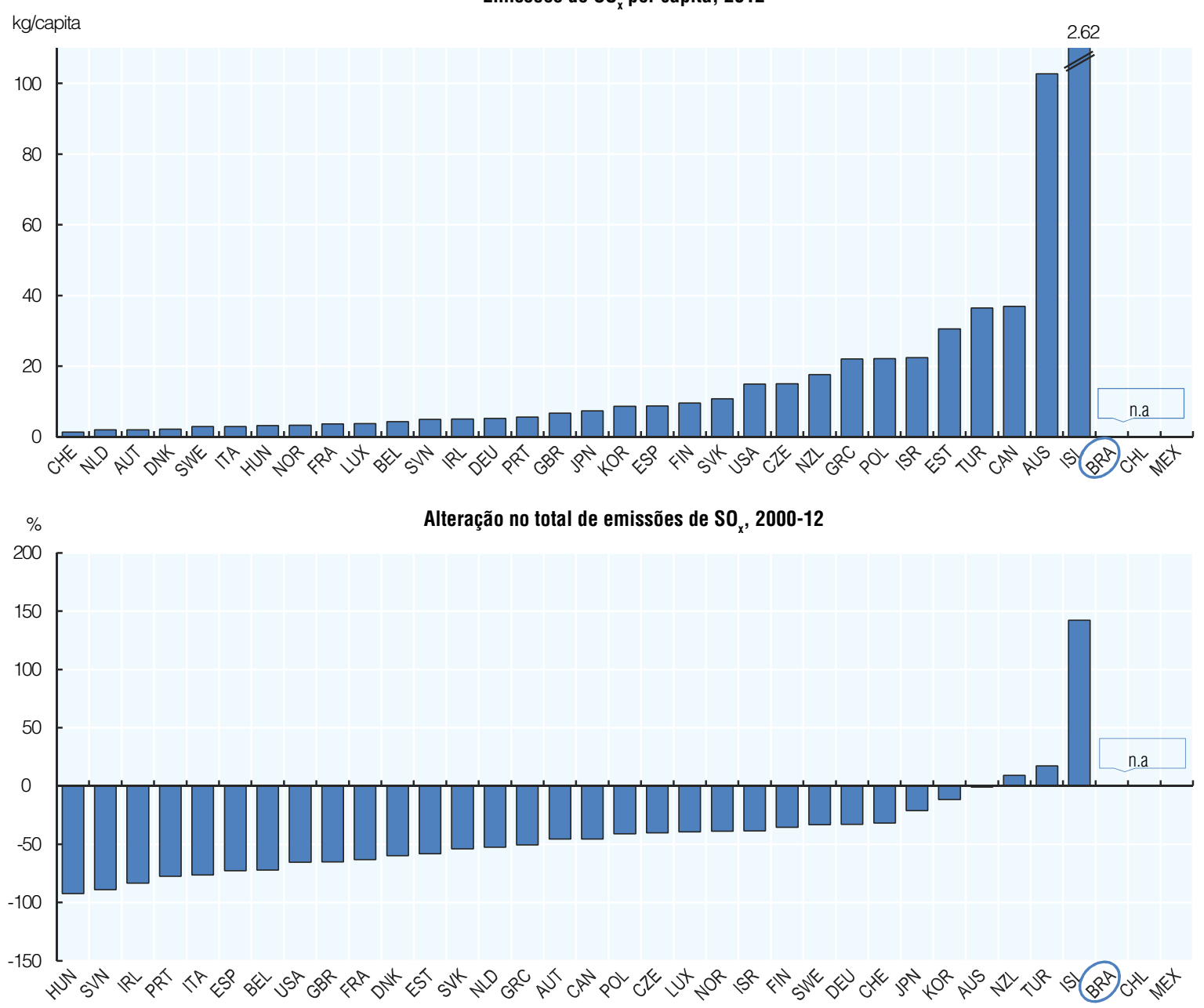

Obs.: Os dados referem-se ao ano indicado ou ao último ano em que estavam disponíveis. Podem incluir números provisórios e estimativas.

PIB a preços de 2005 e paridades de poder de compra.

Fonte: OCDE (2015), "Air emissions by source", OECD Environment Statistics (banco de dados); OECD (2014), "OECD Economic Outlook No. 95", OECD Economic Outlook: Statistics and Projections (banco de dados). 
Figura 1.B4. Emissão e intensidade de $\mathrm{NO}_{\mathrm{x}}$ Emissões de NO por unidade do PIB, 2012
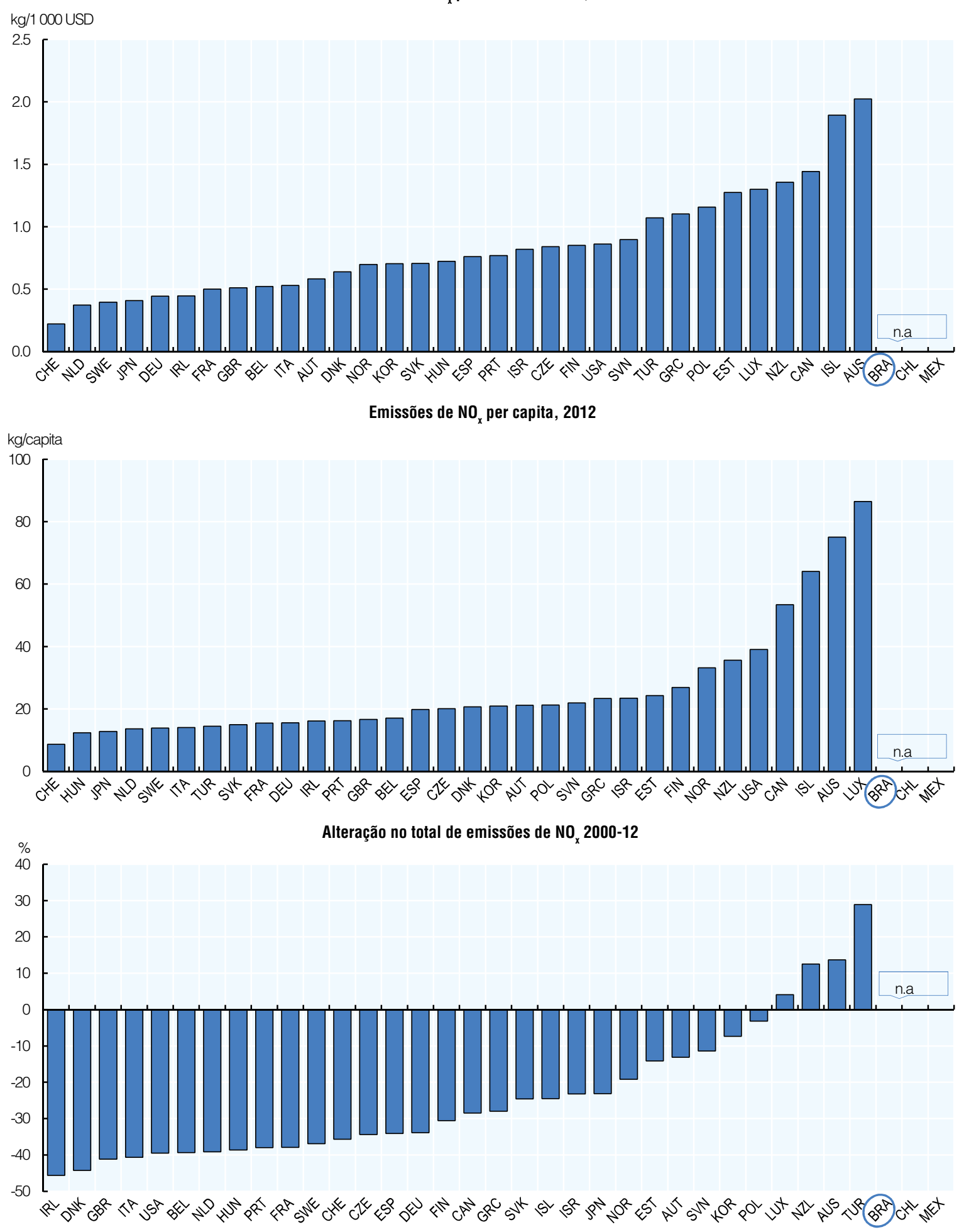

Obs.: Os dados referem-se ao ano indicado ou ao último ano em que estavam disponíveis. Podem incluir números provisórios e estimativas. PIB a preços de 2005 e paridades de poder de compra.

Fonte: OCDE (2015), "Air emissions by source", OECD Environment Statistics (banco de dados); OECD (2014), "OECD Economic Outlook No. 95", OECD Economic Outlook: Statistics and Projections (banco de dados). 
Figura 1.B5. Emissões e poluição por $\mathrm{MP}_{2.5}$ Emissões de $\mathrm{PM}_{2.5}$ per capita, 2012
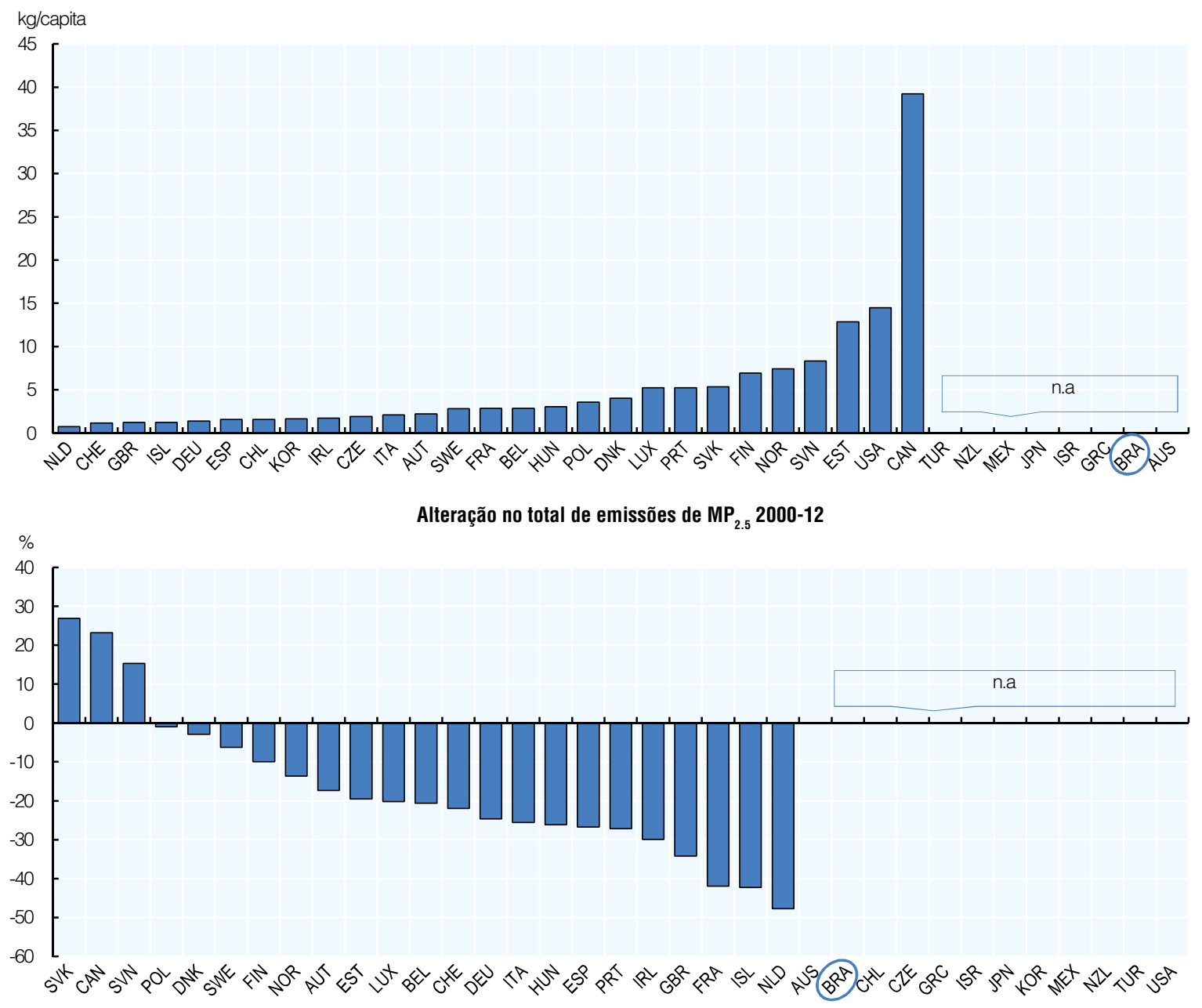

Exposição da população à poluição atmosférica $\left(\mathrm{MP}_{2.5}\right), 2003 \mathrm{e} 2012$

$\checkmark 2012 \diamond 2003$

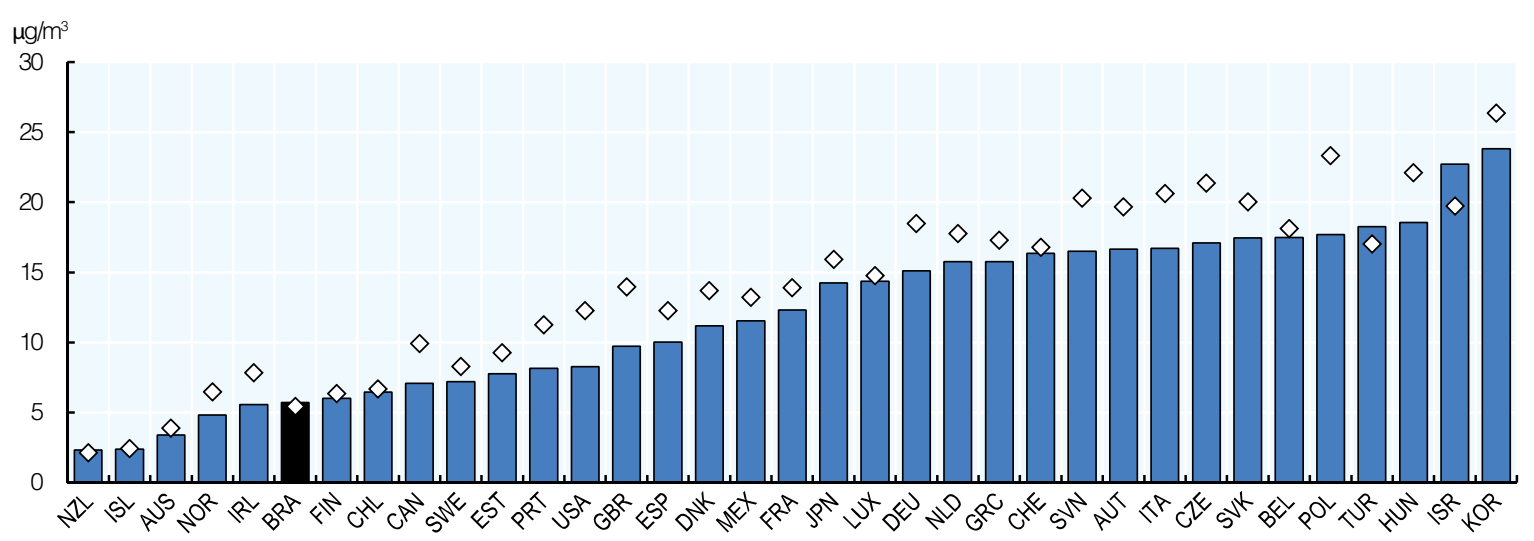

Obs.: Os dados referem-se ao ano indicado ou ao último ano em que estavam disponíveis. Podem incluir números provisórios e estimativas.

Exposicão da população à poluiç̃ão atmosférica: estimativa de exposicão média com base em dados de imagens de satélite; dados da média de três anos.

Fonte: OCDE (2015), "Air emissions by source", OECD Environment Statistics (banco de dados); OECD (2015), OECD Regional Statistics (banco de dados). 
ANEXO 1.C

Dados sobre gestão de resíduos e recursos 


\section{Figura 1.C1. Geração e gestão de resíduos}
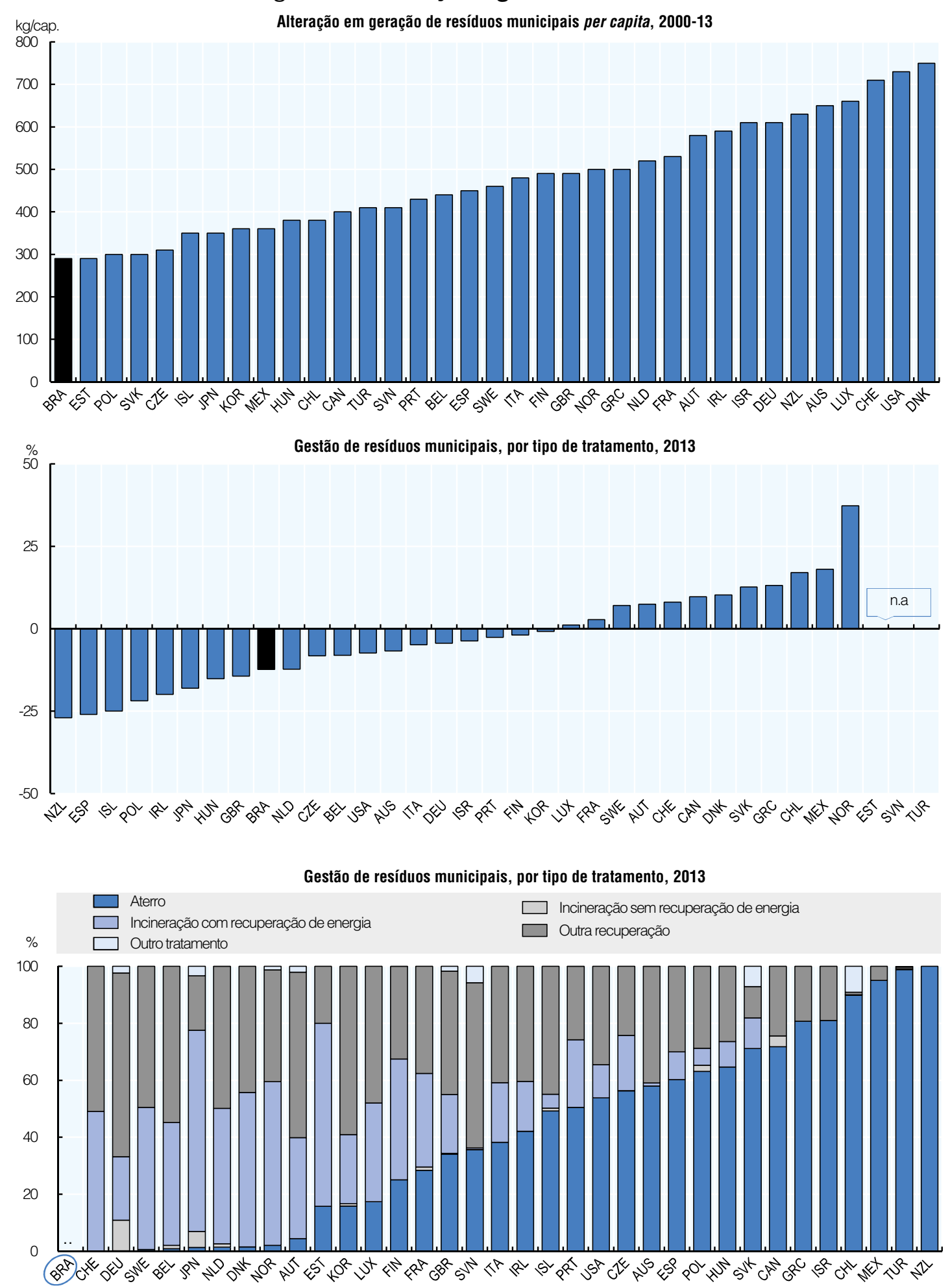

Obs.: Os dados referem-se ao ano indicado ou ao último ano em que estavam disponíveis. Podem incluir números provisórios e estimativas. Quantidades per capita são arredondados. Resíduos coletados por ou para municípios. Inclui resíduos domiciliares, volumosos e comerciais, e resíduos similares manuseados em instalações similares. Não inclui resíduos de construção municipal ou lodo de estações de tratamento de esgoto municipais.

Canadá: apenas resíduos domiciliares e total incinerado; Nova Zelândia: apenas resíduos de aterros.

Fonte: OCDE (2015), "Municipal waste", OECD Environment Statistics (banco de dados). 


\section{Figura 1.C2. Consumo e produtividade de materiais}
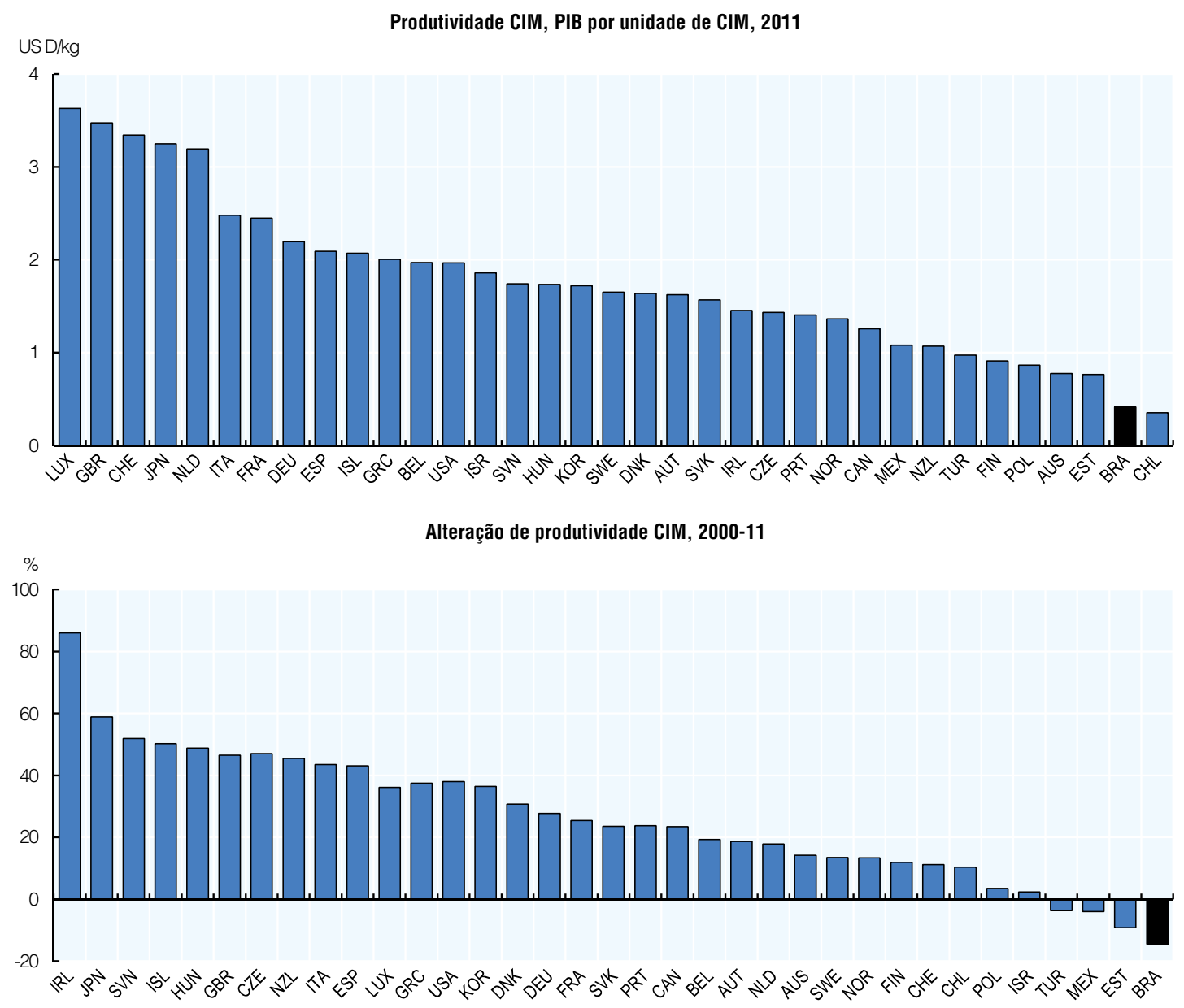

DMC por categoria de material, 2011

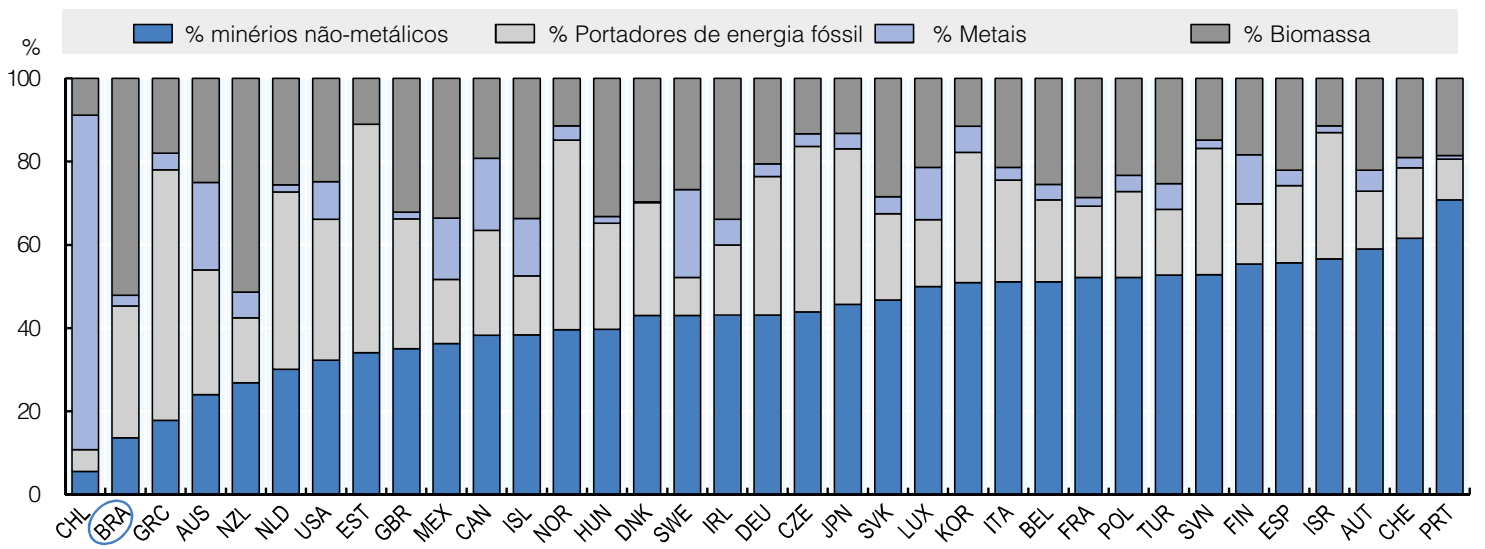

Obs.: Os dados referem-se ao ano indicado ou ao último ano em que estavam disponíveis. Podem incluir números provisórios e estimativas.

Consumo interno de materiais (CIM) é igual à soma de extração interna de materiais utilizadas pela economia e seu balanço comercial (importações menos exportações de matérias primas e produtos manufaturados). Produtividade CIM designa a parcela do PIB gerado por unidade de materiais utilizados e é calculado como coeficiente do PIB a consumo interno de materiais (CIM). PIB a preços de 2005 e paridades de poder de compra.

Categorias de materiais: Minérios não-metálicos: extração interna e comércio de minérios utilizados na indústria e na construção, mais comércio derivado de produtos processados,

Portadores de energia fóssil: carvão mineral, petróleo bruto, gás natural, turfa e produtos derivados do comércio; metais: extração interna de minérios metálicos, mais comércio de minérios metálicos, concentrados de metais, metais refinados, produtos feitos principalmente de metais, e sucata; biomassa: produção interna de agricultura, florestas e pesca, mais comércio de produtos brutos e processados desses setores.

Fonte: OCDE (2015), "Material resources", OECD Environment Statistics (banco de dados); OECD (2014), "OECD Economic Outlook No. 95", OECD Economic Outlook: Statistics and Projections (banco de dados). 
Figura 1.C3. Insumos agrícolas e densidade de rebanhos

$\mathrm{t} / \mathrm{km}^{2}$ terras agrícolas

Aparente consumo de fertilizantes nitrogenados, 2010-12

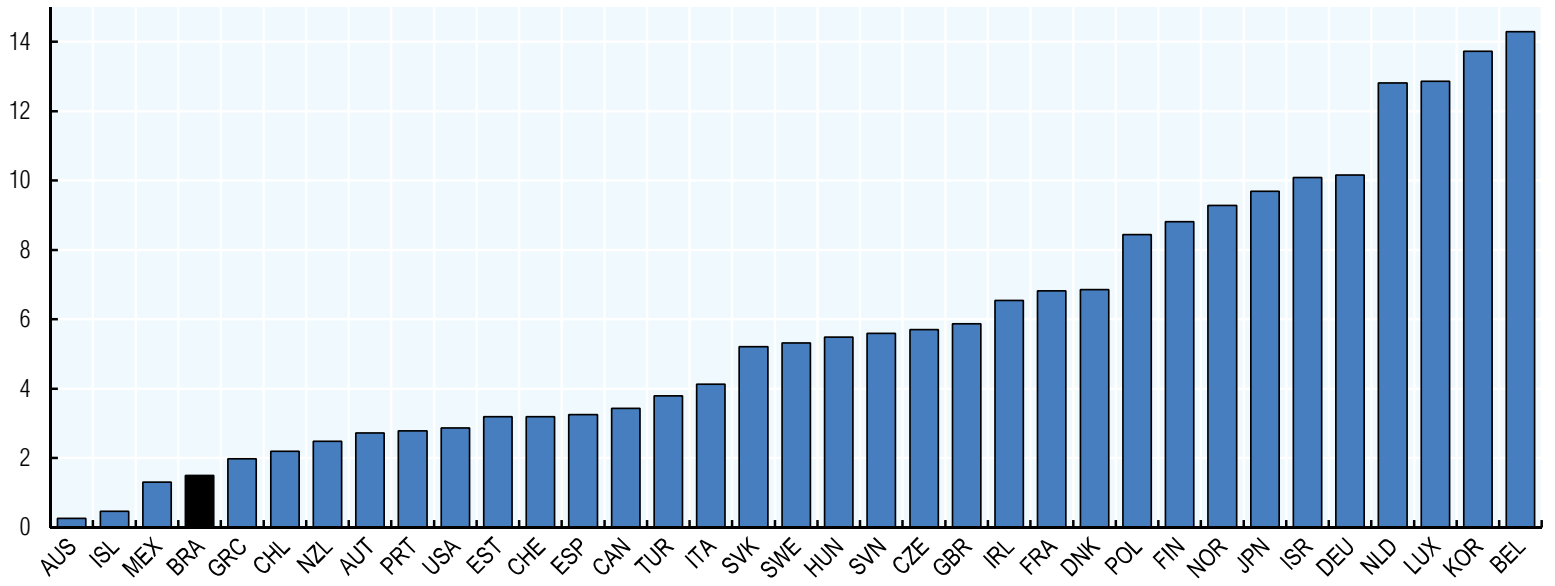

$\mathrm{t} / \mathrm{km}^{2}$ terras agrícolas

Vendas de pesticidas, 2009-11

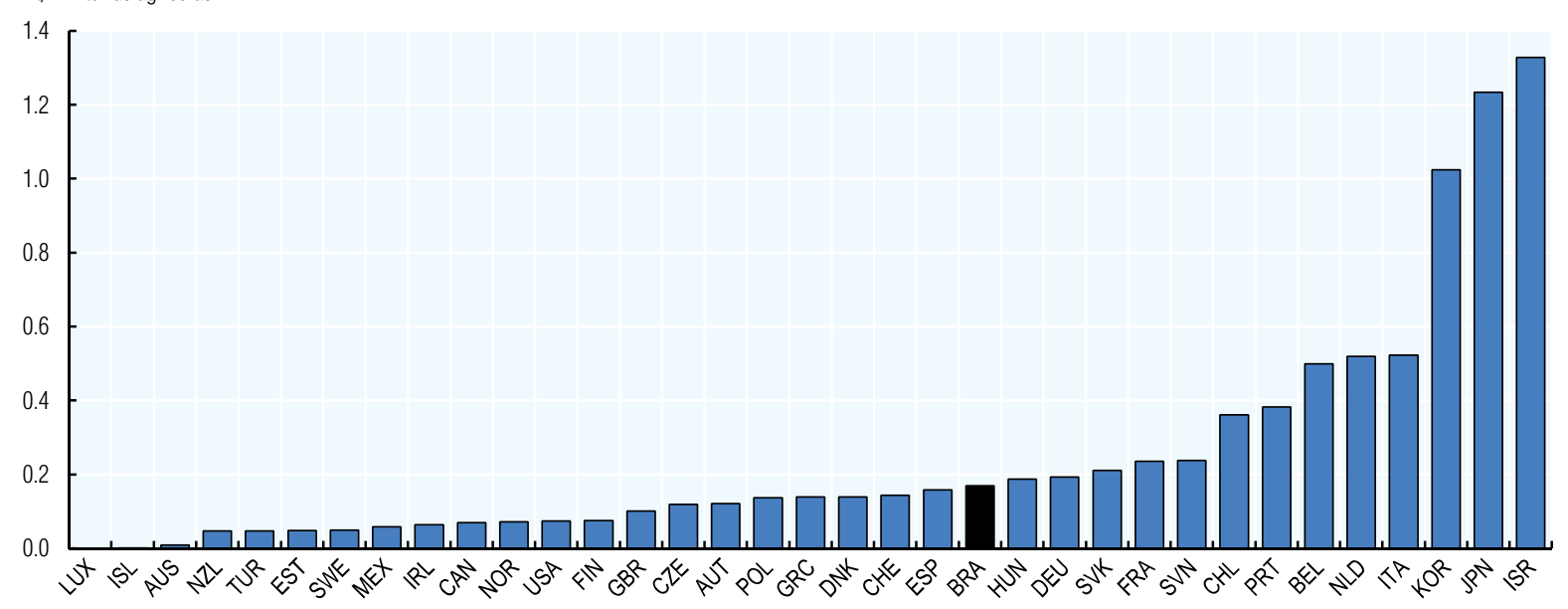

Cabeças de ovinos eq./km² de terras agrícolas

Densidade de rebanhos, 2013

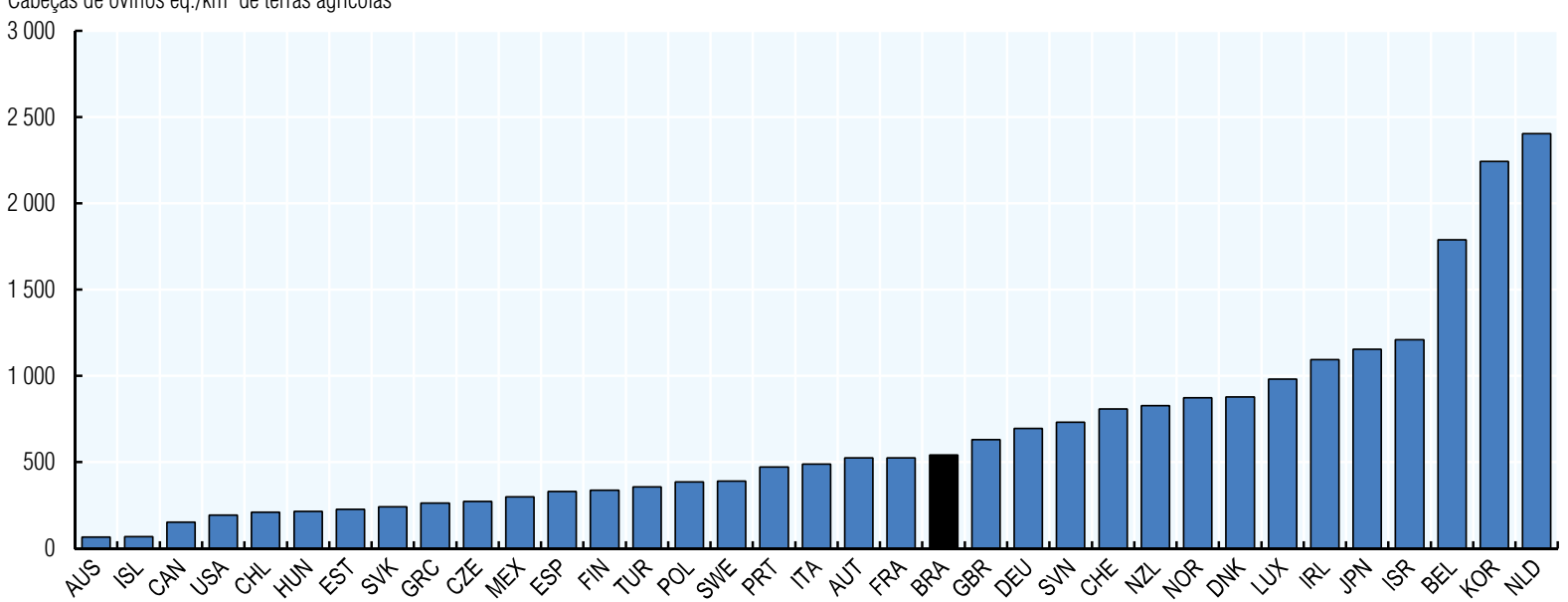

Obs.: Os dados referem-se ao ano indicado ou ao último ano em que estavam disponíveis. Podem incluir números provisórios e estimativas. Fonte: FAO (2015), FAOSTAT (banco de dados); OECD (2015), OECD Environment Statistics (banco de dados). 
ANEXO 1.D

Dados sobre biodiversidade e recursos hídricos 
Figura 1.D1. Captura de peixes e espécies ameaçadas

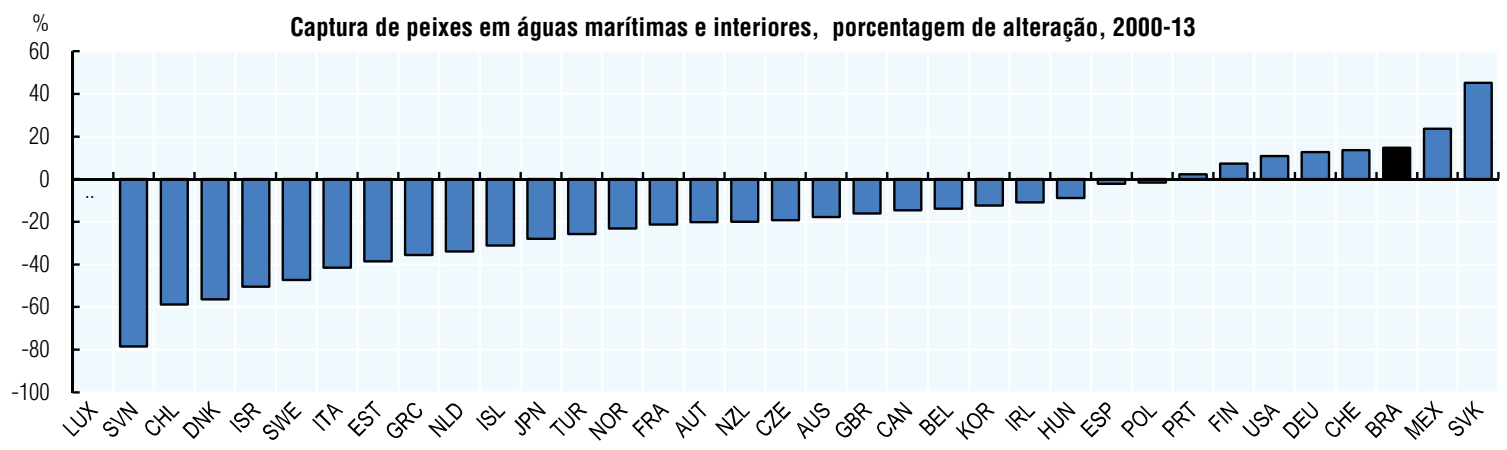

Espécies ameaçadas, percentagem de espécies conhecidas, final dos anos $\mathbf{2 0 0 0}$
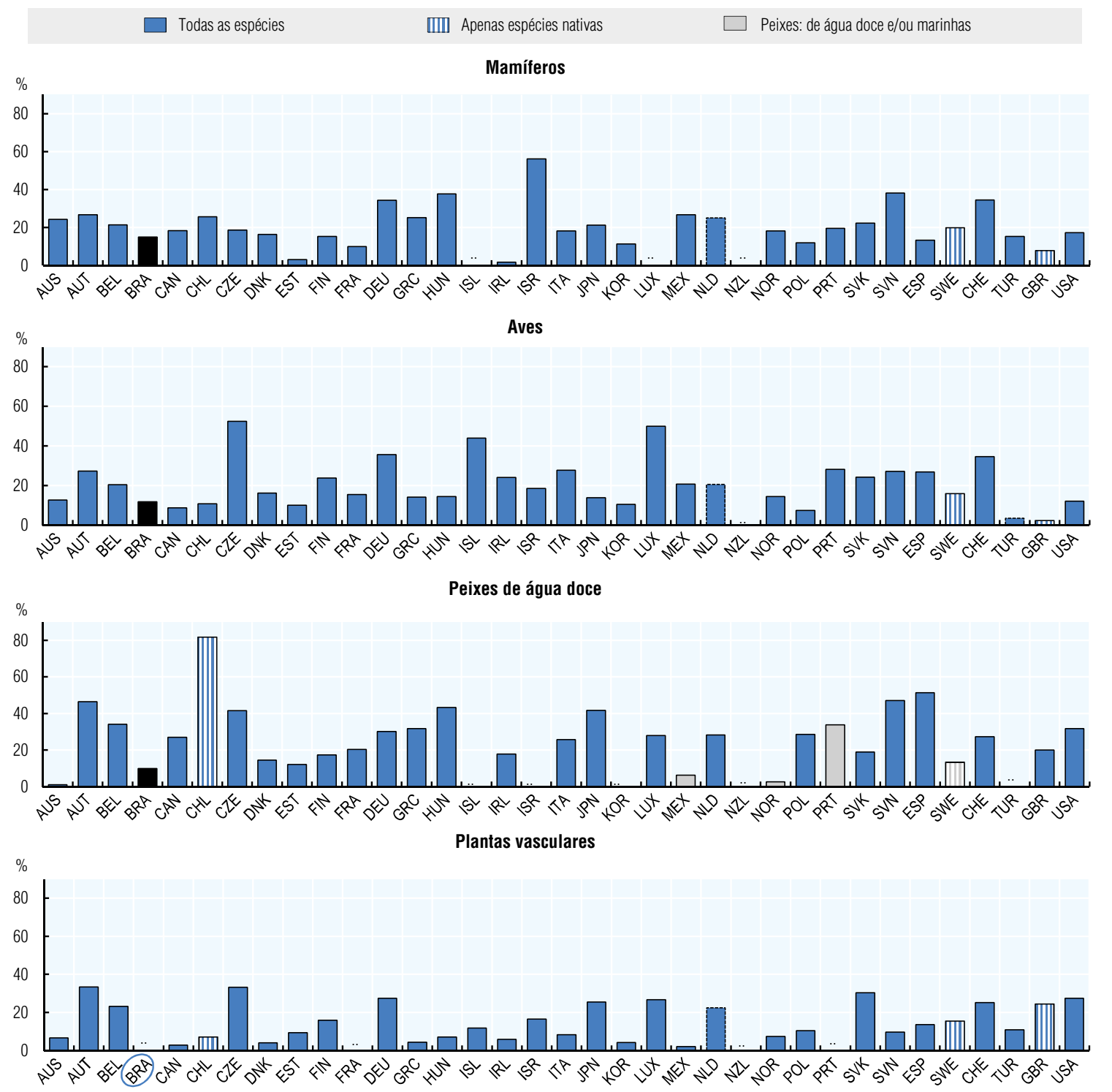

Obs.: Os dados referem-se ao ano indicado ou ao último ano em que estavam disponíveis. Podem incluir números provisórios e estimativas.

Inclui peixes, crustáceos, moluscos e outros animais aquáticos. Exclui mamíferos marinhos, crocodilos e jacarés, e produtos aquáticos diversos.

Fonte: Instituto Chico Mendes de Conservação da Biodiversidade (ICMBio) (2015), "Espécies Ameaçadas - Lista 2014" FA0 (2015), Global Capture Production (banco de dados); MMA (2015), Fifth National Report to the Convention on Biological Diversity, OECD (2015), "Endangered species", OECD Environment Statistics (banco de dados). 
Figura 1.D2. Captação de água e tratamento de águas servidas

Captação de água bruta per capita, 2013

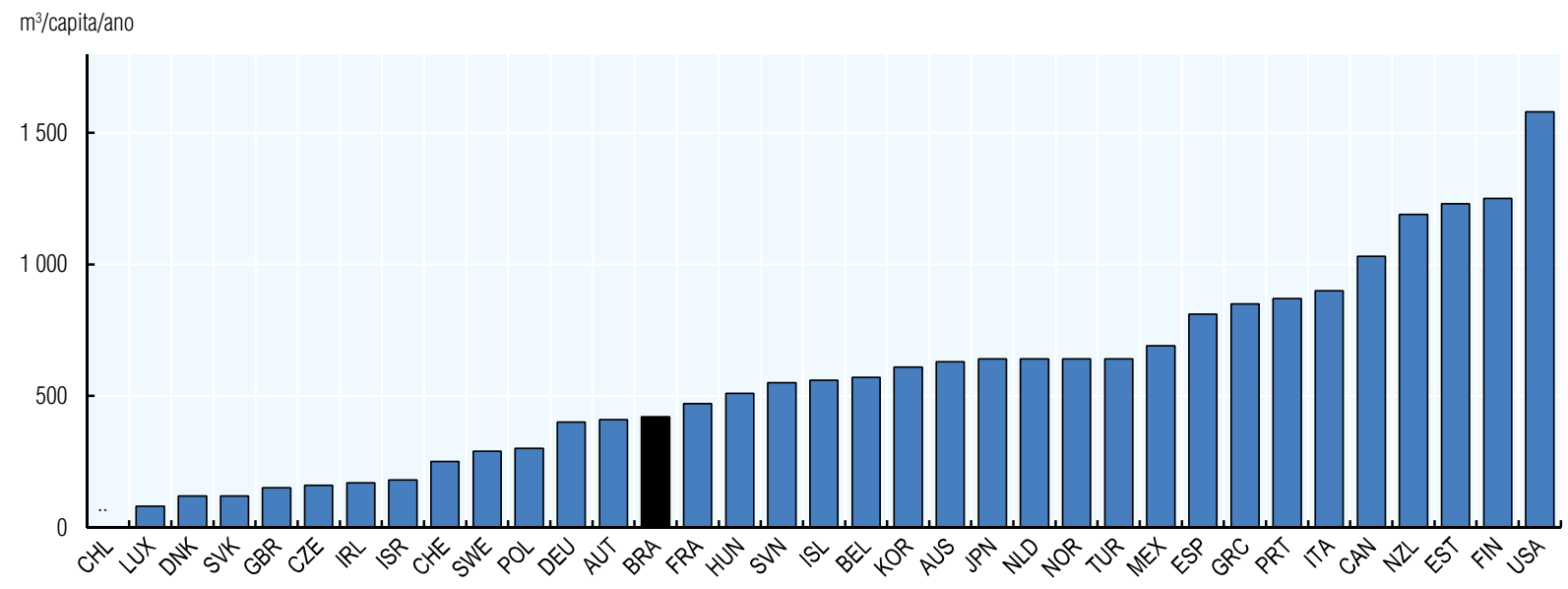

Captação de água bruta como percentagem de fontes renováveis, 2013

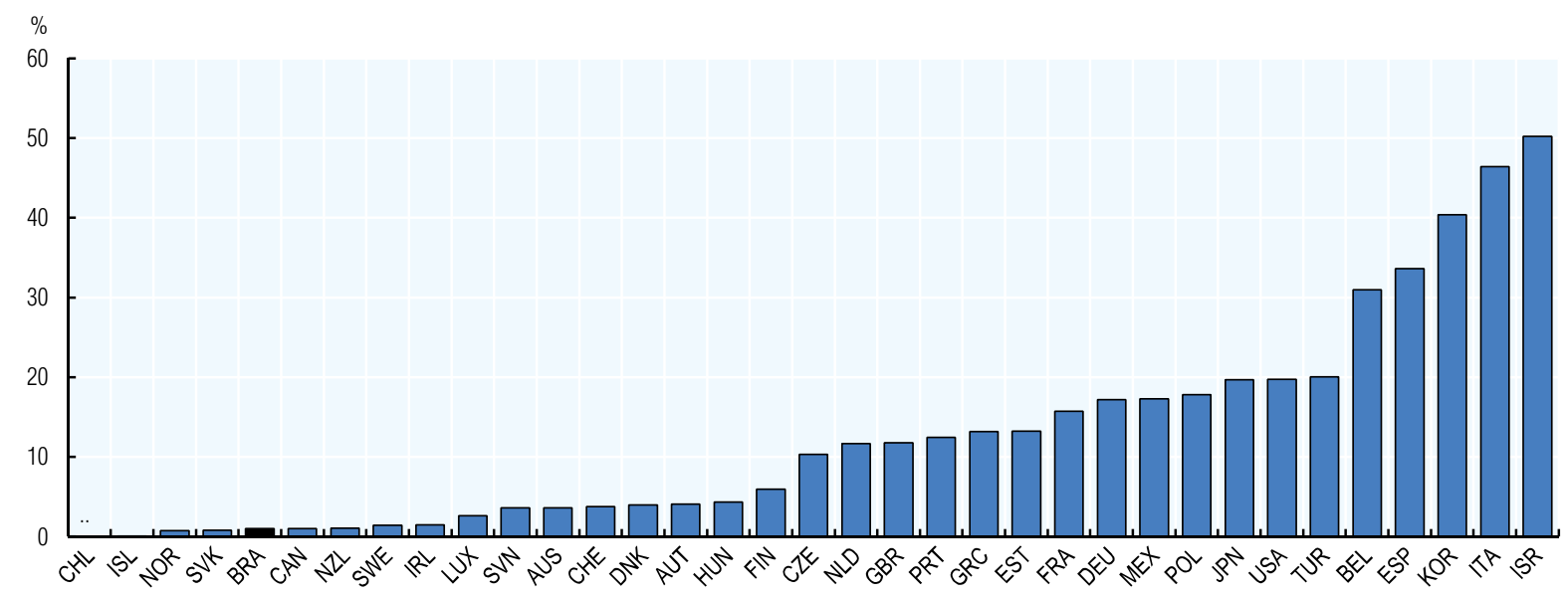

População conectada à rede pública de tratamento de águas servidas, 2013

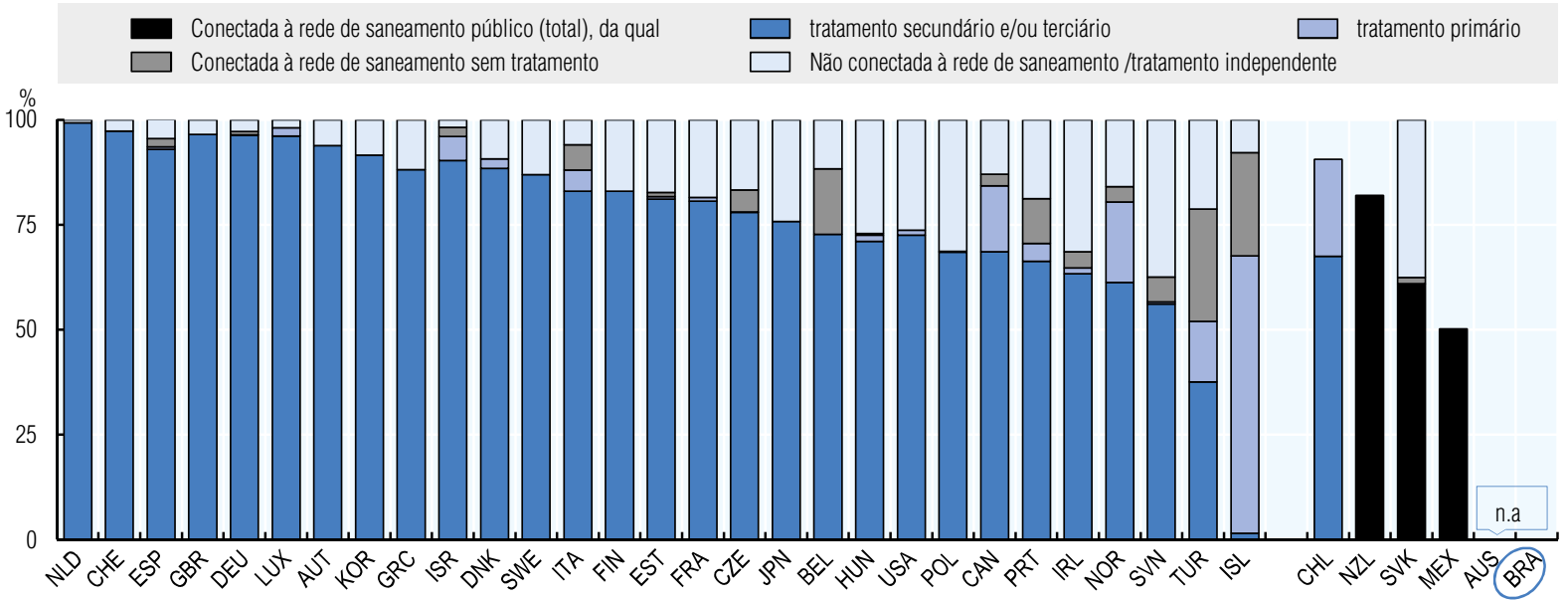

Obs.: Os dados referem-se ao ano indicado ou ao último ano em que estavam disponíveis. Podem incluir números provisórios e estimativas. Reino Unido: apenas Inglaterra e País de Gales. Captação de água doce: para alguns países, os dados referem-se a outorgas de uso da água e não a captações reais. Quantidades per capita são arredondadas. Fonte: OCDE (2015), "Water: Freshwater Abstractions", "Wastewater Treatment (\% Population Connected)", OECD Environment Statistics (banco de dados). 

PARTE 1

Capítulo 2

Governança e gestão ambiental

O Brasil desenvolveu um marco legislativo abrangente e arranjos institucionais avançados. Contudo, a heterogeneidade econômica e social do país e o sistema federativo descentralizado geram desafios à sua implementação. Neste capítulo é analisado o sistema brasileiro de governança ambiental, incluindo os mecanismos de coordenação vertical e horizontal e os orçamentos dos órgãos ambientais. São examinados os marcos regulatórios referentes à gestão do ar, da água e de resíduos e a temática de mudanças climáticas, bem como os mecanismos de avaliação de impacto e licenciamento ambiental. São discutidas também a fiscalização e as garantias de conformidade, e avaliados os avanços da participação da sociedade na tomada de decisão e o acesso a informações, educação e justiça ambiental. 


\section{Marco institucional de governança ambiental em diversas instâncias}

O Brasil tem um sistema federativo de governança, com vinte e seis estados e o Distrito Federal. Os 5.570 municípios (cerca de 70\% dos quais com população inferior a 20.000 habitantes) gozam de ampla autonomia: a Constituição Federal de 1988 atribuiu aos municípios, bem como aos estados, o status de entes federativos. Os estados possuem suas próprias constituições e governos, podendo adotar políticas e leis, de acordo com suas prioridades, dentro do marco geral da lei federal. Os municípios podem legislar sobre todos os assuntos de interesse local e complementar as leis federais e estaduais, exceto sobre matérias exclusivas da União. Apesar de os estados e municípios arrecadarem receitas próprias, o grande volume de transferências diretas efetuado pelo governo federal lhe confere grande influência política.

A Constituição identifica a política ambiental como responsabilidade "comum e convergente" partilhada pelos níveis federal, estadual e municipal. O Sistema Nacional do Meio Ambiente (SISNAMA) criado em 1981 pela Política Nacional do Meio Ambiente (PNMA) reúne relevantes instituições governamentais de todas as instâncias em um complexo sistema de governança, composto por conselhos e órgãos executores (Tabela 2.1). A Lei Complementar $n^{\circ}$ 140/2011 e o Decreto $n^{\circ}$ 8.437/2015 esclarecem limites acerca da competência federal, estadual e municipal, no que diz respeito a certas questões ambientais, notadamente ao licenciamento ambiental e à avaliação de impacto (Seções 4.1 e 4.2).

Tabela 2.1. O SISNAMA em diferentes níveis de governo

\begin{tabular}{lll}
\hline Instância administrativa & Conselho & Órgão Executivo \\
Federal & Conselho Nacional do Meio Ambiente & $\begin{array}{l}\text { Ministério do Meio Ambiente, Instituto Brasileiro do Meio } \\
\text { Ambiente e Recursos Naturais Renováveis, Instituto } \\
\text { Chico Mendes para Conservação da Biodiversidade }\end{array}$ \\
Estadual & Conselho Estadual do Meio Ambiente & $\begin{array}{l}\text { Secretarias ou órgãos do executivo estadual (podem } \\
\text { estar integrados a outras áreas políticas) }\end{array}$ \\
Municipal & Conselho Municipal do Meio Ambiente & $\begin{array}{l}\text { Órgãos do executivo (geralmente integrados a outras } \\
\text { áreas políticas) }\end{array}$ \\
\hline
\end{tabular}

Fonte: CAVALCANTI. Economic Growth and Environmental Protection in Brazil: An Unfavourable trade-off. In: BRETON, A. et al. (Eds). Environmental Governance and Decentralisation. UK: Edward Elgar, Cheltenham, 2007.

\subsection{Instituições nacionais e coordenação horizontal}

O Conselho Nacional do Meio Ambiente (CONAMA) é o principal órgão de coordenação e elaboração da política nacional. Criado em 1981, exerce papel consultivo e deliberativo de alto nível e reúne representantes de todas as instâncias governamentais e os principais atores. ${ }^{1}$ Para preencher a grande lacuna nas regulamentações ambientais nas décadas de 1980 e 1990, o CONAMA foi além do seu mandato consultivo, emitindo grande número de regulamentos nacionais. Suas resoluções ganharam autoridade, tendo força de lei e sobrepondo, em alguma medida, a 
atividade do legislativo em matéria de meio ambiente. Embora o Judiciário nunca tenha contestado o poder regulatório do CONAMA, a postura proativa do conselho tem gerado tensões com outros órgãos reguladores, especialmente em nível estadual, o que tem prejudicado sua reputação como colegiado colaborativo integrado pelos diversos setores interessados. O conselho vem buscando recuperar a confiança dos outros atores ambientais, revendo seu acervo de resoluções e assumindo mais o papel de orientação e coordenação.

O Ministério do Meio Ambiente (MMA) criado em 1992,2 desenvolve, coordena e supervisiona a implementação da política federal ambiental, enquanto que o CONAMA lida com as políticas em todas as instâncias de governo. As atribuições do MMA incluem a elaboração de propostas para estratégias econômicas e sociais e de instrumentos voltados à melhoria da qualidade ambiental e ao aproveitamento sustentável de recursos naturais. A capacidade institucional do MMA cresceu notadamente nos últimos dez anos. No entanto, em comparação com outros ministérios, seu orçamento anual continua entre os mais baixos (Seção 2), e a alta rotatividade de pessoal e a dificuldade em manter quadros de servidores qualificados prejudicam a continuidade institucional.

O Instituto Brasileiro de Meio Ambiente e dos Recursos Naturais Renováveis, (IBAMA) criado em 1989, é o órgão executivo ambiental do nível federal. Como as agências estaduais se encarregam da fiscalização da poluição, o principal enfoque do IBAMA é a gestão de recursos naturais, especialmente em áreas do país com maior vocação para a exploração de tais recursos, como a Amazônia. Em 2007, o IBAMA foi desmembrado em dois órgãos: um manteve o nome IBAMA e as principais atribuições de licenciamento, monitoramento e fiscalização; e outro, o Instituto Chico Mendes para a Conservação da Biodiversidade (ICMBio), que supervisiona todos os aspectos das áreas protegidas federais. A justificativa para essa mudança foi separar a preservação e a gestão de áreas protegidas, da fiscalização e monitoramento de conformidade (Capítulo 5). O Serviço Florestal Brasileiro gerencia as atividades relacionadas às florestas públicas.

O Brasil tem um marco institucional complexo e distinto para a gestão de recursos hídricos, que atua em coordenação com as autoridades ambientais (Box 2.1), um arranjo semelhante ao existente em alguns países da OCDE, como os Países Baixos.

O novo Sistema de Informação Estratégica (SISNAMA - SIES) tem como objetivo mostrar a forma em que as atividades, projetos e instrumentos do MMA e suas instituições se relacionam com as 15 agendas estratégicas estabelecidas no planejamento estratégico do Ministério. O “Plano Estratégico: Gestão por Resultados, 2014-2020", publicado pelo MMA em junho de 2014, estabelece metas qualitativas para cada uma das 15 áreas prioritárias e delineia iniciativas concretas para a sua realização, embora não inclua procedimentos para a avaliação de desempenho ou indicadores de resultado. O SIES ainda está em estágio inicial e acessível apenas internamente, mas o MMA pretende expandi-lo para todas as instituições do SISNAMA.

Vários dos 39 ministérios, entre eles os da Agricultara, Energia e Transportes, compartilham responsabilidades relacionadas ao ambiente e, portanto, são considerados integrantes do SISNAMA. Outros ministérios têm responsabilidades que, em outros países, são da competência do Ministério do Meio Ambiente: por exemplo, o Ministério das Cidades supervisiona a gestão de resíduos e o saneamento; e o Ministério da Ciência, Tecnologia e Inovação (MCTI) administra o inventário de emissões de gases de efeito estufa (GEE). 
A cultura institucional do Brasil se baseia em ministérios verticalizados, com cada um seguindo a sua própria estratégia no nível subnacional e, em geral, sem articulação com outros ministérios. Em outros países também existem sistemas verticalizados, mas no Brasil os problemas se agravam devido ao grande número de ministérios. A falta de transversalização de temas ambientais nas políticas setoriais foi, durante muito tempo, o fator que mais prejudicou o desenvolvimento sustentável do país, uma vez os ministérios setoriais relutavam em abordar questões ambientais, argumentando que esse era o papel dos órgãos ambientais. No início dos anos 2000, o MMA esteve um tanto afastado, ou mesmo excluído da formulação de políticas setoriais (TEIXEIRA, 2012). Em consequência, políticas e programas setoriais específicos deram pouca ênfase aos efeitos ambientais potencialmente negativos.

\section{Box 2.1. Quadro institucional para a governança da água}

A Agência Nacional de Águas (ANA) é responsável pela implementação da Política de Recursos Hídricos e pela regulação do uso da água em rios sob o domínio da União. O Conselho Nacional de Recursos Hídricos (CNRH), um colegiado consultivo em paralelo com o CONAMA, formula a Política Nacional de Recursos Hídricos. ${ }^{3}$ Seus membros representam os órgãos governamentais federais e estaduais, os usuários de recursos hídricos e organizações da sociedade civil. O CNRH e a ANA são supervisionados pela Secretaria de Recursos Hídricos e Ambiente Urbano.

A responsabilidade pela gestão dos recursos hídricos é compartilhada entre o governo federal, para rios sob domínio federal, e os governos estaduais, para rios de competência estadual - incluindo afluentes de rios federais - e águas subterrâneas. A Lei da Política Nacional de Recursos Hídricos estabeleceu as bacias hidrográficas como sendo a principal unidade de planejamento de recursos hídricos e estimulou a criação dos respectivos comitês de bacia e agências.

O marco institucional para a gestão dos recursos hídricos em nível subnacional visa assegurar a descentralização e a participação da sociedade civil, mas as complexidades da estrutura fazem com que haja bastante variação no nível de articulação entre órgãos de gestão dos recursos hídricos e instituições ambientais nos diferentes estados. Em alguns estados (ex., Rio de Janeiro) um único órgão cuida da gestão de recursos hídricos e ambientais, enquanto que em outros, essas competências são exercidas por órgãos distintos. No Rio de Janeiro, a integração foi bem-sucedida devido a uma profunda consciência dos problemas hídricos e uma equipe bem capacitada; em outros estados, a fusão de competências faz com que temas ambientais se sobreponham à gestão de recursos hídricos. A governança hídrica subnacional inclui as seguintes entidades:

Conselhos estaduais de recursos hídricos - colegiados consultivos instituídos pelos estados para formular políticas estaduais de recursos hídricos. Todos os estados, com exceção do Acre, têm um conselho de recursos hídricos, embora o nível de competência varie muito entre eles.

Agências estaduais de gestão de recursos hídricos - organismos que regulam o uso dos recursos em rios estaduais, que muitas vezes compartilham bacias hidrográficas com rios federais. Alguns estados têm agências especiais para gerir os recursos hídricos, enquanto em outros, essas agências fazem parte dos órgãos ambientais e estão sujeitas a reestruturações periódicas.

Comitês de bacias hidrográficas - colegiados deliberativos em nível de bacias hidrográficas que incluem representantes de órgãos governamentais, usuários de água e sociedade civil. Mais de 200 comitês foram criados, abrangendo cerca de um quarto do território nacional, a maior parte nas regiões Sul e Sudeste, em áreas com graves problemas hídricos e mobilização dos usuários de água.

Agências de água - colegiados técnicos que atuam como órgãos executivos dos comitês de bacias hidrográficas. Na prática, os órgãos estaduais de gestão de recursos hídricos tendem a desempenhar esse papel, em vista da carência de recursos humanos e financeiros para a manutenção de instituições distintas, o que faz com que os comitês de bacias hidrográficas dependam do governo estadual para a implementação de suas decisões.

Fonte: OCDE. Water Resources Governance in Brazil. Paris: OCDE Publishing, 2015. 
Nos últimos anos, contudo, houve uma melhora na situação após a criação, em vários ministérios, de grupos temáticos sobre questões ambientais que se articulam com o MMA. O meio ambiente ganhou um espaço mais importante na agenda econômica e social do Brasil. No entanto, falta ao MMA os recursos necessários e o poder de impor a transversalização sistemática de questões ambientais na formulação de políticas. Uma liderança forte com coordenação de alto perfil ajudaria a melhorar a coerência política, fazendo com que o desenvolvimento sustentável se tornasse política de Estado. A articulação em torno dos acordos de coordenação voltados à política de mudança do clima e ao combate ao desmatamento na Amazônia, com o envolvimento direto da Casa Civil da Presidência da República, são experiências positivas a esse respeito (Seção 3.1 e Capítulo 4).

A colaboração interinstitucional vem ganhando espaço em muitas áreas políticas, tais como mudança do clima (Seção 3.1), biodiversidade e florestas. Mais de 400 comitês, conselhos e grupos de trabalho interinstitucionais lidam com vários assuntos relacionados ao meio ambiente. Esses organismos de coordenação horizontal servem para rebater as estruturas verticalizadas, promover o envolvimento da comunidade empresarial e da sociedade civil, e aumentar a consciência ambiental nos setores governamentais. A grande proliferação desses grupos de articulação, no entanto, faz com que a participação se torne onerosa, o que leva, muitas vezes, ao esvaziamento e abandono logo após a sua criação.

\subsection{Instituições subnacionais}

Os estados têm importantes atribuições regulatórias e de fiscalização na gestão de recursos hídricos e no controle da poluição atmosférica, ao passo que, na gestão de resíduos, recursos naturais e biodiversidade, seu papel é mais limitado. No conjunto, as instituições ambientais estaduais espelham as de nível nacional. Cada estado tem um conselho de meio ambiente e uma secretaria ou órgão ambiental (geralmente com atribuições que englobam outras áreas, tais como o planejamento ou a ciência e tecnologia). Os conselhos incluem representantes de municípios e de entidades não governamentais. Alguns estados (ex., Espírito Santo) possuem conselhos ambientais regionais, além do conselho estadual. A orientação fragmentada das secretarias estaduais tem levado alguns estados a criar sistemas de coordenação horizontal (ex., gestão dos recursos hídricos; ver Box 2.1).

O nível de desenvolvimento das instituições ambientais varia consideravelmente entre os estados. São Paulo possui os órgãos ambientais mais fortes, a exemplo da Companhia de Tecnologia de Saneamento Ambiental (CETESB), entidade de controle de poluição que remonta aos anos 1970. Na outra extremidade, a Secretaria de Ciência, Tecnologia e Meio Ambiente do Estado do Pará entrou em funcionamento apenas em meados dos anos 1990 (McAllister, 2008) e permanece institucionalmente fraca. Muitos órgãos estaduais enfrentam dificuldades em manter quadros técnicos qualificados. $O$ IBAMA tem buscado complementar os órgãos estaduais, assumindo maior envolvimento nos estados em que as capacidades institucionais são mais fracas, especialmente nas regiões Norte e Nordeste.

Os municípios gozam de elevado grau de autonomia constitucional. Podem elaborar e aplicar normas ambientais, incluindo regimes de licenciamento; impor encargos ambientais e destinar sua receita a fundos especiais (por exemplo, em apoio a projetos locais de conservação); e criar áreas protegidas de destacado valor cultural e natural. 
Suas atribuições incluem ainda o abastecimento de água, o saneamento e os serviços de gestão de resíduos, bem como o planejamento do uso da terra.

No entanto, a devolução de atribuições de gestão ambiental aos municípios, conforme previsto na Constituição e outras legislações ambientais, tem se comprovado difícil. A capacidade institucional varia bastante entre os municípios devido a diferenças no nível de desenvolvimento socioeconômico, fato que precisa ser considerado quando da formulação e implementação de políticas ambientais federais sobre questões, tais como a gestão de resíduos. Para fortalecer a devolução das atribuições de gestão ambiental aos seus municípios, o Estado de São Paulo adotou um programa com base em incentivos que poderá servir de modelo para outros estados (Box 2.2).

\section{Box 2.2. Programa Município Verde Azul de São Paulo}

Em 2007, a Secretaria de Meio Ambiente do Estado de São Paulo lançou um programa inovador para fortalecer a descentralização da gestão ambiental ao nível municipal. $O$ Programa Município Verde Azul proporciona incentivos aos municípios para desenvolver e implementar planos ambientais, avaliar anualmente o desempenho dos municípios e prestar apoio técnico e capacitação em gestão ambiental.

Embora a participação no programa seja voluntária, é requisito para o acesso a recursos do Fundo Estadual de Prevenção e Controle da Poluição, FECOP. Os municípios podem aderir, firmando um memorando de entendimento no qual concordam em cumprir com ações e metas em dez áreas de gestão ambiental: tratamento de esgoto, gestão de resíduos sólidos, biodiversidade, florestas urbanas, educação ambiental, gestão sustentável da cidade, gestão hídrica, qualidade do ar, governança ambiental e funcionamento de um conselho ambiental. ${ }^{4} \mathrm{O}$ número de municípios participantes no programa aumentou de 44 em 2008, para 645 em 2014.

Ao final de cada exercício, a secretaria estadual avalia o desempenho dos municípios sobre um conjunto de indicadores para cada área de gestão ambiental, com base em relatórios preparados pelos próprios municípios. A secretaria elenca e premia os municípios com melhor desempenho. Os municípios com pontuações mais elevadas ganham um "selo verde" e acesso prioritário a financiamentos; enquanto que aqueles com pontuações baixas recebem apoio técnico. Os critérios de avaliação podem variar de um ano para outro. Por exemplo, no exercício de 2014, os municípios poderiam ganhar 0,5 pontos (de 100) por aderir à campanha das Nações Unidas Construindo Cidades Resilientes, e 210 cidades aderiram.

Fonte: Secretaria do Meio Ambiente do Estado de São Paulo (2015); Município Verde Azul (www.ambiente. sp.gov.br/municipioverdeazul).

O número de municípios dotados de um conselho municipal de meio ambiente cresceu significativamente na última década, embora a atuação desses conselhos varie, e cerca de um quarto esteja inativo (Figura 2.1). Ainda assim, dos municípios com população acima de 100.000 habitantes, praticamente todos possuem instituições ambientais em funcionamento (IBGE, 2014a). Cerca de 1.100 municípios vêm se beneficiando das atividades do Programa Nacional de Capacitação de Gestores Ambientais, promovido pelo MMA desde 2005.

\subsection{Mecanismos de colaboração vertical}

As instituições federais responsáveis pelas relações verticais com outros níveis administrativos são a Subchefia de Assuntos Federativos da Secretaria de Relações Institucionais e o Comitê de Articulação Federativa da Casa Civil da Presidência da República, que se propõem a facilitar o diálogo entre as esferas federal e municipal. No entanto, a atuação desses órgãos em matéria de meio ambiente é apenas marginal. 
Figura 2.1. Muitos municípios criaram uma instituição ambiental

Porcentagem de municípios com instituições ambientais, 2004, 2009 e 2013

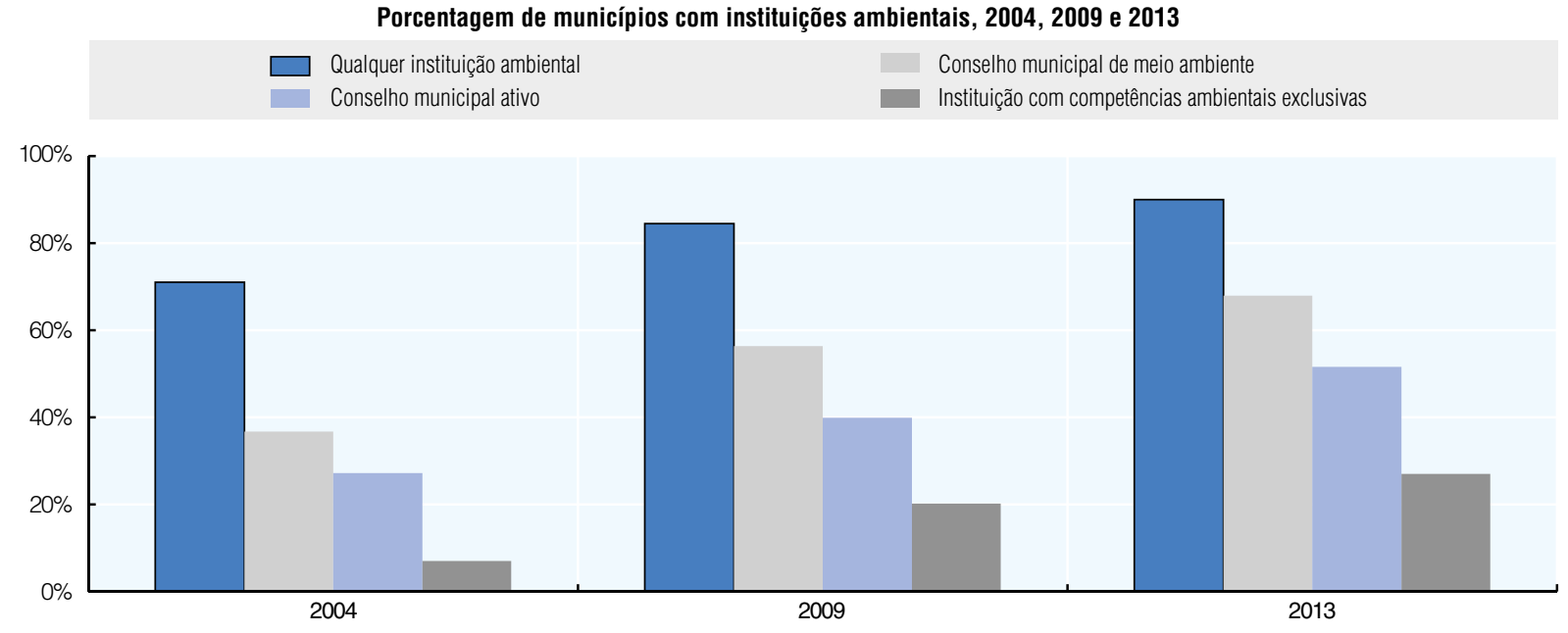

Fonte: IBGE (2013; 2009; 2004), Perfil dos municípios brasileiros.

O CONAMA é o principal mecanismo formal da governança cooperativa ambiental. Entretanto, na realidade, sua composição representativa (Seção 1.1) não corresponde ao nível de engajamento das várias partes interessadas no processo decisório; muitos membros costumam faltar às reuniões (SANO, 2012), e os municípios reclamam de não terem influência sobre suas decisões. Problemas semelhantes são comuns nos conselhos estaduais ambientais, que não parecem constituir uma plataforma eficaz para a colaboração entre estados e municípios.

A Comissão Tripartite Nacional (CTN) foi criada em 2001, para complementar a formulação colaborativa de políticas no CONAMA. Seu objetivo é fortalecer a coordenação vertical entre os três níveis de governo e assim melhorar a implementação da política ambiental. Cada nível é representado por três membros da CTN. Os representantes estaduais são indicados pela Associação Brasileira das Entidades Estaduais do Meio Ambiente (ABEMA) e os municipais pela Associação Nacional de Órgãos Municipais de Meio Ambiente (ANAMMA). A CTN desempenha papel apenas consultivo e, a exemplo de outros órgãos brasileiros de coordenação, carece de ferramentas políticas para assegurar a implementação de suas recomendações.

Todos os estados têm Comissões Técnicas Tripartites Estaduais (CTEs) destinadas a promover o diálogo entre o órgão ambiental estadual e os municípios. Todavia, há indícios de que as CTEs são institucionalmente fracas; carecem de procedimentos claros de trabalho; e recebem pouco ou nenhum apoio do nível federal (SANO, 2012).

A ABEMA e, em menor escala, a ANAMMA empreendem esforços no sentido de promover a cooperação e a troca de informações entre suas instituições componentes e defender, no nível nacional, suas opiniões sobre formulação e implementação da política ambiental. Por exemplo, em 2013, a ABEMA elaborou propostas para melhorar o sistema de licenciamento ambiental (Seção 4.1). Ambas as associações realizaram workshops sobre temas específicos; a ANAMMA, por exemplo, realizou vários eventos sobre saneamento e gestão de resíduos sólidos.

Apesar do grande número de mecanismos de colaboração entre estados e a União (acordos de cooperação técnica, termos de parceria, acordos de execução descentralizada, etc.), 
percebe-se que os laços entre níveis de governo são fracos e permeados por conflitos, levando a uma fragmentação do poder (Costa Neves, 2012). Entraves de coordenação surgem não apenas entre os níveis federal e estadual, mas também entre estados (ex., aqueles que compartilham uma bacia hidrográfica) e entre estados e municípios. Um relatório do Tribunal de Contas da União (TCU) de 2009 sobre a consecução de objetivos climáticos na Amazônia apontou várias debilidades institucionais na governança ambiental multinível, entre elas a distribuição fragmentada de atribuições; objetivos políticos contraditórios; integração vertical e horizontal fraca entre órgãos; e falta de identificação ou propriedade de iniciativas ambientais, muitas vezes provocada por carência de capacidade (TCU, 2009). O TCU também apontou fraquezas em relação ao monitoramento, à produção de relatórios e à avaliação, afirmando que, frequentemente, o governo federal desconhece as atividades que ocorrem no nível estadual.

\section{Orçamentos de instituições ambientais e fundos ambientais}

O Brasil ainda não possui um sistema para o monitoramento sistemático das despesas públicas relativas ao meio ambiente. No entanto, em 2014, o Ministério do Planejamento, Orçamento e Gestão, em parceria com o Instituto de Pesquisa e Estatística Aplicada (IPEA) lançou um projeto para acompanhar e melhor entender todos os gastos e investimentos do governo federal em meio ambiente. Esse projeto tem relevância significativa, pelo fato de o orçamento do MMA ser relativamente pequeno e de outros ministérios e órgãos contribuírem com uma grande parte dos gastos públicos em matéria ambiental. ${ }^{5}$ Por sua vez, o MMA vem empreendendo esforços no sentido de rastrear despesas federais relativas ao clima: estimativas iniciais sugerem que essas despesas totalizaram cerca de $\mathrm{R} \$ 10$ bilhões no período entre 2012 e 2014. Essas iniciativas constituem passos importantes para melhorar a compreensão da eficácia e eficiência da alocação de recursos públicos. Ressalta-se a importância de se dar continuidade a essas iniciativas e, ao longo do tempo, ampliar seu escopo para alcançar também os gastos estaduais e municipais.

O orçamento do MMA e de instituições ambientais foi de $\mathrm{R} \$ 3,6$ bilhões (cerca de US\$ 1,5 bilhão) em 2014, um dos mais baixos entre as entidades federais, correspondendo a $0,15 \%$ do orçamento da União (Senado Federal, 2015). Apesar de recente diminuição no orçamento federal, os recursos alocados para o MMA e órgãos ambientais aumentaram em 16\% em termos reais, entre 2010 e 2014. De forma geral, mais da metade do orçamento do MMA é distribuída aos órgãos ambientais, principalmente o IBAMA e o ICMBio (Figura 2.2). Na classificação orçamentária do Tesouro por função do governo, as alocações para a gestão ambiental cresceram 48\% entre 2010 e 2014, alcançando $0,37 \%$ do orçamento da União. O orçamento do MMA equivale a cerca de $30 \%$ do total das alocações orçamentárias para a gestão ambiental; sendo a maior parte do total destinada ao Ministério da Integração Nacional, encarregado de reduzir disparidades regionais (Senado Federal, 2015).

Uma característica distinta do gasto público relativo ao meio ambiente no Brasil é a utilização de fundos (orçamentário e extra orçamentário) destinados à implementação de políticas e programas ambientais nos níveis federal, estadual e municipal, o que complica ainda mais o rastreamento e a avaliação da alocação de recursos. O MMA coordena cinco fundos federais de porte variado e com objetivos distintos que podem, parcialmente se sobrepor. Seus recursos são provenientes de fontes variadas, incluindo o orçamento da União; royalties da exploração de petróleo e gás (Box 3.2); doações de 
fontes públicas e privadas (incluindo doações baseadas no desempenho); e empréstimos (Tabela 2.2). A destinação de recursos para fundos com objetivos ambientais pode ser necessária para garantir a sua suficiência e confiabilidade, mas pode reduzir a flexibilidade na tomada de decisões fiscais e, portanto, prejudicar a eficiência da alocação de receitas. É essencial que haja um monitoramento regular das atividades dos fundos ambientais, com vistas a assegurar consonância com prioridades políticas, bem como transparência e objetivos de custo benefício. Deve-se evitar a multiplicidade de fundos com a sobreposição de objetivos.

Os dois maiores fundos federais (Fundo Nacional sobre Mudança do Clima e Fundo Amazônia) têm robustos sistemas de monitoramento e conseguiram angariar recursos para projetos, inclusive de fontes de financiamento internacional. Os fundos ambientais também têm sido utilizados para obter financiamento para programas e políticas como, por exemplo, o Programa Áreas Protegidas da Amazônia (ARPA; Capítulo 5). Outros fundos que podem financiar atividades relacionadas ao meio ambiente incluem o Fundo de Defesa dos Direitos Difusos, ${ }^{6}$ fundos setoriais, ${ }^{7}$ Fundo Brasileiro para a Biodiversidade (Capítulo 4) e Fundo de Áreas Protegidas (Capítulo 5).

\section{Figura 2.2. Alocações do orçamento da União para instituições ambientais aumentaram}

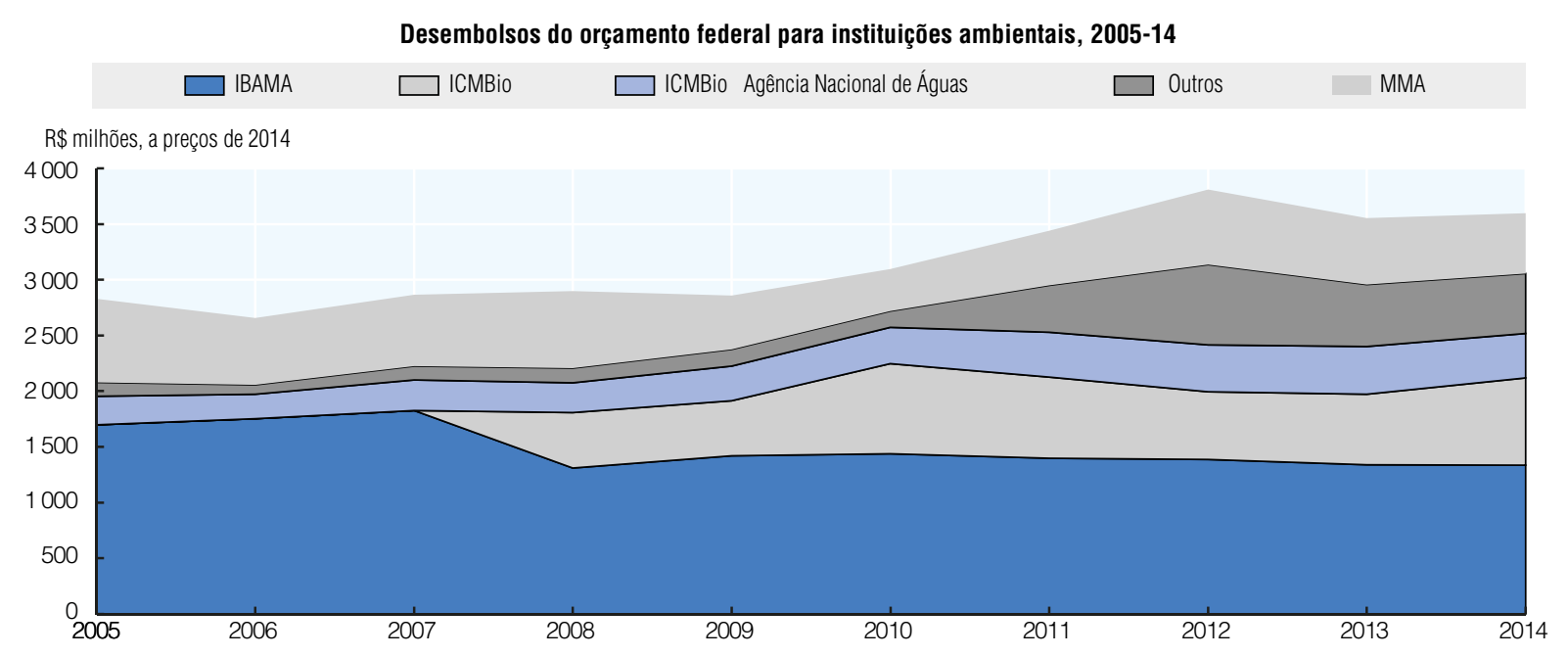

Obs.: Não inclui reservas de contingência; outros incluem: Serviço Florestal Brasileiro, Instituto de Pesquisa do Jardim Botânico do Rio de Janeiro, Fundo Nacional de Meio Ambiente, Fundo Nacional sobre Mudança do Clima e Companhia de Desenvolvimento de Barcarena.

Fonte: Senado Federal (2015), Portal Orçamento (banco de dados).

Os recursos disponíveis às instituições ambientais estaduais totalizaram uma média de 2,2\% dos orçamentos dos estados em 2012 (IBGE, 2014b). Em alguns estados (ex., Amazonas, Pará e Minas Gerais) mais de $6 \%$ do total do orçamento estadual foi destinado ao meio ambiente, enquanto que na metade dos estados, essa parcela era de $1 \%$ ou menos. Na maioria dos estados, os recursos financeiros provêm de diversas fontes, incluindo o orçamento geral do estado, doações nacionais e internacionais, royalties e taxas de licenças ambientais e multas. No Estado do Rio Grande do Sul, os recursos provêm exclusivamente das taxas de licenças ambientais e multas.

Em muitos casos, esses recursos são direcionados por meio de fundos ambientais estaduais. O Distrito Federal e 23 dos 26 estados operam esses fundos (IBGE, 2014b). A lei exige que receitas provenientes de multas ambientais sejam destinadas a esses 
fundos; contudo, isto contraria o propósito principal da execução de ações de fiscalização e sanções, que é coibir infrações. Na maioria dos países da OCDE, as receitas provenientes de multas são direcionadas ao Tesouro para evitar a situação em que os fiscais do órgão ambiental tenham mais interesse na emissão e cobrança de multas, do que em assegurar conformidade.

Tabela 2.2. Fundos ambientais federais

\begin{tabular}{|c|c|c|c|c|}
\hline Fundo & Objetivo & Governança & Fonte de Financiamento & Volume \\
\hline $\begin{array}{l}\text { Fundo Nacional } \\
\text { sobre Mudança } \\
\text { do Clima (2009) }\end{array}$ & $\begin{array}{l}\text { Criado no âmbito da } \\
\text { Política Nacional de } \\
\text { Mudanças Climáticas } \\
\text { (Seção 3.1) para financiar } \\
\text { projetos de mitigação e } \\
\text { adaptação à mudança } \\
\text { climática }\end{array}$ & $\begin{array}{l}\text { Distribui empréstimos } \\
\text { (administrados pelo } \\
\text { BNDES) e recursos } \\
\text { a fundo perdido } \\
\text { (administrados pelo } \\
\text { MMA) }\end{array}$ & $\begin{array}{l}\text { Financiado, em grande parte, } \\
\text { por um imposto especial } \\
\text { sobre a produção de petróleo } \\
\text { (Box 3.2), orçamento da } \\
\text { União, doações, empréstimos } \\
\text { e transferências de fundos } \\
\text { orçamentários não utilizados }\end{array}$ & $\begin{array}{l}\text { Os recursos totais } \\
\text { alcançaram } R \$ 560 \\
\text { milhões em } 2014\end{array}$ \\
\hline $\begin{array}{l}\text { Fundo Amazônia } \\
\text { (2008) }\end{array}$ & $\begin{array}{l}\text { Investir em } \\
\text { conservação florestal } \\
\text { e uso sustentável, } \\
\text { monitoramento } \\
\text { e prevenção do } \\
\text { desmatamento e } \\
\text { reduzir emissões de } \\
\text { GEE decorrentes do } \\
\text { desmatamento e da } \\
\text { degradação florestal }\end{array}$ & $\begin{array}{l}\text { Administrado pelo } \\
\text { BNDES }\end{array}$ & $\begin{array}{l}\text { Doações públicas e privadas; } \\
\text { originalmente, era para } \\
\text { utilizar um mecanismo de } \\
\text { financiamento baseado no } \\
\text { desempenho; }{ }^{8} \text { pelo menos } \\
80 \% \text { dos investimentos } \\
\text { do fundo são destinados à } \\
\text { região amazônica e até } 20 \% \\
\text { podem ser investidos no } \\
\text { monitoramento e controle } \\
\text { do desmatamento em outros } \\
\text { biomas brasileiros ou países } \\
\text { tropicais }\end{array}$ & $\begin{array}{l}\text { Em março de } 2015,0 \\
\text { fundo apoiou } 72 \text { projetos } \\
\text { com R } \$ 339 \text { milhões, } \\
\text { entre os mais de R \$ } \\
2 \text { bilhões em doações } \\
\text { contratadas (Figura 4.10) }\end{array}$ \\
\hline $\begin{array}{l}\text { Fundo Nacional } \\
\text { de Meio } \\
\text { Ambiente (1989) }\end{array}$ & $\begin{array}{l}\text { Financiar a } \\
\text { implementação de } \\
\text { políticas ambientais por } \\
\text { meio da participação de } \\
\text { terceiros }\end{array}$ & Administrado pelo MMA & $\begin{array}{l}\text { Orçamento federal, doações, } \\
\text { juros de investimentos de } \\
\text { ativos, multas ambientais }\end{array}$ & $\begin{array}{l}\text { Desembolso total desde } \\
\text { a sua criação: } R \$ 230 \\
\text { milhões; } 0 \text { desembolso } \\
\text { caiu de quase } \mathrm{R} \$ 32 \\
\text { milhões em 2007, para } \\
\mathrm{R} \$ 2,4 \text { milhões em } 2013\end{array}$ \\
\hline $\begin{array}{l}\text { Fundo } \\
\text { Nacional de } \\
\text { Desenvolvimento } \\
\text { Florestal (2006) }\end{array}$ & $\begin{array}{l}\text { Promover atividades } \\
\text { florestais sustentáveis } \\
\text { e inovação tecnológica } \\
\text { no setor }\end{array}$ & $\begin{array}{l}\text { Administrado pelo } \\
\text { Serviço Florestal } \\
\text { Brasileiro }\end{array}$ & $\begin{array}{l}\text { Provavelmente receberá } \\
\text { cerca de } 20 \% \text { da receita de } \\
\text { concessões florestais em } \\
\text { florestas nacionais, e } 40 \% \\
\text { da receita de concessões em } \\
\text { outras florestas }\end{array}$ & $\begin{array}{l}\text { Ainda não totalmente } \\
\text { operacional }\end{array}$ \\
\hline $\begin{array}{l}\text { Fundo de } \\
\text { Restauração } \\
\text { do Bioma Mata } \\
\text { Atlântica }\end{array}$ & $\begin{array}{l}\text { Financiar restauração } \\
\text { ambiental e pesquisa } \\
\text { científica no bioma Mata } \\
\text { Atlântica }\end{array}$ & Administrado pelo MMA & $\begin{array}{l}\text { Orçamento federal, doações, } \\
\text { rendimentos de investimento } \\
\text { de ativos e outras verbas } \\
\text { destinadas pela legislação } \\
\text { específica }\end{array}$ & $\begin{array}{l}\text { Não totalmente } \\
\text { operacional }\end{array}$ \\
\hline
\end{tabular}

Fonte: MMA. Quinto Relatório Nacional para a Convenção sobre Diversidade Biológica, 2015; MMA. Quarto Relatório Nacional para a Convenção sobre Diversidade Biológica, 2010; Fundo Amazônia, 2015, (www.amazonfund.gov.br).

Em 2012, 21 fundos ambientais estaduais desembolsaram recursos para projetos ambientais em áreas, tais como monitoramento e educação ambiental; proteção da biodiversidade; recursos hídricos e gestão do solo; e reflorestamento. O Fundo de Prevenção e Controle da Poluição do Estado de São Paulo (FECOB) desembolsou R\$ 327 milhões para mais de 2.000 projetos desde o ano de 2000, superando o volume repassado pelo Fundo Nacional do Meio Ambiente (Tabela 2.2). Entretanto, o FECOB é financiado por multas ambientais, e seu volume de recursos varia de um ano para outro: era de $\mathrm{R} \$$ 1,2 milhão em 2000, e de R\$ 51,2 milhões em 2010 (CETESB, s.d). Os fundos ambientais do Estado do Rio de Janeiro também enfrentam grande variação anual de receitas por serem financiados com base em receitas de petróleo e gás.

Alguns municípios operam fundos ambientais, embora sua destinação, rastreamento e divulgação tendam a ser menos rigorosos. Desde 2013, aproximadamente $43 \%$ dos municípios, principalmente nas regiões Sul e Centro-Oeste, contam com esses fundos 
e, atualmente, quase todos os municípios com mais de 500.000 habitantes possuem fundos ambientais (IBGE, 2014a). Cerca da metade dos estados redistribui uma parcela da receita do imposto sobre circulação de mercadorias e serviços (ICMS) com base em critérios ambientais, no âmbito do mecanismo chamado ICMS ecológico (Capítulo 5). O principal parâmetro é a extensão de áreas protegidas e terras indígenas, seguido por serviços de coleta de resíduos municipais e tratamento de águas servidas (IBGE, 2014b). Contudo, a receita de ICMS não é necessariamente destinada a fundos ambientais ou a financiamento de despesas relacionadas ao meio ambiente.

\section{Principais políticas e regulamentos relacionados ao meio ambiente}

O primeiro passo rumo ao desenvolvimento de um abrangente quadro jurídico e institucional para a governança ambiental foi a aprovação da Lei $\mathrm{n}^{\circ} 6.938$, que dispõe sobre a Política Nacional do Meio Ambiente - PNMA, em 1981 (Box 2.3). A PNMA destacou a necessidade de proteger o meio ambiente como patrimônio público e compatibilizar o desenvolvimento socioeconômico com o equilíbrio ecológico.

A Constituição de 1988 enaltece a proteção ambiental, ao dedicar um capítulo inteiro ao tema. Seu artigo 225 reconhece o direito ao meio ambiente ecologicamente equilibrado, bem de uso comum do povo e essencial à sadia qualidade de vida.

\section{Box 2.3 Principais leis federais sobre o meio ambiente}

- Lei 6.938/1981. Dispõe sobre a Política Nacional do Meio Ambiente, seus fins e mecanismos de formulação e aplicação.

- Lei 9.433/1997. Institui a Política Nacional de Recursos Hídricos e cria o Sistema Nacional de Gerenciamento de Recursos Hídricos.

- Lei 9.605/1998. Dispõe sobre as sanções penais e administrativas derivadas de condutas e atividades lesivas ao meio ambiente.

- Lei 9.795/1999. Dispõe sobre a educação ambiental e institui a Política Nacional de Educação Ambiental.

- Lei 9.966/2000. Dispõe sobre a prevenção, controle e fiscalização da poluição causada por lançamento de óleo e outras substâncias nocivas ou perigosas em águas sob jurisdição nacional.

- Lei 9.985/2000. Institui o Sistema Nacional de Unidades de Conservação da Natureza.

- Lei 12.187/2009. Institui a Política Nacional sobre Mudança do Clima - PNMC.

- Lei 12.305/2010. Institui a Política Nacional de Resíduos Sólidos e os requisitos para a produção, transporte, gestão e eliminação de resíduos sólidos.

- Lei Complementar 140/2011. e Decreto 8.437/2015 Regulamentam as responsabilidades compartilhadas dos órgãos ambientais em todos os níveis administrativos para o licenciamento e execução de atividades poluidoras.

- Lei 12.651/2012. Dispõe sobre a proteção da vegetação nativa em propriedades privadas e em algumas áreas sensíveis, ou o Novo Código Florestal Brasileiro.

- Lei 13.123/2015. Dispõe sobre o acesso ao patrimônio genético, sobre a proteção e o acesso ao conhecimento tradicional associado e sobre a repartição de benefícios para conservação e uso sustentável da biodiversidade, ou Lei de Bases da Biodiversidade.

Fonte: Latin Lawyer (2015).Brazil (www.latinlawyer.com/reference/topics/51/jurisdictions/6/brazil).

Apesar de o Congresso Nacional, após anos de debate político, ter contribuído com importantes componentes do marco legislativo ambiental (Box 2.3) a maioria das normas ambientais em vigor provém de resoluções do CONAMA (Seção 1.1). Muitas 
dessas resoluções, no entanto, carecem de qualidade técnica por abrirem margem para interpretação por órgãos subnacionais, ou por serem de impossível aplicação (Sano, 2012). Isto ocorre, principalmente, porque as resoluções do CONAMA tendem a ser elaboradas por seus membros e não por profissionais competentes das áreas específicas ou dos grupos de peritos técnicos (que são consultados apenas ocasionalmente).

O enfoque da legislação ambiental federal tem sido a definição de marcos jurídicos e institucionais para a gestão de recursos naturais, incluindo a silvicultura, a mineração e a proteção de áreas naturais; enquanto que o da legislação estadual tem sido, principalmente, o controle da poluição. O rigor das exigências de controle de poluição varia substancialmente por jurisdição, refletindo as prioridades locais e restrições de capacidade. Assim, existem preocupações quanto ao potencial "dumping ambiental", pelo qual as indústrias altamente poluentes poderiam estabelecer novas (ou realocar suas existentes) unidades produtivas em estados que carecem de capacidade para estabelecer e executar normas ambientais e que poderiam, eventualmente, se aproveitar dessa falha para atrair empreendimentos industriais.

Conforme as seções a seguir mostrarão, as políticas referentes a vários aspectos ambientais (ex., recursos hídricos e gestão de resíduos) foram adotadas por meio de legislação nacional, o que elevou seu status. Os impactos sociais das políticas ambientais recebem destacada atenção; contudo, a formulação das políticas em si e tampouco sua regulamentação passam por uma análise econômica ex-ante. Avaliações ex-post da implementação são realizadas pelo TCU e pelos auditores estaduais, mas as questões de custo são raramente levadas em consideração.

\subsection{Mudança do clima}

O Brasil desenvolveu um abrangente marco político para enfrentar a mudança do clima e, notoriamente, aprovou legislação incorporando sua meta nacional de redução de emissões de GEE. A lei da Política Nacional de Mudança do Clima (PNMC) de 2009 prevê uma redução entre $36,1 \%$ e $38,9 \%$ em relação às projeções do cenário BAU para 2020, o que equivale a uma redução de entre 6\% e 10\%, em relação aos níveis de 2005 (Seroa da Motta, 2011).

A PNMC é frequentemente apontada como exemplo de cooperação e coordenação bem-sucedida entre ministérios e setores. Consolidou ações setoriais já em vigor e designou a coordenação da política ao Comitê Interministerial sobre Mudança do Clima (CIM) sob a liderança do Ministro da Casa Civil. A PNMC estabeleceu instrumentos para alcançar a meta de mitigação de GEE, incluindo a criação do Fundo Nacional sobre Mudança do Clima (Seção 2) e dispôs sobre a possível criação de um mercado nacional de carbono, ligado ao mercado internacional.

A PNMC prevê o desenvolvimento de planos de ação setoriais para mitigação de mudanças climáticas, que englobem metas de redução de emissões quantificáveis, ações políticas e indicadores de acompanhamento para cinco setores, correspondendo às ações de mitigação nacionais a que o Brasil se comprometeu no âmbito da Convenção-Quadro das Nações Unidas sobre Mudança do Clima. Planos para quatro setores adicionais foram finalizados em 2012 (Tabela 2.3). Todos os planos setoriais foram desenvolvidos por meio de processo participativo aberto. Encontra-se em andamento um projeto de desenvolvimento de um sistema modular, conhecido como SMMARE, para monitorar a implementação dos planos setoriais e as consequentes reduções de emissões de GEE. 
Os avanços alcançados na redução do desmatamento colocam o Brasil em boa posição para atingir suas metas, com a redução projetada de desmatamento nos biomas Amazônia e Cerrado respondendo por mais de 60\% da esperada mitigação de GEE. No entanto, não está claro se os programas setoriais atuais têm escala suficiente para promover cortes significativos nas emissões provenientes dos setores energético e da agricultura, capazes de conduzir o país rumo à eficiência energética e à economia de baixo carbono. Aparentemente, importantes oportunidades de desenvolvimento, tais como infraestrutura de transportes sustentável, que poderiam gerar reduções significativas no longo prazo (no período de 2030-50), não estão recebendo a devida atenção (VOGT-SCHILB et al., 2014). Os custos econômicos e os benefícios dos planos setoriais não foram avaliados.

Tabela 2.3. Planos setoriais de mitigação e adaptação à mudança do clima até 2020

\begin{tabular}{|c|c|c|c|}
\hline Setor & Ações & Plano de mitigação & Ministério responsável \\
\hline \multicolumn{4}{|c|}{ Ações de mitigação nacionalmente apropriadas } \\
\hline $\begin{array}{l}\text { Redução do } \\
\text { desmatamento na } \\
\text { Amazônia }\end{array}$ & $\begin{array}{l}\text { Redução de } 80 \% \text { nas taxas anuais de desmatamento da } \\
\text { Amazônia, em relação à média de 1996-2005 }\end{array}$ & $\begin{array}{l}\text { Plano de Ação para Prevenção e } \\
\text { Controle do Desmatamento na } \\
\text { Amazônia Legal }\end{array}$ & MMA \\
\hline $\begin{array}{l}\text { Redução do } \\
\text { desmatamento no } \\
\text { Cerrado }\end{array}$ & $\begin{array}{l}\text { Redução de } 40 \% \text { nas taxas anuais de desmatamento no } \\
\text { bioma Cerrado, em relação à média de 1999-2008 }\end{array}$ & $\begin{array}{l}\text { Plano de Ação para Prevenção e } \\
\text { Controle do Desmatamento e das } \\
\text { Queimadas no Cerrado }\end{array}$ & MMA \\
\hline Energia & $\begin{array}{l}\text { Aumento da eficiência energética } \\
\text { Maior utilização dos biocombustíveis } \\
\text { Aumento da oferta proveniente de usinas hidrelétricas } \\
\text { Aumento da oferta proveniente de fontes renováveis }\end{array}$ & $\begin{array}{l}\text { Plano Decenal de Expansão de } \\
\text { Energia }\end{array}$ & MME \\
\hline Agricultura & $\begin{array}{l}\text { Recuperação de } 150.000 \mathrm{~km}^{2} \text { de pastagens degradadas } \\
\text { Expansão dos sistemas integrados lavoura-pecuária- } \\
\text { floresta em } 40.000 \mathrm{~km}^{2} \\
\text { Expansão da prática de plantio direto em } 80.000 \mathrm{~km}^{2} \\
\text { Expansão da fixação biológica de nitrogênio em } 55.000 \\
\mathrm{~km}^{2} \text { de terras agrícolas, substituindo a utilização de } \\
\text { fertilizantes azotados } \\
\text { Expansão de florestas plantadas em } 30.000 \mathrm{~km}^{2} \\
\text { Expansão da tecnologia para o tratamento de } 4,4 \text { milhões } \\
\text { de } \mathrm{m}^{3} \text { de resíduos animais }\end{array}$ & $\begin{array}{l}\text { Plano de Mitigação e Adaptação } \\
\text { às Mudanças Climáticas para a } \\
\text { Consolidação de uma Economia } \\
\text { de Baixa Emissão de Carbono na } \\
\text { Agricultura }\end{array}$ & $\begin{array}{l}\text { MAPA } \\
\text { MDA }\end{array}$ \\
\hline Siderurgia & $\begin{array}{l}\text { Aumento do uso de carvão vegetal de florestas plantadas } \\
\text { na produção de ferro e aço e melhoria na eficiência da } \\
\text { carbonização }\end{array}$ & $\begin{array}{l}\text { Plano de Redução de Emissões } \\
\text { das Indústrias Siderúrgicas } \\
\text { (carvão vegetal). }\end{array}$ & MDIC \\
\hline
\end{tabular}

\begin{tabular}{|c|c|c|c|}
\hline \multicolumn{4}{|c|}{ Ações nacionais adicionais no âmbito da PNMC } \\
\hline $\begin{array}{l}\text { Indústria } \\
\text { (alumínio, cal, } \\
\text { cimento, ferro e } \\
\text { aço, químicos, } \\
\text { celulose e papel, } \\
\text { vidro) }\end{array}$ & $\begin{array}{l}\text { Redução de } 5 \% \text { das emissões de GEE projetadas até } \\
2020 \text {; estabelecimento progressivo de monitoramento, } \\
\text { relatórios e verificação }\end{array}$ & Plano de indústria & MDIC \\
\hline Mineração & $\begin{array}{l}\text { Mudança de fonte de energia, utilização de novas } \\
\text { tecnologias }\end{array}$ & $\begin{array}{l}\text { Plano de Mineração de Baixa } \\
\text { Emissão de Carbono }\end{array}$ & MME \\
\hline Transporte & $\begin{array}{l}\text { Mudança na modalidade de transporte, desenvolvimento } \\
\text { dos transportes públicos }\end{array}$ & $\begin{array}{l}\text { Plano de Transporte e Mobilidade } \\
\text { Urbana }\end{array}$ & $\begin{array}{l}\text { MT } \\
\text { MCid }\end{array}$ \\
\hline
\end{tabular}

Fonte: Apresentado pelo Brasil. 
Ações de enfrentamento às mudanças do clima estão sendo levadas a cabo também nas instâncias subnacionais. Dezenove estados aprovaram leis e metas de enfrentamento às mudanças do clima, por exemplo: o Estado de São Paulo estabeleceu uma redução de $20 \%$ das emissões até 2020 em relação aos níveis de 2005; e o Estado do Rio de Janeiro estabeleceu uma meta de redução da sua intensidade de carbono para abaixo dos níveis de 2005, até 2030. A Cidade do Rio de Janeiro se comprometeu em reduzir as emissões em $8 \%$ até 2012 em relação aos níveis de 2005; em 16\% até 2016; e em 20\% até 2020 (Mansell; Sopher, 2014). Ambos os estados pretendiam lançar sistemas de comércio de emissões de GEE em nível estadual em 2013, mas a forte oposição da indústria energética e a falta de consenso quanto aos limites de emissão atrasaram a implementação dos planos (Mansell; Sopher, 2014). A PNMC prevê que as ações federais para mitigação de mudanças do clima se articulem com as ações subnacionais; contudo, a falta de arranjos institucionais e jurídicas dificulta essa coordenação (Motta, 2011).

O Brasil está em terceiro lugar entre os países do mundo na produção de certificados de redução de emissões, no contexto do Mecanismo de Desenvolvimento Limpo (MDL), forte instrumento de transferência de tecnologia (Capítulo 3). Ademais, o país recebeu cerca de metade do total do financiamento internacional aprovado por meio do instrumento de Redução de Emissões por Desmatamento e Degradação Florestal (REDD e REDD +) através do inovador Fundo Amazônia (Norman et al., 2014). O fundo foi criado para arrecadar recursos para investir na prevenção e monitoramento do desmatamento e na conservação e uso sustentável de florestas na Amazônia (Tabela 2.2; Capítulo 4). Em junho de 2014, o Brasil foi o primeiro país a apresentar o seu nível de emissão de referência florestal para pagamentos no âmbito da REDD +, conforme previsto pelo Marco de Varsóvia de 2013. Uma estratégia nacional de REDD + vem sendo discutida desde 2010, mas ainda não foi aprovada.

O Brasil vem aplicando recursos significativos no aprimoramento de conhecimento científico sobre os impactos da mudança do clima e no desenvolvimento de sistemas de monitoramento e alerta de inundações, secas e outros desastres naturais, financiados, em parte, pelo Fundo Nacional sobre Mudança do Clima . Em 2010, foi criado um Painel Nacional de Mudanças Climáticas que publicou, em 2013, o primeiro relatório de avaliação nacional sobre mudança do clima. O relatório constatou a probabilidade de aumento dos períodos de estiagem extrema e de secas prolongadas, especialmente nos biomas Amazônia, Cerrado e Caatinga (PBMC, 2013). Outros estudos constataram que, até 2030, o país poderia perder milhões de hectares de terras agrícolas produtivas, notadamente na região Sul. A infraestrutura urbana também é considerada vulnerável, e há uma carência de estimativas de custos para adaptação de infraestruturas urbana, costeira e de transporte (Assad et al., 2013; Unterstell; Margulis, 2014).

Para enfrentar os impactos potencialmente negativos das mudanças do clima em alguns setores econômicos, notadamente a agricultura e a geração de energia elétrica, em 2013 foi dado início a trabalhos sobre um abrangente plano de adaptação nacional. A minuta deste plano abrange água, energia, agricultura e segurança alimentar, biodiversidade e ecossistemas, saúde, grupos vulneráveis, indústria e mineração, centros urbanos, infraestrutura, transporte e gestão costeira. Concluída a fase de consultas interinstitucionais e públicas, espera-se que o plano seja finalizado em 2015. 


\subsection{Controle da poluição atmosférica}

A Resolução CONAMA no 05/1989 estabelece o Programa Nacional de Controle de Poluição do Ar e define padrões nacionais de qualidade do ar para cinco poluentes (Tabela 2.4). É provável que as normas sejam atualizadas em breve, para que as amostragens tenham maior precisão, em conformidade com orientações da Organização Mundial de Saúde (OMS). Os patamares nacionais de qualidade do ar são utilizados apenas na ausência de normas locais de qualidade do ar para áreas abertas (principalmente em cidades menores).

Tabela 2.4. Normas nacionais de qualidade do ar versus diretrizes da OMS

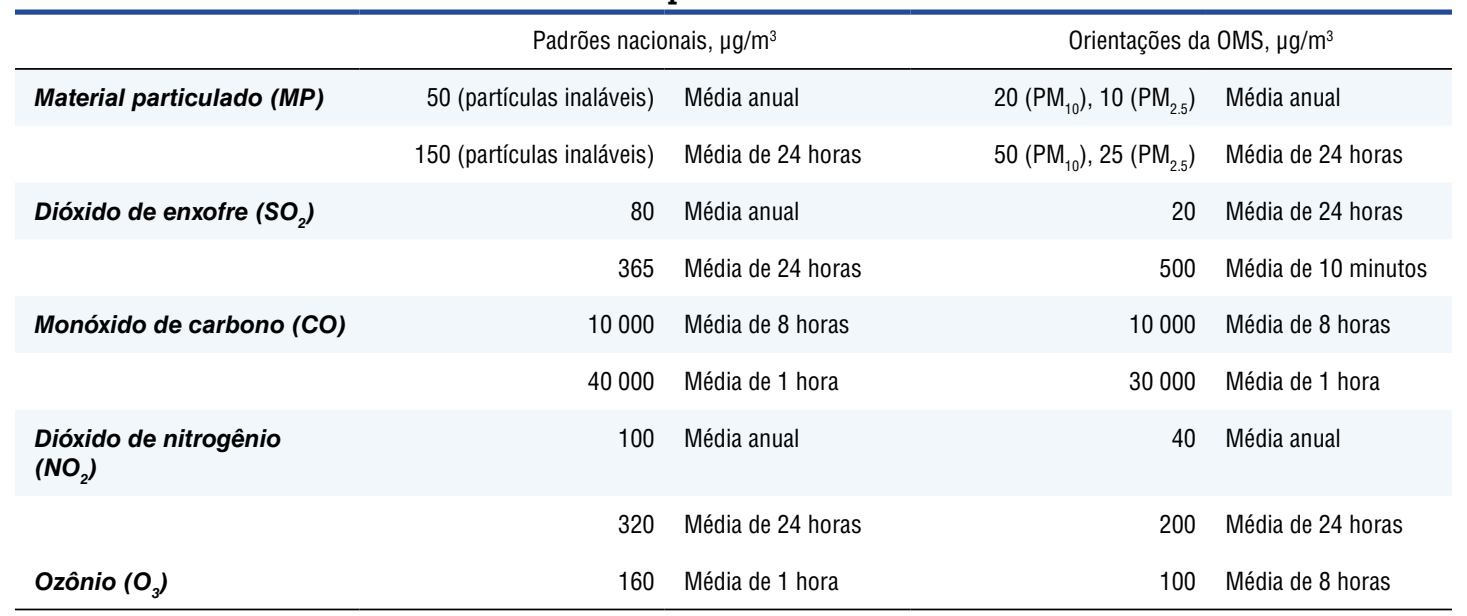

Fonte: Transportpolicy.net. Brazil: Air quality Standards. Disponível em: http://transportpolicy.net. Acesso em: abr. 2015; WHO. Air quality Guidelines - Global Update 2005. Copenhagen: World Health Organization Regional Office for Europe, 2006.

A Resolução CONAMA n 382/2006 regulamenta as emissões atmosféricas provenientes de fontes pontuais e estabelece normas específicas do setor para $\mathrm{CO}, \mathrm{NO}_{\mathrm{x}}$, $\mathrm{SO}_{2}$, MP e hidrocarbonetos para 13 setores industriais. Regras semelhantes também foram adotadas para as emissões de quatro poluentes provenientes de fontes móveis. Ademais, o Decreto 5472/2005 proíbe a produção e utilização de 12 poluentes orgânicos persistentes.

Os estados são responsáveis pela regulação e monitoramento da qualidade do ar, podendo adotar normas de emissão mais rigorosas. Além disso, a maioria das grandes cidades já adotou padrões locais de poluição do ar, com a designação de áreas onde novas fontes pontuais podem ser introduzidas apenas se as emissões existentes forem reduzidas. No entanto, apesar da obrigação legal de monitorar e produzir relatórios anuais sobre a qualidade do ar, em 2012, apenas 12 dos 27 estados (incluindo o DF) tiveram algum tipo de sistema de monitoramento instalado, e poucos fornecem dados consistentes e acessíveis (IEMA, 2012). Menos de $2 \%$ dos municípios monitoram a qualidade do ar (ISS, 2014).

O primeiro instrumento nacional de controle da poluição atmosférica proveniente de fontes móveis foi o Programa de Controle da Poluição do Ar por Veículos Automotores (PROCONVE) assinado em 1986 entre a indústria automotiva e o governo, convertido na Lei 8.723 em 1993. Desde então, foram adotadas normas de emissões veiculares cada vez mais rigorosas, complementadas pelo Programa de Controle da Poluição do Ar por 
Motociclos e Veículos Similares (PROMOT). A mais atual edição do PROCONVE 7 sobre emissões de veículos a diesel teve impacto positivo sobre a qualidade do ar, tanto na redução das emissões provenientes da combustão de diesel, quanto na melhoria da economia de combustível (Capítulo 1). O primeiro Inventário Nacional de Emissões Atmosféricas por Veículos Automotores Rodoviários, publicado em 2011 pelo IBAMA e parceiros da indústria, possibilitou que o governo atualizasse informações sobre a redução de emissões de fontes móveis e identificasse conquistas e desafios na implementação do PROCONVE/PROMOT.

\subsection{Gestão de recursos hídricos}

A Lei n 9.433/1997 instituiu a Política Nacional de Recursos Hídricos e criou o Sistema Nacional de Gerenciamento de Recursos Hídricos. Elaborados com ampla participação social, nos níveis nacional, estadual e de bacia hidrográfica, os planos de recursos hídricos estabelecem prioridades, programas e projetos e orientam a alocação de recursos hídricos. Atualmente, os planos de bacias hidrográficas abrangem apenas 52\% do território nacional. Em 2012, somente os Estados de São Paulo e do Rio de Janeiro haviam concluído planos de bacias hidrográficas para todos os rios sob seu domínio; e nenhum plano havia sido formulado para bacias de rios nos estados da Amazônia (ANA, 2014). Mesmo onde já foram adotados planos de recursos hídricos, após sua formulação, os comitês de bacia têm pouco compromisso com a implementação, e as agências de águas estaduais carecem de influência para assegurar que outros órgãos executivos ou governos municipais se comprometam com a implementação de tais planos (OCDE, 2015).

Em uma abordagem consistente com as melhores práticas nos países da OCDE, o Brasil introduziu um sistema de classificação de corpos de água superficiais, baseado nas principais categorias de uso (ex., aquicultura e pesca, abastecimento público, navegação) e estabeleceu padrões de qualidade da água correspondentes a cada categoria de uso. A Resolução CNRH n 16/2001 estipula que os limites para descarga de águas servidas industriais (expresso como a quantidade de água necessária para diluir a carga poluente) devem ser definidos caso a caso, de modo a atender ao padrão de qualidade aplicável. No entanto, a Resolução CONAMA n 357/2005 estabelece padrões setoriais específicos para descargas de águas servidas distintos dos padrões de qualidade da água com base no uso, o que cria uma inconsistência com a abordagem da classificação geral da qualidade da água.

As outorgas de direito de uso da água (para captação e outros usos) são emitidas pelo órgão nacional ou estadual de gerenciamento de recursos hídricos, dependendo do domínio do corpo d'água. Atualmente, os processos de alocação de água dependem da negociação direta entre usuários de água e as instituições da instância responsável pelo domínio do corpo de água em questão. A demanda e as quantidades de água alocadas são consideradas fixas, e aspectos econômicos são raramente levados em consideração (ANA, 2014). Ademais, os sistemas de outorga federal e estadual carecem de integração, o que dificulta a gestão integrada de bacias hidrográficas de domínio partilhado.

Outro problema que se apresenta na regulação do uso da água é que o sistema nacional de gerenciamento de recursos hídricos não estabelece integração suficiente 
entre a gestão dos recursos hídricos e o saneamento (OCDE, 2015). O saneamento afeta tanto a qualidade quanto a disponibilidade de água, uma vez que o aproveitamento de águas poluídas a jusante demanda custo de tratamento mais elevado. Portanto, a solução de problemas, tais como as secas (no Nordeste) e a poluição hídrica (nos grandes centros urbanos) requer uma estreita coordenação entre gestores dos recursos hídricos e prestadores de serviços de abastecimento de água e de saneamento.

A Lei da Política Nacional de Recursos Hídricos dispõe sobre a cobrança pelo uso da água atrelada à outorga do direito de uso da água, devendo as receitas serem reinvestidas na respectiva bacia hidrográfica. Os comitês de bacia hidrográfica podem definir tarifas, mas cabe à ANA ou à agência estadual efetuar a cobrança. Em alguns estados, o marco jurídico para cobrança pelo uso da água já está em vigor, enquanto que em outros ainda está pendente, ou foi aprovado, mas não está em vigência, devido a dificuldades políticas, sociais e organizacionais. Nos estados mais industrializados e ricos, a exemplo de São Paulo, Rio de Janeiro e Minas Gerais, as tarifas de água estão em vigor porque os principais interessados têm maior disposição para pagar. No entanto, as cobranças foram fixadas sem estudos prévios de economicidade, em níveis baixos demais para afetar o comportamento do consumidor ou prover uma fonte significativa de arrecadação para o setor hídrico. Além disto, as taxas de cobrança são bastante baixas (Capítulo 3).

O Brasil enfrenta sérios desafios na integração da gestão de recursos hídricos, notadamente entre as políticas setoriais de água, ambientais e outras, bem como na harmonização de aspectos da gestão de quantidade e de qualidade. Outro grande desafio é a aplicação desigual das políticas da água nas diferentes regiões. Incompatibilidades entre limites hidrológicos e administrativos têm provocado tensões e incoerências na aplicação de instrumentos de gestão da água em determinadas bacias hidrográficas. Em princípio, um estado pode negociar com a ANA a derrogação da gestão de um rio ou reservatório de domínio federal, desde que a instância estadual possua capacidade suficiente. Os Estados de São Paulo e do Ceará já passaram por essa experiência, mas, no caso de São Paulo, os resultados foram dúbios, sobretudo em vista da escassez aguda de água em 2014. Muitos estados e governos locais carecem de recursos financeiros e técnicos para a formulação e implementação de políticas de água.

Em resposta a esses desafios, foi adotado o Pacto Nacional pela Gestão das Águas (Box 2.4) como estratégia operacional envolvendo autoridades em todos os níveis administrativos. O Pacto inclui metas de gestão de médio e longo prazo, apontando determinadas instituições como responsáveis pela sua realização; não tem a pretensão de sanar todos os desafios de governança relacionados à água, mas, como modelo contratual, poderia servir de instrumento eficaz para aprimorar o diálogo entre órgãos das instâncias federal e estadual e servir de exemplo para outras políticas setoriais.

A sustentabilidade dos resultados desta iniciativa dependerá, em grande parte, da capacidade das agências estaduais de reter quadros de pessoal recentemente capacitado e de garantir recursos financeiros suficientes. Ademais, as agências de água estaduais devem empenhar esforços no sentido de envolver os municípios, com vistas a uma melhor coordenação entre políticas urbanas e de água. 


\section{Box 2.4. Pacto Nacional pela Gestão das Águas}

O Pacto Nacional pela Gestão das Águas é fruto de longas negociações entre a ANA, governos estaduais e os conselhos estaduais de recursos hídricos. Destina-se a reforçar a capacidade institucional das organizações estaduais de gestão de água e a melhorar a colaboração, incluindo o compartilhamento de informações entre os órgãos federais (especialmente a ANA) e grande número de comitês de bacias hidrográficas, agências e órgãos locais envolvidos na gestão da água.

A Declaração de Brasília (2011) formalizou o pacto, que foi assinado por representantes dos governos estaduais. Até meados de 2014, todos os estados, com exceção de São Paulo, haviam manifestado sua disposição em aderir ao pacto. Sua formulação, que deixa a critério dos estados o escopo (expresso na forma de metas e estabelecimento ou melhoria de instrumentos e procedimentos de gestão da água) para os próximos cinco anos (até 2016) facultou a participação dos estados, sem que esses percam sua autonomia ou poder sobre a gestão de recursos hídricos.

O pacto reside nos acordos contratuais entre a ANA, os governos estaduais e os conselhos estaduais de recursos hídricos, que identificam os principais desafios de gestão da água e propõem opções de apoio à governança mais eficaz da água por parte dos estados. Em 2013, foi criado o fundo PROGESTÃO, com US\$ 50 milhões, que proporcionou aos estados incentivos de desempenho para o alcance de metas de gestão de recursos hídricos. O desembolso de recursos federais está condicionado à existência de planos e metas estaduais e de bacias hidrográficas, bem como à alocação de recursos humanos para sua implementação.

Nem todos os estados compartilham os mesmos objetivos e metas, mas todos receberão valores iguais, por meio de um pacote institucional, operacional, de planejamento e de apoio à tomada de decisão. As agências estaduais de água não têm qualquer compromisso quanto à prestação de contas. Embora as subvenções do PROGESTÃO sejam relativamente pequenas em comparação com os investimentos federais de infraestrutura hídrica, elas proporcionam um forte incentivo para que os estados mais pobres participem ativamente na gestão de recursos hídricos. Até novembro de 2014, 19 estados haviam assinado contratos do PROGESTÃO.

Fonte: OECD. Water Resources Governance in Brazil. Paris: OECD Publishing, 2015.

\subsection{Gestão de resíduos}

A Lei n 12.305/2010 institui a Política Nacional de Resíduos Sólidos e regula a produção, transporte, tratamento e deposição de resíduos sólidos. Os municípios são responsáveis pela gestão de resíduos sólidos urbanos (sob ampla supervisão do Ministério das Cidades) e a gestão dos resíduos perigosos é regulada por legislação federal. As competências dos estados se limita à expedição de licenças e fiscalização de aterros, sendo que a maioria deles não presta qualquer apoio aos municípios neste quesito.

O Plano Nacional de Resíduos Sólidos, finalizado em 2011, é sujeito à avaliação e revisão a cada quatro anos. Aos estados e municípios foi concedido prazo, até 2012, para elaborarem seus próprios planos de resíduos sólidos como condição para receber recursos federais para a construção de aterros. ${ }^{9}$ Embora esse prazo tenha sido cumprido por pouco mais de um quarto dos municípios, o governo federal, ao invés de impor sanções, vem prestando apoio e capacitação institucional. Alguns municípios estão compartilhando recursos e elaborando planos de gestão de resíduos intermunicipais. Mais de 2.200 municípios (menos da metade do total) cumpriram com o prazo de instalação de um aterro sanitário ambientalmente saudável até 2014 (Capítulo 3).

Toda pessoa jurídica que gera resíduos (incluindo resíduos perigosos) deve elaborar um plano de gestão de resíduos sólidos e, como condição de licenciamento ambiental, 
comprovar que possui capacidade técnica e financeira para adequadamente gerir e eliminar esses resíduos. Além disto, qualquer pessoa jurídica que, de alguma forma, lide com resíduos perigosos deve obter registro junto ao Cadastro Nacional de Operadores de Resíduos Perigosos e comunicar às autoridades ambientais e sanitárias pertinentes a quantidade, a natureza e o destino temporário ou definitivo dos resíduos sob sua responsabilidade, bem como quaisquer acidentes relacionados a eles.

A política nacional previu a criação de um Sistema Nacional de Informações sobre Gestão de Resíduos Sólidos para integrar dados federais, estaduais e municipais de gestão de resíduos, inclusive sobre cada tipo de resíduo gerado. O previsto era que o sistema fosse lançado em 2013, mas sua execução foi adiada. Em consequência, as estatísticas de resíduos federais permanecem fragmentadas e incompletas, pois o MMA e o Ministério das Cidades não compartilham dados relacionados a resíduos.

Para reduzir gradativamente o volume de resíduos colocados em aterros - atualmente principal método de disposição final - a Lei da Política Nacional de Resíduos Sólidos previu um "sistema de logística reversa", abordagem semelhante aos sistemas de responsabilidade ampliada do produtor adotada na maioria dos países da OCDE. O sistema prevê que fabricantes, distribuidores e varejistas de agrotóxicos, baterias, pneus, óleos lubrificantes, lâmpadas fluorescentes, aparelhos eletrônicos, e seus componentes recolham os produtos no final da sua vida útil. O MMA já firmou acordos com produtores de lâmpadas, pneus e pesticidas, especificando as obrigações de produtores e importadores e definindo metas de recolhimento e reciclagem. No entanto, ainda não foram estabelecidas penalidades pelo descumprimento dessas obrigações. Um acordo semelhante, coordenado pelo Ministério da Indústria e Comércio, para resíduos elétricos e equipamentos eletrônicos está em fase de preparação. A falta de infraestrutura de reciclagem (exceto na região Sudeste) e a baixa capacidade dos municípios para assegurar a coleta seletiva são os principais gargalos na implementação desses programas.

A política nacional tem também uma importante dimensão social. Um de seus objetivos é a inserção de quase meio milhão de catadores no mercado de gestão de resíduos, por meio de apoio à criação de cooperativas para colaborar com os municípios na coleta seletiva e na reciclagem de resíduos sólidos urbanos (Capítulo 3).

\section{Avaliação de impacto e licenciamento ambiental}

\subsection{Licenciamento ambiental}

O licenciamento ambiental foi introduzido pela Lei $n^{\circ} 6.938$ da PNMA, de 1981. A Resolução CONAMA n 237/1997 regulamentou o licenciamento ambiental como exigência legal prévia para a construção, instalação, ampliação e funcionamento de qualquer empreendimento ou atividade considerada efetiva ou potencialmente poluidora, ou causadora de potencial degradação ambiental.

O processo de licenciamento tem três etapas: ${ }^{10}$

- A Licença Prévia (LP) é concedida na fase inicial da atividade, aprovando sua localização e estabelecendo os requisitos básicos e condicionantes a serem atendidos nas próximas etapas. Uma avaliação de impacto ambiental (AIA) e seu respectivo relatório podem ser necessários nessa fase, bem como outros estudos ambientais, dependendo do grau de risco ambiental da atividade 
(Seção 4.2). O empreendedor deve elaborar um projeto de engenharia, seguindo as condições estabelecidas na licença prévia.

- A Licença de Instalação (LI) autoriza a construção ou ampliação de uma instalação ou atividade, de acordo com suas condições. O órgão ambiental local emite uma licença de construção distinta. As condições abrangem emissões atmosféricas, descargas de águas servidas (que, de forma geral, devem estar em conformidade com normas nacionais), gestão de resíduos (qualquer grande instalação ou gerador de resíduos perigosos deve contar com um plano de gestão de resíduos sólidos) e diversas medidas de mitigação ambientais e sociais.

- A Licença de Operação (LO) autoriza o início da obra/empreendimento após verificação do cumprimento dos requisitos das duas licenças anteriores, por parte do órgão ambiental.

A vigência das licenças prévia, de instalação e de operação tem duração variável, geralmente não superior a dez anos. Uma nova licença deve ser requerida no caso de alteração de atividade. Uma Taxa de Controle e Fiscalização Ambiental (TCFA) é cobrada pelo órgão de licenciamento, em valor que cubra os custos de tramitação e inspeção, variando entre $\mathrm{R} \$ 200$ e $\mathrm{R} \$ 10.000$ por ano, por unidade, conforme o tamanho e impacto poluente do empreendimento.

Outras autorizações e permissões podem ser requeridas, dependendo da atividade, ex., autorização de uso da água que englobe a captação de águas de superfície ou subterrâneas (Seção 3.3) ou autorização para uso de produtos químicos. São exigidas autorizações ambientais específicas para a extração de petróleo e gás. O órgão ambiental define quais estudos e documentos devem ser apresentados pelo requerente.

O processo de licenciamento deve ser conduzido pelo órgão ambiental federal, estadual ou municipal:

- O IBAMA é responsável por projetos de grande impacto ambiental no nível nacional, bem como em terras indígenas, na plataforma continental e em áreas interestaduais ou que contêm algum recurso sob domínio federal, a exemplo do petróleo. O IBAMA emite licenças para cerca de 700 atividades e mantém um banco de dados, disponível ao público em seu site.

- Os órgãos estaduais licenciam projetos realizados dentro de unidades de conservação estaduais ou que afetam mais de um município. Embora os órgãos ambientais estaduais exerçam a maior parte do licenciamento ambiental, ao longo dos anos, o IBAMA vem ampliando sua atuação e sobrepondo a competência dos órgãos estaduais, em parte, devido a carências de sua capacidade. No nível federal, não há informações quanto à abrangência das atividades de licenciamento ambiental dos órgãos estaduais.

- Os órgãos municipais têm responsabilidades por atividades com impacto local, ou delegadas pelo estado por meio de convênio ou outro instrumento legal, de acordo com critérios estabelecidos pelo conselho estadual do meio ambiente. Esses arranjos são mais comuns nas regiões Norte e Centro-Oeste, onde abrangem cerca de $15 \%$ dos municípios (IBGE, 2014a).

A Lei Complementar n $n^{\circ}$ 140/2011 tornou mais objetiva a divisão de competências pelo licenciamento ambiental entre os três níveis de governo. Em princípio, é a escala e a localização de um projeto e seu potencial impacto ambiental que determinam qual 
órgão deve emitir a licença. O Decreto $\mathrm{n}^{\circ} \mathrm{8.437}$, de abril de 2015, determina critérios precisos para projetos ou atividades sujeitos a licenciamento federal.

O sistema de licenciamento tem sido amplamente criticado (BIRD, 2008). Alega-se que o processo é excessivamente oneroso (por vezes, devido a falhas de elaboração); que provoca atrasos em importantes projetos de infraestrutura (especialmente no setor energético); e que gera problemas de competitividade. Em resposta a demandas por transparência, o processo vem se tornando um fórum de discussões amplas sobre opções de desenvolvimento e suas consequências ambientais, sociais, entre outras. Tais polêmicas consomem ainda mais tempo e recursos financeiros, suscitando pressão por parte do setor privado para acelerar o processo e colocando os órgãos ambientais no centro das atenções em relação a matérias além da sua competência (ex., questões fundiárias, reassentamento, reforma agrária).

Em relatório sobre licenciamento ambiental (ABEMA, 2013), órgãos ambientais estaduais criticaram a sobreposição de leis de licenciamento federal e estaduais (agora parcialmente sanada pelo Decreto $n^{\circ} 8.437 / 2015$ ), bem como as normas procedimentais defasadas e imprecisas, a qualidade técnica de estudos de impacto ambiental (Seção 4.2) e a falta de articulação com outros instrumentos de política (ex., uso da terra e ordenamento de bacias hidrográficas). A ABEMA identificou vários entraves específicos na formulação e implementação do licenciamento ambiental (Tabela 2.5).

Tabela 2.5. Perspectiva estadual sobre licenciamento ambiental: Desafios e propostas

\begin{tabular}{|c|c|}
\hline Desafios & Propostas \\
\hline $\begin{array}{l}\text { A ausência de uma "dimensão territorial" representa uma das } \\
\text { principais lacunas no processo de licenciamento ambiental. }\end{array}$ & $\begin{array}{l}\text { Institucionalizar a variável locacional como um dos } \\
\text { parâmetros utilizados para classificar os empreendimentos } \\
\text { e orientar o licenciamento ambiental. }\end{array}$ \\
\hline $\begin{array}{l}\text { A falta de objetividade na maioria dos processos de licenciamento em } \\
\text { virtude de normas imprecisas aumenta o grau de discricionariedade } \\
\text { dos gestores, o que leva invariavelmente à solicitação de } \\
\text { informações complementares que retardam os processos e } \\
\text { aumentam em demasia os prazos. Isto causa atrasos significativos } \\
\text { no processo e reduz sua objetividade. }\end{array}$ & $\begin{array}{l}\text { Estabelecer nova classificação de atividades sujeitas a } \\
\text { licenciamento e diferenciar procedimentos por tipo de } \\
\text { atividade. }\end{array}$ \\
\hline $\begin{array}{l}\text { A falta de uma definição e de uma lista das tipologias que podem } \\
\text { provocar significativo impacto ambiental, faz com que qualquer } \\
\text { atividade seja tratada como sendo de impacto significativo, o que } \\
\text { onera excessivamente o processo administrativo. }\end{array}$ & $\begin{array}{l}\text { Definir claramente parâmetros para caracterização de } \\
\text { tipologias de significativo impacto ambiental com base no } \\
\text { porte, localização e potencial poluidor da atividade. }\end{array}$ \\
\hline $\begin{array}{l}\text { As anuências exigidas pelo licenciamento de órgãos e entidades } \\
\text { que atuam fora da órbita da administração de meio ambiente, as } \\
\text { chamadas instituições intervenientes, acabaram criando instâncias } \\
\text { decisórias paralelas e um quadro de confusão institucional. }\end{array}$ & $\begin{array}{l}\text { Desvincular as anuências de instituições intervenientes } \\
\text { que não tratam de assuntos relacionados diretamente } \\
\text { ao licenciamento ambiental e regulamentar prazos para } \\
\text { matérias relacionadas diretamente a este instrumento, } \\
\text { tais como outorga de recursos hídricos e autorização de } \\
\text { supressão de vegetação. }\end{array}$ \\
\hline $\begin{array}{l}\text { Muitas vezes, as medidas compensatórias adotadas no âmbito do } \\
\text { licenciamento ambiental representam condicionantes exigidas por } \\
\text { órgãos intervenientes que nada têm a ver com impactos ambientais. }\end{array}$ & $\begin{array}{l}\text { Por meio de decreto presidencial, estabelecer } \\
\text { procedimentos claros para a definição de medidas } \\
\text { compensatórias. }\end{array}$ \\
\hline $\begin{array}{l}\text { A metodologia utilizada para avaliação dos impactos ambientais tem } \\
\text { dificultado também a qualidade e celeridade do licenciamento. A } \\
\text { avaliação é fragmentada por área de conhecimento, resultando em } \\
\text { opiniões conflitantes e contraditórias e dificultando a concessão da } \\
\text { licença. }\end{array}$ & $\begin{array}{l}\text { Introduzir a análise interdisciplinar dos requerimentos, } \\
\text { reunindo os especialistas requeridos em cada caso. Essa } \\
\text { abordagem favoreceria o diálogo com o empreendedor, } \\
\text { proporcionando melhores opções tecnológicas e de } \\
\text { localização para a atividade. }\end{array}$ \\
\hline $\begin{array}{l}0 \text { atual processo de consulta pública muitas vezes atende a objetivos } \\
\text { não ambientais (i.e., políticos, ideológicos). } 0 \text { formato de audiências } \\
\text { públicas, com tempo muito limitado para o requerente apresentar } 0 \\
\text { projeto e ainda menos tempo para os representantes da comunidade } \\
\text { expressarem suas demandas, é ineficaz. }\end{array}$ & $\begin{array}{l}\text { Permitir acesso público por via eletrônica às propostas } \\
\text { e aprimorar os procedimentos de audiência pública, } \\
\text { para garantir a discussão do impacto ambiental e da sua } \\
\text { mitigação. }\end{array}$ \\
\hline
\end{tabular}

Fonte: ABEMA. Novas propostas para o licenciamento ambiental no Brasil. Brasília: ABEMA, 2013. 
A corrupção e a interferência de poderosos atores políticos e econômicos são problemas frequentemente citados pelos órgãos ambientais, especialmente no nível subnacional. Apesar de menos generalizada que no passado, a prática da "não conformidade negociada" - pela qual algumas empresas conseguem autorização para continuar operando mesmo sem licença - ainda existe, especialmente em instâncias onde os órgãos ambientais são mais fracos (McAllister, 2008). Na última década, no entanto, o IBAMA e outros órgãos ambientais estaduais tomaram providências enérgicas no sentido de enfrentar a corrupção, demitindo e autuando centenas de servidores.

Nos últimos anos, avanços foram alcançados no que tange à simplificação do sistema de licenciamento, com o aprimoramento, pelo MMA e o IBAMA, dos regulamentos de licenciamento (Box 2.5) e a melhoria da capacidade técnica em nível federal. O MMA vem desenvolvendo um Portal Nacional de Licenciamento Ambiental para integrar, sistematizar e divulgar informações sobre licenciamento ambiental em todos os níveis do governo, aumentar a transparência dos processos de gestão pública e fortalecer o controle social sobre as decisões de licenciamento. Desde 2010, não houve casos de anulação judicial de licenças ambientais federais.

\section{Box 2.5 Seleção de regulamentos de licenciamento ambiental}

- O Decreto $n^{\circ} 421 / 2011$ padronizou critérios e agilizou o processamento de requerimentos de licença para certas categorias de projetos, incluindo linhas de transmissão.

- As Portarias $n^{\circ} 288 / 2013$ e n 289/2013 baixaram normas específicas de licenciamento para rodovias, para agilizar o processo de licenciamento desses projetos. Em 2014 por exemplo, foram emitidas licenças ambientais para $3.400 \mathrm{~km}$ de rodovias (no âmbito do Programa Federal de Investimentos em Logística) em 30 dias, em média.

- A Portaria Interministerial n 60/2015 visa melhorar a coordenação interinstitucional do processo de licenciamento ambiental. Regulamenta a participação da Fundação Nacional do Índio, do Instituto do Patrimônio Histórico e Artístico Nacional e do Ministério da Saúde, entre outros, em processos federais de licenciamento ambiental.

Subsistem, no entanto, preocupações quanto à eficácia do sistema. Embora o IBAMA tenha duplicado o número de pessoal técnico dedicado ao licenciamento, de $203 \mathrm{em}$ 2008, para 428 em 2014, e emita em média 3,3 licenças por dia útil, a capacidade dos órgãos ambientais estaduais e municipais varia bastante. Muitos carecem de pessoal qualificado ou de recursos financeiros para determinar, com precisão, os impactos ambientais previstos ou a eficácia das medidas compensatórias propostas. Controvérsias judiciais relacionadas ao licenciamento ambiental são comuns, acarretando custos significativos para requerentes e órgãos ambientais. O MMA vem buscando sanar as limitações de capacidade, através de apoio do Banco Mundial ao Programa Nacional de Meio Ambiente, cuja segunda fase (2009-14) foi direcionada, em grande parte, às questões de licenciamento.

\subsection{Avaliação de impacto ambiental}

Durante muito tempo, a AIA foi a única ferramenta de gestão ambiental amplamente aplicada no país. A ferramenta é obrigatória para todas as atividades com impacto ambiental potencialmente significativo, como parte integrante do processo de licenciamento ambiental. A AIA foi introduzida pela Lei nº 6.938 da PNMA de 1981 e, mais tarde, citada na Constituição Federal. Em nível federal, a Resolução CONAMA 
n 01/1986 estabeleceu o escopo mínimo da AIA (expandido em 1997) embora a maioria dos órgãos estaduais conte com seus próprios requisitos, em geral, dependendo da complexidade da atividade. Apesar da exigência de uma AIA para "atividades potencialmente causadoras de significativa degradação do meio ambiente", esse termo carece de definição regulamentar.

A elaboração de uma AIA inclui a realização de estudo de impacto ambiental, acompanhado por um resumo não técnico com subsídios para a participação social por meio de audiências públicas. Audiências públicas são organizadas a critério do órgão de meio ambiente, ou por solicitação do Ministério Público ou por mais de 50 cidadãos. Diversos órgãos intervenientes, incluindo a Secretaria de Vigilância Sanitária e instituições responsáveis pelo patrimônio histórico, cultural e étnico devem ser consultados durante o processo de AIA.

De forma geral, a AIA vem se tornando um processo eminentemente burocrático, que ignora fatores como localização, dimensão e alternativas tecnológicas. Tende a subestimar ou desprezar o impacto ambiental e raramente são propostas medidas compensatórias adequadas ou programas de monitoramento. Muitas vezes, as audiências públicas são realizadas para justificar decisões já tomadas, e não para refletir as opiniões de partes interessadas.

\subsection{Planejamento do uso da terra}

A Constituição de 1988 reservou aos municípios o principal papel no controle do desenvolvimento do solo urbano, por meio de planos municipais de ordenamento do território. Nas zonas rurais, os governos municipais implementam as decisões dos órgãos estaduais e federais. O Brasil carece de um sistema de ordenamento territorial integrado para dispor sobre ações coordenadas das diferentes instâncias de governo. Embora os governos federal e estaduais tenham atribuições concorrentes para promulgar leis e formular políticas e programas de uso da terra e ordenamento territorial, sua atuação, em geral, é limitada a diretrizes gerais ou direcionada a situações específicas não resolvidas no nível local. Poucos estados contam com disposições constitucionais específicas sobre uso e ordenamento da terra, e pouquíssimos já aprovaram legislação de ordenamento urbano.

Incorporar a dimensão ambiental ao planejamento territorial urbano é um desafio substancial. Historicamente, o planejamento foi realizado sem levar em consideração aspectos ambientais, e os planos diretores municipais (que cada município foi obrigado a desenvolver até 2005) combinam, mas não integram componentes individuais em saneamento, transportes, habitação, etc. Mesmo os planos diretores territoriais melhor concebidos (ex., em Manaus e Belém) quase não foram implementados.

Outro desafio é a falta de articulação entre o planejamento do uso da terra e o gerenciamento de recursos hídricos. Tal descompasso resulta, em parte, da diferença no âmbito do planejamento municipal e das bacias hidrográficas. Seria importante implementar planos de uso da terra de escopo regional, que incorporem aspectos de gestão da água.

A Avaliação Ambiental Estratégica (AAE) dos planos territoriais municipais e de outros programas de desenvolvimento poderia ser utilizada também para integrar perspectivas econômicas, territoriais e ambientais. Não há exigência legal para a realização de AAE e tampouco qualquer plano para sua adoção. Nos anos de 1990, instituições 
como o Banco Interamericano de Desenvolvimento (BID) e o Banco Mundial (BIRD) condicionaram o financiamento de grandes projetos à realização de AAE . No entanto, apesar de esforços do MMA para capacitar servidores de órgãos de infraestrutura na utilização dessa ferramenta, as poucas iniciativas de implementação de AAE realizadas ao longo dos anos foram nos Estados de Minas Gerais, Bahia, São Paulo e Rio de Janeiro. Nos últimos anos, Minas Gerais e Bahia incorporaram a exigência de AAEs à sua legislação (Oberling et al., 2013). Mais recentemente, a ABEMA vem defendendo a introdução de AAE para programas de governo com grande potencial de impacto ambiental, a exemplo de empreendimentos relacionados à energia, extração mineral e infraestrutura (ABEMA, 2013).

O desmatamento continua a ser uma questão crítica para o Brasil, apesar de avanços importantes alcançados nos últimos anos (Capítulos 4 e 5). A legislação que dispõe sobre o uso público e privado do solo em áreas rurais é o Código Florestal. Suas disposições quanto à conservação de terras passaram por grandes alterações desde a sua adoção, em 1934 . 0 Novo Código Florestal de 2012, que dispõe sobre a proteção da vegetação nativa, prevê a criação da chamada Reserva Legal para preservação de até $80 \%$ da cobertura florestal em propriedades rurais privadas na Amazônia; de 20\% a 35\% em áreas de Cerrado; e de 20\% da flora nativa em propriedades privadas em outros biomas. Historicamente, o cumprimento da legislação por parte de proprietários de terras foi baixo, e a falta de rigor na fiscalização em áreas remotas (notadamente na Amazônia) fez com que violações ficassem impunes. A introdução de vigilância por sensoriamento remoto, a partir de 2007, vem melhorando o controle e a conformidade.

Introduzido pelo Novo Código Florestal, o Cadastro Ambiental Rural (CAR) é instrumento importante para auxiliar na regularização de propriedades rurais em apoio à aplicação do Código Florestal e do planejamento estadual e municipal. Cerca de $50 \%$ das propriedades foram registradas no CAR em seu primeiro ano de funcionamento (2014/15) sendo que a meta é o cadastramento e regularização de todas as propriedades rurais do país, até maio de 2016 (Capítulo 4). O código criou também o Sistema de Cadastro Ambiental Rural (SICAR) para integrar os CARs estaduais, muitos dos quais já em vigor.

O Zoneamento Ecológico-Econômico (ZEE) introduzido em 2002 é outro instrumento de gestão de uso da terra rural, destinado à alocação de atividades compatíveis na delimitação de zonas ambientais para manter o uso sustentável dos recursos naturais e o equilíbrio dos ecossistemas existentes (Capítulo 4). Tem como enfoque principal critérios agroeconômicos como, por exemplo, a identificação de áreas apropriadas para o cultivo de cana-de-açúcar. $O$ acesso a crédito por parte de proprietários rurais é condicionado ao cumprimento de requisitos de zoneamento para suas culturas. No entanto, não existe uma metodologia padrão para a produção de estudos ZEE, e a capacidade municipal de implementação de zoneamento é fraca. Vários órgãos ambientais estaduais - no Mato Grosso, por exemplo - buscaram avaliar a eficácia do aproveitamento de terras rurais (para a produção de determinadas culturas) como parte integrante do processo de licenciamento ambiental. Essa abordagem parece ser boa, pois as licenças devem levar em consideração toda a gama de impactos ambientais de uma atividade. 


\section{Garantia de conformidade ambiental}

\subsection{Promoção da conformidade e de práticas verdes}

O engajamento do governo na promoção da conformidade pode reduzir custos de conformidade para as empresas, permitindo que alcancem e mantenham a conformidade da forma mais eficiente possível. Pode também reduzir custos regulatórios, através do aumento da eficiência da fiscalização e do monitoramento da execução. A eficácia da promoção da conformidade é maior quando direcionada a pequenas e médias empresas, onde a não conformidade ocorre principalmente por falta de conhecimento e capacidade, e entre as quais a resistência cultural é maior (Mazur, 2012). A promoção da conformidade está apenas começando a receber a merecida atenção por parte dos órgãos ambientais brasileiros.

Houve um aumento acentuado no número de empresas brasileiras com sistema de gestão ambiental (SGA) certificado pela norma ISO 14001. O número de novas certificações ISO 14001 no Brasil passou de 2.061 em 2005, para 3.695 em 2013 (ISO, 2014). Embora esses sistemas não necessariamente conduzam a melhores resultados ambientais, há indícios de que, em média, a certificação ISO 14001 teve impacto positivo sobre a rentabilidade das empresas (Tognere Ferron et al., 2012). São Paulo, o estado mais industrializado, responde por mais de um quarto do total nacional dessas certificações (De Oliveira, 2010). Enquanto a maioria das grandes empresas industriais obtém a certificação EMS, as pequenas empresas raramente procuram desenvolver um SGA de acordo com a ISO 14001, por considera-lo demasiadamente oneroso e caro. Contudo, os governos federal e estaduais não oferecem incentivos regulatórios (ex., menor frequência de fiscalização, taxas de licenciamento e sanções reduzidas) para a certificação SGA, a exemplo dos oferecidos por vários países da OCDE (Mazur, 2012). ${ }^{11}$

As auditorias ambientais surgem como ferramenta complementar de avaliação de desempenho ambiental. No nível federal, há diretrizes técnicas para auditorias ambientais em conformidade com as normas ISO 14010, ISO 14011 e ISO 14012. Auditorias são obrigatórias apenas no setor de petróleo e gás. No nível estadual, vários estados, incluindo o Rio de Janeiro e o Paraná, aprovaram leis que estabelecem a obrigatoriedade de auditorias ambientais para empreendimentos com elevado nível de impacto ambiental.

Ao mesmo tempo, o MDIC colabora com o Instituto Nacional de Metrologia, Normalização e Qualidade Industrial (INMETRO) e associações empresariais no desenvolvimento de normas de eficiência energética e de recursos, emitindo etiquetas e códigos de boas práticas para importantes setores industriais. Em 2008, pela primeira vez, a política industrial do governo incluiu metas de produção sustentável, entre elas: desenvolvimento de projetos de MDL para mitigação de mudanças do clima ; criação de incentivos para a produção agroindustrial sustentável; apoio à eficiência energética; e práticas de produção mais limpa na indústria. No entanto, a maioria dessas metas não foi alcançada devido, em parte, à crise econômica. Como parte da estratégia para melhorar a competitividade da indústria nacional, o Plano Brasil Maior 2011 incluiu práticas ecológicas como, por exemplo, metas de redução do consumo de energia por unidade do PIB industrial (Capítulo 3).

O governo promove a competitividade e o desenvolvimento sustentável (incluindo a eficiência de recursos) para micro e pequenas empresas (com menos de 100 funcionários 
na indústria, e menos de 50 no comércio e serviços) por meio do Serviço Brasileiro de Apoio às Micro e Pequenas Empresas (SEBRAE). ${ }^{12}$ Em outra iniciativa voltada às pequenas empresas, o MMA, em colaboração com a Confederação Nacional da Indústria (CNI) elaborou um currículo de ensino a distância para potenciais jovens empreendedores com ensino médio, para capacitação em gestão ambiental. A CNI dissemina os cursos por meio do serviço nacional de aprendizagem industrial. O governo pode estimular a difusão de práticas verdes, dando o exemplo e promovendo-as por meio de compras públicas verdes. A Agenda Ambiental na Administração Pública (A3P), criada em 2001, tem como objetivo promover a responsabilidade social e a sustentabilidade ambiental em instituições governamentais de todas as instâncias administrativas. Iniciativas específicas abrangem a eficiência hídrica e energética, a coleta seletiva de resíduos sólidos, a reciclagem, etc. As instituições participantes assinam um "termo de adesão" com o MMA. A A3P inclui um fórum nacional, um prêmio para as melhores práticas e etiquetas (verde, prata e laranja) concedidas em reconhecimento a práticas de gestão sustentável. Atualmente, cerca de 400 órgãos governamentais de todos os níveis participam do programa; em 2007 eram apenas 84.

O Decreto $n^{\circ} 7.746 / 2012$ estabeleceu critérios diferenciados para compras governamentais, dando prioridade aos produtos verdes, aos produzidos por micro e pequenas empresas, ou que tenham mais de $60 \%$ de conteúdo local. Um comitê interministerial sobre compras sustentáveis vem coordenando a elaboração de um catálogo de produtos sustentáveis e seus fornecedores. Compras governamentais verdes têm potencial considerável para estimular a procura e a oferta de bens e serviços ambientais (Capítulo 3). O valor das compras governamentais sustentáveis quase triplicou entre 2010 e 2014, mas os produtos sustentáveis ainda representam menos de $0,1 \%$ dessas compras. As micro e pequenas empresas fornecem quase metade desse volume (MPOG, 2015). O Brasil vem participando ativamente de iniciativas internacionais sobre compras governamentais sustentáveis e etiquetagem ecológica, do Programa das Nações Unidas para o Meio Ambiente (PNUMA) e avaliando suas políticas relacionadas, com vistas à promoção de práticas comerciais verdes.

Mais especificamente, a Resolução 3545/2008 do Banco Central do Brasil condicionou a concessão de crédito rural subsidiado no bioma Amazônia à legitimidade dos títulos fundiários e à prestação de informações que demonstrem conformidade com as normas ambientais (em especial, aquelas de uso da terra, estabelecidas no Código Florestal). Essa Resolução ajudou a reduzir o desmatamento (Capítulo 4). Estima-se que créditos no valor de $\mathrm{R}$ \$ 2,9 bilhões deixaram de ser concedidos entre 2008 e 2011 (Assunção et al. 2013). Quase $90 \%$ desses créditos teriam sido destinados à pecuária e calcula-se que sua restrição evitou o desmatamento de mais de 2.700 km², entre 2009 e 2011.

\section{Responsabilidade socioambiental no setor financeiro}

Aspectos socioambientais podem apresentar riscos significativos às operações de crédito, financiamentos, investimentos e seguros. Ademais, existe incerteza jurídica quanto à responsabilização ambiental de instituições financeiras envolvidas no financiamento de projetos que provocam danos ambientais, e algumas decisões judiciais têm responsabilizado instituições financeiras (GVces / FGV-EAESP, 2014). Para reduzir tais riscos e incertezas, desde 2008, resoluções do Banco Central têm abordado questões socioambientais em atividades financeiras (Tabela 2.6). 
Tabela 2.6. Resoluções e circulares do Banco Central do Brasil relacionadas ao meio ambiente

\begin{tabular}{|c|c|c|}
\hline Resolução/Circular & Operação financeira afetada & Descrição \\
\hline $\begin{array}{l}\text { Resolução } \\
3545 / 2008\end{array}$ & $\begin{array}{l}\text { Crédito rural - Conformidade ambiental } \\
\text { na Amazônia }\end{array}$ & $\begin{array}{l}\text { Aplica-se ao bioma Amazônia e requer que instituições financeiras exijam } \\
\text { documentação de crédito dos mutuários, comprovando conformidade } \\
\text { ambiental. }\end{array}$ \\
\hline $\begin{array}{l}\text { Resolução } \\
3813 / 2009\end{array}$ & $\begin{array}{l}\text { Crédito rural - Expansão da cana-de- } \\
\text { açúcar }\end{array}$ & $\begin{array}{l}\text { Vincula o crédito agroindustrial ao zoneamento agroecológico para a } \\
\text { expansão e industrialização da cana-de-açúcar. Proíbe o financiamento para } \\
\text { expansão da cultura nos biomas Amazônia e Pantanal e na Bacia do Alto } \\
\text { Paraguai, entre outros. }\end{array}$ \\
\hline $\begin{array}{l}\text { Resolução } \\
3896 / 2010\end{array}$ & $\begin{array}{l}\text { Crédito rural - Agricultura de baixa } \\
\text { emissão de carbono }\end{array}$ & $\begin{array}{l}\text { Implementar o Programa Agrícola de Baixo Carbono como parte da Política } \\
\text { Nacional sobre Mudança do Clima. }\end{array}$ \\
\hline $\begin{array}{l}\text { Resolução } \\
4008 / 2011\end{array}$ & $\begin{array}{l}\text { Crédito para mitigação e adaptação das } \\
\text { mudanças do clima }\end{array}$ & $\begin{array}{l}\text { Regras sobre financiamento de projetos voltados à mitigação e adaptação } \\
\text { climática, apoiado por recursos do Plano Nacional sobre Mudança do Clima. }\end{array}$ \\
\hline Circular 3547/2011 & $\begin{array}{l}\text { Processo de Avaliação Interna para } \\
\text { Adequação de Capital }\end{array}$ & $\begin{array}{l}\text { Exige que a instituição demonstre a forma de abordar o risco de exposição a } \\
\text { danos socioambientais em seu processo de avaliação e no cálculo do capital } \\
\text { necessário para cobrir tal risco. }\end{array}$ \\
\hline $\begin{array}{l}\text { Resolução } \\
4327 / 2014\end{array}$ & $\begin{array}{l}\text { Diretrizes para Políticas de } \\
\text { Responsabilidade Social e Ambiental de } \\
\text { Instituições Financeiras }\end{array}$ & $\begin{array}{l}\text { Regras sobre diretrizes a serem cumpridas durante o estabelecimento e } \\
\text { implementação de responsabilidades socioambientais pelas instituições } \\
\text { financeiras. }\end{array}$ \\
\hline
\end{tabular}

Fonte: Adaptado do GVces/FGV-EAESP. The Brazilian Financial System and the Green Economy - Alignment with Sustainable Development, elaborado pelo PNUMA e Febraban no âmbito do Inquérito sobre o projeto de um sistema financeiro sustentável. São Paulo: Febraban, 2014.

A Resolução BACEN n 4.327/2014 determina que instituições financeiras sob supervisão regulatória do Banco Central estabeleçam políticas de responsabilidade e estruturas de governança para aspectos sociais e ambientais, bem como sistemas de gestão de risco socioambiental e planos de ação para monitoramento e mitigação de riscos (GVces/FGV-EAESP, 2014). O Banco Central não especifica o escopo de aplicação das políticas, que devem ser proporcionais à dimensão e à natureza das operações. A Federação Brasileira de Bancos (FEBRABAN) detalhou ainda mais essa resolução, agregando aspectos de sustentabilidade às políticas de concessão de crédito de bancos públicos e privados, em consistência com os Princípios do Equador para a avaliação de riscos ambientais e sociais no financiamento de projetos (Box 2.6).

\section{Box 2.6. Os Princípios do Equador}

Os Princípios do Equador, que as instituições financeiras adotam voluntariamente, são uma estrutura de gerenciamento de risco de crédito para determinar, avaliar e gerir riscos socioambientais em financiamento de projetos. Os três primeiros princípios estabelecem os fundamentos da avaliação ambiental e social:

Princípio 1: Análise e Categorização. Ao receber um pedido de financiamento de projeto, a instituição financeira, como parte do seu processo interno de análise e due diligence fará sua categorização com base na magnitude de seus potenciais riscos e impactos socioambientais.

Princípio 2: Avaliação Socioambiental. Para todos os projetos com potencial de impacto socioambiental adverso, a instituição financeira exigirá que o cliente realize uma avaliação de riscos ambientais e sociais. A documentação relativa à avaliação deve propor medidas para minimizar, mitigar e compensar impactos negativos de modo pertinente e compatível com a natureza e a escala do projeto proposto.

Princípio 3: Padrões Socioambientais Aplicáveis. O processo de avaliação deve verificar a conformidade do projeto com a lei, as regulamentações e licenças pertinentes do país anfitrião, no âmbito socioambiental.

Fonte: Equator Principles Association. The Equator Principles. Disponível em: <www.equator-principles.com>. 


\subsection{Fiscalizações ambientais}

Até recentemente, cabia a qualquer órgão ambiental federal, estadual ou municipal fiscalizar e impor sanções a poluidores, sempre que uma infração ocorresse dentro de sua área de competência. A Lei Complementar 140/2011 sanou a sobreposição constitucional e jurisdicional que havia sido amplamente interpretada como permitindo que qualquer órgão de meio ambiente pudesse exigir o cumprimento de qualquer disposição ou regulamento em vigor em sua esfera de competência territorial. Tal interpretação permitia diversos meios de autuação, apesar das disparidades de capacidade de órgãos das diferentes instâncias. O Artigo 17 dessa lei restringe ao órgão licenciador o poder de fiscalização sobre operações licenciadas, dessa forma limitando o poder de atuação do IBAMA ou de outros órgãos estaduais no que tange a exercer, completar ou anular ações de órgãos de instância inferior. O órgão de instância superior ainda pode fiscalizar um local licenciado pelo órgão de instância inferior, mas deve informá-lo e respeitar sua competência quando da eventual imposição de sanções.

Geralmente, as fiscalizações são realizadas em resposta a denúncias ou ocorrências, ou para coletar informações no âmbito de um processo de licenciamento ambiental. A CETESB, no Estado de São Paulo, é um dos poucos órgãos ambientais dotados dos recursos necessários para realizar fiscalizações planejadas e de rotina, além daquelas desencadeadas por denúncias ou ocorrências; mesmo assim, as rotineiras representam apenas uma em cada oito das fiscalizações realizadas (McAllister, 2008). O IBAMA afirma que $95 \%$ das suas atividades de fiscalização são planejados (no âmbito do seu Plano Nacional de Meio Ambiente); contudo, já que suas fiscalizações se concentram, principalmente, em "questões verdes" como o desmatamento, seus fiscais tendem a se deslocar para áreas problemáticas onde há maior probabilidade de identificar violações.

Há uma insuficiência de fiscais ambientais federais, estaduais e municipais. Em 2002, o IBAMA tinha apenas um fiscal para cada $11.000 \mathrm{~km}^{2}$ na Amazônia, e um servidor para cada $6.000 \mathrm{~km}^{2}$ em outras regiões do país (McAllister, 2008). No IBAMA, a situação melhorou significativamente (dados sobre o atual efetivo de fiscais não foram apresentados); contudo, nos níveis estadual e municipal, há grande variação entre as regiões. Uma forma de preencher essa lacuna seria a criação de oportunidades para a "fiscalização cidadã", com o envolvimento de comunidades locais e organizações da sociedade civil na fiscalização e monitoramento e por meio de disque denúncia, de patrulhas ecológicas voluntárias, etc.

$\mathrm{Na}$ verificação de conformidade com regulamentos de uso da terra e florestais, o sensoriamento remoto, desde 2007, tem se comprovado instrumento eficaz em complementação à atuação de fiscais. Imagens de satélite de custo relativamente baixo mostram, em tempo real, os locais em que violações ocorrem e apontam possíveis responsáveis. Ao colocar dados de sensoriamento remoto on-line, o governo abre espaço para que ativistas verdes atuem na fiscalização da interface entre floresta e fronteira agrícola. Por exemplo, as moratórias brasileiras impostas sobre a soja e a carne provenientes da Amazônia não teriam eficácia sem esses dados (Capítulo 4).

\subsection{Ferramentas de execução}

A Lei no 9605/1998, lei de Crimes Ambientais, é o principal instrumento jurídico que dispõe sobre as sanções ambientais penais e administrativas, de aplicação uniforme 
em todo o país. O Decreto $\mathrm{n}^{\circ}$ 6.514/2008 regulamenta a lei, estabelecendo sanções para mais de 60 tipos de infrações ambientais.

Sanções penais podem incluir multas, serviços comunitários ou prisão de pessoas físicas; ou suspensão da atividade de pessoas jurídicas. O relato espontâneo de uma violação pode atenuar eventuais penalidades. Servidores públicos também podem ser autuados por crimes ambientais como, por exemplo, a emissão de licença que não esteja em conformidade com as normas ambientais. Em 2005, o Superior Tribunal de Justiça admitiu, pela primeira vez, a possibilidade da responsabilização penal de pessoas jurídicas, em conjunto com seus gestores.

Sanções administrativas podem consistir de advertências, multas para pessoas físicas ou jurídicas, e/ou suspensão da atividade. A aplicação de advertências e multas administrativas é semelhante em todos os estados. Ao apurar uma violação, geralmente o fiscal emite um aviso. Caso as fiscalizações subsequentes apurem que a situação não está sendo corrigida, o fiscal pode emitir até três multas de gravidade crescente e, então, passa a impor multa diária. Se essas multas não surtirem efeito, o órgão pode tomar providências no sentido de encerrar a atividade (o que raramente acontece na prática). Esse procedimento varia de acordo com o estado: em alguns (ex., São Paulo) as multas são impostas diretamente pelos fiscais; em outros, a competência pela emissão da multa é do chefe do órgão de meio ambiente.

O montante das multas administrativas depende da extensão do dano ambiental e das providências tomadas pelo poluidor no sentido de prevenir e remediar o problema. Para algumas violações, as multas podem chegar a $\mathrm{R} \$ 50$ milhões. Os órgãos ambientais consideram adequado o valor das multas administrativas; contudo, os valores efetivamente recolhidos são muito baixos (menos de 10\%). Os órgãos ambientais são responsáveis pela cobrança de multas administrativas e beneficiados por suas receitas (Seção 2); no entanto, os instrumentos de cobrança são insuficientes. ${ }^{13}$

Debilidades da atuação administrativa conduziram à intervenção do Ministério Público, que vem acabando com o clima de impunidade que, há muito tempo, prevalece na execução da lei ambiental no Brasil. Promotores públicos federais e estaduais vêm desempenhando um papel cada vez mais ativo na fiscalização e autuação civil e penal de infrações ambientais.

Os poderes de execução da Procuradoria Geral da República (PGR) são mais amplos que os dos órgãos ambientais: muitas vezes, o simples fato de o infrator estar sob investigação da promotoria pública leva a mudanças significativas de comportamento. A perspectiva de uma ação civil pública ou penal (com cobertura da mídia) tende a fazer com que o poluidor aceite um "termo de ajustamento de conduta" pelo qual se compromete a tomar providências para prevenir ou remediar o dano ambiental.

Há mais de 10.000 promotores federais e estaduais, sob o comando da PGR (que tem representantes em cada estado) e seus homólogos estaduais. A maioria tem competência para lidar com casos de execução ambiental, civil ou penal, e alguns trabalham exclusivamente na proteção do meio ambiente.

Em geral, os promotores atuam com base no Código Civil. Podem abrir inquérito civil em resposta a uma denúncia, a um encaminhamento administrativo, mas também podem iniciar inquéritos por conta própria. Após a investigação, muitas vezes buscam resolver o caso sem ação judicial, dessa forma poupando custos e tempo para todos. ${ }^{14}$ Caso o processo não seja resolvido por meio extrajudicial, o Ministério Público tem o 
dever de levá-lo ao tribunal. ${ }^{15}$ Em processos civis, os promotores geralmente buscam uma ordem judicial, exigindo que o infrator tome medidas preventivas ou reparadoras, ao invés do pagamento de compensações financeiras.

Investigações criminais são, em geral, conduzidas pela polícia judiciária, que pode encaminhar os processos à PGR. A partir do momento em que a Procuradoria tome conhecimento de danos ambientais potenciais ou reais, esta passa a ter a obrigação de tomar as medidas cabíveis para a investigação e remediação dos danos (diferentemente de alguns países, no Brasil não há discricionariedade do Ministério Público).

O nível de colaboração entre promotores e órgãos ambientais varia em função de diferentes graus de independência política da Promotoria Geral de cada estado, e da medida em que os promotores podem contar com o auxílio do órgão ambiental estadual no encaminhamento dos processos.

É também da competência dos promotores a supervisão do trabalho dos órgãos ambientais. Normalmente, essa supervisão ocorre quando um promotor solicita de um órgão informações ou explicações sobre determinado problema ou processo. Assim, o promotor pode descobrir, por exemplo, a frequência com que as fiscalizações ocorreram, o que os fiscais encontraram e como o órgão reagiu. O promotor pode, também, solicitar um parecer técnico de um especialista externo para avaliar o trabalho do órgão. Caso a investigação identifique um ato potencialmente ilegal ou omissão na conduta do órgão, o procurador pode: fazer uma recomendação, por escrito, sugerindo mudanças; tentar negociar um "termo de ajustamento de conduta" com o órgão; ou propor medidas judiciais contra o mesmo. O envolvimento de promotores aumenta a eficácia da fiscalização ambiental e serve de mecanismo de responsabilização para órgãos ambientais.

Execução por parte do Ministério Público, contudo, também tem suas desvantagens. A maioria dos promotores não possui capacitação em direito ambiental. Suas ações de execução, pelo caminho extrajudicial ou por encaminhamento ao Judiciário, carecem de consistência no país como um todo. Ademais, por falta de discricionariedade administrativa, os promotores são obrigados a gastar tempo e recursos investigando questões de menor peso, o que compromete sua eficiência (McAllister, 2008).

\subsection{Responsabilidade ambiental}

O Brasil tem um regime de responsabilidade civil ambiental rigoroso, consistente com a boa prática internacional: não há necessidade de se comprovar culpa ou negligência para que seja imputada a responsabilidade pela remediação de danos ambientais. Por exemplo, a imputação de responsabilidade significa que proprietários atuais podem ser responsabilizados por danos já existentes quando da aquisição das terras (contudo podem abrir ação civil contra os proprietários anteriores causadores da contaminação). A Constituição prevê a obrigação específica de poluidores pela recuperação de danos ambientais provocados pela extração mineral.

Em 2009, o Superior Tribunal de Justiça determinou que a responsabilidade por danos ambientais não prescreve, o que significa que o meio ambiente deve ser recuperado, independentemente de quando o dano tenha ocorrido. A Resolução CONAMA n 420/2009 estabelece procedimento padrão para identificação, divulgação pública e recuperação de locais contaminados. Estabelece ainda critérios e princípios que orientam e avaliam o grau de contaminação do solo. Órgãos ambientais e outras entidades competentes, tais como promotores públicos, organizações não governamentais (ONGs) ou pessoas 
físicas, podem exigir que os responsáveis pelas avaliações apresentem um plano de recuperação (que deve ser aprovado pelo órgão ambiental) e procedam à remediação dos danos. As medidas de remediação são impostas por meio de liminar judicial.

Na impossibilidade de correção do dano, o tribunal pode exigir uma compensação financeira. Por exemplo, no caso de poluição atmosférica, um empreendimento que exceda os limites de emissões definidos em uma licença ambiental poderá ficar sujeito a uma avaliação para a compensação de danos. Essa matéria está regulamentada também em nível estadual.

Apesar desse quadro jurídico robusto, as responsabilidades ambientais são atribuídas apenas esporadicamente: as autoridades ambientais carecem de competência para atuar em todos os casos de danos ambientais, de forma que a grande maioria permanece sem solução, deixando não atendidas muitas das exigências legais relacionadas. Por exemplo, a Lei n 12.305/2010 da Política Nacional de Resíduos Sólidos permite que o órgão de licenciamento ambiental exija que operadores que geram ou lidam com resíduos perigosos contratem seguro de responsabilidade civil para cobrir possíveis danos ao ambiente ou à saúde pública. As regras e limites máximos de seguro deveriam ter sido estabelecidos em lei; contudo, ainda não foram regulamentados.

\section{Promoção da democracia ambiental}

\subsection{Participação pública na tomada de decisão ambiental}

A participação social na formulação da política é característica fundamental do modelo SISNAMA. Representantes de ONGs ambientais (cerca de 400, segundo o Cadastro Nacional de Entidades Ambientalistas do MMA) são componentes do CONAMA e participam dos conselhos estaduais e municipais de meio ambiente. Essa participação tende a ser bem mais forte nos níveis federal e estadual, do que no municipal.

A Conferência Nacional do Meio Ambiente foi criada como fórum para aumentar a participação da sociedade civil na discussão e definição dos principais elementos das políticas de desenvolvimento sustentável do Brasil. Os delegados da conferência nacional são selecionados em conferências estaduais, com a paridade de gênero e alocação de $40 \%$ dos assentos para ONGs e movimentos sociais; $30 \%$ para o setor privado; $20 \%$ para os governos; $5 \%$ para as comunidades indígenas; e $5 \%$ para as comunidades tradicionais. A primeira edição da conferência foi realizada em 2003, com outras edições em 2005, 2008 e 2013. As duas últimas foram dedicadas à mudança do clima e à gestão de resíduos sólidos. As deliberações da conferência levaram à elaboração de planos de ação e à formulação de leis relacionadas ao meio ambiente.

A participação de interessados é também um elemento importante de alguns procedimentos formais de governança ambiental. A finalidade do processo de AIA (Seção 4.2) é promover a participação social nas decisões sobre impacto ambiental de projetos de investimento. É comum, as audiências de AIA contarem com a presença de ONGs e pessoas físicas interessadas. No entanto, a participação social não costuma ir além da divulgação de informações ao público e da coleta de subsídios para tomadores de decisão. Não existem regras procedimentais para levar em consideração as opiniões das ONGs. Os participantes carecem de recursos para se engajar ativamente em debates sobre a decisão de emitir uma licença ambiental ou sobre determinações a respeito das condições e medidas de mitigação compensatórias. 
O artigo 231 da Constituição Federal estabelece o direito de serem ouvidas as comunidades afetadas quando da exploração de recursos minerais e hídricos em terras indígenas. Recentes debates públicos relacionados ao licenciamento ambiental de grandes projetos de infraestrutura (ex., a usina nuclear de Angra 3, o complexo hidrelétrico do Rio Madeira e a usina de Belo Monte, no Rio Xingu) foram caracterizados por nítidos conflitos entre os interesses ambientais, sociais e econômicos, que contam com forte lobby no nível federal. A falta de diálogo com comunidades locais levou algumas ONGs a se posicionar contra a exploração de recursos naturais. Na sua visão, embora tenham ampla oportunidade de expressar suas opiniões, muitas vezes, os tomadores de decisão governamentais simplesmente as ignoram.

Ainda assim, o governo repassa recursos financeiros substanciais às ONGs. A Lei $\mathrm{n}^{\circ}$ 13.019/2014 simplifica os procedimentos de parceria entre governo e organizações da sociedade civil, inclusive por meio da prestação de apoio financeiro às ONGs. A lei estabelece novas formas de contratação que permitem, não apenas que ONGs financiem atividades de projeto específicas, mas também que paguem salários de pessoal. Essas medidas devem servir tanto para melhorar a estabilidade institucional das ONGs quanto para ampliar a responsabilização pela prestação de contas.

\subsection{Divulgação e acesso $a$ informações ambientais}

A Lei $n^{\circ} 10.650 / 2003$ dispõe sobre o acesso público a informações existentes nos órgãos e entidades integrantes do SISNAMA. A Lei n $12.527 / 2011$ estendeu essa garantia a informações em posse de todas as instituições públicas, exceto quando sua divulgação possa vir a prejudicar a defesa nacional, a saúde e a segurança pública, a estabilidade do sistema monetário ou outros interesses nacionais. Competes aos órgãos ambientais de todas as instâncias administrativas, manter registros públicos de informações, como licenças ambientais e relatórios de AIA. Alguns estados (ex., São Paulo) vão mais longe, divulgando outras informações ambientais, tais como cadastro de áreas contaminadas. No entanto, em estados com órgãos ambientais institucionalmente mais fracos, mesmo os dados básicos da regulação ambiental tendem a ser fragmentados ou incompletos.

O Sistema Nacional de Informações sobre o Meio Ambiente (SINIMA) gerido pelo MMA, é responsável pelo desenvolvimento de uma política consistente para a produção, coleta, sistematização e divulgação de informações ambientais. O SINIMA compreende três programas: desenvolvimento de ferramentas para permitir acesso às informações disponíveis; integração de bancos de dados e sistemas de informação; e fortalecimento da produção, sistematização e análise de estatísticas e indicadores relacionados às áreas de competência do MMA. O MMA vem trabalhando para fortalecer o SINIMA, inclusive por meio da elaboração de um conjunto de indicadores-chave - o Painel Nacional de Indicadores Ambientais (PNIA). A versão-piloto do PNIA, publicada em 2012, abrangeu 34 indicadores em oito áreas temáticas; a expectativa é que mais 16 indicadores sejam consolidados até $2016 .{ }^{16}$ O projeto não envolve a geração de novos dados, mas tem como objetivo consolidar aqueles relacionados ao meio ambiente já existentes em diversas instituições públicas do Brasil. O MMA também vem colaborando com o IBGE, no sentido de integrar o PNIA aos indicadores de desenvolvimento sustentável do IBGE (Box 2.7), seu conjunto de dados consolidados mais abrangente sobre meio ambiente e outras informações. 


\section{Box 2.7. Indicadores de desenvolvimento sustentável do Brasil}

As iniciativas de rastreamento sistemático dos avanços rumo ao desenvolvimento sustentável tiveram início em 2002, com o lançamento dos Indicadores de Desenvolvimento Sustentável (IDS) do IBGE. Esta foi a primeira tentativa de compilar dados coletados pelo IBGE e dezenas de outras instituições públicas, de modo a acompanhar e apoiar avanços rumo ao desenvolvimento sustentável. Os IDS foram escolhidos e concebidos de acordo com recomendações da Comissão das Nações Unidas sobre Desenvolvimento Sustentável, e ajustados ou ampliados para se adequarem às condições brasileiras. Os indicadores foram apresentados em relatórios de 2004, 2008, 2010 e 2012; mostrando, sempre que possível, os avanços alcançados desde os anos de 1990, com análise diferenciada para cada região. A publicação de 2012 abrangeu 62 indicadores, estruturados em quatro dimensões:

- social (abrangendo população, saúde, educação, habitação, segurança, igualdade de gênero e raça)

- ambiental (abrangendo ar, terra, água, oceanos e áreas costeiras, biodiversidade e saneamento)

- econômica (abrangendo estrutura econômica, desempenho macroeconômico e financeiro, uso e esgotamento de recursos naturais)

- institucional (abrangendo a existência de instituições ambientais e capacidade institucional).

Fonte: IBGE. Indicadores de Desenvolvimento Sustentável, 2012.

A disponibilidade de informações relacionadas ao meio ambiente melhorou consideravelmente. Além das duas iniciativas citadas acima, uma quantidade substancial de dados relacionados ao meio ambiente é coletada pelos ministérios setoriais e outros órgãos, tais como o Ministério das Cidades (dados sobre resíduos e saneamento), a Agência Nacional de Águas (sobre disponibilidade, qualidade e uso da água) e o IBAMA, o ICMBio e o Serviço Florestal (sobre biodiversidade, florestas e silvicultura). Iniciativas nos níveis subnacionais, muitas ainda incipientes, incluem a elaboração de indicadores de desenvolvimento sustentável no Paraná e no Mato Grosso. No entanto, há ainda grandes lacunas em algumas áreas, notadamente aquelas onde as entidades subnacionais são responsáveis pela implementação de políticas e coleta de dados (ex., resíduos sólidos ou qualidade do ar). Muitos municípios carecem de recursos e capacidades técnicas para coletar e processar esses dados, o que resulta em grandes lacunas e inconsistências nos bancos de dados nacionais. Em consequência, a aplicação de indicadores ambientais ou de sustentabilidade permanece muito limitada (MMA, 2014). E assim, mesmo os cidadãos e ONGs tendo o direito de acesso às informações, muitas vezes essas são inexistentes, contraditórias ou mal sistematizadas.

\subsection{Acesso à justiça}

A Lei n ${ }^{\circ} 7.347 / 1985$, sobre Ação Civil Pública, teve amplo impacto sobre a legislação e a prática ambiental. Permite a representação judicial de interesses ambientais por parte de ONGs ambientais criadas há pelo menos um ano, juntamente com o Ministério Público e entidades governamentais, facultando ações coletivas que pleiteiem compensação por danos ambientais convencionais contra a saúde pública e a propriedade. Além disso, processos judiciais relacionados ao meio ambiente, nos termos da Lei $\mathrm{n}^{\circ}$ 4.717/1965, podem ser iniciados pelos cidadãos; mas apenas se diretamente afetados pela atividade em questão. 
Muitas ONGs promovem ações públicas para contestar licenças ambientais que, na sua opinião, são inadequadas no controle do impacto ambiental das atividades (Box 2.8). Em geral, as ONGs não recorrem diretamente ao judiciário, mas encaminham denúncias ao Ministério Público, cujos promotores são, por lei, obrigados a levar adiante os processos.

\section{Box 2.8. Litígio sobre a construção da usina de Belo Monte}

Belo Monte é uma usina hidrelétrica em construção no rio Xingu, no Estado do Pará. Com capacidade instalada prevista de mais de $11 \mathrm{GW}$, será a segunda maior usina hidrelétrica do país e uma das maiores do mundo. Sua construção faz parte dos planos do governo para garantir a segurança energética por meio da construção de usinas hidrelétricas.

Há no Brasil forte oposição ao projeto, com questionamentos quanto à sua viabilidade econômica, eficiência de geração e, principalmente, seu impacto sobre pessoas e meio ambiente. Os críticos, entre eles ONGs como a Amazon Watch, argumentam que o projeto devastará mais de $1.500 \mathrm{~km}^{2}$ de floresta tropical, provocando perdas de biodiversidade, grande aumento nas emissões líquidas de GEE e deslocamento forçado de mais de 20.000 pessoas.

No início de 2010, o IBAMA concedeu uma licença ambiental prévia ao projeto, aprovando a AIA de 2008. Em 2010, mais de 100 organizações nacionais e internacionais, em carta ao então Presidente da República, denunciaram o processo de tomada de decisão na concessão da licença. Com o apoio dessas organizações, 35 ações judiciais civis foram ajuizadas contra o projeto; contudo, o judiciário julgou procedente a licença.

Em 2011, após realização de estudos adicionais, o IBAMA emitiu a licença de instalação e o consórcio empreendedor concordou em pagar US\$1,9 bilhão para sanar pendências sociais e ambientais, incluindo US\$ 40,7 milhões para investimento em reflorestamento e áreas protegidas.

Fonte: Amazon Watch (n.d.). Brazil's Belo Monte Dam. www.amazonwatch.org/work/belo-monte-dam. Acesso em: maio/2015; Portal Brasil. Belo Monte transforma a vida de 11 cidades do Pará. <http://www.brasil. gov.br>. Acesso em: maio/2015.

\subsection{Consciência e educação ambiental}

A educação ambiental é prevista pela Lei no 9.795/1999 da Política Nacional de Educação Ambiental e pelo Decreto $n^{\circ} 4.281 / 2002$. O Programa Nacional de Educação Ambiental (ProNEA) é gerido conjuntamente pelo Departamento de Educação Ambiental do MMA e pela Coordenação-Geral de Educação Ambiental do Ministério da Educação. Vários estados também participam das iniciativas do programa, por meio de acordos de cooperação técnica com o MMA.

A quarta edição do ProNEA foi lançada em 2014. Suas principais ações estratégicas incluem a capacitação de educadores ambientais (mais de 6.000 pessoas participam de um programa ambiental de ensino a distância), a inclusão da educação ambiental em currículos escolares e a comunicação social sobre questões ambientais. Destacam-se duas iniciativas de comunicação social de maior relevo:

- No âmbito da iniciativa Circuito Verde, o MMA abriu uma chamada para vídeos amadores sobre problemas ambientais locais e selecionou cerca de 50 deles, que foram apresentados e utilizados como subsídio para debates públicos organizados em mais de 1.500 locais em todo o país. 
- Mais de 400 "salas verdes" foram criadas em espaços públicos em todo o país (ex., bibliotecas, edifícios públicos) nas quais uma série de publicações ambientais foi colocada em exposição para uso público gratuito.

Outros programas temáticos relevantes incluem a Estratégia Nacional de Educação e Comunicação Ambiental em Unidades de Conservação (áreas protegidas), o Programa de Educação Ambiental e Mobilização Social em Saneamento, o Programa de Educação Ambiental e Agricultura Familiar, a Estratégia para a Educação Ambiental e Comunicação Social em Gestão de Resíduos Sólidos e o Programa Juventude e Meio Ambiente (que incluiu conferências nacionais em 2013 e 2015).

Essas iniciativas resultaram em maior conscientização acerca de questões ambientais entre jovens. Um levantamento da OCDE revelou que mais de $95 \%$ dos jovens de 15 anos afirmam estar familiarizados com questões relacionadas à poluição atmosférica, à extinção de plantas e animais e ao desmatamento - principais problemas ambientais do Brasil (OCDE, 2009).

O conhecimento da população a respeito dos principais conceitos e problemas ambientais parece estar aumentando, não obstante a persistência de nítidas diferenças regionais. Por exemplo, na região Sul $74 \%$ das pessoas sabem o que é uma unidade de conservação, enquanto que, na região Nordeste, apenas $45 \%$ o sabem. No geral, menos de $15 \%$ da população se considera bem informada sobre questões de meio ambiente e ecologia (MMA, 2012).

Pesquisas indicam que os brasileiros se orgulham das riquezas naturais do seu país e que a consciência e preocupação a respeito de pressões ambientais vem aumentando. Em 2012, o meio ambiente ficou em sexto lugar na pauta das principais preocupações dos brasileiros (após saúde, violência, desemprego, educação e política) comparado com o $12^{\circ}$ lugar em 2006, e nenhuma menção em 1992. A maioria dos brasileiros (82\%) não concorda que o progresso econômico seja mais importante que a preservação ambiental; ou que o aumento da poluição seria aceitável se trouxesse mais emprego ou salários mais elevados (87\%) (MMA, 2012; CNI, 2012).

Os brasileiros apontam o desmatamento como o problema ambiental mais premente, seguido pela poluição hídrica, poluição atmosférica, geração e tratamento de resíduos e mudança do clima. Moradores de áreas urbanas apontam a geração de resíduos, a poluição hídrica e a poluição atmosférica como suas principais preocupações ambientais, ficando o desmatamento em quarto lugar (Figura 2.3). Os níveis de satisfação com a ação pública para a proteção ambiental vêm diminuindo, especialmente no que se refere ao desempenho das instâncias subnacionais. 
Figura 2.3. O desmatamento é a principal preocupação ambiental dos brasileiros, exceto entre moradores de áreas urbanas

Preocupações ambientais, frequência de respostas, 2012

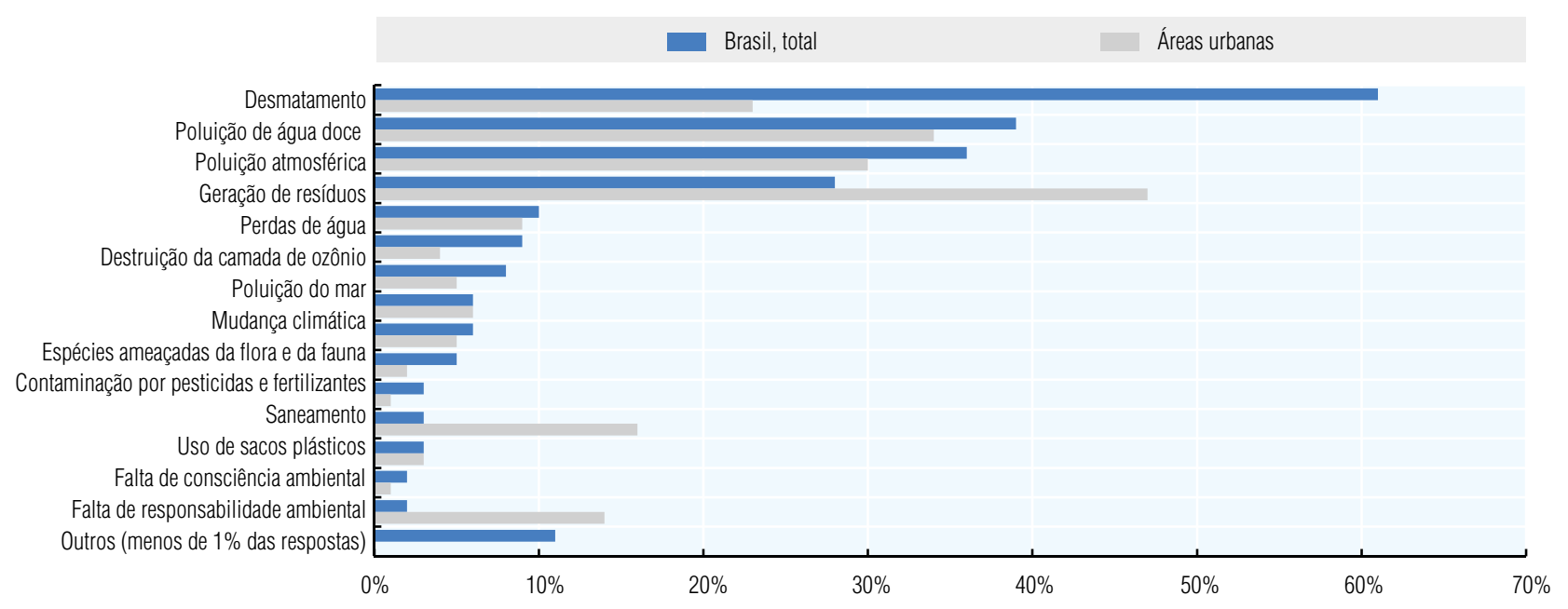

Fonte: MMA (2012), 0 que o brasileiro pensa do meio ambiente e do consumo sustentável - Pesquisa nacional de opinião: principais resultados.

\section{Recomendações sobre gestão e governança ambiental}

Governança ambiental

- Racionalizar a multiplicidade de órgãos de coordenação vertical e horizontalizados, no intuito de eliminar sobreposições e lacunas de responsabilidades e, por último, melhorar a coerência e a eficácia política; considerar a criação de um sistema nacional para controle de qualidade e responsabilização.

- Fomentar, nas associações estaduais (ABEMA) e municipais (ANAMMA) a criação de órgãos ambientais para compor uma rede de reguladores em todas as instâncias administrativas e aumentar sua capacidade por meio da troca de experiências e boas práticas; considerar a implementação de um programa de fortalecimento de capacidades em nível subnacional.

- Considerar a replicação de mecanismos de governança nos diversos níveis para outras áreas da política ambiental, a exemplo do Pacto Nacional de Gestão de Água, com a finalidade de promover a integração e o diálogo entre diferentes instâncias governamentais e reduzir disparidades regionais no desempenho ambiental.

- Racionalizar os fundos voltados aos projetos e à política ambiental; monitorar sistematicamente o uso dos fundos ambientais, para garantir conformidade com as prioridades políticas, em termos de transparência e de custo-benefício.

- Desenvolver um sistema uniforme para coleta e gestão de dados ambientais, inclusive sobre a implementação da legislação ambiental (indicadores de insumos, produtos e resultados) e sobre aspectos econômicos de políticas ambientais (contas de despesas e receitas; bens, serviços e empregos relacionados ao meio ambiente).

\section{Licença ambiental, execução e conformidade}

- Introduzir e aplicar um requisito legal de avaliação estratégica ambiental de planos territoriais municipais e programas de desenvolvimento setorial, que devem ser utilizados para a integração de aspectos econômicos, sociais e ambientais do uso da terra.

- Racionalizar o processo de avaliação de impactos ambientais e os requisitos de licencenciamento ambiental entre as diversas instâncias administrativas; esclarecer os limites entre ações compensatórias com objetivos socioambientais e aquelas com objetivos sociais; desenvolver orientações procedimentais para cada estágio do processo de licenciamento e construir a capacidade dos órgãos de licenciamento.

- Fortalecer a capacidade de fiscais ambientais em todas as instâncias governamentais; enfatizar o controle proativo (planejado) de conformidade; melhorar a colaboração com promotores federais e estaduais; ampliar as oportunidades para a "fiscalização cidadã" por meio do engajamento das comunidades locais no controle da conformidade. 


\section{Notas}

1. Em 2010, o Conama tinha 71 representantes do governo (41 federais, 27 estaduais e 8 municipais), 22 representantes da sociedade civil, academia e sindicatos (11 permanentes e 11 rotativos), 8 do setor empresarial e um membro honorário. Conta com o apoio das câmaras técnicas sobre várias questões políticas.

2. Seu antecessor era a Secretaria Especial do Meio Ambiente do Ministério do Interior

3. A Comissão Permanente de Integração CONAMA/CNRH foi criada em 2006, mas realizou apenas uma reunião e foi posteriormente dissolvida (Sano, 2012).

4. Todas as ações, critérios e metas propostos de 2014 estão disponíveis em: http://www.ambiente. sp.gov.br/municipioverdeazul.

5. As principais despesas relacionadas ao meio ambiente ocorrem, por exemplo, no MDA, que lida com agricultores (orçamento de 2013 de R $\$ 5,3$ bilhões); no MCTI (R $\$$ 9,4 bilhões); no MAPA, que lida com o agronegócio ( $\mathrm{R} \$ 10,5$ bilhões); e no MME (R\$ 10,8 bilhões), MT (R\$ 21,4 bilhões) e no MCid (R\$ 25,6 bilhões).

6. Este fundo, vinculado ao Ministério da Justiça, destina-se a remediar danos causados ao meio ambiente, ao consumidor, a bens e direitos de valor artístico, estético, histórico, turístico ou cênico, e outros interesses coletivos.

7. Os fundos setoriais do MCTI são instrumento fundamental para fortalecer o sistema nacional científico e tecnológico. Alguns desses fundos apoiam atividades relacionadas ao meio ambiente (seção 6 do Capítulo 3).

8. O pagamento para o Fundo Amazônia baseou-se na redução de emissões de GEE, a partir da média histórica das taxas de desmatamento, usando uma fórmula que converteu as reduções de emissões de $\mathrm{CO}_{2}$ estimadas, a partir da redução do desmatamento, contra uma taxa média e aplicou um valor de US $\$ 5$ por tonelada de emissões de GEE evitadas. O ritmo da queda nas taxas de desmatamento, no entanto, foi maior que a taxa de reposição de recursos provenientes de doadores internacionais, principalmente da Noruega, de modo que o mecanismo de financiamento seguiu um cronograma predeterminado de compromissos e desembolsos (Birdsall et al., 2014).

9. O governo federal destinou $\mathrm{R} \$ 1,2$ bilhão ao longo de quatro anos para projetos de infraestrutura de gestão de resíduos, mas os municípios, por falta de capacidade, utilizaram apenas cerca de $10 \%$ desse financiamento.

10. Alguns estados (ex., Bahia) criaram diferentes procedimentos simplificados para a licença ambiental.

11. Exemplos incluem a reduzida frequência de inspeção na Noruega, taxas de licença reduzidas no Reino Unido e penalidades monetárias reduzidas nos EUA.

12. O orçamento do SEBRAE provém de contribuições de $0,3 \%$ a $0,6 \%$ sobre a folha de pagamento de empresas brasileiras.

13. Por exemplo, os meios que o IBAMA utiliza para recolher multas de infratores são a inscrição do nome do devedor no Cadastro Informativo de créditos não quitados do setor público federal (CADIN) 75 dias após o infrator ser informado da dívida; suspensão de serviços para o devedor; inscrição do nome do infrator na dívida ativa da União; ou cobrança judicial da multa. O registro no CADIN significa que o devedor fica inabilitado para obter crédito a partir de recursos públicos.

14. O acúmulo de processos nos tribunais brasileiros faz com que sejam necessários muitos anos para se chegar a uma decisão final. Ademais, em geral, os tribunais carecem do conhecimento especializado necessário para lidar com processos ambientais tecnicamente complexos (McAllister, 2008).

15. Mover uma ação civil não é atribuição exclusiva do Ministério Público, mas, na prática, ele responde por mais de $90 \%$ dessas ações judiciais. Muitas vezes, grupos ambientalistas acionam a Procuradoria Geral da República, ao invés de entrar com seus próprios processos.

16. Ver www.mma.gov.br/pnia

\section{Referências}

ABEMA - Associação Brasileira de Entidades Estaduais de Meio Ambiente (2013), Novas propostas para o licenciamento ambiental no Brasil; Brasília.

ANA - Agência Nacional de Águas (2014), OECD-Brazil Policy Dialogue on Water Governance:, Brasília. 
Assad, E. et al. (2013), Impactos das Mudanças Climáticas na Produção Agrícola Brasileira, BIRD, Washington, DC, www.profor.info/node/2061.

Assunção, J. et al. (2013), "Does Credit Affect Deforestation? Evidence from a Rural Credit Policy in the Brazilian Amazon", CPI Technical Report, Climate Policy Initiative, Rio de Janeiro, http://climatepolicyinitiative.org/ wp-content/uploads/2013/01/Does-Credit-Affect-Deforestation-Evidence-from-a-Rural-Credit-Policyin-the-Brazilian-Amazon-Technical-Paper-English.pdf.

BIRD (2008), Environmental Licensing for Hydroelectric Projects in Brazil: A Contribution to the Debate, Summary Report, Report No. 40995-BR, Washington, DC. Fundo Amazônia (2015), www.amazonfund.gou.br .

Birdsall, N., W. Savedoff and F. Seymour (2014), The Brazil-Norway Agreement for Performance-Based Payments for Forest Conservation: Successes, Challenges, Lessons, CGD Climate and Forest Paper Series No. 4, Center for Global Development, Washington, DC.

Cavalcanti C. (2007), Economic growth and environmental protection in Brazil: An unfavourable tradeoff, in Environmental Governance and Decentralisation, A. Breton et al. (eds.), Edward Elgar Publishing, Cheltenham, UK.

CETESB - Companhia de Tecnologia de Saneamento Ambiental do Estado de São Paulo (n.d.), Financing Climate Action at Subnational Level São Paulo State", ww.nrg4sd.org/sites/default/files/default/files/content/ public/unfccccop17/presentation_nelson_bugalho_cop17_-_tcg_nrg4sd_side_event.pdf .

CNI - Confederação Nacional da Indústria (2012), Pesquisa CNI-IBOPE: Retratos da Sociedade Brasileira: Meio Ambiente CNI-IBOPE Brasília.

Costa Neves, E.M.S. (2012), Environmental policy, municipalities and intergovernmental cooperation in Brazil, Estudos Avançados, Vol. 26, Nr. 74, pp. 137-150.

De Oliveira, O., J.R. Serra and M.H. Salgado (2010), Does ISO 14001 work in Brazil?,Journal of Cleaner Production, Vol. 18, Issue 18, pp. 1797-1806.

FUNDO AMAZÔNIA (2015), www.amazonfund.gov.br .

GVces/FGV-EAESP (2014), The Brazilian Financial System and the Green Economy - Alignment with Sustainable Development", preparado para UNEP e FEBRABAN no marco do Inquiry into the design of a sustainable financial system, FEBRABAN, São Paulo.

IBGE (2012), Indicadores de Desenvolvimento Sustenável: Brasil 2012 Rio de Janeiro.

IBGE (2014b), Perfil dos Estados Brasileiros 2013 Rio de Janeiro.

IBGE (2014a), Perfil dos Municípios Brasileiros 2013, Rio de Janeiro.

IEMA - Instituto de Energia e Meio Ambiente (2012), Padrões de qualidade do ar. Experiência comparada Brasil, EUA e União Europeia www.energiaeambiente.org.br.

ISO - International Organization for Standardization (2014), ISO Survey of Management System Standard Certifications - 2013, , London, www.iso.org/iso/home/standards/certification/iso-survey.htm?certificate=ISO\%209001\& countrycode $=\mathrm{AF}$.

ISS Instituto de Saúde e Sustentabilidade (2014), Monitoramento da Qualidade do Ar no Brasil, www. saudeesustentabilidade.org.br/site/wp-content/uploads/2014/07/Monitoramento-da-Qualidadedo-Ar-noBrasil-2014.pdf.

Mansell, A. \& P. Sopher (2014), The World's Carbon Markets: A Case Study Guide to Emissions Trading - Brazil, Environmental Defense Fund and International Emissions Trading Association, Washington, DC, www.ieta. org/assets/EDFCaseStudyMarch2014/brazil\%20case\%20study\%20march\%20 2014.pdf.

Mazur, E. (2012), Green Transformation of Small Businesses: Achieving and Going Beyond Environmental Requirements, OECD Environment Working Papers, No. 47, OECD Publishing, Paris, http://dx.doi.org/10.1787/5k92r8nmfgxp-en.

McAllister, L. (2008), Making Law Matter: Environmental Protection and Legal Institutions in Brazil, Stanford University Press, Reduced City.

MMA - Ministério do Meio Ambiente (2015), Brazil Fifth National Report to the Convention on Biological Diversity, Brasília, www.cbd.int/doc/world/br/br-nr-05-en.pdf. 
MMA (2014), PNIA 2012: Painal Nacional de Indicadores Ambientais. Referencial teórico, composição e síntese dos indicadores, Brasília.

MMA (2010), Quarto Relatório Nacional para a Convenção sobre Diversidade Biológica, Brasília.

MMA (2012), O que o Brasileiro Pensa do Meio Ambiente e do Consumo Sustentável: Pesquisa Nacional de Opinião: Principais Resultados, Brasília.

MPOG Ministério do Planejamento, Orçamento e Gestão (2015), Informações Gerenciais de Contratações Públicas Sustentáveis, www.comprasgovernamentais.gov.br/arquivos/estatisticas/03-apresentacao-siasgcompras- sustentaveis-_2014.pdf.

Norman, M. et al. (2014), Climate Finance Thematic Briefing: REDD+ Finance, Climate Finance Fundamentals 5, December, Overseas Development Institute, London \& Heinrich Böll Stiftung North America, Washington, DC, www.odi.org/sites/odi.org.uk/files/odi-assets/publications-opinion-files/9330.pdf.

Oberling, D.H., E.L. La Rovere e H.V. de Oliveira Silva (2013), SEA making inroads in land-use planning in Brazil: The case of the extreme south of Bahia with forestry and biofuels, Land Use Policy, Vol. 35, pp. 341-358.

OECD (2009), Green at Fifteen? How 15-Year-Olds Perform in Environmental Science and Geoscience in PISA 2006, OECD Publishing, Paris, http://dx.doi.org/10.1787/9789264063600-en.

OECD (2013), OECD Territorial Reviews: Brazil, OECD Publishing, Paris, http://dx.doi.org/10.1787/9789264123229-en.

OECD (2015), Water Resources Governance in Brazil, OECD Studies on Water, OECD Publishing, Paris, http://dx.doi. org/10.1787/9789264238121-en.

PBMC (2013), Base Científica das Mudanças Climáticas. Contribuição do Grupo de Trabalho 1 ao Primeiro Relatório de Avaliação Nacional do Painel Brasileiro de Mudanças Climáticas, Brasília, www.pbmc. coppe.ufrj.br/documentos/MCTI_PBMC_Sumario\%20Executivo\%204_Finalizado.pdf.

Sano, H. (2012), The Brazilian National Environmental Policy: The challenge of plural environmental governance, Development, Vol. 55, pp. 119-125.

São Paulo Secretariat for the Environment (2015b), “Municipio VerdeAzul” website, São Paulo, www. ambiente.sp.gov.br/municipioverdeazul.

Secretaria de Meio Ambiente do Estado de São Paulo (2015a), Project Portfolio, São Paulo www.ambiente. sp.gou.br/en/files/2015/04/Portf\%C3\%B3lio-03.pdf.

Senado Federal (2015), Portal Orçamento (banco de dados), www12.senado.gou.br/orcamento/loa

Seroa da Motta, R. (2011), The national policy on climate change: regulatory and governance aspects, in Seroa da Motta, R. et al. (eds) (2011), Climate Change in Brazil: Economic, Social and Regulatory aspects, IPEA, Brasília, www.ipea.gou.br/agencia/images/stories/PDFs/liuros/liuros/liuro_climatechange.pdf.

TCU- Tribunal de Contas d União (2009), Auditorias de natureza operacional sobre políticas públicas e mudanças climáticas - Amazônia, Brasília.

Teixeira, I. (2012), Brazil's journey from the Earth Summit to Rio+20: OECD, Development Co-operation Report 2012: Lessons in Linking Sustainability and Development, OECD Publishing, Paris.

Tognere Ferron, R. et al. (2012), Is ISO 14001 Certification Effective? An Experimental Analysis of Firm Profitability, Brazilian Administration Review, Vol. 9, Special Issue, pp. 78-94, Rio de Janeiro.

Unterstell, N. and S. Margulis (2014), Adaptation to Climate Change in Brazil: Scenarios and Alternatives, Strategic Notes, No. 1, March, Strategic Affairs Secretary of the Presidency of the Republic, Brasília.

Vogt-Schilb, A., S. Hallegatte and C. de Gouvello (2014), Marginal abatement cost curves and the quality of emission reductions: A case study on Brazil", Climate Policy, http://dx.doi.org/10.1080/14693062.2014.953908. 



\section{Esverdeamento da economia no contexto do desenvolvimento sustentável}

No Brasil, qualquer debate sobre crescimento econômico deve, imprescindivelmente, levar em consideração o uso sustentável de recursos naturais, a redução da pobreza e a melhoria do acesso a serviços essenciais. O presente capítulo apresenta os avanços alcançados pelo País na articulação de temas ambientais com políticas econômicas e setoriais para a implantação do esverdeamento da economia, rumo ao desenvolvimento sustentável. Examina o uso de instrumentos da política fiscal para alcançar objetivos ambientais e avançar na extinção de subsídios e incentivos que estimulem atividades ambientalmente nocivas. Analisa o investimento público e privado em infraestruturas relacionadas ao meio ambiente, a exemplo daquelas para abastecimento de água, saneamento, resíduos sólidos, energia limpa e transportes. Examina o fomento de tecnologias, produtos e serviços ambientais como forma de alavancar o crescimento econômico e a geração de emprego. Discute também o papel do Brasil tanto como destinatário, quanto como provedor de cooperação para o desenvolvimento internacional em matéria ambiental. 


\section{Introdução}

Em 2014, o Brasil ocupava o sétimo lugar no ranking das maiores economias do mundo. $\mathrm{O}$ forte crescimento econômico durante os anos 2000 aumentou a renda per capita e contribuiu para reduzir, pela metade, o contingente da população vivendo na extrema pobreza (Capítulo 1). O crescimento sustentado também fez com que o Brasil progredisse no alcance de outras Metas de Desenvolvimento do Milênio, tais como o aumento das taxas de alfabetização, a redução de disparidades de gênero e da mortalidade infantil e a melhoria das condições de habitação e de acesso a serviços básicos (Anexo 3.A). No entanto, a partir de 2012, houve uma desaceleração do crescimento. Baixo investimento, persistentes gargalos de infraestrutura e a baixa produtividade e competitividade das empresas nacionais vem restringindo as perspectivas de crescimento.

Não é possível, seja no sentido econômico, seja no social, separar o crescimento econômico do Brasil do uso sustentável de recursos naturais. Os recursos naturais contribuem para atividades econômicas importantes, como agricultura e produção de alimentos, geração de energia, mineração e aproveitamento de recursos florestais e da biodiversidade; são também a principal fonte de emprego e renda para grande parte da população rural. O equilíbrio entre o desenvolvimento socioeconômico e a sustentabilidade ambiental tem se comprovado de difícil alcance, e o crescimento veio acompanhado de prejuízos ao meio ambiente.

O Brasil alcançou notáveis avanços no combate ao desmatamento, embora a expansão e intensificação agrícola continuem a exercer pressões sobre florestas e vegetação nativa, comprometendo a qualidade da água e do solo (Capítulo 4). O crescimento populacional, a urbanização e o aumento da renda resultaram em crescente demanda por água, energia e transportes. Houve aumento nas emissões de gases de efeito estufa (GEE) provenientes do consumo de energia; a frota de veículos dobrou ao longo da última década, com consequente congestionamento do tráfego e poluição atmosférica nos principais centos urbanos. As infraestruturas de saneamento e tratamento de águas servidas têm se comprovado insuficientes no atendimento aos crescentes volumes de efluentes industriais e domésticos, o que resulta em contaminação da água e do solo, especialmente em áreas densamente povoadas (Capítulo 1). A crise hídrica de 2014/2015 no Sudeste demonstrou como o uso insustentável de recursos naturais pode comprometer o desenvolvimento econômico.

$\mathrm{O}$ atual desafio do Brasil consiste em restabelecer o crescimento forte e sustentável, dando continuidade à erradicação da pobreza, à redução da desigualdade e da exclusão social, à ampliação de acesso aos serviços essenciais e, ao mesmo tempo, em garantir a conservação e aproveitamento sustentável de recursos ambientais. Uma abordagem integrada desses desafios proporcionará a oportunidade de avançar rumo a uma economia robusta, inclusiva e verde. 


\section{Marco político para o desenvolvimento sustentável e a economia verde}

O governo, com o apoio da sociedade civil e do setor privado, lançou várias iniciativas que visam a abordar, de forma integrada, aspectos econômicos, sociais e ambientais do desenvolvimento sustentável. Vários programas setoriais integram dimensões ambientais, entre eles o Programa Agricultura de Baixo Carbono (Seção 4.2), o Programa de Aceleração do Crescimento para o desenvolvimento de infraestrutura, o Plano Decenal de Expansão de Energia (Seção 5) e a política nacional industrial e de inovação (Seção 6). No entanto, a soma dessas iniciativas positivas não resulta em um marco político abrangente que possa conduzir a uma economia verde e inclusiva. Com poucas exceções, a integração dos objetivos ambientais, sociais e econômicos tem sido ad hoc, e os impactos ambientais ainda vêm sendo tratados ex-post, ao invés de serem abordados na fase inicial da formulação das políticas.

\subsection{Marco estratégico para o desenvolvimento sustentável}

Em julho de 2002, o Presidente da República assinou a estratégia de desenvolvimento sustentável - Agenda 21 - no contexto dos preparativos para a Cúpula Mundial sobre Desenvolvimento Sustentável. Elaborada ao longo de anos por meio de ampla consulta com todos os setores da sociedade, é referida como um pacto social, e não documento oficial do governo. Observa que "o objetivo comum ... não se restringe à preservação do meio ambiente por si só, mas para o desenvolvimento sustentável progressivo e ampliado, o qual coloca em discussão a busca do equilíbrio entre crescimento econômico, equidade social e preservação do meio ambiente". O pacto define 21 objetivos, incluindo ações e recomendações em áreas como sustentabilidade urbana e rural; proteção da água, biodiversidade e florestas; governança e ética para a promoção da sustentabilidade; e inclusão social.

A Agenda 21 atribuiu a responsabilidade por sua implementação diretamente aos diversos setores da sociedade, incluindo o governo em todas as instâncias, empresas do setor privado e organizações da sociedade civil. O governo federal se comprometeu em integrar as prioridades da Agenda 21 a todas as políticas públicas; contudo, essa integração não foi plenamente realizada. Em 2004, o governo estabeleceu as Políticas de Desenvolvimento Sustentável e o Conselho da Agenda 21, com paridade de representação do governo e da sociedade civil, para coordenar a execução das políticas; este Conselho, no entanto, está inativo há anos. No âmbito da Agenda 21, o governo tem acompanhado os numerosos indicadores ambientais, sociais, econômicos e institucionais que caracterizam as dimensões do desenvolvimento sustentável (Box 2.7). No entanto, por falta de metas quantitativas associadas aos indicadores, seu uso na medição do desempenho e elaboração de políticas fica prejudicado. A Agenda 21 não serve mais de referência para as atividades do MMA e de outros ministérios; no nível local, porém, parece ser um instrumento eficaz para a consulta sobre questões ambientais, sociais e econômicas em mais de 1.000 municípios.

O governo vem procurando reeditar a Agenda 21 para contemplar temas atuais não considerados prioridades quando da aprovação da edição inicial, incluindo mudança do clima e questões urbanas, tais como a gestão de resíduos e o transporte sustentável. Ademais, em 2011, aprovou o Plano de Ação Para Produção e Consumo Sustentáveis (2011-14) que visa à promoção de práticas verdes na administração 
pública e no setor empresarial. Esse plano estabeleceu seis áreas prioritárias: comércio verde (promoção da rotulagem ecológica), gestão de resíduos, construção sustentável (especialmente para a habitação social com financiamento público), compras governamentais sustentáveis, educação ambiental e a Agenda Ambiental na Administração Pública (Capítulo 2).

\subsection{Alinhamento das políticas sociais com os objetivos ambientais}

A redução da pobreza e a inclusão social, pilares do desenvolvimento sustentável, são o foco de programas de redistribuição de renda empreendidos pelo governo brasileiro desde o início dos anos 2000. O carro-chefe dessas iniciativas é o Bolsa Família (Box ${ }^{3} .1$ ), programa exemplar de boa prática para a redução da pobreza e inclusão social que, atualmente, vem sendo replicado em outros países. O governo busca a transversalidade na abordagem de questões sociais por meio de políticas públicas, incluindo aquelas direcionadas ao meio ambiente e, especialmente, à conservação de florestas.

Box 3.1. Bolsa Família, carro-chefe dos programas de proteção social do Brasil

Em 2003, o governo federal lançou o Bolsa Família, unificando quatro programas de proteção social em um único programa de transferência condicionada de renda. Beneficiários do Bolsa Família recebem, em média, $\mathrm{R} \$ 70,00$ por mês em transferências diretas, condicionadas à frequência escolar e ao cumprimento de agendamentos de saúde. Para garantir benefícios do programa a todos os brasileiros carentes, o governo lançou uma política de busca ativa e criou um cadastro único de programas sociais para consolidar informações e estatísticas sobre renda e condições de vida, a partir dos cadastros municipais. Em 2011, como parte de um novo programa direcionado à erradicação da pobreza extrema - Brasil sem Miséria - o Bolsa Família foi expandido para aumentar a renda dos beneficiários, ampliar o acesso a bens e serviços públicos e dar apoio aos que buscam emprego e outras oportunidades de geração de renda. Hoje - Bolsa Família é o maior programa de proteção social do mundo: em 2013 chegou a atender a 11 milhões de famílias, ou 50 milhões de pessoas - mais de um quarto da população brasileira.

Em geral, o Bolsa Família é considerado importante contribuição para a melhoria no padrão de vida das famílias mais pobres do Brasil. Estima-se que o programa seja responsável por entre $33 \%$ e $50 \%$ da queda da pobreza extrema no país, e que tenha ajudado a reduzir em entre $15 \%$ a $20 \%$ a desigualdade (medida pelo coeficiente de Gini). Constata-se também que teve efeito multiplicador, tanto no consumo das famílias $(2,4)$ quanto no aumento do PIB $(1,8)$ e que contribuiu para a redução de desigualdades regionais. Os beneficiários tendem a receber melhor atendimento nos serviços de saúde, suas crianças a apresentar menor taxa de evasão escolar e maior probabilidade de estar na série adequada para a sua idade. Ademais, o cadastro único de programas sociais serviu para consolidar e impedir a fragmentação de dados regionais e locais, permitindo a identificação de municípios com maior concentração de pessoas pobres e carência na prestação de serviços públicos. Apesar da expressiva expansão, o direcionamento e eficiência do programa continuam a ser bons, sendo seu custo total de cerca de $0,5 \%$ do PIB.

Fonte: IPEA (2014), Programa Bolsa Família: uma década de inclusão e cidadania- Sumário Executivo, Instituto de Pesquisa Econômica Aplicada, Brasília.

Frequentemente, questões sociais e ambientais são abordadas simultaneamente, em especial em se tratando de comunidades em áreas florestais. O Bolsa Floresta, por exemplo, paga benefícios mensais de aproximadamente $\mathrm{R} \$ 50,00$ (cerca de US\$ 
20) a famílias que vivem em áreas de conservação, em troca de ações de conservação florestal (ex., redução do desmatamento para formação de roças). Iniciativa pioneira, lançado em 2007 pelo Estado do Amazonas, o Bolsa Floresta é hoje o maior programa de pagamento por serviços ambientais (PSA) do mundo, alcançando em 2013, mais de 35.000 pessoas em 15 unidades de conservação. Com base nessa iniciativa, em 2011, no contexto do programa Brasil sem Miséria, o governo federal lançou o Bolsa Verde que amplia seu papel de proteção social, por meio de pagamentos por serviços ambientais e incentivos à adoção de boas práticas ambientais (Capítulo 4).

O Bolsa Floresta e o Bolsa Verde fazem parte de um conjunto mais amplo de ações governamentais para aumentar a renda e melhorar as condições de vida das populações rurais, mediante a ampliação do aproveitamento econômico sustentável de recursos ambientais. Existem outros programas com objetivos semelhantes, entre eles o Plano Nacional de Proteção das Cadeias de Produtos da Sociobiodiversidade, de 2009, que facilita o acesso de comunidades tradicionais e rurais a crédito, mercados e assistência técnica, com vistas a promover o aproveitamento sustentável da biodiversidade (Capítulo 4). Esse Plano, que inclui preços mínimos para produtos como açaí, borracha natural e castanha do Pará, foi recentemente incorporado ao Programa de Aquisição de Alimentos da Agricultura Familiar do governo federal - um dos maiores programas institucionais do mundo para a compra da produção de pequenos produtores ou da agricultura familiar. Iniciativas semelhantes foram lançadas também a nível estadual (ex., no Estado do Amazonas) com a utilização de compras governamentais para alavancar e dinamizar as cadeias de produção locais (MMA, 2015). Embora existam bons exemplos de políticas e programas que visam alcançar, simultaneamente, objetivos ambientais e sociais, muitas vezes sua expansão tem se comprovado difícil, possivelmente devido ao alto custo de infraestruturas, a volumes de produção insuficientes e, em muitas áreas, também à falta de associações de produtores.

\section{Esverdeamento do sistema de tributos e encargos}

\subsection{Panorama do sistema tributário e o meio ambiente no Brasil O sistema tributário}

A receita tributária total vem aumentado constantemente desde 2000, atingindo, em 2013, 36\% do PIB - participação bem acima da média da OCDE e a maior da América Latina (OCDE et al, 2015). O sistema tributário é fragmentado, complexo e caracterizado por baixa progressividade. O custo de conformidade com obrigações fiscais é excepcionalmente elevado devido, em grande parte, ao sistema de seis impostos indiretos, com regras fiscais e alíquotas que podem variar entre estados (OCDE, 2013a).

A exploração de recursos naturais não renováveis, como minerais e hidrocarbonetos, é importante fonte de receitas fiscais (por meio de diversos tipos de tributos sobre receitas, renda e royalties) embora menos que em outros países latino-americanos. Em 2013, as receitas fiscais provenientes de recursos naturais não renováveis equivaleram a 2,4\% do PIB; em comparação, no México, equivaleram a 8\% (OCDE et al., 2015). Uma parte dessa receita é destinada a fins ambientais (Box 3.2). 


\section{Box 3.2. Destinação de receitas do petróleo e gás para fins ambientais}

O Brasil destina parte das receitas provenientes da exploração de petróleo e gás ao financiamento de despesas relacionadas ao meio ambiente. Até 2010, havia dois tipos de receitas governamentais provenientes do petróleo e gás (além de tributos sobre o lucro das empresas): os royalties e a Participação Especial (PE) - um imposto sobre ganhos inesperados aplicado a campos altamente produtivos. A receita de ambas as fontes é mais ou menos igual, chegando a mais de US\$16 bilhões em 2012 (Goldemberg et al., 2014). Por lei, 10\% da PE são destinados ao MMA e representa importante fonte de receita do Fundo Nacional de Mudança do Clima (Capítulo 2). O Ministério de Minas e Energia recebe $40 \%$ dessa receita; os governos estaduais outros $40 \%$; e os municípios os $10 \%$ restantes. A alíquota de royalties representa $10 \%$ da receita bruta; sendo $28 \%$ destinados ao Ministério da Ciência, Tecnologia e Inovação (MCTI) e ao da Marinha (para proteção costeira). O MCTI aplica as receitas de royalties em fundos setoriais de pesquisa e desenvolvimento (P\&D) em várias áreas, inclusive meio ambiente (Seção 6).

Embora esse sistema tenha sido mantido para a produção existente, a partir de 2010 um novo marco jurídico passou a vigorar para novas áreas de exploração (descobertas do pré-sal). Contratos de partilha de produção dividem a receita de futuras descobertas entre operador e governo (retendo parte para recuperação de custos) retirando a PE, mas mantendo os royalties. A perspectiva de um potencial aumento da produção de petróleo e de receitas provenientes do pré-sal tem gerado acaloradas discussões sobre a partilha de receitas entre estados, inclusive aqueles que não têm produção de petróleo (BIRD, 2013). Inspirado no modelo norueguês de fundo soberano, o Brasil criou um fundo social para gerir parte da receita esperada. Os proventos dos investimentos serão destinados, principalmente, ao financiamento da educação. Na prática, cerca de metade do fundo seria utilizado para gastos sociais imediatos, principalmente na educação, mas também na saúde. O restante seria aplicado em outras áreas, incluindo meio ambiente, ciência e tecnologia.

Diferentemente de outros países federativos latino-americanos, grande parcela da receita tributária brasileira é arrecadada em nível estadual, especialmente através do Imposto de Circulação de Mercadorias (ICMS), uma espécie de imposto de valor agregado estadual (OCDE et al., 2015). Cerca de metade dos estados redistribui parte das receitas do ICMS aos municípios, geralmente de acordo com indicadores ambientais, tais como a extensão de áreas protegidas (ICMS Ecológico, ou ICMS-E; Capítulo 5).

\section{Tributos relacionados ao meio ambiente}

A receita dos tributos relacionados ao meio ambiente é baixa, se comparada à de outros países. Em 2013, tais receitas equivaleram a 0,7\% do PIB, ou 1,9\% do total da arrecadação fiscal; muito abaixo do registrado em todos os países da OCDE, com exceção do México (Figura 3.1; Anexo 3.B). A receita proveniente de tributos relacionados ao meio ambiente diminuiu em termos reais, desde 2000 , notavelmente no período entre 2011 e 2013, quando a alíquota do CIDE foi reduzida a zero e as vendas de veículos diminuíram (Figura 3.1). A exemplo de outros países, os tributos relacionados ao meio ambiente são cobrados, principalmente, sobre veículos e consumo de produtos energéticos; no entanto, vários combustíveis fósseis gozam de isenção (Seções 3.2 e 4.1). A tributação sobre veículos responde por mais de $95 \%$ das receitas fiscais relacionadas ao meio ambiente, mas reflete apenas parcialmente o desempenho ambiental dos veículos (Seção 3.3). Não há tributação sobre aproveitamento de recursos naturais e poluição. As cobranças pela captação ou poluição da água e os encargos por serviços públicos, como saneamento e coleta de resíduos, são aplicadas de forma inconsistente e, muitas vezes, são baixas demais para estimular o aproveitamento eficiente de recursos e financiar a prestação de serviços (Seção 3.4). 
Figura 3.1. Receita de tributos relacionados ao meio ambiente tem diminuído

Receitas de tributos relacionados ao meio ambiente

Como \% do PIB e do total da receita tributária, Brasil, 2002-13

$\%$ do PIB $\quad-\quad$ - $\%$ do total da receita tributária

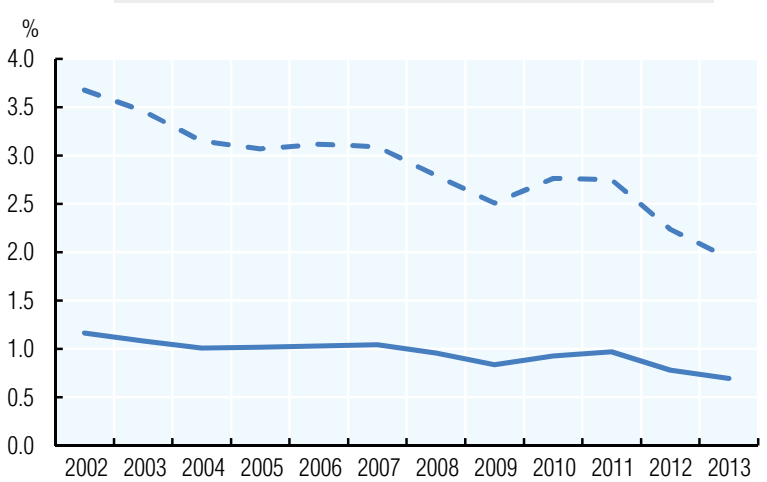

Por base tributária, Brasil, 2002-13

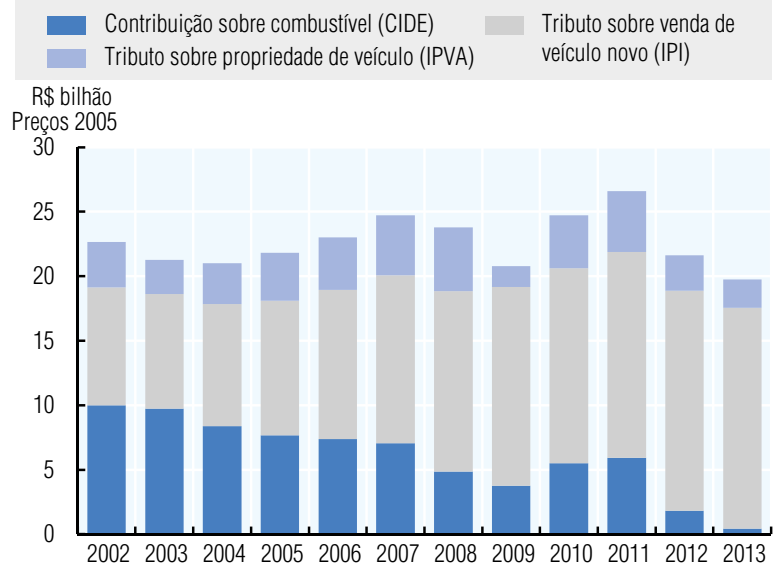

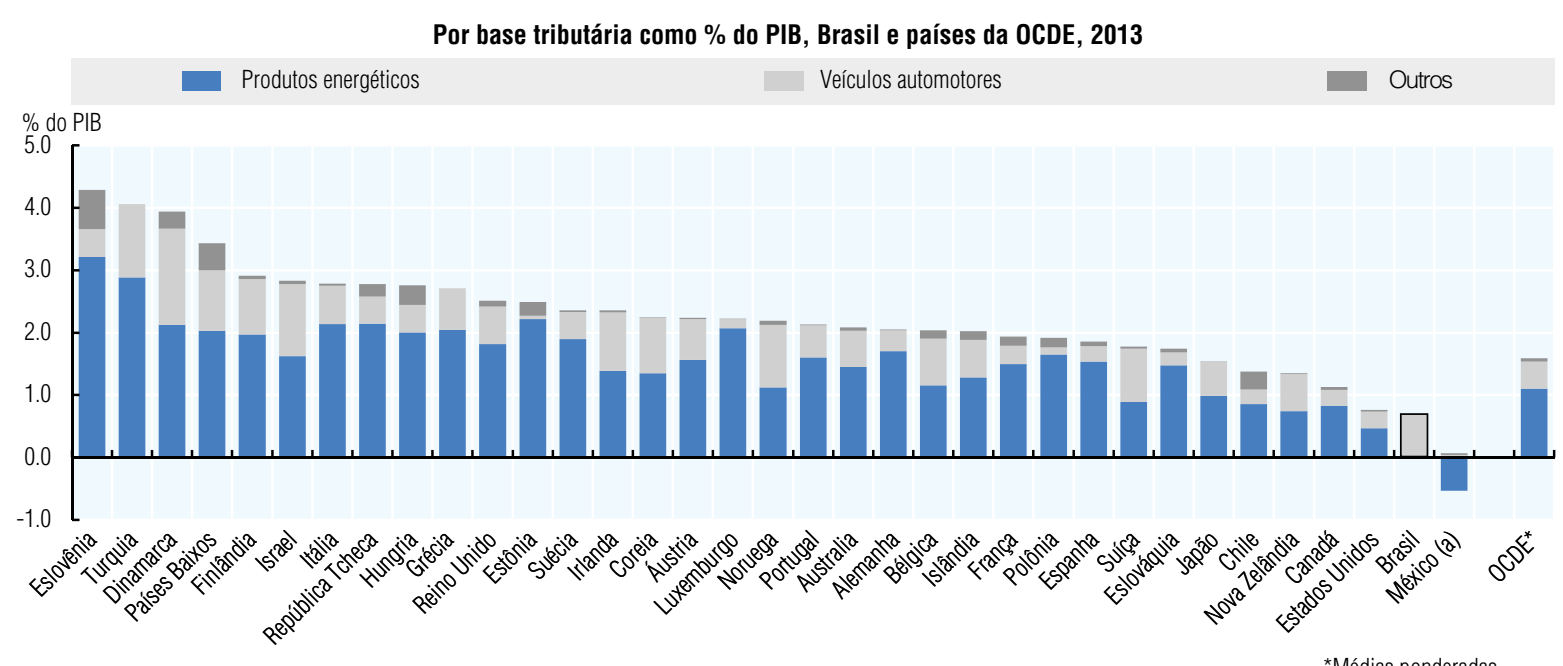

*Médias ponderadas

a) Até 2014, o sistema utilizado para estabilizar o preço final de combustíveis veiculares fez com que as receitas tributárias ficassem negativas (i.e., viraram um subsídio) durante os anos em que o preço internacional do petróleo estava em alta.

A reforma tributária do México de 2013 corrigiu este mecanismo e introduziu um tributo sobre combustíveis fósseis com base no conteúdo de carbono, que gera receitas positivas. Fonte: Baseado em OCDE (2015), OECD Database on Instruments Used for Environmental Policy and Natural Resources Management.

Conforme recomendado em levantamento econômico (Economic Survey 2013) da OCDE, o Brasil precisa avançar com a reforma de seu complexo sistema tributário, com vistas a aliviar a carga tributária e a reduzir distorções que prejudicam a produtividade e a competitividade. Nesse contexto, há margem para ampliar e aprimorar o direcionamento de tributos ambientais e remover subsídios e isenções fiscais potencialmente prejudiciais, de modo a estimular o aproveitamento eficiente e sustentável de recursos. Essas medidas poderiam ampliar a arrecadação do governo e gerar recursos para financiar projetos de infraestrutura e ações em outras áreas prioritárias, como educação e redução da pobreza. Uma reforma dos tributos ambientais poderia auxiliar na redução da pobreza, ao sanar problemas ambientais que prejudicam a saúde e a subsistência de populações carentes (ex., poluição hídrica e atmosférica) e gerar recursos para a ampliação do acesso a serviços básicos tais, como energia elétrica e saneamento (OCDE, 2013b). 
Além de reestruturar tributos sobre produtos energéticos e veículos, o Brasil deve considerar a possibilidade de introduzir tributos sobre fertilizantes e pesticidas para limitar a poluição hídrica; sobre a deposição de resíduos e embalagens; e sobre o aproveitamento de recursos naturais, tais como minério. Tais medidas devem ser introduzidas em etapas claramente definidas para minimizar incertezas sobre o futuro aumento de tributos, auxiliar a economia na adaptação às mudanças de preços relativos e facilitar investimentos de longo prazo. As transferências em espécie do Bolsa Família poderiam servir para amenizar eventuais impactos tributários sobre a grande massa de domicílios de baixa renda.

\subsection{Impostos e encargos energéticos}

A Contribuição de Intervenção no Domínio Econômico (CIDE) é um encargo especial sobre o consumo de combustíveis fósseis que incide, principalmente, sobre o transporte; mas sua alíquota caiu progressivamente até alcançar zero entre 2012 e 2015 (ver abaixo). Em geral, os combustíveis para aquecimento e processos industriais não são tributados. Até 2012, eram relativamente altas as alíquotas cobradas pelo consumo de energia elétrica que, graças ao grande potencial hidroelétrico do País é a fonte de mais baixa emissão de carbono (Capítulo 1). Em resumo, as alíquotas efetivamente aplicadas sobre o consumo de energia no Brasil (expresso em termos de emissões de $\mathrm{CO}_{2}$ ou de teor energético) estão entre as mais baixas das economias da OCDE e dos BRIICS, conforme mostra a Figura 3.2 (OCDE, 2015a).

Existe margem para reestruturar e aumentar a tributação sobre produtos energéticos para refletir as emissões de $\mathrm{CO}_{2}$ gerados por consumo, estimular a eficiência energética e contribuir para a redução de emissões de GEE. Em 2014, o Ministério da Fazenda lançou uma abrangente avaliação econômica e regulatória sobre o impacto de diferentes opções de precificação de carbono, incluindo um imposto sobre carbono e um sistema de comercialização de créditos de emissão de GEE (MF, 2014). Os Estados do Rio de Janeiro e de São Paulo pretendiam introduzir um sistema de comercialização de créditos de carbono no início dos anos 2010, mas sua implementação foi adiada (Capítulo 2). A partir dessas iniciativas, o Brasil poderia aprimorar um sistema que precifique emissões de GEE.

\section{Imposto sobre consumo de combustível}

A Contribuição de Intervenção no Domínio Econômico-Combustíveis (CIDE) tributo federal específico sobre o consumo de combustível, introduzido em 2001, incide sobre a importação de petróleo e a venda no mercado interno de produtos petrolíferos, gás natural e derivados, e também do etanol. ${ }^{1}$ A alíquota da CIDE tem sido usada, principalmente, para suavizar oscilações nos preços dos combustíveis fósseis no mercado interno. Desde 2004, essa alíquota tem sido zero para todos os combustíveis, com exceção da gasolina e do diesel. As alíquotas para gasolina e diesel foram sendo paulatinamente reduzidas, chegando a zero em 2012, para compensar os aumentos nos preços dos combustíveis (Tabela 3.1). Desta forma, foi ampliado o subsídio implícito para combustíveis fósseis, resultante da manutenção de preços internos abaixo dos praticados no mercado internacional (Seção 4.1). 
Figura 3.2. As alíquotas tributárias efetivas sobre emissões de $\mathrm{CO}_{2}$ pelo consumo de energia são baixas

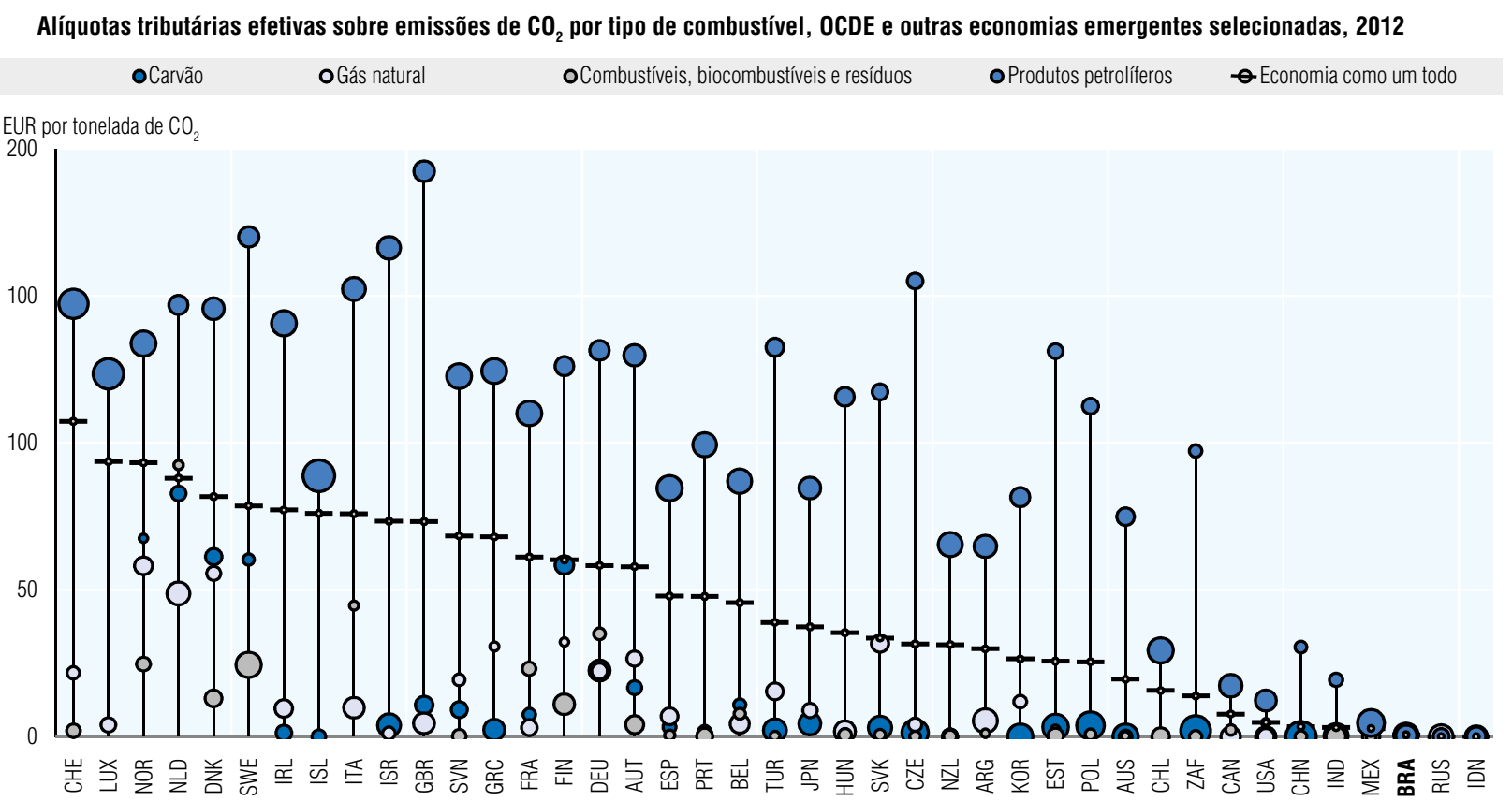

Obs.: Alíquotas de 01 de abril de 2012 (exceto 01 de julho de 2012 para AUS e BRA e 04 de abril de 2012 para ZAF); Dados sobre consumo da energia são para 2009 da IEA (2011). Dados para CAN, IND e USA incluem apenas tributos federais.

Fonte: OCDE (2015), Taxing Energy Use 2015: OECD and Selected Partner Economies, OECD Publishing, Paris.

Tabela 3.1. Alíquotas do imposto sobre consumo de combustível, 2001-15

$\mathrm{R} \$$ (preços nominais)

\begin{tabular}{|c|c|c|c|c|c|c|c|c|c|c|}
\hline & $\begin{array}{c}\text { Dez. } 2001 \\
\text { (Decreto } \\
10.336))\end{array}$ & $\begin{array}{c}\text { Abr. } 2004 \\
\text { (Decreto } \\
5.060)\end{array}$ & $\begin{array}{c}\text { Maio } 2008 \\
\text { (Decreto } \\
6.446)\end{array}$ & $\begin{array}{l}\text { Jun. } 2009 \\
\text { (Decreto } \\
6.875)\end{array}$ & $\begin{array}{c}\text { Fev. } 2010 \\
\text { (Decreto } \\
7.095)\end{array}$ & $\begin{array}{c}\text { Maio } 2010 \\
\text { (Decreto } \\
7.095)\end{array}$ & $\begin{array}{c}\text { Set. } 2011 \\
\text { (Decreto } \\
7.574 \text { ) }\end{array}$ & $\begin{array}{l}\text { Out. } 2011 \\
\text { (Decreto } \\
7.591 \text { ) }\end{array}$ & $\begin{array}{c}\text { Jun. } 2012 \\
\text { (Decreto } \\
7.764)\end{array}$ & $\begin{array}{c}\text { Fev. } \\
2015 \\
\text { (Decreto } \\
8.395 \text { ) }\end{array}$ \\
\hline Gasolina & $860 / \mathrm{m}^{3}$ & $280 / \mathrm{m}^{3}$ & $180 / \mathrm{m}^{3}$ & $230 / \mathrm{m}^{3}$ & $150 / \mathrm{m}^{3}$ & $230 / \mathrm{m}^{3}$ & $192.6 / \mathrm{m}^{3}$ & $91 / \mathrm{m}^{3}$ & 0 & $100 / \mathrm{m}^{3}$ \\
\hline Diesel & $390 / \mathrm{m}^{3}$ & $70 / \mathrm{m}^{3}$ & $30 / \mathrm{m}^{3}$ & $70 / \mathrm{m}^{3}$ & 0 & 0 & 0 & $47 / \mathrm{m}^{3}$ & 0 & $50 / \mathrm{m}^{3}$ \\
\hline Querosene & $92.1 / \mathrm{m}^{3}$ & 0 & 0 & 0 & 0 & 0 & 0 & 0 & 0 & 0 \\
\hline Óleo combustível & $40.9 / \mathrm{t}$ & 0 & 0 & 0 & 0 & 0 & 0 & 0 & 0 & 0 \\
\hline $\begin{array}{l}\text { Gás liquefeito de } \\
\text { petróleo }\end{array}$ & $250 / t$ & 0 & 0 & 0 & 0 & 0 & 0 & 0 & 0 & 0 \\
\hline Álcool combustível & $37.2 / \mathrm{m}^{3}$ & 0 & 0 & 0 & 0 & 0 & 0 & 0 & 0 & 0 \\
\hline
\end{tabular}

Como parte de seus esforços de consolidação fiscal, em fevereiro de 2015, o governo reajustou positivamente as alíquotas sobre o diesel e a gasolina em níveis nominais ligeiramente mais elevados que aqueles em vigor antes de junho de 2012 (Tabela 3.1). As alíquotas desse imposto continuam muito abaixo das médias internacionais, com o diesel ainda tributado por uma alíquota mais baixa do que a da gasolina (Figura 3.3). Essa discrepância, comum na maioria dos países, não tem justificativa ambiental, uma vez que o diesel tem maior teor de carbono e provoca emissões de poluentes atmosféricos locais (Harding 2014). O Brasil deveria considerar um aumento gradativo das alíquotas da CIDE, estabelecendo um vínculo com o teor de carbono do combustível. 
Essa tributação deveria ser gradualmente expandida para outros combustíveis, incluindo o querosene utilizado na aviação nacional.

Figura 3.3. Tributação sobre emissões de $\mathrm{CO}_{2}$ provenientes de combustíveis para transporte é menor que na maioria dos outros países

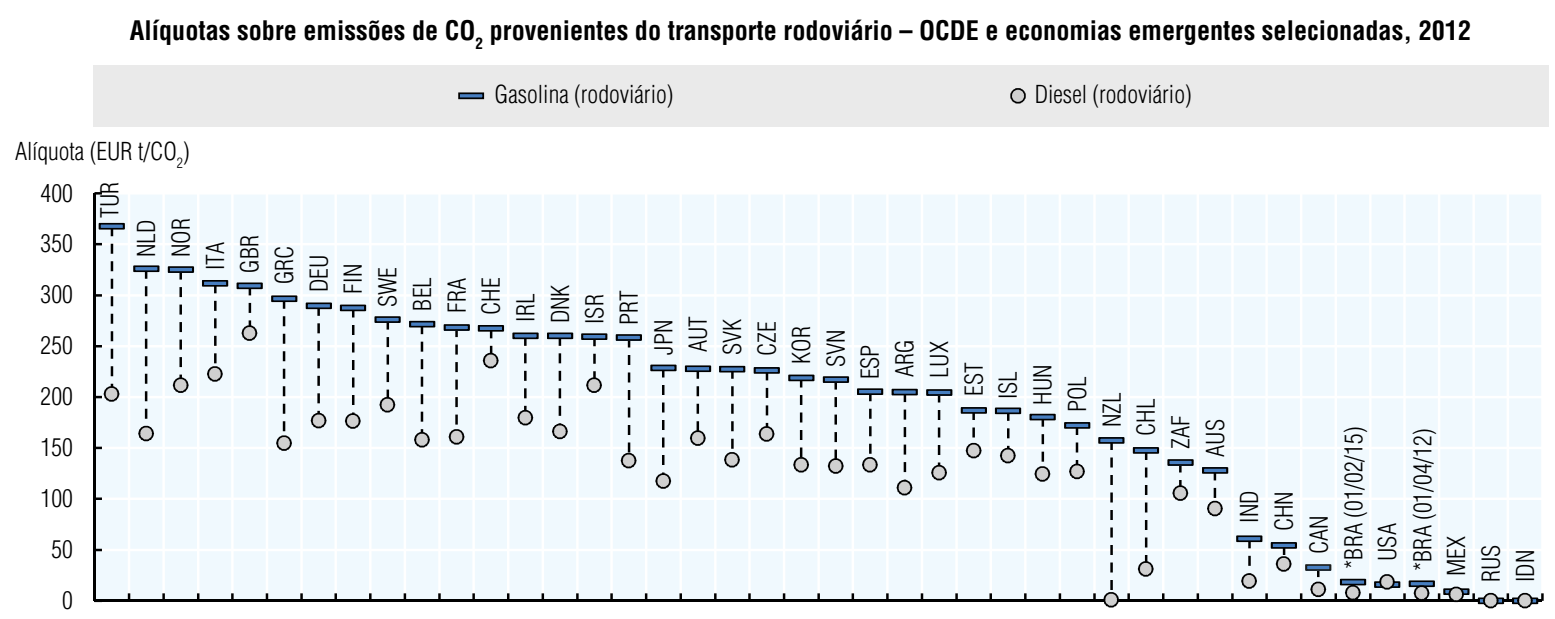

Obs.: Alíquotas de $1^{\circ}$ de abril de 2012 (exceto $1^{\circ}$ de julho de 2012 para AUS e 04 de abril de 2012 para ZAF); Dados para CAN, IND e USA incluem apenas tributos federais.

NZL aplica um encargo de uso de rodovias para o diesel que não está incluída neste dado. Alíquotas convertidas usando fator padrão de emissão de carbono do Painel Intergovernamental sobre Mudança Climática e fatores de conversão energética da IEA.

*Alíquotas brasileiras a partir de $1^{\circ}$ de abril de 2012 e 01 de fevereiro de 2015 para refletir alterações no sistema tributário.

Fonte: Adaptado da OCDE (2015), Taxing Energy Use 2015: OECD and Selected Partner Economies.

\section{Encargos especiais sobre consumo de energia elétrica}

Tradicionalmente, a energia elétrica tem sido sujeita a uma série de encargos e tributos utilizados, em parte, para financiar ações socioambientais, como fontes renováveis e eletrificação rural. O peso e complexidade dessa tributação resultaram em tarifas de energia elétrica para o consumidor final mais altas que em países vizinhos (IEA, 2014; The Economist, 2012) com os tributos respondendo por cerca de $50 \%$ da tarifa final. Em 2012, numa tentativa de reduzir as tarifas de energia elétrica, o governo extinguiu dois encargos e reduziu consideravelmente a contribuição remanescente sobre o consumo, (ver abaixo). ${ }^{2}$ Essas medidas podem ajudar a reequilibrar a tributação sobre produtos energéticos, em termos de emissões de $\mathrm{CO}_{2}$. Os preços da energia elétrica aumentaram substancialmente desde o início de 2015, estando previstos, ainda, outros aumentos (Reuters, 2015a). Os recentes aumentos são, em parte, consequência da estiagem na região Sudeste desde o final de 2013, que reduziu a geração hidrelétrica e aumentou a dependência sobre a energia, mais cara, das usinas termoelétricas.

O único encargo remanescente sobre o consumo de energia elétrica é a Conta de Desenvolvimento Energético (CDE). Em vigor desde 2002, a CDE incide sobre as distribuidoras e é repassada na conta do consumidor final. As alíquotas da CDE foram significativamente reduzidas após a reforma de 2012 (para menos de 73\% do nível de 2012). A receita da CDE, gerida pela ELETROBRAS, é destinada a várias finalidades, incluindo o fomento a fontes renováveis e programas de eletrificação rural, e o subsídio a tarifas para a população de baixa renda e algumas unidades geradoras a diesel ou a carvão. 


\subsection{Tributação sobre veículos}

A receita de tributos sobre veículos aumentou entre 2002 e 2013, acompanhando o crescimento da compra e venda de veículos, embora tenha sido registrada uma ligeira diminuição desde 2011 (Figuras 3.1 e 3.4). Esses tributos incluem o Imposto sobre a Propriedade de Veículos Automotores (IPVA) e outro sobre a compra ou registro do veículo. Nenhum desses impostos reflete critérios ambientais, mas o tributo sobre a compra é reduzido para veículos flex, movidos tanto a gasolina quanto a álcool. O IPVA, tributo estadual, geralmente varia entre $2 \%$ e $5 \%$ do valor do veículo. Sua receita praticamente dobrou em termos reais, desde o início dos anos 2000, alcançando cerca de $\mathrm{R} \$ 30$ bilhões em 2013.

Figura 3.4. A receita de tributos sobre veículos cresceu com o aumento da frota

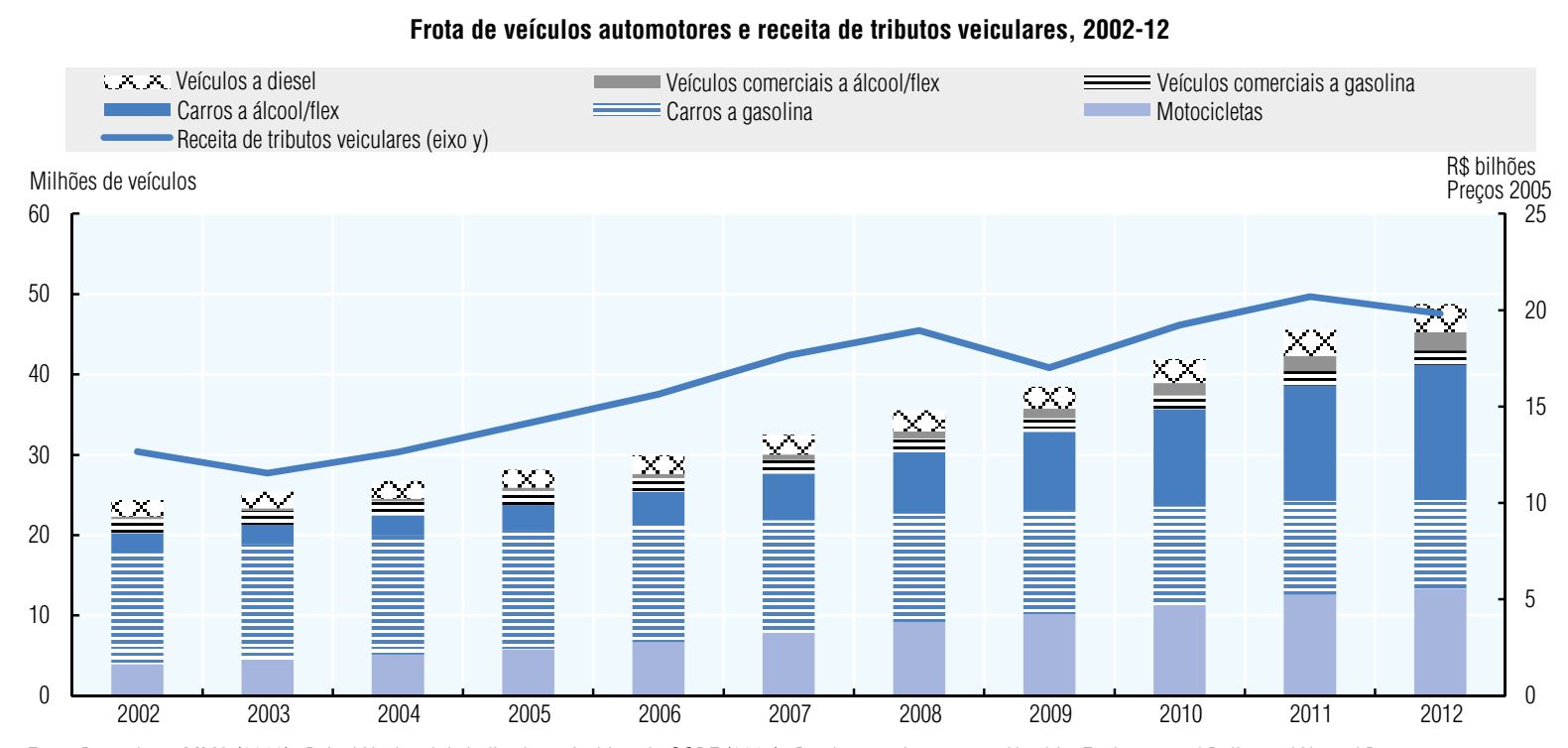

Fonte: Baseado no MMA (2013), Painel Nacional de Indicadores Ambientais; OCDE (2015), Database on Instruments Used for Environmental Policy and Natural Resources Management.

O Imposto sobre Produtos Industrializados (IPI) é um tributo federal sobre o consumo que incide sobre produtos manufaturados, incluindo veículos automotores. A receita aumentou em termos reais entre 2002 e 2011, com uma ligeira queda em 2009, devido à recessão. A arrecadação diminuiu para $\mathrm{R} \$ 3,8$ bilhões em 2013 , devido à queda nas vendas de veículos e à redução da alíquota aplicada entre 2012 e 2014 para estimular a indústria automobilística (MMA, 2015).

A alíquota do IPI varia de acordo com a capacidade do motor, sendo menor (7\%) para veículos motores com até $1000 \mathrm{cc}$. Acima de $1000 \mathrm{cc}$, o IPI varia entre $13 \%$ e $25 \%$ para veículos movidos a gasolina, e é reduzido para $11 \%$ ou $18 \%$ para veículos flex (Barros, 2014). Essa diferenciação tem ajudado a promover as vendas de carros de passeio flex, que responderam por 57\% da frota dessa categoria de veículos em 2012 (Figura 3.4). Os veículos elétricos são tributados com a mesma alíquota que os veículos de combustão.

O programa Inovar-Auto, cujo objetivo é promover inovação tecnológica na indústria automobilística, impõe um aumento entre 30\% e 55\% na alíquota do IPI (dependendo da capacidade do motor do veículo) entre julho de 2014 e dezembro de 2017, mas, ao mesmo tempo, concede reduções de até $30 \%$ às montadoras pelo cumprimento de 
metas de inovação, tais como redução de emissões, eficiência de combustível, $P \& D$, segurança e conteúdo nacional (Transport Policy, 2014). O programa tem estimulado melhorias na eficiência dos veículos, mas a exigência de conteúdo nacional tem servido, principalmente, para fomentar a indústria automobilística nacional (Box 3.5). Em termos de custo-eficiência, provavelmente tributos veiculares com base na eficiência do combustível seriam mais eficazes para estimular a melhoria na tecnologia de veículos e criariam menos distorções de mercado.

Tributos sobre propriedade de veículos são, teoricamente, menos eficientes que tributos sobre combustíveis ou uso de rodovias para a redução de emissões de GEEs e outros poluentes atmosféricos, por terem menor relação com o uso do veículo. Portanto, o Brasil deve considerar, além das atuais alíquotas reduzidas para veículos flex, a tributação diferenciada de veículos com base em parâmetros ambientais (ex., eficiência de combustível, emissões de $\mathrm{CO}_{2}$ ou emissões de poluentes atmosféricos, tais como o $\mathrm{NO}_{\mathrm{X}}$ ). Desta forma, proprietários seriam incentivados a optar por veículos com emissões mais baixas, o que resultaria em uma frota com maior número de veículos menos poluentes.

\subsection{Outros tributos e encargos relacionados ao meio ambiente Tributos sobre a propriedade}

A legislação brasileira permite que impostos sobre a propriedade urbana, calculados sobre o valor do imóvel, sejam apurados de acordo com potenciais aumentos de valor de mercado resultantes de uma melhor prestação de serviços públicos, incluindo aqueles relacionados ao meio ambiente. O pagamento dessa Contribuição de Melhoria também pode ser repassado na forma de aumento de aluguel. Os investimentos contemplados incluem: construção ou expansão de sistemas viários para maior fluidez do trânsito; sistemas de abastecimento de água potável; instalação de redes de esgoto; infraestruturas para distribuição de energia elétrica, transportes e comunicações; e infraestruturas relacionadas ao combate à seca ou proteção contra inundações. Não se sabe qual o alcance da aplicação de tais contribuições, ou em que medida a receita é utilizada para financiar tais investimentos.

\section{Tarifa de coleta de resíduos}

Os municípios podem cobrar tarifas pela prestação de serviços relacionados ao meio ambiente, tais como a coleta de lixo e a manutenção e limpeza urbana. Na maioria dos municípios, a cobrança pela coleta do lixo vem embutida no Imposto Predial Territorial Urbano (IPTU) não tendo qualquer relação com o volume de resíduos coletados, embora possa estar relacionada com a frequência da coleta. O Plano Nacional de Resíduos Sólidos prevê a ampliação da participação de municípios que aplicam encargos ou cobranças específicas (e não o IPTU) de 11\% em 2008, para 75\% em 2031 (MMA, 2012). Embora encargos fixos possam ser de administração mais fácil, não proporcionam qualquer incentivo para diminuir a geração de resíduos ou facilitar a coleta seletiva.

Ademais, as tarifas são geralmente baixas demais para cobrir os custos de prestação do serviço: a Pesquisa Nacional de Saneamento Básico, 2008, constatou que apenas 12\% dos municípios que cobram por serviços de coleta de resíduos conseguem recuperar esses custos (MMA, 2012; IPEA, 2012). Considerando que, na medida em que o Brasil promove a eliminação de lixões a céu aberto e a implantação de aterros controlados e sanitários (Capítulo 1), os custos da gestão de resíduos devem aumentar, faz-se necessária uma reforma do sistema de cobrança (Seção 5.2) para evitar o aumento de pressões sobre o orçamento público e incentivar o investimento privado no setor. 


\section{Cobrança pelo uso da água}

Marcos jurídicos que permitem a cobrança pelo uso da água estão em vigor há várias décadas. A Lei da Política Nacional de Recursos Hídricos, de 1997, formalmente estabeleceu a cobrança pelo uso dos recursos hídricos - tanto para a captação de água, quanto para a descarga de efluentes - como instrumentos a serem utilizados para o gerenciamento dos recursos hídricos. Na prática, a administração da implementação tem se comprovado complexa (Capítulo 2) e poucos comitês de bacias hidrográficas atualmente cobram pelo uso da água (OCDE, 2012). Em março de 2015, a cobrança pelo uso da água estava em vigor em quatro bacias hidrográficas federais ou sendo aplicada por cinco governos estaduais (OCDE, 2015b). Na maioria dos estados que cobram pelo uso da água, os preços unitários são baixos; não são automaticamente reajustados pela inflação; não cobrem despesas de gestão de recursos hídricos; e tiveram pouco efeito sobre decisões quanto à alocação e uso da água (OCDE, 2012; Ioris, 2008).

O Rio de Janeiro é o único estado onde a cobrança pela água é universal. As cobranças são efetuadas por bacia hidrográfica e categoria de uso, por meio de um fundo de gestão centralizado, mas $90 \%$ das receitas são revertidas para as bacias. Essas receitas aumentaram, de R\$ 3 milhões em 2007, para R\$ 35 milhões em 2013. Regulamentos estaduais estipulam que $70 \%$ dos recursos sejam investidos na captação e tratamento de águas servidas municipais, até que seja alcançada a meta de $80 \%$ de coleta e tratamento em cada região hidrográfica. Mesmo assim, essas cobranças representam menos de 15\% dos recursos de investimento necessários no Estado do Rio de Janeiro (OCDE, 2015b). Há indícios de que as cobranças pelo uso da água tenham surtido impacto positivo sobre a eficiência do uso da água no setor industrial, mas não em outros setores usuários (Martinez Júnior, 2011).

Ademais, a Agência Nacional de Águas (ANA) recebe uma receita equivalente a 0,75\% sobre o valor da energia hidroelétrica produzida, a título de Compensação Financeira por áreas inundadas e pelo uso da água na geração de energia, ${ }^{3}$ o que representa mais da metade do seu orçamento (OECD, 2012). Essa compensação, no entanto, não reflete a escassez de água e a concorrência para acessá-la na bacia hidrográfica e tampouco contribui para a gestão eficiente dos recursos hídricos (OECD, 2015c). Há ampla margem para a aplicação de instrumentos econômicos em áreas onde a água é escassa ou a concorrência entre usuários é mais acirrada. Tais instrumentos incluem a cobrança pelo uso da água (aplicada como ferramenta de política e não simplesmente como mecanismo de geração de receita) mas poderiam também incluir algum tipo de comércio/ transferência de direitos ou alocações de uso da água entre usuários. Poderiam vir acompanhados de mecanismos que se adequem às sensibilidades e restrições legais, para alcançar objetivos de políticas públicas, como a compensação ou a transferência facilitada pelo governo (OCDE, 2015c).

As agências reguladoras definem o regime tarifário do abastecimento de água e do saneamento e especificam os mecanismos de reajuste periódico das tarifas. As tarifas de abastecimento de água devem ser estabelecidas de modo a garantir a recuperação de custos e estimular o investimento necessário para a expansão da cobertura dos serviços, assegurando uma rentabilidade adequada sobre os investimentos. As tarifas de saneamento tendem a ser iguais para coleta/disposição final e tratamento, o que desestimula o investimento em serviços de tratamento de águas servidas (Costa e Côrtes, 2014). As tarifas de água são mais elevadas no Brasil do que em outros países da América Latina. Em média, as tarifas permitem a recuperação dos custos de operação e manutenção, mas pouco investimento em novas infraestruturas (Figura 3.5 e Seção 5.2). 
No entanto, existe grande variação de tarifas e de eficiência operacional entre os estados, municípios e prestadores de serviços (MCid, 2014). Assim como em outros países latino-americanos, uma grande parte (cerca de 40\%) da água distribuída não gera receita, devido a consumo não faturado, furto de água, imprecisão de equipamentos de medição e perdas físicas (IBNET, 2015).

Na maioria dos municípios, os domicílios de baixa renda são beneficiados por uma tarifa social no primeiro bloco de consumo de água. Contudo, o direcionamento dessa subvenção nem sempre é adequado, pois muitas vezes, especialmente nas áreas remotas da região Norte, as famílias mais pobres não têm acesso à rede de abastecimento. Em algumas localidades, o direcionamento foi melhorado por meio dos cadastros do programa Bolsa Família (Box 3.1). No entanto, os efeitos desses subsídios cruzados podem dificultar a expansão da rede em áreas rurais carentes, pois a receita pode ser insuficiente para cobrir os respectivos custos (OCDE, 2011). De modo geral, uma maior utilização dos programas de transferência de renda existentes poderia apresentar maior custo-efetividade no apoio a domicílios de baixa renda.

Figura 3.5. As tarifas de água e saneamento são suficientes para cobrir custos operacionais

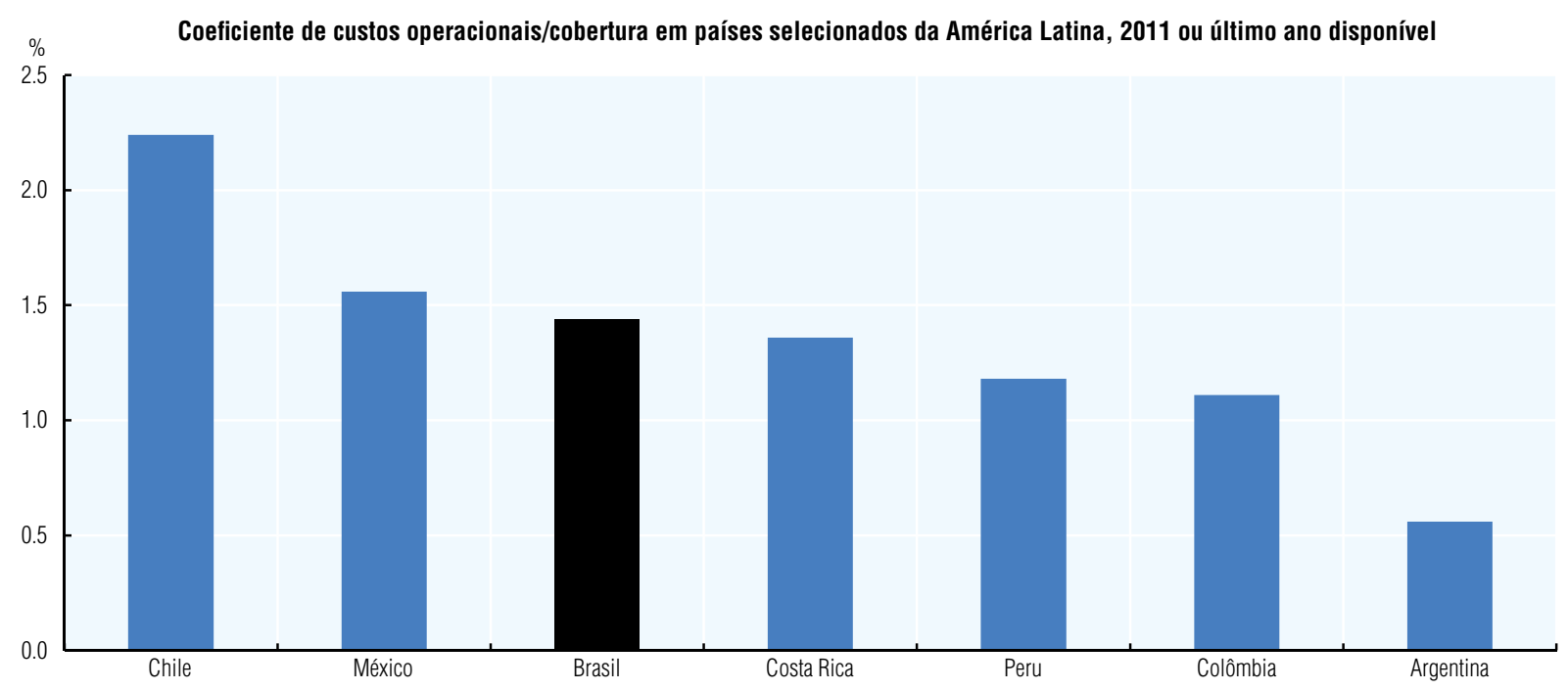

Fonte: The International Benchmarking Network for Water and Sanitation Utilities (2015), IB-NET Database.

\section{Reforma de subsídios e incentivos prejudiciais ao meio ambiente}

\subsection{Apoio à produção e consumo de combustíveis fósseis Apoio ao consumo de combustíveis fósseis}

No Brasil, os subsídios a produção e consumo de energia para promover a industrialização e alcançar objetivos sociais têm uma longa história. Na década de 1990, foi lançada uma agenda de reformas visando a liberalizar o setor energético e a eliminar subsídios. Essa reforma culminou na liberalização dos preços dos combustíveis dos transportes em 2002, mas está, desde então, praticamente parada (De Oliveira e Laan, 2010).

Na prática, o governo continuou a intervir no mercado para limitar a oscilação dos preços de combustíveis no mercado interno: congelou os preços da gasolina, diesel e gás liquefeito de petróleo (GLP) entre 2006 e 2012, e, repetidamente, reduziu alíquotas 
sobre os combustíveis (Tabela 3.1). Os preços internos dos combustíveis foram mantidos abaixo dos preços internacionais de importação pagos pela estatal Petrobras, fazendo com que esta acumulasse crescentes prejuízos financeiros (OCDE, 2015a). Os preços dos combustíveis foram reajustados em 2012 e 2013, mas os aumentos foram parcialmente compensados, em junho de 2012, pela redução a zero da alíquota da CIDE (Seção 3.2). A OCDE (2015a) estima que esse ajuste resultou em uma renúncia fiscal de $\mathrm{R} \$ 5,6$ bilhões em 2012 (Tabela 3.2). Foram restabelecidas alíquotas positivas sobre a gasolina e o diesel no início de 2015 (Seção 3.2) mas, para outros produtos petrolíferos e o gás natural, a alíquota continua sendo zero (Tabela 3.2).

Efetivamente, a combinação de decisões governamentais sobre a precificação de combustíveis com as isenções temporárias da CIDE resultou num subsídio ao consumo de combustíveis fósseis, incentivando o uso individual de automóveis e o aumento da demanda por gasolina em detrimento do etanol (já que proprietários de veículos flex tendem a optar pelo combustível mais barato). A consequência foi uma retração do investimento na indústria do etanol (OECD, 2013a), contrariando o objetivo do governo de promover a produção e consumo do álcool combustível (Seção 5.4). Outros países também implementaram mecanismos semelhantes de suavização dos preços dos combustíveis, com diferentes níveis de intervenção governamental e de impacto sobre os preços. ${ }^{4}$ Suas experiências mostram que, além de sobrecarregar as finanças públicas e incentivar desperdícios de energia, tais mecanismos são ineficazes como medida de redução da pobreza e tendem a ser altamente regressivos (OECD, 2013c). Os benefícios são, em grande parte, apropriados por grupos de renda mais alta, que gastam uma parcela maior de seus rendimentos com automóveis, enquanto famílias de baixa renda tendem a usar o transporte público (Seção 5.3).

A CIDE para o GLP tem alíquota zero desde 2004. Anteriormente, o programa Auxílio Gás, destinado a domicílios de baixa renda, foi incorporado ao Bolsa Família em 2003 (Box 3.1). Assim como as tarifas de água (Seção 3.4) consumidores residenciais de baixa renda são beneficiados por uma tarifa reduzida no primeiro bloco de energia elétrica. A substituição dessas isenções fiscais e descontos nas tarifas por transferências diretas de renda, a exemplo do que foi feito para o GLP, proporcionaria melhores incentivos de eficiência energética.

\section{Estímulo à produção de combustíveis fósseis}

O gás natural e o carvão utilizados na geração de energia elétrica - cerca de metade da oferta total desses combustíveis - estão isentos de vários impostos. Produtores de petróleo e gás desfrutam de regimes fiscais especiais: um para operadores que investem em infraestrutura em certas regiões do país (REPENEC); outro para bens utilizados na exploração e desenvolvimento na indústria de petróleo e gás (REPETRO); e um terceiro para importações de petróleo bruto e de produtos petrolíferos (REPEX). Esses regimes especiais isentam os operadores do PIS/COFINS, ${ }^{5}$ do IPI, e de direitos aduaneiros; e ainda proporcionam potenciais reduções de ICMS. ${ }^{6}$ As transferências orçamentárias do governo relacionadas a esses programas são significativas (Tabela 3.2).

As vendas de cana-de-açúcar para produção de etanol e de todo o álcool combustível são isentas do PIS/COFINS. Os produtores de biodiesel também se beneficiam de reduções e isenções, dependendo da matéria prima e insumos (ex., a tributação é menor para o dendê e a mamona, para incentivar sua utilização) para incentivar a oferta a partir da produção da agricultura familiar, especialmente nas regiões Norte e Nordeste (Barros, 2012; La Rovere. et al, 2011).? 
Os investimentos na exploração e extração de petróleo e gás vêm aumentando desde a descoberta de reservas na plataforma continental, em 2006. O instituto de desenvolvimento internacional do Reino Unido (ODI, 2014) estimou em US\$ $530 \mathrm{mi}$ lhões o investimento público para exploração e extração de petróleo e gás, por meio de subsídios, tais como isenções fiscais e outras medidas de estímulo direto a P\&D e capacitação para a indústria de petróleo e gás. O BNDES também oferece importantes financiamentos para o setor de petróleo e gás no mercado interno (aproximadamente US\$ 3,9 bilhões em 2012) e créditos subsidiados para empresas da cadeia de abastecimento da Petrobras.

Tabela 3.2. Exemplos de estímulo ao consumo de combustíveis fósseis e de despesas fiscais relacionadas

$\mathrm{R} \$$ milhões

\begin{tabular}{|c|c|c|c|c|}
\hline Medida de estímulo & Detalhes & Tipo de estímulo & $\begin{array}{c}\text { Estímulo } \\
\text { estimado, } 2011\end{array}$ & $\begin{array}{l}\text { Estímulo } \\
\text { estimado, 2012 }\end{array}$ \\
\hline \multicolumn{5}{|c|}{ Petróleo } \\
\hline Redução da CIDE sobre combustíveis & $\begin{array}{l}\text { Isenção para importações e vendas no varejo } \\
\text { de gasolina, diesel, querosene, querosene de } \\
\text { aviação e gás natural }\end{array}$ & Consumidor & 817 & 5632 \\
\hline $\begin{array}{l}\text { Redução fiscal sobre a importação e venda } \\
\text { no varejo de nafta }\end{array}$ & Isenção de PIS/COFINS & Consumidor & 364 & 429 \\
\hline Conta de Consumo de Combustíveis (CCC) & $\begin{array}{l}\text { Reembolsos para subsidiar a operação de } \\
\text { unidades de geração térmica a diesel na } \\
\text { região Norte, para compensar custos (compra } \\
\text { e transporte de diesel; isenção de direitos } \\
\text { aduaneiros) }\end{array}$ & Consumidor & 5482 & 4854 \\
\hline $\begin{array}{l}\text { Conta de Desenvolvimento Energético } \\
\text { (CDE) }\end{array}$ & $\begin{array}{l}\text { Estímulo ao consumo de energia elétrica por } \\
\text { famílias de baixa renda, unidades de geração } \\
\text { movidas a diesel e a carvão, expansão da rede } \\
\text { de gás natural, programa Luz Para Todos }\end{array}$ & Consumidor & 32 & 36 \\
\hline $\begin{array}{l}\text { REPENEC (Regime Especial para o } \\
\text { Desenvolvimento da Indústria Petrolífera } \\
\text { nas Regiões Norte, Nordeste e Centro- } \\
\text { Oeste) }\end{array}$ & $\begin{array}{l}\text { Isenção temporária de PIS/COFINS, IPI e } \\
\text { direitos aduaneiros sobre as importações de } \\
\text { certos bens de capital }\end{array}$ & Produtor & 1458 & 2781 \\
\hline $\begin{array}{l}\text { REPETRO (Regime Aduaneiro Especial } \\
\text { de Exportação e Importação de Bens } \\
\text { Destinados à Exploração e à Produção de } \\
\text { Petróleo e de Gás Natural) }\end{array}$ & $\begin{array}{l}\text { Isenção de PIS/COFINS, IPI, direitos } \\
\text { aduaneiros e imposto sobre mercadorias } \\
\text { importadas por via marítima }\end{array}$ & Produtor & 8824 & 7655 \\
\hline $\begin{array}{l}\text { REPEX (Regime Especial de Importação de } \\
\text { Petróleo Bruto e seus Derivados) }\end{array}$ & $\begin{array}{l}\text { Isenção de PIS/COFINS, IPI e direitos } \\
\text { aduaneiros }\end{array}$ & Produtor & 1365 & 4003 \\
\hline \multicolumn{5}{|c|}{ Gás natural } \\
\hline REPETRO & Ver acima & Consumidor & 1146 & n.d. \\
\hline REPENEC & Ver acima & Consumidor & 189 & n.d. \\
\hline \multicolumn{5}{|c|}{ Carvão } \\
\hline $\begin{array}{l}\text { Isenções fiscais para o carvão e o gás } \\
\text { natural usado na geração de energia elétrica }\end{array}$ & $\begin{array}{l}\text { Isenção de PIS/COFINS para as compras de } \\
\text { carvão e gás natural }\end{array}$ & Consumidor & 329 & 153 \\
\hline $\begin{array}{l}\text { Conta de Desenvolvimento Energético } \\
\text { (CDE) }\end{array}$ & Ver acima & Consumidor & 547 & 627 \\
\hline
\end{tabular}

a) Dados provisórios.

Fonte: OECD-IEA (2015), "Fossil Fuel Subsidies and Other Support", www.oecd.org/site/tadffss. 


\subsection{Incentivos à produção agrícola}

\section{Apoio à agricultura}

A agricultura continua sendo um dos pilares da economia, respondendo por $5,7 \%$ do PIB e cerca de 15\% dos empregos (Capítulo 1; ver também Estatísticas Básicas). Durante os anos 1980 e 1990, o Brasil tributava o setor; desde então, passou a oferecer um nível moderado de apoio. Entre os anos 2000 e 2012, a Estimativa de Apoio aos Produtores $(\mathrm{PSE})^{8}$ medida pela OCDE oscilou em torno de $5 \%$ do faturamento bruto do setor agrícola, proporção muito abaixo da observada em países da OCDE e outros BRIICS (Figura 3.6) refletindo a posição do Brasil como exportador agrícola competitivo.

Mesmo assim, a agricultura brasileira conta com grande gama de medidas de apoio. A maior parte deste apoio é direcionada à produção de commodities e ao uso de insumos, na forma de suporte aos preços de mercado (43\% do PSE em 2012) e subsídios aos insumos (54\%) (OCDE, 2013d). Estas formas de apoio à agricultura, por estarem atreladas à produção são, potencialmente, as mais distorsivas e prejudiciais ao meio ambiente. O suporte aos preços é feito por meio da garantia de preços mínimos para uma ampla gama de commodities ${ }^{9}$ e por meio de compras governamentais diretas.

Há muito, os produtores rurais vêm sendo beneficiados por programas de crédito concessional, principalmente no âmbito do Sistema Nacional de Crédito Rural (SNCR). ${ }^{10}$ O total de empréstimos do SNCR alcançou o recorde de R $\$ 111,4$ bilhões (cerca de US\$ 57 bilhões) em 2012, dos quais $85 \%$ foram destinados a grandes produtores rurais (OCDE, 2013d). Desde 2008, o condicionamento do acesso a crédito rural subsidiado na Amazônia à regularidade fundiária e à prestação de informações que demonstrem conformidade com normas ambientais tem efetivamente ajudado a reduzir o desmatamento. Ademais, a partir de outubro de 2017, a concessão de crédito rural estará condicionada ao registro de terras no Cadastro Ambiental Rural (Capítulo 4). Existem várias políticas de apoio à agricultura familiar, que oferecem empréstimos e seguros subsidiados, garantia de preços mínimos e preferência no âmbito do Programa de Aquisição de Alimentos. Os mecanismos de proteção social existentes, como o Bolsa Família - ou a expansão do Bolsa Floresta - poderiam oferecer uma proteção mais eficaz à renda do produtor rural. Há também, programas especiais para apoiar famílias que vivem do extrativismo sustentável de produtos florestais, especialmente no âmbito do Plano Nacional de Promoção das Cadeias de Produtos da Sociobiodiversidade (Capítulo 4).

Por estimular a produção e o uso de insumos e, consequentemente, a intensificação e expansão da fronteira agrícola, esses programas de fomento e crédito aumentam riscos e pressões sobre os recursos naturais. A maioria desses programas se destina à agricultura convencional (sementes híbridas, fertilizantes químicos e pesticidas) e podem provocar impactos negativos sobre o solo e a água. Não incentivam a aplicação mais eficiente de fatores de produção ou a inovação, de modo a ampliar a competitividade. Tendem ainda a estimular a produção agrícola, em detrimento de outros usos da terra, como conservação, restauração e reflorestamento sustentável. Existem programas especiais de apoio à sociobiodiversidade, a produtos orgânicos e à produção sustentável, a exemplo do Programa de Agricultura de Baixo Carbono (Capítulo 4), contudo a escala é muito pequena, quando comparada com o total do apoio oferecido. As transferências gerais para o setor agrícola (pesquisa, treinamento e infraestrutura) são também muito mais baixas que o suporte prestado a produtores rurais individuais. $\mathrm{O}$ apoio à agricultura poderia dar maior ênfase a incentivos de melhoria ambiental e uso mais eficiente de 
insumos, e estar mais direcionado à solução de gargalos de infraestrutura que limitam o desenvolvimento do setor (os produtores tendem a estar localizados longe de seus principais mercados), o que poderia desencadear maior eficiência e crescimento, tanto para grandes produtores comerciais quanto para pequenos agricultores (OCDE, 2015d).

Figura 3.6. Apoio a agricultores aumentou, mas continua moderado, pelos padrões internacionais

Estimativa de apoio ao produtor no Brasil, por categoria, 1995-2012

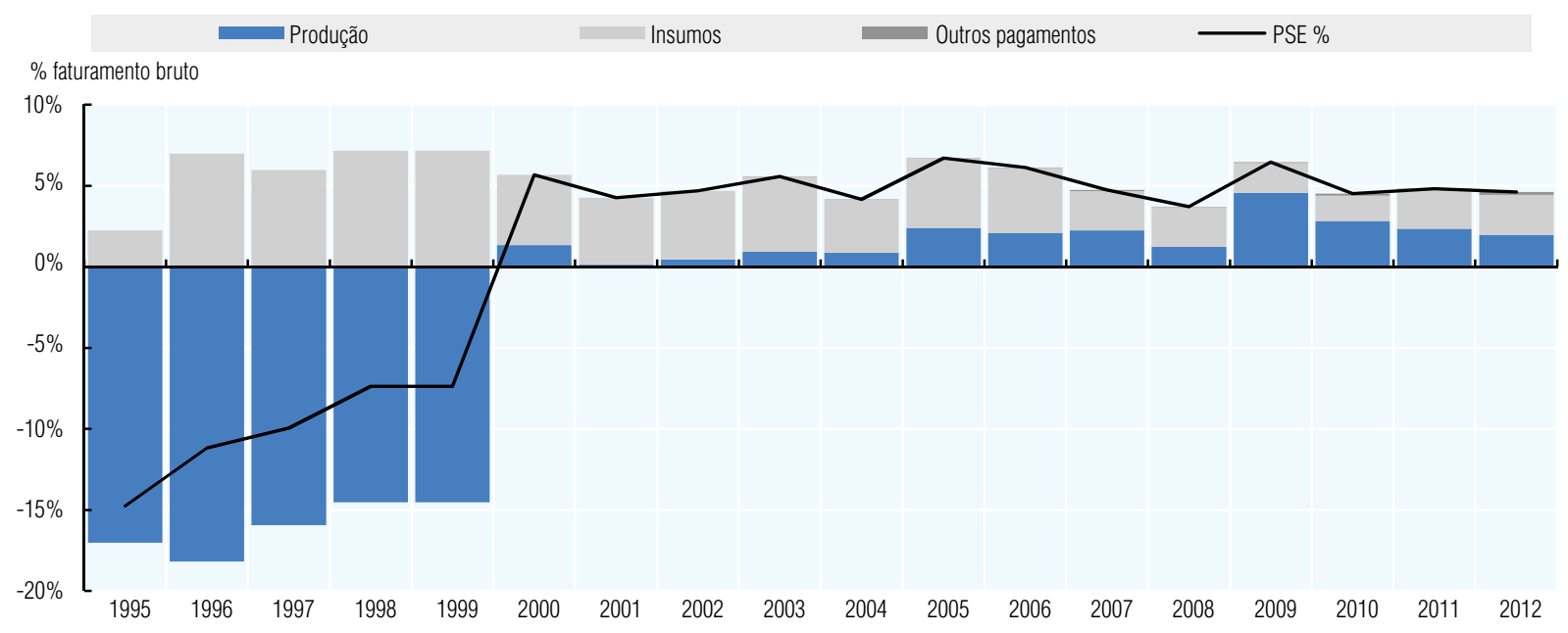

Estimativa de apoio ao produtor, economias BRIICS e OCDE, 1995-97 e 2010-12

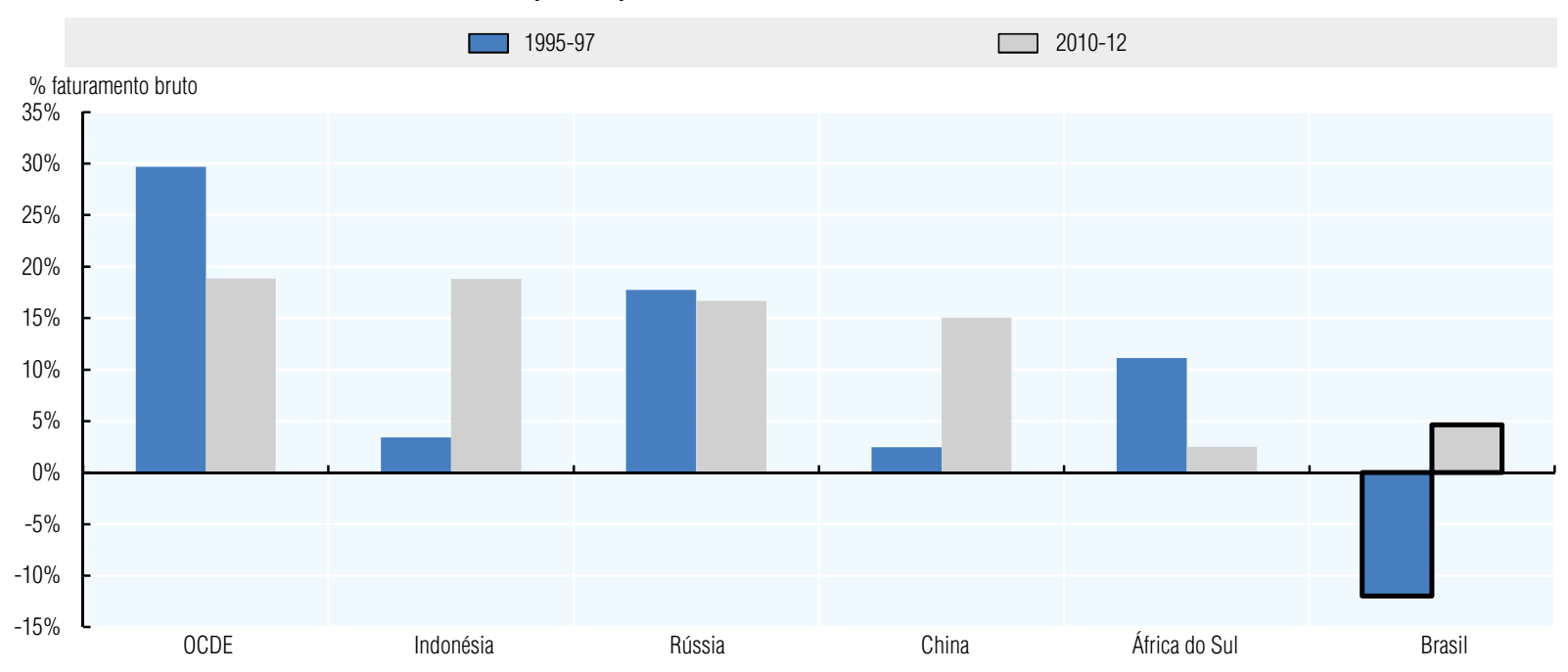

a) Dados para a Índia indisponíveis

Fonte: OECD (2015), "Producer and Consumer Support Estimates", OECD Agriculture statistics (database).

\section{Isenções fiscais e outros incentivos}

Insumos como água, pesticidas e fertilizantes contam com subsídios implícitos. A água é insumo agrícola fundamental: o setor consome mais de 60\% dos recursos hídri$\cos$ (Capítulo 1). No entanto, em muitas regiões, a captação de água para a agricultura não é cobrada. Onde é cobrado o uso da água, os valores tendem a ser baixos demais para estimular o seu aproveitamento eficiente (Seção 3.4). Fertilizantes e pesticidas 
gozam de isenção de alguns tributos federais e estaduais, o que tem aumentado sua utilização, como também a incidência de problemas de saúde a eles relacionados (Capítulo 1). Em 2010, o Projeto de Emenda Constitucional (PEC 491/2010) propôs a total isenção de tributos federais e estaduais sobre insumos agrícolas, fertilizantes, defensivos agrícolas e produtos químicos utilizados na produção de alimentos para consumo humano e animal; entretanto, os defensivos foram excluídos da pauta, após audiências públicas. ${ }^{11}$ As isenções fiscais para fertilizantes e pesticidas devem ser reavaliadas, com vistas a fomentar o uso mais racional de produtos potencialmente prejudiciais à saúde humana, animal e de ecossistemas. Ademais, as atuais normas sobre a aprovação de pesticidas devem ser revisadas, com a exigência de sua renovação periódica, ao invés da aprovação definitiva.

O Imposto sobre Propriedade Territorial Rural (ITR) embora pouco expressivo, também incentiva a produção agrícola, ao invés da conservação. A alíquota do ITR é maior para terras "improdutivas" que para terras com produção agrícola. Áreas de Proteção Permanente e de Reserva Legal em propriedades rurais privadas e Reservas do Patrimônio Natural ${ }^{12}$ são isentas do ITR (Capítulo 4) o que, em parte, compensa o custo de oportunidade por não explorar a terra de modo mais intensivo; no entanto, o valor da isenção é tão baixo que o incentivo é desprezível (MMA, 2015). Há indícios de que, tradicionalmente, a expansão da fronteira agrícola foi impulsionada muito mais pelo baixo custo da conversão de áreas "naturais" em áreas de agropecuária, que pela necessidade de atender às crescentes demandas por alimentos, fibras e combustíveis (Gurgel e Paltsev, 2013). Mais recentemente, contudo, o crescimento da produção agrícola tem resultado mais de melhorias de produtividade que da abundância e baixo custo da terra.

\section{Investimentos em infraestrutura ambiental e de baixo carbono}

\subsection{Panorama}

Para garantir um crescimento forte, sustentável e aprimorar a prestação de serviços, o Brasil precisa ampliar e modernizar sua infraestrutura. Em 2014, o Fórum Econômico Mundial classificou o Brasil, no quesito qualidade de infraestrutura, na $120^{a}$ posição no ranking de 144 países, destacando suas deficiências de infraestrutura como a segunda maior barreira para a realização de negócios (WEF, 2014). A relativa precariedade da infraestrutura nacional, incluindo as relacionadas ao meio ambiente, são consequência de seguidas décadas de baixo investimento (Amann et al, 2014; OCDE, 2013a).

O investimento na ampliação e renovação da infraestrutura aumentou com o Programa de Aceleração do Crescimento (PAC, 2007). O PAC engloba amplos investimentos de infraestrutura ( $\mathrm{R} \$ 504$ bilhões) principalmente para os setores de energia e logística, mas também contempla novos investimentos em infraestrutura urbana, como abastecimento de água, saneamento e transporte ferroviário urbano. Os desembolsos continuam abaixo dos volumes previstos em muitas áreas, especialmente saneamento, energias renováveis, sistema ferroviário e transmissão de energia (TCU, 2011). Embora substanciais, os investimentos do PAC parecem ter ficado muito aquém das necessidades do país, especialmente na região Nordeste (OCDE, 2011).

O PAC foi sucedido pelo PAC 2, que previa $\mathrm{R} \$ 955$ bilhões em investimento público e privado no período entre 2011 e 2014, com a inclusão de forte dimensão ambiental, mais recursos para abastecimento de água e saneamento e forte ênfase no transporte ferroviário (Tabela 3.3). A realização e custeio de projetos melhorou: o total dos 
investimentos superou, em mais de 70\%, a primeira edição do PAC (MPOG, 2015). Ainda assim, critérios ambientais e de sustentabilidade não foram sistematicamente integrados ao PAC 2, como, por exemplo, no desenho e localização de projetos de infraestrutura.

Tabela 3.3. Investimentos no âmbito do PAC 2

$\mathrm{R} \$$ bilhões

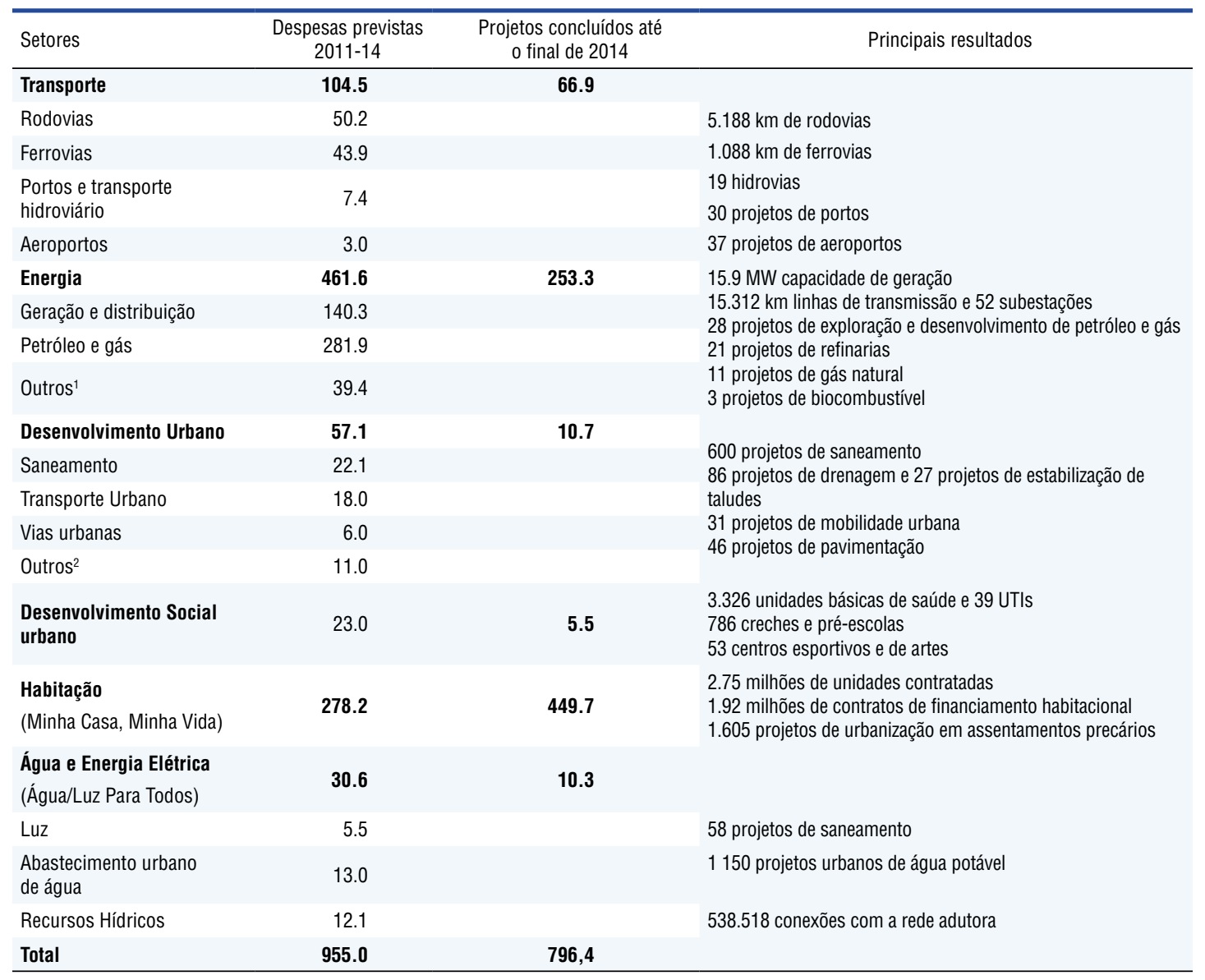

1. Inclui transporte industrial, energias renováveis, eficiência energética e exploração mineral.

2. Inclui controle e prevenção de inundações, deslizamentos de terra e erosão costeira.

Fonte: OCDE (2011), OECD Economic Surveys: Brazil; MPOG (n.d.), "PAC 2" (apresentação); MPOG (2015), PAC 2: Balanço 4 Anos.

Os investimentos em infraestrutura relacionadas ao meio ambiente aumentaram significativamente por meio de créditos do BNDES, principal fonte nacional de financiamento de longo prazo (Quadro 3.3). O volume de créditos direcionados ao meio ambiente aumentou mais rapidamente do que o montante de créditos concedidos pelo BNDES, alcançando R\$ 28 bilhões em 2014 ou 15\% do total concedido no ano. O maior aumento ocorreu na área de energias renováveis, sendo a maior parte destinada a grandes projetos hidrelétricos (Seção 5.4). Desde 2009, desembolsos para água e saneamento básico e para o transporte público aumentaram; ademais, desde 2010, fundos específicos vêm sendo alocados para a adaptação climática e a redução do risco de desastres e, mais recentemente, para a restauração florestal (Figura 3.7). 


\section{Box 3.3. Política de salvaguardas ambientais do BNDES}

O Banco Nacional de Desenvolvimento Econômico e Social - BNDES foi criado em 1952 para fomentar a expansão da indústria e da infraestrutura. Concede empréstimos para projetos de investimento de longo prazo a juros abaixo do mercado (geralmente elevados) para setores como agricultura, indústria, infraestrutura, comércio e serviços. ${ }^{11} \mathrm{O}$ financiamento provém de várias fontes. Desde 2009, o Tesouro Nacional vem sendo a maior fonte individual de financiamento. Seria benéfico para o Brasil reduzir, gradativamente, o apoio governamental ao BNDES, o que facilitaria o surgimento de credores privados e o desenvolvimento de mercados de capitais privados de longo prazo. Desta forma, quando identificada a necessidade de créditos concessionais específicos, por exemplo, para apoiar objetivos sociais ou o desenvolvimento de infraestruturas de interesse do governo que o mercado não possa atender, o apoio estatal deve ser explícito e a oportunidade aberta a todas as instituições de crédito (OCDE, 2013a).

O BNDES mantém uma política ambiental desde 2005 e, desde 2010, realiza análise social e ambiental de todos os grandes projetos aos quais concede créditos diretos ou indiretos. Os empréstimos do Banco para setores com significativo impacto ambiental são sujeitos a políticas setoriais, a exemplo da política de salvaguarda ambiental de 2009 para a indústria frigorífica, que exige a rastreabilidade do gado, assegurando que propriedades produtoras cumpram com a legislação trabalhista e não promovam o desmatamento. Da mesma forma, vêm sendo aplicadas salvaguardas às indústrias de açúcar e etanol desde 2010, e aos produtores de soja, desde 2011, para garantir que seus créditos ao agronegócio não incentivem o desmatamento. Uma política de salvaguarda ambiental se aplica a créditos para usinas térmicas movidas a combustíveis fósseis, desde 2009. Em 2011, foram adotadas diretrizes sociais e ambientais para o setor de abastecimento de água e tratamento de águas servidas.

Fonte: BNDES (2015), "Política de Responsabilidade Social e Ambiental" site.

O marco jurídico para participação privada em investimentos de infraestrutura é semelhante ao observado na maioria dos países da OCDE. O investimento privado em infraestrutura parece ser maior no Brasil do que em outros países da América Latina (OCDE, 2011). Para minimizar o custo orçamentário do desenvolvimento de infraestruturas, o governo vem procurando promover a participação do setor privado por meio de concessões apoiadas por créditos subsidiados, títulos de infraestrutura com isenção fiscal e outros incentivos. ${ }^{14} \mathrm{~A}$ participação privada tem aumentado significativamente nos setores de energia e transportes, mas permanece baixa no setor de água e saneamento. Essa participação tem tomado mais a forma de concessões, do que de parcerias público-privadas (PPPs) (OECD, 2011). ${ }^{15}$ No Brasil, as PPPs têm alcançado maior sucesso nos setores de saúde e educação.

Apesar do recente e massivo aporte de recursos e incentivos para investimentos de infraestrutura, ainda persistem problemas de finalização de projetos. Deficiências de planejamento, implementação e monitoramento, bem como entraves provocados por normas e procedimentos complexos de seleção e avaliação de projetos e de licenciamento ambiental (Capítulo 2) provocam atrasos na execução de programas de investimento e desestimulam a participação do setor privado. Esses entraves são especialmente evidentes, em se tratando de infraestruturas relacionadas ao meio ambiente, como saneamento e transporte urbano, que são da competência direta dos governos locais. É comum municípios não conseguirem aplicar os recursos federais disponibilizados para o desenvolvimento e manutenção de infraestruturas, devido, em parte, à fraca capacidade administrativa e à insuficiência de financiamento a nível local. 


\section{Figura 3.7. Desembolsos do BNDES relacionados ao ambiente aumentaram significativamente}
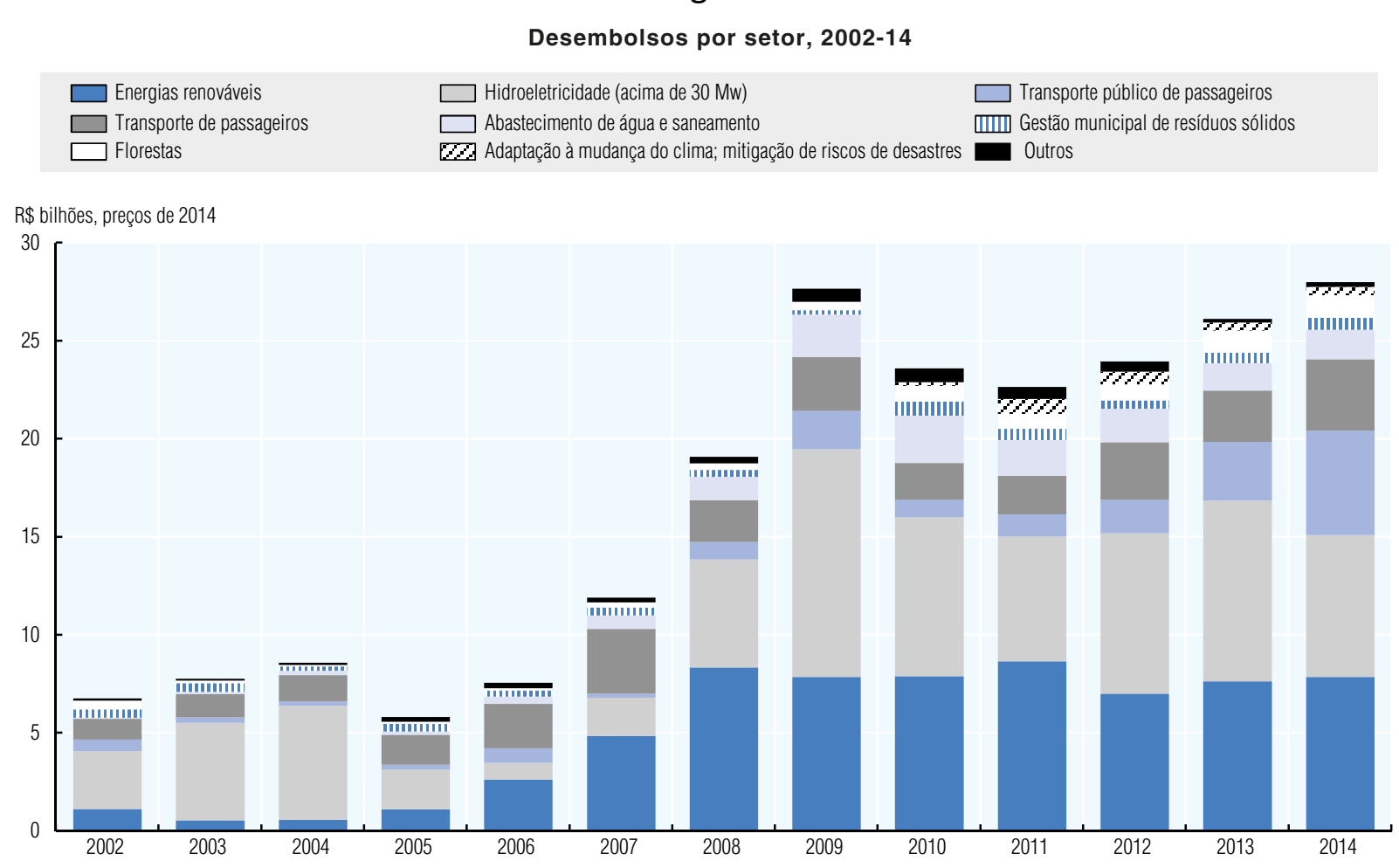

Obs.: Valores desembolsados até 2007 podem estar subestimados devido a alterações na classificação de despesas. Dados de 2014 sobre energias renováveis incluem investimentos do Programa de Eficiência Energética - PROESCO.

Fonte: Baseado no BNDES (2014), Relatório Anual - 2013; BNDES (2013), Relatório Anual 2012.

\subsection{Investimento em abastecimento de água, saneamento e resíduos} Abastecimento de água e saneamento

$\mathrm{O}$ acesso a serviços de abastecimento de água e saneamento melhorou significativamente ao longo das duas últimas décadas (Anexo 3.A). No entanto, o setor de água e saneamento continua sendo o que mais requer investimento. É preciso ampliar e melhorar tanto a cobertura, quanto a qualidade do saneamento, especialmente em áreas rurais e nas regiões Norte e Nordeste (Capítulo 1). O setor começou a receber maiores volumes de financiamento no âmbito do PAC, especialmente do PAC 2 (Tabela 3.3). No entanto, houve atrasos nos desembolsos. ${ }^{16}$ No âmbito do PAC 2, o investimento em água e saneamento foi integrado à segunda fase do programa Minha Casa, Minha Vida, cujos recursos foram desembolsados com sucesso. $\mathrm{O}$ abastecimento de água em áreas rurais foi ampliado pelo programa Água Para Todos, que, no âmbito do PAC 2, instalou mais de 750.000 cisternas em 1.200 municípios.

A maior parte do investimento em infraestrutura de abastecimento de água é pública (principalmente por meio do BNDES); concessões para empresas privadas e contratos de PPP existem para alguns sistemas de abastecimento, mas atendem a menos de um terço da população urbana (WWC e OCDE, 2015). Para estimular o investimento em tratamento de águas servidas, a ANA lançou, em 2001, o primeiro programa no Brasil que paga pelos resultados alcançados: o Programa de Despoluição de Bacias Hidrográficas (PRODES). Investimentos públicos para instalação e tratamento de águas servidas são desembolsados somente após a conclusão da 
construção, e certificação de que as operações cumpram com requisitos e objetivos ambientais. Entre 2001 e 2011, foram contratadas 55 estações de tratamento de esgoto. Do mesmo modo, foi lançado no mesmo ano o Programa Produtor de Água que oferece compensação financeira por investimentos na proteção e recuperação de fontes de água (Capítulo 4). Até 2011, haviam sido implementados 14 projetos em nove estados (Soluções para Água, 2011).

Tem se comprovado difícil garantir a estabilidade do financiamento para a expansão de redes de abastecimento de água e de esgoto e para a gestão dos recursos hídricos. Embora a Lei Nacional de Saneamento de 2007 delegue poderes às agências reguladoras independentes e defina normas para a prestação de serviços e fixação de tarifas, as receitas das tarifas de água e saneamento não cobrem o alto custo de investimento para novas infraestruturas (Seção 3.4), o que contribui para desestimular a participação privada no setor.

\section{Gestão de resíduos}

O investimento em gestão de resíduos sólidos urbanos aumentou com os Planos Municipais instituídos no âmbito da Política de Gestão de Resíduos Sólidos de 2010 (Capítulo 2) e do PAC, mas permanece bem abaixo das necessidades. Estados e municípios deveriam ter elaborado planos de gestão de resíduos sólidos até 2012, como condição para receber recursos federais para a construção de aterros sanitários, mas apenas cerca de um quarto cumpriu com o prazo. Mais de 2.200 municípios (menos da metade do total) a maioria deles da região Sudeste cumpriram com o prazo de instalar, até 2014, um aterro sanitário ambientalmente saudável. O Estado do Rio de Janeiro, por exemplo, por meio de parcerias entre o governo do Estado, municípios e entidades privadas, lançou um ambicioso projeto para substituir aterros irregulares por aterros devidamente licenciados. No entanto, a maioria dos estados não conta com número suficiente de aterros sanitários projetados de acordo com as normas técnicas, e a deposição de resíduos em lixões continua sendo problema grave, particularmente nas regiões Nordeste e Norte (Capítulo 1). Alguns dos aterros sanitários recentemente construídos se degradaram, tornando-se lixões, devido à falta de capacidade local para a sua manutenção. Além disso, devido à carência de aterros sanitários para resíduos perigosos, muitos municípios toleram a deposição ilegal desses resíduos em aterros municipais; a maioria dos estados carece de infraestrutura para reciclagem.

O BNDES vem intensificando ações direcionadas ao desembolso de recursos para a gestão de resíduos, com enfoque sobre a capacitação de municípios para o recebimento desses recursos. A maioria dos custos da gestão de resíduos sólidos está associada à manutenção de aterros, o que destaca a importância de mecanismos eficazes de recuperação de custos (BIRD, 2010a). Conforme indicado na Seção 3.4, a maioria dos municípios não cobra ou cobra muito pouco pela coleta e deposição de resíduos. Por não contemplar a recuperação de custos, há pouco incentivo para o investimento em operações adequadas, uma vez que não há perspectiva de lucro adequado para concessionários privados. A formação de consórcios intermunicipais deve ser incentivada para alcançar economias de escala, cuja falta representa outro impedimento ao investimento privado. O desenvolvimento de linhas de negócios mais especializadas, como a reciclagem e o tratamento de resíduos especiais, poderia tornar as operações do setor financeiramente mais atraentes (BIRD, 2010a). O potencial do negócio é grande: estima-se que o Brasil perde aproximadamente US\$ 3,5 bilhões ao ano com a deposição, em aterros, de resíduos que poderiam ser reciclados (IPEA, 2010a). 
Assim como em muitos países emergentes ou em desenvolvimento, a recuperação de resíduos é feita por catadores: pessoas que ganham a vida coletando e vendendo materiais descartados a empresas privadas de reciclagem. A atividade tem respaldo legal como profissão, mas a maioria dos 400 a 800 mil catadores do Brasil (incluindo os $10 \%$ organizados em associações ou cooperativas informais) não goza de acesso a direitos trabalhistas. A Lei ${ }^{\circ} 12305 / 2010$, que institui a Política Nacional de Resíduos Sólidos, insta os municípios a instituir a coleta seletiva e a promover a participação e responsabilidade compartilhada dos catadores pelo ciclo de vida de produtos recicláveis, e prioriza a criação de cooperativas formais e programas de reciclagem. O programa Pró-Catador tem por objetivo fortalecer as cooperativas, por meio de capacitação e formação técnica, melhoraria das condições de trabalho e maiores oportunidades de inclusão social e econômica (MMA, 2012).

\subsection{Investimentos em transportes sustentáveis Transporte rodoviário}

A infraestrutura rodoviária no Brasil é inadequada. A baixa proporção de estradas pavimentadas e grandes disparidades entre os estados prejudica a competitividade e o desenvolvimento econômico, especialmente pelo fato de grande parte do transporte de mercadorias ser efetuado pelas estradas. O investimento na malha rodoviária vem aumentando desde a década de 1990, quando o governo introduziu contratos de concessão com operadores privados. No entanto, há pouco incentivo para as concessionárias efetuarem investimentos na melhoria e expansão da malha, em parte porque o critério de concessão é o de menor pedágio cobrado, o que dificulta a recuperação de investimentos e a cobertura de custos operacionais (OCDE, 2011). Em todos os trechos de rodovias sob concessão (principalmente nos Estados de São Paulo e do Rio de Janeiro) os pedágios são apurados conforme o tamanho e peso do veículo, sem levar em consideração parâmetros ambientais (ABCR, 2015).

\section{Transporte ferroviário}

A partir do final dos anos 1990, a privatização da rede ferroviária federal serviu de estímulo ao investimento (equivalente a cerca de $\mathrm{R} \$ 1,8$ bilhão ao ano, em média, entre 1997 e 2009) e ao aumento do volume de mercadorias transportadas (OSEC, 2010). No entanto, o setor ferroviário é subdesenvolvido, com serviços ferroviários de longa distância servindo exclusivamente para o transporte de mercadorias e sistemas de trens urbanos de passageiros concentrados nas megacidades de São Paulo e Rio de Janeiro. Essa situação cria limitações econômicas e coloca pressões sobre as infraestruturas rodoviária e aeroportuária (Amann et al., 2014).

Vale destacar que recentes programas de investimento em infraestrutura contemplam a ampliação da rede ferroviária. O Plano Nacional de Logística e Transportes prevê aumento de investimentos relacionados ao setor ferroviário, dos atuais $31 \%$, para $65 \%$ do investimento total em transporte, até 2015. No longo prazo, isto poderá resultar numa redução do congestionamento da malha rodoviária, proporcionando benefícios como menores índices de acidentes e de emissões de GEEs e outros poluentes atmosféricos. Investimentos futuros devem visar à sustentabilidade do sistema ferroviário no longo prazo. $\mathrm{O}$ atual transporte ferroviário de mercadorias é baseado no diesel, e a expansão do uso do diesel traz implicações ambientais e econômicas. É preciso considerar opções tais como misturas com biodiesel, motores híbridos diesel-elétrico e, para o transporte urbano de passageiros, o potencial da eletrificação. 


\section{Transporte público urbano}

A carência de infraestrutura de transportes públicos urbanos, o alto preço das passagens, bem como a força da indústria automotiva nacional e a tributação relativamente baixa sobre a propriedade e uso de veículos (ver Seção 3.3) servem de estímulo para o uso de veículos particulares (Figura 3.4). Na maioria das áreas urbanas, o uso de automóveis particulares aumentou mais do que o de ônibus (Amann et al., 2014). Significativas discrepâncias socioeconômicas caracterizam a propriedade de veículos automotores; em 2012, 28\% das famílias mais pobres possuíam carro, ao passo que $88 \%$ das famílias mais ricas possuíam no mínimo um. O baixo investimento em transportes públicos, portanto, penaliza famílias de baixa renda, trazendo consequências sociais negativas.

A responsabilidade pela infraestrutura de mobilidade urbana recai, principalmente, sobre os municípios. Em princípio, as cidades com mais de 500.000 habitantes devem elaborar planos integrados de transporte urbano. A maioria, no entanto, carece dos recursos financeiros necessários e da imprescindível capacidade técnica, o que, há décadas, vem causando atrasos nos investimentos e na finalização de projetos (Amann et al., 2014). Em resposta, no final dos anos 2000 e início da década de 2010, houve aumento de recursos federais e créditos do BNDES direcionados a projetos de mobilidade urbana, inclusive para os sistemas de metrô (Tabela 3.3). ${ }^{17}$ Ademais, as cidades-sede da Copa do Mundo de 2014 receberam recursos para o aprimoramento de seus sistemas de transporte público. No entanto, grandes carências de investimento persistem. Segundo estimativas do BNDES (2012b), seriam necessários investimentos em transporte público, em 38 áreas metropolitanas, da ordem de $\mathrm{R} \$ 113$ bilhões, simplesmente para compensar deficiências existentes, sem contar com necessidades futuras.

Embora seja positivo o aumento de investimentos em trens urbanos e metrôs, poderia ser dada mais ênfase aos sistemas de ônibus de trânsito rápido (BRT) capazes de proporcionar transporte de qualidade, com menor custo de capital. O desenvolvimento de um abrangente e integrado sistema BRT em Curitiba comprovou-se eficaz na expansão do transporte público a custo moderado (Box 3.4). A maioria dos corredores de ônibus existentes no Brasil precisa de reforma, e a implantação de sistemas BRT pode proporcionar a oportunidade de aumentar a produtividade do trânsito. No entanto, Lindau et al. (2014) identificaram várias barreiras à expansão de sistemas BRT, muitas delas comuns a outros investimentos em infraestrutura, entre elas, insuficiência de capacidade técnica local, conflitos entre partes interessadas e incertezas regulatórias (Seção 5.1).

As receitas do transporte público provêm, quase que exclusivamente, das passagens pagas pelos usuários; enquanto que a participação proveniente do orçamento da prefeitura é bem menor que na maioria das cidades de países da OCDE..$^{18}$ Os serviços de transporte público são, em grande parte, operados por concessionárias privadas que concorrem pelas rotas com base na oferta de menor tarifa. Contudo, o aumento da tarifa pode ser concedido automaticamente, caso haja aumento de custos, o que serve de desincentivo para melhorias de eficiência e redução de custos operacionais (Amann et al., 2014) $\cdot{ }^{19}$ Além disso, em geral, o desempenho financeiro e operacional dos operadores privados sequer é monitorado. ${ }^{20}$ Entre 2005 e 2014, o custo total da propriedade de veículos automotores aumentou em $7 \%$ e o preço da gasolina em $16 \%$; o índice de preços ao consumidor subiu $160 \%$; enquanto que os preços médios das passagens de ônibus nas seis principais áreas metropolitanas aumentaram em 170\% (Amann et al., 2014). 
Para atrair maior investimento no transporte público, é necessário que haja mudanças nas políticas de mobilidade. O restabelecimento de um relativo equilíbrio entre os custos de transporte público e os de uso de veículos particulares pode exigir a adoção de medidas politicamente impopulares, tais como taxas de congestionamento e restrições à circulação. É importante que os municípios tenham agências regulatórias dotadas de recursos humanos capacitados para a análise e aplicação de normas do transporte público, bem como para o monitoramento do desempenho financeiro e operacional das concessionárias, conforme estabelecido nos contratos de concessão.

\section{Box 3.4. Sistema de ônibus BRT de Curitiba}

O BRT de Curitiba é reconhecidamente um sistema pragmático, integrado, eficaz e eficiente. Apesar de a taxa de propriedade de automóveis da cidade estar acima da média nacional, o serviço BRT, aliado a políticas de estacionamento vem, ano a ano, diminuindo o número de viagens de automóvel e reduzindo a poluição atmosférica, atualmente uma das mais baixas entre as capitais brasileiras.

A partir dos anos 1970, o sistema de mobilidade de Curitiba evoluiu, de ônibus convencionais circulando em tráfego misto para o primeiro sistema BRT do mundo, com corredores exclusivos de ônibus, embarque no nível do ônibus, bilhetagem eletrônica e ônibus biarticulados de alta capacidade. A Linha Verde, lançada em 2009, incorporou diversas inovações ambientais, operando $100 \%$ com ônibus articulados movidos a biodiesel.

A operação dos ônibus é contratada junto a empresas privadas. Desde 2010, a Rede Integrada de Transporte Coletivo (RIT) vem reunindo linhas alimentadoras e entre bairros, com estações de integração e tarifa única, o que melhorou consideravelmente a cobertura e eficiência do sistema. A receita tarifária é centralizada e distribuída aos operadores, com base no serviço prestado. Segundo informado, o sistema RIT como um todo, compreendendo uma gama de linhas e tarifa única e abrangendo 14 dos 26 municípios que compõem a região metropolitana, opera sem subsídio.

O desenvolvimento de um sistema BRT eficiente é fruto da bem-sucedida cooperação entre a Urbanização de Curitiba S.A. (URBS), autarquia local responsável pelo planejamento do transporte urbano, e a Secretaria de Desenvolvimento Urbano, responsável pelo ordenamento territorial. Encarregada do planejamento, gestão, operação e controle do sistema, a URBS define as rotas, a capacidade e os horários; regula e controla o sistema; e recolhe todas as tarifas.

Fonte: Lindau et al. (2010), "Bus Rapid Transit in Curitiba, Brazil. A look at the Outcome After 35 Years of BusOriented Development".

\subsection{Investimentos em energia renovável e eficiência energética Energias Renováveis}

O governo mantém seu compromisso de preservar a matriz energética limpa. $\mathrm{O}$ Plano Decenal de Expansão de Energia (PDE 2013-2022) estabelece o marco geral das políticas e investimentos do setor energético. Apesar de contemplar novas centrais nucleares e movidas a carvão e gás natural, o PDE também prevê elevada participação de energias renováveis na matriz energética e uma redução de cerca de $27 \%$ das emissões de GEE do setor energético, até 2020. Com ênfase numa significativa expansão da capacidade hidrelétrica para atender à crescente demanda por energia elétrica, o PDE prevê ainda o aumento da participação de outras fontes renováveis, especialmente a eólica. ${ }^{21} \mathrm{~A}$ implantação de novas usinas hidrelétricas enfrenta problemas de localização: a maioria dos potenciais aproveitamentos está localizada na Amazônia, o que implica em dificuldades com licenciamento ambiental e aceitação pública (Box 2.8). Novas técnicas vêm sendo adotadas e, para minimizar impactos ambientais e sociais, 
a maioria dos novos empreendimentos são a fio d'água, apesar de esse tipo de projeto ter menor capacidade de geração (IEA, 2013). No geral, estima-se que, para alcançar as metas de participação de energias renováveis estabelecidas no PDE, serão necessários investimentos da ordem de $\mathrm{R} \$ 120$ bilhões (FEBRABAN, 2014).

Em 2014, anunciou-se que o Brasil ocupava o sétimo lugar no ranking mundial de investidores em energias renováveis (BNEF, 2015) (Figura 3.8). O investimento total excluindo grandes usinas hidroelétricas - alcançou US $\$ 7,6$ bilhões, o que representou um significativo aumento em relação a 2013 (ano em que foi registrado o menor nível de investimento, desde 2005). Houve oscilações no investimento em energias renováveis durante a última década, em consequência de mudanças no setor de biocombustíveis, na programação de leilões de energias renováveis e de atrasos na construção de infraestruturas (Figura 3.8). Até 2009, a maior parte desse investimento foi direcionada aos biocombustíveis; a partir de 2010, o setor de energia eólica assumiu maior importância e, desde 2011, tem sido o principal destinatário desses investimentos (BNEF, 2014, 2013). Em 2014, a energia eólica atraiu $84 \%$ do investimento, impulsionado por créditos disponibilizados aos vencedores de leilões de energia realizados em 2013.

\section{Figura 3.8. O Brasil está entre os principais investidores mundiais em energias renováveis}

Novos investimentos em energias renováveis, 10 principais países, 2014

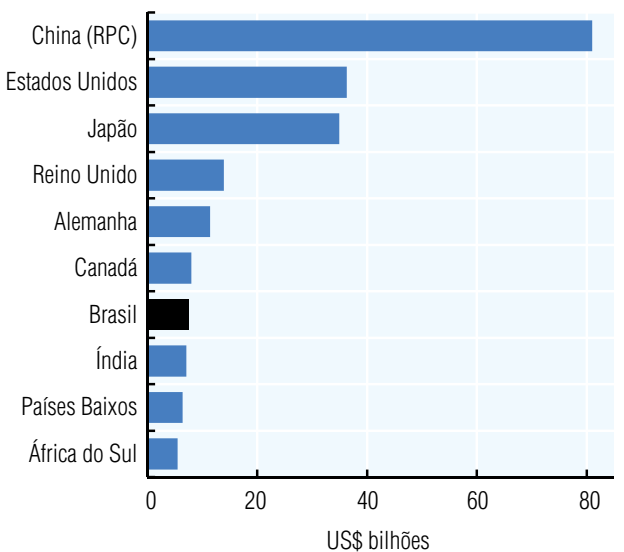

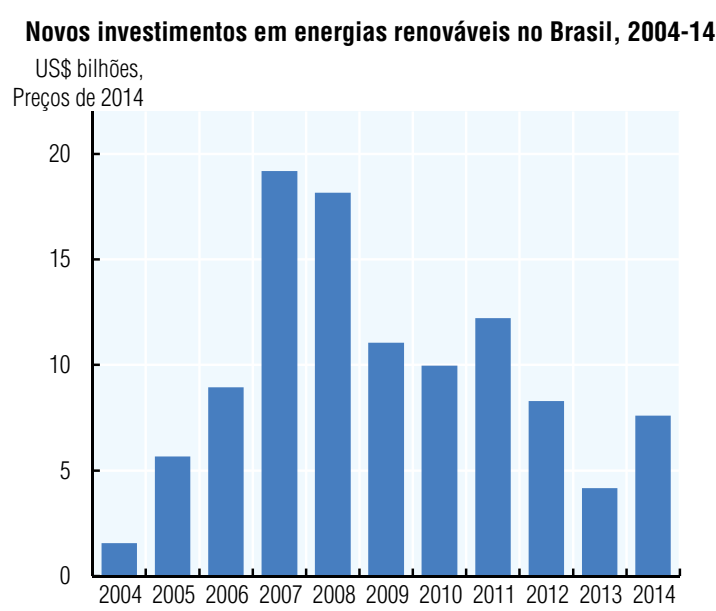

Fonte: Adaptado de BNEF (2015), Global Trends in Renewable Energy Investment 2015.

O investimento em energias renováveis provém de diversas fontes, entre elas o BNDES, o Fundo Nacional sobre Mudança do Clima (Capítulo 2) e vários outros fundos e programas estaduais. Desde 2010, o BNDES vem investindo em torno de R\$ 6 a 7 bilhões ao ano em energias renováveis. Os principais destinatários dos financiamentos do BNDES são as grandes usinas hidrelétricas (acima de $30 \mathrm{MW}$ ) que responderam por $25 \%$ a 35\% dos financiamentos relacionados ao meio ambiente, entre 2010 e 2014 (Figura 3.7). Em 2002, o país começou a apoiar a geração de energia de fonte eólica, de pequenas usinas hidrelétricas e de biomassa, por meio de contratos de oferta padrão (FIT), incluindo os custos do programa nas tarifas de energia elétrica (exceto para consumidores de baixa renda). Contudo, a consecução da meta de 3,3 GW de capacidade nova de energias renováveis sofreu atraso de mais de quatro anos. 
Desde 2009, os leilões de energia vêm se comprovando mais eficazes que os contratos de oferta padrão, como estímulo à expansão da energia eólica. Os preços médios da energia eólica, em 2011, foram menores que os da energia produzida por usinas térmicas movidas a gás natural, embora essa diferença tenha refletido medidas de apoio indireto, tais como créditos do BNDES com juros favorecidos, custos de transmissão e distribuição reduzidos e outros incentivos fiscais (Moarif e Patodia Rastogi, 2012). No Brasil, o primeiro leilão de energia solar foi realizado em outubro de 2014. A energia solar fotovoltaica tem grande potencial, especialmente para uso residencial. A micro geração de energia vem sendo permitida desde 2012; porém a falta de crédito adequado e a incidência do ICMS inviabilizam a sua adoção na maioria dos estados, embora existam isenções fiscais em Minas Gerais e Tocantins (FEBRABAN, 2014).

Problemas relacionados à malha de transmissão, no entanto, provocaram atrasos na implantação e disponibilização da energia de fontes renováveis, especialmente na região Nordeste, onde o potencial eólico é mais forte. Portanto, são necessários maiores investimentos no sistema interligado de transmissão (OECD, 2013a). A exemplo de outros investimentos de infraestrutura, diferenças de normas ambientais entre estados, e conflitos de competência entre órgãos reguladores ambientais resultam, com frequência, em atrasos e custos de transação e administrativos adicionais para os empreendedores (OECD, 2015c).

Créditos do BNDES são condicionados, em parte, às exigências de conteúdo local (ECL): para se habilitar ao financiamento, empreendedores e investidores devem adquirir determinada parcela dos insumos no país (Box 3.5). O fato de quase todos os parques eólicos em operação no Brasil receberem créditos do BNDES levou à criação de uma indústria de energia eólica nacional que, provavelmente, passará por expansão com a aplicação de novas ECLs, a partir de 2016 (Larive International, 2014). Com vistas a estimular a produção local e o desenvolvimento de capacidades, o BNDES impõe - e pretende reforçar ainda mais - requisitos de conteúdo local também para financiamentos de energia solar fotovoltaica (Barth et al., 2014). No entanto, no longo prazo, as ECLs limitam a capacidade produtiva e de financiamento da indústria (Box 3.5). O Brasil deve considerar a supressão progressiva das ECLs sobre energias renováveis e outras tecnologias ambientais emergentes (Seção 6.3). Onde forem implementadas, as ECLs devem ter prazo determinado e ser cuidadosamente projetadas de modo a não prejudicar a competitividade de longo prazo.

\section{Biocombustíveis}

No Brasil, o primeiro estímulo público para o desenvolvimento do etanol de cana-de-açúcar ocorreu em meados dos anos 1970, em resposta ao choque do petróleo de 1973. O Programa Pró-Álcool foi, em grande parte, responsável pelo desenvolvimento da indústria do etanol de cana-de-açúcar em larga escala. ${ }^{22}$ A partir de 2003, a indústria do etanol recebeu estímulo significativo, com o lançamento dos carros flex (La Rovere et al., 2011). Atualmente, a mistura obrigatória, aliada a uma tributação favorecida é o principal incentivo à demanda pelo etanol (Seção 3.2). A OCDE (2013e) estima em 200 euros por cada tonelada de $\mathrm{CO}_{2}$ reduzida, o custo da mistura obrigatória com biocombustível.

No início dos anos de 2010, em resposta ao declínio da produtividade no setor, o governo, por meio do BNDES, voltou a apoiar o investimento na indústria de etanol e na produção de cana de açúcar (Moarif e Patodia Rastogi, 2012). Os produtores de 
etanol enfrentaram preços mais elevados do açúcar e queda nos preços da gasolina e do diesel devido, em parte, à tributação favorecida dos combustíveis fósseis (Seções 3.2 e 4.1). Essa situação desestimulou o investimento no setor, correndo em sentido contrário à política de incentivo para carros flex (Seção 3.3). O imperativo de melhorar a produtividade do setor levou a uma nova ênfase sobre o apoio à P\&D (Seção 6.2). ${ }^{23}$

\section{Box 3.5. Exigências de conteúdo local nos mercados de energias renováveis}

O potencial da energia limpa para estimular a criação de emprego e as exportações de produtos de maior valor agregado levou vários países da OCDE e emergentes a estabelecer ECLs como forma de fomentar o desenvolvimento de energias renováveis. Normas de ECL normalmente estabelecem que empreendedores e investidores adquiram de fornecedores nacionais determinada parcela de componentes, equipamentos e serviços, e que parte dos custos totais do projeto e dos empregos beneficie populações locais, para que o empreendimento possa se habilitar como beneficiário de créditos (ex., contratos de oferta padrão) ou participar de licitações públicas. Até março de 2015, nada menos que 21 países, incluindo 16 países da OCDE e de economias emergentes, haviam planejado ou instituído ECLs para energias eólica e solar fotovoltaica, sobretudo após 2009. Essa situação, desde 2010, deu origem a pelo menos cinco disputas junto à Organização Mundial do Comércio.

A OCDE (2015e) apresentou evidências empíricas de que as ECLs exercem efeito negativo sobre fluxos de investimento global nos setores de energia renovável e prejudica a eficácia de programas de contratos de oferta padrão. Exercem impacto negativo também sobre a criação de emprego local, o valor agregado e a transferência de tecnologia, quando se considera toda a cadeia de valor. Por elevar custo de insumos para empresas do segmento downstream, as ECLs tendem a aumentar custos finais, reduzir a competitividade de preços, desestimular investidores internacionais e elevar preços da energia no atacado.

Portanto, a OCDE aconselha que países com indústrias incipientes ou pouco competitivas de energia solar ou de turbinas eólicas procurem, ao invés de impor ECLs, tentar sanar entraves locais à competitividade da indústria manufatureira nacional. Outras opções incluem: apoio bem direcionado à $\mathrm{P} \& \mathrm{D}$, o que pode estimular inovação em todos os segmentos da cadeia de valor, fomentar capacidades produtivas locais e incentivar a transferência de tecnologias provenientes de importações e do IDE; programas de capacitação e promoção para aprimorar competências tecnológicas dos fabricantes, fortalecer capacidades locais de empresas do segmento downstream e estimular a inovação; e instrumentos de estímulo à demanda ou de precificação mais eficaz do carbono, para aumentar a demanda interna e, finalmente, servir de estímulo à indústria nacional.

Fonte: OECD (2015c): Overcoming Barriers to International Investment in Clean Energy, OECD Publishing, Paris.

Em 2004, o governo lançou o Programa Nacional de Produção e Uso do Biodiesel, contemplando várias formas de fomento à produção do biodiesel, visando, em parte, a redução da dependência do diesel importado. O BNDES passou a oferecer linhas de crédito preferenciais para a produção de biodiesel contendo um percentual mínimo de matéria-prima proveniente da agricultura familiar (Moarif e Patodia Rastogi, 2012). Esse programa, a partir de 2008, foi seguido pela obrigatoriedade da mistura do biodiesel ao diesel. Ambas as medidas tiveram impacto significativo: a produção de biodiesel, inexistente em 2005, alcançou 2,7 milhões de $\mathrm{m}^{3}$ em 2012 (Castanheira et al, 2014).

\section{Acesso à energia elétrica}

Ao longo das duas últimas décadas, programas de investimento público proporcionaram acesso à energia elétrica a milhões de famílias brasileiras, inicialmente por meio do programa Luz no Campo, lançado em 1999 e, desde 2003, por meio do Luz Para Todos. 
Atualmente, 98,8\% da população têm acesso à energia elétrica (BIRD, 2015); sendo que a parcela sem acesso consiste, principalmente, de domicílios localizados em áreas rurais de difícil acesso. O custo de abastecer comunidades isoladas com energia aumentou o custo por domicílio do programa Luz Para Todos em cerca de 90\%, entre 2004 e 2010. Dificuldades técnicas e financeiras de interconexão com a malha de transmissão levaram à adoção de soluções isoladas utilizando painéis solares, mas também pequenos geradores a diesel, que implicam em altos custos de combustível e impactos negativos à saúde. O financiamento do programa provém, principalmente, do orçamento geral da União e, em parte, das tarifas de energia elétrica (Seção 3.2).

\section{Eficiência energética}

Maiores investimentos e uma sistemática incorporação de critérios de eficiência energética a políticas setoriais de planejamento, desenvolvimento e transporte urbano poderiam trazer grandes benefícios para o Brasil (Box 3.6). A Política Nacional de Mudança do Clima introduziu a eficiência energética no âmbito dos planos setoriais, e o Plano Nacional de Eficiência Energética de 2011 estabeleceu como meta uma economia de 106 TWh até 2030, enquanto que o PDE prevê economias de 48 TWh até 2022. Contudo, até o momento, foram pouco expressivas as medidas de estímulo a investimentos em eficiência energética. A exemplo de outros países, normas e programas de rotulagem têm melhorado a eficiência energética dos aparelhos e equipamentos, assim contribuindo para a evolução desses mercados. O Programa Nacional de Conservação de Energia Elétrica (PROCEL) (R\$ 34 milhões em 2013), operado e parcialmente financiado pela ELETROBRAS, oferece capacitação em gestão de energia e serviços para indústrias, saneamento e municípios (ELETROBRAS, 2014).

A maior parte dos recursos desses programas provém de uma participação da receita operacional líquida das empresas de geração, transmissão e distribuição. Os contratos de concessão obrigam as empresas a investir 1\% da receita em eficiência energética ou iniciativas de P\&D relacionadas. Essas mesmas fontes financiam o Fundo Setorial de Energia, gerido pela Financiadora de Estudos e Projetos (FINEP) para a realização de projetos de pesquisa energética aplicada, com ênfase em eficiência energética. ${ }^{24}$

O BNDES criou uma linha de crédito a juros favorecidos, em 2006, para estimular investimentos em eficiência energética e energias renováveis, com o propósito de fomentar o desenvolvimento de empresas prestadoras de serviços de energia. Denominado PROESCO, inicialmente o programa financiou poucos projetos devido, em grande parte, à sua complexidade e exigências administrativas (Moarif e Patodia Rastogi, 2012); até 2012, havia desembolsado menos de R 10 milhões ao ano, mas, desde então, o volume dos desembolsos anuais mais que duplicou. Sob o PAC 2, foi alocado R 1,1 bilhão para a eficiência energética; contudo nenhum desembolso havia sido efetuado até o final de 2013 (TCU, 2014). 


\section{Box 3.6. Eficiência energética potencial do Brasil}

A Agência Internacional de Energia (IEA, 2013) analisou o consumo energético em grandes setores de uso final - indústria, transportes e construção civil - para avaliar potenciais ganhos técnica e economicamente viáveis, por meio da aplicação de medidas e tecnologias de eficiência energética. No setor da construção civil, as medidas incluem novos códigos de construção para edificações novas, normas de desempenho energético mínimo, e melhorias de desempenho energético dos principais aparelhos e equipamentos, com aprimoramentos ao longo do tempo. Na indústria, incluem a adoção da melhor tecnologia disponível para novos equipamentos e uma melhor gestão de energia. No setor de transportes, incluem normas obrigatórias de economia de combustível e rotulagem para promover a utilização de veículos mais eficientes.

A análise postulou que o consumo global de energia em 2035 poderia ser 11\% menor que o projetado, se o Brasil implementasse medidas já existentes, incluindo aquelas apenas anunciadas. A IEA estimou que a demanda por eletricidade poderia cair em cerca de 100 TWh até 2035 (equivalente à produção aproximada da usina hidrelétrica de Itaipu em 2012) o que reduziria a necessidade da instalação de novas usinas geradoras. A demanda por petróleo também cairia consideravelmente, ajudando a reduzir emissões de GEE.

Os principais ganhos seriam no setor de transporte, principalmente por meio de maior economia de combustível. A análise frisou a importância de políticas direcionadas à melhoria da eficiência de carros vendidos no Brasil. O estudo não refletiu todos os potenciais ganhos para o setor de transportes brasileiro, pois grandes ganhos de eficiência poderiam ser alcançados por meio do deslocamento do transporte de mercadorias das estradas para ferrovias e hidrovias (Seção 5.3). Na indústria, ganhos significativos poderiam ser alcançados em setores menos intensivos em energia, como o processamento de alimentos no qual, com frequência, oportunidades são desperdiçadas por falta de conhecimento ou acesso a crédito. No setor residencial, o consumo de energia já é relativamente baixo pelos padrões internacionais devido, em parte, à desnecessidade de aquecimento; portanto, o impacto de novas medidas seria menor que em outros setores. Um maior impacto viria da aplicação rigorosa de normas de eficiência energética para uma grande gama de equipamentos.

Fonte: IEA (2013), World Energy Outlook, IEA/OECD Publishing, Paris.

\section{Promoção da ecoinovação, produtos e serviços ambientais}

\subsection{Política e desempenho da inovação}

A inovação ganhou maior destaque nas políticas públicas brasileiras, ao longo dos anos 2000. O governo reconhece a inovação como fator imprescindível para aprimorar o desempenho e a competitividade econômica e comercial, e tem se empenhado em agregá-la ao sistema de P\&D (PD\&I) por meio de medidas institucionais, orçamentárias e legislativas (Box 3.7). O Brasil possui renomadas empresas, líderes em áreas de alta tecnologia, tais como: exploração de petróleo em águas profundas, aviação, energias renováveis e agrotecnologia. O sistema P\&D agrícola da Empresa Brasileira de Pesquisa Agropecuária (Embrapa) tem contribuído para o desenvolvimento de um setor de agronegócio competitivo que produz e disponibiliza tecnologias de ponta para produtores e agroindústrias e, notadamente, as tecnologias de agricultura tropical que permitiram a expansão agrícola nos cerrados (OECD, 2015d).

Essa liderança concentra-se em um número relativamente reduzido de empresas sem, no entanto, se estender à economia como um todo. As pequenas e médias empresas (PME) investem pouco em PD\&I, e inovam muito pouco. A maioria das atividades de PD\&I focaliza a pesquisa básica e é realizada em universidades públicas e instituições de pesquisa; e há uma grande desconexão entre essas instituições e a comercialização de tecnologias e de produtos inovadores. Vários gargalos restringem a inovação, entre eles, normas restritivas onerosas, sistema tributário complexo, tarifas elevadas e crédito 
de longo prazo muito caro (OECD, 2015d). Consequentemente, não obstante o aumento de despesas com $P \& D$ (Box 3.7), pelos padrões internacionais, os indicadores de desempenho da inovação continuam fracos: embora o número de patentes e marcas tenha aumentado, permanece significativamente abaixo do de países da OCDE e dos outros BRIICS como a China e a Índia (OECD, 2014). O baixo número de patentes pode estar relacionado à falta de incentivos para patenteamento nas instituições públicas, bem como a entraves regulatórios e a elevados custos de requerimento (Frischtak, 2011).

\section{Box 3.7. Políticas gerais de inovação}

O Ministério da Ciência, Tecnologia e Inovação (MCTI) planeja e coordena as atividades nacionais de PD\&I. Vários esforços foram empreendidos para reforçar o marco político e melhorar a coordenação entre as instituições públicas relevantes e as partes interessadas. Esses esforços incluem a Lei $n^{\circ} 10.973$ de 2004 (Lei de Inovação), que dispõe sobre incentivos para cooperação entre centros de pesquisa e empresas, e a Lei no 11.196 , de 2005 (Lei do Bem), que introduziu incentivos fiscais para fomentar a inovação na produção (OECD, 2014).

A Estratégia Nacional de Ciência, Tecnologia e Inovação (ENCTI, 2012-15) que define o marco político, tem como objetivos: i) diminuir o fosso tecnológico com as economias desenvolvidas; ii) apoiar a liderança do Brasil em áreas da economia do conhecimento que otimizem o aproveitamento dos abundantes recursos naturais do país, como a inovação verde, o agronegócio e outras atividades baseadas em recursos naturais; iii) reforçar a internacionalização do sistema nacional de pesquisa; iv) promover o desenvolvimento de uma economia verde; e v) combater substancialmente a desigualdade social e regional do país. A ENCTI está integrada ao Plano Brasil Maior 2011-14 de desenvolvimento industrial, o que atribui à inovação um papel central e inclui propostas de mudanças legislativas significativas.

O foco da política de inovação mudou para fomentar o aumento da participação de empresas em PD\&I. Uma iniciativa de destaque é o Plano Inova Empresa 2011, direcionado ao fomento da inovação empresarial em nove setores estratégicos. ${ }^{25} \mathrm{O}$ plano amplia o apoio a projetos de risco tecnológico e estabelece medidas para ampliar a cooperação público-privada. Esses projetos contemplam a redução da burocracia, a adição de novas modalidades de apoio, tais como, créditos descentralizados e subsídios projetados para alcançar microempresas e PMEs, oferecendo crédito, subvenções e financiamento de capital. Em 2013, o governo criou a Empresa Brasileira de Pesquisa e Inovação Industrial (Embrapii) para agilizar a transformação da pesquisa tecnológica em produtos inovadores. Inspirada no modelo da Embrapa, a intenção da Embrapii é alinhar a pesquisa tecnológica às demandas do setor produtivo, ex., por meio do estabelecimento de redes público-privadas de PD\&I.

A despesa interna bruta em P\&D aumentou para 1,2\% do PIB em 2012. Essa porcentagem é maior do que em outros países da América Latina e de todos os outros países BRIICS com exceção da China, mas permanece significativamente abaixo, tanto da média da OCDE que é de 2,4\%, quanto da meta da ENCTI de investir 1,8\%, até 2014 (OECD, 2014; MCTI, 2011). O investimento público cresceu ligeiramente mais rápido que o investimento privado, alcançando, em 2012, 55\% da despesa total em P\&D. Os fundos setoriais de tecnologia têm sido importante fonte de apoio à $P \& D$, desde o final da década de 1990. Existe um fundo para cada grande setor (quatorze no total) e mais dois fundos transversais. Em 2011, os fundos setoriais desembolsaram R $\$ 1,6$ bilhão para projetos de PD\&I.

\subsection{Marco político e desempenho da ecoinovação}

O Brasil não possui uma estratégia formal de ecoinovação, embora dimensões ambientais estejam presentes em todos os documentos de política estratégica de PD\&I industrial. Dois dos cinco objetivos fundamentais da ENCTI têm enfoque ambiental (Box 3.7). A ENCTI é direcionada a várias áreas ligadas à economia verde (ex., biotecnologia e nanotecnologia, energias renováveis, mudança do clima, biodiversidade, oceanos e zonas costeiras) e, para cada área, estabelece objetivos e etapas chave, embora sem metas quantificadas. Para reforçar a ecoinovação nas empresas, o governo criou o Inova 
Sustentabilidade, um dos nove programas setoriais estratégicos no âmbito do Plano Inova Empresa 2011 (Quadro 3.7). O Inova Sustentabilidade prevê investimento de R\$ 2 bilhões, no período 2014-16, em quatro áreas temáticas de inovação verde (BNDES, 2014). Até agosto de 2014, 126 empresas haviam apresentado planos de negócios. No entanto, a articulação entre o planejamento estratégico para a indústria, a inovação, as mudança do clima e as políticas ambientais, de modo mais ampla, continua fraca.

É difícil determinar o total dos recursos dedicados à ecoinovação, uma vez que as despesas não são explicitamente rastreadas. O MCTI estima que os investimentos para P\&D em "controle e proteção ambiental" em 2010, representaram 0,8\% dos desembolsos públicos para P\&D (MCTI, 2014a), proporção considerada baixa, pelos padrões da OCDE (embora os dados não sejam totalmente comparáveis). ${ }^{26}$ Uma parcela significativa dos recursos destinados à economia verde provém de fundos setoriais (Box 3.7) incluindo aqueles para agronegócio, energia e Amazônia. ${ }^{27} \mathrm{Em} \mathrm{2010,40 \%} \mathrm{dos} \mathrm{projetos} \mathrm{financiados}$ por esses fundos tinham relação com a economia verde (Frischtak, 2011). No entanto, estimativas indicam que o total do investimento público e privado em P\&D para a economia verde diminuiu, de 6\% da despesa total em P\&D em 2000, para 3\% em 2010. A maior parte desse investimento destina-se a energias renováveis (45\%) com 80\% destinados a biocombustíveis; agricultura de baixo carbono (23\%); uso sustentável da biodiversidade (17\%), sendo grande parte para cosméticos naturais; e proteção de ecossistemas (10\%) (Frischtak, 2011).

Seguindo o padrão geral do desempenho da inovação no país, os investimentos em PD\&I relacionada ao meio ambiente ocorrem principalmente em multinacionais e grandes empresas nacionais (com destaque para a EMBRAPA e a PETROBRAS). Um levantamento da indústria, realizado pelo IBGE, revelou que o número de empresas industriais que geram inovações relacionadas ao meio ambiente havia crescido significativamente, mas manteve-se pequeno, em relação ao número total de empresas industriais (IBGE, 2013). Por outro lado, várias multinacionais estabeleceram centros de PD\&I no Brasil, a maioria deles ligados direta ou indiretamente aos recursos naturais (incluindo energias renováveis, minerais, agricultura e biodiversidade), segundo levantamento realizado entre as multinacionais pela OCDE, em conjunto com o BNDES, em 2011. O mesmo levantamento revelou que pesquisas nesse campo tendem a ser sofisticadas, e que os recursos naturais e as tecnologias verdes selecionadas poderiam impulsionar a participação brasileira na dinâmica de inovação global (Arbache et al., 2012).

A intensificação das políticas de fomento, em parte acompanhada pelo financiamento público de P\&D vem contribuindo para melhorar alguns indicadores de desempenho relacionados ao meio ambiente e a tecnologias relacionadas ao clima. Entre 2001 e 2010, o número per capita de requerimento de patentes nessas áreas tecnológicas quadruplicou. Esse aumento no número de patentes ambientais concentrou-se, principalmente, na área de energias renováveis; seguido por água e mitigação da poluição atmosférica; gestão de resíduos; redução de emissões e maior eficiência do combustível nos transportes (Figura 3.9). No entanto, permanece muito limitado o número de patentes em outros campos relacionados ao meio ambiente nos quais o Brasil poderia ter uma vantagem comparativa (ex., agrotecnologia de soja e cana-de-açúcar ou conhecimento em biodiversidade).

As tecnologias relacionadas ao meio ambiente e ao clima responderam por cerca de $9 \%$ de todas as patentes registradas no Brasil, entre 2009 e 2011; enquanto que a média da OCDE foi de $11 \%$ e a dos BRIICS de 7,8\%. A especialização do Brasil em tecnologia ambiental, mensurada pelo índice de vantagem tecnológica revelada 
(RTA) aumentou entre os períodos 2000/2003 e 2009/2011. ${ }^{28}$ O índice RTA do Brasil em tecnologia ambiental está acima da média dos BRIICS, mas abaixo da mediana da OCDE. Nas áreas de biotecnologia e nanotecnologia, o Brasil detém uma vantagem tecnológica revelada em relação, tanto aos BRIICS quanto à OCDE (OECD, 2014).

O Brasil tem aproveitado bem o Mecanismo de Desenvolvimento Limpo (MDL) criado no âmbito da Convenção sobre Mudança do Clima das Nações Unidas para incentivar boas práticas, disseminação do conhecimento e da tecnologia e adoção de padrões de produção sustentáveis. ${ }^{29}$ Em termos mundiais, o Brasil ocupa o terceiro lugar, depois da China e da Índia, na geração de certificados de crédito CDM para redução de emissões de gases, com enfoque sobre: metano (27\%); hidrelétricas (25\%); gás de aterro sanitário (13\%); e energia de biomassa (12\%). O MDL vem servindo de importante estímulo à transferência de tecnologias, notadamente a energia de biomassa e recuperação de biogás em fazendas de criação e aterros sanitários, embora a porcentagem de projetos brasileiros de MDL envolvendo transferência de tecnologias seja menor (em relação ao total de projetos MDL) do que em outros países receptores (25\%, comparado com a média de $40 \%$ ); o número absoluto de projetos envolvendo transferência de tecnologias vem diminuindo desde meados dos anos 2000. Um número expressivo de projetos de MDL vem sendo patrocinado no mercado nacional, o que sugere que o MDL cria incentivos endógenos para iniciativas de base tecnológica (UNFCCC 2010; Seroa da Motta, 2009).

\section{Figura 3.9. Aumentou o número de patentes em tecnologias relacionadas ao meio ambiente e ao clima}

\section{Patentes em áreas de gestão de tecnologias ambientais,} 2000-11
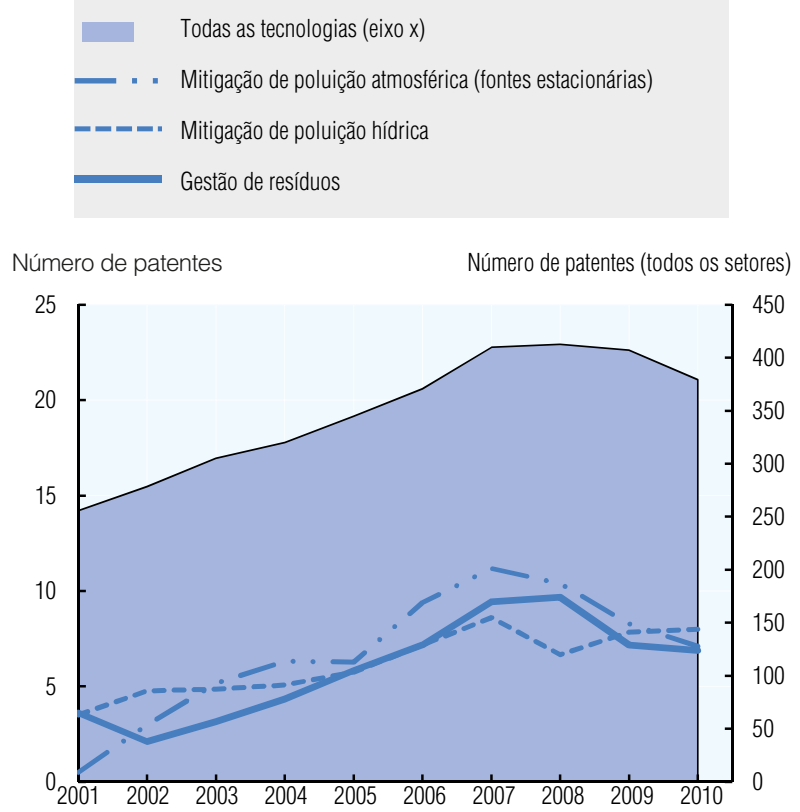

Patentes em tecnologias relacionadas à energia e ao clima, 2000-11
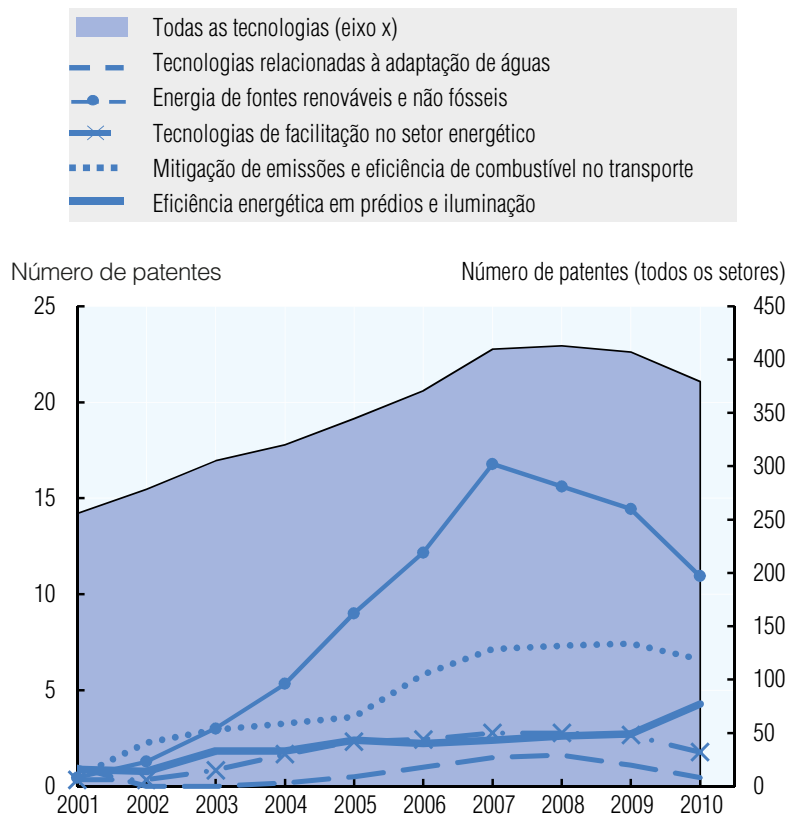

Obs.: Invenções de maior valor que buscaram patentes em pelo menos duas jurisdições. Dados se referem à contagem de requerimentos, com base na data de prioridade e no país de domicílio do inventor. Três anos de prazo, em média.

Fonte: Baseado em: OECD (2015), "Patents in environment-related technologies: Technology development by inventor country", OECD Environment Statistics (database). 
A ecoinovação enfrenta barreiras semelhantes às da inovação em geral, incluindo fraca articulação entre instituições científicas e indústrias, carência de competências, entraves regulatórios, elevados custos de requerimento de patentes e um complexo sistema de incentivos econômicos e fiscais. Várias formas de proteção às empresas nacionais, incluindo a ECL (Box 3.5) e elevadas tarifas aduaneiras, inibem a concorrência e desestimulam a inovação e a adoção de tecnologias mais limpas e eficientes. As políticas de inovação e ecoinovação brasileiras baseiam-se, em grande parte, em medidas que privilegiam a oferta, a exemplo do estímulo oficial para P\&D. Contudo, é fraca a relação entre $P \& D$, de um lado, e o desenvolvimento industrial e comercialização de novas tecnologias, de outro. Como consequência, o impacto na cadeia de abastecimento das atividades de ecoinovação - sobre o emprego, por exemplo - é limitado (Arbache et al., 2012).

Recentemente, vêm sendo aplicadas algumas medidas de estímulo ao consumo, incluindo políticas setoriais que estabelecem metas de desempenho ambiental e requisitos de sustentabilidade para compras governamentais. Por exemplo, o Plano Brasil Maior 2011 foi a primeira estratégia de desenvolvimento industrial a estabelecer metas ambientais específicas (ex., redução da intensidade energética do setor industrial em $9 \%$, até 2014). Em 2012, o governo lançou sua política de compras sustentáveis para priorizar a aquisição de produtos verdes, entre outros, estimulando assim a oferta e a demanda por bens e serviços ambientais (Capítulo 2). ${ }^{30}$ Há margem para ampliar a garantia de investimentos, por exemplo, por meio da definição de requisitos mais ambiciosos de desempenho ambiental para produtos e atividades econômicas (ex., veículos e equipamentos), da promoção de certificação ambiental (ver Seção seguinte) e da aplicação mais rigorosa das normas ambientais existentes (Capítulo 2). Tais medidas ajudariam a expandir os mercados de tecnologia, produtos e serviços ambientais (Seção 6.3).

\subsection{Expansão do mercado de tecnologia, produtos e serviços ambientais}

O Brasil poderia se valer da experiência internacional para aprimorar sua base de informações sobre o mercado de produtos e serviços ambientais e desenvolver um conceito claro de atividades econômicas verdes e indicadores conexos, o que ajudaria na apuração dos efeitos de políticas ambientais e suas consequências socioeconômicas, por facilitar o desenvolvimento e a avaliação das políticas destinadas a acelerar a transição rumo a uma economia verde e sustentável.

Segundo a Environmental Business International, o mercado de produtos e serviços ambientais do Brasil alcançou US\$15,9 bilhões em 2010 (0,7\% do PIB) o que representa $47 \%$ do mercado latino-americano, ou $2 \%$ do mercado global (ABDI, 2012). Um estudo do US Commercial Service (2014) sugere que o volume do mercado brasileiro de tecnologia ambiental (que exclui produtos e servições ambientais não-industrial, tais como ecoturismo ou aproveitamento de produtos naturais e da biodiversidade) alcançou US\$ 12 bilhões, em 2014. Água, saneamento e resíduos sólidos representam a maior parte do mercado, refletindo as ações do governo para expandir a cobertura desses serviços nos últimos anos (Seção 5.2).

São poucos os estudos que tentam quantificar o emprego em setores verdes. A Organização Internacional do Trabalho (OIT) estima que cerca de 3 milhões de brasileiros 
estavam ocupados no setor verde em 2008 (quase 7\% do emprego formal); outros estudos apresentam estimativas que variam entre 1,4 milhão e mais de 16 milhões de empregos verdes (OIT, 2010; Nonato e Maciente, 2012). O International Food Policy Research Institute (IFPRI, 2006) estimou que, por si só, o programa de biocombustíveis do Brasil criou 1,3 milhão de postos de trabalho nas zonas rurais. O Banco Mundial (BIRD, 2010b) estima que a adoção de tecnologias de baixo carbono poderia aumentar o emprego no Brasil em 1,1\% ao ano, entre 2010 e 2030. A experiência de outros países, Espanha por exemplo, mostra que a expansão de setores verdes, como energias renováveis, água e gestão de resíduos, pode criar novas oportunidades de emprego (OCDE, 2015e). No entanto, o grande potencial de criação de empregos, relacionado a metas de aproveitamento de energias renováveis no Brasil (Seção 5.4), por exemplo, não vem sendo considerado ou adequadamente refletido em estudos e políticas governamentais (Bowen, 2012).

O mercado de produtos e serviçoes ambientais no Brasil deverá crescer consideravelmente nos próximos anos. O US Commercial Service (2014) estima que o valor potencial do mercado de tecnologia ambiental representa entre 1\% e 7\% do PIB. Aparentemente, o setor cresceu mais rapidamente que a economia como um todo (ABDI, 2012). É provável que a demanda interna por tecnologia e serviços de consultoria relacionados ao meio ambiente aumente, acompanhando o avanço da legislação ambiental, a fiscalização mais rigorosa e a necessidade de novos investimentos relacionados ao desenvolvimento econômico e à urbanização, em setores como água, ar, resíduos, energia e transportes. O Brasil poderá se aproveitar também da crescente demanda externa por serviços e produtos naturais certificados (ex., manejo florestal e agricultura sustentável, cosméticos naturais) e, em vista da fase relativamente incipiente do setor em toda a região, posicionar-se como principal fornecedor de produtos e serviços ambientais para a América Latina.

Atualmente, os mercados relacionados a produtos e serviços ambientais no Brasil são extremamente heterogêneos. Alguns, como os de tecnologia de geração hidrelétrica, biocombustíveis de primeira geração, conversão de biomassa em carvão vegetal, gaseificação de biomassa, cogeração, e sistemas de célula a combustível e hidrogênio para pequenas empresas, são bem desenvolvidos (Jannuzzi e Poppe, 2014). No entanto, a oferta interna de tecnologias relacionadas à redução de emissões, à eficiência energética e de recursos, à otimização de processos, ao tratamento de resíduos e à reciclagem é limitada; e o acesso à importação de produtos e serviços é relativamente restrito. Tais limitações resultam em custos elevados e desestimulam a opção de empresas por tecnologias e modos de produção mais sustentáveis. O custo de equipamentos para evitar a poluição atmosférica, por exemplo, fica entre $45 \%$ a 50\% maior no Brasil do que em outros países, devido à falta de produtos nacionais e a elevados tributos e direitos alfandegários (IEMA, 2014).

Em resposta à crescente demanda externa, empresas brasileiras vem se envolvendo cada vez mais na certificação e rotulagem ambiental de produtos. Porém, por falta de órgãos nacionais de certificação para diversas linhas de produtos, as empresas se veem obrigadas a buscar certificação internacional, muitas vezes a custos proibitivos, especialmente para PMEs. O MMA lançou, em 2002, o Programa Brasileiro de Rotulagem Ambiental com o objetivo de estimular demanda por produtos com menor impacto ambiental. O programa visava a coordenação e articulação de iniciativas de rotulagem ambiental existentes, mas não alcançou avanços expressivos (IPEA, 2010a). 
Empresas grandes, novas e altamente produtivas tendem a investir mais em tecnologia ambiental (ADBI, 2012). No entanto, uma enquete realizada em 2009 entre as 100 principais empresas brasileiras indicou que elas investiram apenas $1 \%$ do seu faturamento em tecnologia sustentável, sendo as principais barreiras identificadas a insuficiência de disponibilidade, preços elevados e falta de informação e conhecimento sobre tecnologias sustentáveis (AHK, 2009). Esse baixo nível de investimento aponta para uma falta de capacidade técnica na indústria que, por sua vez, impede o desenvolvimento da indústria verde. Não obstante a existência de atividades de desenvolvimento de competências relacionadas ao esverdeamento da economia, essas ainda não foram bem assimiladas pela estratégia ou marco político global (OIT, 2010). Para responder às novas demandas dos setores verdes e reduzir carências de conhecimento e habilidades, será necessária a adoção de novas políticas de desenvolvimento e um melhor alinhamento entre as áreas ambiental, industrial e de mercado de trabalho. $O$ mercado de trabalho e a política social precisam se adequar à tendência de aumento no número de postos de trabalho relacionados ao meio ambiente para inibir qualquer aumento da desigualdade.

\subsection{Práticas empresariais verdes voluntárias}

As empresas brasileiras praticam a responsabilidade social corporativa (RSC) com alto grau de sofisticação, em comparação com as de outros países da América Latina (Scharf, 2009; Galego-Álvarez et al, 2014). O setor empresarial desenvolve ações inovadoras e de grande alcance para o tratamento de impactos sociais e ambientais, e algumas empresas de crescimento dinâmico, como a Natura (Box 3.8) baseiam-se em modelos de negócios norteados pela inovação e a sustentabilidade. No entanto, o desempenho das empresas brasileiras em termos de RSC é heterogêneo; condições de trabalho socialmente inaceitáveis, ineficiências na gestão de recursos naturais e condutas nocivas ao meio ambiente prevalecem em um expressivo número de empresas. No geral, contudo, houve aumento das atividades de RSC nas empresas brasileiras, e não apenas nas de grande porte, ao longo dos anos 2000 (Ethos, 2008).

Para enfrentar os desafios socioambientais do país, foram criadas associações tais como o Compromisso Empresarial para a Reciclagem e o Conselho Empresarial Brasileiro para o Desenvolvimento Sustentável. Existem exemplos bem-sucedidos de cooperação entre associações empresariais e instituições públicas, como a Moratória da Soja de 2006, que teve como objetivo frear o avanço do cultivo de soja em áreas desmatadas da Amazônia. No contexto da moratória, associações representativas da indústria de óleos vegetais e de exportadores de grãos empenharam-se juntamente com o MMA e o Instituto Nacional de Pesquisas Espaciais (INPE) no cadastramento de propriedades rurais na Amazônia e no mapeamento e monitoramento de áreas desmatadas (Capítulo 4).

Cresceu muito o número de empresas brasileiras com sistemas de gestão ambiental certificados pela norma ISO 14001 (Capítulo 2). Embora esses sistemas não conduzam necessariamente a melhores resultados ambientais, há indícios de que a certificação ISO teve, em média, impacto positivo sobre a rentabilidade das empresas brasileiras (Tognere Ferron et al., 2012).

Empresas brasileiras, principalmente as de grande porte, vêm atuando fortemente também na mitigação de mudanças climáticas. Em 2009 - isto é, mesmo antes da adoção de metas e da Política Nacional de Mudança do Clima (PNMC) - 20 grandes empresas se 
comprometeram em reduzir as emissões de GGE por unidade de produção ou receita. Cerca de 100 empresas brasileiras, participantes da Greenhouse Gas Protocol Initiative ${ }^{31}$ preparam, voluntariamente, relatórios de emissões de GEE; algumas vão ainda mais longe, apresentando avaliações e gerindo suas pegadas de carbono.

\section{Box 3.8. Sustentabilidade como modelo de negócio: Natura}

A Natura, empresa brasileira de cosméticos fundada em 1969, está entre as 20 maiores empresas do mundo no segmento da beleza. Detém aproximadamente $20 \%$ do mercado nacional, opera em uma dezena de países e registrou faturamento de $\mathrm{R} \$ 5,5$ bilhões, em 2011. Sua estratégia de negócios baseia-se na inovação, na sustentabilidade proativa e no marketing ambiental como fator de diferenciação no mercado. A empresa busca minimizar seu impacto ambiental ao longo dos ciclos de vida de seus produtos e trabalha com produtores familiares e comunidades tradicionais para promover a geração de renda sustentável.

Em 2010, a Natura lançou um programa estratégico para aumentar a sustentabilidade de sua cadeia de fornecedores. Os fornecedores são avaliados não apenas com base nos preços dos produtos, mas também num "preço sombra" que inclui custos e benefícios sociais e ambientais (ex., emissões de $\mathrm{CO}_{2}$, geração de resíduos, uso da água, educação e treinamento de funcionários, inclusão social, investimento direto na sociedade). Inicialmente, o programa envolveu 50 dos maiores fornecedores da empresa, proporcionando-lhes capacitação sobre a coleta de dados e a metodologia proposta pela empresa. Até 2014, o programa já englobava cerca de $90 \%$ dos fornecedores. A Natura estima em mais de US\$ 750 mil os benefícios socioambientais da seleção de fornecedores com base no desempenho em sustentabilidade, em 2012.

Para desenvolver novos produtos sustentáveis, a Natura estabeleceu parcerias com instituições de pesquisa, fornecedores, produtores locais e ONGs. A empresa recebeu, em 2012, apoio público no valor de US\$ 43 milhões para atividades de inovação, formação, logística e TI.

Fonte: UNEP (2014), The Business Case for Eco-innovation, United Nations Environment Programme, Paris; WRI (2013), "Aligning profit and environmental sustainability: Stories from industry", World Resources Institute, Washington, DC.

\section{Meio ambiente e cooperação para o desenvolvimento}

\subsection{Brasil como beneficiário de cooperação para o desenvolvimento}

Apesar de o Brasil ser um país de renda média, recebe volumes significativos de assistência oficial ao desenvolvimento (AOD). O valor dos desembolsos de AOD aumentou ao longo dos anos 2000, alcançando US\$ 1,4 bilhão em 2012, o que fez do Brasil o maior beneficiário de AOD da América do Sul naquele ano (Figura 3.10). No entanto, em vista do tamanho da sua economia interna, a dependência relativa do país, em relação à ajuda externa, é baixa. Entre 2000 e 2013, a AOD oscilou entre 0,01 e 0,06\% da renda nacional bruta (RNB) ao ano; a AOD média per capita, que antes era de cerca de US\$ 2 ao ano, aumentou para mais de US\$ 5, em 2012-13 (OCDE, 2013e).

O meio ambiente e a economia verde estão entre as principais áreas destinatárias da AOD no Brasil. Em 2013, apenas os recursos direcionados ao Fundo Amazônia somaram US\$ 300 milhões; e cada projeto voltado a energias renováveis, água e saneamento recebeu mais de 400 milhões de dólares (OCDE, 2015f). Segundo o Creditor Reporting System ${ }^{32}$ da OCDE, cerca de $60 \%$ da AOD bilateral contratada para o Brasil ao longo da última década foi direcionado à sustentabilidade ambiental. O total para fins ambientais alcançou cerca de US\$1,8 bilhão em 2012, mas diminuiu em 2013. A parcela desses recursos destinada estritamente ao meio ambiente é relativamente pequena ${ }^{33}$ (em média, US\$ 83 milhões em 2011-13); e a maior parte da assistência é destinada a outros setores com objetivos ambientais secundários (Figura 3.10). A assistência 
para essa última categoria mais do que triplicou entre 2011 e 2012, impulsionada por grandes projetos nos setores de água e saneamento, florestal, transportes e energia. No geral, a AOD relacionada aos objetivos das Convenções do Rio aumentou nos últimos anos, especialmente aquela destinada à mitigação da mudança do clima (Figura 3.10). As maiores doações para a sustentabilidade ambiental provieram da Alemanha, Noruega e Reino Unido.

\section{Figura 3.10. Meio ambiente é uma das principais áreas para a assistência oficial ao desenvolvimento do Brasil}

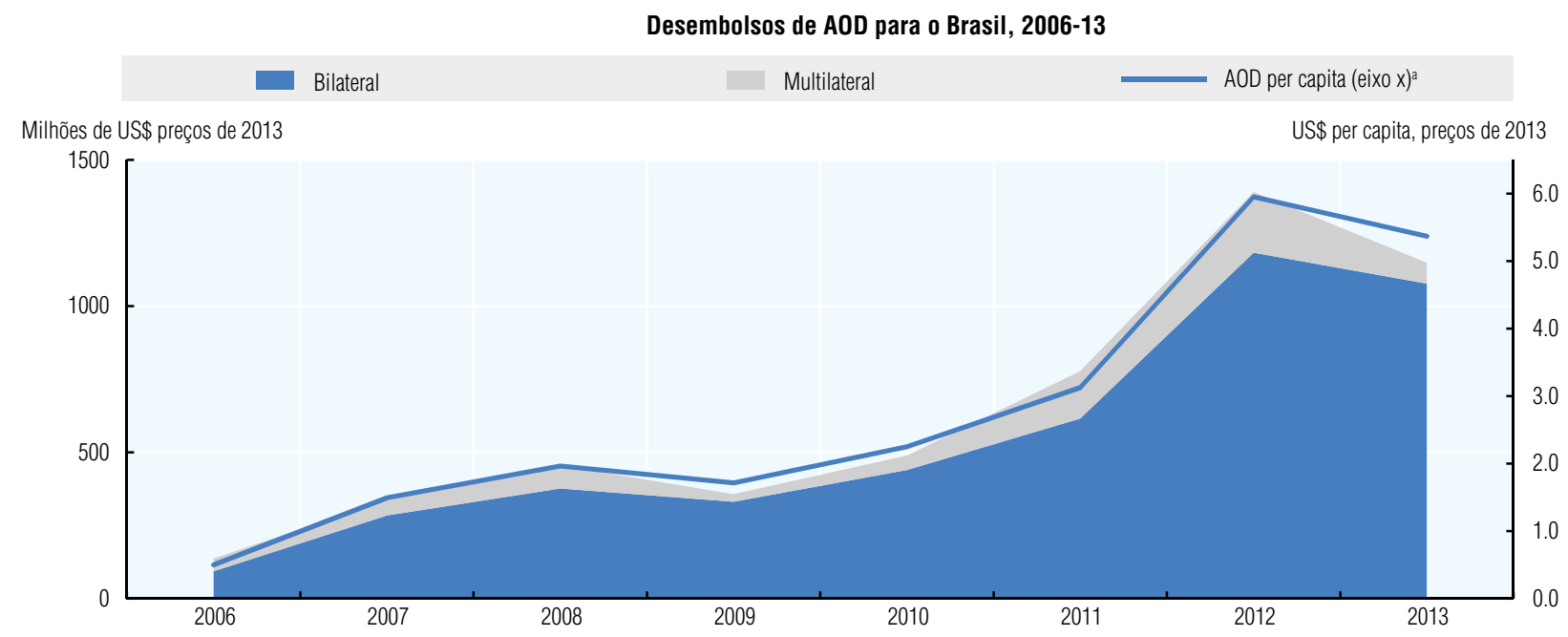

AOD bilateral em apoio ao meio ambiente do Brasil ${ }^{b}$

AOD ambiental, ${ }^{\circ} 2006-13$

\section{Setor ambienta}

Outras atividades direcionadas principalmente ao meio ambiente

Atividades com objetivos ambientais significativos

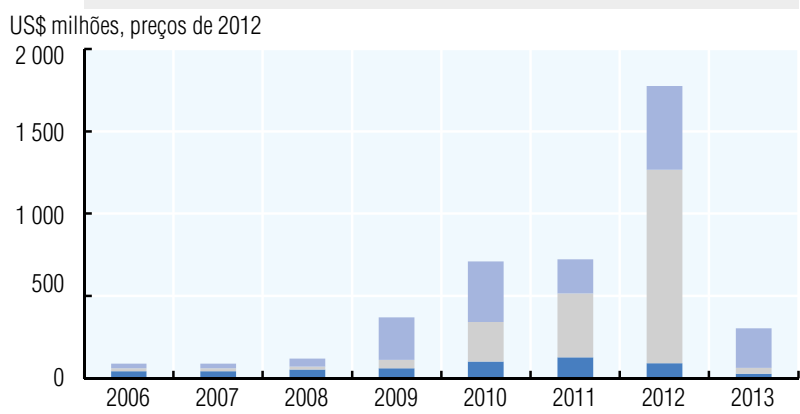

A0D relacionada às Convenç̃es do Rio, 2010-13d

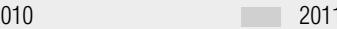

2012

US\$ milhões, preços de 2012

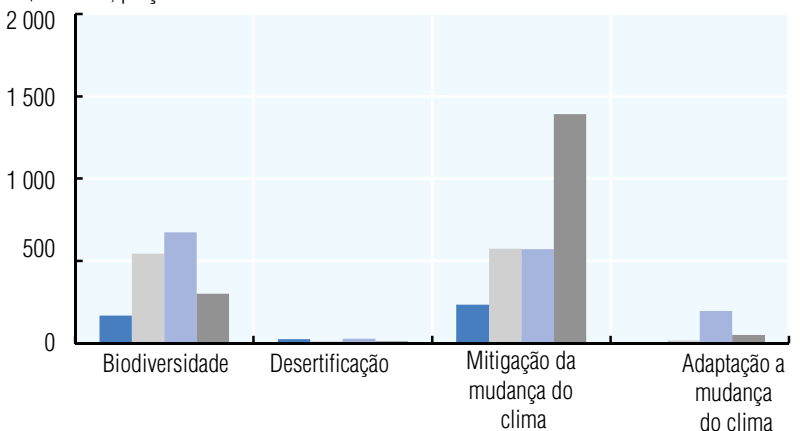

a) Assistência bilateral ao desenvolvimento oficial de membros do Comitê de Assistência ao Desenvolvimento (DAC) da OCDE.

b) Dados do marcador não permitem a quantificação exata de quantias alocadas ou gastas em apoio ao meio ambiente. Proporcionam uma indicação dos fluxos de assistência e descrevem até que ponto os doadores abordam esses objetivos em seus programas de assistência.

c) Setor ambiental: assistência direta em apoio a atividades gerais de proteção ambiental. Outras atividades tendo o meio ambiente como enfoque principal: atividades de apoio em que a proteção ambiental é objetivo explícito da atividade e fundamental para seu design. Atividades em que o meio ambiente é objetivo significativo: atividades em que a proteção ambiental é objetivo importante, mas secundário da atividade.

d) A maioria das atividades direcionadas aos objetivos das Convenções do Rio se encaixam na definição de "assistência focalizada no meio ambiente", mas não há uma combinação direta entre suas respectivas coberturas. Uma atividade pode ser direcionada a objetivos em mais de uma das convenções; portanto, os respectivos fluxos da AOD não devem ser somados.

Fonte: OCDE (2015), OECD International Development Statistics (database). 
O Brasil tem recebido significativos aportes financeiros de mecanismos de financiamento multilateral, estabelecidos no âmbito de iniciativas ambientais internacionais, a exemplo do Fundo Global para o Meio Ambiente (GEF). ${ }^{34}$ Alguns dos principais projetos ambientais, como o Projeto Nacional de Ações Integradas Público-Privadas para Biodiversidade e o programa de Áreas Protegidas da Amazônia (ARPA) (Capítulo 4), recebem recursos do GEF, embora a carteira de projetos do Brasil seja grande e diversificada. Dos atuais 55 projetos nacionais, 23 são direcionados à biodiversidade (representando $45 \%$ do total de doações do GEF) e 13 à mudança do clima (24\%); os demais abordam águas internacionais, degradação do solo e poluentes orgânicos persistentes. O Brasil participou de 34 projetos regionais e globais na América Latina, patrocinados pelo GEF. A avaliação da carteira do GEF no país demonstrou que esse financiamento ajudou a desenvolver a sustentabilidade da capacidade institucional e estimulou o envolvimento do setor privado em projetos de adaptação à mudança do clima (GEF, 2012).

\subsection{Brasil como prestador de cooperação para o desenvolvimento}

O Brasil vem, cada vez mais, atuando como prestador de cooperação para o desenvolvimento. Segundo estimativas oficiais, as despesas federais em cooperação para o desenvolvimento aumentaram, de $\mathrm{R} \$ 384$ milhões em 2005, para $\mathrm{R} \$ 724$ milhões em 2009, podendo esses valores subestimar o total dos gastos de todas as instituições públicas (IPEA, 2010b). ${ }^{35}$ Cerca de dois terços do volume dos gastos entre 2005 e 2009 foram na forma de contribuições para organizações internacionais ou fundos regionais, sendo a maioria dos repasses efetuada por meio do Fundo para a Convergência Estrutural do Mercosul. Estimativas mais atuais indicam que a cooperação brasileira para o desenvolvimento internacional alcançou, em 2010, R\$ 1,6 bilhão (US\$ 927 milhões) (IPEA, 2014). ${ }^{36}$ Pelas estimativas da OCDE, para 2010, US $\$ 500$ milhões dos fluxos podem ser considerados AOD e, desses, $60 \%$ foram repassados por meio de organizações multilaterais (OCDE, 2015g). ${ }^{37}$ No geral, o número de projetos aumentou, de 69 em 2005, para mais de 400 em 2010. Os projetos bilaterais são principalmente de cooperação técnica. Inicialmente, os países latino-americanos e africanos de língua portuguesa foram o principal foco, mas, atualmente, a cooperação brasileira se estende para cerca de 70 países em desenvolvimento na África, Ásia e América Latina.

A cooperação técnica é supervisionada e coordenada pela Agência Brasileira de Cooperação $(A B C)$ do Ministério das Relações Exteriores, com sua execução a cargo de mais de 170 instituições federais (IPEA, 2014). É crescente o envolvimento de instituições públicas brasileiras na negociação e elaboração de projetos de cooperação técnica, geralmente por meio de suas próprias assessorias internacionais, com participação limitada da $A B C$. Aparentemente, a participação da $A B C$ na colaboração envolvendo o MMA é menos rígida do que em outras áreas, como a da saúde e da proteção social.

Nas áreas temáticas, a saúde, a agricultura e a educação foram o principal foco da cooperação brasileira, respondendo por cerca da metade das atividades de cooperação técnica, entre 2003 e 2010. O meio ambiente tem recebido menor destaque; com 
projetos ambientais respondendo por 7,5\% e os de energia por 3,5\%, em 2010 (Cabral e Weinstock, 2010). Ultimamente, o número de projetos ambientais vem crescendo e há boas perspectivas de maior crescimento no futuro próximo; por exemplo, o governo pretende expandir a cooperação sul-sul em recuperação florestal (MCTI, 2014b). Não existe qualquer triagem sistemática para evitar que projetos de cooperação técnica tenham impactos ambientais potencialmente negativos.

O carro-chefe das iniciativas brasileiras de cooperação técnica tem sido a agricultura. A maior delas, o programa Pró-Savana, implementado conjuntamente pelo Brasil, Japão e Moçambique para o desenvolvimento agrícola em áreas da savana moçambicana, tem como inspiração o desenvolvimento dos cerrados brasileiros. Entre os projetos agrícolas lançados em países africanos, entre outros, vários tinham como foco o fomento à agroenergia. A Africa-Brazil Agricultural Innovation Marketplace, de 2010, é uma iniciativa internacional de pesquisa voltada à inovação em áreas agrícolas da África, englobando a recuperação de áreas de pastagem, a gestão de recursos naturais e a produção de energia limpa. O Brasil tem firmado com países africanos vários acordos bilaterais de cooperação na área de biocombustíveis, visando transferências de tecnologia para o desenvolvimento local de indústrias de biocombustíveis.

Em articulação com outros países, o Brasil vem compartilhando sua experiência em monitoramento de florestas e uso da terra. O Instituto Nacional de Pesquisas Espaciais (INPE) que desenvolveu técnicas de sensoriamento remoto do desmatamento na Amazônia (Box 4.4) mantém, em Belém, um centro de treinamento em monitoramento de florestas por satélite (INPE, 2014). Além disso, o Fundo Amazônia passou a financiar projetos fora do Brasil, repassando cerca de US\$ 10 milhões para a Organização do Tratado de Cooperação Amazônica (OTCA) por meio de um projeto que tem como objetivo a ampliação do monitoramento sistemático da cobertura florestal nos outros sete países que compartilham o Bioma Amazônia com o Brasil.

O Brasil se destaca como um dos parceiros mais ativos em cooperação triangular (OCDE, 2013f), modalidade esta que o governo considera fundamental para a ampliação e aprimoramento do impacto da cooperação técnica brasileira. Seus principais parceiros na cooperação triangular são doadores bilaterais e organizações internacionais (OCDE 2013f; OECD, 2015g). Um exemplo de cooperação triangular com enfoque no meio ambiente é o projeto Amazônia Sem Fogo, uma parceria entre Brasil, Itália e Bolívia que tem como objetivo a redução do desmatamento, por meio da oferta de alternativas ao uso de queimadas na agricultura, visando à proteção ambiental e à melhoria das condições de vida de comunidades rurais. Em 2013, o BNDES celebrou acordos com agências de fomento dos países BRIICS para promover a colaboração técnica, incluindo "iniciativas para promoção de uma economia de baixo carbono e para o desenvolvimento da infraestrutura no continente africano" (BNDES, 2013b). 


\section{Recomendações sobre o esverdeamento da economia no contexto do desenvolvimento sustentável}

\section{Esverdeamento do sistema de impostos e encargos}

- Reformar o sistema de tributos e encargos no que tange ao meio ambiente, possivelmente no contexto de uma reforma fiscal mais ampla, incluindo:

* manutenção de alíquotas positivas para a contribuição CIDE sobre combustíveis, ajustando-as de modo a refletir o teor do carbono do combustível e as emissões de poluentes atmosféricos locais; aplicação da CIDE para combustíveis usados na aviação e máquinas estacionárias (por exemplo, nas indústrias);

* introdução de tributos sobre poluição (ex.: emissões atmosféricas), resíduos (materiais de embalagem), aproveitamento de recursos (minerais) e alinhamento de alíquotas de tributos sobre veículos com o desempenho ambiental; e

* garantia de que a cobrança pela captação de água ou pela descarga de poluentes reflita a escassez e as pressões sobre o meio ambiente e seja aplicada, de forma consistente, em todas as bacias hidrográficas do país (em conformidade com a legislação).

- Prosseguir com a avaliação de opções de preço de carbono; considerar o ensaio de precificação de GEEs em um regime de comércio e limites de emissões (cap-and-trade) em nível estadual, visando a adquirir a experiência necessária para a implementação de um sistema nacional interligado aos mercados internacionais de carbono.

\section{Investimentos em infraestrutura e serviços relativos ao meio ambiente}

- Integrar, de forma sistemática, objetivos ambientais às políticas setoriais e aos programas de investimento público, cuja implementação deve contemplar critérios de sustentabilidade ambiental e indicadores para o monitoramento de seu progresso.

- Simplificar os procedimentos administrativos e fomentar a capacitação para melhorar a execução de programas de investimento em infraestrutura relacionados ao meio ambiente, especialmente no nível local. Estimular a forte colaboração intermunicipal, visando a alcançar economias de escala na prestação de serviços de saneamento e de tratamento de resíduos.

- Estender a aplicação de encargos pelo uso da água, pelos serviços de saneamento e coleta de resíduos e reforçar a sua cobrança, com vistas a estimular o uso eficiente de recursos, ampliar a recuperação de custos, melhorar a viabilidade financeira do investimento e alavancar recursos do setor privado; usar transferências sociais para garantir que famílias de baixa renda tenham acesso adequado a esses serviços.

- Reforçar medidas para melhorar a eficiência energética por meio da introdução de normas para prédios e aparelhos, integrando-as aos programas de habitação social e aplicando normas obrigatórias de economia de combustível e rotulagem para promover uma mudança em prol de veículos mais eficientes.

- Continuar a ampliar investimentos em ferrovias e sistemas de transporte público urbano; considerar a ampliação do uso de instrumentos, tais como: pedágios, taxas de congestionamento, cobrança de estacionamento e restrições sobre a circulação de automóveis, com o objetivo de moderar o uso de veículos particulares. 
Recomendações sobre o esverdeamento da economia no contexto do desenvolvimento sustentável (continuação)

\section{Ecoinovação e bens e serviços ambientais}

- Estimular a produção e a difusão de tecnologias, bens e serviços ambientais, por meio das seguintes ações:

* ampliar a consciência sobre melhores práticas e tecnologias disponíveis, particularmente em pequenas e médias empresas;

* facilitar o acesso a financiamentos para investimento em tecnologias em prol do meio ambiente, energias renováveis e eficiência energética;

* monitorar os efeitos de regras de conteúdo local sobre a competitividade de longo prazo da emergente indústria de tecnologia ambiental (ex.: eólica e solar);

* atualizar, regularmente, o catálogo dos bens e serviços para as compras públicas sustentáveis;

* realizar capacitações para gestores de compras públicas sustentáveis;

* racionalizar ainda mais as iniciativas de rotulagem ambiental.

\section{Notas}

1. As receitas da CIDE são arrecadadas pelo governo federal, sendo cerca de $30 \%$ destinadas aos estados proporcionalmente à extensão de suas rodovias, seu consumo de combustíveis e sua população.

2. A reforma de 2012 eliminou a Conta de Consumo de Combustíveis (CCC) e a Reserva Geral de Reversão (RGR). A CCC era paga pelas distribuidoras de energia e repassada ao consumidor final. Suas receitas eram utilizadas pela ELETROBRAS para subsidiar o diesel utilizado em sistemas isolados de geração na região Norte. A RGR não incidia sobre o consumo de energia elétrica, mas era paga pelas empresas geradoras e transmissoras, na alíquota de 2,5\% do valor dos ativos imobilizados em serviço ou até $3 \%$ do faturamento anual das empresas. Era destinada ao financiamento do programa Luz Para Todos (Seção 5.4) e ao programa nacional de iluminação pública eficiente.

3. Faz parte da Compensação Financeira pelo Uso de Recursos Hídricos: geradores de energia hidrelétrica são cobrados a $6,75 \%$ do valor da energia elétrica produzida. A receita proveniente da parte de $6 \%$ do encargo é compartilhada entre o governo federal e os governos estaduais e municipais afetados pelas hidrelétricas. Essa receita não é direcionada a infraestruturas hídricas e fins ambientais (OCDE, 2012). Em 2013, as receitas provenientes dessa fonte somaram cerca de $\mathrm{R} \$ 1,5$ bilhão.

4. Por exemplo, antes da reforma fiscal de 2013, o México aplicava um imposto especial de consumo com alíquota flutuante sobre a gasolina e o diesel. A alíquota variava de acordo com uma fórmula vinculada aos preços internacionais dos combustíveis. Na prática, quando o preço internacional estava em alta, a alíquota se tornava negativa, de modo que os preços internos caíam abaixo do custo de importação da gasolina e do diesel. Por outro lado, um preço internacional mais baixo desencadeava um aumento da alíquota (OECD, 2013b).

5. PIS/COFINS são contribuições sociais que incidem sobre a receita bruta da venda de combustível; geralmente as alíquotas são mais elevadas que o normal.

6. ICMS é um imposto estadual de valor agregado que incide sobre importações e transações intra e interestaduais de bens e serviços. A alíquota normalmente varia entre $17 \%$ e $19 \%$. Em geral, a alíquota que incide sobre a energia elétrica é mais elevada (25\%); a alíquota interestadual padrão incide sobre operações com petróleo e gás; para operações de gás natural, a alíquota é de $12 \%$. Operações interestaduais com petróleo e seus derivados são isentas; o gás natural é geralmente tributado a 12\%, mas nas regiões Norte e Nordeste a alíquota cai para 7\%. As alíquotas para etanol e biodiesel variam em cada estado, podendo ser reduzidas para operações interestaduais.

7. Os produtores de biodiesel podem optar por alíquotas de PIS/COFINS fixas por metro cúbico de combustível.

8. PSE (Percentage Producer Support Estimate) é o valor monetário anual de transferências brutas para produtores rurais, decorrente de medidas políticas de apoio à agricultura, incluindo apoio aos preços de mercado, pagamentos orçamentários e renúncias fiscais. É expresso como uma percentagem da receita bruta da atividade agrícola. 
9. O apoio aos preços de mercado surge a partir de medidas políticas que criam uma diferença entre os preços no mercado interno e os preços mais amplos de um produto agrícola específico. No Brasil, os níveis de preço variam por ano e por região, com apoio concedido a regiões mais afastadas dos principais mercados consumidores. Normalmente, não divergem muito dos preços internacionais.

10. O SNCR inclui bancos federais, estaduais e cooperativas, que repassam créditos oficiais para a agricultura.

11. Emenda Constitucional 491/2010.

12. O Código Florestal obriga proprietários rurais a reservar e manter uma percentagem de suas terras como reserva florestal permanente (Reserva Legal) e proíbe o desmatamento de vegetação primária em encostas íngremes e ao longo de margens de rios e córregos (classificadas como Áreas de Proteção Permanente) (Capítulo 4). Reservas Particulares do Patrimônio Natural são áreas privadas declaradas como unidades de conversação (Capítulo 5). Para se qualificar, a propriedade deve atender a certos requisitos ambientais, como a presença de alta biodiversidade, a aparência cênica ou relevância ecológica.

13. O BNDES concedeu créditos subsidiados a juros de $5,5 \%$ em janeiro de 2015 , quando a taxa de curto prazo do Banco Central era de 11,75\% (Financial Times, 2015).

14. O Regime Especial de Incentivos ao Desenvolvimento da Infraestrutura (REIDI) concede isenções fiscais a projetos de infraestrutura em áreas de interesse público (ex., transportes, portos, energia elétrica, saneamento, irrigação). A lei de 2012 sobre títulos de infraestrutura concede incentivos fiscais para compradores de títulos para o financiamento de projetos aprovados nos setores de transportes e de infraestrutura energética. Apesar desses incentivos fiscais terem se comprovado eficazes em setores como telecomunicações e energias renováveis, os títulos de infraestrutura tiveram desempenho mais lento, respondendo por apenas uma pequena parcela do mercado de títulos corporativos.

15. Concessões são outorgadas para projetos financeiramente viáveis, sem qualquer repasse público para o operador privado (ou seja, dependem unicamente das tarifas); PPPs são firmadas para projetos que requerem subsídios públicos para garantir sua viabilidade financeira.

16. Na primeira fase do PAC, foram desembolsados apenas $4 \%$ do investimento previsto para saneamento; até 2013 , cerca de $20 \%$ dos recursos haviam sido desembolsados, e $54 \%$ dos projetos de saneamento programados como parte do PAC 2 haviam obtido aprovação formal (Amann et al, 2014; TCU, 2014).

17. O BNDES aumentou sua carteira de empréstimos a juros baixos para projetos de mobilidade urbana, e o volume total de créditos vem crescendo desde 2008. Além disso, a partir de 2011, o PAC disponibilizou recursos especiais para projetos de mobilidade urbana, direcionados a médias e grandes cidades (Tabela 3.3). Desde 2010, o MCid - em parceria com a Caixa Econômica Federal - vem operando um programa de empréstimos a juros baixos para investimento no transporte urbano, financiado por contribuições sobre o salário (FAT - FGTS).

18. O orçamento do município de São Paulo cobre cerca de $20 \%$ dos recursos necessários para o transporte de ônibus e metrô (Amann et al., 2014).

19. O modelo de definição de tarifas é baseado sobre uma margem de lucro aplicada sobre o custo básico por passageiro/quilômetro. Qualquer aumento nos custos dos insumos (combustível ou salários) ou redução no número de passageiros gera, automaticamente, aumento da tarifa.

20. Em 2013, o reajuste automático de tarifas de ônibus e a falta de normas de controle provocaram manifestações de massa em São Paulo e em outras cidades (The Economist, 2013).

21. O PDE prevê a adição de $22,7 \mathrm{GW}$ de capacidade a partir de fontes renováveis, não incluindo grandes usinas hidrelétricas, até 2022. A energia eólica representará a maior parte desse acréscimo (15,6 GW), seguida pela biomassa ( $5 \mathrm{GW}$ ) e por pequenas centrais hidrelétricas (2 GW). Recentemente, houve uma pequena expansão da capacidade de energia solar fotovoltaica (2 GW).

22. O Programa Nacional do Álcool incluiu medidas de controle de preços, apoio ao investimento, financiamento preferencial e incentivo fiscal. A Petrobras se encarrega da mistura, armazenamento e distribuição.

23. Em 2011, o BNDES e a Financiadora de Estudos e Projetos (Finep) lançaram um programa de apoio à PD\&I no setor de etanol, para financiamento de 42 projetos, totalizando US\$ 1,6 bilhão (BNDES, 2013a).

24. Criado em 2002, o Fundo Setorial de Energia Elétrica lançou sete chamadas públicas para licitações a ser realizadas até 2009, a maioria com foco no uso eficiente de energia elétrica ( $\mathrm{R} \$ 47,8$ milhões), educação e divulgação ( $\mathrm{R}$ 1,3 milhão), produção e gestão de energia ( $\mathrm{R}$ \$ 4 milhões) e projetos de energia solar fotovoltaica e eólica de pequena escala ( $\mathrm{R} \$ 4$ milhões). 
25. Os programas setoriais neste plano incluem: i) produção sustentável (eficiência energética, resíduos sólidos e tratamento de águas servidas da indústria); ii) recuperação de biomas e produção sustentável de atividades florestais; iii) saneamento ambiental (geração de energia a partir de resíduos, logística reversa e gestão de resíduos municipais, e solos contaminados); e iv) sistemas de monitoramento.

26. A título de comparação, em 2011, as alocações orçamentárias e as despesas do governo em P\&D para fins ambientais equivaleram a apenas $2 \%$ do total médio dos países da OCDE (OCDE, 2014). No entanto, o Brasil não apresenta informações ao escritório de Pesquisa e Desenvolvimento de Estatísticas da OCDE e, portanto, os dados não podem ser diretamente comparados.

27. Os fundos setoriais que financiam a inovação relacionada ao meio ambiente são: CT-Agronegócio (R\$ 5 milhões desembolsados em 2010), CT-Amazônia (R\$ 1,7 milhão), CT-Hidrovias (R\$ 1,6 milhão), CT-Biotecnologia ( $R$ \$ 1,3 milhão), CT-Energia ( $\mathrm{R}$ 2,7 milhões) e CT-Hidro ( $\mathrm{R} \$ 2$ milhões).

28. A "vantagem tecnológica revelada" é definida pela parcela de patentes do país em um campo especifico de tecnologia, dividida pela parcela de participação de patentes em todos os campos. O índice é igual a zero, quando o país não detém patentes em um determinado setor; igual a1, quando a participação do país no setor se iguala à sua quota em todos os campos (sem especialização); e acima de 1, quando uma especialização é observada (OECD, 2014).

29. O MDL foi desenvolvido a partir de uma proposta brasileira nas negociações do Protocolo de Quioto de 1997.

30. O valor das compras governamentais sustentáveis mais do que triplicou entre 2010 e 2013, mas produtos ambientalmente sustentáveis ainda representam menos de 0,1\% das aquisições (MMA, 2015).

31. O Protocolo sobre GEE, desenvolvido pelo World Resources Institute e pelo World Business Council on Sustainable Development, estabelece o padrão global para a medição, gestão e informação sobre emissões de GEE. Para maiores informações acesse: www.ghgprotocol.org.

32. No Banco de Dados de Atividades de Assistência do Sistema de Relatos de Credores da OCDE, os países utilizam um marcador de políticas para identificar atividades com objetivos ambientais. Durante a última década, aproximadamente $80 \%$ dos projetos passaram por triagem pelo Sistema de Relatos de Credores.

33. A categoria "setor ambiental" inclui fluxos de AOD direcionados à política ambiental e à gestão administrativa (ex., normas, instituições e práticas), proteção da biosfera, biodiversidade, preservação local, prevenção e controle de inundações, capacitação e educação ambiental, e pesquisa ambiental.

34. Desde a sua criação, em 1991, o GEF repassou US\$ 427 milhões em doações para a proteção ambiental brasileira (com contrapartidas de US\$1.4 milhão) (GEF, 2014).

35. As estimativas para o período 2005 e 2009 foram uma primeira tentativa oficial de quantificar o desenvolvimento e a cooperação brasileira. Há uma impressão difundida de que esse número subestima o volume real dedicado à cooperação internacional, devido à falta de coordenação na coleta de dados e à dispersão na execução de projetos (a maioria dos projetos de cooperação técnica do Brasil é implementada por instituições públicas que não cobram pela sua participação e experiência). Além disso, as estimativas do IPEA contemplam apenas as despesas do governo federal, sem incluir empréstimos concedidos pelos bancos públicos federais como o BNDES, créditos para exportações e perdão de dívidas.

36. As estimativas de 2010 tentaram incluir projetos de cooperação técnica implementados por instituições públicas, o que explica, em parte, o número significativamente maior. O aumento entre 2009 e 2010 também está ligado a um aumento de R\$ 460 milhões em despesas para operações de paz.

37. A divergência significativa entre as estimativas oficiais, para 2010, de cooperação para o desenvolvimento do Brasil e a estimativa da OCDE se deve a diferentes metodologias contábeis. As estimativas da OCDE são baseadas em dados oficiais brasileiros, mas podem excluir algumas atividades que, se apresentadas, seriam classificadas pela OCDE como cooperação para o desenvolvimento. Além disso, as estimativas da OCDE incluem apenas atividades em países de baixa e média renda e as contribuições para organismos multilaterais, cujo principal objetivo é promover o desenvolvimento econômico e o bem-estar de países em desenvolvimento, mas excluem atividades bilaterais de operações de paz. 


\section{Referências}

ABCR (2015), Tarifas de Pedágio, Associação Brasileira de Concessionárias de Rodovias www.abcr.org.br/ TarifasPedagio/TarifaPedagio.aspx.

ABDI (2012) Relatório de Acompanhamento Setorial: Competitividade do Setor de Bens e Serviços Ambientais, Agência Brasileira de Desenvolvimento Industrial, Brasília, www3.eco.unicamp.br/neit/images/stories/ arquivos/Relatorios_NEIT/Bens-e-Servcos-Ambientais-Setembro-de-2012.pdf.

AHK (2009), Green Technologies in Brasil. An Overview of the Sustainability Market, AHK Câmara de Indústria de Comercio Alemã no Brasil e Roland Berger Strategy Consultants, São Paulo, www.renewablesb2b.com/ data/ahk_brazil/publications/files/GreenTechStudy_AHK_RB.pdf.

Amann, E. et al. (2014), "Infrastructure and its Role in Brazil’s Development Process", IRIBA Working Paper 10, International Research Initiative on Brazil and Africa (IRIBA), University of Manchester, Manchester.

Arbache, J., A. Goldstein e F. Marquesurce (2012), “O Brasil e a nova geografia da inovação”, Pontes, Vol. 8, No. 2. Barros, S. (2014), "Brazil Biofuels Annual - 2014”, GAIN Report No. BR14004, US Department of Agriculture, Global Agricultural Information Network, Washington, DC.

Barth, B. et al. (2014), Framework Assessment for the Photovoltaic Business Opportunities in Brazil, BSW Solar and eclareon $\mathrm{GmbH}$, report for the Deutsche Gesellschaft für Internationale Zusammenarbeit (GIZ) GmbH, Berlin.

BIRD (2010a), "Brazil - Integrated Solid Waste Management and Carbon Finance Project - Project Appraisal Document”, Report No. 50292-BR, 29 de setembro, World Bank, Washington, DC, www.wri.org/sites/default/files/pdf/ aligning_profit_and_environmental_sustainability_stories_from_industry.pdf.

BIRD (2010b), Brazil Low-carbon Country Case Study, World Bank, Washington, http://siteresources.worldbank. org/BRAZILEXTN/Resources/Brazil_LowcarbonStudy.pdf.

BIRD (2013), Impact and Implications of Recent and Potential Changes to Brazil's Subnational Fiscal Framework. Report No. ACS5885, Washington, DC, http://siteresources.worldbank.org/EXTPREMNET/Resources/EP147.pdf.

BIRD (2015), World Development Indicators (banco de dados), World Bank, Washington, DC, http://data. worldbank.org/data-catalog/world-development-indicators.

BNDES (2013b), "BNDES and other development banks in the BRICS sign cooperation agreements", BNDES, www.bndes.gou.br/SiteBNDES/bndes/bndes_en/Institucional/Press/Noticias/2013/20130327_brics.html

BNDES (2013a), “The BNDES and the Sugar-ethanol Industry in 2012: Innovation as Priority", Sectorial Report, Industrial Division, junho de 2013 No. 25, BNDES, Rio de Janeiro.

BNDES (2014), “Plano Inova Sustentabilidade” www.bndes.gov.br/SiteBNDES/bndes/bndes_pt/Institucional/ Apoio_Financeiro/Plano_inova_empresa/inovasustentabilidade.html

BNDES (2015), "Social and Environmental Responsibility”, www.bndes.gou.br/SiteBNDES/bndes/bndes_en/ Institucional/Social_and_Environmental_Responsibility

BNEF (2013), Climatescope 2013, encomendado pelo Fundo de Investimento Multilateral do BID, Bloomberg New Energy Finance, New York.

BNEF (2014), Climatescope 2014, encomendado pelo Fundo de Investimento Multilateral do BID, o UK Department for International Development, Power Africa, Bloomberg New Energy Finance, New York.

BNEF (2015), Global Trends in Renewable Energy Investment 2015, Bloomberg New Energy Finance and Frankfurt School-UNEP Centre, Frankfurt am Main, http://apps.unep.org/publications/pmtdocuments/-Global_trends_ in_renewable_energy_investment_2015-201515028nefvisual8-mediumres.pdf.pdf.

Bowen, A. (2012), “'Green' Growth, 'Green' Jobs and Labor Markets”, Policy Research Working Papers, No. 5990, World Bank, Washington.

Cabral e Weinstrock (2010), "Brazilian technical cooperation for development. Drivers, mechanics and future prospects”, Overseas Development Institute, London, www.odi.org/sites/odi.org.uk/files/odi-assets/publicationsopinion-files/6137.pdf. 
Castanheira, E.G. et al. (2014), “Environmental Sustainability of Biodiesel in Brazil”, Energy Policy, Vol. 65, pp. 680-691.

Costa, S.A.B e L.S. Côrtes (2014), "Tariff Disincentives: Obstacles to the Expansion of Sewage Treatment Services in Brazil”, trabalho apresentado ao European Consortium for Political Research (ECPR) 5th Standing Group on Regulatory Governance, Barcelona Institute of International Studies, 25-27 junho, Barcelona.

De Oliveira, A e T. Laan (2010), Lessons Learned from Brazil's Experience with Fossil-Fuel Subsidies and their Reform, Global Subsidies Initiative, International Institute for Sustainable Development, Winnipeg, www.iisd. org/pdf/2010/lessons_brazil_fuel_subsidies.pdf.

ELETROBRAS (2014), Executive Summary: Procel Results 2014 - Base year 2013, Eletrobras Procel, Brasilía.

ETHOS (2008), Práticas e Perspectivas da Responsabilidade Social Empresarial no Brasil 2008 Instituto Ethos para Negócios de Sustentabilidade e Responsabilidade Social, São Paulo, www3.ethos.org.br/ wp-content/uploads/2012/12/1Sum\%C3\%A1rio-da-Pesquisa-Relat\%C3\%B3rio-publicado.pdf.

FEBRABAN (2014), The Brazilian Financial System and the Green Economy Alignment with Sustainable Development, São Paulo.

Financial Times (2015), "BNDES: Lender of first resort for Brazil's tycoons”, 11 de janeiro, Financial Times, London.

Frischtak (2011), "Vantagens Comparativas, Inovação e Economia Verde”, trabalho preparado para o Fórum Nacional do BNDES, 21 de setembro de 2011, www.bndes.gou.br/SiteBNDES/export/sites/default/bndes_pt/ Galerias/Arquivos/empresa/download/inovacao_paper_05.pdf.

Galego-Álvarez, I., H. Formigoni e M.T. Pompa Arunes (2014), “Corporate social responsibility practices at Brazilian firms”, Revista de Administração de Empresas, Vol. 54, No. 1, 2014.

GEF (2014), “Country Profile for Brazil”, www.thegef.org/gef/country_profile

GEF (2012), GEF Country Portfolio Evaluation. Brazil (1991-2011), www.thegef.org/gef/sites/thegef.org/files/ documents/CPE-Brazil-v1.pdf.

Goldemberg, J. et al. (2014), "Oil and natural gas prospects in South America: Can the petroleum industry pave the way for renewables in Brazil?”, Energy Policy, Vol. 64, pp. 58-70, http://dx.doi.org/10.1016/j.enpol.2013.05.064.

Gurgel, A.C. e S. Paltsev (2013), “Costs of reducing GHG emissions in Brazil”, Climate Policy, Vol. 14, No. 2, pp. 209-223, http://dx.doi.org/10.1080/14693062.2013.835655.

Harding, M. (2014), "The Diesel Differential: Differences in the Tax Treatment of Gasoline and Diesel for Road Use", OECD Taxation Working Papers, No. 21, OECD Publishing, Paris, http://dx.doi.org/10.1787/5jz14cd7hk6b-en.

IBGE (2013), Pesquisa de Inovação, Rio de Janeiro, www.pintec.ibge.gou.br/downloads/pintec2011\%20publicacao\%20 completa.pdf.

IBNET (2015), The International Benchmarking Network for Water and Sanitation Utilities (Database), http:// database.ib-net.org/Default.

IEA (2013), World Energy Outlook 2013, International Energy Agency, IEA, Paris, http://dx.doi.org/10.1787/weo2013-en.

IEMA (2014), $1^{\circ}$ Diagnóstico da Rede de Monitoramento da Qualidade do Ar no Brasil, Instituto Estadual de Meio Ambiente, São Paulo.

International Food Policy Research Institute (2006), "Bioenergy and Agriculture: Promises and Challenges. Brazil's Experience with Bioenergy”, Brief No. 8/2006, www.ifpri.org/sites/default/files/publications/focus14_08.pdf.

Ioris, A. (2008), “The limits of integrated water resources management: A case study of Brazil's Paraíba do Sul River Basin", Sustainability: Science, Practice \& Policy, Vol. 4, Issue 2, Proquest, Maryland.

IPEA (2014), Brazilian cooperation for international development: 2010, Brasília.

IPEA (2012), Diagnóstico dos Resíduos Sólidos no Brasil, Brasília. 
IPEA (2010b), Cooperação brasileira para o desenvolvimento internacional: 2005-2009, Brasília.

IPEA (2010a), Sustentabilidade Ambiental no Brasil: biodiversidade, economia e bem-estar humano, Brasília, www. ipea.gov.br/agencia/images/stories/PDFs/liuros/livros/livro07_sustentabilidadeambienta.pdf.

Jannuzzi, G. e M Poppe (2014), “Development, Cooperation and Transfer of low carbon technologies” em Seroa da Motta, R. et al. (eds) (2011), Climate Change in Brazil: Economic, Social and Regulatory Aspects, IPEA, Brasília, www.ipea.gov.br/agencia/images/stories/PDFs/livros/liuros/liuro_climatechange.pdf.

Larive International (2014), Market Study: Wind Energy in Brazil, Ministry of Economic Affairs of the Netherlands, The Hague, Larive International, Zeist, and Transfer LBC, Rotterdam.

La Rovere, E.L., A.S. Pereira e A.F. Simões (2011), "Biofuels and Sustainable Energy Development in Brazil”, World Development, Vol. 39, No. 6, pp. 1026-1036.

Lindau, L., D. Hidalgo and D. Facchini (2010), "Bus Rapid Transit in Curitiba, Brazil. A Look at the Outcome After 35 Years of Bus-Oriented Development”, Transportation Research Record, Vol. 2193, pp. 17-27.

Lindau, L., D. Hidalgo e A. de Almeida Lobo (2014), "Barriers to planning and implementing Bus Rapid Transit systems”, Research in Transportation Economics, Vol. 48, pp. 9-15.

Martinez Júnior, F. (2011), “A eficiência da cobrança pela utilização da água para o uso racional e o financiamento do sistema de gestão dos recursos hídricos na bacia do Rio Paraíba do Sul”, Trabalho apresentado no XIX Simpósio Brasileiro de Recursos Hídricos, www.abrh.org.br/sgcu3/UserFiles/ Sumarios/11e152b6915be81e862115107a899557_0d84c07b909d1b9527de2d55fedfa7ac.pdf.

MCid (2014), Diagnóstico dos Serviços de Água e Esgotos. Brasília, www.snis.gou.br/diag2013/Diagnostico_AE2013.zip.

MCTI (2011), Estratégia Nacional de Ciência, Tecnologia e Inovação (ENCTI) 2012-2015. Balanço das Atividades Estruturantes 2011, Brasília.

MCTI (2014b), First Biennial Update Report (BUR) under the United Nations Framework Convention on Climate Change (UNFCCC), http://unfccc.int/resource/docs/natc/brbur1.pdf.

MCTI (2014a), “Indicadores Nacionais de Ciência, Tecnologia e Inovação”, www.mcti.gou.br/indicadores.

Ministério da Fazenda (2014), Market Readiness Proposal, relatório do Partnership for Market Readiness Program, Brasília, www.thepmr.org/system/files/documents/Final\%20MRP\%20Brazil_29-08-2014.pdf.

MMA (2012), Plano Nacional de Resíduos Sólidos, Brasília, www.sinir.gou.br/documents/10180/12308/PNRS_ Revisao_Decreto_280812.pdf/.

MMA (2015), Quinto Relatório Nacional da Convenção sobre Diversidade Biológica, Brasília, www.cbd.int/ doc/world/br/br-nr-05-en.pdf.

Moarif, S. e N. Patodia Rastogi (2012), Market-based Climate Mitigation Policies in Emerging Economies, Center for Climate and Energy Solutions, Arlington.

MPOG (n.a.), "PAC 2", www.pac.gou.br/pub/up/relatorio/c9fba67e144c9237b839e2c5adf32e99.pdf.

MPOG (2015), PAC 2. Balanço 4 Anos, Brasília, www.pac.gou.br/pub/up/relatorio/f9d3db229b483b35923b338906b022ce. $p d f$.

Nonato, F. e A. Maciente (2012), "A identificação de empregos verdes, ou com potencial verde, sob as óticas ocupacional e setorial no Brasil”, newsletter Radar: tecnologia, produção e comércio exterior, IPEA, www. ipea.gou.br/agencia/images/stories/PDFs/radar/121217_radar23_cap5.

OCDE (2013c), OECD Environmental Performance Reviews: Mexico 2013, OECD Publishing, Paris, http://dx.doi. org/10.1787/9789264180109-en.

OCDE (2013d), Agricultural Policy Monitoring and Evaluation, OECD Publishing, Paris, http://dx.doi.org/10.1787/ agr_pol-2013-en.

OCDE (2013e), Effective Carbon Prices - Country Note on Brazil, OECD Publishing, Paris, www.oecd.org/env/toolsevaluation/Effective-Carbon-Prices-in-Brazil.pdf. 
OCDE (2015g), Development Co-operation Report 2015: Making Partnerships Effective Coalitions for Action, OCDE Publishing, Paris, http://dx.doi.org/10.1787/dcr-2015-en.

OCDE (2012), A Framework for Financing Water Resources Management, OECD Studies on Water, OECD Publishing, Paris, http://dx.doi.org/10.1787/9789264179820-en.

OCDE (2015d), Innovation, Agricultural Productivity and Sustainability in Brazil, OECD Publishing, Paris, http:// dx.doi.org/10.1787/9789264237056-en.

OCDE (2011), OECD Economic Surveys: Brazil, OECD Publishing, Paris, http://dx.doi.org/10.1787/eco_surveysbra-2011-en.

OCDE (2013a), OECD Economic Surveys: Brazil, OECD Publishing, Paris, http://dx.doi.org/10.1787/eco_surveysbra-2013-en.

OCDE (2014), OECD Science, Technology and Industry Outlook 2014, OECD Publishing, Paris, http://dx.doi. org/10.1787/sti_outlook-2014-en.

OCDE (2015e), OECD Environmental Performance Reviews: Spain 2015, OECD Publishing, Paris, http://dx.doi. org/10.1787/9789264226883-en.

OCDE (2013f), "Triangular co-operation: What can we learn from a survey of actors involved?, relatório preparado pela OECD Development Co-operation Directorate, maio de 2013, OECD, www.oecd.org/dac/dacglobal-relations/ OECD\%20Triangluar\%20Co-operation\%20Survey\%20Report\%20-\%20June\%202013.pdf.

OCDE (2013b), Putting Green Growth at the Heart of Development, OECD Green Growth Studies, OECD Publishing, Paris, http://dx.doi.org/10.1787/9789264181144-en.

OCDE (2015a), Taxing Energy Use 2015: OECD and Selected Partner Economies, OECD Publishing, Paris, http:// dx.doi.org/10.1787/9789264232334-en.

OCDE et al. (2015), Revenue Statistics in Latin America and the Caribbean 2015, OECD Publishing, Paris, http:// dx.doi.org/10.1787/rev_lat-2015-3-en-fr.

OCDE (2015b), Water Resources Governance in Brazil, OECD Studies on Water, OECD Publishing, Paris, http:// dx.doi.org/10.1787/9789264238121-en.

OCDE (2015f), OECD International Development Statistics (banco de dados), http://dx.doi.org/10.1787/dev-data-en

OECD (2015c), Overcoming Barriers to International Investment in Clean Energy, Green Finance and Investment, OECD, Paris, $h$ ttp://dx.doi.org/10.1787/9789264227064-en.

ODI (2014), The fossil fuel bailout: G20 subsidies for oil, gas and coal exploration, Overseas Development Institute, London, www.odi.org/sites/odi.org.uk/files/odi-assets/publications-opinion-files/9234.pdf.

OIT (2010), "Skills for green jobs in Brazil". Estudo inédito OIT Departamento de capacidades para o trabalho, Organização Internacional do Trabalho, www.ilo.org/wcmsp5/groups/public/---ed_emp/---ifp_skills/ documents/publication/wcms_142300.pdf.

OSEC (2010), The Brazilian Market for Railway Technologies, dezembro, Osec Business Network, Zurique, Suíça.

PNUMA (2014), The Business Case for Eco-innovation, United Nations Environment Programme, Paris, www. unep.org/resourceefficiency/Portals/24147/Business-Ressource\%20Efficency/BCFOREIFORWEB.pdf.

Reuters (2015), "Brazil power rates may jump 60 pct on drought, subsidies - source”, 16 de janeiro, Reuters, www. reuters.com/article/2015/01/16/brazil-electricity-rates-idUSL1NOUV1VX20150116

Scharf, R. (2009), "Why Brazil leads the region in CSR”, Americas Quarterly, Vol. 2(1), No. 68.

Seroa da Motta, Ronaldo (2009), "Eco-Innovation in Brazil", apresentação realizada no OECD Global Forum on Environment on Eco-Innovation, Paris 4-5 novembro de 2009, www.oecd.org/env/consumptioninnovation/44053422.pdf.

Solutions for Water (2011), "1974 - Payment for Environmental Services in Water Resources Management in Brazil”, 26 de dezembro, Solutions for Water Platform, 6º́rum Mundial da Água, 2012, Marseille. 
TCU (2011), Relatório e Parecer Prévio sobre as Contas do Governo da República Exercício de 2010: Ficha 6.1 - Programa de Aceleração do Crescimento, Brasília.

TCU (2014), Relatório e Parecer Prévio sobre as Contas do Governo da República Exercício de 2013, Brasília.

The Economist (2013), “Taking to the streets”, 22 de junho, The Economist Newspaper, London, www.economist. com/news/americas/21579857-bubbling-anger-about-high-prices-corruption-and-poorpublic-services-boils-over.

The Economist (2012), "Untangling the custo Brasil: Electricity taxes in Brazil”, Americas View, 20 de agosto, The Economist Newspaper, London.

Tognere Ferron, R., et al. (2012), "Is ISO 14001 Certification Effective? An Experimental Analysis of Firm Profitability", Brazilian Administration Review, Vol. 9, Edição Especial, pp. 78-94.

TransportPolicy (2014), "Brazil: Light-duty: Fiscal Incentive”, atualização agosto de 2014, The International Council on Clean Transportation, Washington, DC.

UNFCCC (2010), The Contribution of the Clean Development Mechanism under the Kyoto Protocol to Technology Transfer, United Nations Framework Convention on Climate Change, Bonn, http://cdm.unfccc.int/Reference/ Reports/TTreport/TTrep10.pdf.

U.S. Commercial Service (2014), "Doing Business in Brazil - Country Commercial Guide for U.S. Companies”, U.S. \& Foreign Commercial Service and U.S. Department of State.

WEF (2014), The Global Competitiveness Report 2014-15, World Economic Forum, Genebra.

WRI (2013), "Aligning profit and environmental sustainability: Stories from industry", Working Paper, fevereiro de 2013, World Resources Institute, Washington.

WWC e OCDE (2015), "Water: Fit for finance? catalyzing national growth through investment in water security", report of the High Level Panel on Financing Infrastructure for a water-secure World, World Water Council and OECD, Marseille, www.worldwatercouncil.org/fileadmin/world_water_council/documents/mailing/ mail_wwf7_documents/WWC_OECD_Water-fit-to-finance_Report.pdf. 
ANEXO 3.A

Avanços na Consecução dos Objetivos de Desenvolvimento do Milênio 
Tabela 3.A.1. Objetivos de Desenvolvimento do Milênio metas e indicadores selecionados

\begin{tabular}{|c|c|c|c|c|c|c|}
\hline \multicolumn{2}{|c|}{ Objetivos de Desenvolvimento do Milénio, metas e indicadores selecionados } & \multicolumn{2}{|c|}{$\begin{array}{l}\text { Brasil, linha de } \\
\text { base }\end{array}$} & \multicolumn{2}{|c|}{$\begin{array}{l}\text { Brasil último } \\
\text { ano disponível }\end{array}$} & \multirow[t]{2}{*}{$\begin{array}{l}\text { ALC, último ano } \\
\text { disponível }\end{array}$} \\
\hline ODM 1: & Erradicar a Extrema Pobreza e a Fome & & & & & \\
\hline Meta 1.A: & $\begin{array}{l}\text { Entre } 1990 \text { e } 2015, \text { reduzir pela metade a proporção de pessoas vivendo com menos de US\$ } \\
1,25 \text { por dia }\end{array}$ & & & & & \\
\hline Indicador 1.1 & População vivendo com menos de USD 1.25 (PPC) por dia (\%) & 1990 & 17.2 & 2010 & 6.1 & 5.5 \\
\hline Indicador 1.2 & Hiato de pobreza extrema (\%) & 1990 & 7.2 & 2009 & 3.6 & 2.9 \\
\hline Indicador 1.3 & Percentagem da renda nacional detida pelos $20 \%$ mais pobres & 1990 & 2.2 & 2009 & 2.9 & . \\
\hline Meta 1.B: & $\begin{array}{l}\text { Assegurar trabalho decente e produtivo para todos, promovendo a inclusão de mulheres e } \\
\text { jovens }\end{array}$ & & & & & \\
\hline Indicador 1.4 & Crescimento anual do PIB por trabalhador ocupado (em R\$) (\%) & 1993 & 2.82 & 2009 & -0.7 & \\
\hline Indicador 1.5 & Taxa de ocupação da população em idade ativa (em \%) & 1990 & 54.7 & 2011 & 61.7 & 62.1 \\
\hline Indicador 1.6 & Percentagem da população ocupada vivendo com menos do que US\$ 1,25 (PPC) por dia & 1992 & 10.1 & 2009 & 3.3 & 2.9 \\
\hline Meta 1.C: & Entre 1990 e 2015 , reduzir pela metade a proporção de pessoas passando fome & & & & & \\
\hline Indicador 1.9 & $\begin{array}{l}\text { Proporção da população cujo consumo de alimentos está abaixo do nível mínimo recomendado } \\
(\%)\end{array}$ & 1991 & 14.8 & 2013 & 5 & 7.9 \\
\hline ODM 2: & Universalizar a Educação Primária & & & & & \\
\hline Meta 2.A: & $\begin{array}{l}\text { Até 2015, garantir que meninos e meninas tenham a oportunidade de terminar o ensino primá- } \\
\text { rio }\end{array}$ & & & & & \\
\hline Indicador 2.2 & Porcentagem de alunos que ingressam na $1^{\text {a }}$ série e completam $01^{\circ}$ grau $(\%)$ & 1992 & 70.3 & 2009 & 53.7 & 76.7 \\
\hline Indicador 2.3 & Taxa de alfabetização da população de ambos os sexos de 15 a 24 anos (\%) & 2000 & 94.2 & 2012 & 98.6 & 97.8 \\
\hline ODM 3: & Promover a Igualdade entre os Sexos e a Autonomia das Mulheres & & & & & \\
\hline Meta 3.A: & Até 2015, eliminar as disparidades entre os sexos em todos os níveis de ensino & & & & & \\
\hline Indicador 3.2 & Percentagem de mulheres nas ocupações assalariadas não agrícolas & 1990 & 40.2 & 2012 & 47.2 & 43.8 \\
\hline Indicador 3.3 & Percentagem de deputadas federais e senadoras por legislatura & 1990 & 5.3 & 2014 & 8.6 & 25.9 \\
\hline ODM 4: & Reduzir a Mortalidade na Infância & & & & & \\
\hline Meta 4.A: & Até 2015, reduzir a mortalidade na infância a dois terços do nível de 1990 & & & & & \\
\hline Indicador 4.1 & Taxa de mortalidade na infância (abaixo de 5 anos, por cada 1.000 nascidos vivos) & 1990 & 61.5 & 2013 & 13.7 & 19 \\
\hline Indicador 4.2 & Taxa de mortalidade na infância (por cada 1.000 nascidos vivos) & 1990 & 51.4 & 2013 & 12.3 & 16 \\
\hline ODM 5: & Melhorar a Saúde Materna & & & & & \\
\hline Meta 5.A: & Até 2015, reduzir a mortalidade materna a três quartos do nível observado em 1990 & & & & & \\
\hline Indicador 5.1 & Razão de mortalidade materna (por 100000 nascidos vivos) & 1990 & 120 & 2013 & 69 & 85 \\
\hline Meta 5.B: & Até 2015, universalizar o acesso à saúde sexual e reprodutiva & & & & & \\
\hline Indicador 5.4 & Taxa de fecundidade das mulheres de 15 a 19 anos (por 100 mulheres) & 1996 & 83.9 & 2011 & 64.8 & 75.9 \\
\hline ODM 6: & Combater o HIV/AIDS, a Malária e outras Doenças & & & & & \\
\hline Meta 6.A: & Até 2015, interromper a propagação e diminuir a incidência de HIV/AIDS & & & & & \\
\hline \multirow[t]{4}{*}{ Indicador 6.9} & Taxa de incidência de mortalidade por tuberculose (por 100000 habitantes) & & & & & \\
\hline & Incidência & 1990 & 84 & 2012 & 46 & 43 \\
\hline & Prevalência & 1990 & 140 & 2012 & 59 & 61 \\
\hline & Óbito & 1990 & 7 & 2012 & 2.5 & 3 \\
\hline ODM 7: & Garantir a Sustentabilidade Ambiental & & & & & \\
\hline Meta 7.A: & $\begin{array}{l}\text { Integrar os princípios do desenvolvimento sustentável nas políticas e programas e reverter a } \\
\text { perda de recursos ambientais }\end{array}$ & & & & & \\
\hline Indicador 7.1 & Cobertura florestal do território nacional & 1990 & 68.8 & 2010 & 62.4 & 47.4 \\
\hline \multirow[t]{3}{*}{ Indicador 7.3} & Consumo de substâncias que destroem a camada de ozônio (ODP toneladas) & & & & & \\
\hline & Todas as substâncias que destroem a camada de ozônio, & 1990 & 39337 & 2012 & 1388 & 5166 \\
\hline & CFCs que destroem a camada de ozônio & 1990 & 8539 & 2012 & 0 & \\
\hline Indicador 7.6 & Proporção de áreas terrestres e marinhas protegidas (\%) & 1990 & 7.06 & 2012 & 25.97 & 20.3 \\
\hline Meta 7.C: & $\begin{array}{l}\text { Reduzir pela metade, até } 2015 \text {, a proporção da população sem acesso permanente e sustentá- } \\
\text { vel à água potável e ao esgotamento sanitário }\end{array}$ & & & & & \\
\hline \multirow[t]{3}{*}{ Indicador 7.8} & Proporção da população com acesso à água potável & 1990 & 88 & 2012 & 98 & 94 \\
\hline & Urbana $(\%)$ & 1990 & 96 & 2012 & 100 & 97 \\
\hline & Rural (\%) & 1990 & 68 & 2012 & 85 & 82 \\
\hline \multirow[t]{3}{*}{ Indicador 7.9} & Proporção da população com acesso ao esgotamento sanitário & 1990 & 67 & 2012 & 81 & 82 \\
\hline & Urbana $(\%)$ & 1990 & 79 & 2012 & 87 & 87 \\
\hline & Rural $(\%)$ & 1990 & 31 & 2012 & 49 & 63 \\
\hline \multirow{2}{*}{$\begin{array}{l}\text { Meta 7.D: } \\
\text { Indicador } 7.10\end{array}$} & $\begin{array}{l}\text { Até } 2020 \text {, ter alcançado uma melhora significativa na vida de pelo menos } 100 \text { milhões de } \\
\text { habitantes de assentamentos precários }\end{array}$ & & & & & \\
\hline & Percentagem da população urbana vivendo em moradias inadequadas & 1990 & 36.7 & 2009 & 26.9 & 23.5 \\
\hline ODM 8: & Estabelecer uma Parceria Mundial para o Desenvolvimento & & & & & \\
\hline Indicador 8.12 & Serviço da dívida como porcentagem das exportações de bens e serviços (\%) & 1990 & 18.6 & 2012 & 4 & 6.6 \\
\hline Indicador 8.15 & Assinatura de telefonia celular (por 100 habitantes) & 1990 & 0 & 2013 & 135.3 & 109.1 \\
\hline Indicador 8.16 & Usuários de internet (por 100 habitantes) & 1992 & 0.01 & 2013 & 51.6 & 43.4 \\
\hline
\end{tabular}


ANEXO 3.B

\section{Dados Sobre o Desempenho do Crescimento Verde}




\section{Figura 3.B1. Impostos relacionados ao meio ambiente}

$\%$ do total da receita fiscal

Receitas fiscais relacionadas ao meio ambiente, 2013

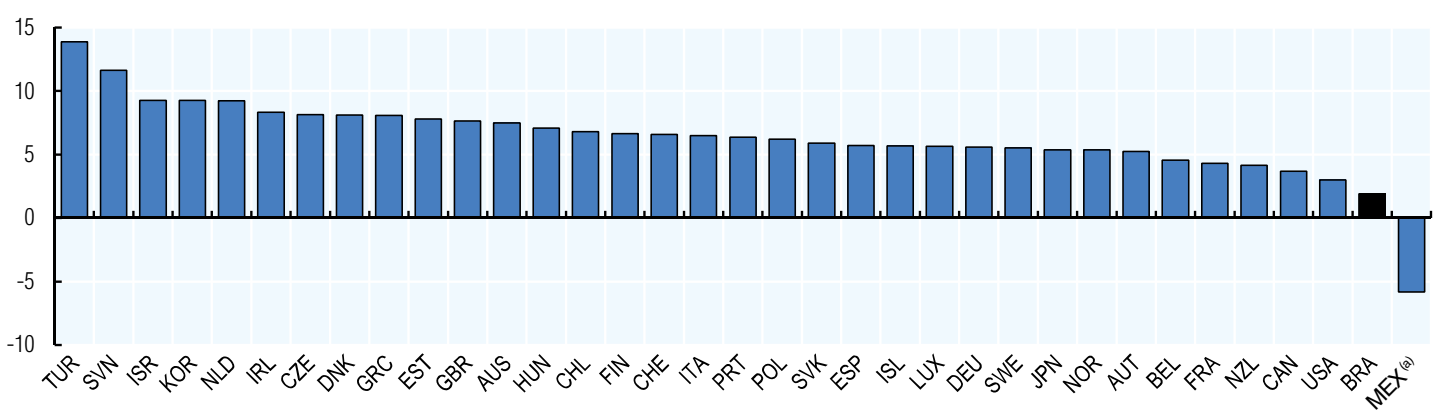

Composição das receitas fiscais relacionadas ao meio ambiente, por base fiscal, 2013

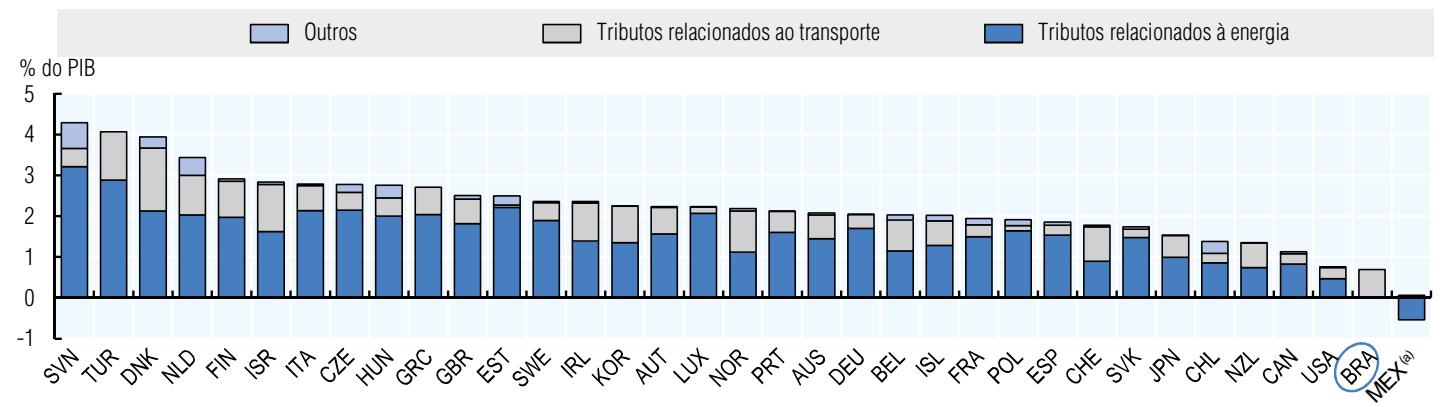

Diesel, 2014

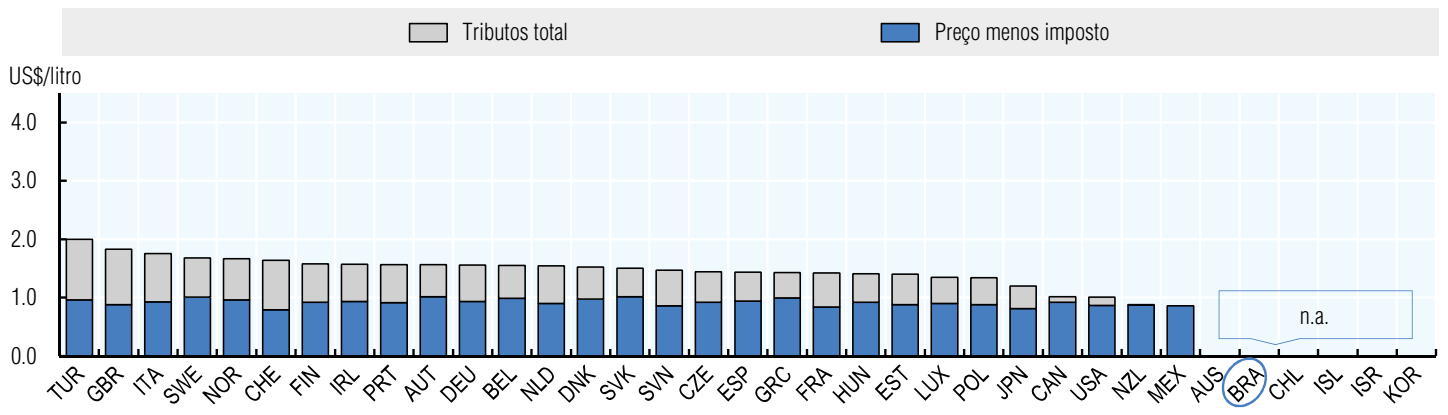

Gasolina comum, 2014

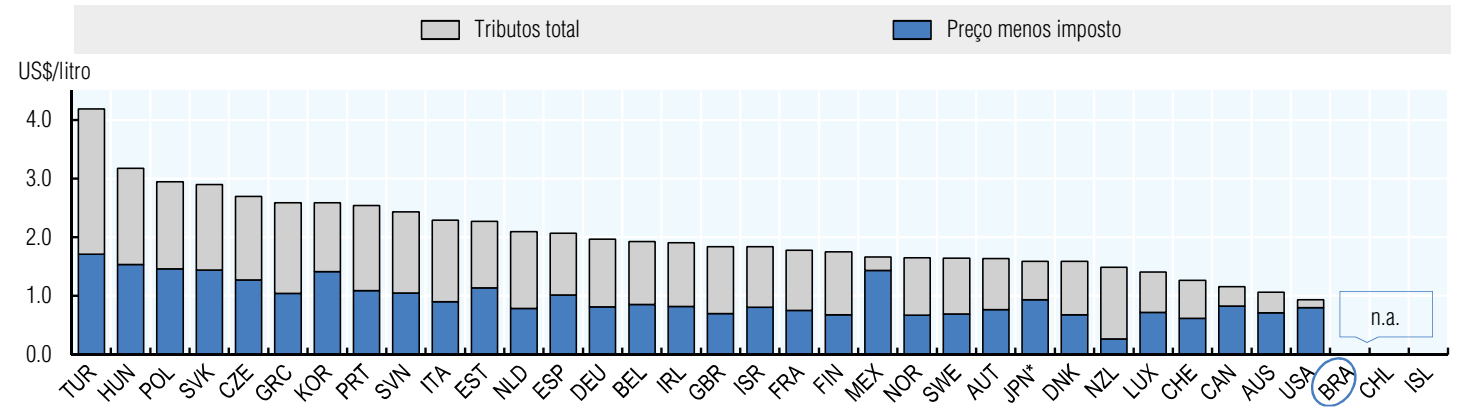

Obs.: Dados se referem ao ano indicado ou ao último ano disponível. Podem incluir números provisórios e estimativas.

a) Até 2014 , 0 sistema utilizado para estabilizar o preço final de combustíveis automotores fez com que as receitas ficassem negativas (i.e., se tornaram subsídio) em anos em que o preço internacional do petróleo estava em alta. A reforma tributária do México de 2013 corrigiu esse mecanismo e introduziu um tributo sobre combustíveis fósseis com base no conteúdo de carbono, que gerará receitas positivas.

b) Diesel: diesel automotivo para uso comercial, em US\$ a preçoS atuais; gasolina comum; gasolina premium (RON 95), exceto Japão (gasolina comum), em US\$ a preçoS atuais e paridade de preço de compra.

Fonte: IEA (2015), IEA Energy Prices and Taxes Statistics (database); OECD (2015), OECD Database on Instruments Used for Environmental Policies and Natural Resource Management (database) 
Figura 3.B2. Inovação verde

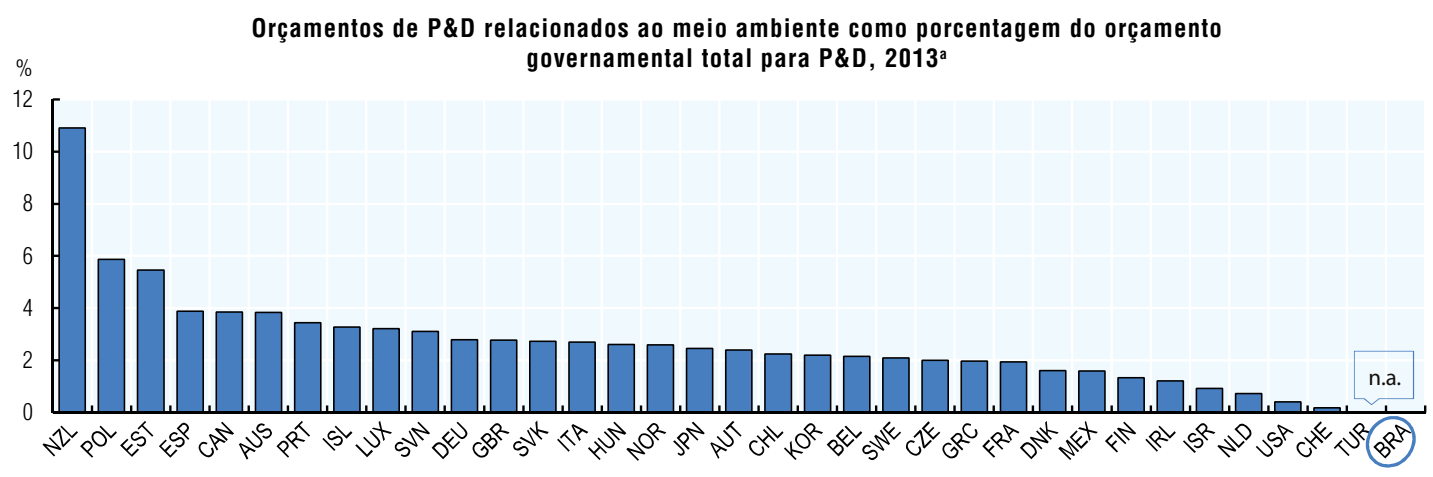

Orçamentos de pesquisa, desenvolvimento e demonstração (PD\&D) para fontes renováveis de energia, porcentagem do total de PD\&D pública em energia, 2013

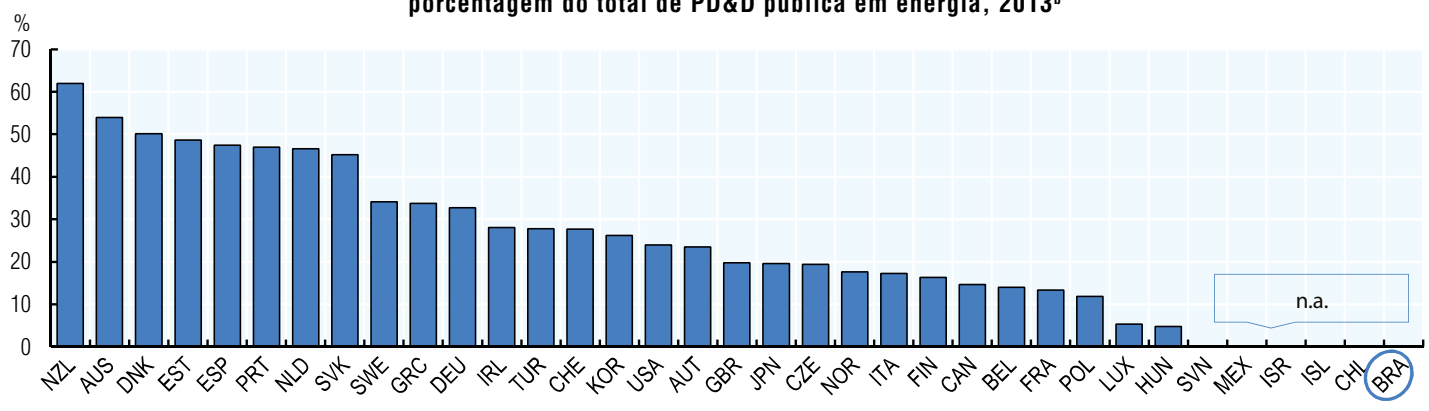

Requerimento de patentes em tecnologias relacionadas ao meio ambiente, porcentagem de todas as tecnologias, 2011

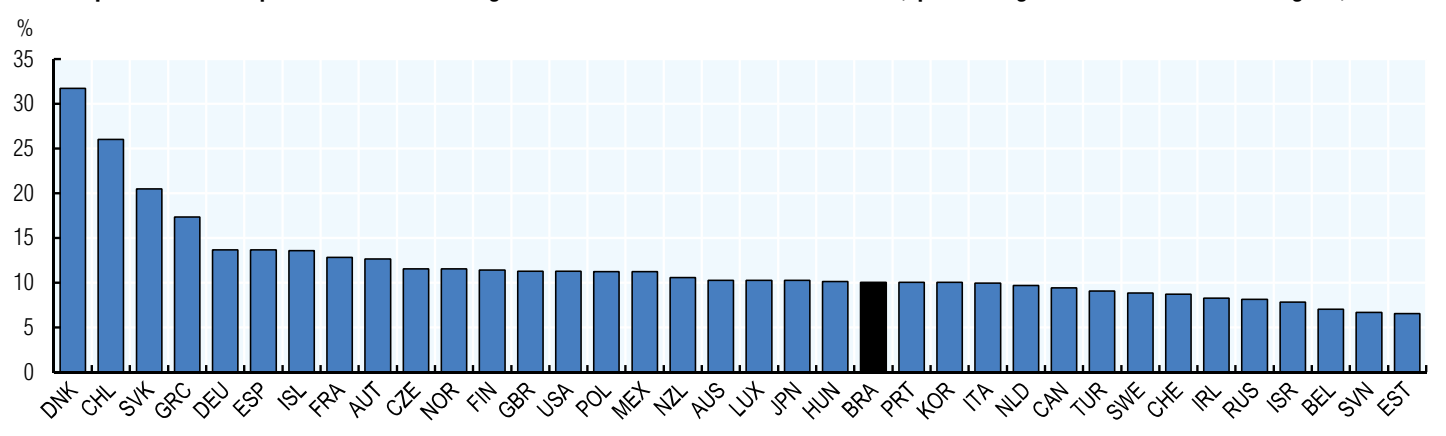

Requerimento de patentes em tecnologias relacionadas ao meio ambiente,

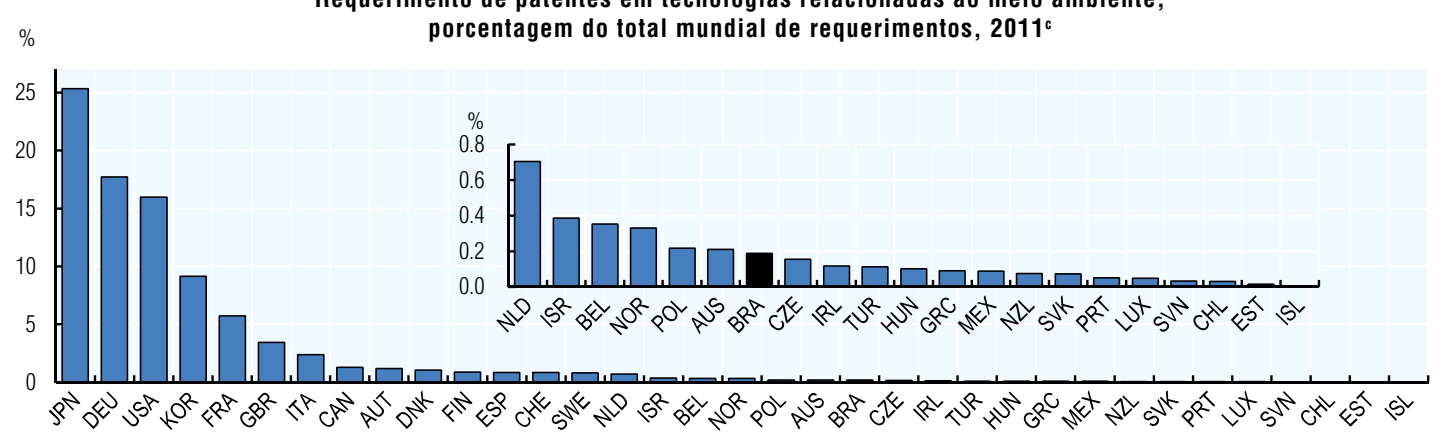

Obs.: Dados se referem ao ano indicado ou ao último ano disponível. Podem incluir números provisórios e estimativas.

a) Desagregação das apropriações ou despesas com P\&D; desagregação segundo a classificação NABS 2007.

b) Orçamento público para pesquisa, desenvolvimento e demonstração (PD\&D) em tecnologias energéticas.

c) Invenções de maior valor que buscaram proteção de patentes em pelo menos duas jurisdições. Os dados se baseiam em requisições registradas no Worldwide Patent statistical database 

PARTE II

\section{Progresso rumo a objetivos ambientais selecionados}



Capítulo 4

\section{Conservação e uso sustentável da biodiversidade}

O Brasil é o país com a maior biodiversidade do mundo. O presente capítulo analisa o estado e as tendências atuais da biodiversidade brasileira, bem como pressões provenientes de diversas fontes. Examina a política e o marco institucional brasileiros para a biodiversidade, inclusive a estratégia integrada de combate ao desmatamento. Avalia avanços no financiamento da conservação da biodiversidade, na transversalização da conservação da biodiversidade em políticas setoriais, no aprimoramento da base de conhecimentos e na valoração econômica da biodiversidade e dos ecossistemas brasileiros. 


\section{Situação e tendências da biodiversidade brasileira}

O Brasil, país com a maior diversidade biológica do mundo, abriga cerca de um décimo das espécies conhecidas e maior número de espécies endêmicas que a maioria dos outros países ( $C D B$, n.d.). ${ }^{1}$ Com extensão territorial de 8,5 milhões de $\mathrm{km}^{2}$ abrangendo quase metade do continente sul-americano, é o quinto maior país do mundo. Seu extenso litoral de cerca de $7.500 \mathrm{~km}$, delimita uma vasta área marítima com mais de 4,5 milhões de $\mathrm{km}^{2}$. A maioria da população brasileira vive ao longo da costa, onde a densidade demográfica média é cerca de seis vezes maior que a média nacional (ver Estatísticas Básicas).

Por ser um país de dimensões continentais, o Brasil apresenta grandes variações de características físicas, assim como de clima, vegetação e padrões de uso da terra. Abriga seis grandes ecossistemas terrestres, ou biomas, ${ }^{2}$ a saber: Amazônia, Cerrado, Caatinga, Mata Atlântica, Pantanal e Pampa. O maior desses biomas, a Amazônia, ocupa quase metade do território nacional, seguido pelo Cerrado (Box 4.1). Os biomas Mata Atlântica e Cerrado são duas das 35 áreas mundiais identificadas como hotspots, ou seja, biomas que conjugam alto índice de espécies endêmicas com alto grau de ameaça (Conservation International, 2015).

\subsection{Ecossistemas terrestres}

Apesar de esforços para proteger o patrimônio natural nacional, pressões sobre a biodiversidade terrestre ainda persistem. Em conjunto, a agropecuária, a extração de recursos naturais e o desenvolvimento de infraestruturas respondem por mais de $80 \%$ das perdas de habitat. Outras pressões incluem: espécies invasivas, doenças exóticas, sobre-exploração, poluição, incêndios e mudanças climáticas (Figura 1.13). No geral, cerca de $70 \%$ do território total do país ainda é coberto por vegetação nativa, em diferentes graus de conservação (MMA, 2010). A parcela da vegetação nativa remanescente varia amplamente entre biomas, com a Amazônia e o Pantanal mantendo mais de $80 \%$, e o bioma Mata Atlântica, onde vivem quase três quartos dos brasileiros, apenas cerca de $20 \%$ (Figura 1.13).

O estado de conservação da biodiversidade varia muito entre regiões e estados (Figura 4.1). O Índice de Conservação da Biodiversidade indica que a biodiversidade na região Norte é geralmente melhor preservada, devido à vasta cobertura de vegetação nativa e à maior extensão de áreas protegidas e de terras indígenas, ao passo que os índices de muitos estados das regiões Sul e Sudeste apresentam valores menores (MMA, 2015). No entanto, o índice não reflete a real situação de ecossistemas dentro de áreas protegidas (Capítulo 5).

\section{Desmatamento}

O Brasil tem a segunda maior área florestal do mundo, atrás apenas da Rússia (Figura 4.2) e abriga a maior floresta tropical do planeta (SBF, 2013). Seus imensos 
recursos florestais se estendem por quase 5 milhões de $\mathrm{km}^{2}$, e quase dois terços de seu território é coberto por florestas ou outras terras arborizadas. Quase todas as florestas do Brasil (98,5\%) são naturais, ou seja, não plantadas. Embora a taxa de desmatamento tenha diminuído significativamente, o Brasil é o país com a maior média anual de redução da cobertura florestal total (Figura 4.2). No geral, a área total de florestas encolheu cerca de 5\%, desde 2000; e 10\%, desde 1990 (FAO, 2015).

\section{Box 4.1. Os seis biomas terrestres do Brasil}

Os ecossistemas do Brasil foram mapeados e classificados pelo IBGE em seis grandes biomas terrestres. Abaixo, uma breve descrição desses biomas.

Amazônia (49\% do território): uma floresta latifoliada úmida que representa cerca de $30 \%$ da área de floresta tropical do mundo. Abriga mais de 600 tipos de habitats terrestres e de água doce e vastos estoques de madeira comercial e de carbono. É habitada por centenas de povos indígenas e comunidades tradicionais, como seringueiros, extrativistas de produtos florestais não madeireiros e ribeirinhos. $O$ bioma Amazônia tem enfrentado o maior avanço da fronteira agrícola do mundo, em termos de perda de

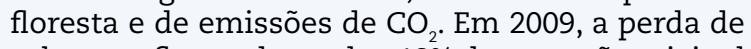
cobertura florestal excedeu $18 \%$ da extensão original da floresta. Além do avanço da agropecuária, as pressões incluem: incêndios florestais, grilagem de terras, extração de madeira, construção de estradas, hidrelétricas e projetos de mineração.

Cerrado (24\%): biologicamente, a savana tropical mais rica do mundo. É também cenário de importantes parcelas da produção brasileira de soja (50\%), milho (20\%), arroz (15\%) e feijão (11\%). Essas atividades econômicas e também os incêndios florestais representam graves ameaças às espécies nativas e aos ecossistemas do cerrado. A velocidade da perda de cobertura vegetal original do Cerrado tem sido maior do que em outros biomas, equivalendo a uma área quase do tamanho do Egito.

Caatinga (10\%): um ecossistema semiárido constituído, principalmente, por savana estépica com enclaves de floresta tropical úmida. É uma das vegetações arbustivas e áridas mais ricas no mundo, e o único bioma exclusivamente brasileiro. Vem sofrendo elevadas taxas de desmatamento, provocadas pela extração de madeira, sobrepastoreio e conversão para pastagens, bem como pela expansão da soja e da cana-de-açúcar. A irrigação para a produção de frutas tem contribuído para a desertificação, que afeta $15 \%$ deste bioma.

Mata Atlântica (13\%): o bioma que margeia a costa leste do Brasil. É composta por uma floresta tropical, subtropical seca ou latifoliada úmida, cerrados e manguezais, e abriga grande número de espécies, muitas das quais endêmicas. Cerca de $80 \%$ de sua vegetação original foi perdida devido à colonização, urbanização e extração de recursos naturais, e as áreas remanescentes estão altamente fragmentadas. Concentra cerca de $70 \%$ da população e da atividade industrial do país e a maior parte da produção agrícola destinada ao mercado interno.

Pantanal (2\%): maior zona tropical úmida de água doce do mundo. Abriga vasta riqueza de biodiversidade terrestre e aquática. O Pantanal está bem preservado, mas enfrenta pressões provenientes da expansão da agricultura e da pecuária não sustentáveis e da erosão, assoreamento e contaminação dos rios por pesticidas.

Pampa (1,8\%): bioma caracterizado por campos abertos subtropicais, amplamente explorado para a pecuária extensiva e a produção de arroz, milho, trigo e soja, o que tem degradado a fertilidade do solo e causado erosão. Outra ameaça importante à biodiversidade no Pampa tem sido a expansão urbana.

Fonte: MMA (2014), "Biomas”, www.mma.gov.br/biomas; MMA (2010), Fourth National Report to the Convention on Biological Diversity; Pinto et al. (2012), "Mata Atlantica", SFB (2014), "Os Biomas e Suas Florestas", www.florestal.gov.br/snif/recursos-florestais/os-biomase-suas-florestas. 
Figura 4.1. O estado de conservação da biodiversidade varia muito entre regiões e estados Índice de conservação da biodiversidade, por estado e região

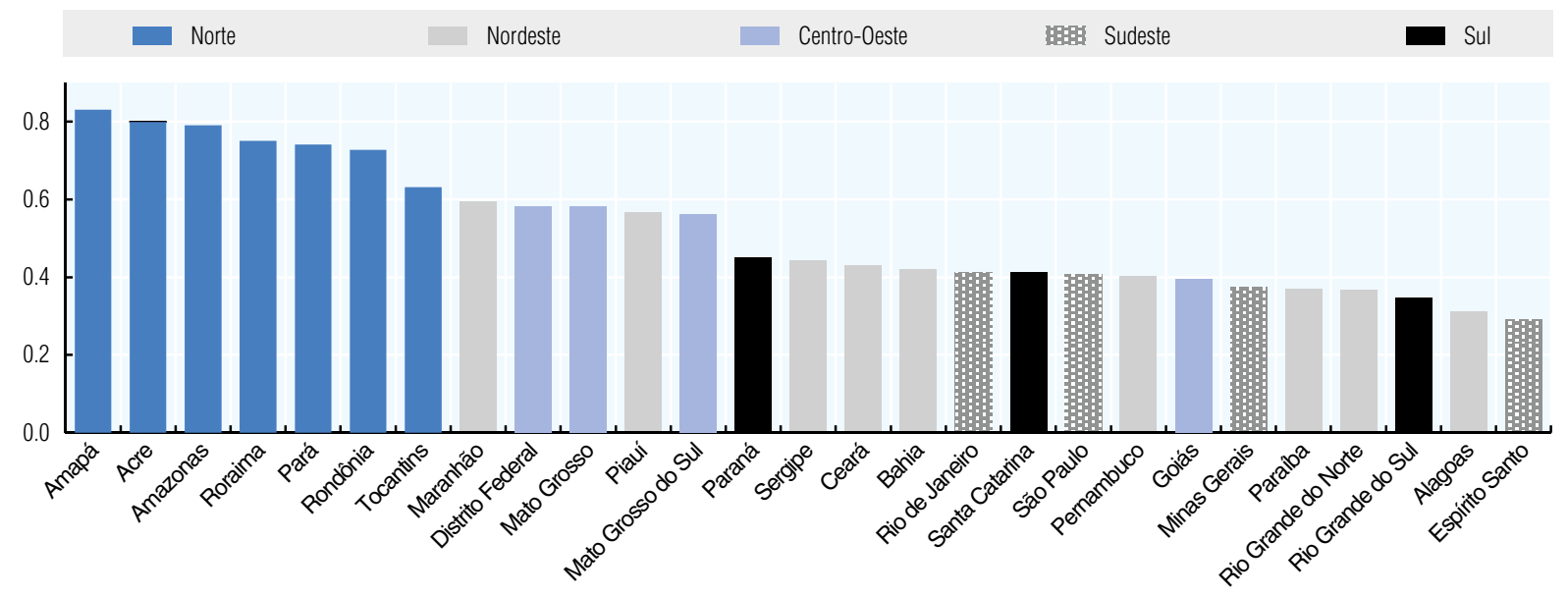

Obs.: 0 índice de conservação da biodiversidade baseia-se no número de espécies ameaçadas, na extensão de áreas protegidas oficiais e de terras indígenas, na vegetação nativa remanescente e no número de locais de conservação da biodiversidade.

0 índice varia entre 0 (estado de conservação muito ruim) e 1 (estado de conservação muito bom).

Fonte: MMA (2015), Quinto Relatório Nacional para a Convenção sobre a Biodiversidade

Figura 4.2. O Brasil tem a segunda maior área de florestas do mundo e a maior taxa de desmatamento

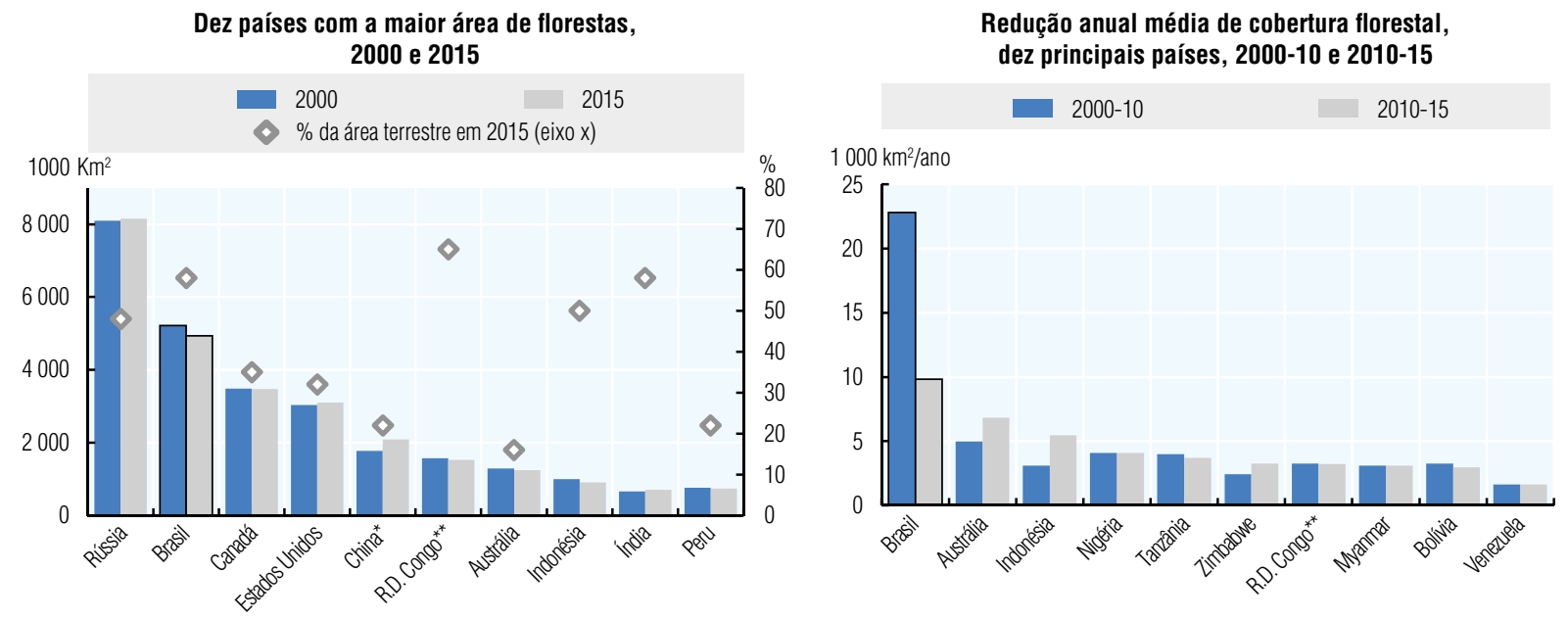

* China (RPC);:* República Democrática do Congo.

Fonte: FAO (2015), Global Forest Resources Assessment 2015.

A extração ilegal de madeira e a grilagem de terras fizeram com que a Amazônia Legal ${ }^{3}$ ficasse conhecida como área de alto risco ambiental (hotspot) nos anos de 1990 e início dos anos de 2000, com picos de desmatamento ocorrendo em 1994 e 2004 (Figura 4.3). Até 2010, aproximadamente dois terços das áreas desmatadas haviam sido convertidos em pastagens (MMA, 2015). Indefinições quanto à situação fundiária, especialmente na Amazônia, estão entre os principais vetores do desmatamento, uma vez que posse da terra pode ser reclamada através de mudança no uso do solo, o que estimula a grilagem de terras por meio do desmatamento (Seroa da Motta, 2011). Ademais, áreas convertidas têm valor de mercado superior ao de áreas de floresta, o que estimula o desmatamento 
para fins especulativos (WWF, 2015). Em 2011, apenas 4\% da Amazônia (ou 11\% das terras não públicas) eram legitimamente escrituradas (Figura 4.4).

\section{Figura 4.3. As taxas anuais de desmatamento diminuíram na maioria dos biomas brasileiros}

Desmatamento anual na Amazônia Legal, 1991-2014

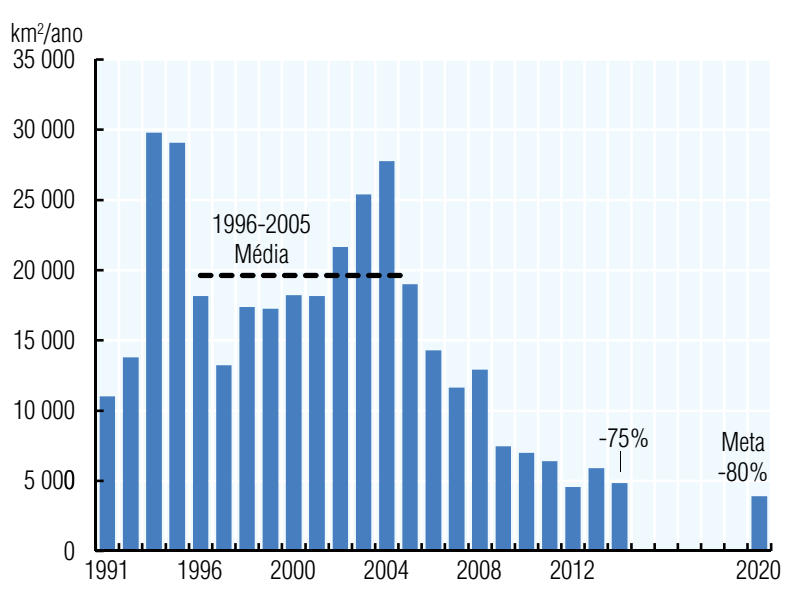

Desmatamento em outros biomas, 2008-09

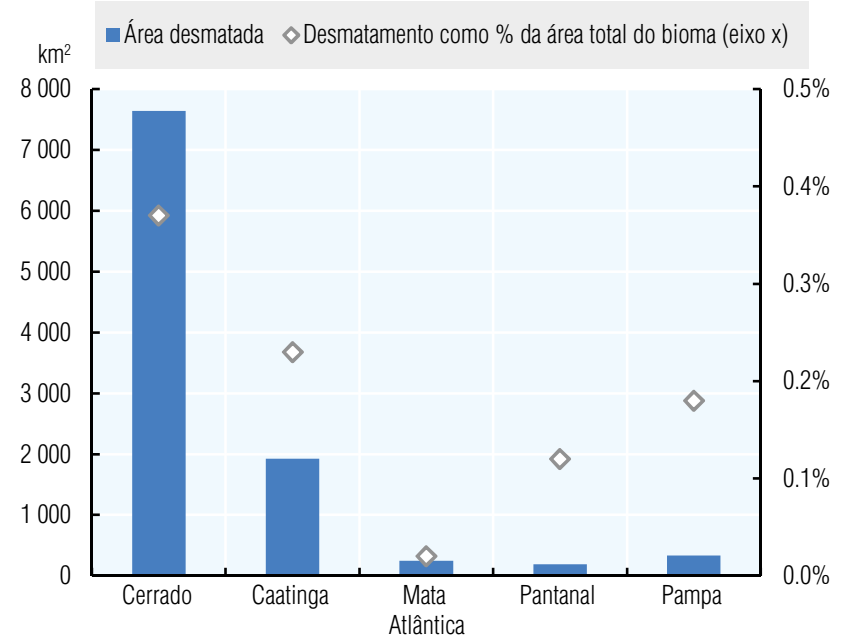

Fonte: Baseado em IBAMA (2015), "Projeto de Monitoramento do Desmatamento dos Biomas Brasileiros por Satélite - PMDBBS"; INPE (2015), "Projeto PRODES: Monitoramento da floresta Amazônica Brasileira por satélite".

Figura 4.4. Os direitos de propriedade ainda estão indefinidos para grande parte das terras da Amazônia

Distribuição de direitos fundiários na Amazônia, final dos anos 2000

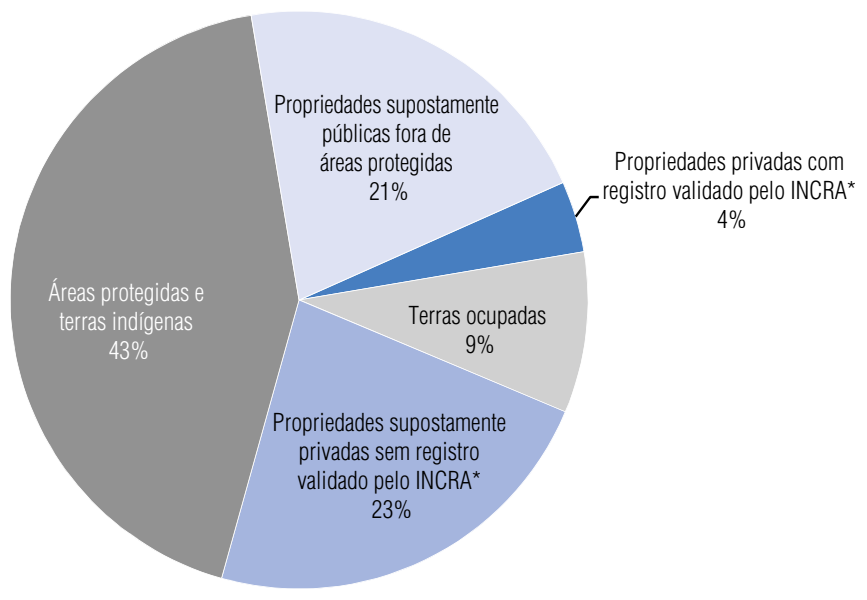

* INCRA: Instituto Nacional de Colonização e Reforma Agrária.

Fonte: Brito B. e P. Barreto (2009), "Os riscos e os princípios para a regularização fundiária na Amazônia”, Imazon No. 10, março 2009.

Em 2006, o governo assumiu o compromisso de reduzir o desmatamento na Amazônia Legal em 80\% até 2020 (em comparação com a média dos 10 anos anteriores) e, desde então, tem intensificado ações direcionadas ao combate do desmatamento (Seção 4; ver também Capítulo 5 sobre áreas protegidas). Essas ações contribuíram para uma 
redução do desmatamento, de $27.700 \mathrm{~km}^{2}$ para $4.800 \mathrm{~km}^{2}$ ao ano, entre 2004 e 2014 . Até 2014, a taxa de desmatamento anual havia caído em 75\% (Figura 4.3) (INPE, 2015) o que contribuiu para a redução das emissões de GEE (Capítulo 1). No entanto, no atual ritmo de desmatamento, o Brasil perde uma área de floresta equivalente ao tamanho do Estado de Sergipe (ou da Eslovénia) a cada quatro anos. A sistemática implementação do Novo Código Florestal e do Cadastro Ambiental Rural (Seção 5.2) deverá contribuir em muito para o controle do desmatamento.

Nos últimos anos, também houve diminuição nas taxas de desmatamento na maioria - mas não em todos - os biomas. ${ }^{4}$ Para a Mata Atlântica, por exemplo, estima-se que o desmatamento tenha diminuído em cerca de $80 \%$ nos últimos vinte anos. Por outro lado, ainda existem fortes pressões sobre o Cerrado, que sofreu as mais altas taxas de desmatamento absolutos e relativos, entre 2008 e 2009 (IBAMA, 2015; Figura 4.3). Segundo algumas estimativas, no Cerrado, o desmatamento anual mais do que duplicou entre 2009 e 2012 (Soares-Filho et al., 2014a).

\section{Incêndios florestais}

Incêndios florestais descontrolados provocados pelo homem são importante causa de degradação em vários biomas, notadamente na Amazônia e no Cerrado. Na Amazônia, a incidência de queimadas está intimamente relacionada com a exploração madeireira e a conversão de florestas em áreas para a agropecuária (MMA, 2015; 2010). As ocorrências de incêndios florestais vêm oscilando entre 100.000 e 250.000 ao ano, desde 2000, e são monitoradas diariamente por instituições federais, por meio de imagens de satélite. O governo intensificou ações de combate a incêndios florestais nos últimos anos, com a aquisição de equipamentos e a capacitação de brigadistas, e vem elaborando uma política nacional, com lançamento previsto para 2015.

\subsection{Ecossistemas marinho e aquático}

O Brasil abriga ricos ecossistemas de recifes de coral e a maior área contígua de manguezais do mundo. Suas águas marinhas abarcam uma vasta gama de recursos pesqueiros, vertebrados, invertebrados, mamíferos, aves e quelônios. Estimativas sugerem que cerca de $25 \%$ dos ecossistemas de mangue já foram perdidos (MMA, 2015). Os principais vetores da perda da biodiversidade marinha e costeira incluem: desmatamento de matas ciliares e manguezais; expansão urbana ao longo do litoral; atividades da indústria de petróleo e gás; pesca predatória e aquicultura mal planejada; introdução de espécies exóticas; poluição hídrica e descuidado com o lixo; e mudanças do clima (Prates, 2014). Atualmente, apenas 1,5\% das áreas marinhas brasileiras (incluindo a zona econômica exclusiva) estão sob proteção (Capítulo 5).

A poluição por efluentes industriais, agrícolas e urbanos e o desenvolvimento de infraestruturas são as principais causas da perda de habitats de água doce. Potencialmente, a implantação de usinas hidrelétricas, principal fonte de energia elétrica no Brasil, pode provocar fragmentação de rios e afetar habitats de espécies aquáticas, assim como impactos sobre comunidades locais que, muitas vezes tiram seu sustento da agricultura de pequena escala e da pesca. Algumas iniciativas pontuais tentam mitigar o impacto de barragens, por exemplo, a instalação de escadas para subida de peixes. No entanto, são raros os estudos que avaliam os impactos cumulativos de uma série de barragens construídas no mesmo rio (MMA, 2015) (Seção 7.4). 


\section{Recursos pesqueiros e da aquicultura}

A captura de peixes provenientes de águas marinhas e de água doce aumentou em quase 15\% entre 2000 e 2013 (Figura 4.5). Vários estoques de peixes costeiros e de águas interiores estão no limite de exploração ou predatoriamente superexplorados em consequência da pesca em excesso, geralmente a industrial (FAO, 2013). A sobrepesca e a diminuição dos estoques de certas espécies estão associadas a conflitos entre adeptos da pesca artesanal e da industrial e entre comunidades de pescadores. A pesca artesanal lidera a produção comercial com mais de $60 \%$ do total capturado, sendo que na pesca em águas interiores, a parcela é ainda maior (OCDE-FAO, 2015).

\section{Figura 4.5. A produção de peixes tem aumentado consideravelmente, desde 2000}

\section{Produção pesqueira em águas interiores e em áreas marinhas, 2000-13}

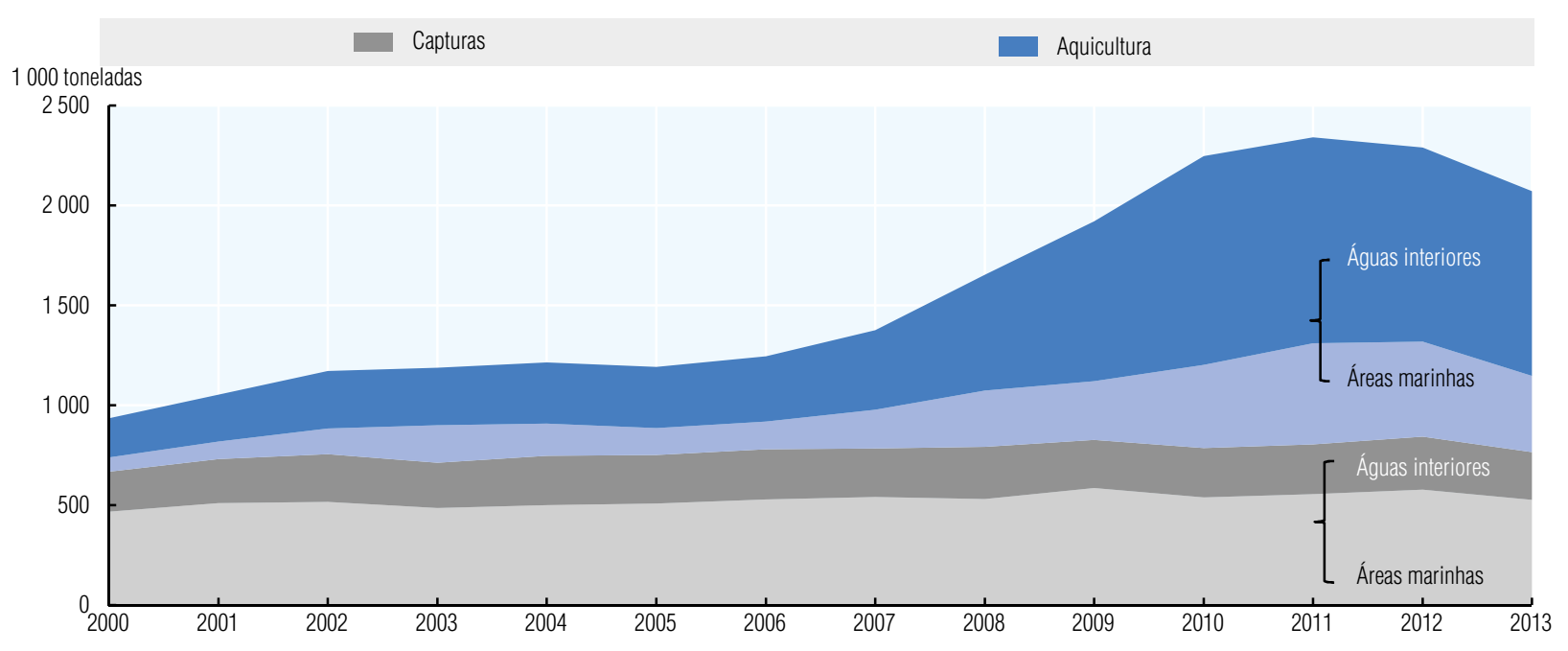

Obs.: Inclui peixes, crustáceos, moluscos e outros animais aquáticos; exclui mamíferos marinhos, jacarés e crocodilos, e plantas aquáticas. Fonte: FAO (2015), FAO Global Capture and Aquaculture Production Statistics (database).

A aquicultura aumentou quase $400 \%$ entre 2000 e 2013, notadamente em águas interiores (Figura 4.5) chegando a representar mais de 60\% da produção total de pescado em 2013. Embora a aquicultura possa aumentar a disponibilidade de pescado e reduzir a pressão sobre recursos pesqueiros naturais, sua rápida expansão pode trazer prejuízos para a biodiversidade e os serviços ecossistêmicos.

\subsection{Espécies}

O Brasil abriga cerca de 44.000 espécies de plantas e mais de 104.500 espécies de vertebrados e invertebrados (MMA, 2015). ${ }^{5}$ Várias espécies nativas brasileiras constituem importante fonte de alimentos em escala regional e local. ${ }^{6}$ Alguns estudos buscam quantificar o número de espécies conhecidas por bioma, mas os dados não são totalmente comparáveis (Tabela 4.1).

A lista de espécies da flora brasileira ameaçadas de extinção, de 2014, aponta que 46\% do total aproximado de 4.600 espécies de plantas avaliadas enfrentam ameaças, segundo várias categorias de risco. ${ }^{7} \mathrm{O}$ bioma Mata Atlântica abriga o maior quantitativo 
de espécies de plantas ameaçadas, entre aquelas que foram avaliadas, em consequência de elevadas pressões provocadas pela urbanização, desenvolvimento e fragmentação de habitats; seguido pelo bioma Cerrado, onde as pressões da expansão agrícola têm se intensificado (Figura 4.6).

Tabela 4.1. Estimativa quantitativa de espécies em biomas terrestres brasileiros

\begin{tabular}{lrrrrrr}
\hline & Amazônia & Mata Atlântica & Caatinga & Cerrado & Pantanal & Pampa \\
\hline Número de espécies & $\mathbf{1 8 ~ 0 2 6}$ & $\mathbf{2 1 \mathbf { 1 5 6 }}$ & $\mathbf{5 5 1 2}$ & $\mathbf{1 5 4 5 4}$ & $\mathbf{4 8 1 8}$ & $\mathbf{2 5 6 4}$ \\
Plantas & 13993 & 18951 & 4508 & 13014 & 3500 & 1675 \\
Mamíferos & 399 & 298 & 153 & 251 & 159 & 102 \\
Aves & 1300 & 1020 & 510 & 837 & 656 & 476 \\
Répteis & 284 & 197 & 107 & 202 & 98 & 110 \\
Anfíbios & 250 & 340 & 49 & 150 & 53 & 50 \\
Peixes & 1800 & 350 & 185 & 1000 & 352 & 151 \\
\hline
\end{tabular}

Obs.: Como muitas espécies estão presentes em mais de um bioma, o quantitativo de espécies entre os diferentes biomas brasileiros não deve ser somado. Fonte: MMA (2015), Quinto Relatório Nacional para a Convenção sobre a Diversidade Biológica

\section{Figura 4.6. Os planos de conservação cobrem cerca de metade das espécies da fauna ameaçada}
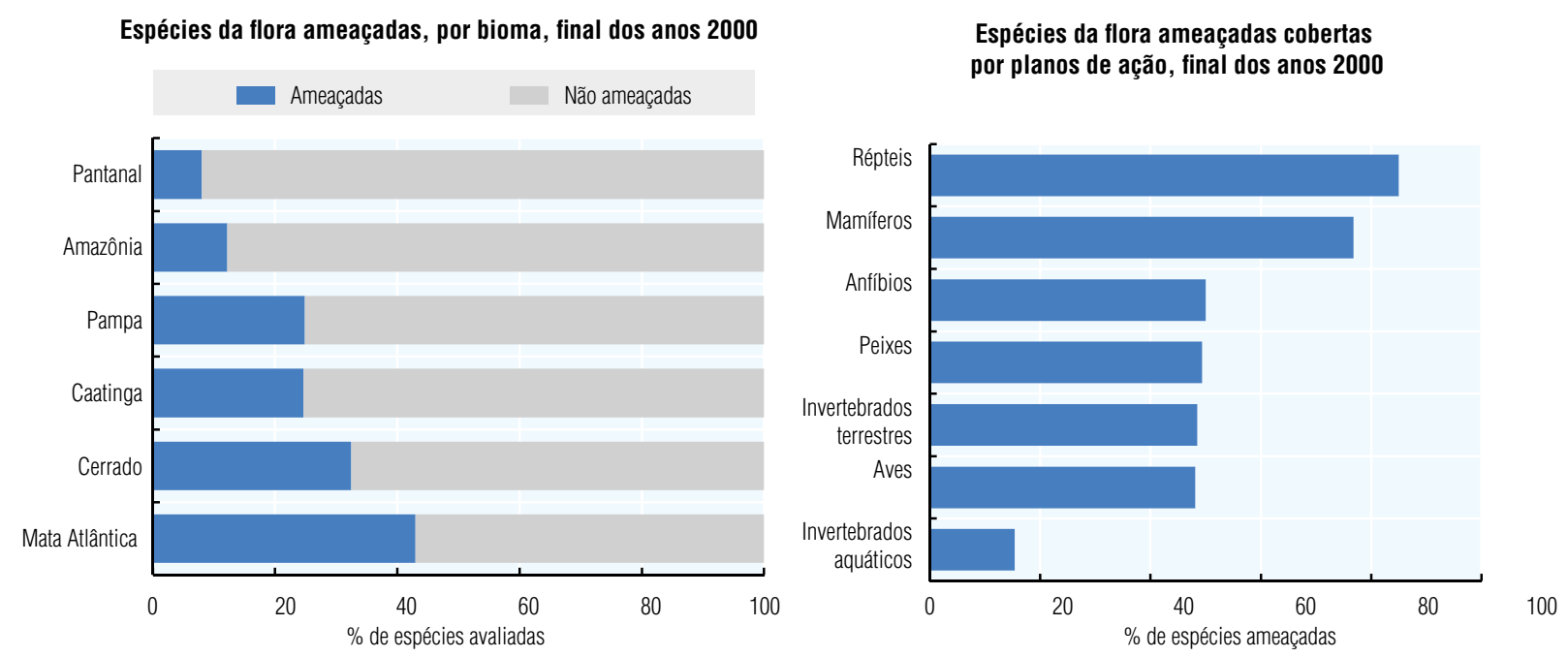

Fonte: MMA (2015), Quinto Relatório Nacional para a Convenção sobre a Diversidade Biológica

A lista de espécies da fauna brasileira ameaçadas de extinção, de 2014, aponta que, dentre as mais de 12.000 espécies avaliadas, 1.173 estão ameaçadas, incluindo 110 de mamíferos, 234 de aves e 409 de peixes marinhos e de água doce (ICMBio, 2015). Esses quantitativos representam quase o dobro das espécies ameaçadas identificadas na avaliação anterior devido, principalmente, à melhoria do conhecimento científico e a uma avaliação mais extensiva.

Aumentaram as ações para a proteção de espécies ameaçadas. Até o final de 2013, - Brasil já havia lançado 48 planos de ação para a preservação de espécies ameaçadas, incluindo as costeiras e marinhas. Em 2012, cerca de 50\% de todas as espécies ameaçadas da fauna já estavam sob proteção de um plano de ação voltado à sua conservação - 
em contraste com 4\% em 2008 - com cobertura variando de acordo com o grupo taxonômico e o nível de execução (Figura 4.6). Atualmente, as unidades de conservação federais abrigam cerca de $60 \%$ das espécies ameaçadas da flora e da fauna (Capítulo 5). No geral, desde as avaliações anteriores, a situação da conservação de 126 espécies tem melhorado (MMA, 2015).

Estimativas indicam que o tráfico ilegal de animais silvestres gera cerca de US\$2,5 bilhões ao ano e que, a cada ano, cerca de 38 milhões de animais silvestres são retirados da natureza, dos quais cerca de 4 milhões são comercializados. O Brasil alcançou avanços no combate ao comércio ilegal de espécies ameaçadas de extinção, com a introdução de normas rígidas e melhor coordenação entre agências; porém ainda enfrenta desafios, tais como insuficiência de pessoal, de equipamentos e de capacitação.

Aproximadamente 330 espécies invasoras foram identificadas, principalmente no bioma Mata Atlântica. Estima-se que três quartos das espécies exóticas invasoras foram propositadamente introduzidos, algumas para atividades econômicas (incluindo a agricultura) mas principalmente para fins ornamentais (IBGE, 2013; MMA, 2010). A introdução de espécies de plantas exóticas levou à transformação de paisagens inteiras, aumentando a fragmentação florestal e a degradação de habitats. ${ }^{8}$ A estimativa é que a presença de espécies invasoras provoque prejuízos anuais de US\$ 43 bilhões (MMA, 2015). O Brasil ainda não desenvolveu políticas e ações abrangentes para o controle e monitoramento de espécies invasoras; mas implementa programas direcionados a espécies específicas (ex., para o mexilhão dourado).

\section{Principais atores na política de biodiversidade}

\subsection{Instituições}

Nos anos 2000, o Brasil reforçou o marco institucional da política da biodiversidade, atribuindo ao Ministério do Meio Ambiente (MMA) a responsabilidade pela conservação, restauração e uso sustentável da biodiversidade. Entre as agências federais incumbidas da execução de políticas estão: o Instituto Chico Mendes de Conservação da Biodiversidade (ICMBio), o Instituto Brasileiro do Meio Ambiente e dos Recursos Naturais Renováveis (IBAMA), a Agência Nacional de Águas (ANA), o Instituto de Pesquisas Jardim Botânico do Rio de Janeiro (JBRJ) e o Serviço Florestal Brasileiro (SFB). O ICMBio, criado em 2007, é responsável pela implementação da política nacional sobre as unidades de conservação federais e pela conservação de espécies ameaçadas. O IBAMA é o principal responsável pelo licenciamento e fiscalização, em estreita articulação com o ICMBio (em se tratando de áreas protegidas) e com agências estaduais e municipais (Capítulos 2 e 5).

A Comissão Nacional de Biodiversidade (CONABIO) é responsável pela coordenação e elaboração da Política Nacional da Biodiversidade e pela supervisão de sua implementação, bem como pelo acompanhamento do cumprimento de compromissos do Brasil, assumidos no âmbito da Convenção sobre Diversidade Biológica (CDB) das Nações Unidas. Criada em 2003, a CONABIO é presidida pelo MMA e conta com representação de nove ministérios, da sociedade civil, do setor privado e de acadêmicos. Vários outros ministérios e órgãos federais estão envolvidos na coordenação da política de biodiversidade. ${ }^{9}$ No entanto, a exemplo do que acontece em outras áreas da política ambiental, é comum uma sobreposição de responsabilidades entre instituições e instâncias governamentais, o que compromete a eficácia da coordenação (Capítulo 2). 


\subsection{Organizações não governamentais e a cooperação internacional}

As organizações não governamentais (ONGs), os organismos internacionais de cooperação e países parceiros desempenham papel fundamental no apoio à formulação e implementação da política de biodiversidade no Brasil, fornecendo capacidade técnica, experiência e assessoria e agilizando financiamentos. Auxiliam, também, na adoção de abordagens inovadoras para a conservação e uso sustentável da biodiversidade, bem como para a proteção dos direitos de comunidades tradicionais. Muitas vezes, as ONGs prestam apoio in situ à implementação de políticas e programas, quando a capacidade institucional é insuficiente (Capítulo 2).

Até dezembro de 2011, o Brasil havia celebrado 233 acordos de cooperação bilateral e multilateral, sendo que 22\% deles abordam temas ambientais. Entre 2010 e 2013, a Alemanha e a Noruega foram os maiores doadores para projetos de sustentabilidade ambiental (Capítulo 3). A cooperação com a Alemanha e a Noruega tem como foco a proteção de florestas tropicais e a prevenção do desmatamento na Amazônia. Esses dois países estão entre os maiores doadores do Fundo Amazônia (Seção 6.2). Entre os atuais 55 projetos financiados pelo Fundo Global para o Meio Ambiente (GEF) no Brasil, 23 - incluindo o Programa Áreas Protegidas da Amazônia (ARPA) e o Projeto Nacional de Biodiversidade - tratam da biodiversidade e respondem por $45 \%$ do total dos recursos recebidos (GEF, 2012).

\section{Marco estratégico de políticas para conservação e uso sustentável da biodiversidade}

O Brasil foi o primeiro signatário da Convenção sobre Diversidade Biológica, em 1992 e, desde então, elaborou um marco político e institucional consistente com os compromissos assumidos no âmbito da CDB. Consequentemente, sua política de biodiversidade vem, gradativamente, abandonando a abordagem de cercar, proteger e fiscalizar, em favor de uma abordagem pautada pelo desenvolvimento sustentável, que identifica regiões prioritárias de biodiversidade e reconhece o papel das comunidades rurais, tradicionais e indígenas na preservação de ecossistemas.

Em 2002, o Brasil aprovou sua Estratégia Nacional de Biodiversidade e Plano de Ação, estabelecendo 51 metas para 2010, sendo algumas mais ambiciosas que as metas globais da CDB à época. Essas metas resultaram em avanços apenas modestos, e o MMA reconhece que a debilidade de critérios e de processos na definição dessas metas, assim como a falta de indicadores de acompanhamento, foram os principais obstáculos para o sucesso da estratégia (MMA, 2015).

Após a definição das 20 Metas de Aichi na Conferência das Partes da CDB (COP-10), o Brasil realizou amplo processo de consulta para definir novas metas nacionais de biodiversidade até $2020 .{ }^{10} \mathrm{Em} \mathrm{2013}$, a CONABIO aprovou 5 objetivos estratégicos e 20 metas nacionais de biodiversidade, em linha com o Plano Estratégico 2011-20 da CDB (Anexo 4.A). Ademais, em 2014, o MMA promoveu um diálogo multissetorial para a elaboração de um Plano de Ação Governamental para Conservação e Uso Sustentável da Biodiversidade.

Para superar dificuldades de implementação da estratégia de 2002, o PainelBio vem conduzindo um processo participativo de definição de indicadores de acompanhamento para a avaliação do progresso alcançado rumo às metas de 2020. Uma avaliação intercalar indica que o Brasil está no caminho certo para alcançar a maioria de suas metas, embora esforços adicionais sejam necessários (MMA, 2015). Avanços notáveis foram 
alcançados na redução da perda e degradação de habitats e na ampliação da área sob proteção na Amazônia (Anexo 4.A).

O Brasil desenvolveu um marco legislativo abrangente e rigoroso para a conservação e uso sustentável da biodiversidade, com o lançamento de várias políticas e programas relacionados. Entre os principais dispositivos legais, está a lei que institui o Sistema Nacional de Unidades de Conservação da Natureza (SNUC) de 2000 (Capítulo 5); a Lei de Proteção da Vegetação Nativa de 2012, que institui o Código Florestal, regulamenta a proteção de florestas em propriedades privadas e cria o Cadastro Ambiental Rural (Seção 5.2); e uma legislação abrangente sobre acesso a recursos genéticos e partilha de benefícios (Seção 5.8).

Alguns estados, entre eles São Paulo, Paraná e Rio Grande do Sul, têm desenvolvido suas próprias estratégias, planos de ação ou programas de biodiversidade (Box 4.2). O desafio, no entanto, é assegurar a coerência e a sinergia com políticas federais, programas e metas de biodiversidade.

A política brasileira de biodiversidade tem se concentrado fortemente no combate ao desmatamento e na criação de um sistema de áreas protegidas, em parte em resposta a pressões internacionais. Mesmo mantendo um alto grau de atenção nesta área, o Brasil deve ampliar suas ações políticas direcionadas aos ecossistemas marinhos, costeiros e de água doce. No geral, desde a década de 2000, houve uma proliferação de planos e programas relacionados à biodiversidade, muitas vezes com sobreposição de objetivos. É difícil determinar em que medida essas ações chegaram a ser implementadas, ou quais foram os resultados alcançados. Com poucas exceções, a implementação de políticas e planos de biodiversidade não passa por monitoramento sistemático; e raramente é realizada qualquer avaliação de sua eficácia, custos e benefícios.

\section{Estratégia integrada de combate ao desmatamento}

O aumento dos índices de desmatamento na Amazônia no início dos anos 2000 deu origem a uma crescente pressão por parte da sociedade civil e da comunidade internacional

\section{Box 4.2. Plano de ação para a biodiversidade do Estado de São Paulo}

O estado de São Paulo foi pioneiro no desenvolvimento de um plano estadual em apoio à implementação da CDB. O Plano de Ação do Estado de São Paulo 2011-20, lançado em 2013, consolidou iniciativas já em andamento que contribuem para as 20 metas da convenção, e identificou outras ações necessárias. A Comissão Paulista da Biodiversidade supervisiona sua implementação.

Para facilitar e estruturar a implementação do plano, foram avaliadas as atividades e propostas já existentes, por três critérios - geração de impactos positivos, resultados mensuráveis e simplicidade agrupadas em sete eixos de ação: i) conscientização para a biodiversidade; ii) avaliação da biodiversidade de São Paulo; iii) redução das pressões sobre a biodiversidade de São Paulo; iv) apoio à produção e ao consumo sustentáveis; v) instrumentos para a conservação da biodiversidade; vi) restauração ecológica; e vii) gestão do conhecimento. Para cada eixo de ação foi criada uma linha de projetos com várias metas e resultados concretos. Entre os exemplos de ações específicas no âmbito do plano estão: a criação de um portal da biodiversidade (www.portaldabiodiversidade.sp.gov.br); a elaboração de indicadores de biodiversidade e projetos de desmatamento zero; o controle de incêndios florestais; espécies exóticas invasoras; economia verde e sustentabilidade setorial; áreas protegidas; e desenvolvimento de um sistema de apoio para a restauração florestal. A Secretaria Estadual de Meio Ambiente estima o valor do plano em mais de $\mathrm{R} \$ 100$ milhões.

Fonte: MMA (2015), Quinto Relatório Nacional para a Convenção sobre a Diversidade Biológica; SMA (2013), Plano de Ação do Estado de São Paulo. Metas Aichi 2020. 
para que medidas enérgicas fossem tomadas. Como resposta, o governo brasileiro aumentou consideravelmente suas ações de combate ao desmatamento, lançando, em 2004, o Plano de Ação para Prevenção e Controle do Desmatamento na Amazônia Legal (PPCDAm). Em 2006, o governo se comprometeu em reduzir o desmatamento na Amazônia Legal em $80 \%$ até 2020 (em comparação com a média dos últimos 10 anos). Esse compromisso foi posteriormente incorporado à Política Nacional de Mudanças Climáticas, como elemento-chave da estratégia do Brasil para a redução de gases de efeito estufa (GEE) (Capítulo 2) e reforçado como parte das metas nacionais de biodiversidade (Meta 5; ver Anexo 4.A).

O PPCDAm estabeleceu uma estratégia integrada e uma estrutura inovadora de governança, o que colocou o desmatamento na agenda de outros setores (CEPAL et al., 2011). A execução do programa foi realizada por 13 ministérios e coordenada pela Casa Civil da Presidência da República. O plano, atualmente em sua terceira fase (2012-15) baseia-se em três eixos principais de trabalho, discutidos abaixo.

O primeiro eixo tem por objetivo esclarecer a situação fundiária na Amazônia e reduzir o incentivo ao desmatamento (Seção 1.1; Figura 4.4). Numa ação conjunta com o programa ARPA (Capítulo 5) foram criadas unidades de conservação federais e estaduais cobrindo mais de 500 mil km², principalmente ao longo do chamado "arco do desmatamento" (que compreende os limites leste e sul da floresta nos Estados de Rondônia, Mato Grosso e Pará) e em áreas aguardando a implantação de infraestrutura rodoviária. Tais ações foram essenciais para retardar o avanço do desmatamento para fins especulativos (CEPAL et al, 2011; Pires, 2014). Além disso, $100 \mathrm{mil} \mathrm{km}^{2}$ de terras indígenas foram demarcados e reconhecidos, e milhares de propriedades rurais foram georreferenciadas por meio do programa Terra Legal (Box 4.3).

O segundo eixo de trabalho concentra-se no fortalecimento do monitoramento, execução e cumprimento do plano. Os sistemas de monitoramento ambiental foram aprimorados para alcançar padrões mundiais (Box 4.4). Esses aprimoramentos foram fundamentais para a identificação de locais prioritários para a criação de novas unidades de conservação e para o planejamento e execução de ações de fiscalização.

\section{Box 4.3. Programa Terra Legal}

O programa Terra Legal, lançado em 2009 pelo Ministério do Desenvolvimento Agrário destina-se a regularizar a ocupação de terras públicas federais na Amazônia, combater a grilagem, controlar o desmatamento e promover iniciativas de desenvolvimento sustentável. Visa a emissão de escrituras para aproximadamente 300 mil propriedades rurais ocupadas antes de $1^{\circ}$ de dezembro de 2004, correspondendo a uma área de 674 mil km². Essa regularização proporciona a necessária segurança jurídica aos produtores rurais, pois a escrituração evita novos conflitos sobre a posse da terra.

O processo de regularização envolve reuniões periódicas interinstitucionais de consulta, e é baseado em dados espaciais confiáveis. Em 2014, mais de 60 mil glebas de terra (abrangendo 390 mil km²) haviam sido georreferenciadas, e mais de 10 mil escrituras haviam sido emitidas sobre mais de $55 \mathrm{mil} \mathrm{km}^{2}$ de terras (MDA, 2014). Essas conquistas são notáveis e apontam o caminho para ações subsequentes. Além disso, cerca de 50 mil $\mathrm{km}^{2}$ de terras públicas federais foram transferidos ao MMA, para a criação de unidades de conservação (Capítulo 5).

Fonte: MDA (2014), Programa Terra Legal 


\section{Box 4.4. Sistemas de monitoramento do desmatamento no Brasil}

O Instituto Nacional de Pesquisas Espaciais (INPE) tem monitorado a cobertura florestal na Amazônia Legal anualmente, desde 1988. A partir de 2002, com a adoção da tecnologia de classificação digital de imagens proporcionada pelo Projeto de Monitoramento do Desmatamento na Amazônia Legal por Satélite (PRODES), foi significativamente melhorada a precisão desse monitoramento. O INPE também opera o Sistema de Detecção do Desmatamento em Tempo Real (DETER) que emite alertas a cada dois ou três dias, e tem se comprovado ferramenta fundamental para a eficácia de ações estratégicas de fiscalização na Amazônia. Além disto, o Sistema de Mapeamento da Degradação Florestal na Amazônia Brasileira (DEGRAD) monitora a degradação florestal, e o projeto TerraClass analisa e avalia mudanças no uso da terra em áreas já desmatadas (MMA, 2015). Segundo dados do TerraClass, cerca de um terço das terras florestais desmatadas na Amazônia está em vias de recuperação.

Fora da Amazônia, o IBAMA lançou, em 2008, o Projeto de Monitoramento do Desmatamento dos Biomas Brasileiros por Satélite (PMDBBS) para monitorar desdobramentos na cobertura florestal nos outros cinco biomas terrestres brasileiros. No entanto, os sistemas utilizados pelo PRODES oferecem maior precisão que os do PMDBBS e, atualmente, o INPE e o IBAMA vêm colaborando no desenvolvimento de um sistema de monitoramento único, capaz de gerar séries de dados contínuas e compatíveis sobre desmatamento, cobertura vegetal e uso da terra em todos os biomas, abrangendo todo o território nacional.

O papel da sociedade civil em apoio ao monitoramento também tem sido de grande relevância. Por exemplo, a ONG SOS Mata Atlântica vem apoiando o monitoramento da cobertura vegetal no Bioma Mata Atlântica; e a ONG Imazon lançou recentemente um novo sistema de monitoramento do desmatamento e da degradação florestal na Amazônia.

Centenas de operações conjuntas de fiscalização foram realizadas pelo Ibama, Polícia Federal, Força Nacional e Exército, com base em critérios técnicos e prioridades territoriais. Desde 2008, as fiscalizações resultaram também no embargo econômico de áreas ilegalmente desmatadas: ficando os detentores de terras proibidos de comercializar produtos provenientes dessas áreas, com essa responsabilidade ambiental se estendendo ao longo da cadeia de comercialização. Essas operações resultaram em mais de $\mathrm{R} \$ 7$ bilhões em multas, penas de prisão para mais de 600 pessoas, apreensão de cerca de $860 \mathrm{mil} \mathrm{m}^{3}$ de madeira extraída ilegalmente e embargo sobre $600 \mathrm{~km}^{2}$ de terras utilizadas para fins ilegais (WWF, 2015).

Restrições de crédito impostas por instituições financeiras públicas a detentores de terras em municípios com níveis críticos de desmatamento têm melhorado a eficácia da fiscalização e reforçado o cumprimento da legislação. Desde 2007, o MMA mantém uma lista negra desses municípios. Essa iniciativa tem levado proprietários rurais e autoridades locais a se unir, em esforço conjunto, para retirar seus municípios dessa lista. Além disso, uma resolução do Banco Central do Brasil de 2008, condicionou o acesso a crédito rural subsidiado na Amazônia à legitimidade da posse de terras e à prestação de informações comprovando conformidade com normas ambientais, especialmente com o Código Florestal (Seção 5.2). Em consequência dessa resolução, estima-se que créditos no valor de $\mathrm{R} \$ 2,9$ bilhões deixaram de ser contratados entre 2008 e 2011, cerca de $90 \%$ dos quais ligados à pecuária (Assunção et al. 2013) e que isto tenha evitado o desmatamento de mais de $2.700 \mathrm{~km}^{2}$ de terra entre 2009 e 2011.

O terceiro fluxo de trabalho do Plano para Prevenção e Controle do Desmatamento na Amazônia (PPCDAm) promove cadeias sustentáveis de produção que criam alternativas ao desmatamento e oferecem tecnologias e inovação para o desenvolvimento sustentável da Amazônia (Box 4.5). As ações realizadas incluem treinamento e capacitação para o manejo florestal sustentável, práticas de produção agrícola e pecuária, 
concessões para a extração sustentável de madeira e políticas de garantia de preços mínimos para produtos alimentícios da Amazônia (Seção 5.7 e 7.2 ).

\section{Box 4.5. Instituto Nacional de Pesquisas da Amazônia}

O Instituto Nacional de Pesquisas da Amazônia (INPA), criado em 1952, é um dos maiores e mais importantes institutos de pesquisa do mundo em biologia tropical. Inicialmente, tinha como foco a elaboração de inventários de plantas e animais, mas sua missão atual é ampliar o conhecimento científico sobre o bioma amazônico, com vistas a promover a conservação da floresta e o aproveitamento econômico de seus recursos naturais.

O INPA promove uma ampla gama de pesquisas em quatro grandes áreas temáticas: biodiversidade; dinâmicas ambientais; tecnologia e inovação; e sociedade, meio ambiente e saúde. Coordena ainda vários programas de graduação e pós-graduação e atua como importante centro de formação para atender à crescente demanda por pessoal qualificado. Desde 2014, capacitou mais de 1.500 profissionais.

Com vistas a promover a melhoria do aproveitamento sustentável da biodiversidade, o INPA vem atuando junto às comunidades locais, por meio da oferta de oficinas educativas e técnicas e de outras formas de capacitação para disseminar o conhecimento gerado. Os tópicos abordados incluem: divulgação de conhecimentos sobre práticas agrícolas sustentáveis para a melhoria da qualidade do solo e da produção; purificação da água; madeiras alternativas para uso em construções; e aproveitamento de formas alternativas de biomassa para geração de energia.

Fonte: Baseado no INPA (2015), INPA website, http://portal.inpa.gov.br/.

O PPCDAm é reconhecido como uma estratégia eficaz, que pode servir de modelo para outros países (WWF, 2015). Em conjunto com as restrições de crédito rural e o embargo econômico de áreas ilegalmente desmatadas, este plano contribuiu fortemente para a redução do desmatamento na Amazônia e, como resultado, é provável que o Brasil supere sua meta para 2020 (secção 1; Figuras 4.3 e 4.7). Segundo estimativas, essas políticas evitaram o desmatamento de 62 mil km² entre 2005 e 2009 (Assunção et al. 2013) mas, outros fatores, incluindo a baixa nos preços de commodities agrícolas, podem ter contribuído para esse resultado. Com base no sucesso do PPCDAm, o governo lançou um programa semelhante para controle do desmatamento no bioma Cerrado (Box 4.6).

\section{Box 4.6. Plano de Ação para a Prevenção e Controle do Desmatamento e das Queimadas no Cerrado}

O Plano de Ação para a Prevenção e Controle do Desmatamento e das Queimadas no Cerrado (PPCerrado) tem como objetivo a redução do desmatamento em $40 \%$ até 2020, em relação aos índices históricos. Foi inicialmente implementado em 2009 e, com sua integração à Política Nacional de Mudanças do Clima no início de 2010, seu escopo foi ampliado para envolver várias agências do governo (Capítulo 2). O plano está estruturado em torno dos mesmos três eixos de trabalho do PPCDAm.

Um aspecto importante do PPCerrado foi a elaboração de uma lista prioritária de áreas de desmatamento, que inclui 52 municípios. A lista baseia-se em níveis de desmatamento observados entre 2009 e 2010, na cobertura florestal nativa remanescente e na presença de áreas protegidas no município. Os municípios constantes da lista prioritária correspondem a apenas $4 \%$ do total de municípios do bioma Cerrado, mas foram responsáveis por $44 \%$ do desmatamento e detêm $22 \%$ da cobertura florestal nativa remanescente. Para melhorar o monitoramento e a avaliação da eficácia do plano, o IBAMA e o INPE estão elaborando uma linha de base de referência e aprimorando o sistema de monitoramento da cobertura florestal (Box 4.4).

Fonte: MMA (2015), Brasil Quinto Relatório Nacional para a Convenção sobre a Diversidade Biológica 
A Amazônia ainda apresenta grandes desafios; o ritmo dos avanços tem sido desigual nos diferentes estados que integram a região, com o Pará, Mato Grosso e Rondônia ainda apresentando os maiores índices de desmatamento (Figura 4.7). Em 2014, por exemplo, cerca de 12\% do desmatamento ilegal no Estado do Mato Grosso e 16\% no Estado do Pará ocorreu em áreas de Reserva Legal (Gibbs et al., 2015) que, pela legislação florestal, devem ser preservadas (Seção 5.2). Indefinições quanto à situação fundiária continuam sendo grande problema (Figura 4.4) e servem de estímulo para o desmatamento para fins especulativos.

\section{Figura 4.7. As medidas políticas têm efetivamente ajudado a conter o desmatamento}

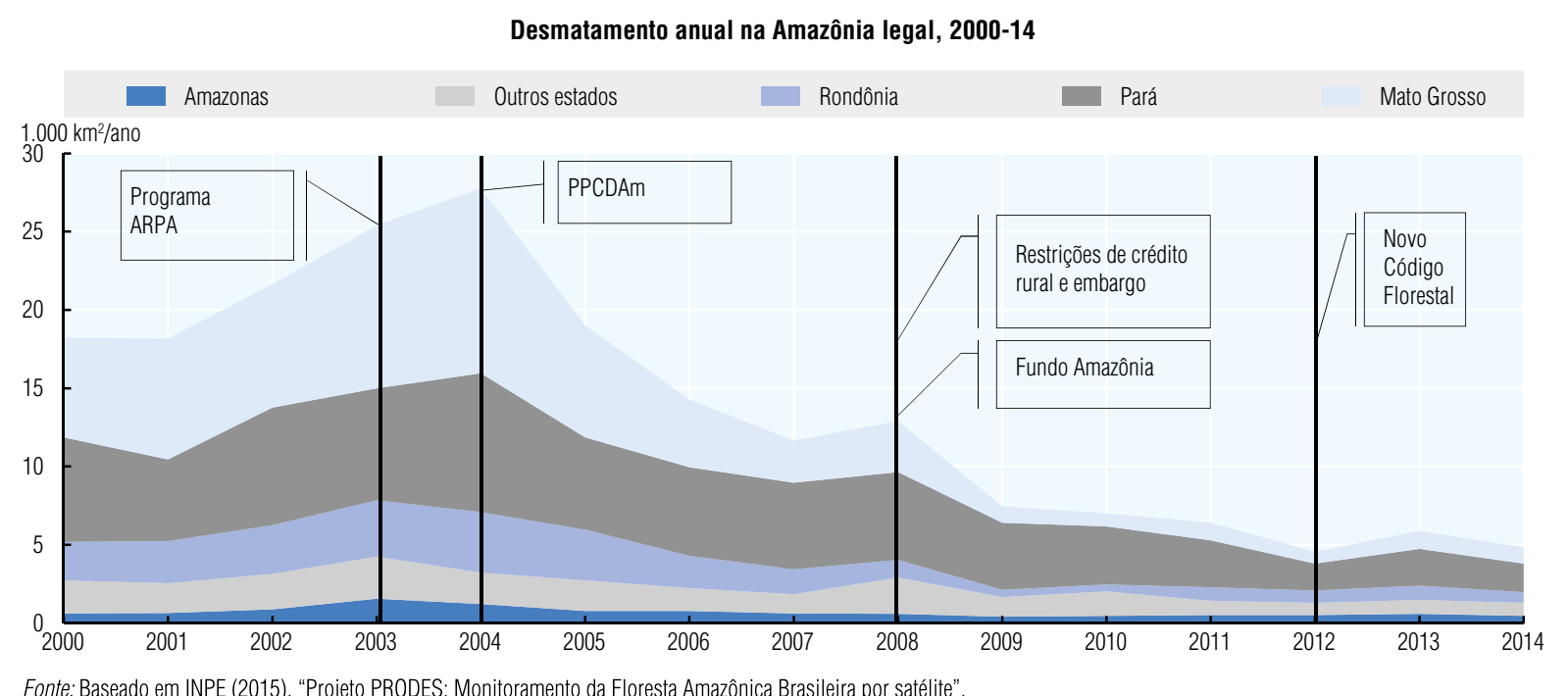

Até o momento, o pilar mais bem-sucedido do PPCDAm tem sido o de comando e controle. No entanto, na medida em que melhoram os sistemas de monitoramento e as ações de fiscalização, mais sofisticadas se tornam as estratégias de desmatamento ilegal (ex., a abertura de pequenas parcelas e a extração seletiva de madeira de alto valor). Isto, por sua vez, aumenta custos, devido à necessidade de atualização de sistemas de monitoramento, investimento em equipamentos (ex. veículos) e formação de fiscais (WWF, 2015). O Brasil deve continuar a reforçar os sistemas de monitoramento por satélite (Box 4.4) especialmente nos biomas Caatinga e Cerrado, onde é previsto o maior desmatamento futuro, adaptando-os para detectar a degradação da floresta. Mesmo esperando que a plena implementação do Cadastro Ambiental Rural melhore a execução e o cumprimento do PPCDAm (Seção 5.2), o acompanhamento de milhares de pequenas ocorrências de desmatamento em toda a vasta região Amazônica brasileira continuará sendo grande desafio para o governo e suas agências.

Para garantir o sucesso do PPCDAm e do PPCerrado, é essencial que as ações de monitoramento e fiscalização sejam acompanhadas por atividades que promovam a sustentabilidade (Box 4.6). É necessário que as cadeias legais de produção madeireira e de outros produtos florestais sustentáveis se tornem mais atraentes que a extração ilegal de madeira e a grilagem de terras, e que sejam oferecidas fontes alternativas de renda para comunidades locais e tradicionais. A madeira extraída ilegalmente chega a ser $40 \%$ mais barata que a produzida legalmente, o que contribui para a inviabilidade 
econômica do manejo florestal sustentável (Nogueron e Cheung, 2013). Os custos de transação da gestão florestal sustentável ainda são elevadíssimos, e muitas famílias rurais carecem de conhecimento e dos recursos necessários para a adoção de práticas florestais e de produção agrícola sustentáveis (WWF, 2015) (Seção 7.2). Essa situação requer uma abordagem integrada de promoção à pesquisa, capacitação, fornecimento de tecnologia, crédito, assistência técnica e acesso a mercados, além de maior envolvimento por parte do setor empresarial (CEPAL et al., 2011).

\section{Instrumentos da política de conservação e uso sustentável da biodiversidade}

O Brasil implementou um amplo conjunto de instrumentos políticos para a promoção, proteção, restauração e uso sustentável da biodiversidade. Seguindo as categorias utilizadas pela OCDE (2013), estes instrumentos de política podem ser classificados como regulatório, econômico e facultativo/informativo. A Tabela 4.2 apresenta os principais instrumentos implementados pelo Brasil em cada categoria, com a indicação de onde são abordados neste relatório.

De forma geral, a política de biodiversidade do Brasil baseia-se em abordagens regulatórias, mas a aplicação de instrumentos econômicos para a conservação e o uso sustentável da biodiversidade vem sendo ampliada. A maioria desses instrumentos visa premiar ações favoráveis à biodiversidade, como a adoção de boas práticas agrícolas (Seção 7.1). Incentivos positivos desta natureza podem ser eficazes, pois a maioria das propriedades privadas são de pequeno porte e as populações rurais estão entre as mais pobres do país e dependem do aproveitamento de recursos naturais para seu sustento.

Tabela 4.2. Principais instrumentos da política de conservação e uso sustentável da biodiversidade no Brasil

\begin{tabular}{|c|c|c|}
\hline Instrumentos regulatórios & Instrumentos econômicos & $\begin{array}{l}\text { Abordagens informativas e } \\
\text { facultativas }\end{array}$ \\
\hline $\begin{array}{l}\text { Restrições ou proibições de utilização } \\
\text { ou acesso: } \\
\text { - Áreas protegidas (Capítulo 5) } \\
\text { - Reserva de áreas de vegetação nativa, } \\
\text { conforme previsto no Código Florestal } \\
\text { de } 2012 \text { (Seção 5.2) } \\
\text { - Cadastro Ambiental Rural (Seção 5.2) } \\
\text { - Normas que regulamentam o acesso } \\
\text { aos recursos genéticos e à repartição } \\
\text { de benefícios (Seção 5.8) } \\
\text { - Embargo de áreas ilegalmente } \\
\text { desmatadas (Seção 4) } \\
\text { Instrumentos de planejamento e } \\
\text { licenciamento: } \\
\text { - Zoneamento ecológico-econômico } \\
\text { (Seção 5.1) } \\
\text { - Licenciamento ambiental (Capítulo 2) } \\
\text { Permissões e quotas } \\
\text { - Concessões para a exploração } \\
\text { madeireira sustentável (Seção 7.2) }\end{array}$ & $\begin{array}{l}\text { Sistema de pagamentos por serviços ambientais e programas } \\
\text { de transferência condicional de renda (Seção 5.5) incluindo: } \\
\text { - Bolsa Floresta } \\
\text { - Bolsa Verde } \\
\text { - Programa Produtor de Água } \\
\text { Quotas negociáveis de reserva ambiental (Seção 5.3) } \\
\text { Compensações de biodiversidade (Seção 5.4) } \\
\text { - Compensações de reserva ambiental, conforme previsto no } \\
\text { Código Florestal de } 2012 \\
\text { - Compensações ambientais no contexto do licenciamento } \\
\text { ambiental (Capítulos } 2 \text { e 5) } \\
\text { - Compensações financeiras pelo uso de recursos hídricos e } \\
\text { de mineração } \\
\text { Cobrança pela captação de água e lançamentos de efluentes } \\
\text { (Capítulo 3) } \\
\text { Cobrança de ingressos para acesso a parques nacionais } \\
\text { (Capítulo 5) } \\
\text { Subsídios (ex., para boas práticas agrícolas) (Seção 7.1) } \\
\text { Restrições de crédito rural (Seção 4) } \\
\text { Remoção de subsídios prejudiciais ao meio ambiente. }\end{array}$ & $\begin{array}{l}\text { Rotulagem e certificação } \\
\text { ambiental: } \\
\text { - Certificação de produtos } \\
\text { orgânicos (Seção 7.1) } \\
\text { - Certificação de madeira } \\
\text { (Seção 7.2) } \\
\text { - Certificação LIFE (Seção 5.6) } \\
\text { Compras públicas verdes: } \\
\text { - Plano Nacional para a } \\
\text { Promoção dos Produtos da } \\
\text { Sociobiodiversidade } \\
\text { (Seção 5.7) } \\
\text { Acordos facultativos } \\
\text { - Moratória da Soja (Box 4.9) }\end{array}$ \\
\hline
\end{tabular}

Fonte: Adaptado da OCDE (2013), Scaling-up Finance Mechanisms for Biodiversity. 
A utilização de impostos, cobranças e tarifas é muito limitada. A Lei da Política Nacional de Recursos Hídricos de 1997 introduziu a cobrança pelo uso da água e pelo lançamento de efluentes, como ferramentas de gestão dos recursos hídricos. No entanto, apenas alguns estados e bacias hidrográficas cobram pelo uso da água. Mesmo onde são aplicadas essas cobranças, as taxas unitárias tendem a ser demasiadamente baixas para afetar decisões sobre alocação e uso da água (Capítulo 3). Os parques nacionais podem cobrar ingressos, mas poucos o fazem, ou mesmo têm capacidade para efetuar tal cobrança (Capítulo 5).

Alguns avanços foram alcançados por meio da integração de critérios de biodiversidade às políticas de apoio financeiro, ex., condicionamento do crédito rural concessional à conformidade com normas ambientais (Seção 7.1). No entanto, quase não houve avanços na identificação e progressiva eliminação de subsídios potencialmente prejudiciais à biodiversidade e aos ecossistemas, conforme previsto na meta 3 da política nacional de biodiversidade. Estes incluem subsídios implícitos, tais como isenções fiscais para fertilizantes e pesticidas (Seção 7.1). O Brasil poderia se beneficiar de uma melhor análise dos subsídios potencialmente nocivos ao meio ambiente, com vistas à paulatina eliminação daqueles não justificados por motivos econômicos, sociais e ambientais. Para a construção de uma base de apoio à reforma da política de subsídios, é necessário que sejam disponibilizadas informações bem fundamentadas sobre a magnitude e o impacto desses subsídios.

\subsection{Zoneamento ecológico-econômico}

A Política Nacional do Meio Ambiente introduziu o zoneamento ecológico-econômico (ZEE) ou ambiental, como instrumento de planejamento e gestão da paisagem natural, visando à distribuição de atividades em áreas ambientais definidas e compatíveis, de modo a manter o uso sustentável dos recursos naturais e o equilíbrio do ecossistema. A ZEE tem sido efetivamente utilizada desde 2002; em 2013, o MMA divulgou diretrizes metodológicas, em apoio à criação de ZEEs em nível subnacional e à sua coordenação com outros instrumentos de planejamento territorial (ex., planos de recursos hídricos).

O MMA liderou a elaboração do Macrozoneamento Ecológico-Econômico (MacroZEE) da Amazônia Legal, aprovado em 2010; até o fechamento do presente relatório, os macro ZEEs do bioma Cerrado e da bacia do rio São Francisco ainda se encontravam em fase de elaboração. Vários estados elaboraram seus próprios ZEEs estaduais. Em 2013, os ZEEs já englobavam 73\% do território nacional (Figura 4.8) incluindo a totalidade dos biomas da Amazônia e do Pantanal. Os ZEEs atualmente englobam cerca de $62 \%$ do bioma Cerrado e 22\% do bioma da Mata Atlântica, mas menos de 2\% do bioma da Caatinga (MMA, 2015).

Mapas e diretrizes dos ZEEs são disponibilizados como ferramentas de planejamento e desenvolvimento territorial; mas não há qualquer evidência de que sejam efetivamente utilizados no ordenamento territorial ou na formulação de políticas. Além disso, os municípios carecem de capacidade para implementar e cumprir requisitos de zoneamento (Capítulo 2). O fato de o Código Florestal de 2012 (Seção 5.2) prever que todos os estados devem aprovar seus ZEEs até 2017 é considerado um avanço positivo. 
Figura 4.8. Expansão da área sob zoneamento ecológico-econômico

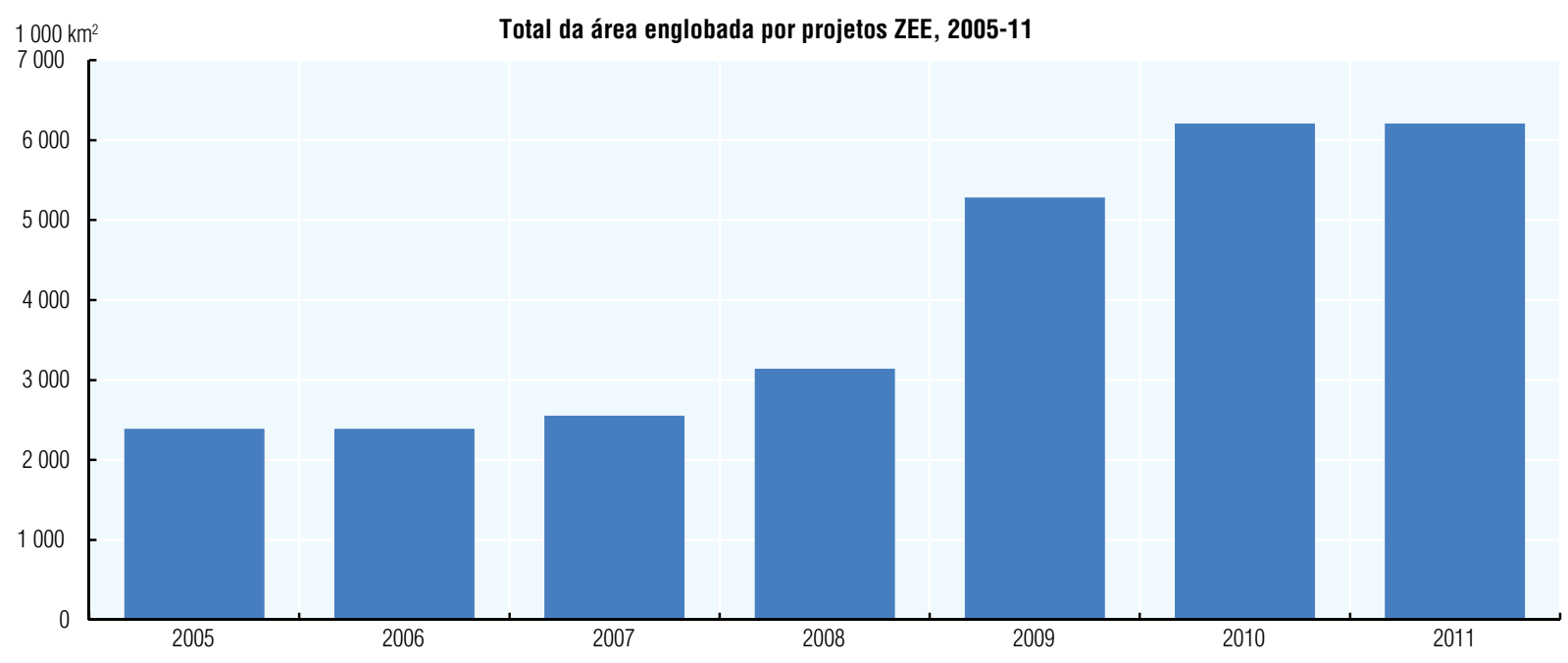

Obs.: Não é considerada a sobreposição de áreas estaduais e federais.

Fonte: MMA (2014), PNIA 2012: Painel Nacional de Indicadores Ambientais. Referencial teórico, composição e síntese dos indicadores.

\subsection{Obrigações de conservação e restauração florestal em propriedades privadas}

Em 2012, o Brasil aprovou o Novo Código Florestal que dispõe sobre a proteção da vegetação nativa, em substituição e atualização ao código de 1965. O Novo Código Florestal tem por objetivo preservar a biodiversidade e as florestas assegurando, ao mesmo tempo, um bom ambiente comercial para a agropecuária, setor de grande importância para a economia do país.

Durante muito tempo, o Código Florestal brasileiro de 1965, com suas diversas emendas foi o mais importante instrumento jurídico para a proteção da vegetação nativa em propriedades privadas. Continha a exigência de que proprietários de terras mantivessem a vegetação nativa em certa proporção de suas propriedades (Reserva Legal - RL); e ao longo das margens de corpos d'água e de áreas sensíveis, para proteger os recursos hídricos e evitar erosões (Área de Preservação Permanente - APP). Historicamente, no entanto, a conformidade com essas normas foi baixa e, em consequência, grandes áreas acabaram sendo ilegalmente desmatadas.

O Novo Código Florestal, por sua vez, introduziu instrumentos de fiscalização mais eficazes, embora algumas de suas disposições tenham sido criticadas como excessivamente favoráveis aos interesses comerciais e menos protetivas que as do código antigo (Box 4.7). A nova lei manteve os requisitos de conservação e restauração da cobertura vegetal em áreas de RL e APP, embora tenha alterado as definições dessas áreas. O percentual de cada propriedade rural a ser mantido como RL varia de acordo com o bioma: até $80 \%$ na Amazônia, $20 \%$ a $35 \%$ no Cerrado e $20 \%$ na Mata Atlântica e outros biomas.

Para melhorar o monitoramento e a conformidade com as normas de conservação florestal, o novo código introduziu o Cadastro Ambiental Rural (CAR) que utiliza imagens de satélite de alta resolução para a localização e registro de cada gleba rural. Todas as propriedades e posses rurais devem, obrigatoriamente, ser inscritas no CAR até maio de 2016, incluindo informações sobre as respectivas áreas de RL e APP. Qualquer propriedade 
rural que não esteja em conformidade com as obrigações de reserva deverá participar de um programa de regularização ambiental estadual. Conforme resolução do Banco Central do Brasil, a partir de outubro de 2017, o acesso a crédito rural, proveniente de bancos públicos e privados, estará condicionado ao registro no CAR. Embora o objetivo da criação do CAR não seja a regularização de direitos de propriedade, as autoridades responsáveis pelo desenvolvimento rural e assentamentos podem usar informações georreferenciadas sobre a localização de glebas rurais (conforme declarado pelos proprietários ou posseiros) para esclarecimento da situação fundiária.

\section{Box 4.7. Novo Código Florestal: Alguns elementos críticos}

O Código Florestal de 2012 foi aprovado após longo e intenso debate nacional e tem sido muito criticado pelos ambientalistas. Entre os elementos criticados estão a anistia parcial concedida sobre o desmatamento ilegal ocorrido antes de 2008; a ampliação da possibilidade de compensação por dano ambiental ao ecossistema; e a transferência de competências legislativas aos estados (Leitão, 2014).

A nova lei reduziu a área total de APPs e RLs anteriormente exigida, por meio de um ajuste de definição. A alteração na definição de APPs em morros e encostas, por exemplo, reduziu a área total preservada em $87 \%$. Cerca de $90 \%$ das propriedades rurais (menos de $30 \%$ da zona rural) foram qualificadas pela nova lei como "pequenas" propriedades*, beneficiando-se, assim, da anistia sobre o desmatamento ocorrido em áreas de RL e APP antes de 2008. Pelo código florestal anterior, esses proprietários seriam obrigados a restaurar as áreas desmatadas ilegalmente, às suas próprias custas. No geral, as alterações introduzidas pelo Novo Código Florestal reduziram em $58 \%$ a área florestal total a ser restaurada (cerca de $210 \mathrm{mil} \mathrm{km}^{2}$ ) com efeitos sentidos, principalmente, na Amazônia, Mata Atlântica e Cerrado (Soares-Filho et al., 2014b).

${ }^{*}$ A lei define pequenas propriedades como sendo aquelas com tamanho variando entre $20 \mathrm{ha}\left(0,2 \mathrm{~km}^{2}\right) \mathrm{na}$ região Sul e 440 ha $\left(4,4 \mathrm{~km}^{2}\right)$ na Amazônia.

A implementação do CAR está correndo de acordo com o cronograma: até abril de 2015, cerca de 53\% do total das áreas rurais privadas já estavam inscritas. Os estados são responsáveis pela implementação do CAR, mas, em muitos deles, especialmente na região Nordeste, menos de $20 \%$ da área rural prevista foram cadastrados (SFB, 2015a). Em grande parte, esse atraso se deve à carência de pessoal e de recursos nos níveis estadual e municipal. O governo federal vem investindo na implantação de um sistema de informação e na capacitação para sua implementação em nível estadual. Elaborou também um plano detalhado de implementação do CAR, incluindo previsão orçamentária, cronograma e metas.

Espera-se que a aplicação rigorosa do novo código, bem como o esclarecimento de questões fundiárias levem a uma maior redução dos índices de desmatamento. Serão necessários maiores esforços de conscientização sobre o CAR (ex., campanhas informativas de incentivo ao cadastramento) assim como ações de capacitação nos estados e municípios para a sua implementação. Os estados precisam, ainda, acelerar o desenvolvimento de programas de regularização ambiental, exigindo dos proprietários rurais conformidade com o novo código. Medidas de incentivo, a exemplo do pagamento por serviços ecossistêmicos (Seção 5.5) e pelo mecanismo REDD+, devem ser adotadas como forma de estimular o cadastramento e recompensar proprietários que estejam em conformidade com a legislação. 


\subsection{Quotas florestais negociáveis}

O Novo Código Florestal introduziu Cotas de Reserva Ambiental (CRAs), instrumento econômico para facilitar o cumprimento das obrigações de reserva. Cotas podem ser emitidas para cada hectare de vegetação nativa preservada que exceda as exigências de RL, e utilizadas para compensar déficits de RL em uma propriedade diferente no mesmo bioma, de preferência, dentro do mesmo estado. Na prática, proprietários rurais inadimplentes com suas obrigações de RL podem restaurar a cobertura florestal da área ou, alternativamente, comprar uma quantidade equivalente de CRAs. Apenas as propriedades que tiveram déficits de RL antes de 2008 podem utilizar esse mecanismo. O sistema cria demanda por áreas florestais e possibilita o surgimento de um mercado para a conservação de terras privadas. Em última análise, serve de incentivo para a manutenção da cobertura florestal em áreas que excedam os níveis de RL (que poderiam ser legalmente desmatadas) e oferece uma alternativa à restauração da cobertura florestal em áreas já desmatadas (Soares-Filho et al, 2014b).

Quatro milhões, dos aproximadamente 5,6 milhões de propriedades rurais, estão inadimplentes com suas obrigações legais de cobertura vegetal. Embora as dimensões dessa inadimplência somente venham a ser reveladas após a plena implementação

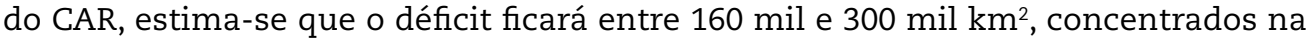
Amazônia, Mata Atlântica e Cerrado (BV Rio, 2014). A restauração de um hectare da Floresta Amazônica pode custar até $\mathrm{R} \$ 15.000,00$ (além dos custos de oportunidade do uso alternativo do solo) o que pode ser proibitivo para pequenos proprietários rurais (Financial Times, 2012). Segundo estimativas, compensar esse déficit de RL por meio da compra de CRAs seria menos oneroso que a restauração de cerca de $92.000 \mathrm{~km}^{2}$ (Soares-Filho et al. 2014b). Potencialmente, a demanda por CRAs é grande, o que pode representar uma forma de assegurar conformidade com a legislação florestal. Por exemplo, Bernasconi (2013) estima uma redução de $76 \%$ nos custos de conformidade no Estado de São Paulo.

As transações de CRAs precisam ser registradas no CAR, que ainda está em fase de implantação e, portanto, nenhuma CRA foi emitida ainda. A Bolsa Verde do Rio de Janeiro, organização sem fins lucrativos, lançou uma plataforma para possibilitar futuras trocas de CRAs. Até o final de 2013, essa plataforma havia cadastrado 1.600 participantes e mais de $15.000 \mathrm{~km}^{2}$ de propriedades rurais oferecendo CRAs, o que sinaliza boas perspectivas de mercado (BV Rio, 2014).

O sistema de Cotas de Reserva Ambiental é promissor; contudo, há o risco de que apenas áreas de baixo custo de oportunidade sejam competitivas no mercado, o que poderia levar a um aumento da conservação de áreas que não têm necessariamente o maior valor da biodiversidade. Ajustar o sistema para permitir trocas de CRAs apenas dentro das mesmas áreas prioritárias em termos de valor de biodiversidade, provavelmente elevaria custos de conformidade, mas melhoraria a eficácia ambiental (Bernasconi, 2013). Assim, é possível que seja necessária a oferta de incentivos adicionais para garantir que áreas de alto valor de biodiversidade sejam restauradas. O funcionamento do sistema deverá ser sistematicamente monitorado, para que os ajustes necessários para alcançar seus objetivos de conservação e restauração da floresta possam ser implementados.

\subsection{Compensações ambientais}

Além do mercado de CRAs, a legislação prevê a compensação de déficits de RL por meio da aquisição, em nome do governo, de propriedades privadas localizadas dentro 
de áreas protegidas oficiais; ou seja, através da indenização de proprietários de terras em áreas protegidas e da transferência do título de propriedade ao governo. Este mecanismo de compensação permitirá a consolidação de áreas protegidas, muitas das quais incluindo grandes extensões de terras privadas (Capítulo 5).

Existe um mecanismo de compensação no âmbito do processo de licenciamento ambiental. Para a construção, instalação, ampliação e funcionamento de qualquer empreendimento ou atividade considerada efetiva ou potencialmente poluidora, ou que possa causar degradação ambiental, faz-se necessária a requisição de uma licença ambiental (Capítulo 2). Além de atender às exigências de redução dos impactos ambientais indicados na licença, os empreendedores do projeto podem ser obrigados a pagar uma compensação, cujo montante varia de acordo com a gravidade do impacto ambiental do projeto. Ainda não há mecanismos claros para a monetarização do impacto ambiental e do montante da compensação. Todas as receitas provenientes de compensações ambientais são destinadas às áreas protegidas (Capítulo 5).

Os requisitos de compensação financeira também se aplicam a operadores de usinas hidrelétricas (6,75\% do valor da eletricidade produzida) e a mineradoras (entre $1 \%$ e $3 \%$ do faturamento) como compensação pelo uso da água e dos recursos naturais. Os valores são substanciais e são compartilhados entre o governo federal e os governos estaduais e municipais afetados pelos empreendimentos. Esses encargos, no entanto, não refletem o real valor dos recursos (ex., escassez de água) e não contribuem para seu uso eficiente (OCDE, 2015) e, tampouco as receitas se destinam à compensação da degradação ambiental. Em alguns outros países, como a Colômbia, a receita da compensação financeira proveniente de usinas hidrelétricas é, em parte, destinada à proteção ambiental e de bacias hidrográficas (OCDE, 2015b).

\subsection{Pagamento por serviços ambientais e programas de transferência condicional de renda}

O Brasil tem implementado várias iniciativas de pagamento por serviços ambientais (PSA) e programas de transferência condicional de renda que agregam exigências ambientais, tanto no nível federal quanto no estadual; os exemplos incluem o Bolsa Floresta e o Bolsa Verde, discutidos abaixo. Outro exemplo é o Programa Produtor de Água, lançado em 2011 pela Agência Nacional de Águas, para compensar financeiramente investimentos na proteção do solo e da água, em bacias hidrográficas cujos recursos hídricos abastecem áreas de grande população. As atividades de conservação incluem a implementação de curvas de nível e obras de contenção e infiltração, a restauração e proteção da mata ciliar e a adoção de práticas agrícolas sustentáveis.

Um projeto lei para a criação de uma política nacional e um programa federal de PSA está em tramitação no Congresso Nacional, desde 2007. Apesar de o Brasil ainda não dispor de um marco jurídico nacional para o PSA, o Novo Código Florestal abre a possibilidade da utilização desse instrumento no nível federal. Na ausência de um abrangente marco jurídico nacional, vários estados e municípios têm elaborado suas próprias leis e programas de PSA, conforme mostra a Tabela 4.3. Foram identificados 78 desses programas para a conservação da água, armazenamento de carbono e proteção da biodiversidade no bioma Mata Atlântica (Guedes e Seehusen, 2011).

Os programas de PSA e de transferência de renda, bem como a legislação atualmente em vigor, variam amplamente entre estados e agências federais em termos de método de pagamento e avaliação, de dispositivos de salvaguardas socioambientais, de arranjos 
institucionais e de fontes de recursos. Os beneficiários são, em sua maioria, produtores rurais familiares e assentados, comunidades tradicionais e povos indígenas. Esses programas raramente contam com sistemas sólidos de monitoramento, e sua eficácia não é sistematicamente avaliada. Por exemplo, o Programa Produtor de Água tem gerado renda para mais de 1.000 pessoas no meio rural (MMA, 2015) mas falta clareza quanto aos resultados em termos do aumento da proteção das fontes de recursos hídricos.

Tabela 4.3. Exemplos da legislação estadual sobre PSA

\begin{tabular}{ll}
\hline Região/ Estado & \multicolumn{1}{c}{ Lei } \\
\hline Norte & Sistema de Incentivos a Serviços Ambientais (SISA; Lei Estadual 2.308/2010) \\
Acre & $\begin{array}{l}\text { Política Estadual sobre Mudanças Climáticas, Conservação Ambiental e Desenvolvimento Sustentável do Amazonas } \\
\text { (Leis Estaduais 3135/2007 e 3184/2007) }\end{array}$ \\
Amazonas & $\begin{array}{l}\text { Sistema Estadual de Redução de Emissões por Desmatamento e da Degradação Florestal, Conservação, Manejo } \\
\text { Sustentável de Florestas e aumento de Estoques de Carbono Florestal (REDD+) }\end{array}$ \\
Mato Grosso & \\
Sudeste & $\begin{array}{l}\text { Lei do PSA (Lei 8.995/2009) } \\
\text { Espírito Santo } \\
\text { Minas Gerais }\end{array}$ \\
São Paulo & Lei da Bolsa Verde (Lei 17.727/2008) \\
\hline
\end{tabular}

Fonte: Adaptado de Guedes e Seehusen (2011), Pagamentos por Serviços Ambientais na Mata Atlântica, Lições Aprendidas e Desafios.

A maioria dos PSA e dos programas de transferência condicional de renda é financiada pelo governo. Em vista dos altos custos desses programas (incluindo investimento em atividades de campo e custos administrativos), faz-se necessária a identificação de fontes alternativas de financiamento, para que se possa ampliar sua escala e escopo, alcançando assim maior número de beneficiários (Guedes e Seehusen, 2011). O desenvolvimento de programas mais padronizados também ajudaria a reduzir custos de transação. O desenvolvimento de um marco jurídico para o PSA poderia trazer grandes benefícios para o Brasil, pois melhoraria a consistência dos programas em todo o país. Faz-se necessária também a implantação de um sistema de monitoramento eficaz para a verificação da efetiva entrega dos serviços ambientais contratados. Se vinculado ao CAR, esse sistema poderia servir de importante fonte de informações para o aprimoramento do monitoramento.

\section{Bolsa Floresta}

O Bolsa Floresta é um programa pioneiro de PSA, lançado pelo Estado do Amazonas em 2007. Trata-se, essencialmente, de um sistema de transferência de renda com alguns requisitos ambientais. Destina-se a compensar famílias de comunidades tradicionais vivendo em reservas estaduais de desenvolvimento sustentável por ações de conservação ambiental, e seu objetivo principal é limitar a área de floresta desmatada para fins agrícolas (Box 4.8). É o primeiro programa desse tipo no Brasil com certificação internacional e um dos maiores projetos-piloto de REDD+ do mundo, proporcionando renda para mais de 35 mil pessoas em centenas de comunidades. Os recursos para este programa provêm de uma parceria entre o governo do Estado do Amazonas e algumas grandes empresas.

Há relatos de impactos positivos do Bolsa Floresta na qualidade de vida local e na conservação da biodiversidade em áreas selecionadas para uso sustentável (Börner et al. 2013). 
Das famílias entrevistadas, $86 \%$ relataram que o acesso à renda, à saúde e à educação melhorou e que, em consequência, estão melhor posicionadas para resistir a pressões vindas de fora da comunidade, a favor do desmatamento. Ademais, o desmatamento diminuiu mais rapidamente nas áreas protegidas participantes do programa do que em outras áreas.

Até o presente, o programa vem sendo implementado em áreas com populações homogêneas e pouca pressão sobre os recursos florestais. Para a maioria dos participantes, o custo de oportunidade de cumprimento com as normas do programa é relativamente baixo. Segundo Börner et al. (2013), para que o programa seja intensificado e ampliado para áreas que sofrem maiores pressões de desmatamento, serão necessários incentivos maiores e mais diversificados para assegurar o engajamento dos participantes em atividades de monitoramento e vigilância contra ameaças externas.

\section{Box 4.8. Bolsa Floresta e Bolsa Verde}

O programa Bolsa Floresta tem quatro componentes:

(i) O Bolsa Floresta Renda é um incentivo às atividades sustentáveis de geração de renda (ex., piscicultura, produtos florestais não madeireiros ou ecoturismo) que investe anualmente $\mathrm{R} \$ 140$ mil em cada área protegida.

(ii) O Bolsa Floresta Social tem o objetivo de melhorar o desenvolvimento da comunidade, a prestação de serviços públicos e a qualidade de vida de comunidades isoladas, investindo anualmente $\mathrm{R} \$ 140$ mil em cada área protegida, de acordo com um plano de trabalho participativo.

(iii) O Bolsa Floresta Familiar é um incentivo para reduzir o desmatamento, por meio do pagamento de uma recompensa mensal de $R \$ 50$ às mães de famílias residentes dentro de unidades de conservação, que estejam dispostas a assumir um compromisso de conservação ambiental e desenvolvimento sustentável (principalmente o de não desmatar e não usar recursos de maneira insustentável).

(iv) O Bolsa Floresta Associação concede o equivalente a 10\% do valor total pago pelo Bolsa Floresta Familiar, para fortalecer associações de produtores locais compostas por famílias que vivem em áreas protegidas. Seus recursos são usados também para promover o controle social sobre o programa Bolsa Floresta.

O programa Bolsa Verde tem quatro objetivos principais: (i) promover a conservação e o uso sustentável do ecossistema; (ii) promover a participação da comunidade e a melhoria da qualidade de vida dos participantes; (iii) aumentar a renda de pessoas que vivem em extrema pobreza e que realizam atividades para a conservação dos recursos naturais nas zonas rurais; e (iv) promover a participação dos beneficiários em atividades de capacitação ambiental, social, técnica e profissional.

O Bolsa Verde oferece pagamentos trimestrais de $\mathrm{R} \$ 300$ para famílias extremamente pobres vivendo em unidades de conservação federais e outras áreas designadas* em troca de compromissos com determinadas ações de conservação e atividades de uso sustentável. Ao incluir territórios ocupados por comunidades tradicionais e indígenas, o programa reconhece o papel dessas comunidades na preservação dos serviços ambientais. Para participar do programa, as famílias devem ser beneficiárias do Bolsa Família e estar registradas no Cadastro Único (Box 3.1). Os pagamentos pelo Bolsa Verde são complementares aos benefícios recebidos do Bolsa Família. O benefício pode ser concedido por dois anos, com opção de renovação.

* Entre as áreas federais estão: áreas protegidas de uso sustentável, projetos de assentamento ambientalmente diferenciados, territórios de povos e comunidades tradicionais, e outras áreas rurais definidas por decreto como prioritárias. Famílias em situação de extrema pobreza são definidas pelo governo federal como aquelas que recebem menos de R\$ 77 (US\$ 33) per capita, por mês. 


\section{Bolsa Verde}

A partir da iniciativa do Bolsa Floresta, o governo federal lançou, em 2011, o Bolsa Verde como componente do programa Brasil Sem Miséria (Capítulo 3) que inclui, no sistema federal de proteção social, pagamentos condicionais pelo uso de práticas ambientalmente sustentáveis. O programa também se destina a promover a participação dos beneficiários em programas de capacitação ambiental, social e técnica.

O número de domicílios inscritos no programa vem crescendo constantemente, principalmente no bioma Amazônia e no Estado do Pará (Figura 4.9). Em 2014, 30\% dos beneficiários viviam em unidades de conservação federais. $O$ governo estima que ainda existam 213 mil potenciais famílias beneficiárias vivendo em 1,45 milhão de $\mathrm{km}^{2}$ de áreas prioritárias; e que, para abarcar todas, seria necessário desembolsar, anualmente, $\mathrm{R} \$ 1,72$ por hectare (MMA, 2015). Em vista dos potenciais resultados, em termos da melhoria das condições de vida dessa população e da conservação dos recursos naturais, este é um preço bastante razoável, desde que os novos beneficiários efetivamente se empenhem nas ações de conservação patrocinadas pelo programa.

\section{Figura 4.9. A participação no programa Bolsa Verde vem crescendo constantemente}

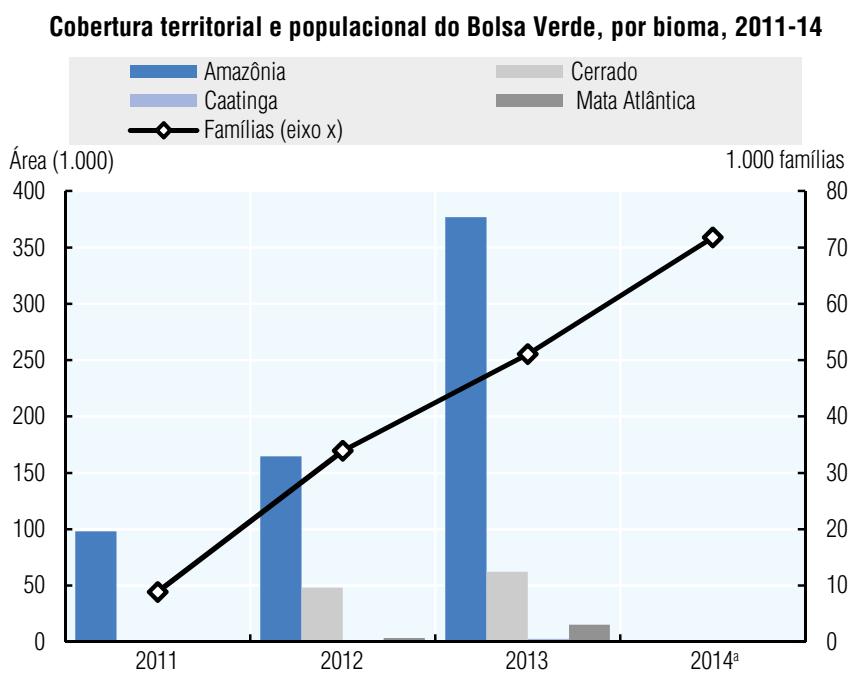

Beneficiários do Bolsa Verde, por estado, 2014

a) Número de famílias beneficiárias, em 25 de janeiro de 2015.

Fonte: MMA (2015), "Bolsa Verde", MMA em Números (site); MMA (2014), PNIA 2012: Painel Nacional de Indicadores Ambientais. Referencial teórico, composição e síntese dos indicadores.

No entanto, o programa enfrenta dificuldades em manter a base de dados dos beneficiários; até o presente momento, não existe qualquer processo de monitoramento ou critérios de avaliação da conformidade com os compromissos de conservação (CGU, 2014). Apesar da preeminente necessidade de ações de capacitação que auxiliem os beneficiários a cumprir com seus compromissos, não havia sido realizada, até julho de 2014, qualquer atividade de treinamento. Além disso, o fato de envolver diversas instituições e de sua gestão ser centralizada e distante dos beneficiários, o programa parece ser excessivamente complexo do ponto de vista administrativo. Viana (2015) sugere que, para melhorar a execução do programa e alcançar uma maior parcela da população alvo, sua gestão seja delegada aos estados.

A falta de monitoramento impede a avaliação da eficácia do Bolsa Verde em promover a conservação da biodiversidade nas áreas alvo. É necessário que seja desenvolvido um 
processo de monitoramento, baseado em indicadores de conservação ambiental, que garanta a capacidade do programa de gerar benefícios ambientais, complementares aos benefícios sociais produzidos pelo programa Bolsa Família (Box 3.1).

\subsection{Acordos voluntários e certificação de empresas}

Cada vez mais, o setor empresarial, especialmente as empresas de grande porte, tem se engajado no apoio a iniciativas de conservação da biodiversidade e uso sustentável e na oferta de financiamento. ${ }^{11}$ Um número cada vez maior de produtores agrícolas e pecuaristas vem aderindo a iniciativas de certificação voluntária e assumindo compromissos com a melhoria do desempenho social e ambiental (Soares-Filho et al., 2014b). No entanto, até 2014, apenas duas empresas brasileiras haviam recebido a Certificação LIFE, processo voluntário que avalia a gestão ambiental da empresa e seu impacto sobre a biodiversidade (Instituto LIFE, 2014). ${ }^{12}$

O setor empresarial tem ajudado a combater o desmatamento na Amazônia. Em 2006, em resposta a um relatório do Greenpeace e a pressões de consumidores, um grupo de grandes empresas, em cooperação com o MMA, celebrou um acordo para governança da cadeia de suprimentos - denominado Moratória da Soja - pelo qual concordaram em não comercializar soja produzida em áreas desmatadas da Amazônia Brasileira. Esta iniciativa foi um dos primeiros acordos voluntários de desmatamento zero do mundo (Box 4.9). Outra iniciativa semelhante - denominada Moratória da Carne - foi celebrada com a indústria frigorifíca.

\section{Box 4.9. Moratória da Soja}

Em 2006, grandes empresas, incluindo o McDonald's e o Wal-Mart, decidiram parar de comprar soja produzida em áreas florestais desmatadas da Amazônia brasileira, lançando assim a Moratória da Soja. A moratória colocou pressão sobre comercializadores de commodities, como a Cargill, que então concordaram em deixar de comprar soja de produtores cujas propriedades incluíam áreas desmatadas da floresta amazônica. Ao todo, 47 empresas, incluindo 12 afiliadas à Associação Brasileira das Indústrias de Óleos Vegetais (ABIOVE) e 35 da Associação Nacional dos Produtores de Cereais (ANEC) aderiram à moratória. Desde o início, a iniciativa contou com forte apoio e participação de oito organizações da sociedade civil: Conservation International, Greenpeace, IPAM, TNC, WWF-Brasil, Amigos da Terra Amazônia Brasileira, Imaflora e o STTR de Santarém e, desde 2008, o MMA também tem participado dessa iniciativa.

Um estudo de avaliação dos acordos analisou imagens de satélite da cobertura vegetal da Floresta Amazônica e dos Cerrados entre 2000 e 2014, com o objetivo de medir a área desmatada para a expansão do plantio da soja. Esse estudo mostrou que a moratória contribuiu para uma significativa redução do desmatamento associado à produção de soja. Constatou que, em 2004 e 2005, quase 30\% da expansão da soja havia ocorrido em áreas de desmatamento; e que, até 2014, essa taxa havia caído para cerca de $1 \%$ no bioma Amazônia. O estudo constatou ainda que as áreas já desmatadas na Amazônia seriam suficientes para expandir a produção de soja em $600 \%$. No bioma Cerrado, onde a Moratória da Soja não se aplica, a taxa anual de expansão da soja sobre a vegetação nativa continua elevada, oscilando entre $11 \%$ e $23 \%$ ao ano entre 2007 e 2011 (Gibbs et al., 2015).

Fonte: Gibbs et al. (2015), "Brazil's Soy Moratorium. Supply-chain governance is needed to avoid deforestation".

A eficácia da Moratória da Soja se deve ao fato de os produtores serem sensíveis às exigências do mercado. Segundo Gibbs et al. (2015) os produtores são cinco vezes menos propensos a violar acordos celebrados com o setor privado do que aqueles estabelecidos como política de governo. Por conseguinte, abrem-se oportunidades para dar continuidade à ampliação de iniciativas voluntárias, após o término da Moratória da 
Soja, em 2016, e estendê-las para o bioma Cerrado, onde os índices de desmatamento permanecem elevados. De forma mais ampla, existe margem para ampliação do envolvimento do setor empresarial na proteção da biodiversidade, por meio da promoção de planos sustentáveis de produção e consumo.

\subsection{Compras públicas verdes}

Em 2012, o governo lançou sua política de compras públicas sustentáveis, com o objetivo, entre outros, de priorizar bens e serviços ambientais (Capítulo 2). Existe também um programa nacional de compras públicas especificamente direcionado a produtos da biodiversidade, bem como iniciativas semelhantes nos estados (ex., no Estado do Amazonas) (MMA, 2015).

O Plano Nacional para a Promoção das Cadeias de Produtos da Sociobiodiversidade (PNPSB) de 2009, visa reforçar a produção e comercialização de 30 produtos não madeireiros tradicionais, provenientes do manejo florestal sustentável (Seção 7.2). O plano facilita o acesso a crédito, a mercados e à assistência técnica. Um dos componentes do PNPSB é a garantia de preços mínimos para produtos da sociobiodiversidade (PGPMBio), tais como o açaí, a borracha natural e a castanha do Brasil, ${ }^{13}$ e tem como objetivo aumentar a renda do produtor. Recentemente, foi integrado ao Programa de Aquisição de Alimentos do governo federal, um dos maiores programas de compras governamentais do mundo direcionado a pequenos produtores e à agricultura familiar. ${ }^{14}$

O volume da produção subsidiada e o número de extrativistas beneficiados pelo programa desde a sua criação, em 2009, tem flutuado, mas a tendência é crescente; em 2013, o PGPMBio alcançou 12 mil extrativistas em seis estados, principalmente na Amazônia e Mata Atlântica. Os subsídios desembolsados alcançaram o valor de US\$ 2,6 milhões, cerca de $25 \%$ do orçamento disponível, devido aos elevados preços de mercado (acima dos preços garantidos) mas também a dificuldades com a operacionalização dos pagamentos (Viana, 2015). ${ }^{15}$ No geral, o subsídio beneficia apenas uma pequena fração da produção total dos produtos contemplados. ${ }^{16}$ No entanto, o estímulo do PGPMBio tem levado a um aumento da produção e comercialização de produtos da sociobiodiversidade, e a uma maior concorrência entre compradores, com reflexos positivos na renda de trabalhadores extrativistas (MMA, 2015).

O PNPSB e o PGPMBio foram implementados em áreas selecionadas, incluindo áreas protegidas de uso sustentável (Capítulo 5). Muitos produtores, atualmente não residentes nessas áreas, vem reivindicando que o status de área protegida - especialmente o de reserva extrativista - seja concedido às áreas em que vivem e trabalham, para que possam ter acesso ao PNPSB, ao PGPMBio e a outros serviços públicos.

\subsection{Acesso a recursos genéticos e repartição de benefícios}

As terras indígenas compõem $13 \%$ do território nacional, e o país abriga milhares de quilombolas e membros de comunidades tradicionais (Box 5.2) que detêm amplo conhecimento sobre aproveitamento e manejo da flora e fauna. Destaca-se, portanto, a importância de assegurar o acesso aos ativos genéticos e à repartição equitativa dos benefícios deles derivados, tanto para garantir a proteção e o uso sustentável desses recursos, quanto para assegurar o bem-estar dessas comunidades. Em 2011, o Brasil assinou o Protocolo de Nagoya no contexto do CBD sobre acesso e repartição de benefícios (ARB) e sua ratificação está em tramitação. Até maio de 2015, a norma brasileira 
estava incorporada a uma medida provisória emergencial com data de 2001, quando uma proposta comercial para acesso e desenvolvimento do patrimônio genético brasileiro provocou uma reação pública contra a "biopirataria". Essa medida provisória restringiu fortemente o acesso a recursos genéticos, tanto para fins comerciais, quanto científicos (Cabrera, et al., 2014).

A norma emergencial introduziu um procedimento de licenciamento moroso e altamente burocrático para o acesso a recursos genéticos e a conhecimentos tradicionais. Caso o acesso fosse para fins comerciais, fazia-se necessário a celebração de um contrato bilateral para explicitar a forma em que seriam compartilhados os benefícios provenientes da comercialização. Não obstante esforços de esclarecimento dos termos e do escopo da norma provisória, criou-se um alto grau de incerteza regulatória e, em consequência, apenas um pequeno número de contratos chegou a ser aprovado, enquanto que grande número permaneceu pendente (IEEP et al., 2012). A pesquisa e a inovação também ficaram prejudicadas. ${ }^{17}$

Em reconhecimento à necessidade de melhorar as normas, em 2006, foram iniciadas amplas consultas públicas com o intuito de substituir a norma provisória por uma legislação mais abrangente. Em maio de 2015, o Congresso Nacional aprovou a Lei do Marco da Biodiversidade, cujo objetivo é reduzir o ônus administrativo e aprimorar a participação de comunidades indígenas e tradicionais no processo decisório. A Lei estabelece regras claras e cria um fundo para repartição de benefícios. Espera-se que as novas medidas reduzam os custos de transação associados aos contratos de compartilhamento de benefícios, incluindo aqueles provenientes do fato de, muitas vezes, vários povos indígenas e comunidades tradicionais deterem os mesmos recursos e conhecimentos (IEEP et al., 2012). A regulamentação dessas normas está prevista para novembro de 2015 .

Para superar gargalos associados às normas de ARB e assegurar a participação efetiva de povos indígenas e comunidades tradicionais, o Brasil precisa dar celeridade à implementação da nova legislação. Entre os benefícios que poderiam afluir da nova lei, estão o estímulo à inovação e às oportunidades comerciais que, por sua vez, poderiam ajudar populações vulneráveis que dependem dos recursos genéticos a promover seu uso sustentável, dessa forma gerando recursos para a conservação e uso sustentável da biodiversidade em áreas protegidas e terras indígenas, por exemplo.

\section{Financiamento da conservação e uso sustentável da biodiversidade}

\subsection{Orçamento federal para atividades relacionadas à biodiversidade}

O financiamento da conservação e uso sustentável da biodiversidade provém de várias fontes. Para que o Brasil alcance suas metas nacionais de biodiversidade, seria de grande valia o desenvolvimento de uma estratégia de mobilização de recursos, pois o país atualmente carece de informações completas e coerentes sobre despesas pública e privada relacionadas à biodiversidade. $\mathrm{O}$ orçamento federal destinado a determinados programas relacionados à biodiversidade - inclusive a gestão de áreas protegidas e monitoramento do desmatamento na Amazônia - é indicativo do volume de recursos públicos disponível para a conservação da biodiversidade, embora esses valores sejam, provavelmente, subestimados (Tabela 4.4). Entre 2010 e 2014, os desembolsos do orçamento federal para programas relacionados à biodiversidade aumentaram quase $50 \%$ em termos reais, acompanhando o crescimento geral dos gastos do orçamento 
federal para a gestão ambiental (segundo classificação orçamentária do Tesouro, por função; ver Capítulo 2). Em 2014, 9\% do orçamento referente à gestão ambiental foram dedicados a esses programas relacionados à biodiversidade.

Tabela 4.4. Desembolsos orçamentários federais para determinados programas relacionados à biodiversidade

$\mathrm{R} \$$ milhões (valores nominais), 2010-14

\begin{tabular}{lrrrcc}
\hline Programa & 2010 & 2011 & 2012 & 2013 & 2014 \\
\hline Informações Integradas para Proteção da Amazônia & 99.9 & 88.9 & - & - & - \\
Conservação e uso sustentável da biodiversidade e dos recursos genéticos & 129.0 & 129.6 & - & - & - \\
Florestas & 56.7 & 48.8 & - & - & - \\
Conservação e restauração dos biomas brasileiros & 96.8 & 89.4 & - & - & - \\
Conservação, manejo e uso sustentável da agrobiodiversidade & 23.6 & 29.4 & - & - & - \\
Biodiversidade & - & - & 344.5 & 263.7 & 514.0 \\
Florestas, prevenção e controle do desmatamento e das queimadas & - & - & 162.0 & 249.8 & 266.3 \\
Total & 406.0 & 386.1 & 506.4 & 513.6 & 780.3 \\
Participação da Gestão Ambiental no total dos desembolsos orçamentários federais & $8.9 \%$ & $8.5 \%$ & $8.0 \%$ & $6.4 \%$ & $8.9 \%$ \\
\hline Fonte: Senado Federal (2015), Portal do Orçamento (base de dados). & & & & &
\end{tabular}

Do orçamento destinado a programas relacionados à biodiversidade, a maior parte se destina ao ICMBio para a gestão das unidades de conservação federais (Capítulo 5); o MMA administra uma parte menor. Desde a criação, em 2008, o orçamento real do ICMBio aumentou em 57\%, alcançando, em 2014, R\$ 783 milhões (Capítulo 2). Em 2013, cerca de metade do orçamento do ICMBio foi utilizada para remuneração de pessoal, enquanto que o investimento representou entre 2\% e 11\% (Funbio, 2014).

\subsection{Fundos específicos da biodiversidade e outras fontes de financiamento}

Diversos fundos orçamentários e extra orçamentários contribuem para o financiamento de despesas relacionadas à biodiversidade, entre eles, o Fundo Nacional do Meio Ambiente (Capítulo 2); o Fundo de Áreas Protegidas (Capítulo 5); o Fundo de Desenvolvimento Florestal, gerido pelo Serviço Florestal Brasileiro, que promove o manejo florestal sustentável; e o Fundo de Restauração da Mata Atlântica, gerido pelo MMA, que financia a restauração ambiental e a pesquisa científica no bioma da Mata Atlântica (Tabela 2.2).

Um dos principais fundos, o inovador Fundo Amazônia, foi criado em 2008 para investir na conservação florestal e uso sustentável e na prevenção e monitoramento do desmatamento, com vistas a contribuir para a redução das emissões de gases de efeito estufa decorrentes do desmatamento e da degradação florestal. Nada menos que $80 \%$ dos investimentos do fundo são destinados à região amazônica, enquanto que os outros $20 \%$ podem ser investidos no monitoramento e controle do desmatamento em outros biomas brasileiros ou em países tropicais. O Fundo Amazônia é gerido pelo BNDES, em coordenação com o MMA. A maioria dos recursos provém de doadores internacionais, principalmente a Noruega e, em menor grau, a Alemanha, mas também de empresas, ex., Petrobras, empresa petrolífera gerida pelo governo brasileiro. ${ }^{18} \mathrm{O}$ montante das contribuições recebidas entre 2009 e início de 2015 aumentou em mais de $\mathrm{R} \$ 2$ bilhões (ou US\$ 970 milhões). Em comparação, a dotação orçamentária federal para o ICMBio entre 2009 e 2014 foi de $\mathrm{R} \$ 4$ bilhões (preços de 2014). O fundo vem apoiando um número crescente de projetos (Figura 4.10). Até março de 2015, havia apoiado 72 projetos, 
com o montante de US\$ 339 milhões, a maioria nos Estados do Pará, Amazonas e Mato Grosso (Fundo Amazônia, 2015).

\section{Figura 4.10. O Fundo Amazônia vem apoiando um número crescente de projetos}

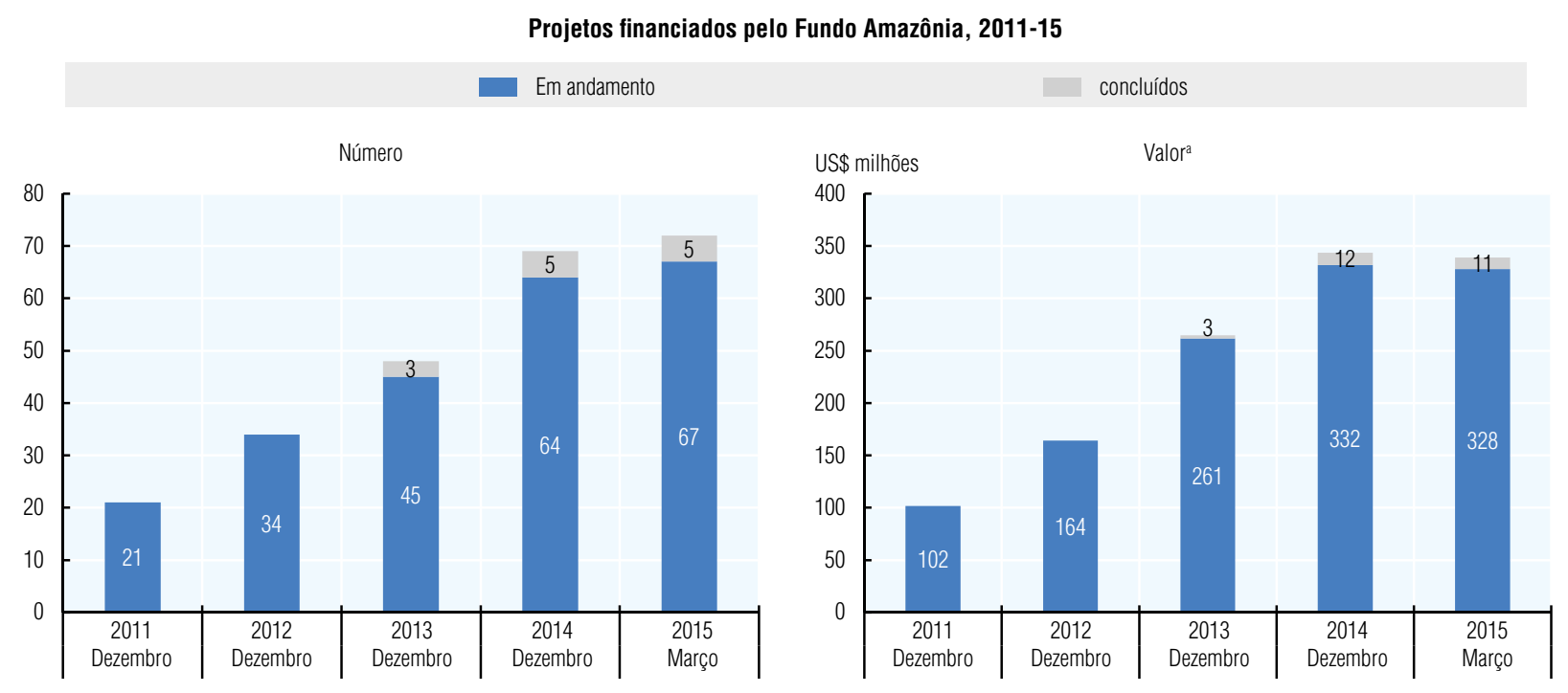

a) A preços e câmbio de 2015

Fonte: Baseado em Fundo Amazônia (2015), Relatório, 31 de março de 2015.

Parte dos recursos do Fundo Amazônia são repassados ao Fundo Brasileiro para a Biodiversidade (Funbio), associação civil sem fins lucrativos que arrecada e investe recursos financeiros para a conservação da biodiversidade, principalmente em áreas protegidas federais e estaduais. Além do Fundo Amazônia, o Funbio gerencia recursos provenientes de países parceiros e organizações multilaterais, como o GEF (Capítulo 5).

O Brasil recebeu cerca da metade do total do financiamento internacional aprovado para a redução de emissões provenientes do desmatamento e da degradação florestal (REDD e REDD+) por meio do Fundo Amazônia (Norman et al., 2014). Em junho de 2014, foi o primeiro país a submeter seu nível de referência de emissões florestais para pagamentos no âmbito do REDD+, conforme exigido pelo Marco de Varsóvia de 2013. Uma estratégia nacional de REDD+ vem sendo discutida desde 2010, mas ainda não foi aprovada.

De forma geral, mecanismos multilaterais e bilaterais de cooperação internacional, assim como empresas e fundações privadas, desempenham importante papel na oferta de financiamento para a proteção da biodiversidade, especialmente na Amazônia. Segundo estatísticas da OCDE sobre a assistência oficial ao desenvolvimento (AOD), entre 2010 e 2012, o fluxo de recursos para o Brasil, destinado ao cumprimento das metas da CDB atingiu o montante de US\$ 675 milhões (preços de 2012). Contudo, em 2013, o montante desses recursos despencou para menos da metade desse valor (Figura 3.10).

Segundo estimativas de Castro de La Mata e Riega-Campos (2014), entre 2007 e meados de 2013, o montante do financiamento internacional destinado à conservação da totalidade da Floresta Amazônica (incluindo áreas fora do território brasileiro) foi de US\$ 1,34 bilhão (ou US\$ 206,2 milhões ao ano). A Amazônia brasileira recebeu aproximadamente $50 \%$ desses recursos. Sete, dentre os dez principais doadores, foram agências internacionais multilaterais ou bilaterais; dois, fundações privadas; e o outro, uma organização não governamental internacional. 


\section{Transversalização do tema da biodiversidade nas políticas setoriais}

\subsection{Agricultura}

O Brasil é grande produtor e exportador agrícola; a agricultura responde por cerca de 15\% dos empregos (Capítulo 1; ver também Estatística Básica). Desde meados dos anos 2000, o governo vem ampliando o foco sobre a adoção de novas tecnologias, fomentando práticas agrícolas sustentáveis e desestimulando a transformação de florestas em áreas de produção agrícola. Conforme descrito na Seção 4, desde 2008, o acesso ao crédito rural subsidiado no bioma Amazônia está condicionado à legitimidade fundiária e ao cumprimento da legislação ambiental e, a partir de outubro de 2017, o acesso ao crédito rural estará condicionado ao cadastramento da propriedade no Cadastro Ambiental Rural (Seção 5.2).

Programas especiais, a exemplo do Plano Nacional de Agroecologia e Produção Orgânica 2012-15, estimulam a agricultura orgânica e a produção sustentável e prestam apoio a pequenas propriedades familiares. Outro exemplo é o Proambiente, programa de desenvolvimento socioambiental da produção familiar rural na Amazônia, que premia agricultores e pecuaristas, com até um terço do salário mínimo, pela adoção de boas práticas ambientais de produção, ex., sem uso de pesticidas, ou técnicas de gestão agroflorestal sustentável (OCDE, 2013). Em 2010, o governo lançou o programa Agricultura de Baixo Carbono, que oferece créditos subsidiados para a implementação de boas práticas ambientais. Embora o foco seja a redução das emissões de GEE, o programa contribui também para atenuar impactos sobre a biodiversidade (Box 4.10).

\section{Box 4.10. Programa Agricultura de Baixa Emissão de Carbono}

O programa Agricultura de Baixa Emissão de Carbono (ABC), lançado em 2010 como componente da Política Nacional de Mudanças do Clima (Capítulo 2), consolidou uma série de linhas de crédito concessional, condicionado a boas práticas ambientais e à redução das emissões de GEE, com vistas a facilitar o investimento. Ao contrário das linhas de crédito rural anteriores, o programa não financia itens específicos (ex., máquinas, sementes, fertilizantes) mas pode financiar ações que, em conjunto, reduzam impactos ambientais. O programa demorou para deslanchar, devido a vários desafios técnicos e de capacidade, mas, a partir de 2012, o volume de desembolsos cresceu com a adesão de novos intermediários financeiros e, consequentemente, a taxa de juros baixou, a capacidade técnica foi reforçada e a disseminação de informações sobre o programa melhorada. O total das operações contratadas em 2013/14 somou R $\$ 3$ bilhões, quase o dobro do montante da safra de 2011/12. Em julho de 2014, o total das operações contratadas havia atingido $\mathrm{R} \$ 8,2$ bilhões; $62 \%$ do valor previsto (FEBRABAN, 2014).

Apesar da melhora, os bancos intermediários continuam a mostrar pouco interesse no programa: 91\% dos desembolsos foram executados pelo Banco do Brasil (público) enquanto que apenas $9 \%$ foram transferidos pelos bancos privados, com recursos provenientes do BNDES. Em parte, esse desinteresse se deve ao fato de os créditos $A B C$ do BNDES envolverem elevados custos de transação (Febraban, 2014). A divulgação de informações sobre o programa deve ser melhorada e mais recursos serão necessários para a formação de agentes técnicos e financeiros. A priorização de áreas para expansão (ex., onde o potencial de redução de GEE é maior) poderia ajudar a aumentar a eficácia do programa, na medida em que é gradativamente ampliado. Na medida que o programa avança, devem ser realizadas ações para o monitoramento da sua efetividade na redução das emissões de GEE e de pressões sobre a biodiversidade. No geral, comparado ao apoio convencional à agricultura, o volume e a dimensão do programa $A B C$ são pequenos.

A demanda por produtos orgânicos tem crescido nos últimos anos. Este crescimento, aliado a preços mais elevados comandados por esses produtos, representa 
uma oportunidade viável de aumento de renda para pequenos produtores rurais. $O$ MAPA desenvolveu um sistema on-line de cadastramento de produtores orgânicos e, em 2014, mais de 7.100 produtores orgânicos já haviam efetuado cadastro no sistema (MMA, 2015). No entanto, a agricultura orgânica representa uma parcela muito pequena da produção agrícola e menos de $1 \%$ da área sob cultivo; ademais, a área dedicada a práticas orgânicas vem diminuindo desde 2010 (Figura 4.11).

No geral, o montante repassado pelos programas de estímulo à agricultura sustentável é pequeno em comparação com o total do apoio prestado à produção rural. A maior parte do apoio e dos créditos agrícolas é destinada à agricultura baseada em práticas convencionais (sementes híbridas, fertilizantes químicos e pesticidas), podendo trazer impactos negativos sobre o solo e a água. A grande maioria do apoio está vinculada à produção, medida pelo volume de commodities produzido e pelo consumo de insumos (Capítulo 3). Esta forma de apoio à agricultura é a mais distorciva e potencialmente prejudicial ao meio ambiente.

\section{Figura 4.11. A área dedicada à agricultura orgânica é pequena e vem diminuindo}

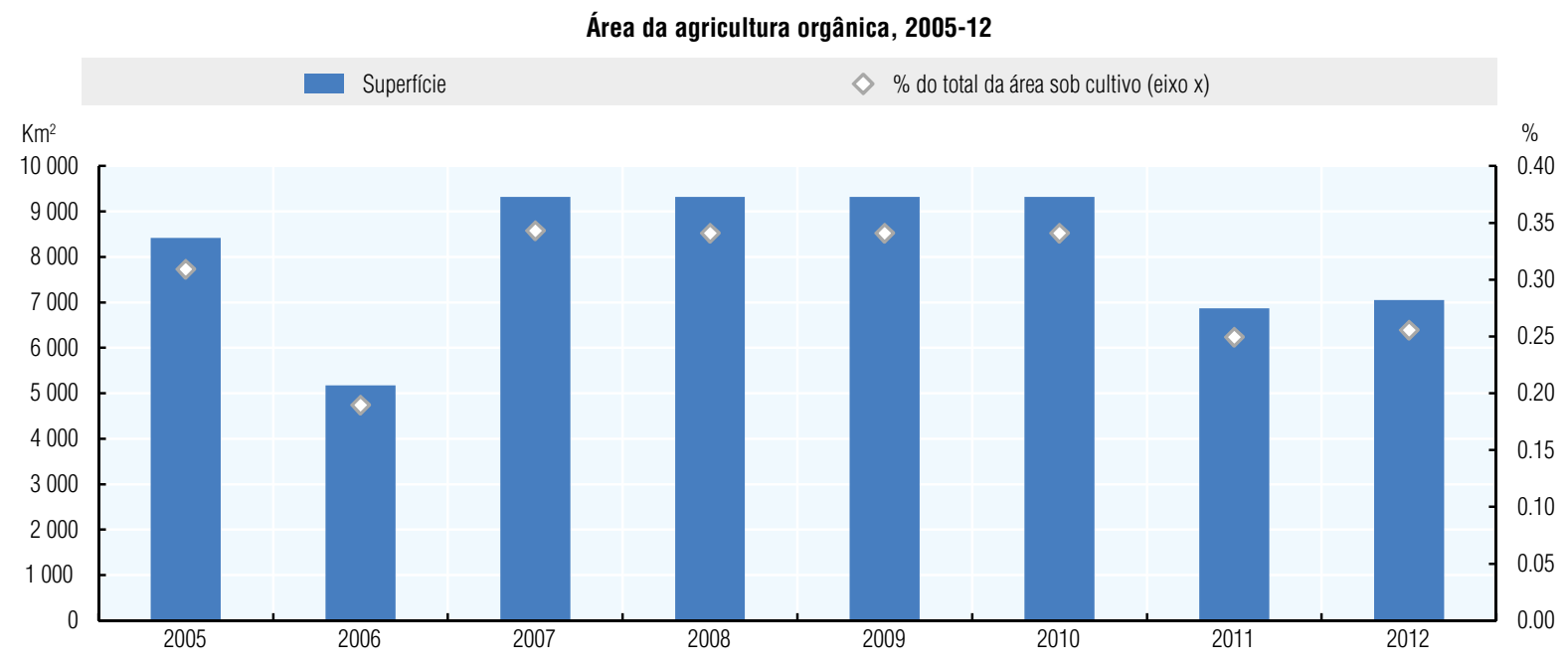

Fonte: FAO (2015), FAOSTAT (base de dados).

Por estimular a produção e o consumo intensivo de insumos e, por consequência, a intensificação e expansão agrícola, esses programas de apoio e crédito correm o risco de aumentar pressões sobre os recursos naturais e servir de estímulo ao desmatamento. Reduzem o incentivo à utilização mais eficiente de fatores de produção, e tendem a prestigiar a produção agrícola em detrimento de outros usos da terra, tais como conservação, restauração e manejo florestal sustentável. O apoio à agricultura deveria ser mais fortemente direcionado ao incentivo à melhoria ambiental e ao uso mais eficiente de insumos, bem como à superação de deficiências de infraestrutura. Esse enfoque poderia melhorar a produtividade da agropecuária brasileira e reduzir o ritmo da expansão agrícola e do desmatamento de florestas.

Além disso, importantes insumos agrícolas, como água, pesticidas e fertilizantes, gozam de subsídios implícitos. Em muitas regiões, não há cobrança pela captação de água (Seção 5). Fertilizantes e pesticidas têm isenção de alguns tributos federais e estaduais, o que tem aumentado não apenas a sua utilização, mas também os impactos na saúde humana, nos ecossistemas e na qualidade da água e do solo. O Brasil é um 
dos maiores consumidores mundiais de fertilizantes (depois da China, Índia e Estados Unidos) sendo o uso desses insumos especialmente elevado em determinadas culturas, como a soja, e nas regiões Sul e Sudeste, onde predomina a agricultura de grande escala (Capítulo 1). Vários dos pesticidas amplamente utilizados são tóxicos ou altamente tóxicos e prejudiciais ao meio ambiente e aos polinizadores (MMA, 2015); ademais, é bastante comum o uso de pesticidas não autorizados (Jardim e Caldas, 2012).

Os atuais procedimentos de aprovação do registro de pesticidas devem ser revistos, incluindo a exigência de renovação periódica, ao invés da aprovação definitiva (MMA, 2015). Quando exigida, o processo de revalidação de registro pode levar vários anos (Friedrich, 2013). Além disso, devem ser reconsideradas as isenções fiscais para fertilizantes e pesticidas, com o objetivo de estimular a utilização mais racional de produtos que podem prejudicar a saúde humana e animal e os ecossistemas. Experiências de outros países mostram que tais medidas podem trazer benefícios econômicos e ambientais. A Indonésia, por exemplo, promoveu uma remoção gradativa dos subsídios a pesticidas e, ao mesmo tempo, apoiou a adoção de abordagens integradas de gestão de pragas pelos produtores rurais. Após três anos, essas iniciativas resultaram em recordes de produção de arroz e em uma economia de mais de US\$ 100 milhões (OCDE, 2013).

O Imposto sobre Propriedade Territorial Rural (ITR) embora pouco significativo, também incentiva a produção agrícola, em detrimento da conservação. O ITR é maior para terras "improdutivas" do que para terras com produção agrícola. Áreas de RL e de APP gozam do benefício de isenção do ITR o que, em parte, compensa o custo de oportunidade pela não exploração mais intensiva da terra; no entanto, o baixo valor dessa isenção torna o incentivo insignificante (MMA, 2015).

\subsection{Manejo florestal}

\section{Madeira e recursos não madeireiros}

O Brasil é grande produtor e consumidor de madeira tropical. Em 2007, o setor florestal respondia por 3,5\% do PIB e 7,3\% das exportações, e empregava cerca de 7 milhões de pessoas (SFB, 2015b). Menos de $1 \%$ da área total de florestas foi designado à produção madeireira, em 2011/12 (SFB, 2013). ${ }^{19}$ Entre 2007 e 2010, a madeira legalmente extraída de florestas nativas veio do manejo florestal sustentável (49\%) e do desmatamento autorizado (51\%). A extração proveniente de florestas plantadas quase que dobrou desde 2000, chegando a cerca de cinco vezes o volume da madeira extraída de florestas nativas em 2013. As florestas plantadas podem ajudar a reduzir a demanda por madeira de florestas nativas e a gerar emprego e renda. A maior parte das florestas plantadas está localizada na região Sul; já a madeira de florestas nativas provém, principalmente, da Amazônia e, em menor escala, da Mata Atlântica (SFB, 2015b).

Os produtos florestais não madeireiros geraram, em 2011, R\$ 936 milhões, ou 5,1\% do total da produção florestal primária (MMA, 2015). A extração de produtos florestais não madeireiros é uma atividade econômica informal e difusa, praticada principalmente - mas não exclusivamente - em regiões remotas por comunidades tradicionais e rurais, para as quais essas atividades representam a mais importante se não a única - fonte de renda. Entre os produtos economicamente explorados estão: borracha, piaçava, juncos, folhas, fibras, sementes, resinas e óleos essenciais; contudo, a escala de produção varia bastante, e a sustentabilidade ambiental e de espécies está longe de ser garantida (MMA, 2015). 
A produção extrativista vem sendo incentivada por meio de programas federais, como o PNPSB (Seção 5.7) e da criação de áreas protegidas de uso sustentável (Capítulo 5). Em Manaus e Belém, vêm sendo desenvolvidas cadeias produtivas que visam promover articulação entre as atividades extrativistas praticadas por comunidades florestais e setores econômicos urbanos, pequenas e médias indústrias de transformação, instituições de apoio tecnológico e pesquisa local e outros setores relevantes (MMA, 2015). No entanto, a produção florestal extrativista praticada em condições sustentáveis representa menos de 0,2\% do PIB dos municípios da Amazônia Legal devido, principalmente, à baixa demanda e a uma lacuna entre produção e comercialização (WWF, 2015).

\section{Concessões para o manejo florestal sustentável}

O governo, em reconhecimento da necessidade de oferecer alternativas econômicas sustentáveis para populações locais, e de evitar o desmatamento e outras práticas prejudiciais ao meio ambiente, vem se empenhando em fomentar o uso sustentável de seus recursos florestais.

A Lei n 11.284 de 2006, que dispõe sobre a gestão de florestas públicas para a produção sustentável, reforçou o direito de comunidades locais de gerir suas florestas, ${ }^{20}$ introduziu concessões como instrumento de gestão sustentável de florestas para a produção madeireira, e criou o Sistema Florestal Brasileiro (SFB) para gerir as concessões. A lei permite que os governos federal, estaduais e municipais concedam a empresas privadas, por processo licitatório, o direito à extração de madeira e de produtos florestais não madeireiros, desde que a floresta seja gerida de forma sustentável. ${ }^{21}$ A seleção dos concessionários é feita com base na oferta de melhor preço e critérios técnicos, tais como menor impacto ambiental e maiores benefícios sociais. A concessão de áreas florestais deve ser precedida de audiências públicas. Parte da área de concessão deve ser mantida como reserva, e as atividades extrativistas devem respeitar as populações locais (SFB, 2013).

Apesar da imensa extensão de áreas de florestas públicas, apenas uma pequena parcela está sob manejo florestal sustentável, em regime de concessão. Em novembro de 2012, havia uma área de 3,1 milhões de $\mathrm{km}^{2}$, equivalente a 36\% do território nacional, registrada no Cadastro Nacional de Florestas Públicas (CNPF) ${ }^{22}$ (SFB, 2013). As primeiras concessões florestais foram concedidas em 2008, mas, até 2013, apenas 0,2\% da área de florestas públicas disponíveis estava sob regime de concessão federal ou estadual.

Entre as causas da morosidade da implantação de concessões estão: carência de conhecimentos tecnológicos para o manejo florestal sustentável nas empresas; insuficiência de capacidades técnica e econômica para a gestão das concessões nas instâncias governamentais; falta de infraestrutura nas áreas de concessão; e conflitos fundiários não resolvidos. As empresas florestais reclamam frequentemente das elevadas taxas de concessão (por metro cúbico de madeira extraída) e das especificações técnicas dos contratos. As comunidades rurais têm dificuldade em participar das concessões, por falta de capacidade para competir no processo altamente burocrático (WWF, 2015). Faz-se necessário um monitoramento sistemático das áreas sob concessão para garantir que as florestas sejam manejadas de forma sustentável e de acordo com as especificações do contrato, para que alcancem os resultados ambientais e sociais esperados.

\section{Certificação da madeira}

No Brasil, o manejo florestal e a cadeia de custódia e certificação estão a cargo de várias empresas, por meio de dois sistemas de certificação: o Programa Brasileiro de 
Certificação Florestal (Cerflor), vinculado ao Programme for the Endorsement of Forest Certification (PEFC), e o Forest Stewardship Council (FSC). A área total de florestas certificadas

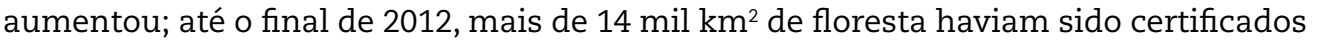
pelo Cerflor, e outros $72 \mathrm{mil} \mathrm{km²}$ pelo FSC (SFB, 2013).

\section{Restauração Florestal}

Conforme indicado na Seção 5.2, grande parte das propriedades rurais não cumpre com as obrigações de conservação estabelecidas no Código Florestal de 2012, e a cobertura vegetal deve ser restaurada nessas áreas, sobretudo nos biomas Amazônia, Mata Atlântica e Cerrado. Segundo dados do CAR de abril de 2015, há pendências de restauração florestal numa área de $80 \mathrm{mil} \mathrm{km²}$ (SFB, 2015a).

O Plano Nacional de Recuperação da Vegetação Nativa (Planaveg) elaborado pelo MMA e atualmente em consulta pública, visa promover uma ampla restauração de áreas florestais. A proposta é recuperar, pelo menos, $125 \mathrm{mil} \mathrm{km}^{2}$ dentro de 20 anos, ${ }^{23}$ principalmente em APPs (46\%) e RLs (37\%), mas também em áreas degradadas de baixa produtividade, onde a restauração não é exigida por lei. O plano prevê várias ações, entre elas, medidas de conscientização, disponibilização de mudas a preços acessíveis, criação de mercados para produtos provenientes de florestas restauradas e introdução de novos mecanismos de financiamento (como a ampliação da isenção fiscal concedida a títulos de infraestrutura para investimentos em restauração). A expectativa é que o plano complemente outras iniciativas, como o programa ABC (Box 4.10) e as ações de regularização fundiária atualmente em curso. Ademais, o MMA espera que o plano possa gerar até 191 mil empregos diretos em áreas rurais.

Os custos de restauração são altos e podem ser proibitivos para detentores de pequenas áreas de terra. O cumprimento das metas brasileiras de restauração é, portanto, um desafio que demandará a mobilização de significativos recursos financeiros e humanos. O orçamento preliminar para implementação do plano é de R 181 milhões para os primeiros cinco anos, ${ }^{24}$ mas ainda falta identificar fontes de financiamento. Além de apresentar estimativas de custos, o Brasil deve apontar as áreas mais importantes para restauração (ex., mapas indicando áreas prioritárias para a produção de água e a proteção da biodiversidade).

\subsection{Pesca e aquicultura}

O governo brasileiro está empenhado em fomentar o setor pesqueiro, como importante ferramenta de segurança alimentar e de desenvolvimento socioeconômico regional. A capacidade e os equipamentos das embarcações pesqueiras vêm sendo melhorados, levando a um aumento da produção (Seção 1.2). No entanto, grande parte da pesca é realizada por frotas obsoletas que perseguem estoques pesqueiros já fortemente explorados, o que traz consequências negativas tanto para a biodiversidade quanto para a eficiência. Conflitos sobre a exploração de recursos pesqueiros entre a pesca artesanal e a industrial e dentro das comunidades de pescadores tendem a agravar as pressões sobre os estoques (OCDE-FAO, 2015).

A produção da aquicultura aumentou em quase cinco vezes desde 2000, e o previsto é que aumente ainda mais, impulsionada pela crescente demanda interna e pela política de estímulo ao setor (OCDE-FAO, 2015). ${ }^{25} \mathrm{~A}$ expansão da aquicultura pode contribuir para ampliar a oferta de peixes e de produtos pesqueiros e, ao mesmo tempo, reduzir pressões sobre estoques pesqueiros naturais; contudo, as políticas voltadas à 
expansão da aquicultura devem levar em consideração eventuais impactos negativos sobre a biodiversidade e os ecossistemas, especialmente em se tratando do cultivo de espécies exóticas (ou espécies brasileiras de outros habitats). As atividades de aquicultura requerem licenciamento ambiental.

O Brasil adotou um modelo de gestão compartilhada da pesca, baseado em comitês permanentes de gestão e com a participação de instituições governamentais e da sociedade civil, com o objetivo de promover a sustentabilidade ambiental e a inclusão social. Não há exigência formal de licenciamento ambiental para atividades pesqueiras, mas várias medidas se aplicam para limitar o impacto ambiental da pesca (ex., períodos de defeso, áreas de pesca e equipamentos). No entanto, uma auditoria realizada pelo TCU revelou que essa estrutura não está totalmente implementada, e que medidas para o uso sustentável de recursos pesqueiros continuam sendo realizadas apenas pelo governo. Ademais, limitações relacionadas a dados sobre habitats aquáticos e recursos pesqueiros, insuficiência de mecanismos para o monitoramento e controle de conformidade com as normas, e a difícil cooperação entre o MMA e o Ministério da Pesca e Aquicultura foram destacadas como entraves à gestão sustentável da pesca (MMA, 2015).

As medidas adicionais necessárias incluem: quotas de captura; planos de gestão eficazes para espécies superexploradas; e ampliação das áreas protegidas, especialmente em zonas costeiras e marinhas, onde os estoques pesqueiros estão no limite. O Plano Setorial para os Recursos do Mar (PSRM) inclui uma iniciativa com foco na avaliação, monitoramento e conservação da biodiversidade marinha (REVIMAR). Para 2012-15, essa iniciativa previa a criação de programas de monitoramento de espécies marinhas; a continuidade de ações de avaliação e monitoramento de áreas de manguezais e áreas protegidas contendo recifes de corais; um aumento do número de planos de conservação para espécies marinhas ameaçadas; e a expansão do total de áreas protegidas marinhas para 4\% das águas territoriais e da zona econômica exclusiva brasileira (Capítulo 5).

\subsection{Desenvolvimento da infraestrutura: o caso da energia hídrica}

A matriz hídrica é e continuará sendo importante fonte energética; sua expansão, contudo, é limitada por questões de localização: a maioria dos potenciais aproveitamentos está localizada na Amazônia, o que suscita entraves de licenciamento ambiental e de aceitação pública (Box 2.8). Encontram-se em desenvolvimento novas técnicas de geração hidrelétrica como, por exemplo, usinas-plataforma e, quando possível, do tipo a fio d'água, projetadas para reduzir os impactos ambientais associados às grandes usinas hidrelétricas (IEA, 2013). No entanto, usinas hidrelétricas podem provocar uma série de impactos negativos sobre a biodiversidade, ao interromper a conectividade entre rios, mudar habitats e interferir com os ciclos naturais de espécies aquáticas. A implantação de barragens para grandes hidrelétricas também pode incentivar a construção de estradas, a migração e a urbanização, assim aumentando ainda mais as pressões sobre a vegetação nativa. Cerca de $95 \%$ do desmatamento na Amazônia ocorre num raio 5 $\mathrm{km}$ das estradas (ou rios) (Barber et al., 2014).

Como qualquer projeto de infraestrutura, as usinas hidrelétricas estão sujeitas a licenciamento ambiental e avaliação de impacto (Capítulo 2). No entanto, o processo de licenciamento e de outorga de direito de uso da água tem dado pouca atenção à manutenção de fluxos ambientais, ou seja, a quantidade de água necessária para sustentar ecossistemas de água doce e serviços ecossistêmicos e evitar impactos negativos (muitas vezes inesperados). Em muitos países, a legislação requer que a quantidade de 
água necessária para a manutenção ambiental seja levada em consideração, quando da requisição do licenciamento (OCDE, 2015).

A transversalização do tema biodiversidade para incorporar grandes projetos de infraestrutura tem sido objeto de estreita cooperação entre o MMA e o MME. Com poucas exceções, no entanto, os impactos são abordados por meio de medidas de mitigação ex-post, ao invés de considerados nas fases iniciais do planejamento. Uma melhor integração entre os marcos regulatórios e institucionais dos setores ambiental e energético permitiria a mudança, do planejamento baseado em projetos, para uma integração estratégica dos objetivos de desenvolvimento energético e conservação ambiental. O Brasil poderia considerar o uso de avaliação ambiental estratégica, quando da implantação de usinas hidrelétricas (Capítulo 2). Isto tornaria possível, por exemplo, a identificação do local em que a capacidade de geração poderia ser implantada com menor impacto ambiental, levando em conta, também, o impacto cumulativo (ex., de uma série de barragens num mesmo rio). Tornaria possível ainda a redução do custo de mitigação de impactos ambientais e sociais da implantação de usinas hidrelétricas, conforme identificados na licença ambiental, o que representa até $12 \%$ dos custos totais desses projetos (BIRD, 2008).

\section{Acervo de conhecimento e valoração da biodiversidade na formulação de políticas}

\subsection{Acervo de conhecimento}

O Brasil tem avançado rumo ao cumprimento da meta nacional 19 da biodiversidade sobre o incremento e sistematização de conhecimentos relacionados à biodiversidade (Anexo 4.A). Em 2014, o MMA, após extensa avaliação científica, divulgou listas atualizadas das espécies da flora e da fauna ameaçadas de extinção, e o ICMBio vem acompanhando o estado de conservação da biodiversidade em áreas protegidas (Capítulo 5). Anualmente, o SFB coordena o inventário nacional florestal, e diversas outras iniciativas vêm sendo realizadas para monitorar a biodiversidade em áreas protegidas (Capítulo 5).

O Brasil é líder mundial em monitoramento do desmatamento via imagens de satélite, abordagem que tem se mostrado fundamental no apoio às ações de fiscalização e combate ao desmatamento no bioma Amazônia (Seção 4). Sistemas de monitoramento do desmatamento via satélite vêm sendo implementados também para outros biomas, mas são menos sofisticados e nem sempre os dados são compatíveis entre eles. Reforçar os sistemas de monitoramento do desmatamento via satélite para todos os biomas e adaptá-los para detectar a degradação florestal será fundamental para a aplicação do Novo Código Florestal e para reduzir ainda mais o desmatamento (Seção 5.2).

Em 2010, o MCTI lançou o Sistema de Informação sobre a Biodiversidade Brasileira ( $\mathrm{SiBBr})$, que visa organizar informações sobre a biodiversidade e os ecossistemas brasileiros, em apoio a pesquisas e políticas públicas. O primeiro conjunto desses dados científicos já foi disponibilizado via Internet. ${ }^{26}$ No entanto, o sistema ainda enfrenta desafios relacionados à atualização contínua de dados e à facilitação do seu manuseio (MMA, 2015). Seria de grande valia para o Brasil a efetiva implementação de um sistema abrangente - como o SiBBr - capaz de compilar, consolidar, sistematizar e atualizar regularmente as existentes e as novas informações relacionadas à biodiversidade, tornando-as mais acessíveis para a pesquisa, formulação e avaliação de políticas. 


\subsection{Valoração econômica da biodiversidade e dos ecossistemas}

Não obstante a vasta quantidade de informações disponíveis, os avanços alcançados em termos de valoração econômica da biodiversidade e dos ecossistemas têm sido modestos. Em 2012, o IPEA fez um levantamento dos estudos existentes no Brasil sobre valoração da biodiversidade e dos ecossistemas, com vistas a identificar lacunas de conhecimento. Após a análise de 103 estudos, o IPEA concluiu que a maioria tratava de localidades específicas e que, portanto, não servia como base para estimar valores, em escala maior (Roma et al., 2013). Uma notável exceção foi um estudo que avalia a contribuição das áreas protegidas para a economia nacional (Box 5.3).

No entanto, estudos de valoração são raramente consultados para instruir processos de tomada de decisão. Alguns avanços foram alcançados, a exemplo da inclusão do valor dos recursos hídricos na contabilidade nacional; e trabalhos sobre a contabilidade econômica florestal estão em andamento. O Brasil deve aproveitar essas experiências para alcançar a plena integração dos valores da biodiversidade e de serviços ecossistêmicos na contabilidade nacional. Será necessária a ampliação de esforços para dilucidar esses valores, bem como os riscos associados à perda deles, como instrumento de sensibilização da opinião pública em apoio à formulação de políticas para sua preservação.

\section{Box 4.11. Iniciativa Valoração do Capital Natural do Brasil}

A iniciativa Valoração do Capital Natural do Brasil é uma ampla parceria entre o MMA, outros ministérios e agências federais, organizações da indústria e parceiros internacionais*. A EEB tem três componentes inter-relacionados: (i) políticas nacionais (TEEB-Nacional); (ii) assimilação do valor dos serviços ecossistêmicos nos processos de tomada de decisão (TEEB-Regional-Local); e (iii) riscos e custos da perda de biodiversidade para o setor empresarial (TEEB-Empresarial).

Em novembro de 2013, a parceria EEB identificou prioridades temáticas a serem abordadas na primeira fase do TEEB-Nacional: (i) promoção de cadeias de produção sustentável, por meio de processos de licitação pública; (ii) a economia da restauração ecológica; (iii) impactos e dependência do setor agrícola sobre serviços ecossistêmicos; e (iv) mapeamento de serviços ecossistêmicos. A iniciativa encomendou estudos para a elaboração de um plano de trabalho para o tratamento desses quatro temas prioritários. O próximo passo envolverá o engajamento de atores estratégicos, especialmente de setores com menor consciência a respeito desses temas.

A agência alemã GIZ apoia o desenvolvimento do TEEB Regional-Local, por meio da realização de projetos-piloto voltados à melhoria da compreensão sobre instrumentos econômicos e financeiros para proteção da biodiversidade e de abordagens para incorporar os valores da biodiversidade e dos serviços ecossistêmicos aos processos de formulação de políticas, a nível regional e local. Como parte do projeto, foi publicado o manual Integração de Serviços Ecossistêmicos ao Planejamento do Desenvolvimento: Um guia passo-a-passo para profissionais, com base na iniciativa TEEB; e realizados dois eventos internacionais, em 2014: (i) Diálogo TEEB Brasil-Índia-Alemanha; e (ii) Workshop Internacional sobre Negócios e Capital Natural, um evento aberto para a consecução dos objetivos da CDB, por meio do fortalecimento da cooperação entre governos, setores empresarial e acadêmico e sociedade civil.

O TEEB-Empresarial tem como objetivo destacar os benefícios econômicos de iniciativas empresariais que favoreçam a conservação da biodiversidade e a manutenção de serviços ecossistêmicos. Em março de 2014, foi publicado um estudo comparativo do valor ambiental de diferentes práticas na produção de óleo de palma (dendê) e de soja, em projetos-piloto das empresas Natura e Monsanto. Em ambos os casos, os resultados sugerem que a preservação do capital natural é bom negócio.

* O EEB é uma parceria entre MMA, MF MCTI, IPEA, SAE/PR, IBGE, PNUMA, CNI, Conservation International Brasil e a agência de cooperação técnica alemã (GIZ).

Fonte: MMA (2015), Quinto Relatório Nacional para a Convenção sobre Diversidade Biológica. 
Alguns avanços foram alcançados nesse sentido. Como parte do compromisso internacional do Brasil no âmbito da CDB para implementar a economia dos ecossistemas e da biodiversidade (a chamada TEEB-Nacional) o MMA lançou, em 2013, a iniciativa Valoração do Capital Natural do Brasil (EEB). O MMA e alguns parceiros estão empenhados em: (i) identificar e destacar os benefícios da conservação e uso sustentável da biodiversidade e dos serviços ecossistêmicos nacionais, bem como estimar os custos de sua perda; (ii) promover a transversalização da economia dos ecossistemas e da biodiversidade nos processos de tomada de decisão em diferentes instâncias, para que as decisões possam conduzir ao uso sustentável dos recursos naturais; e (iii) influenciar a implementação de políticas públicas e de instrumentos de gestão e promover mudanças comportamentais para garantir, no longo prazo, a disponibilidade dos recursos naturais. O Box 4.11 descreve as principais atividades e resultados da EEB.

\section{Recomendações sobre conservação e uso sustentável da biodiversidade}

\section{Base de conhecimento e avaliação}

- Expandir o Sistema de Informação sobre a Biodiversidade Brasileira para compilar, consolidar e sistematizar informações sobre biodiversidade novas e já existentes e torná-las mais acessíveis à pesquisa e à formulação e avaliação da política; garantir que o sistema seja regular e tempestivamente atualizado.

- Dar continuidade ao desenvolvimento de sistemas de monitoramento por satélite capazes de detectar o desmatamento florestal e a degradação, dando cobertura a todos os biomas, especialmente o Cerrado, a Caatinga e o Pampa, onde está prevista a maior parte da devastação da vegetação; garantir que os sistemas gerem séries de dados compatíveis e atualizados.

- Dar prosseguimento à Iniciativa de Valoração do Capital Natural do Brasil; realizar, na primeira oportunidade, uma avaliação nacional de ecossistemas para melhorar o conhecimento dos valores da biodiversidade e serviços ambientais, bem como dos riscos associados com suas perdas; garantir que os valores dos serviços ambientais sejam incluídos nas contas nacionais, na formulação e na avaliação de políticas.

\section{Moldura política}

- Manter o enfoque das políticas sobre o combate ao desmatamento e na regularização fundiária, e estendê-lo a todos os biomas terrestres e ecossistemas aquáticos, marinhos, costeiros.

- Racionalizar a multiplicidade de programas e planos de biodiversidade, com vistas a eliminar a sobreposição e a duplicação de esforços e aumentar o custo-benefício; avaliar sistematicamente a implementação de políticas e medidas, em termos de resultados, custos e benefícios, com a consequente correção de rumos de políticas e programas.

\section{Conservação, restauração e manejo sustentável de florestas}

- Fortalecer a implementação do CAR por meio de incentivos econômicos, para estimular o cadastramento, promover a conformidade e apoiar o manejo sustentável e a restauração de áreas de reserva; expandir o sistema de informação do CAR para melhorar o monitoramento das conformidades, o planejamento da paisagem e o estabelecimento de prioridades políticas.

- Apoiar o desenvolvimento de programas estaduais de regularização ambiental e ampliar a capacidade de implementação de estados e municípios.

- Considerar o ajuste do sistema de Cotas de Reserva Ambiental para permitir trocas dentro das mesmas áreas prioritárias, em termos de valor da biodiversidade; monitorar sistematicamente o funcionamento do sistema e permitir os ajustes necessários para alcançar seus objetivos de preservação e restauração de florestas. 


\section{Recomendações sobre conservação e uso sustentável da biodiversidade (Continuação)}

- Incrementar o apoio às práticas florestais e agrícolas sustentáveis, inclusive em áreas protegidas, por meio de capacitação e assistência técnica às comunidades tradicionais e rurais e pequenas propriedades agrícolas, e de facilitar seu acesso aos mercados de crédito e produtos.

- Agilizar o uso de concessões para a gestão sustentável de florestas, inclusive em áreas protegidas, pela simplificação de procedimentos e pelo aumento da capacidade de servidores do governo em elaborar e negociar contratos de concessão; monitorar sistematicamente as áreas sob concessão para assegurar conformidade com as especificações do contrato e a entrega dos resultados ambientais e sociais esperados.

- Acelerar o desenvolvimento do Plano Nacional de Recuperação da Vegetação Nativa proposto, estimar seus custos e identificar áreas prioritárias (com alto valor de biodiversidade) para restauração; identificar fontes de financiamento e avaliar a viabilidade de estender a isenção fiscal concedida a títulos de infraestrutura a investimentos em restauração.

- Prover o setor privado de mais estímulo para implementar cadeias de valor sustentáveis e rastreáveis que minimizariam seu impacto sobre a biodiversidade e os ecossistemas, incluindo o desmatamento.

- Adotar, na primeira oportunidade, uma estratégia nacional de REDD+, indicando objetivos, ações, arranjos institucionais, mecanismos de monitoramento e alocação de recursos necessários.

\section{Pagamentos por serviços ambientais (PSA)}

- Dar continuidade ao debate sobre o projeto de lei federal atual e adotar uma lei de PSA abrangente que sirva de marco para a implementação de PSA e aprimoramento da consistência entre regulamentos e programas dos estados.

- Instituir, em todo o país, um sistema de monitoramento de programas de PSA, possivelmente no âmbito da lei federal de PSA, com vistas a verificar sua eficácia na manutenção dos serviços ambientais que estão sendo pagos.

- Ampliar e incrementar a gestão do Bolsa Verde e reforçar seu vínculo com o CAR; assegurar treinamento adequado aos beneficiários, com vistas a ajudá-los a cumprir com seus compromissos de conservação.

\section{Integração da biodiversidade nas políticas setoriais}

- Reorientar o apoio à agricultura para estimular a melhoria ambiental e o uso eficiente dos insumos agrícolas.

- Reformar a tributação territorial, incentivar a conservação da terra e remover gradualmente as isenções fiscais sobre fertilizantes e agrotóxicos; utilizar as receitas fiscais resultantes para aprimorar os conhecimentos dos produtores sobre boas práticas agrícolas, ex.: métodos alternativos de controle de pragas; reavaliar as normas sobre pesticidas, sujeitando as licenças à renovação periódica e intensificando medidas para coibir o uso de pesticidas não autorizados.

- Introduzir medidas para melhorar a sustentabilidade da pesca em águas marinhas e interiores, incluindo cotas de captura, planos de manejo para espécies sobrexplotadas e ampliação das áreas marinhas protegidas, especialmente nas zonas marinhas e costeiras onde os recursos pesqueiros estão no seu limite.

- Introduzir o planejamento estratégico, incluindo procedimentos de avaliação ambiental para o desenvolvimento de hidrelétricas, de modo a identificar onde o potencial energético poderia ser utilizado com menor impacto ambiental, levando em consideração efeitos cumulativos e, por último, reduzir os custos da mitigação de impactos ambientais e sociais.

- Elucidar as regras das compensações ambientais e financeiras no âmbito do processo de licenciamento; melhorar a quantificação do impacto de projetos de infraestrutura sobre biodiversidade e ecossistemas e a definição de medidas compensatórias associadas. 


\section{Notas}

1. Juntos, os 17 países megadiversos do mundo contêm cerca de $70 \%$ da biodiversidade do planeta.

2. Bioma é uma grande comunidade natural de flora e fauna que ocupa uma região geográfica.

3. A macrorregião da Amazônia Legal corresponde a uma área maior que o bioma Amazônia, abrangendo a Floresta Amazônica (cerca de 4,1 milhões de $\mathrm{km}^{2}$ ) e vegetação de transição (1 milhão de $\mathrm{km}^{2}$ ); o bioma Amazônia abrange apenas a área de floresta. A Amazônia Legal engloba nove estados: Amazonas, Pará, Acre, Roraima, Rondônia, Amapá e Tocantins, e parte do Mato Grosso e do Maranhão.

4. O monitoramento do desmatamento nos outros cinco biomas brasileiros começou mais tarde que na Amazônia. Os dados anuais de desmatamento começaram a ser produzidos em 2009.

5. Incluem 732 mamíferos, 1.980 aves e 4.507 espécies de peixes de águas marinhas e doce.

6. Incluem mandioca, abacaxi, amendoim, cacau, caju, cupuaçu, maracujá, castanha do Pará, guaraná e jabuticaba.

7. A lista de espécies da flora ameaçada é baseada no Livro Vermelho da Flora do Brasil 2013 pelo Centro Nacional de Conservação da Flora, do Instituto de Pesquisas Jardim Botânico do Rio de Janeiro.

8. Por exemplo, o pinheiro norte-americano substituiu o habitat da estepe no sul do Brasil, por habitat florestal simplificado (MMA, 2015).

9. Incluem o Conselho Nacional do Meio Ambiente (CONAMA) (Capítulo 2), o Conselho Nacional para a Amazônia Legal (CONAMAZ), o Conselho de Gestão do Patrimônio Genético, a Comissão de Gestão de Florestas Públicas e a Comissão Interministerial para os Recursos do Mar (CIRM).

10. O processo de consulta, chamado "Diálogos sobre Biodiversidade: construindo a estratégia brasileira para 2020", envolveu participantes de todos os setores, incluindo empresas, ONGs, universidades, governos federal e estaduais, povos indígenas e comunidades tradicionais, e a sociedade em geral, por meio de processo de consulta pública online.

11. Alguns exemplos são a Companhia Vale, que investe por meio do Fundo Vale; A Petrobras, que investe por meio da Petrobras Ambiental; a empresa de cosméticos O Boticário, que investe por meio da Fundação Boticário; e a empresa de cosméticos Natura (Box 3.8), que investe por meio da Fundação Natura.

12. A certificação LIFE foi lançada em 2009 sob a égide da CDB... Para obter a certificação, a empresa deve implementar um conjunto mínimo de ações de conservação da biodiversidade e mitigação de impactos.

13. Alguns exemplos; polpa de pequi, pinhão, umbu e licuri, piaçava, babaçu, buriti, carnaúba, castanha do Pará, andiroba e copaíba.

14. A Companhia Nacional de Abastecimento (CONAB) implementa o programa, define os preços mínimos e é responsável pela operacionalização do pagamento dos benefícios.

15. A operacionalização do pagamento de subsídio é burocrática; requer que os extrativistas possuam documentação pessoal e uma conta corrente.

16. No caso da amêndoa do babaçu, a porcentagem da produção subsidiada pelo PGPMBio foi inferior a 2\%. Para a borracha, a porcentagem subsidiada foi maior, chegando a quase 27\%, em 2012.

17. Normalmente, demora cerca de três anos para se obter uma permissão. Alguns pesquisadores reclamam da exigência da obtenção de anuência das comunidades, argumentando que nem sempre sabem, com antecedência, onde o recurso genético será encontrado.

18. Os pagamentos para o Fundo Amazônia foram baseados na redução de emissões de GEE, em relação aos índices médios históricos de desmatamento, usando uma fórmula que converte estimativas das reduções de emissões de $\mathrm{CO}^{2}$ alcançadas por meio da redução do desmatamento contra uma taxa média, aplicando o valor de US\$ 5 por tonelada de emissões de GEE evitada. O ritmo de queda nos índices de desmatamento, no entanto, foi realmente maior do que o índice previsto pelos doadores internacionais (principalmente a Noruega) de modo que o mecanismo de financiamento seguiu um cronograma predeterminado de compromisso de desembolso (Birdsall et al., 2014).

19. Inclui florestas nacionais, florestas estaduais e florestas plantadas.

20. Florestas comunitárias são aquelas designadas para o uso de comunidades tradicionais, povos indígenas, agricultores familiares e assentados cadastrados no programa nacional de reforma agrária. A constituição brasileira garante o direito dos povos indígenas e grupos quilombolas aos seus territórios ancestrais. Em 2012, as florestas comunitárias representavam 62\% das florestas públicas nacionais registadas, a maioria das quais sendo terras indígenas ou áreas protegidas (reservas extrativistas e reservas de desenvolvimento sustentável). 
21. Para se qualificar para o manejo florestal sustentável, os produtores só podem explorar floresta ou formar uma floresta secundária com a aprovação prévia de um plano de manejo florestal sustentável que detalhe as diretrizes e procedimentos técnicos, elaborado por uma agência florestal competente. O sistema de manejo florestal utilizado na Amazônia é policíclico, baseado em um ciclo de 35 anos de corte e com base em critérios técnicos e ambientais para promover a regeneração das espécies florestais gerenciadas. Na prática, apenas quatro a seis árvores são derrubadas por hectare. O manejo florestal na Caatinga é baseado em um sistema monocíclico, com um período de rotação estimado entre 12 a 15 anos. Árvores são cortadas perto da base, para permitir a regeneração por rebrota (SFB, 2013).

22. O CNPF foi criado para produzir e compilar informações detalhadas sobre uso, conservação e restauração de todos os recursos florestais, incluindo aqueles não designados para produção. Reúne dados biofísicos, socioambientais e paisagísticos que englobam todo o território nacional.

23. A área total a ser restaurada sob o Planaveg foi definida com base em Soares-Filho et al. (2014) que

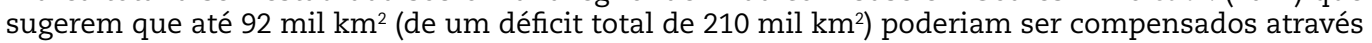
de CRAs. O Planaveg sugere ainda que $15 \mathrm{mil} \mathrm{km} \mathrm{km}^{2}$ poderiam ser compensados através da compra de posses encravadas em áreas protegidas (Seção 5.4). Assim, a meta do Planaveg ultrapassa, em 22 mil $\mathrm{km}^{2}$ a estimativa de restauração necessária para alcançar conformidade com o novo Código Florestal.

24. O plano prevê que o governo realize uma avaliação após dez anos de sua implementação, bem como análises intercaladas após 5 anos, com o propósito de aperfeiçoar as estratégias e ações, com base nos resultados alcançados, lições aprendidas e avanços no conhecimento e experiência, e de atender a eventuais novas exigências públicas e privadas.

25. O Plano Safra da Pesca e Aquicultura 2012-14 prevê investimentos de R\$ 9,8 bilhões para a expansão da aquicultura e modernização e fortalecimento da indústria e do comércio pesqueiro.

26. Outros programas estão sendo implementados por meio do Conselho Nacional de Desenvolvimento Científico e Tecnológico, incluindo o Sistema Nacional de Pesquisa em Biodiversidade (SISBIOTA), o Programa de Pesquisa em Biodiversidade (PPBio) e o Simpósio Internacional da Biodiversidade (SINBIO) com informações sobre inventários biológicos compatíveis com SiBBr.

\section{Referências}

Assunção, J. et al. (2013), Deforestation Slowdown in the Legal Amazon: Prices or Policies? Climate Policy Initiative, Rio de Janeiro.

Barber, C.P. et al. (2014), "Roads, deforestation, and the mitigating effect of protected areas in the Amazon”, Biological Conservation, Vol. 177, pp. 203-209.

Bernasconi, P. (2013), Custo-efetividade ecológica da compensação de reserva legal entre propriedades no Estado de São Paulo, projeto Policymix financiado pela Comissão Europeia, Diretoria Geral de Pesquisa, Bruxelas, www.esaf.fazenda.gov.br/premios/premios-1/i-premio-florestal-brasileiro/3o-lugar-010p.pdf.

BIRD (2008), “Summary report”, Environmental Licensing for Hydroelectric Projects in Brazil: A Contribution to the Debate, Vol. 1 (of 3), World Bank, Washington, DC, http://documents.worldbank.org/curated/en/2008/03/10155469/ environmental-licensing-hydroelectric-projects-brazil-contribution-debatevol-1-3-summary-report.

Birdsall, N., W. Savedoff and F. Seymour (2014), The Brazil-Norway Agreement for Performance-Based Payments for Forest Conservation: Successes, Challenges, Lessons, CGD Climate and Forest Paper Series No. 4, Center for Global Development, Washington, DC, www.cgdev.org/publication/ft/brazil-norwayagreement-performancebased-payments-forest-conservation-successes.

Börner, J. et al. (2013), Promoting Forest Stewardship in the Bolsa Floresta Programme: Local Livelihood Strategies and Preliminary Impacts, Center for International Forestry Research, Rio de Janeiro, Fundação Amazonas Sustentável, Manaus, Zentrum für Entwicklungsforschung, Bonn, http://fas-amazonas.org/versao/2012/ wordpress/wp-content/uploads/2014/02/BF_report_ENG_web.pdf.

Brito B. and P. Barreto (2009), "Os riscos e os princípios para a regularização fundiária na Amazônia”, Imazon Belém, http://imazon.org.br_PDFimazon/Portugues/estado_da_amazonia/os-riscos-e-os-principiospara-a-regularizacao.pdf.

BV Rio (2014), Relatório de Atividades 2011-13, Bolsa Verde Rio de Janeiro, www.burio.org/site/images/publicacoes/ relatorio2013_ing_04.pdf. 
Cabrera, J. et al. (2014), Overview of National and Regional Measures on Access and Benefit Sharing. Challenges and Opportunities in Implementing the Nagoya Protocol, Centre for International Sustainable Development Law, Montreal, www.cisdl.org/aichilex/files/Global\%200verview\%20of\%20ABS\%20Measures_FINAL_SBSTTA18.pdf.

Castro de La Mata, G. and S. Riega-Campos (2014), An Analysis of International Funding in the Amazon, Moore Foundation, Ecosystems Services, www.vale.com/brasil/PT/aboutvale/news/Documents/AmazonConservation-Funding-Analysis-Publication-2014.pdf.

CDB (n.d.), "Brasil - Relatório Nacional”, Convenção sobre Diversidade Biológica das Nações Unidas, ww.cbd. int/countries/profile/default.shtml?country=br - facts (accessed May 2015).

CEPAL, GIZ e IPEA (2011), Avaliação do Plano de Prevenção e Controle do Desmatamento na Amazônia Legal: PPCDAm: 2007-2010, A Comissão Econômica para a América Latina e o Caribe das Nações Unidas, Brasília, IPEA, Brasília, e Deutche Gesellschaft fur International Zusammenarbeit (GIZ) GMbH, Bonn, www. cepal.org/ dmaah/publicaciones/sinsigla/xml/7/45887/IPEA_GIZ_Cepal_2011_Avaliacao_PPCDAm_2007-2011_web.pdf.

CGU (2014), “Relatório de Acompanhamento n 07/2014 Programa Bolsa Verde”, Brasília.

Conservation International (2015), "Hotspots", www.conservation.org/How/Pages/Hotspots.aspx.

FAO (2013), "Fishery and Aquaculture Country Profiles: Brazil", Roma, www.fao.org/fishery/facp/BRA/.

FAO (2015), Global Forest Resource Assessment, FAO, Roma.

FEBRABAN (2014), O Sistema Financeiro Brasileiro e a Economia Verde Alinhamento ao Desenvolvimento Sustentável, São Paulo.

Financial Times (2015), "Brazil farmers eye gains on eco exchange” by J. Leahy, Financial Times, London, www. ft.com/cms/s/0/60b19182-42ef-11e2-a3d2-00144feabdc0.html\#ixzz3aUikxlS2.

Friedrich, K. (2013), “Desafios para a avaliação toxicológica de agrotóxicos no Brasil: desregulação endócrina e imunotoxicidade”, Vigilância Sanitária em Debate, Vol. 1, No. 2, pp. 2-15, http://dx.doi.org/10.3395/vd.v1i2.30.

FUNBIO (2014), O Futuro do Ambiente Financeiro das Áreas Protegidas, Rio de Janeiro, www.funbio.org. br/o-funbio/tendencias-o-futuro-do-ambientefinanceiro-das-areas-protegidas.

Fundo Amazônia (2015), "Relatório Anual de Atividades, março 15”, Brasília, www.amazonfund.gov.br/ FundoAmazonia/export/sites/default/site_en/Galerias/Arquivos/Informes/2015_03_informe_31mar15_engl.pdf.

GEF (2012), GEF Country Portfolio Evaluation. Brazil (1991-2011), Fundo Global para o Meio Ambiente, Washington, DC, www.thegef. org/gef/sites/thegef.org/files/documents/CPE-Brazil-v1.pdf.

Gibbs, H. et al. (2015), "Brazil’s Soy Moratorium. Supply-chain governance is needed to avoid deforestation”, Science, 23 de janeiro de 2015, Vol. 347, Edição 6220, www.sciencemag.org/content/347/6220/377.full.pdf.

Guedes, F. and S. Seehusen (2011), Pagamento por Serviços Ambientais na Mata Atlântica. Lições Aprendidas e Desafios, MMA, Brasília, www.mma.gov.br/estruturas/202/_arquivos/psa_na_mata_atlantico_licoes_ apredidas_e_desafios_202.pdf.

IBAMA (2015), "Projeto de Monitoramento do Desmatamento dos Biomas Brasileiros por Satélite - PMDBBS", Brasília, http://siscom.ibama.gov.br/monitorabiomas/index.htm.

IBGE (2013), Indicadores de Desenvolvimento Sustentável (banco de dados), Rio de Janeiro.

ICMBio (2015), “Espécies Ameaçadas - Lista 2014”, www.icmbio.gov.br/portal/biodiversidade/fauna-brasileira/ listade-especies.html.

IEA (2013), World Energy Outlook 2013, Agência Internacional de Energia, IEA/OECD Publishing, Paris, http:// dx.doi.org/10.1787/weo-2013-en.

IEEP, Ecologic and GHK (2012), "Study to analyse legal and economic aspects of implementing the Nagoya Protocol on ABS in the European Union", relatório final para a Comissão Europeia, DG Environment, Institute for European Environmental Policy, Bruxelas e Londres, abril de 2012, http://ec.europa.eu/environment/nature/ biodiversity/international/abs/pdf/ABS\%20FINAL\%20REPORT.pdf. 
INPA (2015), INPA website, http://portal.inpa.gou.br/.

INPE (2015), "Projeto PRODES: Monitoramento da floresta Amazônia Brasileira por satélite”, www.obt.inpe. br/prodes/index.php.

Instituto Life (2014), Curitiba, www.institutolife.org/.

Jardim, A. and E. Caldas (2012), "Brazilian monitoring programs for pesticide residues in food - Results from 2001 to 2010", Food Control, Vol. 25, Issue 2, pp. 607-616, http://dx.doi.org/10.1016/j.foodcont.2011.11.001.

Leitão, S. (2014), "Isso é só o começo: sobre o Código Florestal”, em P. Little, Os novos desafios da política ambiental brasileira, IEB, Brasília.

MDA (2014), “Programa Terra Legal” Brasília, www.mda.gou.br/sitemda/secretaria/serfal/apresenta\%C3\%A7\%C3\%A30

MMA (2014), “Biomas” [Biomes], MMA, Brasília, www.mma.gou.br/biomas.

MMA (2010), Quarto Relatório Nacional para a Convenção sobre Diversidade Biológica, MMA, Brasília.

MMA (2015), Quinto Relatório Nacional para a Convenção sobre Diversidade Biológica, MMA, Brasília, www. cbd.int/doc/world/br/br-nr-05-en.pdf.

Nogueron R. and L. Cheung (2013), Leveling the Playing Field for Legal Timber in Brazil, World Resource Institute, Washington, DC, www.wri.org/blog/2013/09/leveling-playing-field-legal-timber-brazil.

Norman, M. et al. (2014), “Climate Finance Thematic Briefing: REDD+ Finance”, Climate Finance Fundamentals 5 de dezembro de 2014, Overseas Development Institute, London e Heinrich Böll Stiftung North America, Washington, DC, www.odi.org/sites/odi.org.uk/files/odi-assets/publications-opinion-files/9330.pdf.

Os novos desafios da política ambiental brasileira, IEB, Brasília.

OECD (2012), A Framework for Financing Water Resources Management, OECD Studies on Water, OECD Publishing, Paris, http://dx.doi.org/10.1787/9789264179820-en.

OECD (2013), Scaling-up Finance Mechanisms for Biodiversity, OECD Publishing, Paris, http://dx.doi. org/10.1787/9789264193833-en.

OECD (2015), Water Resources Governance in Brazil, OECD Studies on Water, OECD Publishing, Paris, http:// dx.doi.org/10.1787/9789264238121-en.

OECD-CEPAL (2014), OECD Environmental Performance Reviews: Colombia 2014, OECD Publishing, Paris, http:// dx.doi.org/10.1787/9789264208292-en.

OECD-FAO (2015), "Brazilian agriculture: Prospects and challenges", in OECD/FAO, OECD-FAO Agricultural Outlook 2015, OECD Publishing, Paris, http://dx.doi.org/10.1787/agr_outlook-2015-5-en.

Pinto, L.P. et al. (2012), "Mata Atlântica” em Scarano, F. et al. (eds), Biomas do Brasil: retratos de um país plural, Casa da Palavra, Rio de Janeiro.

Pires, M.O. (2014), “A política de combate ao desmatamento na Amazônia e no Cerrado”, em P. Little, Os novos desafios da política ambiental brasileira IEB, Brasília.

Prates, A. (2014), “Gestão da biodiversidade costeira e marinha: desafios da era do pré-sal”, em P. Little,

Roma, J. et al. (2013), A Economia dos Ecossistemas e da Biodiversidade (TEEB - Brasil): Análise de Lacunas: IPEA, Brasília, www.ipea.gov.br/portal/images/stories/PDFs/TDs/td_1912.pdf.

Santos, P. et al. (2012), Marco regulatório sobre pagamento por serviços ambientais no Brasil, IMAZON, GVces, Belém.

Senado Federal (2015), “Portal Orçamento”, www12.senado.gou.br/orcamento/.

Seroa da Motta, R. et al. (2011), Climate change in Brazil: Economic, social and regulatory aspects, IPEA, Brasília, www.ipea.gou.br/agencia/images/stories/PDFs/livros/liuros/liuro_climatechange.pdf.

SFB (2014), “Os Biomas e Suas Florestas”, Brasília, www.florestal.gov.br/snif/recursos-florestais/os-biomas-esuas-florestas. 
SFB (2013), Brazilian Forests at a Glance, Brazilian Forest Service, Brasília, www.forestcarbonpartnership.org/ sites/fcp/files/2015/March/Brazilian_Forests_at_a_glance_2013\%20(1).pdf.

SFB (2015a), “Cadastro Ambiental Rural: Boletim Informativo”, 30 de abril de 2015, Brasília, www.florestal. gou.br/noticiasdo-sfb/balanco-do-cadastro-ambiental-rural-car.

SFB (2015b), "Fundo Nacional do Desenvolvimento Florestal”, SBF, Brasília www.florestal.gou.br/extensaoe-fomento-florestal/fundo-nacional-dodesenvolvimento-florestal/fundo-nacional-de-desenvolvimento-florestal.

SMA (2013), Plano de Ação do Estado de São Paulo. Metas Aichi 2020. Implementação no Estado de São Paulo, Governo do Estado de São Paulo, Secretaria de Meio Ambiente, www.ambiente.sp.gou.br/en/ files/2015/04/Aichi_impressao_21_2_14_pdf_ENG_V.pdf.

Soares-Filho, B. et al. (2014b), “Cracking Brazil’s Forest Code”, Science 25 April, Vol. 344 no. 6182 pp. 363-364, http://dx.doi.org/ 10.1126/science.1246663.

Soares-Filho, B. et al. (2014a), Supplementary material for "Cracking Brazil's Forest Code", Science 25 de abril, Vol. 344 no. 6182, http://dx.doi.org/ 10.1126/science.1246663.

Viana (2015), "Leveraging public programmes with socio-economic and development objectives to support conservation and restoration of ecosystems: the price-support policy for socio-biodiversity derived products and the Green Grant Programme of Brazil", IPEA, Brasília, www.cbd.int/ecorestoration/doc/Brazilcase-study-Final-Version-20150114.pdf.

WWF (2015), The Brazilian Amazon: challenges facing an effective policy to curb deforestation, WWF-Brasil, Brasília, http://wwf.panda.org/?240971/Brazilian-Amazon-challenges-to-an-effective-policyto-curb-deforestation. 


\section{Metas nacionais de biodiversidade 2011-2020}

\begin{abstract}
Meta Nacional de Biodiversidade preocupações com biodiversidade permeiem governo e sociedade

Meta Nacional 1: Até 2020, no mais tardar, a população brasileira terá conhecimento dos valores da biodiversidade e das medidas que poderá tornar para conservá-la e utilizá-la de forma sustentável.

Meta Nacional 2: Até 2020, no mais tardar, os valores da biodiversidade, geodiversidade e sociodiversidade serão integrados em estratégias nacionais e locais de desenvolvimento e erradicação da pobreza e redução da desigualdade, sendo incorporado em contas nacionais, conforme o caso, e em procedimentos de planejamento e sistemas de relatoria.

Meta Nacional 3: Até 2020, no mais tardar, incentivos que possam afetar à biodiversidade, inclusive os chamados subsídios perversos, terão sido reduzidos ou reformados, visando minimizar os impactos negativos. Incentivos positivos para a conservação e uso sustentável de biodiversidade terão sido elaborados e aplicados, de forma consistente e em conformidade com a CDB, levando em conta as condições socioeconômicas nacionais e regionais.
\end{abstract}

Objetivo estratégico A - Tratar das causas fundamentais de perda de biodiversidade fazendo com que

Meta Nacional 4: Até 2020, no mais tardar, governos, setor privado e grupos de interesse em todos os níveis terão adotado medidas ou implementado planos de produção e consumo sustentáveis para mitigar ou evitar os impactos negativos da utilização de recursos naturais.
No caminho certo, mas medidas adicionais são necessárias.

No caminho certo, mas medidas adicionais são necessárias.

No caminho certo, mas medidas adicionais são necessárias.

No caminho certo, mas medidas adicionais são necessárias.

Objetivo estratégico B - Reduzir as pressões diretas sobre a biodiversidade e promover 0 uso sustentável

Meta Nacional 5: Até 2020 a taxa de perda de ambientes nativos será reduzida em pelo menos 50\% (em relação às taxas de 2009) e, na medida do possível, levada a perto de zero e a degradação e fragmentação terão sido reduzidas significativamente em todos os biomas.

Meta Nacional 6: Até 2020, o manejo e captura de quaisquer estoques de organismos aquáticos serão sustentáveis, legais e feitos com aplicação de abordagens ecossistêmicas, de modo a evitar a sobre exploração, colocar em prática planos e medidas de recuperação para espécies exauridas, fazer com que a pesca não tenha impactos adversos significativos sobre espécies ameaçadas e ecossistemas vulneráveis, e fazer com que os impactos da pesca sobre estoques, espécies e ecossistemas permaneçam dentro de limites ecológicos seguros, quando estabelecidos cientificamente.

Meta Nacional 7: Até 2020, estarão disseminadas e fomentadas a incorporação de práticas de manejo sustentáveis na agricultura, pecuária, aquicultura, silvicultura, extrativismo, manejo florestal e da fauna, assegurando a conservação da biodiversidade.

Meta Nacional 8: Até 2020, a poluição, inclusive resultante de excesso de nutrientes, terá sido reduzida a níveis não prejudiciais ao funcionamento de ecossistemas e da biodiversidade.

Meta Nacional 9: Até 2020, a Estratégia Nacional sobre Espécies Exóticas Invasoras deverá estar totalmente implementada, com participação e comprometimento dos estados e com a formulação de urna Política Nacional, garantindo o diagnóstico continuado e atualizado das espécies e a efetividade dos Planos de Ação de Prevenção, Contenção, Controle.

Meta Nacional 10: Até 2015, as múltiplas pressões antropogênicas sobre recifes de coral e demais ecossistemas marinhos e costeiros impactados por mudanças de clima ou acidificação oceânica terão sido minimizadas para que sua integridade e funcionamento sejam mantidos.
A meta pode ser superada na Amazônia, mas são necessárias medidas adicionais em outros biomas.

No caminho certo, mas medidas adicionais são necessárias, especialmente para a recuperação de espécies superexploradas e limitação do impacto da pesca sobre os estoques, espécies e ecossistemas.

No caminho certo para atingir a meta na silvicultura, mas medidas adicionais são necessárias em outros setores.

No caminho certo, mas medidas adicionais são necessárias.

No caminho certo, mas medidas adicionais são necessárias.

No caminho certo, mas medidas adicionais são necessárias.

\section{Objetivo estratégico C: Melhorar a situação da biodiversidade protegendo ecossistemas, espécies ediversidade genética}

Meta Nacional 11: Até 2020, serão conservadas, por meio de unidades de conservação previstas na Lei do SNUC e outras categorias de áreas oficialmente protegidas, como APPs, reservas legais e terras indígenas com vegetação nativa, pelo menos $30 \%$ da Amazônia, $17 \%$ de cada um dos demais biomas terrestres e 10\% de áreas marinhas e costeiras, principalmente áreas de especial importância para biodiversidade e serviços ecossistêmicos, assegurada e respeitada a demarcação, regularização e a gestão efetiva e equitativa, visando garantir a interligação, integração e representação ecológica em paisagens terrestres e marinhas mais amplas.

Meta Nacional 12: Até 2020, o risco de extinção de espécies ameaçadas terá sido reduzido significativamente, tendendo a zero, e sua situação de conservação, em especial daquelas sofrendo maior declínio, terá sido melhorada.

Meta Nacional 13: Até 2020, a diversidade genética de microrganismos, plantas cultivadas, e animais criados e domesticados e de variedades silvestres, inclusive de espécies de valor socioeconômico e/ou cultural, terá sido mantida e estratégias terão sido elaboradas e implementadas para minimizar a perda de variabilidade No caminho para atingir a meta na Amazônia, mas medidas adicionais são necessárias em outros biomas (ver também Capítulo 5). genética. 


\begin{tabular}{|c|c|}
\hline Meta Nacional de Biodiversidade & Avaliação em médio-prazo \\
\hline $\begin{array}{l}\text { Meta Nacional 14: Até } 2020 \text {, ecossistemas provedores de serviços essenciais, inclusive serviços relativos à } \\
\text { água e que contribuem à saúde, meios de vida e bem-estar, terão sido restaurados e preservados, levando } \\
\text { em conta as necessidades das mulheres, povos e comunidades tradicionais, povos indígenas e comunidades } \\
\text { locais, e de pobres e vulneráveis. }\end{array}$ & $\begin{array}{l}\text { No caminho certo, mas medidas adicionais são } \\
\text { necessárias. }\end{array}$ \\
\hline $\begin{array}{l}\text { Meta Nacional 15: Até } 2020 \text {, a resiliência de ecossistemas e a contribuição da biodiversidade para estoques } \\
\text { de carbono terão sido aumentadas através de ações de conservação e recuperação, inclusive por meio da } \\
\text { recuperação de pelo menos } 15 \% \text { dos ecossistemas degradados, priorizando biomas, bacias hidrográficas } \\
\text { e ecorregiões mais devastados, contribuindo para mitigação e adaptação à mudança climática e para } 0 \\
\text { combate à desertificação }\end{array}$ & $\begin{array}{l}\text { No caminho para atingir a meta na Amazônia, mas } \\
\text { medidas adicionais são necessárias em outros } \\
\text { biomas. }\end{array}$ \\
\hline $\begin{array}{l}\text { Meta Nacional 16: Até } 2015, \text { o Protocolo de Nagoya sobre Acesso a Recursos Genéticos e a Repartição Justa } \\
\text { e Equitativa dos Benefícios Derivados de sua Utilização terá entrado em vigor e estará operacionalizado, em } \\
\text { conformidade com a legislação nacional. }\end{array}$ & $\begin{array}{l}\text { No caminho certo, mas medidas adicionais são } \\
\text { necessárias. }\end{array}$ \\
\hline \multicolumn{2}{|c|}{ Objetivo estratégico E: Aumentar a implementação por meio de planejamento participativo, gestão de conhecimento e capacitação } \\
\hline $\begin{array}{l}\text { Meta Nacional 17: Até 2014, a estratégia nacional de biodiversidade será atualizada e adotada como } \\
\text { instrumento de política, com planos de ação efetivos, participativos e atualizados, que deverá prever } \\
\text { monitoramento e avaliações periódicas. }\end{array}$ & $\begin{array}{l}\text { No caminho certo, mas medidas adicionais são } \\
\text { necessárias. }\end{array}$ \\
\hline $\begin{array}{l}\text { Meta Nacional 18: Até 2020, os conhecimentos tradicionais, inovações e práticas de Povos Indígenas, } \\
\text { agricultores familiares e Comunidades Tradicionais relevantes à conservação e uso sustentável da } \\
\text { biodiversidade, e a utilização consuetudinária de recursos biológicos terão sido respeitados, de acordo com } \\
\text { seus usos, costumes e tradições, a legislação nacional e os compromissos internacionais relevantes, e } \\
\text { plenamente integrados e refletidos na implementação da CDB com a participação plena e efetiva de Povos } \\
\text { Indígenas, agricultores familiares e Comunidades tradicionais em todos os níveis relevantes }\end{array}$ & $\begin{array}{l}\text { No caminho certo, mas medidas adicionais são } \\
\text { necessárias. }\end{array}$ \\
\hline $\begin{array}{l}\text { Meta Nacional 19: Até 2020, as bases científicas e as tecnologias necessárias para o conhecimento sobre a } \\
\text { biodiversidade, seus valores, funcionamento e tendências e sobre as consequências de sua perda terão sido } \\
\text { ampliados e compartilhados, e o uso sustentável, a geração de tecnologia e inovação a partir da biodiversidade } \\
\text { estarão apoiados, devidamente transferidos e aplicados. Até } 2017 \text {, a compilação completa dos registros já } \\
\text { existentes da fauna, flora e microbiota, aquáticas e terrestres, estarão finalizadas e disponibilizadas em bases } \\
\text { de dados permanentes e de livre acesso, resguardadas as especificidades, com vistas à identificação das } \\
\text { lacunas de conhecimento nos biomas e grupos taxonômicos. }\end{array}$ & $\begin{array}{l}\text { De maneira geral, no caminho certo, mas medidas } \\
\text { adicionais são necessárias para o apoio e aplicação } \\
\text { do uso sustentável da biodiversidade e da tecnologia } \\
\text { baseada na biodiversidade e inovação. }\end{array}$ \\
\hline $\begin{array}{l}\text { Meta Nacional 20: Imediatamente após a aprovação das metas brasileiras, serão realizadas avaliações } \\
\text { da necessidade de recursos para sua implementação, seguidas de mobilização e alocação dos recursos } \\
\text { financeiros para viabilizar, a partir de } 2015 \text {, a implementação, o monitoramento do Plano Estratégico de } \\
\text { Biodiversidade } 2011-2020 \text {, bem como o cumprimento de suas metas. }\end{array}$ & $\begin{array}{l}\text { No caminho certo, mas medidas adicionais são } \\
\text { necessárias. }\end{array}$ \\
\hline
\end{tabular}

Fonte: MMA (2015), Quinto Relatório Nacional para a Convenção sobre a Biodiversidadeaaaaaaa 


\section{PARTE II}

\section{Capítulo 5}

\section{Áreas protegidas}

Houve grande incremento da rede de áreas protegidas do Brasil. O presente capítulo examina os avanços alcançados na ampliação das áreas terrestres e marinhas sob proteção ambiental. Examina conquistas e desafios relacionados à gestão de áreas protegidas, inclusive em termos de sustentabilidade financeira. Descreve ainda o papel das áreas protegidas na qualidade de vida e bem-estar de comunidades tradicionais. Finalmente, discute oportunidades para o manejo florestal sustentável e a conveniência da abertura de acesso público às áreas protegidas para turismo, lazer e educação ambiental. 


\section{Categorias, extensão e benefícios das áreas protegidas}

\subsection{Sistema Nacional de Áreas Protegidas}

No Brasil, áreas protegidas têm uma longa história e são a pedra angular da política de biodiversidade. Em 2000, para melhorar a eficácia dessas áreas e preservar florestas tropicais, foi criado o Sistema Nacional de Unidades de Conservação (SNUC). ${ }^{1}$ O SNUC incorporou em um único sistema nacional a paisagem heterogênea composta por unidades de conservação criadas pelos governos federal, estaduais e municipais, bem como aquelas propostas por atores privados (pessoas físicas, empresas, organizações não governamentais) proporcionando definições comuns de áreas protegidas e criando um marco para a coordenação da gestão e implementação entre diferentes níveis de governo. Também introduziu, em 2006, o Cadastro Nacional de Unidades de Conservação (CNUC) para a consolidação de informações sobre áreas protegidas em todos os níveis de governo.

O SNUC definiu 12 categorias de gestão (consolidando categorias já existentes e criando algumas novas) em dois grandes grupos: i) áreas de proteção integral, cujo objetivo primordial é conservar a biodiversidade, sendo proibido o uso direto ou o consumo de recursos naturais; e ii) áreas de uso sustentável, visando principalmente a conservação, mas permitindo assentamentos humanos e o aproveitamento dos recursos naturais, de acordo com um plano de gestão sustentável. A Tabela 5.1 proporciona uma visão geral dos objetivos e atividades permitidas para cada categoria. Por vários motivos, cerca de dois terços da área sob proteção encontram-se em categorias de uso sustentável (Figura 5.1). O uso sustentável goza de maior aceitação política e social, por impor menos restrições ao uso da terra e ao aproveitamento de recursos; por respeitar os direitos de comunidades tradicionais e contar com apoio de movimentos da sociedade civil; e por estar alinhado com o objetivo do governo de estimular a exploração madeireira sustentável em florestas nacionais (Veríssimo et al., 2011). As reservas extrativistas brasileiras têm servido de exemplo na definição da classificação internacional de áreas protegidas (Tabela 5.1).

Resultado de 12 anos de debate parlamentar, a Lei no 9985/ 2000, que instituiu o SNUC, estabeleceu o marco jurídico para a gestão de áreas protegidas e lançou as bases para o notável incremento do número e cobertura das áreas protegidas. ${ }^{2}$

\subsection{Extensão e cobertura das unidades de conservação}

Na última década, o Brasil se tornou um dos mais importantes contribuintes mundiais para o aumento de áreas sob proteção ambiental, conforme previsto no Plano Estratégico 2002-2010 da Convenção da Diversidade Biológica das Nações Unidas (CDB). Respondeu por mais de $70 \%$ da criação de novas áreas de terras sob proteção ambiental (Jenkins e Joppa, 2009) entre 2003 e 2008, período que coincide com as primeiras etapas da implementação do Plano de Ação para Prevenção e Controle do Desmatamento na Amazônia Legal (PPCDAm) (Capítulo 4) e do programa de Áreas Protegidas da Amazônia (ARPA) (Box 5.1). 
Tabela 5.1. Categorias de unidades de conservação do SNUC

\begin{tabular}{|c|c|c|c|c|c|}
\hline $\begin{array}{l}\text { Categoria gestão } \\
\text { brasileira }\end{array}$ & $\begin{array}{l}\text { Propriedade } \\
\text { da terra }\end{array}$ & Meta principal & Principais características & $\begin{array}{l}\text { Categoria de gestão } \\
\text { internacional }\end{array}$ & Área $\left(\mathrm{km}^{2}\right)$ \\
\hline \multicolumn{6}{|c|}{ Áreas de proteção integral } \\
\hline Estação ecológica & Pública & $\begin{array}{l}\text { Preservação da natureza e pesquisa } \\
\text { científica }\end{array}$ & 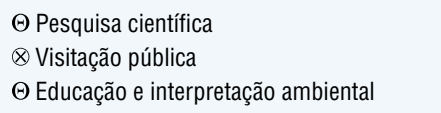 & la - Área de proteção integral & $\begin{array}{l}\text { Federal: } 74.691 \\
\text { Estadual: } 47.513 \\
\text { Municipal: } 9\end{array}$ \\
\hline Reserva biológica & Pública & $\begin{array}{l}\text { Preservação integral da biota e de outros } \\
\text { recursos naturais }\end{array}$ & 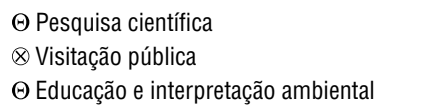 & la - Área de proteção integral & $\begin{array}{l}\text { Federal: } 39.034 \\
\text { Estadual: } 13.449 \\
\text { Municipal: } 48\end{array}$ \\
\hline $\begin{array}{l}\text { Parque nacional/ } \\
\text { estadual/municipal }\end{array}$ & Pública & $\begin{array}{l}\text { Preservação de sítios naturais de } \\
\text { relevância ecológica ou de beleza cênica }\end{array}$ & 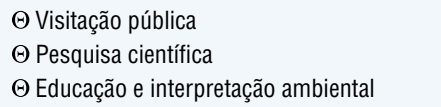 & II - Parque nacional & $\begin{array}{l}\text { Federal: } 252.978 \\
\text { Estadual: } 94.889 \\
\text { Municipal: } 221\end{array}$ \\
\hline Monumento natural & $\begin{array}{l}\text { Pública ou } \\
\text { privada }\end{array}$ & $\begin{array}{l}\text { Preservação de sítios naturais raros, ou } \\
\text { de grande beleza cênica }\end{array}$ & 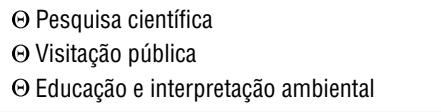 & $\begin{array}{l}\text { III - Monumento natural ou } \\
\text { característico }\end{array}$ & $\begin{array}{l}\text { Federal: } 443 \\
\text { Estadual: } 892 \\
\text { Municipal: } 73\end{array}$ \\
\hline $\begin{array}{l}\text { Refúgio nacional da } \\
\text { vida silvestre }\end{array}$ & $\begin{array}{l}\text { Pública ou } \\
\text { privada }\end{array}$ & $\begin{array}{l}\text { Proteção de ambientes naturais para } \\
\text { garantir condições de existência ou } \\
\text { reprodução de flora e fauna local }\end{array}$ & 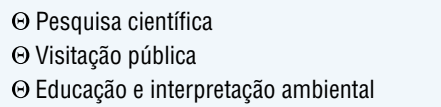 & $\begin{array}{l}\text { III - Monumento natural ou } \\
\text { característico }\end{array}$ & $\begin{array}{l}\text { Federal: } 2.017 \\
\text { Estadual: } 1.729 \\
\text { Municipal: } 22\end{array}$ \\
\hline \multicolumn{6}{|c|}{ Áreas de uso sustentável } \\
\hline $\begin{array}{l}\text { Área de proteção } \\
\text { ambiental }\end{array}$ & $\begin{array}{l}\text { Pública ou } \\
\text { privada }\end{array}$ & $\begin{array}{l}\text { Proteção de áreas importantes para a } \\
\text { qualidade de vida e o bem-estar humano, } \\
\text { pela proteção da biodiversidade }\end{array}$ & $\begin{array}{l}\text { (Vastas áreas; sem zona de amortecimento) } \\
\checkmark \text { Visitação pública } \\
\checkmark \text { Pesquisa científica }\end{array}$ & $\begin{array}{l}V \text { - Paisagem terrestre/marinha } \\
\text { protegida }\end{array}$ & $\begin{array}{l}\text { Federal: } 100.101 \\
\text { Estadual: } 334.898 \\
\text { Municipal: } 25.922\end{array}$ \\
\hline $\begin{array}{l}\text { Área de relevante } \\
\text { interesse ecológico }\end{array}$ & $\begin{array}{l}\text { Pública ou } \\
\text { privada }\end{array}$ & $\begin{array}{l}\text { Manutenção de ecossistemas naturais de } \\
\text { importância local ou regional }\end{array}$ & $\begin{array}{l}\text { (Pequenas áreas) } \\
\checkmark \text { Visitação pública } \\
\checkmark \text { Pesquisa científica }\end{array}$ & $\begin{array}{l}\text { Principalmente } \\
\text { considerada como } \\
\text { IV - Área de Gestão de } \\
\text { Habitats/Espécies }\end{array}$ & $\begin{array}{l}\text { Federal: } 447 \\
\text { Estadual: } 443 \\
\text { Municipal: } 32\end{array}$ \\
\hline $\begin{array}{l}\text { Florestas nacional/ } \\
\text { estadual/municipal }\end{array}$ & $\begin{array}{l}\text { Pública ou } \\
\text { privada }\end{array}$ & $\begin{array}{l}\text { Múltiplo uso dos recursos florestais e } \\
\text { pesquisas científicas, com ênfase em } \\
\text { métodos de uso sustentável das florestas } \\
\text { nativas }\end{array}$ & $\begin{array}{l}\checkmark \text { Permanência das comunidades } \\
\text { tradicionais que lá viviam quando da criação } \\
\text { da área protegida } \\
\checkmark \text { Visitação pública } \\
\checkmark \text { Pesquisa científica }\end{array}$ & $\begin{array}{l}\mathrm{VI} \text { - Áreas protegidas de } \\
\text { uso sustentável de recursos } \\
\text { naturais (permanência } \\
\text { de comunidades locais / } \\
\text { tradicionais no caso brasileiro) }\end{array}$ & $\begin{array}{l}\text { Federal: } 163.913 \\
\text { Estadual: } 136.053 \\
\text { Municipal: } 0\end{array}$ \\
\hline Reserva extrativista & Pública & $\begin{array}{l}\text { Proteção de áreas habitadas por } \\
\text { populações tradicionais que vivem } \\
\text { da extração de recursos naturais, } \\
\text { assegurando o uso sustentável da área } \\
\text { protegida }\end{array}$ & $\begin{array}{l}\checkmark \text { Extração de recursos naturais por } \\
\text { populações tradicionais vivendo no local } \\
\checkmark \text { Visitação pública } \\
\checkmark \text { Pesquisa científica } \\
\vee \text { Exploração de recursos minerais } \\
\vee \text { Caça (nenhuma, amador ou profissional) } \\
\Theta \text { Exploração comercial de madeira }\end{array}$ & $\begin{array}{l}\mathrm{VI} \text { - Áreas protegidas com } \\
\text { uso sustentável dos recursos } \\
\text { naturais (com cogestão } \\
\text { das comunidades locais / } \\
\text { tradicionais, no caso brasileiro) }\end{array}$ & $\begin{array}{l}\text { Federal: } 124.362 \\
\text { Estadual: } 20.208 \\
\text { Municipal: } 0\end{array}$ \\
\hline $\begin{array}{l}\text { Reserva de } \\
\text { desenvolvimento } \\
\text { sustentável }\end{array}$ & Pública & $\begin{array}{l}\text { Proteção de áreas habitadas por } \\
\text { populações tradicionais que praticam } \\
\text { a exploração e o uso sustentável dos } \\
\text { recursos }\end{array}$ & $\begin{array}{l}\checkmark \text { Visitação pública } \\
\checkmark \text { Pesquisa científica } \\
\checkmark \text { Exploração sustentável de recursos } \\
\text { naturais } \\
\checkmark \text { Substituição da vegetação por espécies } \\
\text { cultiváveis }\end{array}$ & $\begin{array}{l}\text { VI - Áreas protegidas com } \\
\text { uso sustentável dos recursos } \\
\text { naturais (com cogestão } \\
\text { das comunidades locais / } \\
\text { tradicionais, no caso brasileiro) }\end{array}$ & $\begin{array}{l}\text { Federal: } 1.026 \\
\text { Estadual: } 110.090 \\
\text { Municipal: } 176\end{array}$ \\
\hline $\begin{array}{l}\text { Refúgio de vida } \\
\text { silvestre }\end{array}$ & Pública & $\begin{array}{l}\text { Investigação técnica e científica sobre } \\
\text { a gestão econômica sustentável dos } \\
\text { recursos da vida silvestre }\end{array}$ & $\begin{array}{l}\Theta \text { Visitação pública } \\
\checkmark \text { Pesquisa científica } \\
\text { V Caça (nenhuma, amador ou profissional) }\end{array}$ & $\begin{array}{l}\text { IV - Área de gestão de } \\
\text { habitats/espécies }\end{array}$ & $\begin{array}{l}\text { Federal: } 0 \\
\text { Estadual: } 0 \\
\text { Municipal: } 0\end{array}$ \\
\hline $\begin{array}{l}\text { Reservas privadas } \\
\text { do patrimônio } \\
\text { natural }\end{array}$ & Privada & Conservação da biodiversidade & $\begin{array}{l}\text { (sem zona de amortecimento) } \\
\checkmark \text { Visitação pública } \\
\checkmark \text { Pesquisa científica }\end{array}$ & $\begin{array}{l}\text { IV - Área de gestão de } \\
\text { habitats/espécies }\end{array}$ & $\begin{array}{l}\text { Federal: } 4.832 \\
\text { Estadual: } 686 \\
\text { Municipal: } 0\end{array}$ \\
\hline
\end{tabular}

Notas: $\checkmark$ Atividades permitidas / estimuladas desde que compatíveis com o plano de gestão

$\boldsymbol{\Theta}$ Atividades permitidas com restriçõ̃es estabelecidas pelo plano de gestão ou em circunstâncias especiais

$\otimes$ Atividades proibidas. Visitação pública inclui turismo, lazer e educação ambiental.

Fonte: IUCN (2008), Guidelines for Applying Protected Area Management Categories; MMA (2015a), "Areas protegidas", www.mma.gov.br/areas-protegidas; MMA (2015), "Cadastro Nacional de Unidades de Conservação" (acessado: Fev 2015); WCMC-UNEP and IUCN (2015), "World Database on Protected Areas ", www.protectedplanet.net. 


\section{Figura 5.1. Categorias de proteção integral abrangem cerca de um terço das áreas protegidas \\ Unidades de conservação oficias, por categoria, 2015}

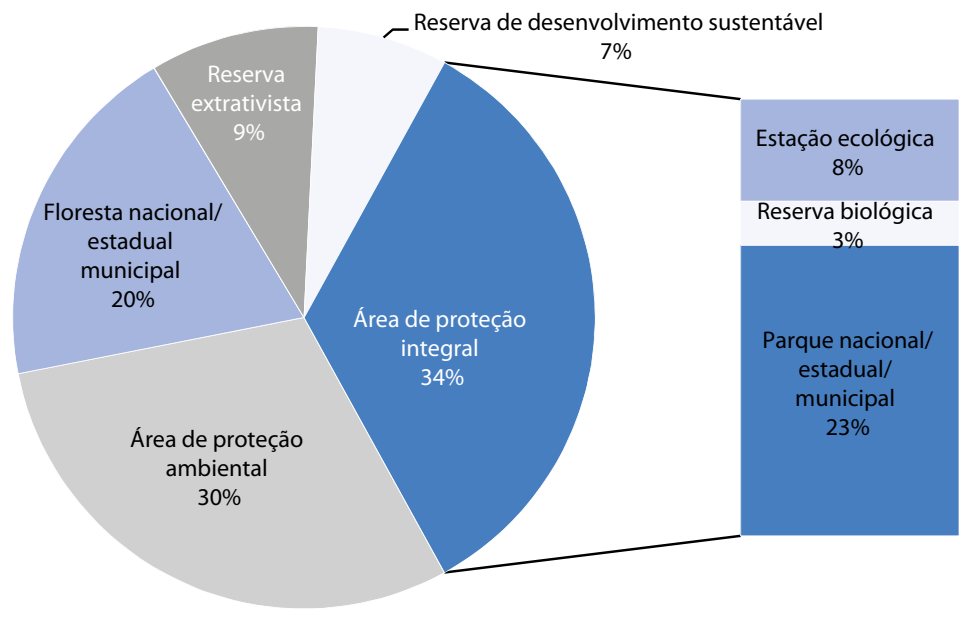

Obs.: Exclui monumentos naturais, refúgios de vida silvestre, áreas de relevante interesse ecológico, reservas de fauna e reservas particulares do patrimônio natural que, em conjunto, representam $0,7 \%$ do total das Unidades de Conservação oficias.

Fonte: MMA (2015), Cadastro Nacional de Unidades de Conservação.

Entre 2000 e 2014, o número e a extensão das unidades de conservação do SNUC mais do que duplicou. No início de 2015, 1.940 unidades de conservação englobavam uma área superior a 1,5 milhão de $\mathrm{km}^{2}$ (quase três vezes o tamanho da França), equivalente a $17,2 \%$ das áreas terrestres e de águas interiores, e a 1,5\% das zonas costeiras e marinhas incluindo a zona econômica exclusiva (Figura 5.2). Portanto, bem antes do previsto, o Brasil alcançou a meta Aichi para 2020 de proteger pelo menos 17\% das áreas terrestres e de águas interiores do país. ${ }^{3} \mathrm{~A}$ taxa de incremento de áreas sob proteção diminuiu desde 2010, embora o número de unidades de conservação continue crescendo, o que reflete a tendência mais recente de focalizar iniciativas de pequena escala, bem como a retirada parcial de algumas áreas do SNUC (descadastramento).

Figura 5.2. Área terrestre sob proteção ambiental mais do que duplicou Unidades de Conservação, por tipo, 2000-14

Unidades de Conservação por tipo e nível, 2014

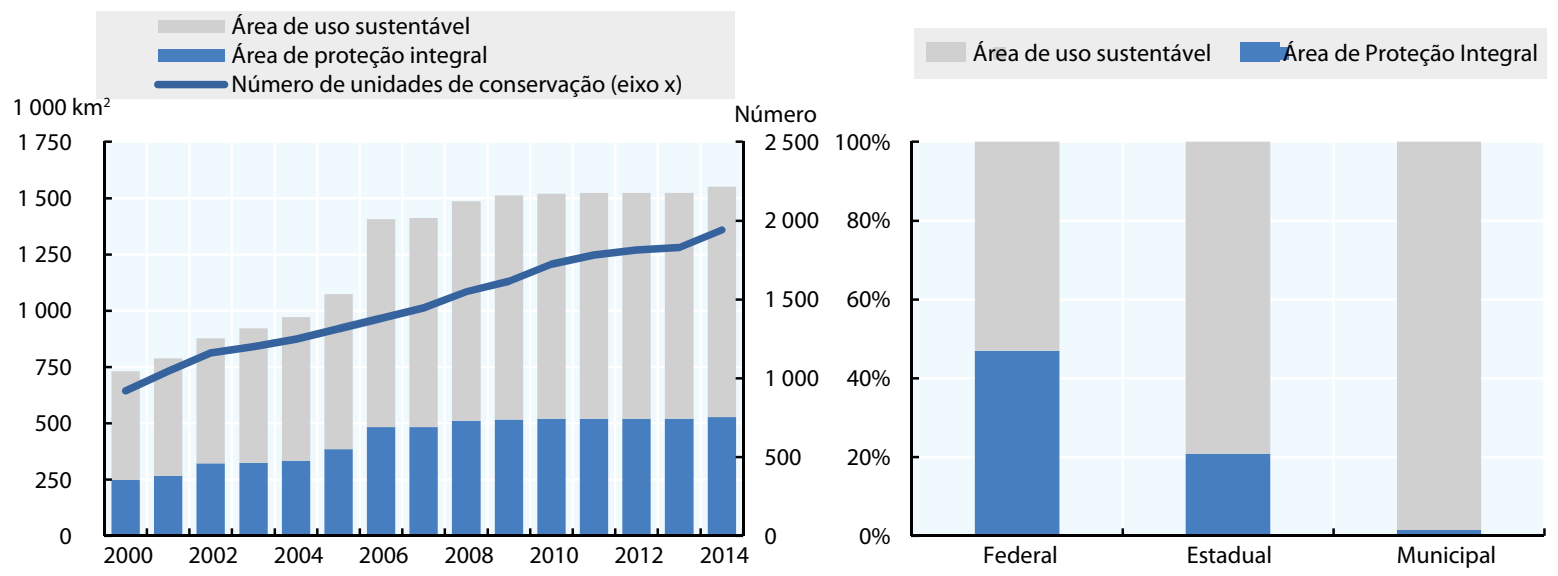

Fonte: MMA (2015), Cadastro Nacional de Unidades de Conservação. 


\section{Box 5.1. Programa de Áreas Protegidas da Amazônia}

O ARPA é um dos maiores programas de conservação de florestas tropicais do mundo. Foi criado com o objetivo de ampliar e fortalecer o SNUC na Amazônia, por meio da criação de unidades de conservação cobrindo uma área de $600 \mathrm{mil} \mathrm{km}^{2}$. O programa é orientado a resultados e tem quatro componentes principais: criação de novas unidades de conservação; consolidação e gestão; sustentabilidade financeira; e monitoramento, coordenação e gerenciamento. Sua coordenação é realizada pelo MMA e a gestão pelo Funbio (Box 5.7). Conta com recursos do Fundo Global para o Meio Ambiente (GEF), do Ministério Federal Alemão para Cooperação Econômica e Desenvolvimento por meio do Banco Alemão de Desenvolvimento (KfW), do WWF e do Fundo Amazônia (Capítulo 4).

O ARPA foi lançado em 2002 e concebido para ser implementado em três fases. A primeira (2003-2010) teve como objetivo estabelecer $180 \mathrm{mil} \mathrm{km²}$ de novas unidades de conservação na Amazônia e iniciar um processo de consolidação em 70 mil km². Até 2010, ambas as metas já haviam sido superadas. O programa investiu US\$ 83 milhões ao longo da primeira fase, metade dos quais para custos operacionais.

A segunda fase (2010-2015) visava a criação adicional de mais $135 \mathrm{mil} \mathrm{km²}$ e a consolidação de 320 mil km² de áreas sob proteção. Também visava angariar US\$ 70 milhões para o Fundo de Áreas Protegidas (FAP) criado na primeira fase. As despesas durante a segunda fase (excluindo os desembolsos do FAP) atingiram US\$115 milhões.

A terceira fase visa garantir a sustentabilidade financeira do programa no longo prazo. A Iniciativa ARPA para a Vida (ARPA for Life) foi lançada em maio de 2014 (paralelamente à implementação da segunda fase) para facilitar a transição - de um sistema baseado em doações - para um sistema financiado pelos orçamentos federal e estaduais e pela compensação ambiental (Seção 4.4) a . Durante 25 anos, a previsão é que as dotações orçamentárias do governo alocadas para o ARPA aumentem gradativamente, enquanto que vários parceiros contribuiriam com US\$ 250 milhões para um fundo de transição (Fundo ARPA for Life) ${ }^{\mathrm{b}}$.

a) O Funbio e o WWF estimaram o custo financeiro do programa ARPA ao longo do período 2011-2020 em mais de $\mathrm{R} \$ 800$ milhões, incluindo tanto o investimento quanto os custos operacionais. A receita para o mesmo período foi estimada em $\mathrm{R} \$ 530$ milhões, com um déficit financeiro de $\mathrm{R} \$ 270$ milhões (Funbio, 2012).

b) O Ministério para Cooperação e Desenvolvimento da Alemanha, o BID, o FUNBIO, a Fundação Gordon e Betty Moore, o WWF-Brasil, o WWF-EUA e o GEF.

Fonte: MMA (2015), Quinto Relatório Nacional para a Convenção sobre a Diversidade Biológica; Funbio (2012), Quanto custa o Programa Áreas Protegidas da Amazônia? Uma modelagem financeira para as Unidades de Conservação do Arpa.

As unidades de conservação federais e estaduais correspondem a 98\% da área total sob proteção. As Reservas Particulares do Patrimônio Natural correspondem a aproximadamente $40 \%$ das áreas protegidas, mas cobrem menos de $1 \%$ da área total do SNUC. As unidades de conservação municipais são, muitas vezes, localizadas em áreas urbanas, sendo, portanto, significativamente menores. No nível federal, existe um equilíbrio entre as unidades de proteção integral e as de uso sustentável; enquanto que, nas instâncias subnacionais, predominam áreas de uso sustentável (Figura 5.2). Para os municípios e muitos dos estados, áreas protegidas são consideradas, essencialmente, instrumentos de gestão territorial.

As unidades de conservação integrantes do SNUC são complementadas por outras que admitem diversas formas de uso ou manejo da terra que visam - ou contribuem para - a conservação ambiental. Estas incluem terras indígenas (referidas como áreas de proteção latu senso) e terras quilombolas (Box 5.2), bem como as Áreas de Preservação Permanente (APP) e as Reservas Legais (RL) que proprietários são obrigados a preservar conforme o Código Florestal de 2012 (Lei de Proteção da Vegetação Nativa). Estima-se que áreas de APP e de RL cobrem 12\% e 30\%, respectivamente, do território nacional 
(MMA, 2010), áreas essas que correspondem a mais que o dobro das áreas integrantes do SNUC. No entanto, em muitas terras privadas, as áreas de APP e de RL não são respeitadas (Capítulo 4). O Brasil abriga, também, vários sítios do Patrimônio Natural Mundial e 12 zonas úmidas de importância internacional no âmbito da Convenção de Ramsar, designadas como áreas protegidas, cobrindo mais de $65 \mathrm{mil} \mathrm{km}^{2}$. Até 2017, o governo espera obter a designação de mais 10 sítios Ramsar (MMA, 2015b).

A área terrestre do Brasil é tipificada por seis grandes ecossistemas ou biomas: ${ }^{4}$ Amazônia, Mata Atlântica, Caatinga, Cerrado, Pampa e Pantanal (Box 4.1). Áreas de uso sustentável predominam em todos os biomas, exceto no Pantanal (Figura 5.3). A área de cobertura das unidades de conservação varia muito entre os diferentes biomas brasileiros. Mais de três quartos das áreas integrantes do SNUC estão localizados no bioma Amazônia, correspondendo a quase $27 \%$ da região, incluindo seus vastos corpos d'agua (Figura 5.3 e Tabela 5.2), o que reflete o uso das áreas protegidas como instrumento fundamental da política de combate ao desmatamento na região. Nos outros biomas, a cobertura do SNUC é menor e mais fragmentada, variando entre $9 \%$ na Mata Atlântica e cerca de 3\% no Pampa (Tabela 5.2). Não obstante os avanços alcançados, o Brasil não cumpriu sua ambiciosa meta de proteger $10 \%$ da área terrestre de cada bioma, e 30\% da Amazônia, até 2010.

Figura 5.3. A maioria das unidades de conservação estão na Amazônia Unidades de conservação, por bioma, 2015 Unidades de conservação, por categoria, 2015
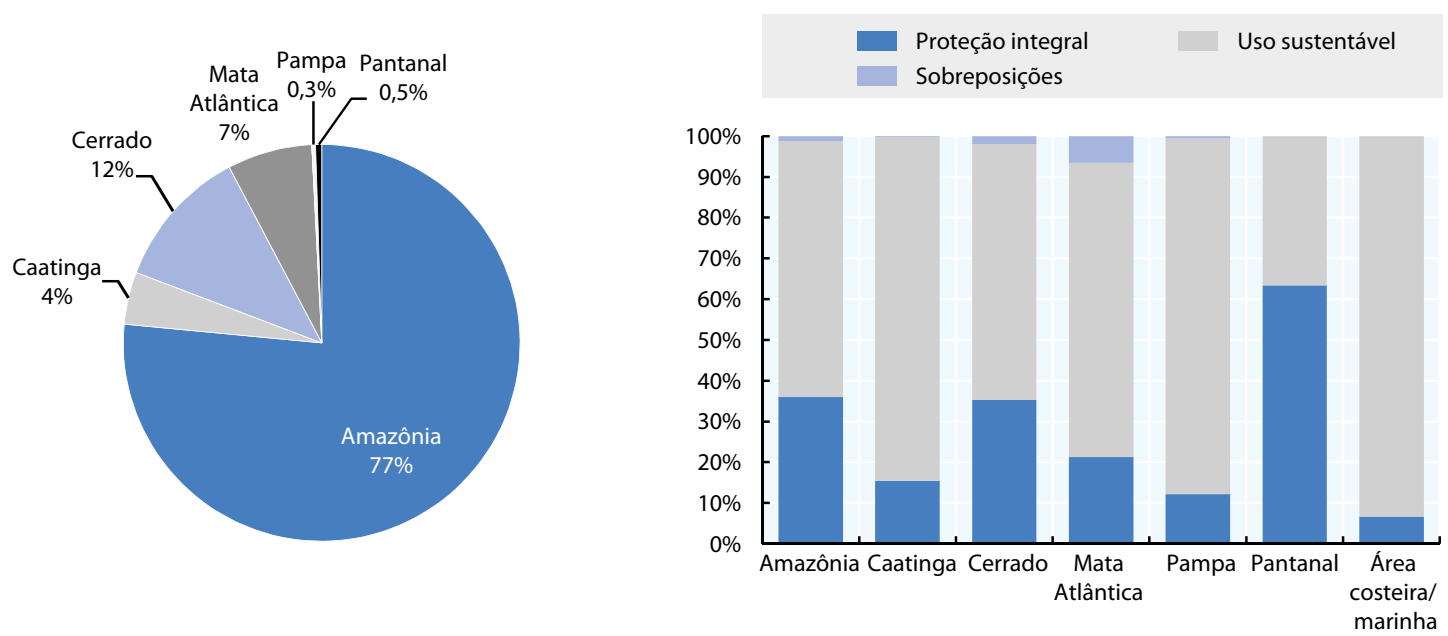

Fonte: MMA (2015), Cadastro Nacional de Unidades de Conservação (site).

Em 2013, o Brasil adotou como nova meta nacional a proteção de 30\% da Amazônia, $17 \%$ dos outros biomas terrestres, e $10 \%$ das zonas costeiras e marinhas. Ao mesmo tempo, ampliou a definição de áreas protegidas para além das previstas na Lei do SNUC para incluir também terras indígenas, APPs e RLs, de forma a melhor refletir as diversas ações de conservação em curso no país. ${ }^{5}$ Quando incluídas terras indígenas, metade da Amazônia está coberta por áreas sob proteção - proporção bem acima da meta (Tabela 5.2). 
Tabela 5.2. Áreas protegidas e terras indígenas, por bioma, 2015

\begin{tabular}{|c|c|c|c|c|c|c|c|c|}
\hline & \multicolumn{6}{|c|}{ \% da área total do bioma } & \multirow{2}{*}{$\begin{array}{l}\text { \% da área terrestre e } \\
\text { de águas interiores }\end{array}$} & \multirow{2}{*}{$\begin{array}{c}\% \text { da área costeira } \\
\text { marinha }\end{array}$} \\
\hline & Amazônia & Caatinga & Cerrado & $\begin{array}{c}\text { Mata } \\
\text { Atlântica }\end{array}$ & Pampa & Pantanal & & \\
\hline Meta $2020^{\text {a) }}$ & $30 \%$ & $17 \%$ & $17 \%$ & $17 \%$ & $17 \%$ & $17 \%$ & $17 \%$ & $10 \%$ \\
\hline Meta $2010^{b)}$ & $30 \%$ & $10 \%$ & $10 \%$ & $10 \%$ & $10 \%$ & $10 \%$ & $10 \%$ & $10 \%$ \\
\hline Áreas protegidas SNUC') & $26,6 \%$ & $7,6 \%$ & $8,2 \%$ & $9,0 \%$ & $2,7 \%$ & $4,6 \%$ & $17,2 \%$ & $1,5 \%$ \\
\hline Proteção integral & $9,6 \%$ & $1,2 \%$ & $2,9 \%$ & $1,9 \%$ & $0,3 \%$ & $2,9 \%$ & $5,8 \%$ & $0,1 \%$ \\
\hline Uso sustentável & $16,7 \%$ & $6,4 \%$ & $5,2 \%$ & $6,5 \%$ & $2,4 \%$ & $1,7 \%$ & $11,0 \%$ & $1,4 \%$ \\
\hline Terras indígenas & $23,6 \%$ & $0,4 \%$ & $4,5 \%$ & $0,6 \%$ & $0,0 \%$ & $1,8 \%$ & $12,9 \%$ & - \\
\hline Total $^{d}$ & $50,2 \%$ & $8,0 \%$ & $12,7 \%$ & $9,6 \%$ & $2,7 \%$ & $6,4 \%$ & $30,1 \%$ & $1,5 \%$ \\
\hline
\end{tabular}

Obs.: a) Inclui áreas protegidas do SNUC, terras indígenas e APPS e RLs em terras privadas, conforme exigido pelo Novo Código Florestal.

b) As metas de 2010 incluem apenas áreas protegidas que fazem parte do SNUC

c) A totalidade de áreas do SNUC exclui sobreposições entre áreas de proteção permanente e áreas de uso sustentável, i. e., pode ser menor que a soma das áreas das duas categorias.

d) 0 total exclui RLs e APPs.

Fonte: Baseado no MMA (2015), Cadastro Nacional de Unidades de Conservação (acessado: Fev 2015); MMA (2010), Quarto Relatório Nacional para a Convenção sobre a Diversidade Biológica.

\section{Box 5.2. Terras indígenas}

Aproximadamente $13 \%$ do território nacional está sob proteção de 600 Terras indígenas, ${ }^{a}$ a maioria localizada na Amazônia e habitada por 230 povos indígenas. Terras indígenas não fazem parte do SNUC, por ser sua função fundamental relacionada a fatores culturais e sociais; contudo, contribuem, reconhecidamente, para a conservação da natureza sendo, portanto, consideradas áreas protegidas no âmbito da CDB e incluídas no Plano Nacional de Áreas Protegidas do Brasil de 2006 (Seção 4.2). Terras indígenas tendem a ser bem preservadas, dada a longa tradição de uso sustentável dos recursos naturais pelas comunidades indígenas. Por exemplo, os índices de desmatamento nesses territórios estão entre os mais baixos do país: em 2014, apenas 1\% do desmatamento total na Amazônia ocorreu dentro dessas áreas. As terras indígenas estão integradas aos "mosaicos de paisagem" (Box 5.6). A Constituição concede às comunidades remanescentes de quilombos, direitos coletivos de posse das terras por elas ocupadas desde os tempos coloniais. ${ }^{b}$

Avanços legislativos a respeito de terras indígenas têm auxiliado na resolução de questões sociais associadas à gestão de áreas protegidas (Irving, 2010). A Política Nacional de Desenvolvimento Sustentável dos Povos e Comunidades Tradicionais, de 2007 e a Política Nacional de Gestão Territorial e Ambiental em Terras Indígenas, de 2012, têm por objetivo promover o uso sustentável de recursos naturais em terras indígenas, bem como defender o conhecimento tradicional das comunidades envolvidas. Essas políticas ajudaram a reforçar as relações entre ONGs ambientalistas, governo e organizações que trabalham com povos indígenas. Várias outras iniciativas estão em curso, algumas das quais apoiadas pelo Fundo Nacional do Meio Ambiente (Capítulo 2) e organizações internacionais. No entanto, a coordenação entre os programas e as instituições envolvidas é fraca (Irving, 2010). Conflitos envolvendo os direitos de uso da terra nas terras indígenas ainda podem surgir, inclusive com madeireiros, agricultores e mineradores (Funai, 2015).

a) De acordo com a Constituição Brasileira, são as " terras tradicionalmente ocupadas pelos índios, as por eles habitadas em caráter permanente, as utilizadas para suas atividades produtivas, as imprescindíveis à preservação dos recursos ambientais necessários a seu bem-estar, e as necessárias à sua reprodução física e cultural, segundo seus usos, costumes e tradições. As terras tradicionalmente ocupadas pelos índios destinam-se à sua posse permanente, cabendo-lhes o usufruto exclusivo das riquezas do solo, dos rios e dos lagos nelas existentes".

b) Quilombolas são grupos ou comunidades tradicionais de origem Africana. 
Em 2015, áreas marinhas protegidas cobriam apenas 1,5\% do total das áreas costeiras e marinhas do Brasil. Há bastante tempo, as áreas marinhas protegidas vêm sendo utilizadas para a conservação da biodiversidade e a proteção de habitat marinhos essenciais. Aproximadamente $70 \%$ dos manguezais estão localizados dentro de áreas protegidas (MMA, 2015b). Mais recentemente, as áreas marinhas protegidas vêm sendo reconhecidas como ferramenta de gestão da pesca, servindo para reduzir conflitos entre comunidades tradicionais de pescadores e empresas de pesca industrial (OCDE-FAO, 2015; ver também Capítulo 4), conforme evidenciado pelo crescimento das áreas marinhas de uso sustentável, onde apenas atividades de pesca tradicional são permitidas. O Plano Setorial para os Recursos do Mar prevê a expansão do total de áreas marinhas protegidas para $4 \%$ das águas territoriais e da zona econômica exclusiva brasileira, até 2015. O governo vem intensificando esforços no sentido de incrementar essa porcentagem para 5\%, até 2020. O projeto Áreas Marinhas e Costeiras Protegidas, apoiado pelo GEF, contribuirá para o alcance desse objetivo.

Segundo constatação do WWF e do ICMBio (2012) as áreas protegidas federais não são totalmente representativas do conjunto de ecossistemas brasileiros e tampouco proporcionam proteção adequada contra grandes reduções de populações - ou mesmo extinção - de espécies, especialmente no bioma Pampa (MMA, 2010). As áreas federais protegidas abrigam cerca de $60 \%$ das espécies da flora e da fauna ameaçadas (Capítulo 4). Ao mesmo tempo em que o Brasil deve manter o foco sobre o bioma Amazônia, ações futuras deverão ser direcionadas às áreas marinhas e outros biomas terrestres, especialmente o Cerrado e a Caatinga, onde o nível de proteção proporcionado pelo zoneamento é inadequado, e a maior parte do desmatamento futuro é prevista (Soares-Filho et al, 2014; ver também Capítulo 4). A representatividade ecossistêmica das ações de conservação poderá assumir um melhor equilíbrio a partir da implementação e monitoramento das áreas de reserva (APPs e RLs) previstas no Novo Código Florestal.

\subsection{Benefícios ambientais e econômicos das áreas protegidas}

A rápida expansão das áreas protegidas no bioma Amazônia resulta, principalmente, de uma estratégia integrada e coordenada de combate ao desmatamento e à grilagem de terras, por meio dos programas ARPA e PPCDAm. Essa expansão foi impulsionada, também, pelo anseio de reconhecimento dos direitos das comunidades locais e tradicionais. Desde meados dos anos 2000, unidades de conservação federal e estaduais, cobrindo mais de 500 mil km² foram criadas na Amazônia, inclusive no chamado "arco do desmatamento" (nos limites leste e sul da floresta nos Estados de Rondônia, Mato Grosso e Pará) e em áreas onde há previsão de implantação de infraestruturas rodoviárias. Essas novas unidades de conservação desempenharam papel fundamental no retardamento do avanço do desmatamento para fins especulativos, fenômeno muito comum às margens de novas estradas que facilitam o acesso à floresta (CEPAL et al., 2011).

Conforme mostra a Figura 5.4, a criação de unidades de conservação, juntamente com outras medidas discutidas no Capítulo 4, contribuiu significativamente para o forte declínio dos índices de desmatamento no bioma Amazônia na segunda metade dos anos 2000. Entre 2008 e 2012, quase 95\% do desmatamento na região ocorreu fora das unidades de conservação. É quatro vezes menos provável que o desmatamento ocorra dentro das áreas protegidas do que fora delas (TCU, 2013). A redução do desmatamento também ajudou a frear as emissões de gases de efeito estufa (GEE); no período 19962006, as unidades de conservação no bioma Amazônia, por si só, absorveram quase duas toneladas de $\mathrm{CO}_{2}$ por hectare (TCU, 2013). 
As unidades de conservação contribuem significativamente para a proteção e conservação dos recursos hídricos, produzem benefícios econômicos por meio do turismo e da comercialização de produtos florestais e da biodiversidade, além de gerar receitas fiscais (Box 5.3). Há também evidências de que as áreas marinhas protegidas ajudam a proteger os estoques pesqueiros (MMA, 2015a).

\section{Figura 5.4. Expansão das unidades de conservação reduziu consideravelmente o desmatamento na Amazônia \\ Unidades de conservação e índices de desmatamento na Amazônia, 2000-14}

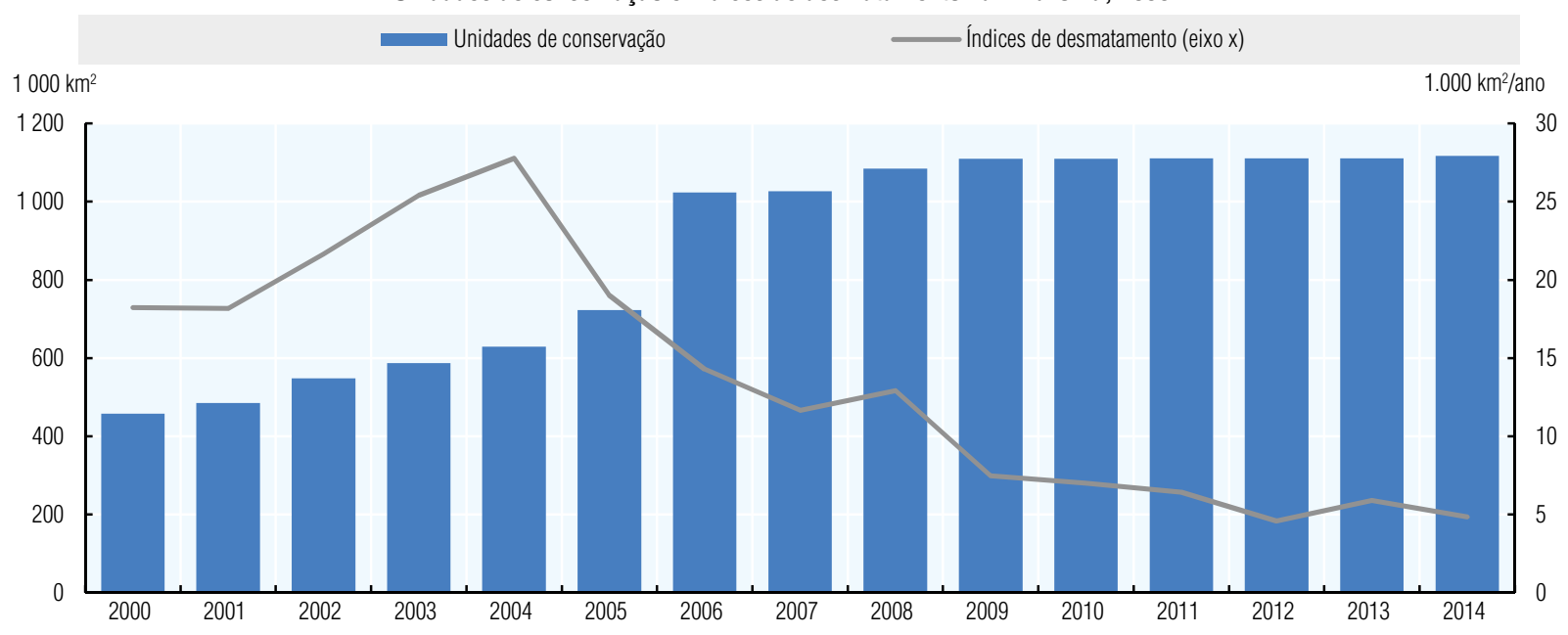

Obs.: Taxas de desmatamento se referem à Amazônia Legal, que engloba a Floresta Amazônica (cerca de 4,1 milhões de km²) e a vegetação transicional (1 milhão de km²). Fonte: INPE (2015), "Projeto PRODES: Monitoramento da floresta Amazônia Brasileira por satélite”; MMA (2015), Cadastro Nacional de Unidades de Conservação.

\section{Box 5.3. Valor econômico das áreas protegidas brasileiras}

Segundo estimativas de Medeiros e Young (2011), a exploração sustentável de madeira nas unidades de conservação da Amazônia renderam um valor anual entre $R \$ 1,2$ e $R \$ 2,2$ bilhões. Estimaram também que o extrativismo de produtos florestais não madeireiros, como a borracha e a castanha do Pará (proveniente de reservas extrativistas) gerou entre $\mathrm{R} \$ 16$ e R\$ 39 milhões ao ano. Investimentos para aumentar a capacidade produtiva de trabalhadores nessas reservas poderiam incrementar significativamente os ganhos anuais; e a certificação poderia agregar valor aos produtos finais.

Os potenciais ganhos econômicos provenientes do turismo em parques nacionais são estimados em cerca de $R$ \$1,6 bilhão ao ano, enquanto que receitas provenientes de todas as áreas protegidas federais e estaduais poderão chegar a $\mathrm{R} \$ 2,2$ bilhões em 2016 , quando o Brasil sediará os Jogos Olímpicos. No entanto, dificuldades de acesso a muitas unidades de conservação impedem um maior fluxo de turistas. Ainda há espaço para incrementar o potencial turístico das áreas protegidas (Seção 5.1).

Estima-se que o sistema de unidades de conservação do Brasil tenha impedido o lançamento de cerca de 2,8 bilhões de toneladas de carbono na atmosfera, o que corresponderia, em termos monetários, a cerca de $\mathrm{R} \$ 96$ bilhões. Ademais, o SNUC contribuiu significativamente para a disponibilização e conservação de recursos hídricos. Aproximadamente $80 \%$ da energia hídrica utilizada na geração de energia elétrica provêm de fontes localizadas dentro ou a jusante de unidades de conservação federais; $9 \%$ da água potável são diretamente captados em unidades de conservação e $26 \%$ em fontes a jusante; e 4\% da água utilizada na agricultura e irrigação provêm de fontes dentro ou a jusante de unidades de conservação.

Fonte: Medeiros, R. and C. Young (2011), Contribuição das unidades de conservação brasileiras para a economia nacional: Relatório Final. 


\section{Marco institucional das unidades de conservação}

\section{Instituições governamentais}

O sistema nacional de unidades de conservação envolve articulação entre instituições das esferas federal, estadual e municipal. O MMA coordena o SNUC, enquanto que as agências executoras em cada instância de governo são responsáveis por sua implementação, incluindo a proposição e criação de novas unidades de conservação, sua operação e gestão. A agência executora responsável pelas unidades de conservação federais é o Instituto Chico Mendes de Conservação da Biodiversidade (ICMBio), criado em 2007 com o desmembramento do Instituto Brasileiro do Meio Ambiente e dos Recursos Naturais Renováveis (IBAMA). Uma agência, com atribuições de licenciamento, monitoramento e fiscalização manteve o nome IBAMA; enquanto que o ICMBio assumiu a supervisão da criação, gestão e monitoramento das unidades de conservação federais no âmbito do SNUC. ${ }^{6}$ A justificativa para esta mudança foi a necessidade de fortalecer a governança do crescente número de unidades de conservação federais, bem como a de separar as atribuições de preservação e gestão daquelas de monitoramento da fiscalização e conformidade.

Por estarem as unidades de conservação federais espalhadas por um vasto território, foram criadas onze Coordenações Regionais do ICMBio para agilizar a comunicação e a coordenação entre a instância federal, os relevantes governos subnacionais e os atores locais. As unidades de conservação estaduais e municipais são administradas pelas suas respectivas instituições de meio ambiente, muitas vezes com o apoio do ICMBio, de ONGs e de agências internacionais de cooperação e desenvolvimento.

Outros países federativos, como o Canadá e a Colômbia, criaram agências para a supervisão de todos os aspectos pertinentes a unidades de conservação federais (OCDE-CEPAL, 2014) e, no Brasil, a criação do ICMBio ajudou a melhorar a transparência e a eficácia do SNUC (Veríssimo et al., 2011). O grande número de unidades de conservação em todas as instâncias de governo suscita desafios à coordenação eficaz e à cooperação entre instituições. O TCU avaliou a governança e a eficácia das unidades de conservação no bioma Amazônia e constatou que, muitas vezes, insuficiências de coordenação resultam em duplicação de esforços e em redução de eficiência. O relatório aponta que cerca de $70 \%$ dos gestores de unidades de conservação relatam que a articulação entre eles, os órgãos governamentais e as ONGs é fraca (TCU, 2013).

\section{Organizações não governamentais}

Muitas ONGs desempenham papel complementar na criação e gestão de unidades de conservação e no apoio às comunidades locais que vivem dentro e no entorno delas. Em virtude das limitações de recursos financeiros e humanos do SNUC (Seções 4.3 e 4.4) é permitido às ONGs apoiar atividades, tais como: elaboração de estudos técnicos e planos de gestão, implementação de ações de gestão e promoção da participação social.

As ONGs também estão empenhadas no monitoramento da biodiversidade em florestas localizadas em unidades de conservação. Por exemplo, a SOS Mata Atlântica apoiou o monitoramento da cobertura vegetal do bioma Mata Atlântica, o Imazon opera um sistema de monitoramento do desmatamento e degradação florestal na Amazônia, e o Instituto Socioambiental implementou um programa de monitoramento em unidades de conservação e terras indígenas da Amazônia. 


\section{Criação das unidades de conservação}

No Brasil, assim como em todos os países, a maioria das terras que são ou podem ser incluídas em unidades de conservação estão habitadas. Ademais, certas áreas podem ser potencialmente importantes para a implantação de infraestruturas (principalmente estradas e hidrelétricas) ou de atividades econômicas, como a agricultura e a mineração. Geralmente, a concorrência entre interesses ambientais, sociais e econômicos é mais acirrada nas cidades, visto que as áreas protegidas urbanas tendem a estar localizadas em terras de alto valor, com potencial para expansão urbana (Box 5.4). Para que unidades de conservação possam ser criadas e geridas de forma eficaz, é necessário que todos esses interesses conflitantes sejam conciliados de modo a evitar prejuízos ambientais, sociais e econômicos.

\section{Box 5.4. Unidades de conservação urbanas no Brasil}

Os serviços ecossistêmicos, tais como água potável e oportunidades de lazer e educação ambiental, prestados por unidades de conservação localizadas dentro ou na periferia de grandes centros urbanos (ex., São Paulo, Rio de Janeiro e Salvador), são de inestimável valor. Ajudam a melhorar o bem-estar da população urbana e a construir bases de apoio para a conservação da natureza. No entanto, a criação e o manejo dessas unidades suscitam complexidades específicas. A proteção ambiental em áreas urbanas pode enfrentar oposição de diversos interesses, por visar áreas potenciais para residências, comércio, indústrias e edifícios públicos e de infraestruturas urbanas, como estradas e aterros sanitários.

No Brasil, a gestão das unidades de conservação urbanas está a cargo, principalmente, dos governos municipais; mas há exemplos de unidades de conservação urbanas de competência estadual (ex., em Belo Horizonte e São Paulo). Poucas estão sob a jurisdição federal, mas entre essas estão algumas das maiores unidades de conservação urbanas do país (ex., Parque Nacional da Tijuca e Parque Nacional de Brasília).

O Parque Nacional da Tijuca, na Cidade do Rio de Janeiro, abrange cerca de $40 \mathrm{~km}^{2}$ e é gerido pelo ICMBio, em colaboração com os governos municipal e estadual. A colaboração foi estabelecida no final dos anos 1990, com vistas a conciliar interesses urbanos relacionados ao lazer e ao transporte e dar resposta às crescentes pressões da expansão urbana, especialmente das favelas vizinhas. Em 2011, 28 unidades de conservação de competência nacional, estadual e municipal foram consolidadas para formar o Mosaico Carioca de Áreas Protegidas. O Parque Nacional da Tijuca é um exemplo do quanto uma forte cooperação interinstitucional pode auxiliar na regeneração de grandes áreas degradadas de Mata Atlântica.

O Parque Estadual da Cantareira, parte do Cinturão Verde de São Paulo, atende a quase metade da demanda pelo abastecimento de água da área urbana. Em resposta a pressões da expansão urbana sobre a Serra da Cantareira, em 2009, o governo estadual lançou um processo destinado a quase quadruplicar a área sob proteção do Estado, o que implicou na compra, transferência ou desapropriação de terras privadas, em sete municípios. Para este fim, o governo estadual, em estreita colaboração com proprietários de terras e municípios, procedeu ao levantamento do perímetro das áreas protegidas propostas, de modo a adequar seus limites à atual conjuntura ecológica, econômica e política. Para permitir a continuidade de usos compatíveis, foram adotadas diversas categorias de área protegida. Esta bem-sucedida cooperação entre diferentes níveis de governo, comunidades locais e proprietários privados resultou, em 2010, na criação da unidade de conservação.

Fonte: Trzyna, (2014), Urban Protected Areas: Profiles and best practice guidelines.

Em reconhecimento a essa necessidade, a Lei do SNUC prevê que, antes da criação de qualquer unidade de conservação, sejam realizadas consultas públicas com a participação de comunidades locais, órgãos governamentais de todas as instâncias e outras 
partes interessadas (com isenção para reservas biológicas e estações ecológicas). Este é um dos principais avanços promovidos pelo SNUC. Ademais, a criação de uma unidade de conservação federal exige que sejam realizadas consultas prévias junto aos ministérios responsáveis por todos os setores potencialmente afetados (ex., minas, geração de energia, infraestrutura de transportes, agricultura) e junto aos governos estaduais. A exemplo do que ocorre em outros países, um processo de consulta pode se estender por vários anos. Embora as consultas públicas sejam uma forma de reduzir potenciais conflitos, o desafio de conciliar os diversos interesses conflitantes na busca de consenso tem, algumas vezes, frustrado a criação de unidades de conservação propostas.

Algumas categorias de unidade de conservação no âmbito do SNUC, incluindo parques nacionais, são exclusivamente de domínio público (Tabela 5.1) e sua criação requer que quaisquer terras privadas localizadas dentro dos seus limites sejam desapropriadas, e seus proprietários indenizados. É permitido às comunidades tradicionais residir em reservas de desenvolvimento sustentável e reservas extrativistas onde, embora não sejam proprietárias, mantêm a posse e o direito de usufruto dos recursos naturais, conforme acordado em contratos ou planos de manejo celebrados com os órgãos responsáveis pela gestão das reservas (Seção 5.3). Na prática, atividades de aproveitamento de recursos naturais são permitidas em $88 \%$ da área total do SNUC, inclusive em algumas áreas de proteção integral; nas demais, o governo procura impor restrição total ao uso direto dos recursos naturais (Gurgel et al., 2009). Em algumas categorias de unidades de conservação, é permitida a propriedade privada, desde que o uso da terra seja compatível com os objetivos da categoria (Tabela 5.1); há também as Reservas Particulares do Patrimônio Natural, reconhecidas como parte do SNUC mediante solicitação do proprietário do terreno.

Algumas ações e normas de implementação do SNUC foram aprovadas e executadas com considerável atraso, especialmente aquelas que dizem respeito à desapropriação e indenização de terras, mas também as que tangem a atividades permitidas em áreas de uso sustentável. A incerteza regulatória foi reduzida; no entanto, conflitos sobre posse da terra e categorias de uso permanecem. Por vezes, algumas autoridades locais, proprietários de terras e comunidades recebem a notícia da criação de uma unidade de conservação com ressentimento, por temerem (às vezes justificadamente) a perda de suas terras ou por verem frustradas suas expectativas de posse futura. Por exemplo, a criação da Reserva Biológica Mata Escura, em 2003, a título de compensação ambiental pela instalação de uma usina hidrelétrica, provocou conflitos com a comunidade quilombola local. O conflito foi resolvido apenas em 2012, por meio de um acordo firmado entre a comunidade e o ICMBio, permitindo sua permanência no local, sob certas condições (Vilela, 2013). O Parque Nacional Pontões Capixabas, criado em 2002 tinha, dentro de seus limites, cerca de 400 propriedades rurais; e o desfecho foi que, em 2008, a unidade teve que ser reclassificada como monumento natural, categoria em que a propriedade privada é permitida.

Ao mesmo tempo em que a redefinição de limites e a reclassificação de unidades de conservação podem, em alguns casos, facultar uma gestão mais eficaz e equitativa, o processo também pode desvendar a cobiça de interesses econômicos por terras em áreas atualmente sob proteção ambiental (Mascia et al., 2014). Em 2014, quatro unidades de conservação foram descredenciadas, sob pretexto de interesse estratégico nacional, como a implantação de usinas hidrelétricas. Em alguns estados foram aprovadas normas mais flexíveis que facilitam esse tipo de descredenciamento. 
A criação de áreas de uso sustentável é geralmente menos penosa, por serem as restrições ao aproveitamento de recursos menos rígidas. As comunidades tradicionais, visando melhorar suas condições de vida e o acesso a serviços públicos e benefícios sociais vêm, cada vez mais, solicitando a criação desse tipo de unidade de conservação (Seção 5.3). Em 2014, apenas por parte de pescadores tradicionais, foram apresentados mais de 50 novos requerimentos de criação de reservas extrativistas (Prates, 2014).

A desapropriação e indenização de propriedades localizadas em áreas públicas dedicadas exclusivamente à proteção ambiental apresentam grande desafio, especialmente devido à insuficiência de recursos financeiros e, em menor escala, a indefinições quanto à posse da terra. Em 2011, 20\% da área da Amazônia eram compostos por terras supostamente públicas, o que facilita a criação de unidades de conservação, enquanto que apenas $4 \%$ correspondiam a áreas privadas regularmente escrituradas (Figura 4.4). Aproximadamente $70 \%$ das unidades de conservação federais, ou $7 \%$ da área de superfície sob proteção federal, incluem terras onde há reivindicações de posse, principalmente nos biomas Amazônia, Cerrado e Mata Atlântica (TCU, 2013; Veríssimo et al, 2011). Segundo estimativa do TCU (2013) seriam necessários R 7,1 bilhões para resolver essa situação; e o orçamento federal destinou cerca de $\mathrm{R} \$ 70$ milhões ao ano, no período 2009-2012, para esta finalidade. Neste ritmo, levaria mais de um século para finalizar o processo. Muitas vezes, a resolução de problemas relacionados à consolidação territorial e à regularização fundiária vai muito além da capacidade e competência das autoridades ambientais (TCU, 2013).

A expectativa é que o Programa Terra Legal, lançado em 2009 com o objetivo de regularizar a ocupação de terras públicas federais na Amazônia (Box 4.3) conduza à criação de novas unidades de conservação sem pendências fundiárias. O programa ajuda a esclarecer questões de posse e de direitos dos usuários de terras públicas perante as agências federais e estaduais. Aproximadamente $50 \mathrm{mil} \mathrm{km}^{2}$ de terras públicas federais foram destinadas ao MMA para a criação de unidades de conservação. Uma (a Estação Ecológica Maués) foi criada em 2014, e um conjunto de novas unidades de conservação, totalizando mais de 35 mil km², está em vias de criação ao longo da rodovia Transamazônica no sul do Amazonas, um recente foco de desmatamento.

O Novo Código Florestal introduziu um mecanismo de compensação que poderá ajudar na consolidação de unidades de conservação públicas, ao permitir que proprietários de terras com pendências de reserva legal possam efetuar a compensação por meio da compra, em nome do governo, de títulos de propriedades privadas localizadas em unidades de conservação oficiais. Para que este mecanismo opere, será necessária a plena implementação do Cadastro Ambiental Rural (Capítulo 4).

Além desses esforços, o Brasil poderia considerar formas alternativas de aumentar a área de terras sob proteção ambiental, incluindo a ampliação da rede de reservas particulares de patrimônio natural, que atualmente corresponde a uma parcela insignificante das áreas do SNUC. O estímulo a acordos contratuais com proprietários poderia representar uma forma econômica e eficaz de garantir a conservação da biodiversidade e o uso sustentável. Na África do Sul, por exemplo, o custo do Stewardship Programme, uma parceria entre o governo e proprietários de terras, é estimado em apenas um décimo do valor da aquisição definitiva de terras (OCDE, 2013). Além do aspecto econômico, uma abordagem dessa natureza permitiria a expansão das unidades de conservação de uma forma que leve em consideração os direitos e interesses dos proprietários. 


\section{Gestão das unidades de conservação}

\subsection{Comitês e planos de gestão}

A Lei do SNUC prevê a criação de comitês de gestão, cuja principal função é estimular a participação ativa das comunidades locais e partes interessadas em decisões inerentes às unidades de conservação. Esses comitês, com participação de representantes do governo, da sociedade civil e do setor privado, têm papel consultivo ou decisório, dependendo da categoria de gestão. Em 2013, das 320 unidades de conservação federais (excluindo reservas particulares de patrimônio natural), 253 já haviam estabelecido seus comitês, e 25 estavam em processo de estabelecê-los (ICMBio, 2014).

Alguns fatores podem limitar a participação social efetiva, incluindo o treinamento inadequado de gestores e membros dos comitês, o fraco envolvimento de partes interessadas e a falta de recursos financeiros (Mendonça et al., 2014). Além disso, a maioria dos comitês de gestão ainda não aprovaram seus estatutos e, portanto, ainda há risco de exacerbação de conflitos entre seus membros (Veríssimo et al., 2011).

O plano de gestão da unidade de conservação é o principal instrumento do cotidiano do planejamento e gestão. Deve observar os objetivos da unidade de conservação, suas características físicas e socioeconômicas, o zoneamento e as normas que orientam o aproveitamento dos recursos naturais da área. A existência do plano de gestão é condição fundamental para as atividades de uso público (como turismo e educação ambiental) assim como para a exploração sustentável de madeira e o aproveitamento de recursos pela comunidade local. A Lei do SNUC prevê que a elaboração do plano de gestão seja concluída dentro de um prazo de cinco anos após a criação da unidade de conservação, e que a proteção da natureza e a gestão básica necessária para garantir a integridade da área sejam implementadas até que a elaboração do plano seja concluída. O plano de gestão pode ser complementado por outros instrumentos: ex., algumas áreas de uso sustentável, como primeira etapa do plano de gestão, adotam um "plano de utilização" que permite a colocação de sinalização e a regularização fundiária.

No entanto, por falta de recursos e carência de capacidade, mesmo vencido o prazo de cinco anos, muitas unidades de conservação continuam sem um plano de gestão. Em 2012, das 247 unidades de conservação federais e estaduais até então criadas no bioma Amazônia, apenas 94 contavam com um plano aprovado; 40 unidades de conservação federais vinham operando, há mais de 10 anos, sem plano de gestão (TCU, 2013). Essa situação é verificada também em outros biomas; apenas no bioma Mata Atlântica, mais da metade das unidades de conservação federais contavam com um plano de gestão aprovado em 2013. A falta de um plano de gestão significa que o gerenciamento se limita a monitoramento e pesquisa; cerceando, portanto, o desenvolvimento socioeconômico, a exemplo da situação descrita no Box 5.5.

Ações voltadas à elaboração e aprovação de planos de gestão vêm ganhando força nos últimos anos; todavia, grandes lacunas permanecem (Veríssimo et al., 2011). Muitas vezes, os planos de gestão, quando existem, têm como base sólidas informações e análises científicas; no entanto, tendem a carecer de ferramentas de gestão e aplicabilidade prática, o que, no geral, resulta em baixo nível de implementação. Em 2012, metade dos planos de gestão das unidades de conservação federais e estaduais da Amazônia vinha sendo muito pouco aplicada, ou mesmo ignorada (TCU, 2013). Outros estudos apontaram níveis de implementação ainda mais baixos (SEMEIA, 2012b). 
A elaboração de um plano de gestão tende a ser onerosa e demorada. O baixo nível de implementação realça a necessidade da elaboração de abordagens e metas de gestão que se adéquam à unidade de conservação específica, de modo a, na prática, garantir a aplicabilidade de cada plano elaborado (Kinouchi, 2014). Os planos de gestão devem incluir a análise financeira e ser periodicamente revisados e ajustados, caso se revelem ineficazes. A capacitação dos gestores das unidades de conservação também precisa ser melhorada, com a promoção da articulação e do intercâmbio de experiências e de boas práticas entre eles.

\section{Box 5.5. Sem plano de manejo, sem turismo: o caso do Parque Nacional de Anavilhanas}

Anavilhanas é um dos mais extensos arquipélagos de água doce do mundo. Contém mais de 400 ilhas, centenas de rios e lagos e, durante a estação da seca, praias de areia branca. No início dos anos 1980, foi criada uma estação ecológica para assegurar a proteção integral da área, permitindo acesso apenas para fins científicos. Em virtude do potencial turístico da região, em 2008, a unidade foi reclassificada como parque nacional; contudo, seu plano de manejo, que havia sido elaborado para cumprir com objetivos de estação ecológica, ainda não foi revisto. Em 2012, o ICMBio emitiu uma autorização temporária para atividades de turismo no parque, sob certas condições. No entanto, em 2014, em face da crescente demanda por atividades de turismo e de carências de capacidade de gestão no local, o ICMBio exigiu que a administração do parque restringisse o acesso de visitantes, sob o argumento de que, na ausência de um plano de manejo válido, o turismo poderia provocar inaceitáveis impactos sobre a biodiversidade.

\subsection{Gestão integrada de múltiplas unidades de conservação}

A Lei do SNUC também introduziu instrumentos de gestão de unidades de conservação em escala da paisagem, de forma a permitir que conexões entre e dentro de ecossistemas sejam mantidas ou ampliadas. Reconhece os corredores ecológicos como instrumentos de gestão territorial para a manutenção de processos ecológicos ${ }^{7}$ e introduz a possibilidade de integrar múltiplas unidades de conservação em um "mosaico", caso ocorram próximas, justapostas ou sobrepostas.

O objetivo dos mosaicos é facilitar a coordenação entre gestores e populações locais participantes das unidades de conservação, no sentido de equacionar, de forma compartilhada, problemas comuns referentes ao uso da terra e aproveitamento de recursos em zonas limítrofes, ao acesso a unidades de conservação, à fiscalização, monitoramento e avaliação de planos de gestão, à pesquisa científica e à alocação de recursos (MMA, 2010). Até 2014, o MMA havia aprovado 14 mosaicos; o Box 5.6 descreve um exemplo. No entanto, a implementação dos mosaicos apresenta desafios; muitas unidades de conservação no Brasil continuam sendo gerenciadas como unidades administrativas estanques.

O Plano Estratégico Nacional de Áreas Protegidas, de 2006, também tentou integrar as várias categorias de unidades de conservação, inclusive as abrangidas e não abrangidas pelo SNUC (ex., terras indígenas) em um processo holístico de planejamento territorial que levasse em conta a contribuição das unidades de conservação para a erradicação da pobreza e a inclusão social. Este plano não foi totalmente implementado, provavelmente, por conter um excesso de objetivos potencialmente conflitantes. A heterogeneidade das características e das necessidades das diversas áreas dificultou o consenso entre as agências governamentais responsáveis. 


\section{Box 5.6. Gestão das unidades de conservação em escala da paisagem: o Mosaico Baixo Rio Negro}

O Mosaico Baixo Rio Negro, no Estado do Amazonas, abrange mais de $70 \mathrm{mil} \mathrm{km²}$ englobando 11 unidades de conservação (três federais, sete estaduais e uma municipal) em cinco municípios. A área inclui dezenas de comunidades ribeirinhas e aldeias indígenas que vivem da agricultura de pequena escala e de atividades extrativistas. Oficialmente reconhecido em dezembro de 2010, o mosaico tem como objetivo melhorar a gestão das unidades de conservação participantes, por meio da adoção de um modelo de gestão compartilhada e participativa.

O mosaico conta com um comitê comum de gestão, presidido pelo chefe de um parque nacional participante, e com um plano de gestão conjunta, além dos planos de gestão de cada unidade envolvida. Esta estrutura permite que os chefes de parques compartilhem seus conhecimentos, infraestrutura e equipamentos e melhorem o envolvimento com as comunidades residentes nas zonas limítrofes. Por exemplo, o quadro de pessoal de uma determinada unidade de conservação se dedica não apenas a questões relacionadas à sua unidade, mas também assume responsabilidades temáticas comuns ao mosaico como um todo. A estrutura de mosaico ajuda no enfrentamento de desafios ambientais e socioeconômicos, muitos dos quais comuns a todas as unidades integrantes, facilitando a resolução de eventuais conflitos em zonas limítrofes; conflitos esses muitas vezes relacionados ao monitoramento e controle do uso dos recursos naturais.

Em dois dos parques nacionais do mosaico (Anavilhanas e Jaú) por exemplo, membros das comunidades locais das proximidades realizam atividades tradicionais - como pesca de tartarugas, lavra de areia e extração de madeira - proibidas pelas normas dos parques. Mesmo que essas atividades tradicionais sejam realizadas principalmente para o consumo da comunidade, as vendas de produtos a empresas comerciais têm aumentado; o tráfico de tartarugas, por exemplo, vem se tornando um grande desafio na região. A aplicação das normas dos parques tem levado muitas famílias a se mudar para a reserva extrativista vizinha, onde o aproveitamento dos recursos naturais é permitido.

\subsection{Recursos humanos}

A gestão do vasto território coberto pelo SNUC exige grande contingente de servidores capacitados; no entanto, há indícios de que o efetivo de recursos humanos é insuficiente. Segundo o ICMBio (2014), havia 1.079 servidores públicos diretamente engajados na gestão de unidades de conservação federais, em agosto de 2014. Isso significa que há, em média, um servidor público para cada 700 km² de unidade de conservação federal. Em 2010, havia 305 pessoas empregadas nas unidades de conservação de nível estadual na Amazônia, mas com grande variação entre estados. No Estado do Amazonas, por exemplo, havia apenas um servidor para cada $5.900 \mathrm{~km}^{2}$ (Veríssimo et al., 2011). Medeiros e Young (2011) estimaram que, no final dos anos 2000, a densidade de servidores nas unidades de conservação brasileiras era uma das mais baixas do mundo. De acordo sua análise, em média, um servidor de área protegida brasileira exercia a gestão de cerca de $200 \mathrm{~km}^{2}$; em contraste com menos que $20 \mathrm{~km}^{2}$ na África do Sul (Figura 5.5).

A falta de recursos humanos é uma das principais razões para a insuficiente implementação de muitas atividades, especialmente aquelas relacionadas à vigilância, administração de conflitos, promoção e controle de acesso público e monitoramento da biodiversidade. Estimativas sugerem a necessidade da contratação para as unidades de conservação federais e estaduais de, no mínimo, 19 mil novos trabalhadores, sendo 13 mil apenas para atividades de campo (MMA, 2009). Apenas no ICMBio o déficit no quadro funcional é de sete mil, entre servidores, brigadistas e voluntários, embora em nível federal novos processos de contratação venham ajudando a reduzir esse hiato nos últimos anos. De acordo com o TCU (2013), em 2012, um quarto das unidades de 
conservação federais e estaduais da região amazônica não possuíam funcionários; apenas três unidades de conservação informaram que o quadro de funcionários era suficiente.

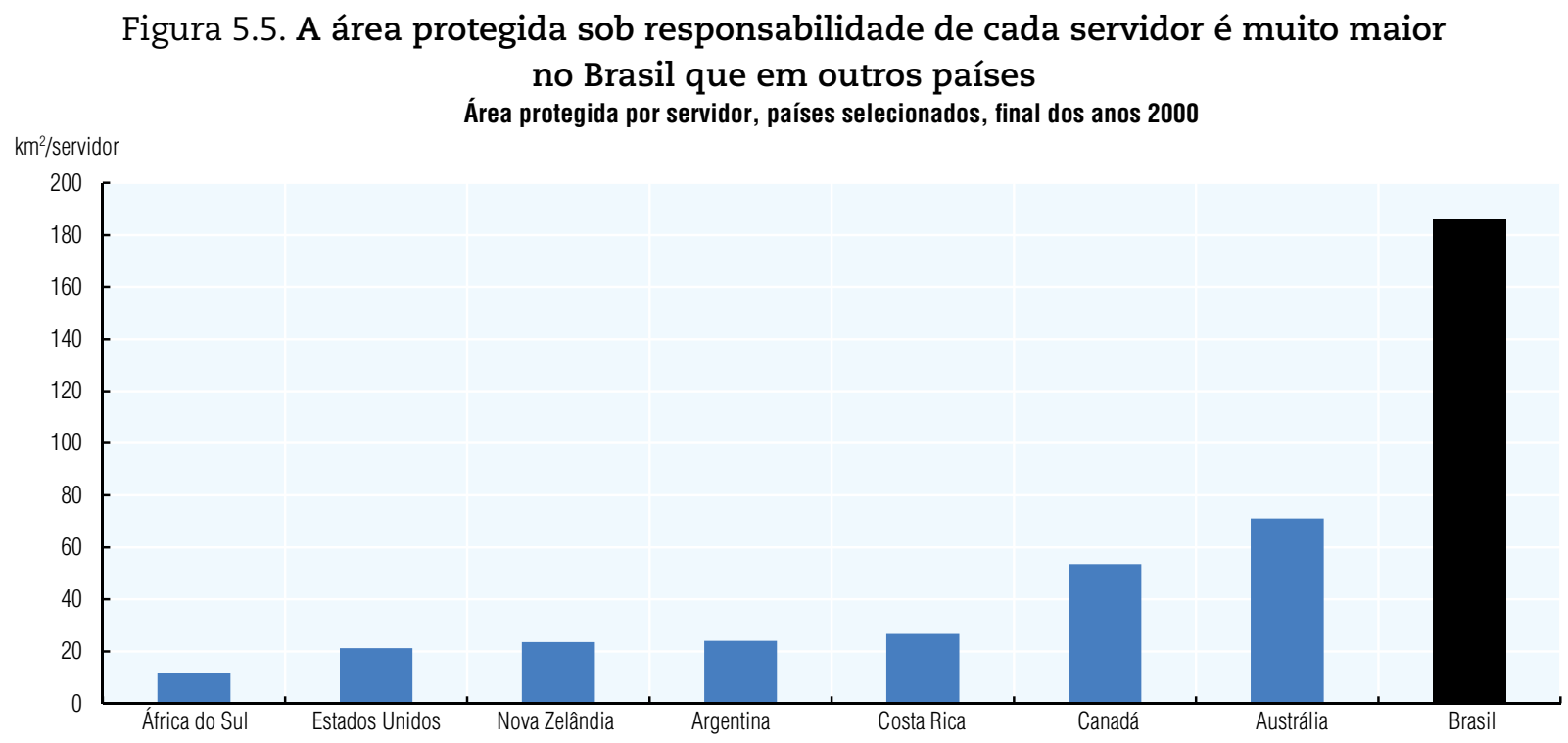

Fonte: Medeiros, R. e C. Young (2011), Contribuição das unidades de conservação brasileiras para a economia nacional: Relatório final.

A rotatividade de pessoal cria dificuldades adicionais para uma gestão eficaz. Atrair servidores para uma permanência de longo prazo em algumas áreas tem sido difícil, especialmente em se tratando de localidades mais remotas da Amazônia, onde são precárias as condições de vida e de trabalho (ex., saúde, educação, habitação, transporte). Condições de trabalho satisfatórias são a exceção, em vista da precariedade de infraestrutura, recursos e capacidades. A falta de pessoal em unidades de conservação também tem a ver com a rigidez da legislação trabalhista brasileira e com a burocracia inerente à contratação no setor público.

Apesar de ser, em geral, altamente motivados, comprometidos e com boa formação em ciências naturais, grande parte dos gestores e servidores carece das capacidades necessárias para enfrentar os desafios da gestão cotidiana, especialmente as relacionadas ao acesso público a unidades de conservação (ex., turismo, lazer e educação ambiental e concessões florestais) ou à administração de eventuais conflitos com ou entre as comunidades locais. Esta falta de capacidade resulta em projetos de baixa qualidade, na dificuldade de atrair recursos financeiros e na incapacidade de executar, de forma eficiente, as verbas disponibilizadas. Esforços vêm sendo empreendidos no sentido de reduzir esse déficit de conhecimento, inclusive por meio de treinamentos oferecidos pelas ONGs, WWF e IPE, a gestores de unidades de conservação participantes do programa ARPA, e de capacitações internas do ICMBio, ministradas pela ACADEBio.

\subsection{Recursos financeiros}

A Lei do SNUC prevê a alocação de recursos financeiros suficientes para as unidades de conservação, com vistas a garantir sua gestão eficaz e o alcance de suas metas. No entanto, a expansão das áreas sob proteção não veio acompanhada de um aumento proporcional de recursos. Um levantamento realizado em 2012 entre gestores de unidades de conservação revelou que $60 \%$ não dispunham de recursos suficientes para levar a cabo suas atividades (SEMEIA, 2013). 
Embora não seja conhecido o montante exato dos recursos financeiros disponibilizados ao SNUC, diversos estudos apontam para um déficit considerável para a gestão eficaz da enorme área sob proteção, a exemplo do que ocorre em outros países da América Latina (Bovarnick et al, 2010). O MMA (2009) estimou que, para manter as unidades de conservação federais em "condições operacionais satisfatórias", seria necessário um reforço orçamentário da ordem de $\mathrm{R} \$ 540$ milhões; no nível estadual, o déficit orçamentário foi estimado em $\mathrm{R} \$ 360$ milhões. Estimou ainda que seriam necessários $\mathrm{R} \$ 610$ milhões para a adequada consolidação das unidades de conservação federais (ex., implantação da infraestrutura necessária) além de $\mathrm{R} \$ 1,2$ bilhão para as unidades de conservação estaduais (Funbio, 2009). O Brasil investe bem menos na manutenção de suas unidades de conservação que outros países, inclusive os da América Latina e outros de economia emergente (Figura 5.6). A falta de recursos financeiros cria forte limitação à atuação dos gestores de unidades de conservação, no que diz respeito à consecução de metas e contratação de pessoal (Seção 4.3).

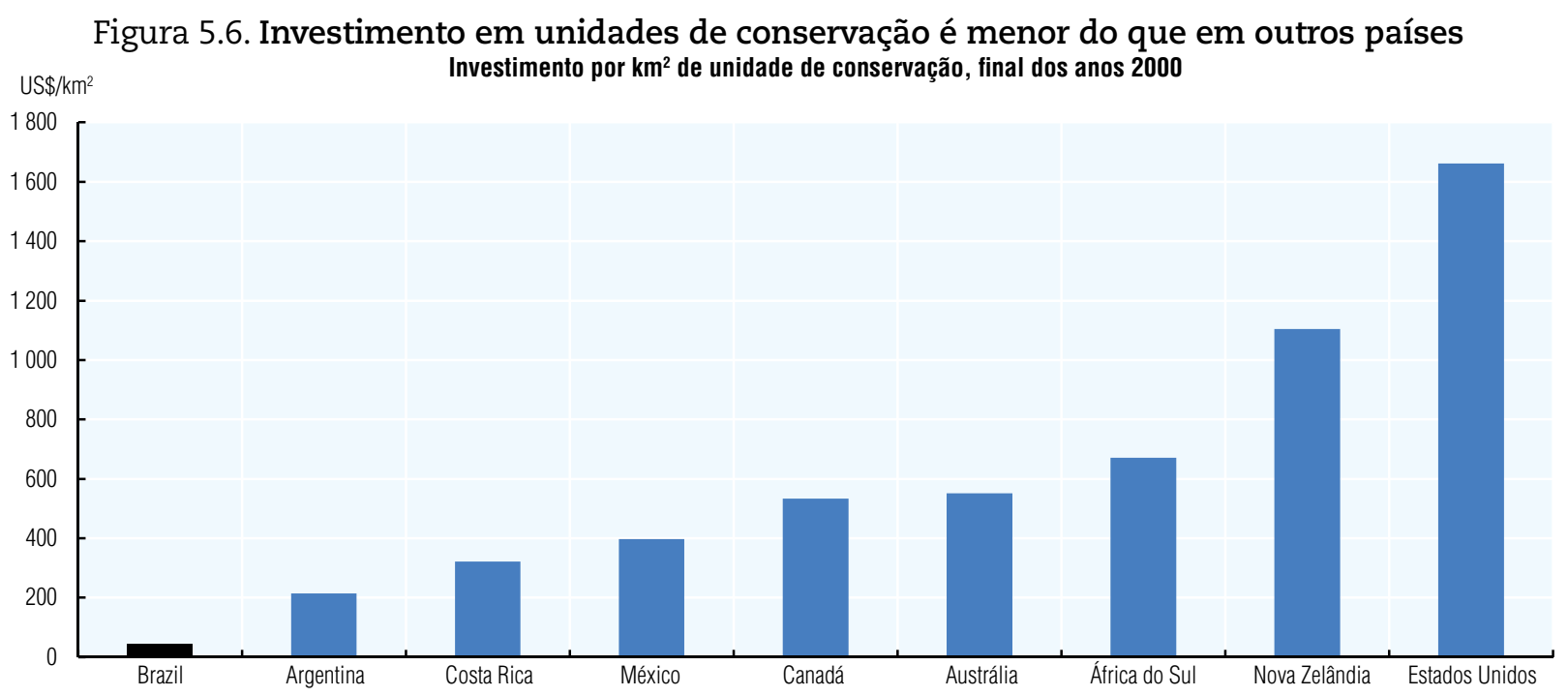

Fonte: Medeiros, R. e C. Young (2011), Contribuição das unidades de conservação brasileiras para a economia nacional: Relatório final.

Os recursos para a gestão das unidades de conservação provêm de diversas fontes, sendo o Orçamento Federal a mais significativa. O montante dos recursos públicos destinados ao SNUC não é acompanhado sistematicamente. A última avaliação dos recursos disponibilizados às unidades de conservação federais, realizada em 2009 pelo MMA e MPOG ${ }^{8}$ indicou que $85 \%$ vieram de dotações orçamentárias do ICMBio, 10\% de dotações orçamentárias de outras instituições ambientais ${ }^{9}$ e $5 \%$ de fontes não orçamentárias (MMA, 2009). Outras fontes incluem valores relativamente limitados provenientes de compensações ambientais, de contribuições de doadores nacionais e internacionais e de receitas provenientes do turismo e da gestão florestal sustentável (Seções 5.1 e 5.2).

As operações do SNUC são altamente dependentes de orçamentos públicos, especialmente do orçamento federal. O mesmo ocorre em outros países latino-americanos; contudo, as unidades de conservação brasileiras apresentam um nível especialmente elevado de dependência das dotações governamentais, o que torna o financiamento vulnerável a fatores externos e políticos (Bovarnick et al., 2010). O Brasil deveria desenvolver uma estratégia financeira integrada para garantir maior eficiência e eficácia na 
disponibilização de recursos, tanto para unidades de conservação, quanto para a política de biodiversidade de forma geral e, ainda, explorar novas e alternativas fontes de receitas, tais como: pagamento por serviços ambientais (ex., abastecimento de água e sequestro de carbono); ingressos pelo acesso a unidades de conservação; merchandising e venda de produtos; uma parcela dos royalties e da compensação financeira paga por operadores de hidrelétricas e mineradoras; e receitas provenientes do acesso a recursos genéticos (Capítulo 4).

O Brasil poderia ampliar o uso de concessões para a oferta de serviços de turismo e a gestão sustentável de florestas e, de forma mais abrangente, estimular o engajamento do setor empresarial na implantação de infraestruturas e na prestação de serviços em unidades de conservação. Poderia ainda, estender o uso das parcerias público-privadas (PPPs) para abranger a gestão total ou parcial de áreas protegidas, incluindo a conservação ambiental. Desta forma, o poder público poderia abrir mão da gestão direta e concentrar suas ações na supervisão de unidades de conservação que demandaria menos recursos, mas exigiria que o quadro funcional fosse dotado de um conjunto diferente de capacidades e habilidades. Já existem várias concessões em vigor para atividades de turismo, mas o primeiro contrato de gestão completo foi celebrado apenas em 2015 (Box 5.7).

\section{Box 5.7. Rota Lund: primeira parceria público-privada do Brasil para a gestão de unidades de conservação}

Em 2012, o Governo do Estado de Minas Gerais, em parceria com a ONG Semeia ${ }^{\text {lançou a }}$ primeira PPP brasileira para a gestão de unidades de conservação. Trata-se da Rota Peter Lund, uma trilha de caminhada que passa por três unidades de conservação, cobrindo $24 \mathrm{~km}^{2}$, ao norte da Área Metropolitana de Belo Horizonte. O objetivo da PPP é fomentar o turismo e, ao mesmo tempo, melhorar a efetividade da conservação.

Por meio de um contrato de concessão com duração de 30 anos, a concessionária assume responsabilidade por todas as atividades de conservação, incluindo controle de incêndios, controle de espécies e pesquisa científica. O papel do governo fica limitado ao monitoramento e supervisão do desempenho da concessionária, usando indicadores definidos.

O modelo de PPP proposto foi aberto a consulta pública durante 60 dias, e foram realizadas várias oficinas e debates. O processo de licitação foi submetido a consulta pública em novembro de 2013; em março de 2015, foi celebrado o contrato de concessão.

a) Semeia é uma organização sem fins lucrativos que apoia o desenvolvimento e a implementação de novos modelos de gestão para as unidades de conservação brasileiras. Seu objetivo é estimular o diálogo entre atores do governo, do setor privado e da sociedade civil e promover a criação de PPPs para gerir as unidades de conservação.

Fonte: Semeia (2013), Semeia Relatório Anual, 2013.

\section{Dotações orçamentárias}

O orçamento disponível para o SNUC diminuiu em cerca de $35 \%$ em termos reais entre 2000 e 2008 (MMA, 2009) não obstante a significativa expansão do sistema (Seção 1). Por outro lado, a partir de 2008, o orçamento do ICMBio, principal fonte de financiamento do SNUC, cresceu 57\%, alcançando R\$ 783 milhões em 2014 (Capítulo 2). Esses recursos destinam-se, principalmente, a despesas com pessoal e custos operacionais, enquanto que os gastos com investimento representam entre 2\% e 11\% (Funbio, 2014A). Não há dados consolidados sobre dotações orçamentárias e gastos dos entes subnacionais para/com as unidades de conservação. 


\section{Compensação ambiental}

A compensação ambiental é a principal contribuição privada para o financiamento de unidades de conservação. Trata-se de pagamentos obrigatórios efetuados por empreendedores de projetos que requeiram licenciamento ambiental para instalações e infraestruturas potencialmente causadoras de degradação ambiental ou poluição (Capítulo 2). No nível federal, a compensação pode alcançar 0,5\% dos custos totais de um projeto, dependendo da gravidade do seu impacto. A Lei do SNUC prevê que a totalidade dos recursos provenientes da compensação ambiental seja destinada às unidades de conservação, dando prioridade às áreas de proteção integral. Cabe ao IBAMA definir o valor da compensação ambiental e determinar quais unidades de conservação devem se beneficiar dos recursos arrecadados. Os pagamentos podem ser efetuados diretamente, na forma de produtos ou serviços que beneficiem a área protegida, ou indiretamente por meio de um fundo administrado pelo ICMBio ou por terceiros..$^{10} \mathrm{O}$ nível de execução é, no entanto, muito baixo; no período 2008-2014, apenas $8 \%$ do volume dos recursos disponíveis provenientes de compensação ambiental foram efetivamente executados. A insegurança jurídica relacionada ao processo de compensação impõe grande gargalo à execução mais eficiente desses recursos; outro obstáculo é a falta de projetos adequados nos quais os recursos possam ser investidos (Funbio, 2014A).

\section{ICMS ecológico}

O Brasil foi pioneiro no uso de transferências fiscais como incentivo para a conservação da biodiversidade em unidades de conservação. ${ }^{11}$ Aproximadamente metade dos estados redistribui uma parcela da receita do Imposto sobre Circulação de Mercadorias e Serviços para fins ambientais, o chamado ICMS ecológico (ou ICMS-E). De longe, o principal critério de distribuição é a extensão (e tipo) das unidades de conservação e de terras indígenas, seguido pela presença de serviços de coleta de resíduos urbanos, mananciais públicos e tratamento de efluentes (IBGE, 2014). Geralmente, as áreas de proteção integral recebem maior pontuação. Um mecanismo semelhante, que prevê a redistribuição de tributos federais relacionados à renda aos estados, com base em unidades de conservação está, há anos, em tramitação no Congresso.

O ICMS-E foi criado para compensar os municípios pelo custo de oportunidade de manter parte de seu território sob proteção ambiental, visto que restrições de uso da terra restringem atividades econômicas que poderiam gerar receitas fiscais. Para municípios com grandes áreas dedicadas a unidades de conservação, a receita do ICMS-E representa uma parcela significativa do orçamento municipal. ${ }^{12}$ É possível, mas não obrigatório, destinar a receita do ICMS-E ao custeio de despesas em unidades de conservação ou a finalidades ambientais mais amplas.

O ICMS-E tem ajudado a aumentar o número e a extensão das unidades de conservação brasileiras, embora não esteja muito claro o seu impacto sobre a conservação da biodiversidade (May et al., 2012). Estudos empíricos mostram que, em alguns estados, a cobertura de unidades de conservação aumentou desde a introdução do ICMS-E, embora outros fatores também possam ter contribuído. Vários municípios criaram extensas áreas de Proteção Ambiental (APAs) sujeitas a tênues restrições de uso da terra (Tabela 5.1) com o objetivo único de aumentar suas receitas ( Ring et al., 2011). As APAs abrangem $98 \%$ das unidades de conservação municipais, geralmente com baixa eficácia em termos de proteção da biodiversidade. 
Entre os estados, apenas o Paraná, que introduziu o ICMS-E no início dos anos 1990, exige que as transferências de receitas sejam condicionadas a indicadores de qualidade da situação das unidades de conservação e de suas zonas de amortecimento e ao montante de recursos municipais destinados a ações de conservação. Potencialmente, esta abordagem seria mais eficaz no estímulo a boas práticas de gestão de áreas protegidas; contudo, implica em custos adicionais, inclusive para fiscalizações periódicas. De forma mais ampla, o êxito alcançado na expansão da cobertura de unidades de conservação parece estar correlacionado com a capacidade técnica e institucional nos níveis estaduais e municipais (Peters, 2012).

\section{Captação de recursos e parcerias internacionais}

O Brasil conseguiu firmar parcerias com organizações de cooperação e desenvolvimento bilaterais e multilaterais, com vistas a angariar fundos para o financiamento de atividades relacionadas às unidades de conservação. Apesar de os recursos internacionais representarem apenas uma pequena parcela do orçamento total do SNUC (8\% da dotação para unidades de conservação federais em 2008), ajudam a alavancar recursos nacionais, melhorar a eficácia da execução orçamentária e romper com alguns dos principais gargalos. No entanto, é provável que nos próximos anos, haja uma gradativa diminuição do fluxo de financiamentos provenientes de fontes internacionais.

O programa ARPA e seu Fundo de Áreas Protegidas (Box 5.1) são a mais importante fonte extra orçamentária de financiamento para unidades de conservação federais, estaduais e municipais na Amazônia. O Funbio foi designado pelo MMA para realizar a gestão financeira do programa (Box 5.8) que recebe grandes doações internacionais (a Alemanha é o maior doador). O Fundo Amazônia também ajuda a financiar o programa ARPA e outras atividades para controlar o desmatamento, inclusive em unidades de conservação (Capítulo 4).

\section{Box 5.8. Fundo Brasileiro para a Biodiversidade}

O Fundo Brasileiro para a Biodiversidade (Funbio) foi criado em 1996 como organização privada sem fins lucrativos para investir na conservação da biodiversidade. Sua criação, por iniciativa do MMA e do GEF, visava complementar esforços diretos do governo, com a justificativa de que uma instituição privada seria menos suscetível a descontinuidades governamentais e mais capaz de atrair financiamento privado. A principal atividade do Funbio é a assistência às unidades de conservação brasileiras. $O$ volume e escopo dessa assistência expandiu exponencialmente em 2003, com o lançamento do programa ARPA. Em 2014, uma em cada cinco unidades de conservação públicas no Brasil recebeu o apoio do Funbio, seja diretamente (ex., planos de manejo, obras de infraestrutura, aquisição de equipamentos, capacitação de conselhos gestores e resolução de questões fundiárias) ou indiretamente (projetos de pesquisa, gestão e monitoramento de espécies, capacitação para chefes de parques, educação ambiental).

Desde a sua criação, o Funbio mobilizou cerca de US $\$ 500$ milhões. Os recursos, em grande parte, provêm de instituições bilaterais e multilaterais (sendo o GEF um dos maiores doadores), do Fundo Amazônia e, em menor escala, de doações privadas. O Funbio desenvolveu esquemas criativos de financiamento para angariar recursos privados, a exemplo do programa Adote um Parque, pelo qual empresas privadas podem financiar infraestruturas e instalações num determinado parque. Também lançou mecanismos destinados a receber recursos provenientes de multas e compensações ambientais, e administra a troca de uma parcela da dívida externa por investimentos em conservação ambiental (acordos debt-for-swap).

Fonte: Funbio (2014b), Funbio + Áreas Protegidas: 2014. 


\section{Doações e engajamento do setor privado}

Com exceção das contribuições de alguns parceiros internacionais, as doações voluntárias privadas para o SNUC são pouco expressivas. Esta situação é atribuída à falta de incentivos fiscais para doadores e à fraca tradição de filantropia ambiental na cultura brasileira (Funbio, 2014b). Em geral, conseguir o apoio de empresas e empresários locais tem se comprovado difícil, e as perspectivas de parceria são limitadas. Por exemplo, a possibilidade de doadores associarem sua marca a alguma área específica ou serviço dentro de uma unidade de conservação é pequena. No entanto, iniciativas específicas de doação têm sido bem-sucedidas na obtenção de recursos adicionais; no programa Adote um Parque da Funbio, por exemplo, as empresas de energia OGX e MPX se comprometeram em apoiar os parques nacionais de Fernando de Noronha e dos Lençóis Maranhenses com mais de R 4 milhões cada, ao longo dos anos 20122018 (Funbio, 2014b).

Existem alguns poucos exemplos de empresas privadas que financiam infraestruturas e outros investimentos em unidades de conservação, entre elas, as que doaram ao programa ARPA (Natura, O Boticário e Anglo American). A Petrobras e a Vale têm patrocinado várias iniciativas de preservação da biodiversidade, inclusive em unidades de conservação. A Petrobras apoia o projeto Tamar para a preservação de tartarugas marinhas e suas áreas de desova como, por exemplo, o Parque Nacional Marinho de Fernando de Noronha. A Vale financia o manejo de mais de $12 \mathrm{mil} \mathrm{km}^{2}$ de áreas protegidas, localizadas nos biomas Mata Atlântica, Amazônia e Cerrado (de Bulhões Mossri, 2012).

\subsection{Avaliação da efetividade do manejo e conservação da biodiversidade}

\section{Efetividade do manejo}

Após a notável expansão das unidades de conservação ao longo dos anos 2000, o Brasil enfrenta agora o desafio de garantir a gestão efetiva dessas áreas. Em muitas delas, os gestores enfrentam grandes dificuldades em alcançar seus objetivos, agravadas - conforme mostrado em seções anteriores deste relatório - por problemas relacionados à falta de recursos humanos e financeiros.

Uma avaliação das unidades de conservação federais, realizada pelo WWF e o ICMBio (2012) constatou que, em 2010, o nível de eficácia de gestão em 30\% delas era baixo; no entanto, isto representou uma significativa melhora em relação à avaliação anterior, de 2006, na qual a porcentagem foi superior a 50\% (Figura 5.7) $\cdot{ }^{13}$ Melhorias foram constatadas, especialmente, no planejamento, nos recursos humanos e nas infraestruturas disponíveis. A eficácia da gestão apresentou melhoria, principalmente, nas reservas extrativistas, nas estações ecológicas e nas florestas nacionais, bem como nas unidades de conservação localizadas nos biomas Amazônia e Cerrado.

As áreas assistidas pelo programa ARPA (Box 5.1) mostraram um nível de efetividade maior que as outras unidades de conservação federais (Figura 5.7). Esse melhor desempenho pode ser diretamente atribuído à abordagem focada em resultados adotada pelo ARPA, ao significativo volume de recursos financeiros a ele direcionados e ao compromisso conjunto dos governos federal e estadual de contribuir com recursos humanos para a gestão das unidades participantes (WWF e ICMBio, 2012). O fato de terem que prestar contas aos doadores internacionais também contribuiu para essa melhoria de efetividade. 
Figura 5.7. A efetividade da gestão em muitas unidades de conservação é baixa Índice de efetividade do manejo de unidades de conservação federais, 2005-06 e 2010
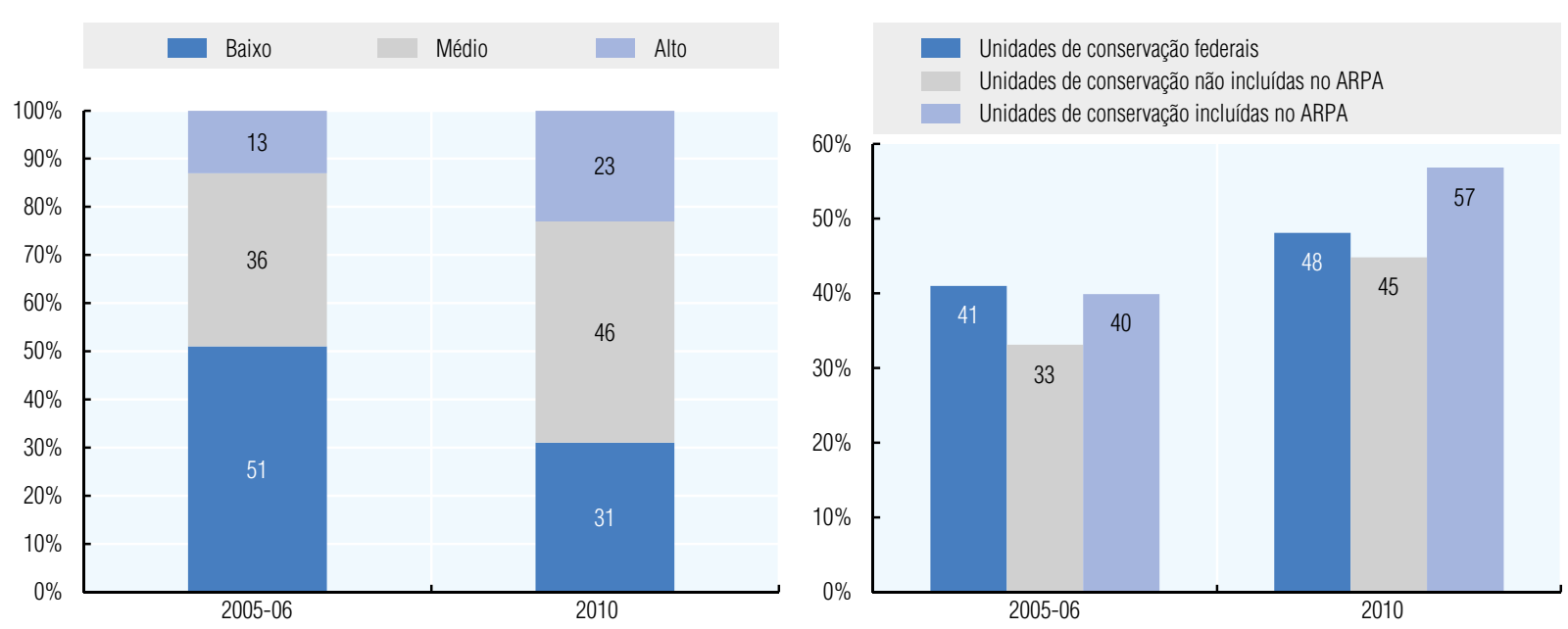

Obs.: Índice de efetividade da gestão de unidades de conservação, segundo a metodologia de Avaliação Rápida e Priorização do Manejo de Áreas Protegidas (RAPPAM). A efetividade geral do desempenho (com base na avaliação de contexto, planejamento, insumos, processo e resultados) é expressa como porcentagem da efetividade máxima que poderia ser alcançada. Os intervalos $<40 \% ; 40 \%-60 \%$; e $>60 \%$ definem as respectivas classes de baixa, média e alta efetividade de gestão.

Fonte: WWF e ICMBIO (2012), Avaliação comparada das aplicações do método Rappam nas unidades de conservação federais, nos ciclos 2005-06 e 2010.

Não obstante essa melhoria, o desempenho geral da gestão é insatisfatório. Uma avaliação mais recente das unidades de conservação federais e estaduais no bioma Amazônia constatou que, em apenas 4\%, o grau de implementação e gestão foi suficiente para cumprir com os objetivos definidos (TCU, 2013). Embora a disponibilidade de recursos financeiros tenha aumentado nos últimos anos, a efetividade da execução desses recursos piorou, refletindo uma carência de capacidades de gestão e entraves burocráticos. O baixo nível de efetividade da gestão é motivo de preocupação, mormente à luz das crescentes pressões sobre as unidades de conservação de forma geral, entre elas, a implantação de infraestruturas, a caça predatória, a extração de recursos naturais e invasões de espécies exóticas (WWF e ICMBio, 2012). De forma mais ampla, o fraco desempenho da gestão resulta em desperdício de potenciais oportunidades econômicas, sociais e ambientais das unidades de conservação, especialmente no que tange ao uso público (turismo, lazer e educação), ao manejo florestal sustentável e a outras oportunidades de geração de renda para as comunidades tradicionais (Seção 5).

Embora muitos avanços tenham sido alcançados no cadastramento, por meio do Cadastro Nacional de Unidades de Conservação (CNUC), especialmente no que diz respeito às unidades de conservação federais e estaduais, as informações disponibilizadas são, geralmente, limitadas (dados jurídicos e espaciais básicos), sem muito conteúdo sobre gestão e atividades. Até o início de 2014, apenas 40\% das unidades cadastradas haviam fornecido estatísticas sobre quadro de servidores e número de visitantes (SEMEIA, 2014). Quando totalmente implementado, o CNUC poderá servir de importante fonte de informações para avaliação da efetividade das unidades de conservação (Prates e Sousa, 2014).

\section{Efetividade socioambiental}

O monitoramento e a avaliação da efetividade da gestão requerem a compreensão das tendências da biodiversidade nas unidades de conservação e da evolução das condições socioeconômicas das comunidades locais afetadas. No entanto, na maioria 
das unidades, o monitoramento não é realizado de forma sistemática. Dois terços dos gestores das unidades de conservação federais e estaduais no bioma Amazônia não realizam, há anos, o monitoramento da biodiversidade, em grande parte por falta de infraestruturas e equipamentos e por dificuldades de acesso (TCU, 2013). Mais da metade dos gestores das reservas extrativistas e de desenvolvimento sustentável da Amazônia informam que carecem de ferramentas para o monitoramento dos resultados das atividades de desenvolvimento social e ambiental.

O ICMBio mantém um sistema eletrônico (SISBIO) que emite autorizações para que pesquisadores possam coletar material biológico em unidades de conservação federais e que reúne as informações resultantes das pesquisas. O sistema vem monitorando recifes de corais em áreas de proteção marinhas, desde 2002. Os resultados do monitoramento sugerem que os estoques pesqueiros são mais prolíficos e que a diversidade de espécies é mais rica em áreas de exclusão de pesca do que em unidades de uso sustentável marinho. Desde 2010, o ICMBio realiza programas de monitoramento in loco em várias unidades de conservação federais nos biomas Amazônia, Mata Atlântica, Caatinga e Cerrado.

Esses programas poderiam ser ampliados de modo a gerar as informações necessárias para a avaliação da efetividade de ações de conservação. De forma mais ampla, o Brasil deve investir mais no monitoramento e avaliação da efetividade das unidades de conservação e apurar seus benefícios ambientais, sociais e econômicos, com vistas a conquistar maior apoio político e social em favor das unidades de conservação e mobilizar os recursos necessários.

\section{Uso sustentável das unidades de conservação}

\subsection{Turismo e lazer}

Segundo o Fórum Econômico Mundial, em termos de recursos naturais, o Brasil tem o maior potencial turístico do mundo, mas figura apenas no $53^{\circ}$ lugar no ranking de competitividade do turismo (TCU, 2013). Portanto, ainda há espaço para explorar melhor as oportunidades econômicas relacionadas à riqueza natural do Brasil e suas unidades de conservação. Estima-se que grandes benefícios econômicos poderiam fruir da visitação pública (turismo, lazer e educação ambiental) em unidades de conservação e que, por si só, os parques nacionais brasileiros poderiam gerar entre $\mathrm{R} \$ 1,6$ e 1,8 bilhão anualmente, até 2016 (Medeiros e Young, 2011; ver também Box 5.3). A Semeia (2014) estima que a renda potencial do turismo em unidades de conservação poderia alcançar R 53 bilhões, ao longo de 10 anos.

O número de visitantes às unidades de conservação federais mais do que triplicou entre 2006 e 2013, chegando a 6,3 milhões (Figura 5.8). Os parques nacionais atraem a grande maioria desses visitantes. Em 2013, apenas os parques nacionais de Iguaçu e da Tijuca responderam por quase $60 \%$ dos visitantes. O investimento público em infraestrutura e serviços, no âmbito de programas como o Parques da Copa e o Turismo nos Parques, bem como concessões a operadores privados tem ajudado a aumentar a presença de turistas (ICMBio, 2012b). As concessões a operadores privados, por exemplo, foram imprescindíveis para o fomento do turismo no Parque Nacional do Iguaçu, por permitirem a construção de infraestruturas turísticas, tais como estacionamentos, centro de visitantes, transporte interno nos parques, serviços de alimentação e bebidas e atividades de lazer e aventura. Concessões deste tipo também vêm sendo outorgadas a 
outros parques importantes, como o da Tijuca e de Fernando de Noronha, e há previsão de novas concessões, nos próximos anos (ICMBio, 2012b).

Embora em expansão, a visitação pública ainda é incipiente. Entre as categorias de unidades de conservação - com exceção de duas - todas estão abertas à visitação; contudo, grande parte recebe pouquíssimas visitas (algumas, apesar de receber visitas, não mantém qualquer registro). Em 2012, dos 68 parques nacionais, apenas 26 encontravam-se oficialmente abertos ao turismo; o restante recebeu alguns visitantes, mas sem maior planejamento e controle (ICMBio, 2012a). Segundo uma pesquisa realizada no mesmo ano entre gestores de unidades de conservação, cerca de um terço das unidades não recebeu nenhum visitante; e quase 50\% receberam menos de 50 mil visitantes ao ano. Ademais, apenas $17 \%$ das unidades de conservação com potencial para receber visitantes gerou alguma receita proveniente da visitação pública; sendo essa participação ligeiramente maior para os parques nacionais (Semeia, 2012b). ${ }^{14} \mathrm{Em}$ grande parte, a falta de infraestrutura e de serviços adequados é a principal causa dessa situação (TCU, 2013; Semeia, 2012b), conforme mostra o caso do Parque Nacional da Chapada dos Veadeiros (Box 5.9). Em outros casos, a organização de sistemas de cobrança de ingressos tem sido uma das maiores dificuldades.

\section{Figura 5.8. O número de visitantes a parques nacionais vem aumentando} Visitantes às unidades de conservação, 2006-13
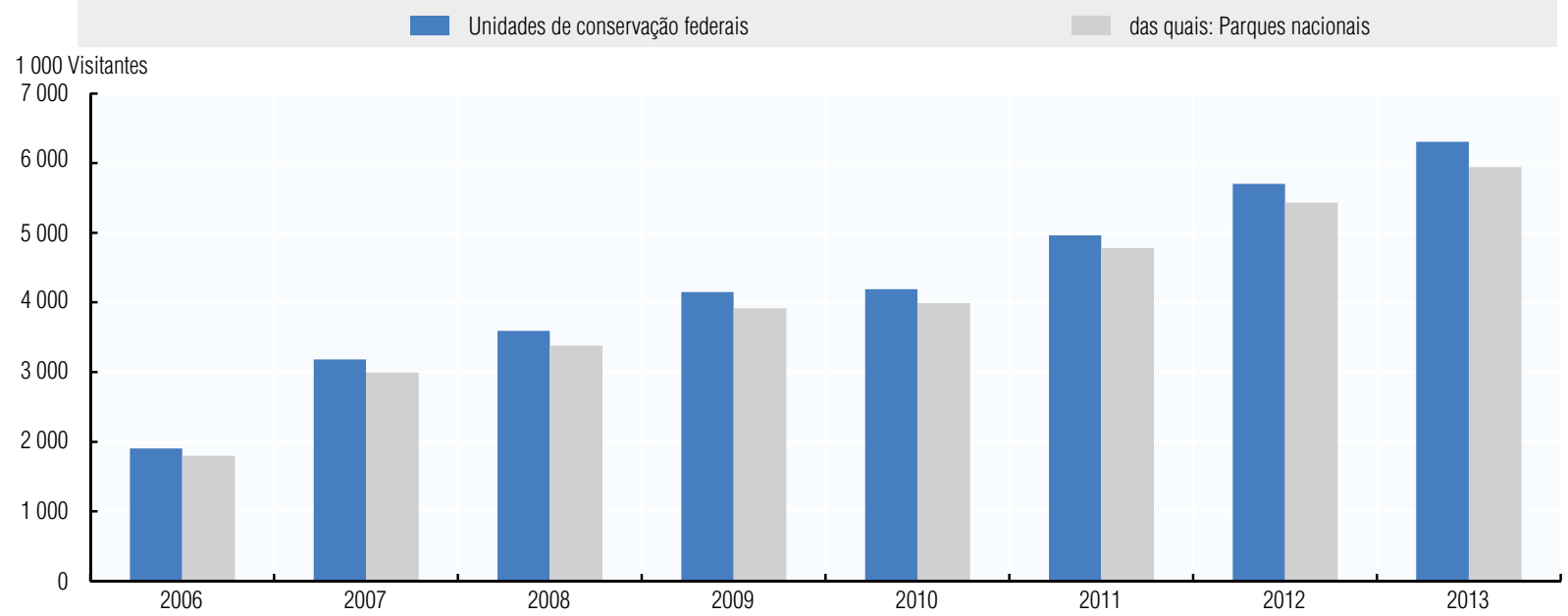

Fonte: ICMBio (2014), Relatório de Gestão 2013.

A ampliação da visitação pública poderia ajudar a melhorar a sustentabilidade financeira do SNUC e a mobilizar apoio social às unidades de conservação, conforme mostra o exemplo do Canadá (Box 5.10). O turismo e outras formas de visitação pública em unidades de conservação são uma fonte significativa de receitas em outros países. $\mathrm{Na}$ África do Sul, por exemplo, 75\% do orçamento do órgão público responsável pela administração dos parques nacionais provêm de taxas pagas por concessionários e de investimentos privados relacionados ao turismo (Semeia, 2012a). Seria possível ampliar a arrecadação de recursos, por meio da cobrança de ingressos e pela prestação de serviços relacionados ao turismo (ex., transportes, alimentação/bebidas e lazer). Em 2011, o ICMBio recebeu $\mathrm{R} \$ 24$ milhões provenientes de ingressos e de serviços oferecidos em parques federais, sendo que quatro parques responderam pela maior parte dessa receita (ICMBio, 2012a). 


\section{Box 5.9. O potencial turístico inexplorado do Parque Nacional da Chapada dos Veadeiros}

O Parque Nacional da Chapada dos Veadeiros, integrante do Patrimônio Natural da Humanidade, engloba vegetação única do bioma Cerrado, com centenas de cachoeiras e outros corpos d'água e trilhas para caminhada. É um dos destinos prediletos de fins de semana e feriados das pessoas da região Centro-Oeste, especialmente de Brasília. Em 2009, um total de 22.950 turistas visitou o parque (Medeiros e Young, 2011). Apenas uma pequena parte da área protegida conta com infraestrutura adequada para o turismo e há apenas uma entrada oficial, no distrito de São Jorge, município de Alto Paraíso de Goiás. A cidade de Cavalcante, onde o turismo vem crescendo em virtude das tradições populares, cachoeiras e trilhas em terrenos privados, não tem qualquer acesso ao parque.

Apesar do potencial de geração de receita por meio da cobrança de ingressos, e da demanda reprimida por serviços como venda de alimentos, bebidas e souvenirs, o ICMBio carece de pessoal e de infraestruturas para implantar e explorar esses serviços. Entraves burocráticos e restrições administrativas, bem como limitações de capacidade no próprio parque, vem frustrando a organização de um processo de licitação para a concessão de serviços relacionados ao turismo. Em consequência, o parque continua pouco conhecido e pouco visitado por turistas brasileiros e internacionais, o que resulta em oportunidades desperdiçadas de geração de receitas e de mobilização de apoio político e social para a causa da preservação ambiental.

\section{Box 5.10. O valor da visitação a áreas protegidas: $\mathbf{O}$ caso da Parks Canada}

A Parks Canada, agência encarregada das áreas protegidas, realiza pesquisas periódicas sobre as atitudes da população canadense acerca dos parques naturais. A Pesquisa Nacional Canadense de 2012 revelou que a visitação pública é fundamental para despertar o interesse da população pelas áreas preservadas e mobilizar apoio às instituições que as administram.*

Em 2012, mais de três quartos das pessoas que haviam visitado um dos parques nacionais do país reportaram que nutriam um "sentimento de identificação" para com os mesmos. Apenas cerca de $15 \%$ das pessoas que não haviam visitado um parque nacional foram capazes de dizer o mesmo. A visitação é fator importante para que as pessoas desenvolvam um senso de responsabilidade (stewardship) para com seus parques nacionais. Em 2012, mais de nove em cada dez pessoas que haviam visitado parques nacionais opinaram com firmeza que os parques existem para serem apreciados, não apenas pelas pessoas de hoje, mas também pelas gerações futuras; e quase $80 \%$ que iriam sentir falta dos parques nacionais, caso desaparecessem; entre as pessoas que não haviam visitado um parque, ambas as porcentagens foram menores.

Os canadenses que haviam visitado um parque nacional se revelaram mais propensos a aprovar as atividades realizadas pela Parks Canada no cumprimento de suas atribuições. Em 2012, aproximadamente metade dos visitantes entrevistados eram favoráveis ao uso do dinheiro do contribuinte para a criação de novos parques, em contraste com $40 \%$ das pessoas que nunca haviam visitado um parque. Cerca de $80 \%$ dos visitantes também se posicionaram a favor do uso de recursos públicos para a manutenção dos parques nacionais existentes, em contraste com cerca de metade dos não visitantes.

*A pesquisa foi realizada por telefone, em fevereiro e março de 2012. No total, 3.786 adultos responderam. Visitantes: aqueles que haviam visitado um parque nacional administrado pela Parks Canada nos últimos três anos; não visitantes: aqueles que nunca haviam visitado um parque nacional administrado pela Parks Canada.

Fonte: Parks Canada (2012), The VALUE of Visiting...continues.

As unidades de conservação ainda não estão totalmente integradas à estratégia nacional do turismo brasileiro; poucos turistas têm ciência de que algumas das principais atrações turísticas do país estão localizados em unidades de conservação (TCU, 2013). Uma pesquisa realizada em 2012 constatou que 44\% dos brasileiros não sabiam 
o que é uma unidade de conservação; e que apenas $1 \%$ dos que tinham conhecimento dessas unidades sabia que o lazer e o turismo fazem parte da sua finalidade (MMA, 2012). A legislação e as normas que regem as unidades de conservação parecem pouco adequadas à promoção do turismo e da visitação pública. Isto se deve, em parte, ao fato de que as unidades de conservação criadas ao longo dos anos 2000 tinham como objetivo principal o controle do desmatamento e que, até então, não havia sido elaborada qualquer estratégia global de promoção à visitação pública. Recentemente, contudo, o governo vem intensificando ações no sentido de promover o uso público (Burns e Moreira, 2013). Ainda há espaço para uma melhor integração das unidades de conservação à estratégia brasileira de fomento ao turismo, bem como para a capacitação de chefes de parques para a elaboração de estratégias e formação de parcerias que ampliem a atratividade de serviços relacionados ao turismo e à educação ambiental.

São poucos os exemplos de parcerias com empresas privadas e organizações sem fins lucrativos para o gerenciamento de serviços de visitação. A Semeia (2012b) constatou que, apesar de a maioria dos gestores demonstrar interesse, apenas $13 \%$ das unidades de conservação contavam com contratos de PPP ou concessões em vigor. Os principais obstáculos apontados foram: entraves regulatórios, falta de planos de gestão adequados e carência de recursos e de capacidades administrativas. Ao mesmo tempo, empresas privadas (especialmente as de pequeno e médio porte) geralmente carecem das capacidades necessárias para se adequar às exigências legais para celebrar parcerias com órgãos do governo. A elaboração e negociação de projetos de convênio e de acordos de parceria são processos que exigem tempo e recursos e que, muitas vezes, extrapolam a capacidade dos chefes de parques. Foram tomadas algumas medidas para estimular a adoção de PPPs e concessões, inclusive por meio de programas de capacitação. Em 2011, o MMA e o MPOG autorizaram o lançamento de contratos-piloto de PPP em dez parques nacionais identificados por seu alto potencial turístico. Um maior aproveitamento de PPPs e concessões seria benéfico para o Brasil, pois possibilitaria melhorias das infraestruturas e de serviços para o turismo e a visitação pública, superando a escassez de recursos públicos e limitações de capacidades.

\subsection{Uso sustentável e concessões florestais}

Desde 2008, o governo vem outorgando a empresas privadas concessões para manejar florestas públicas e explorar a extração de madeira em bases sustentáveis; contudo, tais concessões atualmente respondem por apenas uma pequena parcela da área potencial (Capítulo 4). O MMA estimou, para o período 2010-2020, as potenciais receitas de concessões florestais em cerca de $R \$ 190$ milhões ao ano (MMA, 2010). A maioria das florestas com potencial para concessões encontra-se fora de unidades de conservação; mas algumas unidades como, por exemplo, florestas nacionais (FLONAs) podem ser objeto de concessões. Concessões de manejo florestal de larga escala podem ser onerosas; contudo, a extração de madeira praticada em pequena escala por comunidades tradicionais residentes em florestas públicas é potencialmente mais rentável. $\mathrm{Na}$ Floresta Nacional do Tapajós no Estado do Pará, por exemplo, a exploração madeireira de pequena escala gerou mais de R\$ 3 milhões em 2012 (TCU, 2013).

Não obstante o interesse dos gestores de florestas nacionais, a utilização de concessões florestais em unidades de conservação é limitada. No início dos anos 2000, das 65 florestas nacionais, apenas 3 haviam outorgado concessões, sendo parte da receita revertida às unidades de conservação (Funbio, 2014A). Em parte, esta situação se explica 
pelo fato de a maioria das unidades de conservação ainda não contar com um plano de gestão aprovado - etapa indispensável para a realização dessas atividades - ou com as necessárias disposições de zoneamento (TCU, 2013). Esses problemas se somam aos desafios comuns enfrentados pelas concessões de manejo florestal sustentável em áreas fora de unidades de conservação, entre eles, carências de capacidade técnica, falta de infraestruturas e conflitos fundiários mal resolvidos (Capítulo 4).

\subsection{Uso sustentável de recursos naturais por comunidades locais}

Muitas das unidades de conservação brasileiras são habitadas por pequenas comunidades tradicionais que dependem do aproveitamento de recursos naturais (ex., peixe, madeira, castanha, óleos, borracha) para sua subsistência. Para alcançar a gestão eficaz dessas áreas, é preciso que sejam oferecidas às comunidades locais oportunidades econômicas significativas de comercialização de seus recursos naturais. Embora essas comunidades tenham, em geral, um bom conhecimento a respeito do aproveitamento dos seus recursos, costumam carecer da experiência necessária para a prática da agricultura, do manejo florestal e da pesca sustentáveis, em escala que atenda às demandas de mercado e, ainda, enfrentam dificuldades de comercialização da sua produção (Prates e Sousa, 2014). Essas carências, por sua vez, podem incorrer em risco de aumento de pressões sobre a base de ativos naturais.

Por exemplo, nos anos 2000, houve um aumento no índice de desmatamento na Reserva Extrativista Chico Mendes no Acre, devido, em parte, à queda da demanda e aos baixos preços da borracha e da castanha, bem como ao descontrole de mercados locais de carne bovina, combinação esta que tornou mais atraente a derrubada da floresta para a formação de pastos (TCU, 2013). Da mesma forma, a baixa rentabilidade sobre a coleta de caranguejos na Reserva Extrativista Marinha de Soure, no Estado do Pará, somada à dificuldade do seu transporte até mercados urbanos, poderia resultar na intensificação da coleta e em consequentes pressões sobre o ecossistema dos manguezais. ${ }^{15}$

As reservas extrativistas ainda enfrentam problemas de implementação, entre eles, a falta de planos de manejo e de acordos de gestão junto às comunidades locais para disciplinar o uso dos recursos naturais. Ademais, a má delimitação e a falta de sinalização em algumas áreas geram incertezas quanto aos limites das unidades de conservação e às restrições de uso associadas. Apenas $25 \%$ das unidades de conservação do bioma Amazônia são delimitados e sinalizados (TCU, 2013). O quadro de pessoal é insuficiente para gerir as reservas extrativistas. No início dos anos 2010, por exemplo, o quadro de pessoal da Reserva Extrativista Tapajós-Arapuins no Estado do Pará, contava com apenas três servidores para administrar uma área de mais de 6,7 milhões de km², com cerca de 18 mil habitantes (TCU, 2013).

Além de carecer de formas viáveis de subsistência, grande parte dos habitantes das reservas extrativistas reivindica melhor acesso aos serviços sociais, como educação, saúde, habitação e saneamento. Trata-se de demandas que extrapolam as atribuições do MMA e de outros órgãos ambientais e que requerem maior coordenação intersetorial.

Entre os diversos instrumentos de política direcionados à abordagem dessas questões, estão os programas de transferência condicionada de renda - o Bolsa Floresta e o Bolsa Verde - e o Plano Nacional de Promoção das Cadeias de Produtos da Sociobiodiversidade (PNPSB). Conforme mencionado no Capítulo 4, o objetivo do Bolsa Floresta e do Bolsa 
Verde é melhorar a qualidade de vida das comunidades tradicionais e carentes que tiram seu sustento do aproveitamento de recursos naturais, recompensando-as pelo compromisso de combater o desmatamento e de praticar a sustentabilidade ambiental. Devido ao fato de muitas das famílias beneficiárias habitar unidades de conservação, esses programas aumentam a viabilidade econômica dessas comunidades. O PNPSB inclui uma política de preços mínimos para produtos da sociobiodiversidade. Considerando que famílias que residem em uma unidade de conservação de uso sustentável tendem a ter maior facilidade de acesso aos benefícios desses programas, algumas comunidades que tiram seu sustento do extrativismo vêm reivindicando a criação de reservas extrativistas nas áreas em que vivem e trabalham.

\section{Recomendações sobre áreas protegidas Expansão e consolidação do Sistema Nacional de Unidades de Conservação}

- Fortalecer a cooperação interinstitucional, com vistas a equacionar questões fundiárias dentro de unidades de conservação existentes ou novas unidades propostas, e melhorar a prestação de serviços sociais às comunidades vivendo nas reservas de uso sustentável.

- Expandir mais ainda a área sob proteção ambiental para o pleno cumprimento das metas nacionais para 2020 e de compromissos internacionais (inclusive através de unidades de conservação oficiais, terras indígenas e áreas de reserva, conforme determina o Código Florestal); priorizar áreas com alto valor de biodiversidade, onde pressões provocadas pela implantação de infraestruturas, urbanização e agricultura são mais altas; expandir a cobertura de áreas protegidas em zonas marinhas e costeiras para alcançar a meta Aichi.

- Desenvolver uma estratégia para a consolidação territorial de áreas protegidas; estimular o uso de mecanismos financeiros e de compensação previstos na legislação de áreas protegidas e no Código Florestal, a partir do momento em que o CAR esteja em pleno vigor; verificar a viabilidade de acordos contratuais transitórios com proprietários de áreas dentro de unidades de conservação, para assegurar a compatibilidade de uso da terra, até que a situação fundiária seja esclarecida.

\section{Gestão de áreas protegidas}

- Desenvolver uma estratégia financeira abrangente para o SNUC, com vistas a reduzir a dependência sobre o orçamento público e financiamentos internacionais; investigar fontes alternativas de financiamento, incluindo pagamentos por serviços ambientais, ingressos e benefícios gerados a partir de recursos genéticos.

- Intensificar esforços para desenvolver planos de manejo para áreas protegidas e avaliar sua implementação; garantir que os planos estabeleçam prioridades, metas e indicadores de progresso claros.

- Desenvolver programas de capacitação e fortalecimento de competências direcionados a gestores e funcionários de unidades de conservação, com vistas a aumentar a eficácia da gestão; promover as redes de gestores de áreas protegidas, a troca de experiências e as melhores práticas.

- Dar continuidade periódica à avaliação da eficiência e da eficácia da gestão de áreas protegidas; dar maior estímulo aos gestores de áreas protegidas para que forneçam informações precisas e oportunas ao CNUC; sistematicamente avaliar essas informações, com vistas a produzir recomendações em nível de sistema.

- Desenvolver métodos padronizados de monitoramento da biodiversidade, com vistas a gerar toda a informação necessária para a avaliação da eficácia ambiental de áreas protegidas; expandir ainda mais programas federais de monitoramento. 


\section{Recomendações sobre áreas protegidas (Continuação)}

Intensificar a visitação pública

- Integrar unidades de conservação às estratégias nacionais e estaduais de turismo e identificar áreas de alto potencial turístico; desenvolver produtos turísticos vinculados às áreas protegidas.

- Ampliar o uso de concessões e de outras parcerias público-privadas para a visitação púbica e o turismo em áreas protegidas; simplificar os procedimentos e melhorar a capacidade de servidores públicos e gestores de áreas protegidas para a elaboração e negociação de contratos; implementar programas-piloto, para testar e desenvolver novos modelos de gestão.

- Considerar a inclusão de visitação regular de grupos de crianças em idade escolar a áreas protegidas.

\section{Notas}

1. O SNUC foi instituído pela Lei 9.985/2000 e é regulamentado pelo Decreto 4.340/2002.

2. Este capítulo utiliza o termo "unidade de conservação" para referir-se a áreas protegidas stricto sensu, definidas e regulamentadas pela lei do SNUC.

3. Em 2010, as partes da Convenção sobre Diversidade Biológica adotaram o Plano Estratégico para a Biodiversidade 2011-2020, com o objetivo de interromper a perda da biodiversidade e ampliar os benefícios por ela proporcionados. O Plano Estratégico inclui 20 metas (Metas de Aichi) organizadas em torno de cinco objetivos estratégicos.

4. Bioma é uma grande comunidade natural de flora e fauna que ocupa uma região geográfica.

5. O MMA vem elaborando uma metodologia para avaliar o estado ecológico das terras indígenas, bem como sua gestão, demarcação e regularização fundiária, para verificar sua contribuição às metas nacionais de áreas protegidas (MMA, 2015a). A contribuição das APPs e RLs só será conhecida após o pleno cadastramento dessas terras no CAR (Capítulo 4).

6. Em maio de 2015, o ICMBio foi responsável pela gestão de 320 unidades de conservação (todas as unidades federais, exceto as Reservas Particulares do Patrimônio Natural).

7. Corredores ecológicos são áreas de habitat que ligam populações de fauna e flora separados por atividades humanas, abertura de estradas ou exploração madeireira.

8. O orçamento disponível para unidades de conservação estaduais e municipais não foi estudado.

9. O MMA, por exemplo, direcionou $20 \%$ do seu orçamento de 2008 para o SNUC, e o Serviço Florestal Brasileiro alocou $30 \%$ para as florestas nacionais do SNUC. O IBAMA contribuiu para o orçamento do SNUC através de suas atividades de prevenção e controle de incêndios (MMA, 2009).

10. Os recursos de compensação ambiental podem ser usados para atividades como a regularização fundiária e demarcação de terras, planos de gestão, aquisição de bens e serviços, estudos técnicos e programas de educação ambiental.

11. Em 2011, apenas Portugal havia acompanhado o Brasil, embora sistemas semelhantes tenham sido propostos na Índia e na Indonésia.

12. Em 2009, os 11 estados que haviam implementado o ICMS-E receberam entre US\$ 312 milhões e US\$ 1,5 bilhão para distribuição entre os municípios (MMA, 2010).

13. A avaliação foi baseada na ferramenta Rapid Assessment and Prioritization of Protected Area Management (RAPPAM) metodologia adotada pela WWF, reconhecida internacionalmente para avaliação da eficácia da gestão das áreas protegidas. Entende-se como eficácia a capacidade de atingir os objetivos da área protegida.

14. Os parques nacionais geram entre $R \$ 50$ mil e $R \$ 1$ milhão ao ano (Semeia, 2012b).

15. Aproximadamente 10 mil pessoas vivem na reserva, onde a catação de caranguejo é a principal atividade econômica. O transporte inadequado de caranguejos resulta na morte de muitos caranguejos, que deveriam ser comercializados vivos. 


\section{Referências}

Bovarnick, A. et al. (2010), Financial Sustainability of Protected Areas in Latin America and the Caribbean: Investment Policy Guidance, PNUD e The Nature Conservancy, www.undp.org/content/dam/aplaws/publication/ en/publications/environment-energy/www-ee-library/biodiversity/financial-sustainability-of-protected-areasin-latin-america-and-the-caribbean/financial_sus_pa_lac.pdf.

Burns, R. e J. Moreira (2013), "Visitor Management in Brazil’s Protected Areas: Benchmarking for Best Practices in Resource Management”, The George Wright Forum, Vol. 30, No. 2, pp. 163-170.

CEPAL, GIZ e IPEA (2011), Avaliação do Plano de Ação para a Prevenção e Controle do Desmatamento na Amazônia Legal: PPCDAm: 2007-2010, CEPAL, Brasília, IPEA, Brasília, e GIZ GMbH, Bonn, www. cepal.org/ dmaah/publicaciones/sinsigla/xml/7/45887/IPEA_GIZ_Cepal_2011_Avaliacao_PPCDAm_2007-2011_web.pdf.

De Bulhões Mossri, B. (2012), Biodiversidade e Indústria: Informações para uma Gestão Responsável, CNI, Brasília.

Funai (2015), “Terras Indígenas”, www.funai.gov.br/index.php/indios-no-brasil/terras-indigenas.

FUNBIO (2014b), Funbio and Protected Areas. 2014, Rio de Janeiro, www.funbio.org.br/wp-content/uploads/2014/11/ Livro_Funbio_Areas_Protegidas_Web_Ing.pdf.

FUNBIO (2014a), O futuro do ambiente financeiro das áreas protegidas, Rio de Janeiro, www.funbio.org. br/o-funbio/tendencias-o-futuro-doambiente-financeiro-das-areas-protegidas.

FUNBIO (2012), Quanto custa o Programa Áreas Protegidas da Amazônia? Uma modelagem financeira para as Unidades de Conservação do Arpa, Rio de Janeiro.

FUNBIO (2009), Quanto custa uma unidade de conservação federal? Uma visão estratégica para o financiamento do Sistema Nacional de Unidades de Conservação (Snuc), Rio de Janeiro.

Gurgel, H. et al. (2009), "Unidades de conservação e o falso dilema entre conservação e desenvolvimento", Boletim Regional, Urbano e Ambiental, No. 3, pp. 109-120. IBGE (2014a), Perfil dos Estados Brasileiros 2013, Rio de Janeiro.

ICMBio (2012b), "Com o ICMBio, parques receberam mais investimentos e visitação triplicou”, Brasília, www.icmbio.gov.br/portal/comunicacao/noticias/icmbio-5-anos/3295-com-o-icmbio-parques-receberam-maisinvestimentos-e-visitacao-triplicou.html.

ICMBio (2012a), "Dos 68 parques nacionais, 26 estão oficialmente abertos ao turismo”, www.icmbio.gov. br/portal/comunicacao/noticias/4-geral/3280-dos-69-parques-nacionais-26-estaooficialmente-abertos-aosturistas.html.

ICMBio (2014), Relatório de Gestão 2013, Brasília, www.icmbio.gou.br/portal/images/stories/o-que-somos/relatorio gestaoicmbio2013_.pdf.

Irving, M.A. (2010), "Áreas protegidas e inclusão social - uma equação possível em políticas públicas de proteção da natureza no Brasil?”, Sinais Sociais, Vol. 4, No. 12, pp. 122-147.

IUCN (2008), Guidelines for Applying Protected Area Management Categories, International Union for Conservation of Nature and Natural Resources, Gland.

Jenkins, C.N. e L. Joppa (2009), "Expansion of the Global Terrestrial Protected Area System”, Biological Conservation, Vol. 142, No. 10, pp. 2166-2174.

Kinouchi, M. (2014), "Plano de manejo: fundamentos para a mudança”, em Bensusan e Prates (2014), A diversidade cabe na unidade? Áreas protegidas no Brasil, pp. 220-248, Mil Folhas IEB, Brasília.

Mascia, M.B. et al. (2014), "Protected area downgrading, downsizing, and degazettement (PADDD) in Africa, Asia, and Latin America and the Caribbean, 1900-2010", Biological Conservation 169, pp. 355-361. 
May, P. et al. (2012), “The 'Ecological' Value Added Tax (ICMS-Ecológico) in Brazil and its effectiveness in State biodiversity conservation: a comparative analysis", trabalho apresentado na 12th Biennial Conference of the International Society for Ecological Economics, Rio de Janeiro.

Medeiros, R. e C. Young (2011), Contribuição das unidades de conservação brasileiras para a economia nacional: Relatório final, PNUMA -WCMC, Brasília.

Mendonça, F.C., V. Talbot e H.S. Macedo (2014), "Reflexões sobre participação social em unidades de conservação e a contribuição do Instituto Chico Mendes de Conservação da Biodiversidade" em Bensusan e Prates (2014) A diversidade cabe da unidade ? Áreas protegidas no Brasil, pp. 268-306, Mil Folhas IEB, Brasília.

MMA (2015b), "Áreas protegidas”, Brasília, www.mma.gov.br/areas-protegidas.

MMA (2015c), “Cadastro Nacional de Unidades de Conservação”, Brasília, www.mma.gou.br/areas-protegidas/ cadastro-nacional-de-ucs.

MMA (2009), Pilares para a Sustentabilidade Financeira do SNUC, $2^{\text {a }}$ edição, Brasília.

MMA (2010), Quarto Relatório Nacional para a Convenção sobre a Diversidade Biológica, Brasília.

MMA (2012), O que o Brasileiro Pensa do Meio Ambiente e do Consumo Sustentável: Pesquisa Nacional de Opinião: Principais Resultados, Brasília.

MMA (2015a), Quinto Relatório Nacional para a Convenção sobre a Diversidade Biológica, Brasília.

OCDE (2013), OECD Environmental Performance Reviews: South Africa 2013, OECD Publishing, Paris, http:// dx.doi.org/10.1787/9789264202887-en.

OCDE-CEPAL (2014), OECD Environmental Performance Reviews: Colombia 2014, OECD Publishing, Paris, http:// dx.doi.org/10.1787/9789264208292-en.

OCDE-FAO (2015), "Brazilian agriculture: Prospects and challenges”, em OECD/FAO, OECD-FAO Agricultural Outlook 2015, OECD Publishing, Paris, http://dx.doi.org/10.1787/agr_outlook-2015-5-en.

Parks Canada (2012), The VALUE of Visiting...continues, Parks Canada, Gatineau.

Peters, S. (2012), "The Role of Green Fiscal Mechanisms in Developing Countries: Lessons Learned - Case Study", BID, Technical Notes IDB-TN-364, March.

Prates, A.P. (2014), “Oceanos, a nova fronteira de conservação no Brasil: desafios para o cumprimento da meta 11 de Aichi”, em Bensusan e Prates (2014), A diversidade cabe da unidade? Áreas protegidas no Brasil, pp. 82-118.

Prates, A.P e N. Sousa (2014), "Panorama geral das áreas protegidas no Brasil: desafios para o cumprimento da meta 11 de Aichi”, em Bensusan e Prates (2014) A diversidade cabe da unidade? Áreas protegidas no Brasil.

Ring, I. et al. (2011), "Assessing Fiscal Transfers for Conservation Policies and Their Role in a Policy Mix", Trabalho apresentado no 9th International Conference of the European Society for Ecological Economics, Istanbul, www.esee2011.org/registration/fullpapers/esee2011_761c79_1_1304087168_4605_2321.pdf.

SEMEIA (2012b), Análise 2012: Uso Público e Parcerias para Conservação e Desenvolvimento, Instituto Semeia, São Paulo.

SEMEIA (2012a), "Braços adicionais para conservação: o papel estratégico das parcerias com o setor privado”, em NEXUCS, Unidades de Conservação no Brasil - o Caminho da Gestão para Resultados, Instituto Semeia, São Paulo.

SEMEIA (2013), Semeia Annual Report 2013, Instituto Semeia, São Paulo.

SEMEIA (2014), Unidades de conservação no Brasil: a contribuição do uso público para o desenvolvimento socioeconômico, Instituto Semeia, São Paulo. 
Soares-Filho, B. et al. (2014), “Cracking Brazil’s Forest Code”, Science, Vol. 344, No. 6182, pp. 363-364.

TCU (2013), Relatório de Auditoria Operacional: Governança das Unidades de Conservação do Bioma Amazônia, Brasília.

Trzyna, T. (2014), Urban Protected Areas: Profiles and Best Practice Guidelines, Best Practice Protected Area Guidelines Series No. 22, International Union for Conservation of Nature, Gland.

Veríssimo, A. et al. (eds) (2011), Protected Areas in the Brazilian Amazon: Challenges and Opportunities, Imazon, Belém; Instituto Socioambiental, São Paulo, www.socioambiental.org/banco_imagens/pdfs/10381.pdf.

Vilela, R.O. (2013), “Quilombos contemporâneos e a proteção da Biodiversidade: o caso da Reserva Biológica da Mata Escura e da Comunidade Mumbuca”, Vale do Jequitinhonha/MG, 2013, Dissertação, UnB, Brasília.

WCMC-UNEP and IUCN (2015), "World Database on Protected Areas", World Conservation Monitoring Centre of the United Nations Environment Programme and International Union for Conservation of Nature, www. protectedplanet.net.

WWF e ICMBIO (2012), Avaliação comparada das aplicações do método Rappam nas unidades de conservação federais, nos ciclos 2005-06 e 2010, Brasília, www.icmbio.gov.br/portal/images/stories/comunicacao/ downloads/relatrio\%20rappam\%202005\%20x\%202010\%20-\%20verso\%20integral.pdf. 




\section{OCDE - Avaliações de Desempenho Ambiental}

\section{BRASIL}

As Avaliações de Desempenho Ambiental da OCDE proporcionam avaliações independentes dos avanços de cada país no cumprimento de suas políticas ambientais e realiza recomendações pertinentes sobre essas políticas. Essas avaliações promovem o aprendizado mútuo, fortalecem a prestação de contas dos governos e fornecem recomendações específicas para melhorar o desempenho ambiental, tanto de forma individual como coletiva. Elas apoiam-se em uma ampla gama de dados econômicos e ambientais e análises baseadas em evidências. Cada ciclo das Avaliações de Desempenho Ambiental engloba todos os países-membros da OCDE e países parceiros selecionados. As avaliações mais recentes incluem: Polônia (2015), Espanha (2015) e Países Baixos (2015).

Este relatório é a primeira Avaliação de Desempenho Ambiental do Brasil. Avalia os avanços do desenvolvimento sustentável e da economia verde, com foco na conservação da biodiversidade e do uso sustentável e das áreas protegidas.

A versão original deste livro foi publicada sob o título OECD Environmental Performance Reviews: Brazil 2015 (ISBN 9789264240063/DOI: http//dx.doi.org/10.1787/9789264240094-en), Organização para a Cooperação e Desenvolvimento Econômico (OCDE), Paris.

Esta tradução é publicada mediante acordo com a OCDE. Não é uma tradução oficial da OCDE.

www.oecdbookshop.org - OECD on line bookshop

www.oecd-ilibrary.org - OECD e-library

www.oecd.org/oecddirect - OECD title alerting service 